


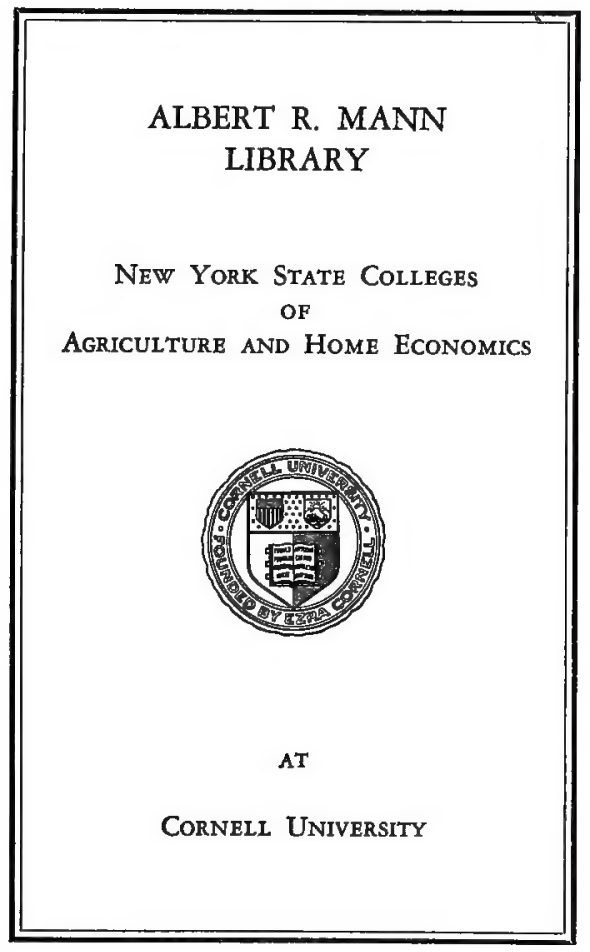


SH 421.R12 ${ }^{\text {Cornell University Library }}$

Fishing from the earliest times,

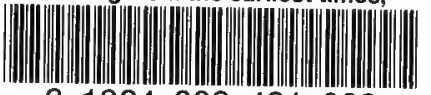

$\begin{array}{lllll}3 & 1924003 & 431 & 008\end{array}$ 


\section{Cornell University Library}

The original of this book is in the Cornell University Library.

There are no known copyright restrictions in the United States on the use of the text.

http://www.archive.org/details/cu31924003431008 


FISHING FROM THE EARLIEST TIMES 

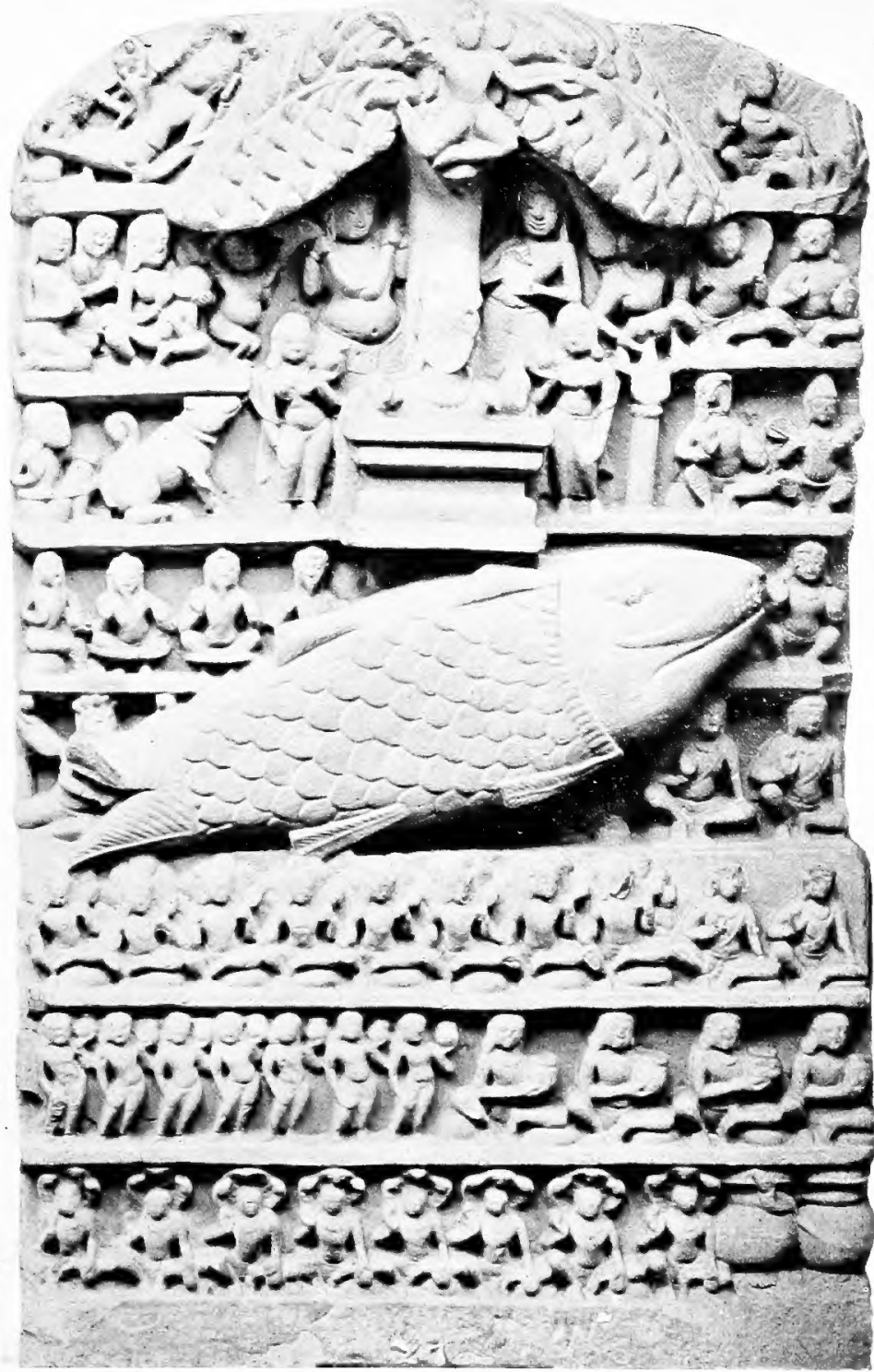

THE FISH-AVATAR OF VISHNL, WTII SCENES IILUSTRATING THE LIFE OF IKRISENA. 


\title{
FISHING FROM THE EARLIEST TIMES
}

\author{
BY \\ WILLIAM RADCLIFFE \\ SOMETIME OF BALLIOL COLLEGE, OXFORD
}

WITH ILLUSTRATIONS

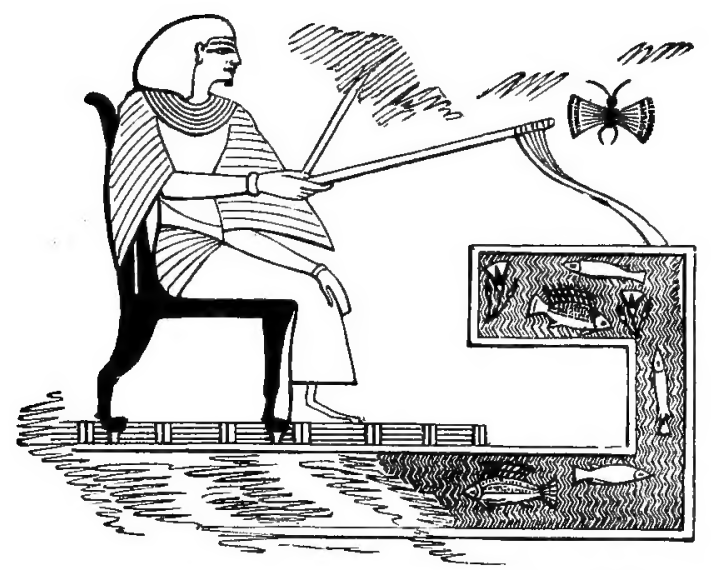

THE OLDEST REPRESENTATION (BUT ONE) OF ANGLING, C. I400 B.C.

\section{LONDON}

JOHN MURRAY, ALBEMARLE STREET, W. 


\section{6}

All rights reserved 
MY FISHING HOSTS AND FISHING FRIENDS IN AFRICA, AUSTRALASIA, AMERICA, THE WEST INDIES, AND EUROPE.

UPON THEM, UPON ME MAY THE GODS BESTOW THE BOON CRAVED BY MR. ANDREW LANG!

"Within the streams, Pausanias saith, That down Cocytus valley flow, Girdling the grey domain of Death, The spectral fishes come and go; The ghosts of trout fly to and fro, Persephone, fulfil my wish, And grant that in the shades below My ghost may land the ghosts of fish/" 



\section{PREFACE}

DESPITE Francis Bacon's dictum that "prefaces are great wastes of time, and, though they seem to proceed of modesty, they are bravery," I hazard a few words as to this book, which, like Topsy, "growed, I 'spects," from a chance request for a quotation from Homer on Fishing with a Rod for my sister's game-book.

It is, as far as I can discover, the first attempt to examine classical and other ancient writers on Fishing from the standpoint of one who has not only been a practical Pisciculturist for many years and an Angler all his life, but has also been taught (though somewhat forgotten) his Greek and Latin.

If my work, in the main, is necessarily based on the compilations of others, it yet by serendipity (to adopt Horace Walpole's mintage) has unearthed some rare authors, who, judging from lack of mention, were unknown to previous writers on the subject. It contains also-if I may venture a "bravery "- several points which are apparently original.

Instances of these are :-

(I) The definite establishment of Aristotle as our first, if through lack of microscope primitive, scale-reader ;

(2) The acquittal without a stain on his character of Plutarch from the charge, under which he has lain for centuries, of libelling and contemning Fishing ;

(3) The discussion by whom, Martial or Alian, was the use of $(a)$ the natural, or $(b)$ the artificial fly first suggested or implied ;

(4) The examination whether the crescens harundo of Martial was a jointed Rod, somewhat like our own; 
(5) The conclusion that the Rod was apparently never employed by the Ancient Assyrians or the Israelites, despite their long connection with Egypt, where as early as c. 2000 B.C. it is depicted in actual use ;

(6) The point which, if not original, is rarely made or insufficiently pressed, that the Line of both the ancients and moderns down till the seventeenth century was a tight, as opposed to a running Line.

May I, as a last "bravery," state that apart from articles in Magazines and Encyclopædias, I do not know, with the exception of Bates's Ancient Egyptian Fishing; of any work in English on Fishing, not Fish, in ancient Egypt, Assyria, Palestine, or China, nor, with the exception of Mainzer's magazine article on Jewish Fishing, have I come across one in French or German?

If any object that I have cast my net too wide and enclosed a few things that are neither Fish nor Fishing, I must insist that as these waters are not, as yet, adequately charted, it is well-nigh impossible to avoid some infringement of the three miles' territorial limit. To drop metaphor, in the present state of archæological research, it is notorious that no one subject can be fully investigated without trenching here and there on allied topics. This indeed is not merely necessary, but desirable, unless important side-lights are simply to be ignored.

Moreover, every good Waltonian prefers the discursive to the cursive style, and would rather take part in a leisurely exploration of his preserves than skim the surface in a manner hasty and in-Compleat.

Whatever the demerits of my volume, written at intervals between war-work and illness, I do trust that of the three counts of the indictment brought against Nicander's Theriaca, "longa, incondita, et nullius farrago fidei," the verdict of my readers will, at any rate as regards the last, be "Not Guilty," for on this head I have stoutly striven to avoid conviction.

Reference to aid from any book or person is usually set forth in my pages; but here and at once I acknowledge with glad 
gratitude the debt I owe for counsel and help to certain of my friends, whose names I yet hesitate to state, "pour ne point leur donner une part de responsabilité dans les fautes que je suis seul coupable d'avoir laissé subsister."

They are: Mr. A. B. Cook, Reader in Classical Archæology at Cambridge; Dr. Bernard Grenfell, Professor of Papyrology at Oxford; Dr. A. R. S. Kennedy, Professor of Hebrew and Semitic Languages at Edinburgh ; the late, alas! Dr. Leonard W. King, of the Assyrian Department of the British Museum; Dr. S. Langdon, Professor of Assyriology at Oxford; Dr. J. W. Mackail; Dr. A. Shewan; and last, but very far from least, Mr. H. T. Sheringham. 



\section{CONTENTS}

Preface • . . . . . . . . . . . . vii

INTRODUCTION

\section{GREEK AND ROMAN FISHING}

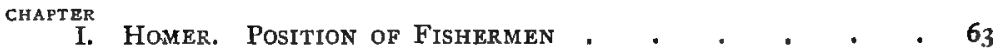

II. Homer. Methods of Fishing . . . . . . 74

III. Contest between Homer and Hesiod. Homer's Death • 86

IV. The Dolphin, Herodotus. The Ichthyophagi. The

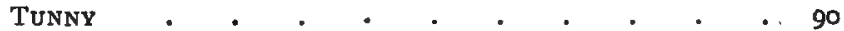

V. Plato. Aristotle the First-Scale Reader. Senses of FISH • . . . . . . . . . . . I06

WT. Characteristics of Fishermen in Greece and Rome.

Deities of Fishing . . . . . . . . . . 116

VII. Theocritus, The Greek Epigrammatists • • • 133

乙 UiII. The Two Plinys. Martial. Was the Rod Jointed? . $14 \mathrm{I}$

IX. The EIRST MENTION- $\theta$ F- FLY . . . . . . 152

X. The Scarus. The First Notice, "Fishing Prohibited" - 159

XI. Plutarch : Charge against Him of contemning Fishing

False. 'Cleopatra's Fishing. Oppian. The Torpedo

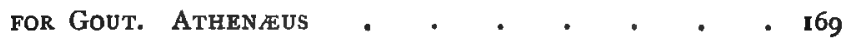

XII. Elian. The Macedonian Invention, oR the First mention of an ARtificial Fly . . . . . 185

XiII. Ausonius. Salmo. Salar and Fario. First Mention of the Pike in Classical Literature • . . . . 194

Xiv. Infatuation for Fish. Extravagant Prices. Costly

Entertainments, Vitellius. Cleopatra. Apicius, Cooks.

Sauces 
CHAPTER

XV. Fish in SACrifices. PTCKLed Fish. VIVARIA. Oysters. ARCHIMEDES . . . . . . . . . 215

XVi. Legal Regulations of Rome as regards Fishing • . 231

XVII. Tackle. Curious Methods of Fishing for the Sargus The Skate, the Sirords, and The ERl. What was the SILERJS? Wild Theories as to the Propagation of EELS • • . • . . . • • . 235

XViII. The Nine Fish most highly prized .. . . . . 254

XIX. Fish in Mxths, Symbols, Diet, and Medicine. • . 270

XX. Diocletian's Edict, 301 And. Prices of Fish and other ARticles Then and Now . . . . . . . 285

XXI. Difference between Roman and Modern Pisciculture 289 XXiI. The Ring of Helen . . . . . . . . 295

\section{EGYPTIAN FISHING}

XXIII. “The NILE IS EgYPT" . . . . . . . 301

XXIV. TACKLE . . . . . . . . . . . 307

XXV. ABstention from Fish . . . . . . . . 319

XXVI. SACRED FISH $. \quad . \quad \cdot \quad \cdot \quad \cdot \quad \cdot \quad \cdot \quad \cdot \quad \cdot 327$

XXVII. Fisheries. Attempted Correlation of the Price of

Fish Then and Now. Sfawning . . . . 333

XXXVIII. Fishing with the Hair of THE DeAd . . . . 340

XXIX. The Ring of Polycrates . . . . . . . 344

\section{ASSYRIAN FISHING}

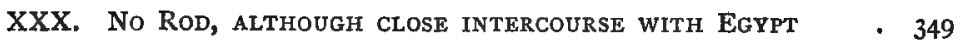

XXXI. Fishing Methods . . . . . . . . 355

XXXII. The Earliest Recorded Contract of Fishing • . 360

XXXIII. FISH-GODS. DAGON • . . • • . • • 363

XXXIV. The Legends of AdAPA, and of the Flood • • . 369

XXXV. Fish. Vitalala The First Instance of Poaching • • 373

XXXVI. Fish in Offerings, Magic Auguries . . • • $\quad 382$

XXXVII. The Fight between Marduk and Tiämat • • . 39i 


\section{JEWISH FISHING}

CHAPTER

PAGE With EGypt. Reasons suggested for AbSENCE • 397

XXXIX, Fish with and without Scales. Methods of Fishing.

VIVARIA . . . . . . . . . 414

XL. IChthyolatry improbable. Fish not in SACRIfices

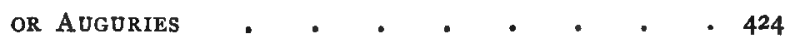

Xli. The Fish of Tobias. Demonic Possession • • . 43 I

XLII. The Fish of Moses, Jonah, Solomon's Ring • $\quad 43^{8}$

\section{CHINESE FISHING}

XLIII. "Plus UN PAYS PRODUIT DES POISSONS, PLUS IL PRODUIT

D'HOMMES" . . . . . . . . . . . 449

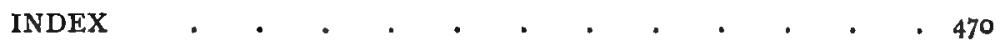





\section{LIST OF ILLUSTRATIONS}

The Fish avatar of Vishnu, with Scenes Illustrating Life of KRISHNA . . . . . . . . . . Frontispiece

The Oldest (save ONe) Representation of Angling, c. I400 B.c. Title page

Poseidon, Hrracles, and HrRmes Fishing . • . . - . II

Aztec Fishing . . . . . . . . . . . 22

Aztec Boating $\quad$ • . . . . . . . . . . . 23

Palfolithic Engravings : Seals, Dead Trout, and (?) Eels . . 26 Alaskan Hook with a Wizard's Head - $\quad$ - . . $\quad 28$

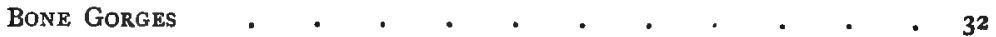

(1) THE EDRToANTHA Latro. (2) HOOK MADE FROM ITS LEg JoINTs facing 34

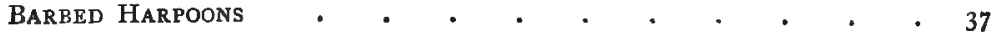

BROKRN HARPOON FROM KENT'S CAVE . . . . . . . 37

Fishing Net spun by Spiders $\quad$ * . . . . . . . facing 42

Fishermen on the Vase of Phylakopi $\quad$. . . . . $\quad$, 63

"IN AT The Death" • . . . . . . . . . . 72

Methods of Fishing, From Roman Mosaic . . . . . . 75

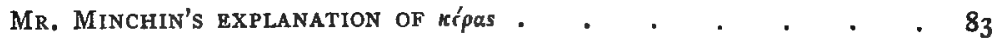

The Dolphin and THE BoY of Iasos • . . . . . . 96 
Cutting up the Tunny . . . . . . . . . . . . IOO

Artemis with a large Fish painted on her Dress . . . - 127

"The Happy Fisherman" . . . . . , . . . I3I

THE FowleR's ROD . . . . . . . . . . . 149

Venus and CUPID ANgling . . . . . . . . . . . . 168

TORPEDO FISH . . . . . . . . . . . facing 180

(1) Fisherman and Son. (2) Son saluting Wayside Hermes . . 186

The Naked Fisherman of the Vatican . . . . facing $20 \mathrm{r}$

Two MEN Fishtng . . . . . . . . . . . 220

ARethusa . . . . . . . . . . . . 22 I

A Greek ANgler . . . . . . . . . facing 235

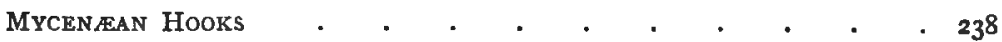

Angling with Wine, from a Mosaic at Melos . . . facing 240

Fish on a Pompeian Mosaic in the Naples Museum a $\quad$, 254

Head of Tiberius. Temple with two Columns in shape of Fish,

FROM A COIN OF ABDERA $\quad . \quad$. . . . . . . 273

The Rape of Helen, from a Fifth Century b.C. Scyphos . . 294

The Return of Helen $\quad$ " $\quad$ " $\quad$, $\quad$ " $\quad . \quad .296$

Egyptians Carrying a LARge Fish . . . . . . . 300

EARLy Harpoons • . . . . . . . . . . . 308

An Egyptian Reel $\cdot \quad \cdot \quad \cdot \quad \cdot \quad \cdot \quad \cdot \quad \cdot \quad \cdot \quad$ facing 309

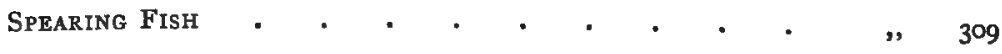

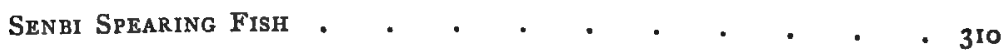

The Earliest Representation of Angling and Hand-Lining facing $3 \mathbf{3}^{\mathrm{I}} 4$ 

A Fishing Scene . . . . . . . . . . . facing 318

The Oxyrhyncus taking the place of the Bird Soul . $\quad . \quad 328$ Fisherman wading with Creel round Neck . . . facing 349 Men Fishing astride Goatskins . . . . . . $\quad$ " 355

The Net of Ningirsu (SO-Called) . . . . . . " " 358

FISH-GOD . . . . . . . . . . . . . 365

Gilgamesh Carrying Fish . . . . . . . . . . $\quad 3^{67}$

The Demon of the South-West Wind . . . . . . . 370

The Fight between Marduk and Tiämat. . . . facing 392

Tobias, in La Madonna del PEsce, by Raphael. * • $\quad$ " 397

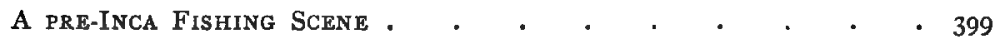

Atargatis, from a Coin of Hierapolis . • • • • • $\quad 426$

Jonah entering the Whale's Mouth, from a i4th Century MS. • 439

JONAH LEAVING $\quad$ " $\quad$ " $\quad, \quad, \quad, \quad 442$

Chinese Angling . • . . . . . . . . facing 449

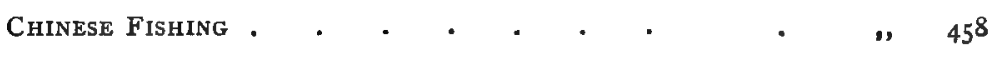



INTRODUCTION 



\section{ANCIENT FISHING}

\section{INTRODUCTION}

\section{PART I}

"And first for the Antiquity of Angling, I shall not say much; but onely this: Some say, it is as ancient as Deucalion's Floud: and others (which I like better) say that Belus (who was the inventer of godly and vertuous Recreations) was the Inventer of it: and some others say (for former times have had their Disquisitions about it) that Seth, one of the sons of Adam, taught it to his sons, and that by them it was derived to Posterity. Others say, that he left it engraven on those Pillars, which hee erected to preserve the knowledge of Mathematicks, Musick, and the rest of those precious Arts, which by God's appointment or allowance, and his noble industry were thereby preserved from perishing in Noah's Floud."-IsAAK WALION, The Compleat Angler.

"You see the way the Fisherman doth take

To catch the Fish; what Engins doth he make?

Behold how he ingageth all his wits,

Also his Snares, Lines, Angles, Hooks, and Nets.

Yet fish there be, that neither Hook, nor Line,

Nor Snare, nor Net, nor Engin can make thine;

They must be grop't for, and be tickled too,

Or they will not be catch't, whate'er you do."

John Bunyan, The Pilgrim's Progress. (The Author's Apology for his book.)

"Elle extend ses filets, elle invente de nouveaux moyens de succès, elle s'attache un plus grand nombre d'hommes. Elle pénètre dan les profondeurs des abîmes, elle arrache aux angles les plus secrets, elle poursuit jusqu'aux extrémités du globe les objets de sa constante recherche."-G. E. LACÈPÉDE, Hist. Nat. des poissons.

"What song the Sirens sang, or what name Achilles assumed, when he hid himself among women, though puzzling questions are not beyond all Conjecture."-Sir Thomas BRowne, Urne-Buriall.

$$
\text { * * * * * * * * * * * }
$$

THE craft of Fishing possesses an ancestry so ancient, or according to a Polynesian legend so literally abysmal, that for those who have their business on the waters, deep or shallow, 
it is but seemly, it is certainly of interest, to essay the tracing of its pedigree, and the linking of the generations of its far-flung lineage.

What were, and whence came its first forbears, and of what manner and of what matter were the original parents of its devices are questions which should appeal to the large majority of its followers. The sansculottes, however stalwart, who does not in his heart of hearts rejoice in owning, or claiming, some genealogical garments, wherein to hide his nakedness, is rare and abnormal.

The pedigree is like and unlike its celebrated Urquhart brother. Like in the gaps in generations, which in his endeavour directly to deduce his family from Adam even Sir Thomas's ingenuity failed to bridge, despite the prolongation when necessary of the lives of his ancestors to ten times the allotted span. Unlike in antiquity, since it stretches far, very far beyond "Deucalion's Floud" and Adam's Paradise.

Angling, despite wide ramifications, has perhaps stamped its stock more vividly and has bred truer to original type than its elder brother Hunting. The variance of a repeating rifle from what some hold to be their common first sire, a sharpened pole, is larger and more marked than that of our most up-todate Rod.

The riddle, as in other cases of disputed succession, of identifying the first real head of the family or the earliest begetter of the race is rendered more complex by wide geographical dispersion. It is possibly insoluble.

Nevertheless to this labour of love I now address myself.

The question of priority of the implement used for catching fish has been often moot, sometimes acute, for, in Walton's words, "former times have had their Disquisitions about it."

How did the earliest fisherman secure his prey? Was it by means of the Spear, under which term I include harpoons and barbed fishing spears of any kind, the Net, or the Line? None of these has lacked its champions, of whom the Line has attracted the fewest, the Spear the most. 
Uncertainty as to the order of precedence was not really remarkable. We lacked even as late as the beginning of the last century both the data as to Egyptian and Assyrian fishing, which the discovery of the key to the hieroglyphs by Champollion and to the cuneiform by Rawlinson has laid bare, and the data as to the fishing of the Troglodytes which scientific examination of the caves of France and Spain has revealed.

The outlook of our forefathers was necessarily limited, indeed monotopical. No big maps of the archæological world widened their vision. Some sectional sketches, and these badly charted, obscured their perspective.

The priority of the Net at one time probably enrolled the majority of adherents. Nor can we wonder, when we realise that in the case of a country so ancient as India we light on no method of fishing other than Netting-and even that till the post-Vedic literature after 200 B.C. most rarely-in Sanskrit or Pāli literature before 400 A.D. ${ }^{1}$ Hence came the deduction, not unnatural but illogical, since it stresses too strongly the argument of silence or omission-i.e. because no specimen or representation of a thing exists the thing itself never existedthat the Net must have been the first implement.

And even now after many years of exploration in Mesopotamia a champion of the Net or of the Line, if he similarly disregarded logic and all save Assyrian remains, might not unreasonably proclaim their antecedence to the Spear, of which no mention or representation as a method of fishing has yet been unearthed.

In the case of Egypt the advocate either of the Spear or Net has not as strong, certainly not so clear, a case. Although examples of the first have been discovered in pre-historic graves, the Net finds representation earlier than the Spear. Be this how it may, the Spear, Net, Line, Rod flourish synchronously in the XIIth Dynasty c. 2000, or according to Petrie's chronology about 3500 B.C.

In China, unless the sentence of the quite modern $I$ shin chi shih, that in the reign of the legendary Emperor who first taught the use of fire, "fishermen used the silk of the cocoons 
for their lines, a piece of sharpened iron for their hooks, thornsticks for their rods, and split grain for their bait," be potent enough to produce a protagonist for the priority of the Rod, the boldest advocate would shrink from championing either the Spear or Net. The first mention c. 900 B.C. (I know of none actually written before this date ${ }^{1}$ ), shows them, and the Rod, in general and simultaneous operation.

From Crete shines out no guiding light. The débris recovered from centres of the 'Minoan' civilisation yields frequent and in the main vivid pictures of fish, e.g. those on the Phaistos Disc (which is considered the earliest instance of printing in Europe at any rate) and the flying fish on glazed pottery from Knossos. But unfortunately neither in the Annual Reports of Sir Arthur Evans to the British School at Athens nor (he tells me) in his forthcoming book do modi piscandi obtain notice.

In Greece, a champion of any single method would be sadly to seek. The Spear, the Net, the Line, and the Rod all occur in our earliest authority, Homer, and, curious to note, as a rule in similes. From the fact that the Spear finds mention but once, the Net twice, and the Line (with or without the Rod) thrice, a real enthusiast has deduced an argument for the priority of the last two over the Spear !

This short survey forces the conclusion that we cannot fix definitely which was the method adopted by the earliest historical fishermen.

Before proceeding on our search for further data two points should be emphasised. First, the period covered even by the longest historical or semi-historical record counts but as a fraction of the time since geology and archæology prove Man to have existed on earth.

Grant, if you will, the demand of the most exacting Egyptologists or Sumerologists, to whom a thousand years are as nothing ; concede their postulated five or six thousand years ; of what account is one lustrum of millenniums when compared

1 The recent discovery of the inscribed bone fragments in Honan apparently adds some six hundred years to the history, as apart from the legends of China, for $\iota . \quad$ I 500 B.C. instead of c. 900 B.C. seems now our starting point. See infra, p. $45^{\circ}$. 
with the years-not less than two million according to some geologists 1 -which have elapsed since Man first came on the scene?

Second, all the above nations possessed an advanced civilisation. Neither civilisation nor fishing is a Jovelike creation, springing into existence armed $c a p-a-p i e$. Both, like our friend Topsy, "growed," and both demanded long periods for growth and development from their primitive origin.

In fishing these were retarded by the innate conservatism of the followers of the cult. The psychology of the faithful is an odd blend of dogged, perhaps unconscious, adherence to the olden ways and of an almost Athenian curiosity about " any new thing," which as often as not sees itself discarded in favour of the ancient devices.

Even in this year of our Lord a cousin of mine, who Ulysseslike many rivers has known, much tackle tested, habitually (influenced no doubt by the recipe for the line given by Plutarch and passed on by Dame Juliana Berners) inserts between his line and his gut some eighteen inches of horse hair! But even in him the law of development works, for he does not Pharisaically adhere to the strict letter of the text, and insist that the hair comes only from the tail of a stallion or gelding ! 2

Then, again, not less than two thousand odd years were needed for the Rod and the Line of Elian's Macedonian angler to take unto themselves a cubit or so more of length than their Egyptian predecessors. ${ }^{3}$ The latter may, however, have been rendered shorter than actually used from the regard paid to artistic convention by the craftsman of Beni-Hasan.

But the connection of the line to the rod furnishes the most arresting instance of conservatism or slow development.

1 Cf. Dr. J. T. Jehu's Lectures before the Royal Society, 19r9. It is noteworthy that whatever be the geological date of Man, the oldest true fish, as we understand the term, seems the Shark family, which, although extremely archaic, has but little altered. Next in seniority comes probably the Ceradotus; if now "merely a living fossil" and found only in Queensland, its form, hardly modified, corresponds with remains found all over the world as early as from the Trias.

2 The urination of a mare was thought to weaken her hairs. Plutarch, De Sol., 24 .

? $\mathrm{Cf}$, however, postea, $3 \mathrm{I} 5$. 
Progress from the Egyptian method, which made fast the line to the top of the rod," to a "running line" took, so far as discoverable records show, no less a period than that between c. 2000 B.c. and our sixteenth or seventeenth century, i.e. some 3600 , or (according to Petrie) over 5000, years!

The Reel, which, however rude, would appear a much more complicated device than other conceivable methods of a running line, seems yet to be mentioned first. The earliest description occurs in The Art of Angling, by T. Barker, I65I, the first propagator of the heresy of the salmon roe, and according to Dr. Turrell " the father of poachers." The earliest picture figures in his enlarged edition of 1657 . The Reel affords another instance of slow growth. Its employment except with salmon or big pike only coincides with the beginning of the nineteenth century.

The development to the more subtle method of play by means of spare line can only be conjectured.

It was obviously invented somewhere between I496 (The Boke of St. Albans, where we are expressly told to " dubbe the lyne and frette it fast in $\dot{y}$ toppe with a bowe to fasten on your lyne ") and I65I, when Barker mentions the "wind" (which was set in a hole two feet or so from the bottom of the rod) as a device employed by a namesake of his own, and presumably by few beside at that time.

Walton four years later, but anticipating Barker by two as to its employment in salmon fishing, writes of the "wheele" about the middle of the rod or nearer the hand as evidently an uncommon device, "which is to be observed better by seeing one of them than by a large demonstration of words."

Focussing a perplexed eye on the picture vouchsafed by Barker in his enlarged edition of 1657 , we are impressed by the wisdom of Father Izaak. Frankly it is not easy to discern from it what Barker's "wind " was intended to be or what the method of working. Apparently he had in mind two distinct implements, a "wheele" similar to Walton's (such perhaps as

1 Oric Bates, Ancient Egyptian Fishing, Harvard African Studies, I., I9I7, p. 248 . With a "running line," Leintz in U.S.A. cast April, I92 I, 437 ft. 7 in, 
is figured in the title page of The Experienced Angler by their contemporary Venables) and a crude winder, such as survives to-day in our sea-fishing, but intended as an attachment to a Rod. 1

This marks a logical and likely step in evolution. It is inconceivable that invention should have soared to a Reel without there having been some intermediate stage between it and the "tight" line. The advantage of extra line for emergencies must have been recognised pretty early, and a wire ring at the top of the Rod, through which the line could run, naturally resulted from such recognition.

The method of disposing of the "spare" line may be presumed from survival of primitive practice. Not many years ago pike fishers in rustic parts of England often dispensed with a reel. They either let their spare with a cork at its end trail behind on the ground, or wound it on a bobbin or a piece of wood, stowed away in a pocket. Nicholas explains Walton's (chap. v.) " running line, that is to say, when you fish for a trout by hand at the ground" as "a line, so called, because it runs along the ground."

It seems impossible to fix with certainty the period at which fishing with a running line made its first appearance. No early data exist, nor do the few early pictures of mediæval rods indicate the presence of a wire top ring. I had a lively hope, when I recalled its many plates and figures, of extracting some guidance from the most important French work of early

1 Dr. Turrell, the author of that researchful book, Ancient Angling Authors, London, I9ro, while of opinion that the "wheele" was in the course of time evolved from the "wind " of the troller, differentiates between their uses in fishing. Barker " put in a wind to turn with a barrell, to gather up his line and loose at his pleasure: this was his manner of trouling." Walton's words are, " a line of wire through which the line may run to as great a length as is needful when (the fish is) hook'd and for that end some use a wheele," etc. The use of the "wind " as described by Barker in his first edition was simply to gather up the slack line in working the bait, "this was the manner of his trouling " ; while that of Walton's "wheele "was to let the line go, in playing the rushes of salmon, of which his experience seems mainly vicarious.

Sea-anglers of the present day prefer in many cases man-handling the line to using the reel: thus the Spanish fisherman on striking a tunny throws the whole Rod back into the boat, the crew of which seize the line (which is of great thickness) and haul the fish in by sheer brute force. (See The Rod on the Rivieras (I91 I), p. 232.) 
date (I660) dealing with fishing, Les Ruses Innocentes, which may be described (mutatis mutandis) as the counterpart of The Boke of St. Albans.

The first four books are concerned with " divers methods" (of most of which the author, a la Barker, claims the invention) for the making and the using of all kinds of nets for the capture of birds, both of passage and indigenous, and of many kinds of animals.

The fifth confides to us "les plus beaux secrets de la pêche dans les Rivières ou dans les Etangs." As the secrets are concerned almost entirely with Net fishing, little light reaches us. Both the instructions and illustrations in chap. xxvi., Invention pour prendre les Brochets a la ligne volante, show that the line after being attached about the middle of the pole was twisted round and round till made fast at the end of the pole, from which depended some eighteen feet of line. 1

Setting conjecture aside and faced by the fact that the Egyptian line was certainly made fast at the top and that neither illustrations nor writings (so far as I have been able to discover) indicate any other condition, we are driven by a mass of evidence, negative though it be, to the conclusion that the ancients ${ }^{2}$ and the moderns down to some date between I496 and I65I fished with "tight" lines.

I With good reason the author styles his work, "Ouvrage très curieux, utile, et recreatif pour toutes personnes qui font leur séjour à la campagne."

a No example of a running line has ever been produced from either ancient Iiterature or ancient art, but on the other hand numerous illustrations of the tight line on vases, frescoes, mosaics, etc., are extant. To the examples collected by G. Lafaye in Daremberg and Saglio, Dict. des antiquites, iv. 489 , ff. s.v. 'piscatio,' can be added: (a) Ivory relief from Sparta, seventh century B.C., published by R. M. Dawkins in the Annual Report of the Brit. School at Athens, Igo6 7 , xiii. Ioo, ff., pl. 4. (b) Black figured lekythos from Hope Collection (Sale Cat. No. 22), published by E. M. W. Tillyard in Essays and Studies presented to $W$. Ridgetvay, Cambridge, I9r3, edited by E. C. Quiggin, p. I86, ff. with plate. (c) Græco-Roman gem in A. Furtwăngler, Beschreibung der geschnittenen Steine im Antiquarium (zu Berlin), Berlin, 1896, p. 257 , No. 6898, pl. 5r. Cf. the same author, Die Antiken Gemmen, LeipzigBerlin, I900, i. pl. 28, 25, and pl. 36, 5 ; ii. r40 and r74. A. H. Smith, Cat. of Engraved Gems in the Brit. Museum, London, 1888, p. I9I, Nos. I797-99, and p. 206, No. 2043. (d) Coins of Carteia in Spain, well represented by A. Heiss, Description gentrale des Monnaies antiques de l'Espagne, Paris, 1870 , p. 33 I f., pl. 49, r9-2I. (e) Mosaic in Melos, see R. C. Bosanquet in the Jour. of Hell. Siudies, r898, xviii. $7 \mathrm{r}$ ff., pl. I. ( $f$ ) Silver krater from Hildesheim shows Cupids with fishing rods and tridents catching all sorts of 


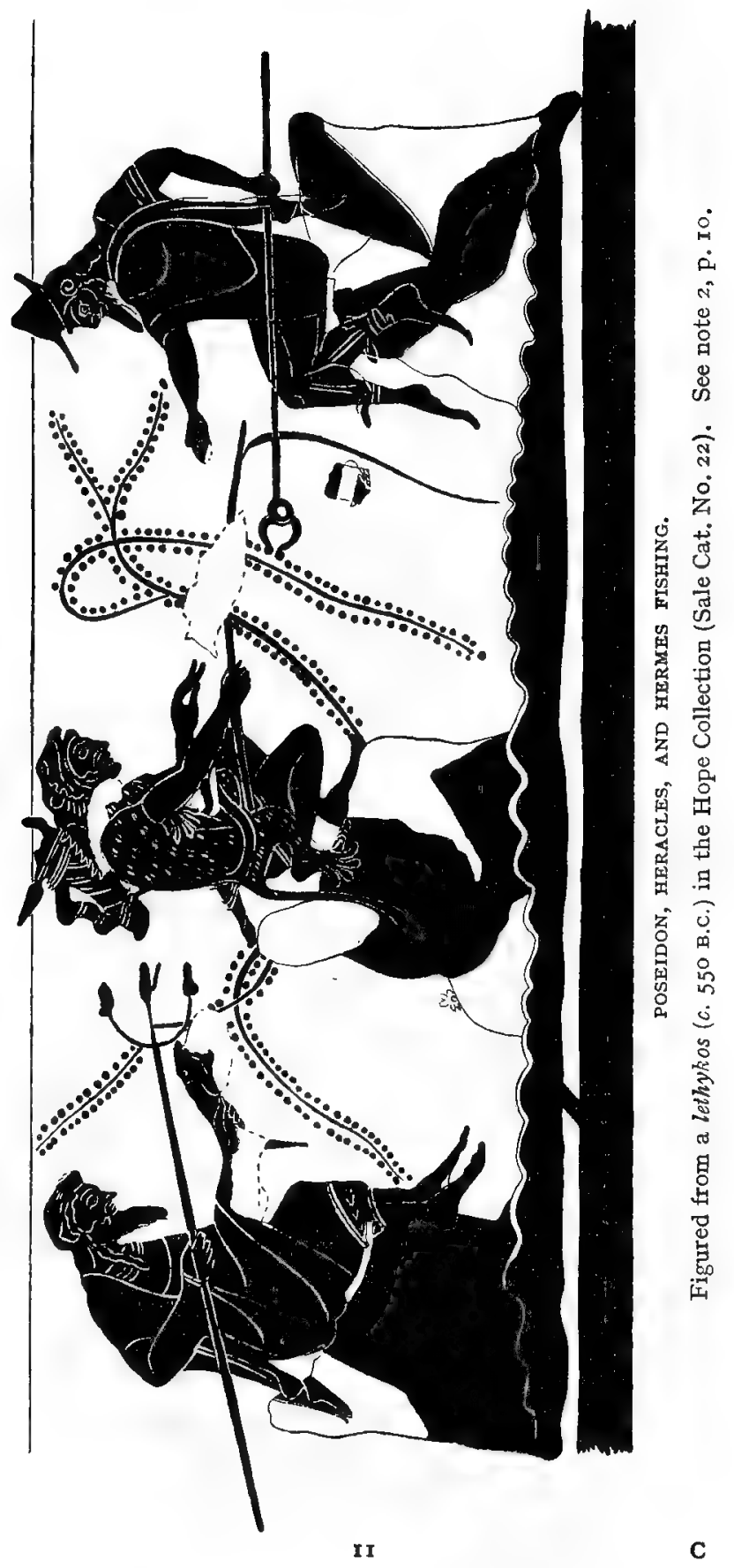


These were either fastened to the Rod whip-fashion, or possibly looped to it. The distinction is only important in so far as a horse-hair loop at the end of the Rod may have developed into a top ring of wire, which must not be confused with rings fixed along the Rod, which $\mathrm{R}$. Howlett, in The Angler's Sure Guide, I706, seems the first to note.

Why the Greeks or Romans should not have emancipated themselves from the tight line of Egypt and evolved the running line by the mere force of their inventive genius causes much astonishment. This grows acute when we remember that they knew a fish whose properties and predatory endowments furnished an ideal example of the advantages of the running line.

Of the angler fish and its methods of securing food Aristotle, Plutarch, and Elian are eloquent. ${ }^{1}$ From Plutarch we learn that "the cuttle fish useth likewise the same craft as the fishing-frog doth. His manner is to hang down, as if it were an angle line, a certain small string or gut from about his neck, which is of that nature that he can let out in length a great way, when it is loose, and draw it in close together very quickly when he listeth. Now when he perceiveth some small fish near unto him," he forthwith plies his nature-given tackle.

With the tight line play can only be given to a fish by craft of hand and rod. Anglers know to their sorrow that although much may be thus accomplished, occasions too frequently arise when the most expert handling can avail naught.

In Walton's time the custom, as indeed it was the only present help, in the event of a big fish being hooked was to throw the Rod into the water and await its retrieval, if the deities of fishing so willed, till such time as the fish by pulling it all over the water had played himself out.

sea-beasties. E. Pernice and F. Winter, Der Hildesheimer Silberfund, Berlin, Igor, pls. 32, 33. Cf. S. Reinach, Repertoive de Reliefs grecs et romains, Paris, Igog, i. I65 f. (g) H. B. Walters, Cat. of Greek and Roman Lamps in the Brit. Museum, London, I9I4, p. 79 f., No. 527. Pl, 16, p. 99 f.; No. 656, pl. 22, p. 96, No. 635. The accompanying illustration is reproduced by kind permission of Mr. E. M. W. Tillyard and of the University Press, Cambridge.

1 Aristotle, N.H. ix. 37. Plutarch, De Sol. Anim. 27, translated by Holland. Elian, N.H. ix. 24. See Pliny, N.H. ix. $4^{2}$. 
But the existence of some method of releasing line rather earlier than Barker and Walton may perhaps be inferred from the following passage in William Browne's Britannia's Pastorals (Fifth Song), published I6I3-16:-

" He, knowing it a fish of stubborn sway, Puls up his rod, but soft : (as having skill)

Wherewith the hooke fast holds the fishe's gill.

Then all his line he freely yeeldeth him,

Whilst furiously all up and downe doth swimme

Th' insnared fish. ...

By this the pike, cleane wearied, underneath

A willow lyes and pants (if fishes breathe) :

Wherewith the fisher gently puls him to him, And, least his haste might happen to undo him, Lays down his rod, then takes his line in hand, And by degrees getting the fish to land, Walkes to another poole."

A few years suffice to span the interval between William Browne and Barker, whereas between Theocritus and Barker a great gulf of time yawns unbridged. Thus we have renderings of the former (Idyll XXI.) and of other classical authors by translators (more especially when they happen to be also anglers!) which demonstrate ignorance or ignoring of the fixity of line and the absence of reel.

These, if not palpably anachronous, afford at any rate evidence of incuriosity concerning facts. Their " then I gave him slack" and other similar expressions, true enough of our present line, can be no way applicable to the conditions of ancient Angling, unless the words mean-and then only by strained construing-that their " slack" was given by depression of Rod rather than by lengthening of line.

With the hook also we are confronted with a similar slowness of development. This is so well attested that we need more than even the authority of Butcher and Lang to establish

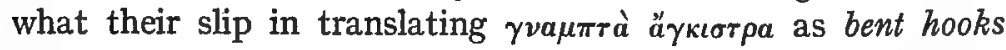
in Odyssey IV., 369, and as barbed hooks in Odyssey XII., 332, would suggest, viz. a synonymous form of a synchronous invention. 
Since it is impossible to fix the length of time, if any, which separates the New Stone from the Copper Age, we can make no adequate guess as to how many generations of men and how many centuries of time were needed to transform the bent into the barbed hook. Perhaps Eneolithic experts can.

Extant examples from Egypt of both furnish, however, some chronological data. If the argument from silence, or rather from non-survival in one particular country, be not pressed unduly, these tend to prove that so far from their being twin brethren, the birth of the bent anteceded that of the barbed hook by at any rate the number of years which separated the Ist from the XVIIIth Dynasty, before which the occurrence of a barbed hook is rare.

The first implement of fishing, be it what you please, was no split-cane Rod, nor the " town-like Net " of Oppian, but some simple device created by the insistent necessity of procuring food. With our primitive ancestors, as with the companions of Menelaus, often "was hunger gnawing at their bellies," a hunger accentuated at one period by the retreat further into the primeval forests or at another by the actual decrease of the animals, which had hitherto furnished the staple of Man's sustenance.

Fortunately other data more ancient and more authoritative than the Egyptian or Sumerian as to priority of implement help the quest of Archæologists.

Blazing their trail backwards in the half-light of nonhistorical forests, they hap on many a cache of ancient devices in the settlements of the New Stone Man. Pausing merely to examine these, they cut their way through yet denser and darker timber, until eventually they emerge at an opening wherein once stood the ultimate if scarcely the original storehouse, whence Neolithic Man drew and in the course of long travel bettered his materials-the dwelling place of the Old Stone Man.

To this store-house we too must press, tarrying only at the caches to note cursorily Neolithic betterment or invention. The dwelling place is one of many mansions, or rather of many rude caverns dotted over Europe. 
Of such are Kent's Cave near Torquay (which from its remains of animals may have been a mansion, or technically a "station," as early as any), the Kesserloch in Switzerland, the shelters, or cavernes, in Southern France, of which La Madelaine in Dordogne, earliest to be discovered, ranks still the most famous, and a score or so of stations in Spain-not limited we now realise to its north-west corner-of which Altamira, not far from Santander, stands out pre-eminent.

With their exploration a remoter vista has opened out in recent years; a wholly new standpoint has been gained from which to review the early history of the human race. A brilliant band of pre-historic archæologists has brought together such a mass of striking materials as to place the evolution of human art and appliances in the Quaternary Period on a level far higher than had been previously ever suspected. The investigations of Lartet, Cartailhac, Piette, Breuil, Obermaier, etc., have revolutionised our knowledge of a phase of human culture which goes so far back beyond the limits of any continuous story that it may well be said to belong to an older world.

These sentences of Sir Arthur Evans ${ }^{1}$ gain further emphasis from Professor Boyd-Dawkins: "It is not too much to state that the frescoed caves in Southern France and Northern Spain throw as much light on the life of those times as the Egyptian tombs do on the daily life of Egypt, or the walls of the Minoan palace on the luxury of Crete, before the Achæan conquest."

The picture of Palæolithic life revealed by these dwelling places attracts from every point of view. But as our last is fish and fishing, to fish and fishing we must stick. I shall therefore limit myself to the caves which furnish specimens or representations of ichthyic interest, with the one exception of "marvellous Altamira," which, though it unfortunately yields us no portrayals of fishing, from every other aspect compels mention.

So astonishing was the discovery of this cave with its whole

1 Presidential Address to the British Association for the Advancement of Science (Newcastle, I9I6), pp. 6-9. Cf. M. Burkitt, Prehistory, Cambridge, I 921 , chs. iv $-\mathrm{xx}$. 
galleries of painted designs on the walls and ceilings that it required a quarter of a century and the corroboration of repeated finds on the French side of the Pyrenees for general recognition that these rock paintings were of the Palæolithic age, and that features, which had been hitherto reckoned as exclusively belonging to the New Stone Man, can now be classed as the original property of the Man of the Old Stone Age in the final production of his evolution.

These primeval frescoes in their most developed state (Evans, ibid., tells us) show not only a consummate mastery of natural design, but also an extraordinary technical resource. Apart from the charcoal used in certain outlines, the chief colouring matter was red and yellow ochre, mortars and palettes for the preparation of which have come to light. In single animals the tints are varied from black to dark and ruddy brown or brilliant orange, and so by fine gradations to paler nuances, obtained by scraping and washing.

The greatest marvel is that such polychrome masterpieces as the bisons standing and couchant or with limbs huddled together were executed on the ceilings of inner vaults and galleries, where the light of day never penetrated. Nowhere does smoke blur their outlines, probably (as Parkyn ${ }^{1}$ suggests) because of long oxidisation. The art of artificial illumination had evidently progressed far. We now, indeed, know that stone lamps, decorated in one case with the head of an ibex, already existed.

"Les extremes se touchent" was here aptly exemplified, for to a very young child was it reserved to discover the very oldest art gallery in the world. In I879 Señor de Santuola chanced to be digging in a cave on his property, when he heard his little daughter cry, "Toros, toros!" Realising quickly that this was no warning of an impending charge by bulls, he followed her gaze to the vaulted ceiling, where his eyes there espied " the finest expression of Palæolithic art extant."

This little Spanish girl was the first for many, many thousands of years to behold a collection of pictures, which

1 E. A. Parkyn, Prehistoric Art, London, I9I5. 
demonstrate not only the high point of excellence to which the art of the Troglodytes had attained, but also, from the absence of perspective and of decorative as compared with pictorial composition, indicate how long is probably the interval and how far is the separation between them and the Men of the Neolithic Age.

Not only in the character of their Art, which if more specialised in subjects was superior in representative quality, but also in the substance and in the method of fashioning their fishing and hunting implements, the separation between the Old Stone and the New Stone Man is very marked.

The former for their stone implements almost always used flint. They worked it to shape merely by flaking or chipping. The latter employed also diorite, quartzite, etc., and in addition to flaking fashioned them by grinding and polishing. ${ }^{1}$

It must, I fear, be acknowledged that the caches of the New Stone Age fail to give us the help expected towards settling what was the first implement employed. It is true that they yield hooks, nets, net-sinkers, which may have been merely developments of Troglodyte tackle, but, judging from the absence of any surviving Palæolithic example, were more probably new inventions.

But neither these nor the implements of succeeding Ages furnish us with evidence sufficient to decide the tackle first employed by the earliest fisherman, or even by the Old Stone Man, for, as Cartailhac truly warns us, "Ce n'est pas, comme on l'a dit à tort, le début de l'art que nous découvrons. L'art de l'âge du renne est beaucoup trop ancien." 2

And here it may well be objected, if the New Stone Age does not disclose any priority of implement, why further pursue what thus must be the insoluble? Why, indeed, especially if it be true that their tackle with some additional

1 The Neolithic stage, some hold, is characterised by the presence of polished stone implements and in particular the stone axe, which, judging from its perforation, so as to be more effectually fastened to a wooden handle, was probably used rather for wood than conflict. T. Peísker, Cambridge Medicaval History, IgII, vol. i., has much of interest on the domestication of this period.

${ }_{2}$ Les Peintures préhistoriques de la Caverne d'Altamira, Annales du Muséb Guimet, Paris, I904, tome Xv. P. I3I. 
devices merely shows up as a development and improvement of that of their predecessors, to whom in point of time they surely stand nearer than any other known race?

The objection is pertinent. But, startling as the statement may seem, there now exist, or have within the last century existed, races, who in the actual material, and in the mode of fashioning, of their weapons are, in the opinion of experts, nearer akin to and resemble more closely Palæolithic than did Neolithic man.

Speaking of the Eskimos, Cartailhac simply summarises the evidence of many authorities, when he writes " the likenesses in the above points are so striking that one sees in them the true descendants of the Troglodytes of Perigord."

Professor Boyd-Dawkins goes farther. He finds the Eskimos so intimately connected with the Cave Men in their manners and customs, in their art, especially in their method of representing animals, and in their implements and weapons, that "the only possible explanation is that they belong to the same race: that they are representatives of the Troglodytes, protected within the Arctic circle from those causes by which their forbears had been driven from Europe and Asia. They stand at the present day wholly apart from other living races, and are cut off from all by the philologer and the craniologist." 1

Food supply probably effected the migration of the Eskimos, or rather of their ancestors from Europe. ${ }^{2}$ At the close of the last ice age, as the ice cap retreated Northwards, the reindeer followed the ice, and the Eskimo followed the reindeer.

Of the aborigines of Tasmania Professor E. B. Tylor testifies: "If there have remained anywhere up to modern times men, whose condition has changed little since the early Stone Age, the Tasmanians seem such a people. Many tribes of the late Stone Age have lasted on into modern times, but it appears that the Tasmanians by the workmanship of their

1 Émile de Cartailhac et $\mathrm{H}$. Breuil, La Caverne d'Altamira, Paris, I9o6, p. 145. Professor Boyd-Dawkins, Early Man in Britain, London, 1880, p. 233. But their technique in flaking, etc., suggests a later date.

2 The route was probably by Russia, Siberia, and across the land now cut by the Behring Straits. 
stone implements represent rather the condition of Palæolithic man." 1

Sollas goes even farther: "The Tasmanians, however, though recent were at the same time a Palæolithic or even, it has been suggested, an Eolithic race: they thus afford us an opportunity of interpreting the past by the present-a saving procedure in a subject where fantasy is only too likely to play a leading part." 2 But their usual technique is against Eolithicism.

If these authoritative statements be accurate, can we not hazard a shrewd conjecture from examination of the implements and of the methods prevalent amongst the backward or uncivilised tribes closely resembling our Cave Dwellers, as to which was probably the first implement or method employed for catching fish ? Can we, in fact, from the data available from the Eskimos, Tasmanians, and other similar races so reconstruct our men of Dordogne and elsewhere as to adjudge approximately whether first in their hands at any rate was the Spear, the Hook, or the Net?

Such a quest seems one of the incidental motives of G. de Mortillet in Les Origines de la Chasse et de la Pêche, I8go, which modifies in several particulars his earlier Les Origines de la Pêche et de la Navigation, 1867. We find from his pages and those of Rau's Prehistoric Fishing (1884), and of Parkyn's Prehistoric Art (IgI6), that a comparative examination of the above races, as it ramifies, discloses not only a close resemblance to Palæolithic Man in the material, nature, and fashioning of their tackle, but also in their art and method of expressing their art.

Such similarity of art, evident in the Eskimos, stands revealed by the Bushmen of Africa (especially in the caves formerly used for habitations by the tribes of the Madobo range) in no less obvious or striking degree. "The nearest parallels to the finer class of rock carvings in the Dordogne are in fact to be found among the more ancient specimens of similar

1 In H. Ling Roth's The Aborigines of Tasmania, London, 1890 (see Preface by Tylor on page vi), "It is thus apparent that the Tasmanians were at a somewhat less advanced stage in the art of stone implement making than the Palzolithic men of Europe."

Cf. W. J. Sollas, Ancient Hunters, London, I91 I, p. $7^{\circ}$. 
work in South Africa, while the rock paintings of Spain find their best analogies among the Bushmen."' 1

The Africans, it is true, perfected their engravings on the surface of the rocks more frequently by " pecking." But both they and Palæolithic man make free and successful use of colours, of which the African possesses six as against the three or four of his European brethren. Each race depicts fish and animals so life-like as to be easily identifiable.

What evidence as to priority do the Eskimo methods of to-day yield us? Cartailhac but echoes Rau, Salomon Reinach, and Hoffmann 2 in his assertion that the prehistoric Reindeer Age compares practically with the actual age of the Eskimos. Their fishing spears in material, shape, and barb resemble the Palæolithic.

Their carvings and engravings of fishing and whaling scenes on bone and ivory show clear kinship to the Dordognese.

Hoffmann's able study of the Eskimos not only brings out these similarities, but also specially notes the closeness with which they observe and the exactitude with which they render anatomical peculiarities of fish and animals. As portrayers of the human form, on the other hand, they must be reckoned far from expert. The caves of France and those of Spain in general, although the paintings of the human form at Calapata and other places are far more finished and far more frequent than the French drawings, disclose curiously the same power and the same deficiency as characteristic of Troglodyte art. ${ }^{3}$

No race probably in the world depends so greatly on fishing for a livelihood as the Eskimos. From them, if from any, we should derive most light and leading. With them the Spear and the Hook form the chief, and till recently probably the only, tackle. Nets, on account of the ice, play little part.

1 Evans, op. cit., p. 9. See also an interesting essay by Professor E. T. Hamy, L'Anthropologie, tome xix. p. 385 ff., on La Figure humaine cher le sauvage et ches l'enfant.

2 C. Rau, op. cit., Washington, I884. Salomon Reinach, Antiquités Nationales, vol. i., 1889. W. I. Hoffmann, The Graphic Art of the Eskimo, Report to Smithsonian Museum, I895, p. 75 T.

At Cogul the sacral dance is performed by women clad from the waist downwards in well-cut gowns, which at Alpera are supplemented by flying sashes, and at Cueva de la Vieja reach to the bosom. Verily, we are already a long way from Eve! Cf. Evans, op. cit., p. 8. 
To any claim for precedence of the former over the latter, a champion of the Net demurs on the ground of climatic conditions, which he not unreasonably urges prevent any proper analogy in this respect being drawn between them and our Cave Men.

Touching the similarity of the Tasmanian to the Troglodyte, Ling Roth amplifies, especially as regards the material, etc. of the Spear, the evidence contained in Tylor's already quoted sentence. This in conjunction with Captain Cook's earlier statement that the Tasmanians, while experts with the Spear, were ignorant of the use of a Hook, and, according to Wentworth, of a Net, would have gone far in helping our quest and in establishing the precedence of the Spear.

Unfortunately the evidence of Lloyd and others that these aborigines speared fish as a pastime, coupled with the fact that while they consumed crustacea they abstained (probably from reasons of tabu or totem) from eating scaled fish, sharply differentiates their Kultur from that of our prehistoric fishermen " at whose bellies hunger was gnawing." 1

From Mexico, and especially from the representations in Yucatan, I had hoped for new factors helping to solve our problem. First, because these had so far escaped the meticulous examination of the Madelainian, and second, because they were the product of an ancient people, the Mayas, who ranked fish as an important item of their diet, and pursued fishing with the Spear and the Net. ${ }^{2}$

With the Aztecs, who in the thirteenth century inherited the Maya culture, now dated as regards their architecture back to the first three centuries A.D., ${ }^{3}$ the hook arrives, or rather appears. Aztec skill in fishing stands well attested. Their artificial fishponds or vivaria, and the importance which they

1 Cook's Third Voyage, Bk. I. ch. vi. W. C. Wentworth, A Statistical, stc., Description of New South Wales and Van Diemen's Land, London, 1819, p. II5: "They have no knowledge whatever of the art of fishing "; the only fishing was done by women diving for shell-fish. G. T. Lloyd, Thirty-three Years in Tasmania and Victoria, London, I862, pp. 50-52. Ling Roth, op. cit., p. 75 .

2 No Maya hook has as yet been brought to light, although this was employed by practically all the races aboriginal or other from Alaska to Peru.

${ }^{3}$ C f. T. A. Joyce, Mexican Archeology, London, I9I4. 
attached to fish as a food extract favourable comment from Cortez. ${ }^{1}$

In spite of the pictographs, known as the Mendoza Codex, ${ }^{2}$ being executed several centuries after the date I have roughly allotted myself, viz. 500 A.D., I cannot resist inserting two of these on account of their fourfold interest.

They show first, that Mexican lads received early in their teens education in fishing. Second, that the Aztecs were

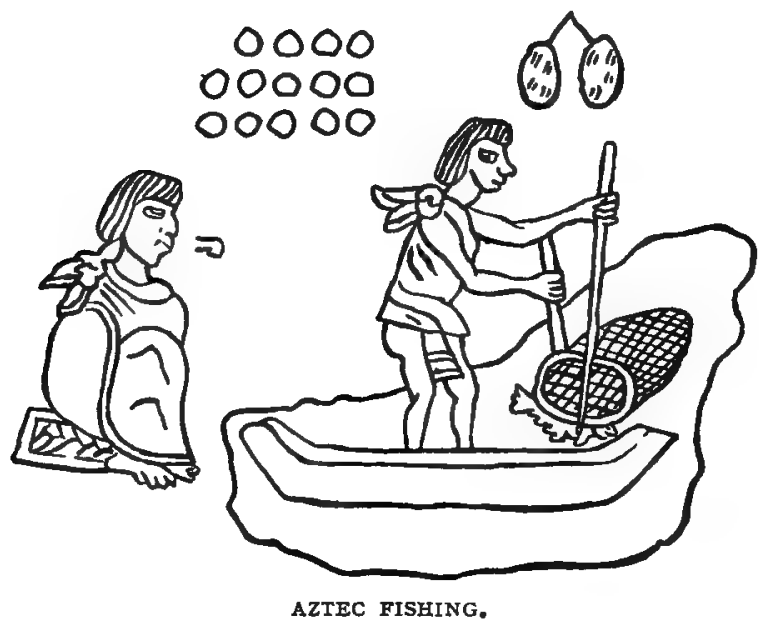

From the Mendoz a Codex, vol. i. pl. 6r, fig. 4 .

familiar with scoop nets. Third-and this surely will go to the heart of our Food Controller-that food was rationed.

1 Montezuma's table was provided with fish from the Gulf of Mexico brought to the capital within twenty-four hours of capture by means of relays of runners. Some five gods of fishing, of whom the chief seems to have been Opochtli, were worshipped: to him was ascribed the invention of the net and the minacachalli or trident. Cf. de Sahagun, Histoire general des choses de la Nouvelle Espagne, traduite et annotée par D. Jourdanet et Rémi Simeon, p. 36, Paris, I880. De Sahagun, a Franciscan, came to Mexico in I 529 and died there in I590. See also, C. Rau, op. cit., p. 2I4, and T. Joyce, op. cit., pp. 165, 221. A not uncommon practice was co-operative fishing, by which, after a portion had been set aside for the feudal lord, the rest of the catch was divided in fixed shares; see Joyce, p. 300.

2 These pictographs were made by native artists shortly after the conquest of Mexico, and were sent by the Viceroy Mendoza, with interpretations in Aztec and Spanish, to the Emperor Charles the Fifth. A copy of this Codex in the Bodleian was reproduced by Lord Kingsborough in his first volume of Antiquities of Mexico (183r). 
From the circles or dots we learn that the age of one youth depicted was thirteen, and from the two connected ovals marked with small dashes that his allowance of food consisted of two cakes or tortillas a meal. Fourth, by the symbol before his mouth, that the father is speaking. The symbol very roughly reminds us of the Assyrian system of signs which determine the nature or subject of a word, as the two hundred odd fish mentioned in Asur-bani-pal's library at Nineveh signify.
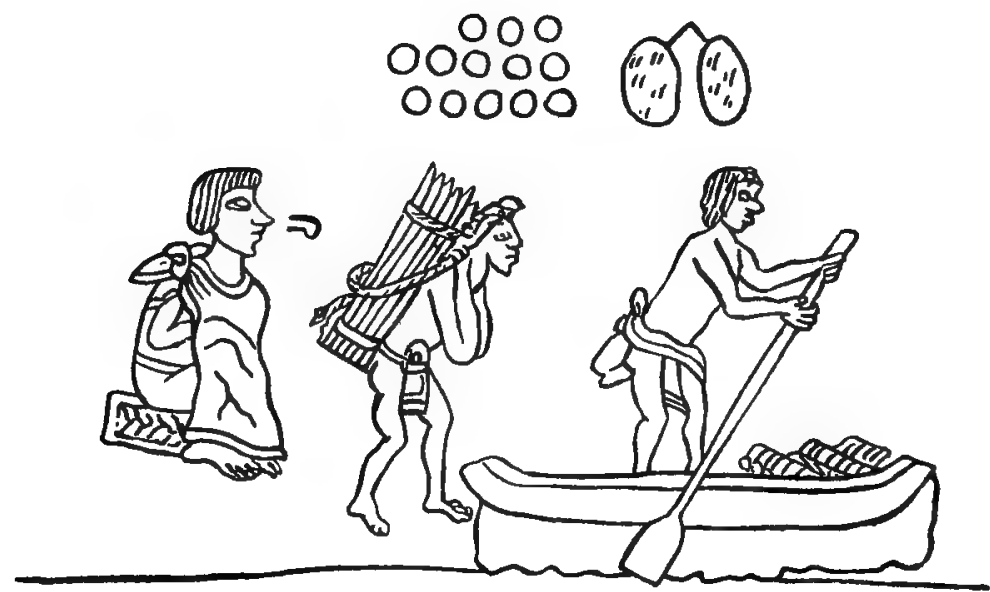

AZTEC BOATING.

From the Mendoza Codex, vol. i. pl.6r, fig. 3 .

But Mexico as a staff in our quest of priority breaks in our hands. The Museo Nacional a few years ago contained nothing of prehistoric fishing interest except perhaps a notched stone sinker. Greater disappointment still, the wealth of ancient Maya information from the monuments of Merida yields us sometimes fish, but never fishing scenes. ${ }^{1}$

From ancient Peru I had hoped help, but neither the four

1 From a letter from the representative in Mexico of the Smithsonian Institute, who adds: "My belief is that the Mayas used the Spear, the Net, and the Bow and Arrow. That is all I can give you at present: should anything else turn up. I will let you know." In $A$ Study of Maya Avt, an elaborate work by Herbert J. Spinder (Peabody Museum Memoirs, Harvard University, I9I3), I have failed to find any fishing scenes or any ancient fishing implements depicted. 
massive tomes of Ancient Peruvian Art by A. Baessler, nor The Fish in Peruvian Art by Charles W. Mead vouchsafe it.

To the absence among the ancient Peruvians of any written language Mead attributes the very early arrival of conventionalism in art. In consequence of conventionalism, fish at the period reached are merely rendered as various designs, notably that of the "interlocked fishes," i.e. a pattern of parts of two fish turned in opposite directions, a curious example of which may be found in Mead, Plate I. fig. 9. The mythological monster, part fish part man, in Plate II. fig. I3, compares and contrasts with similar Assyrian representations.

The tomes of The Necropolis of Ancon fail also to aid us. Among the hundreds of objects of Inca civilization depicted, nothing piscatorial, except some copper fishing hooks and a few spears, comes to view.1 Joyce, however, gives a fishing scene depicted on a pot from the Truxillo district of the coast, which the author dates pre-Inca, or anywhere between 200 B.C. and A.D. ${ }^{2}$

From his book emerge two interesting points of comparative mythology. The first-which compares with Assyrian and other similar legends 3 -the tradition that culture was first brought to Ecuador by men of great stature coming from the sea, who lived by fishing with nets; the second-which compares with the Egyptian practice-the custom among certain primitive coast tribes of placing provisions, among which were fish, in the graves of the dead. ${ }^{4}$

Other races of the world present many points of similarity to the French cave men. The Bushmen of Africa, and the Bushmen of Australia, inter alios, exemplify this. Banfield, in dealing with the drawings or so-called frescoes of men, animals, and fish on Dunk Island, vouches for the latter as " of talent,

1 Baessler translated by A. H. Keane (Asher \& Co.), London, 1902-3. Mead's monograph is in the Putnam Anniversary Volume, New York, I9o9. The Necropolis of Ancon, by Reiss and Stübel, translated by A. H. Keane, Berlin, I880-87.

12 T. A. Joyce, South American Archaology, London, I9I2, p. 126.

s See infra, p. 37 I.

- Indian Notes and Monographs, published by the Heye Foundation, New York, 1919, p. 56, show in the tombs of Cayuga fish-hooks, harpoons, and fish-bones, "most of which objects are unique or unusual as grave finds." 
original and academic. Here is the sheer beginning, the spontaneous germ of art, the labourings of a savage soul controlled by wilful æsthetic emotions." 1

This review of the fishing weapons and methods of the races cited-especially of the Eskimos and the Tasmanians, the races closest to the Troglodytes-provides data which make for a plausible conjecture, but none, owing to differing conditions caused by climate or custom, which enable a definite decision as to priority of implement.

Let us return from this survey of races to the cavernes and examine their contents. ${ }^{2}$ Their débris (at times ten feet deep and seventy long) manifests that these stations served as habitations for several generations of men.

From nearly all the French stations neighbouring the sea or rivers, bones of fish, especially of salmon, have been recovered. These have been identified, but not without some dissent, as belonging to the Tunny, Labrax lupus, Eel, Carp, Barbel, Trout, and Esox lucius.

The presence of the last, our pike, in this (and again in Neolithic) débris excites our interest as evidence that the Troglodytes knew and made use of a fish whose absence, despite its wide geographical distribution, from all Greek and Latin literature until we reach the time of Ausonius, Cuvier, or more strictly Valenciennes, notes with extreme surprise. ${ }^{3}$

While in La Madelaine and elsewhere fish occur abundantly in the débris, at some cavernes in the Vézère Valley, notably Le Moustier, they cannot be traced. Their absence coupled with the presence of animal bones has led some archæologists to the conclusion that Le Moustier and other stations were earlier inhabited than La Madelaine, at a time, in fact, when according to Paul Broca, "Man hunted the smaller animals as

1 E. J. Banfield, Confessions of a Beachcomber, London, I9I3.

2 For descriptions of Palæolithic life, see Worthington G. Smith, Man the Primal Sauage, London, I894, and J. J. Atkinson, Primal Law, London, I903. For the community assumed by the former, Atkinson substitutes a family group.

s Cuvier and Valenciennes, Hist. Nat. des Poissons, vol. xvili. pp. 279-8o, Paris, 1846 . Since in this volume the geographical distribution of the pike, as known at the time, is set forth without any mention of Greece, it is rather difficult to understand the surprise of Valenciennes, who wrote the volume in question; Cuvier died in 1832 . 


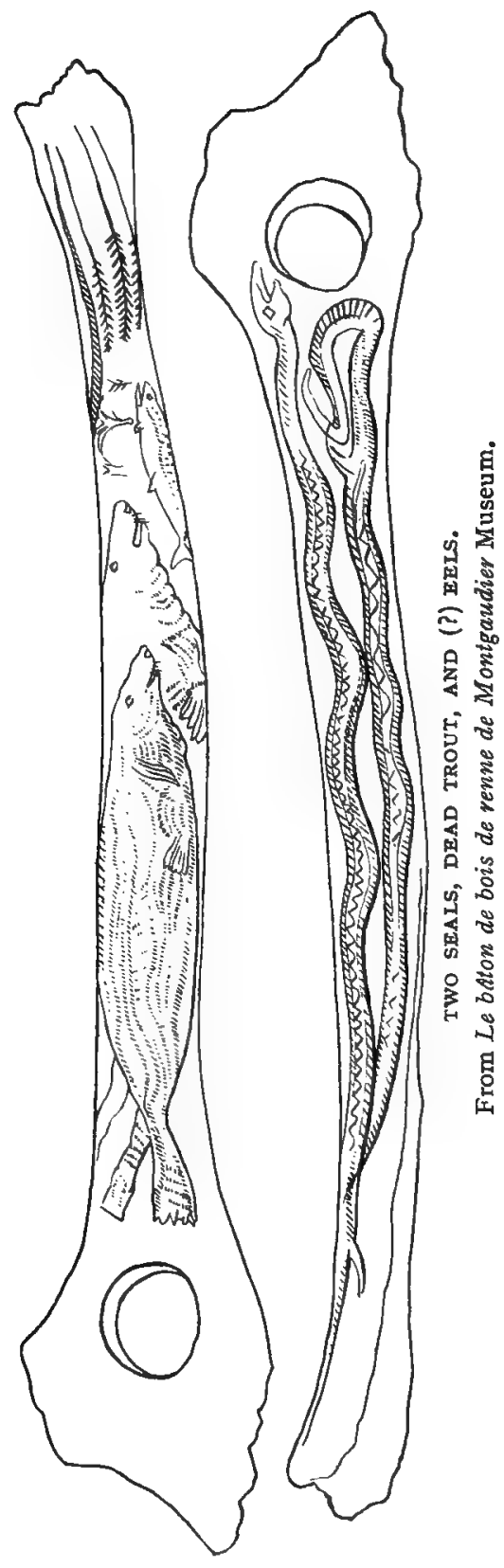

well as large game, but had not yet learned how to reach the fish."

In addition to osseous deposits, numerous ichthyic carvings and engravings on materials and weapons present themselves. It is curious, however, to note that (at any rate up to I9I5) of all the caves and grottoes two only, Pindal on the wall, and Niaux (the latest discovered French cave where black is the solitary colour employed) on the floor, furnish us with representations of fish on wall or floor.

These Old Stone Men not only observed closely, but portrayed the results of their observations with remarkable faithfulness. The reliefs of bisons mounted in clay and the effigies of women carved in ivory, the paintings of bisons instinct with life and movement, the figures of two seals (engraved on a bâton from Montgaudier) with a dead trout, l of another seal engraved on a drilled bear's tooth (from Duruthy), and of an otter

1 E. Cartailhac, La France Prehistorique, Paris, I889, p. 82, fig. 4I. 
with a fish incised on a reindeer antler from Laugerie-Basse, ${ }^{1}$ evoke the lively admiration of de Mortillet and Parkyn.

Such is their graphic truthfulness and attention to detail that, according to the former writer, the trout which the seals have killed floats, as dead fish do, belly up, and is not only perfectly characterised in general form, but is rendered with the spots on the top of the back dotted quite accurately. ${ }^{2}$ Not less admirable is the bas-relief of a fish in reindeer horn from Mas d'Azil, or of another pierced by a spear. ${ }^{3}$

The frequent engravings of animals and of fish prompt S. Reinach and others to the interesting surmise that since all or most portray creatures desired for food by hunters and fishermen, they were executed not for amusement, " mais sont les talismans de chasseurs qui craignent de manquer de gibier. L'objet des artistes a été d'exercer une attraction magique sur les animaux de la smême espece. Les indigènes de l'Australie Centrale peignent aussi sur les roches ou le sol des figures des animaux dans le but avoué d'en favoriser par la même raison, qui dans certaines campagnes fait qu'on évite de prononcer le nom du loup." 4

After pointing out that the representations of the Reindeer

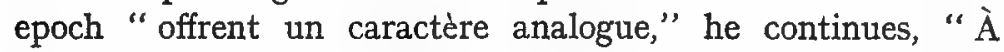
cette phase très ancienne d'evolution humaine la religion (au sens moderne de ce mot) n'existe pas encore, mais la magie

1 E. Cartailhac, Materiaux pour l'histoire de l'homme, xiii. p. 395. The Magdalenian workmanship on bone was extraordinarily fine. Their bone needles (according to de Mortillet) are much superior to those of the later. even of historical times, down to the Renaissance. The Romashs never possessed needles comparable with them.

2 G. de Mortillet, Origines de la Chasse et de la Pêche (Paris, x 89o), p. 222. Our learned author nods. If the seals had killed the trout, it would nòt have floated " belly up," but instantly down their bellies.

${ }^{3} \mathrm{~S}$. Reinach, Repertoire de l'Art Quaternaire (Paris, I9I3), p. $\mathrm{r}_{56}$, which is a complete summary of the various finds in excavations, etc. See p. 8 for a seal, and P. II 4 for a fine representation from Laugerie Basse of two fish meeting.

- Fishermen in Malay, while they are at sea, studiously avoid mentionlng the names of birds or beasts : all animals are called "cheweh," a meaningless word, which is believed not to be understood by the creatures (J. G. Fraze", The Golden Bough, second edition, 1900, vol. i. p. 460). So, too, fishermet from some villages on the N.E. coast of Scotland never pronounce, while at sea, under penalty of poor catches, certain words such as " minister," "salmon," " trout," "swine," etc. The first, poor fellow ! "que diable allait-il faire dans cette galere ?" is invariably referred to as "the man with the black "guyte" (Ibid., p. 453). 
joue un rôle considerable et s'associe à toutes les formes de l'activité." I

Magic, especially imitative magic, according to Frazer and others, plays a great part in the measures taken by the rude hunter or fisherman to secure an abundant supply of food.

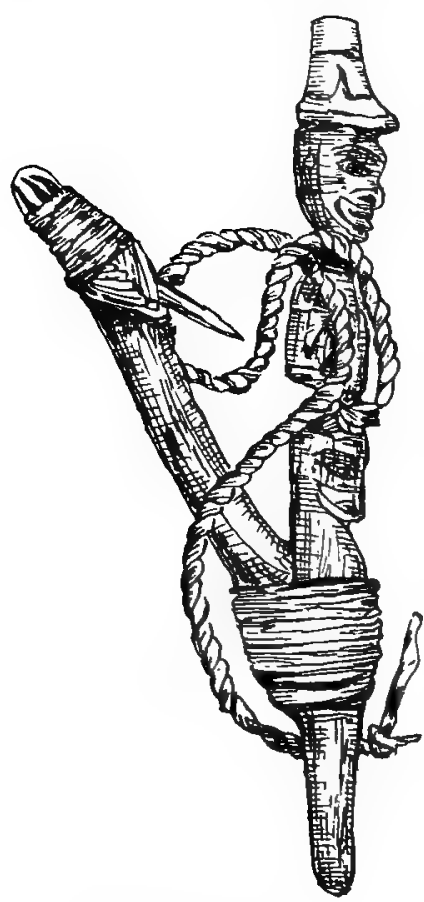

AN AIF SKAN HOOK WITH A

V IZARD'S HEAD.

From E. Krause's Voygeschichtliche Fischereigeräle, fig. 345.
On the principle that like produces like, many things are done by him or for him by his friends in deliberate imitation of the result sought.

Confirmatory evidence from races, past and present the world over, stands ready to call. The Point Barrow Eskimos, when following the whale, always carry a whale-shaped amulet of stone or wood. The North African fisherman of the present day, in obedience to an ancient Moslem work on Magic, fashions a tin image of the fish which he desires, inscribes it with four mystic letters, and fastens it to his line.

If at the due season fish fail to appear, the Nootka wizard constructs of wood ${ }^{2}$ a fish swimming, and launches it in the direction whence the schools generally arrive. This simulacrum, plus incantations, compels the laggards in no time. ${ }^{3}$

In Cambodia, if a netsman be unsuccessful, he strips naked and withdraws a short distaruce : then strolling up to the net, as if he saw it not, he lets himself be caught in the meshes, whereupon he calls

1 Acad. des Sciences, Paris, séance du 22 juin, Igo3.

2 The pictured hook is of special interest. The head, considered by Krause that of a wizard, was intended to endow the hook with an extra power of magic.

${ }^{3}$ F. Boaz, 6th Report on N.W. Tribes of Canada, p. 45. 
out, "What is this? I fear I am caught." Such procedure is believed to attract the fish efficaciously and to ensure a good haul. ${ }^{1}$

Scotland not a century ago witnessed pantomimes of similar character, according to the Rev. J. Macdonald, minister of Reay. Fishermen, when dogged by ill luck, threw one of their number overboard and then hauled him out of the water, exactly as if he were a fish. This Jonah-like ruse apparently induced appetite, for " soon after trout, or sillock, would begin to nibble."

The comparative ethnologist detects in all these cases an attempt to establish direct relations between the hunter or the fisher and bis quarry. Primitive man in search for food frequently seeks to establish an impalpable but in his eyes very serviceable connection between himself and the object of his quest by working a likeness of his desired prey.

Such a likeness, according to the doctrine that a simulacrum is actively en rapport with that which it represents, bestows on its possessor power over the original- "l'auteur ou le possesseur d'une image peut influencer ce qu'elle représente." 2 The cases are simply the commonplaces of homœpathic or

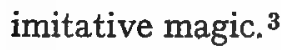

We find that just as the savage attempts to appease the ghosts of men he has slain, so he essays to propitiate the spirits of the animals and fish he has killed: for this purpose elaborate ceremonies of propitiation are widely observed. 4 Of similar character and intent are the taboos observed by fishermen before the season opens, and the purifications performed on returning with their booty.

Magic, exercised not so much to propitiate as to avoid offending some power-in the following instance the element of water-originated the rule (existent among the Eskimos fifty years ago) that forbade during the salmon season any Ibid.

1 E. Aymonier, Cochinchene Françoise, No. 16, p. 157, as quoted by Frazer.

2 S. Reinach, L'Anthropologie (1903), p. 257.

s Such is the solution which Bates (Ancient Egyptian Fishing, 19r7, p. 205) offers of the presence in the pre-dynastic Egyptian graves of the numerous slate palettes bearing the profile of a fish or beast.

- Frazer, Golden Bough. Taboo, Part ii. (London, IgI I), p. IgI ff. 
water being boiled in a house, because "this is bad for the fishing." Frazer suggests that the Commandment in Exodus xxxiv. 26, "Not to seethe a kid in its mother's milk," embodies a like illustration. 1

From carvings, whether executed for purposes of amusement or of magic, and from specimens found in the débris of the stations, we derive our knowledge of the earliest implements and methods employed in Perigord and elsewhere for taking fish.

A study of these warrants, to my mind, the conclusion that only two weapons can be traceably attributed to Palæolithic Man. First and pre-eminent the Spear (or Harpoon with its various congeners) with possibly adjustable flint-heads, and second, but to a far less extent, the Gorge, or as it has been better termed, "the bait-holder."

Of a Troglodyte Net no representation exists, no specimen survives. The absence of an actual specimen can perhaps be explained by the perishable nature of the fibres or wythes used for its construction.

The undeniable survival of pieces of Nets among the lake dwellers seems somewhat to negative the explanation. ${ }^{2}$ But these may have survived because of the presence, while those of the Palæolithic Age may have perished because of the absence of some preservative power in the substance in which they were embedded.

The absence from the latter and the presence in the former débris of Net sinkers, etc., strongly, if not conclusively, corroborate Broca's conclusion that the Cave men of the Vézère Valley and elsewhere were strangers to the Net.

We possess, in my opinion, no evidence of Hooks (as

1 W. H. Dall, "Social Life among the Aborigines," The American Naturalist (1878), vol, xii. J. G. Frazer, Folk Love in the Old Testament (London, I9I8), vol. iii. P. 123.

" See Dr. F. Keller's The Lake Dwellers in Switzerland (translated, London, I878, by John Edward Lee), vol. ii. pl. 136, fig. 2. This net of cord with meshes not quite three-eighths of an inch in width was almost certainly made, it was certainly well suited, for fishing. Another example with meshes two inches wide, probably formed part of a hunting net. $R$. Munro, The Lake Dwellings of Europe (London, I89o), p. 504, mentions fishing-nets from Robenhausen and Vinetz-both belonging to the late Neolithic Age. 0 . Schrader, Reallexikon der indogermanischen Altertumskunde (Strassburg, rgor), p. $24^{2}$, records " remains of nets" in the Stone Age settlements of Denmark and Sweden, which he classes as fishing nets. 
distinct from Gorges) or of anything resembling Hooks properviz. hooks made out of one piece, recurved, and with sharpened ends-being used by the Old Stone Man.

De Mortillet, it is true, writing in 1867,1 states that " hooks belonging to the reindeer epoch have been found in the Caves of Dordogne. Along with those of the simple form (the gorges) others were met with of much more perfect shape." In his later work (op. cit.) of 1890 he contents himself with claiming the existence of a hook, but of very primitive type, " a small piece of bone tapered at either end "-in fact, nothing more than the Gorge. ${ }^{2}$

S. Reinach, again, instances " three fish-hooks," but whittles them away till they become " two sharp points more in the nature of a gorge." 3 Osborne, commenting on the numerous pigmy flints discovered in the Tardenoisian débris, writes that "it would appear that a large number of these were adapted for insertion in small harpoons, or that those of the grooved form might even have been used as fish-hooks." 4 With the opinion of Christy (co-explorer with Lartet of La Madelaine) that those pointed bone rods or gorges " may have formed part of fish-hooks, having been tied to other bones or sticks obliquely," 5 the evidence in favour of the Hook practically finishes.

The case, I venture to maintain, breaks down. And this, too, in spite of the view expressed and the evidence adduced by so eminent an authority as Abbé $\mathrm{H}$. Breuil, and in spite of the gravure de Fontarnaud figurant un poisson mordant (?)-the

1 Les Origines de la Pêche et de la Navigation, Paris.

2 An excellent monograph, with hundreds of illustrations, by $E$. Krause ("Vorgeschichtliche Fischereigeräte und Neuere Vergleichsstüche") contained in the magazine, Zeitschrift für Fischerei, xi. Band 3/4 Heft (Berlin, I904), p. 208, states that hooks of the Stone Age are numerous, but unfortunately he does not discriminate between the Old and New Stone Ages. Palæolithic finds mention but once in his 176 pages.

S Types de la Madelaine, p. 222, fig. 78.

- H. J. Osborne, The Men of the Stone Age (1915), p. 465.

- Reliquice Aquitanice (London, I875), ii. p. 58. Christy's solitary buttress for his opinion is a reference to " a Nootka Sound fishing implement," which is identical (according to Rau, fig. 9) with a hook described in Mr. J. G. Swan's The Indians of Cape Flattery, as used by the Makahs solely (and successfully) for the halibut, because "its mouth is vertical, instead of horizontal, like most fish." The absence of halibut from debris or repre. sentations scarcely strengthens Christy's opinion. 
query is Breuil's-d l'hameçon. The gravure fails to convince, chiefly because les hameçons figured do not recurve in the proper sense. They seem to be more in the nature of gorges curved back and much improved in the course of generations. ${ }^{1}$

The evolution of the primitive gorge, in particular those with ends slightly curved, into a double fish-hook was, I suggest, probably an easy process, more especially with the discovery of the adaptability of bronze. But these gorges

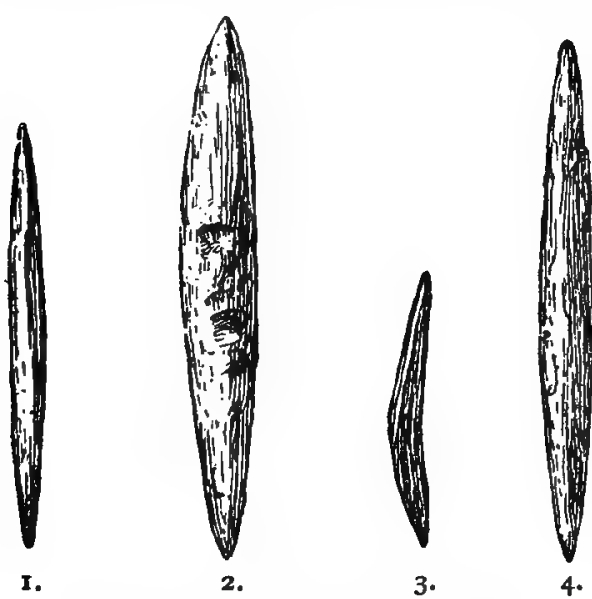

BONE GORGE OR BAITHOLDERS,

1. From La Madelaine. 2. From La Madelaine, grooved for attaching the line. 3 and 4 . From Santa Cruz, California. The slight curving of 3 may be possibly the first step towards the more rounded gorge, and eventually the bent hook.

suffice for what was required. Thus farther curve might be added for this ostensible purpose, with the result that in

1 L'Anthropologie, tome xix. pp. 184-19o, especially p. 187, where the author attempts une reconstitution hypothetique de la façon, dont cette interprétation admise, on pourrait confevoir la fixation de ces "hamepons." The inverted commas do not suggest confidence.

2 If both the ends of the gorge were as much bent up as a hook, the tendency would be for the gorge, when its points got fast, to be rotated by the pull on the line and to assume, owing to greater curvature, a bent-back position, which would allow of its easy withdrawal and defeat the object-the capture of the fish. Some Santa Cruz gorges are of an angular type, but with the points turned somewhat down. The double hook of bronze or copper, e.g. of Ancient Peru, seems to support my suggestion of gorge evolution, although, fair to add, it was suspended from the centre. 
time the hook supersedes the gorge, to which it is superior in several respects, not least in ease and speed of extraction from a fish when landed.

Small bone rods tapering towards both ends, and sometimes frooved in the middle probably for attachment of a line, form the gorges of the Caves. Their descendants or kinsmen found all the world over vary in shape and material. But whether fashioned of bone, or flake of flint, or of turtle-shell, with cocoa nut used as trimmers, whether straight or curved at the ends, the purpose and operation of one and all is the same-to be swallowed (buried in bait) by the fish end first. The tightening of the line soon alters this position into one crosswise in the stomach or gullet. Even at the present time in some parts of England the needle, buried in a worm when "sniggling" for eels, works successfully in similar fashion.

It is not possible here to discuss fully the various materials and shapes of the first Hook proper. This (according to my view) Neolithic, certainly post-Palæolithic, ${ }^{1}$ creation developed doubtless from the over-education of fish, a complaint possibly as rife then as in our own day.

No writer, despite zealous endeavours, has sueceeded in determining which material-stone (rarely found), bone, shell, or thorn 2-was first employed for the purpose. On that which lay readiest would probably be essayed the prentice hand of each particular race. To dwellers near the shore the large supply and easy adaptability of shells would of a surety appeal. These could be fashioned so as to be used alone, or lashed with fibre to a piece of wood or bone so as to form the bend, while the wood or bone constituted the shank of the hook. ${ }^{3}$

1 Sanchouniathon, as translated by Philo of Byblus, ap. Euseb., Praep. Ev. i. Io, 9 , in what purports to be a Phonician account, would bring the invention right down to the Iron Age. "Many generations later Agreus and Halieus sprang from the stock of Hypsouranios. They were the discoverers of hunting and fishing, hunters and fishers being called after them. From these in turn sprang two brothers, inventors of iron and iron-working. One of these brothers, Chrysor, practised spells and charms and oracles. He is Hephaistos, and he it is who invented hook and bait and line and boat, being the first of all men to set sail. Wherefore also they worshipped him as a god after his death, and named him Zeus Meilichios."

$2 \mathrm{E}$. Krause, op. cit., 208, holds that the most primitive hook was made of wood: bind a thorn or sprig crossways and your hook is to hand.

${ }^{8} \mathrm{H}$. T. Sheringham holds that both early and recent specimens of Fijian 
Prehistoric Man often with a limited local supply was driven to adopt and adapt any material which could be forced into his purpose of a hook. To this cause has been ascribed one of the most extraordinary hooks on record. This relic, now in the Berlin Museum, of the lacustrine dwellers is formed out of the upper mandible of an eagle, notched down to the base.

But the mostinteresting natural fish-hook known to me (found in Goodenough Island, New Guinea) is the thick upper joint of the hind leg of an insect, Eurycantha latro, furnished, however, only by the male, who is endowed with the long, stout recurved spur, suitable for fishing, The leg joints and therefore the hooks got from them (about I $\frac{5}{8}$ inches long) are supplied ready made by Nature : they merely require to be fastened to a tapered snood of twisted vegetable matter for immediate employment. 1

Where flints, shells, and horn were absent or, if present, were not turned to account, an abundance of thorns with bend and point ready made and with proved capacities of piercing and holding would attract the notice and serve the purpose of the New Stone Man. Such later on was the case in Babylon and Israel (in both of which countries the primary sense of the word equalling hook seems, according to some authorities,

hooks bear out this view (Ency. Brit., ed. xi., s.v. "Angling "). "The progressive order of hooks used by the Indians or their predecessors in title in North America was, after the simple device of attaching the bait to the end of a fibrous line, (I) a gorge, a spike of wood or bone, sharpened at both ends and fastened at its middle to a line ; (2) a spike set obliquely in the end of a pliant shaft: (3) a plain hook; (4) a barbed hook ; (5) a barbed hook combined with sinker and lure. This series does not exactly represent stages of invention: the evolution may have been affected by the habits of the different species of fish or their increasing wariness. The above progressive order applies, I believe, on the whole all over the world, if due allowance be made for varying conditions" (Smithsonian Handbook of American Indians (Washington), p. 460).

1 See Man, Feb., 1915, "Note on the new kind of Fish-hook," by Henry Balfour. The illustration is reproduced by the kind permission of $\mathrm{Mr}$. $\mathrm{H}$. Balfour and the Royal Anthropological Institute.

Another notable hook is one of wood about four inches long with a claw (said to be that of a bird) attached, which Vancouver collected on his voyage in N.W. American waters (see Ethnographical Coll. at Brit. Mus.). The whalebone in this must not be mistaken for anything else but a snood. For the ingenious derivation of certain hooks in some South Sea Islands from their similarity to the bones of common fish, e.g. Cod and Haddock, see T. McKenny Hughes, in Archaol. Jour., vol. 58, No. 230, pp. I99-2I3. See also J. G. Wood, Nature's Teaching (London, 1877), pp. I $1_{5}-6$, on the point. 


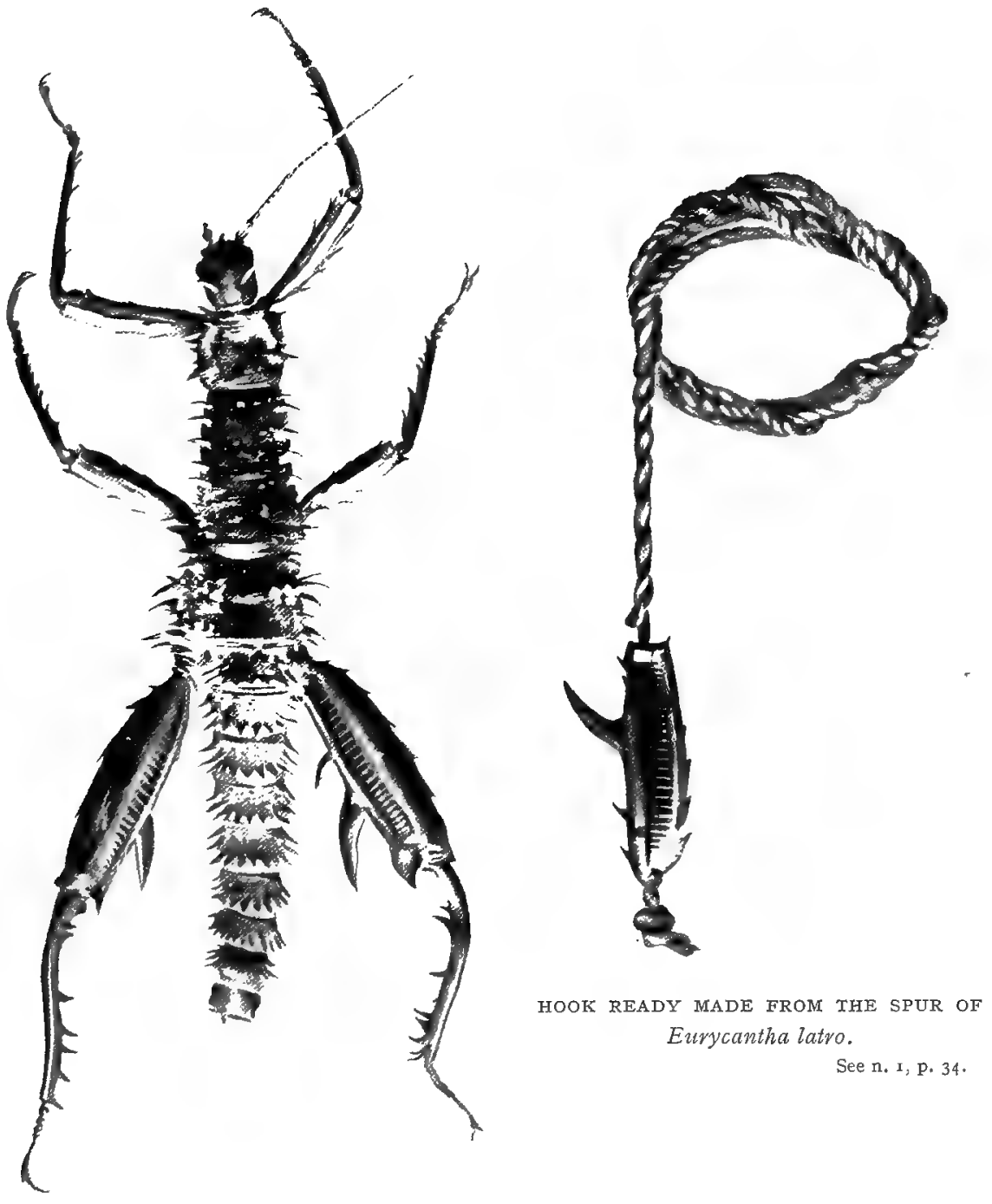

THE Eurycantha latro.

See n. 1, p. 34 . 

to have been thorn 1 ), and is the case even now with our fishermen in Essex and the Mohave Indians in Arizona. ${ }^{2}$

The suggestion that the choice of material was generally prompted by abundance or proximity of supply seems reasonable. But it must not be pushed as far as the assumption (of which a glance at the evidence as to material adduced by Joyce detects the absurdity) that, because gold was very abundant in Columbia and because gold fish-hooks have been unearthed in Cauca and elsewhere, the primitive angler of that country employed gold as the chief constituent of his hook ! ${ }^{3}$

Nor, again, is it possible for me to dwell on the evolution or in some countries the possible pari passu development of the single into the double hook (mentioned in England first in The Experienc'd Angler of Venables, I676), nor yet to trace the various stages by which the simple bone or tusk hook of Wangen or Moosseedorf blossomed out into the barbed metal hook of the Copper Age. ${ }^{4}$

The Spear-Harpoon and some points of reindeer horn alone remain for consideration. Opinion is divided as to the nature

1 See infra, p. 357.

2 My own Mohave Rod is of 'ihora, the red willow of that district, barked and straightened by an ingenious Indian method. The line is of the prepared bast of 'ido, another species of willow, and the hook of barrel cactus thorn. Hooks made out of Echinocactus wislizeni are better adapted for fish which do not nibble at the bait, but bolt it hook and all; for this reason the Indians fasten the bait below the hook (E. Palmer, "Fish-hooks of the Mohave Indians," Amerian Naturalist, vol. xii. p. 403). On the north-west coast the Indians a generation ago invariably used spruce-wood for their halibut hooks (Rau, p. 139). Some Maori hooks are of human bone and pawa, with kiwi feathers.

a I do not think that these gold hooks were a unit of currency, as the lari of the Persian Gulf were, according to W. Ridgeway, The Origin of Metallic Currency, etc. (Cambridge), r892, p. 276.

This gold hook must not be confounded with the silver hook not infrequently employed in the remoter districts of Great Britain by certain anglers, who in their anxiety to avoid being greeted with Martial's " ecce redit sporta piscator inani," cross with silver the palm of more fortunate brethren, and

\section{"Take with high erected comb \\ The fish, or else the story, home \\ And cook it."}

- See R. Munro's Lake Dwellings of Europe, pp. 127, 499, 509. Flinders Petrie, Tools and Weapons (London, I9I 7 ), p. $37 \mathrm{f}$, has a section on fish-hooks with good illustrations, pl. 44 , figs. $61-87$, pl. 43 , figs. $59,60,88-102$. "Considering how much the Lake-dwellers relied upon fishing, the moderate number of hooks found points to their depending more on nets. The few copied here, 88-94, are merely rounded, without any peculiar form." 
and use of these points. Some pronounce them mere arrow heads. 1

Against this view leans the fact that, while they have been recovered mainly from the French caves, no real proof as yet exists of Palæolithic Man north of the Pyrenees being acquainted with the bow. Paintings discovered in I9ro at Alpera in the south-east of Spain show, however, men carrying and drawing bows, and arrows with barbed points and feathered shafts, but no quivers. Northern Man, if he did not paint, may well have employed, arrows, for hunting scenes, in which they should figure, as at Minatada and Alpera, are wanting in France.

Other writers maintain that these points were the armatures of hunting spears, others, arguing from their easy detachment, that they were the heads of fish-spears or harpoons. But this contrivance seems far too complicated for our primitive piscator. No writer proves conclusively what was the exact purpose of these points, or whether, in fact, the fishspears or harpoons had detachable heads. E. Krause suggests that as the earliest fish-spears were of wood, they readily lost or broke their points when striking rocks, etc.; hence came bone and then flint points. ${ }^{2}$

The Spear-Harpoon stands out as the one fishing weapon whose existence is undeniable, whose employment is predominant. It is too world-wide and too well-known to need lengthy description.

Reindeer-horn supplied in general the material of the earlier heads, stag-horn of the later. ${ }^{3}$ The heads tapered (like Eskimo and other harpoon heads) to a point and were barbed (as the two accompanying illustrations indicate) on both sides. They have sometimes toward the lower end little eminences or knobs, and sometimes barbs provided with incisions or grooves, which some surmise held poison.

1 Many of the Solutréan tanged blades and pointes d cran are small enough to suggest their use as arrow-heads, and Rutot has described tanged and barbed "arrowheads" from Palæolithic deposits in Belgium.

2 Op. cit., p. 160. But why? Flint points break quicker than wood.

3 See Julie Schlemm, Wörterbuch zur Vorgeschichte (Berlin, I908), pp. 555-7. The immediate successors of the single spear were probably the bident and trident. Owing to the refraction of light and other reasons a spear is difficult of accurate direction, but the broader surface of the trident helps to lessen the factor of error. 
The Harpoon makes its appearance in the middle or (according to Osborne) early Magdalenian deposits. Its crudest form shows a short, straight piece of bone, deeply grooved on one face,

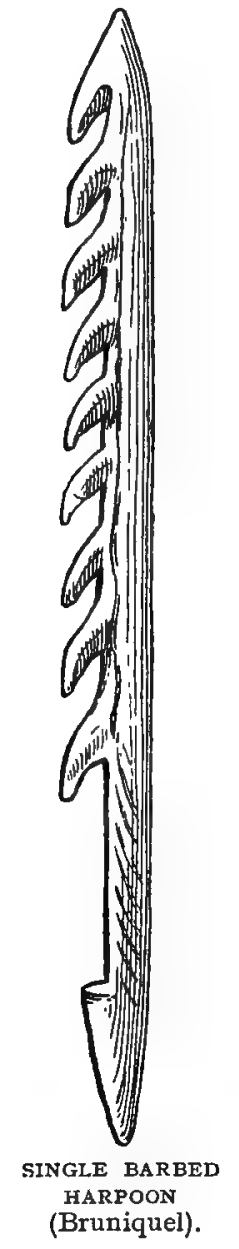

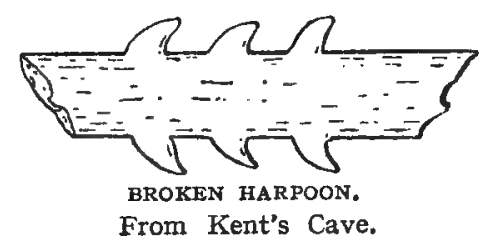

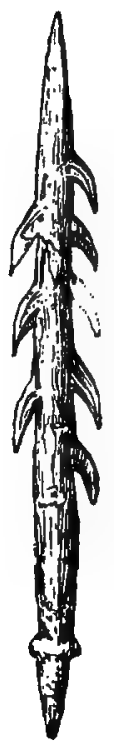

DOUBLE BARBED REINDEER HARPOON (La Madelaine).

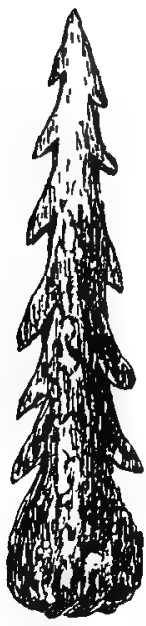

DOTIBLE BARBED HARPOON. Neolithic.

From Sutz, Switzerland. Observe the hole for attaching the line.

the ridges and notches along one edge being the only indications of what later developed into the recurved barbed points of the typical Harpoon. These barbs or points, retroverted in such a manner as to hold their place in the flesh of the fish, do not 
suddenly appear like an inventive mutation, but very slowly evolve as their usefulness is demonstrated by practice.

The shaft is very rarely perforated at the base for the attachment of a line 1 ; it is cylindrical (later flat) in form adapted to the capture of large fish in streams. The harpoons may possibly have been projected by means of the so-called propulseurs or dart throwers, which resemble the Eskimo and Australian implements of to-day.

Amidst the clash of opinion as to the exact use and method of use of these weapons, my conclusion, admitttedly incapable of absolute proof, holds that the Palæolithic fisher owes to the hunter the inception of the chief weapon of his equipment, the Spear-Harpoon.

Paul Broca's dictum ${ }^{2}$ that Man hunted before he fished seems, perhaps, despite Dall's excavation of Eskimo débris, ${ }^{3}$ to be borne out by Troglodyte records both positive and negative. The Gorge or bait-holder was employed by the hunter (according to some) even earlier than by the fisher. Gorges have been from time immemorial and still are in vogue in the Untersee for the capture of marine birds, as is the case to-day with the Eskimos of Norton Sound.

From the chronicles of Rau, H. Philips, and others can be built a Table of Generations, or the story of how the Hunting Spear begat the Fishing Spear, which begat the Harpoon unilaterally barbed, which in turn begat the Harpoon bilaterally barbed, until about the tenth or twentieth generation -one is appalled at the amount of Succession Duty which such

1 H. J. Osborne (op. cit., p. $3^{8} 5 \mathrm{ff}$.) states that, with the exception of one half-finished hole in a Harpoon from La Madelaine, the side hole for the attachment of the thong to the Harpoon does not appear in the French Magdalenian Harpoon, although in those from Cantabria it is nearly always present. The Azilian weapon usually bears a hole.

${ }^{2}$ The Troglodytes of the Vezere Valley. Smithsonian Report, I872, p. 95.

s In Contributions to North American Ethnology, 1877, i. p. 43, Dall states that the debris of the heaps show tolerably uniform division into three stages, characterised by the food which formed the staple of subsistence and by the weapons for obtaining as well as the utensils for preparing the food. The stages are: Ist, The Littoral period, represented by the Echinus layer; 2nd, The Fishing period, represented by the Fish-bone layer; 3rd, The Hunting period, represented by the Mammalian layer. This antecedence of fishing before hunting, if Dall be correct, was, I imagine, caused probably by local or climatic conditions in the Arctic Circle; it is not the general rule elsewhere. 
degrees of descent would now involve!-something begat the Rod.

From this genealogical table I venture to dissent. I claim that the hunting Spear, Protean in possibilities, was either itself the Rod, or was, if " matre pulchra filia pulchrior" do not apply, at least the direct parent of the primitive Rod. In the bigger hunting of our own sorrowful day the same principle manifests itself, for the British soldier in France often angled with his line attached to his bayoneted rifle.

Many writers have attempted, some like de Mortillet with typical French logic, some with none, to set down the sequential development of fishing. As the Censor has not as yet banned free expression of piscatorial opinions, I conclude this chapter with essaying a scheme of reconstruction of my own.

First came fishing with the hand, la pêche à la main, which, according to Abel Hovelacque, "est le mode le plus élémentaire et certainement le moins productif." 1 This method we may surmise was first exercised on fish left half stranded in small pools by the action of tides or floods, or on fish spawning in the shallow redds. ${ }^{2}$

As la pêche da la main was the first to arrive, so was it the first to cease from the functions of parentage or of fission, for with " tickling," described by Elian as even in his day an ancient device, further evolution of this method practically ended. ${ }^{3}$

Second came the hunting Spear, used originally on fish lying in pools, small of size but of depth sufficient to prevent

1 Les Debuts de l'humanite, etc. (Paris, 1881), p. 69. E. Krause, op. cit., p. 153, agrees.

"Apes know how to get oysters thrown up on the shore, but man has been endowed with the knowledge how to get them in and out of the sea." The sentiment, if not the style, of this sentence-to prove the superior design and creation of man over the animal creation-seems not quite unworthy of Izaak Walton's pages.

"His pleasant description of "tickling" and his " viro Britanno" must be my excuse for introducing a writer in Latin so late after my limit of 500 A.D. as Parthenius, better known as Giannettasi, the author of Halieutica, pub. lished at Naples in 1689 :

" Paulatim digitis piscator molliter alvum Defricat, et sensim palpando repit in ipsas

Cæruleas branchas, subituque apprendit: et illa Blanditiis decepta viro fit praeda Britanno." 
hand fishing, and then, later, on fish elsewhere in a river. On the latter, especially in the case of the salmon-in Pliny's day still abundant in Aquitania, which comprised the Loire and many Palæolithic cavernes - the weapon, even if as bident or trident it had added unto itself a prong or two, would frequently be found ineffective, owing to lack of prehensility. Hence came about a modification, perhaps due either to the happy chance of a spear on which a point or thorn had inadvertently been left, or to the inventive faculty of some Troglodyte Hardy.

We later reach a Spear Harpoon with barbs on one side only, whence " line upon line," or rather barb upon barb, we attain unto the later type, which had a barbed head so socketed as to come free from the shaft (when the quarry has been struck) but made fast to the head by a line for retrieving the fish. In due, if differing, gradation we ultimately attain either unto the existing device of the aboriginal Tsuy Hwan of Formosa, an arrow shaped like a trident shot from but attached to a bow, or unto le dernier cri, our whaling Harpoon shot from a gun. ${ }^{1}$

Third comes fishing with a line of some sort. This was devised doubtless by some hungry but perforce merely meditative Magdalenian observing how dropped morsels were seized by fish in a pool, whose depth or environment set at naught both his hand and his spear.

The problem how to reach and how to land them was eventually solved by the method-happily christened by Sheringham, "Entanglement by Appetite" - of fastening a gorge through or a thorn holding some kind of bait to an animal sinew, a wythe, or a hardened thong of one of the whip-like alge. This wythe or what not in the procession of the ages was (according to Pepys) to betaper itself into the first English catgut line of 1667 , and (according to The Compleat Fisherman,

1 For a similar use of bow and harpoon arrow by the Bororo tribes in the Amazon valley, see W. A. Cork, Through the Wilderness of Brazil, p. 380. Our gaff, a descendant, possibly, of the unilaterally one-barbed spear, seems possessed of perpetual youth. The first description of its use in Angling in England occurs, according to Mr. Marston (Walton and the Earlier Fishing Writers (1898), p. 97), in T. Barker's $A r t$ of Angling (1651), but according to Dr. Turrell, op. cit., pp. 85 and 91, only in Barker's 2nd of I657, " a good large landing hook." From the definition, however, by Blount, Glossage, in I657, "Gaffe, an iron wherewith seamen pull great Fishes into their ships," its previous existence and employment at sea can be deduced. 
London, I724) into the first silkworm line, and eventually into telerana and similar tenuities of our day.

"Entanglement by Appetite," of which a primitive form exists among the Fuegians, 1 did literally "line upon line," almost wythe upon wythe multiply its seed, if not quite like the sand of the sea, yet freely. Proofs of this fecundity exist in the varying and world-wide forms of its issue. A strong family likeness enables us roughly to divide these descendants into two classes.

The first (A) where (to quote our leading law case) " the human element" is absent, as in night lining, or in " trimmering," or in its distant and nowadays probably illegal connection, the method of live-baiting for pike with the aid of a goose or a duck, as set forth by $T$. Barker with his customary gusto. ${ }^{2}$

The second (B) where "the human element" is present, as in hand-lining and in its very latest descendant, invented for " big game fishing " off Santa Catalina, viz. a line attached to a kite, which device secures the required "skittering" along the surface and from wave to wave of the flying fish-bait. ${ }^{3}$

1 There is no hook; only a piece of whalebone or a stem of sea-weed, with a feather stuck at the end, attached to which is a running knot, which holds the bait. As soon as the fish has swallowed feather and bait, the women, for the men disdain fishing, draw it to the surface and quickly seize it. Cf. Darwin, Jour. of Researches, etc., during the Voyage of H.M.S. Beagle (London, I860), ch. x, p. 213 .

2 "The principall sport to take a Pike is to take a Goose or Gander or Duck, take one of the Pike Lines as I have showed you before; tye the line under the left wing and over the right wing, and about the bodie as a man weareth his belt; turne the Goose off into a Pond where Pikes are ; there is no doubt of sport with much pleasure betwixt the Goose and the Pike. It is the greatest pleasure that a noble Gentleman in Shropshire doth give his friends for entertainment. There is no question among all this fishing but we shall take a brace of good Pikes."

- For a full description of this method, see Sport on Land and Water, by F. G. Griswold, privately printed (New York, I916), and The Game Fishes of the World, by C. F. Holder (London, Igr3). To the kite, which is of the ordinary 28-inch type, is allowed 700 feet of old fishing line from off a reel ; the fisherman's line is tied to the kite about 20 feet from the bait with a piece of cotton twine. When a Tuna fish takes the bait the cotton line breaks, and the kite is either reeled in or falls into the sea. The Santa Catalina fishing, with its records of enormous Tuna, of Sword fish (the largest $463 \mathrm{lbs}$.), sometimes fighting for $\mathrm{I}_{4}$ hours, sounding 48 times, and leading the launch for a distance of 29 miles, and of Giant Bass weighing 493 lbs., fills a British angler with envious despair, a despair which is heightened when one reads that the regulation tackle prescribed by the Tuna Club is, or was not long ago, a sixteen ounce Rod and a line not over No. 24! In Mr. Zane Grey's enthralling 
Even this very up-to-date device is no new invention. In the Malayan Archipelago and many Melanesian islands a kite has long been employed, sometimes as in the Solomon group, with a hookless bait of a spider's web, which, as wool with eels, gets itself firmly entangled in the small teeth of the Gar fish."

Next arose, as snags and obnoxious branches in primitive days abounded, and water bailiffs did not, the further crux, not quite unknown even to-day, how to get the bait over the intervening obstacles which the mere hand line was incapable of clearing, or how to obtain the length necessary to place the bait properly before the fish. ${ }^{2}$

The difficulty was in time overcome by attaching the tackle, wythe, gorge, and bait to the hunting Spear. It is at this stage I claim that the hunting Spear with wythe, gorge, and bait so attached became, in fact for all purposes was, the original pole, or at any rate was the immediate sire by a more springy sapling of what in the procession of the ages was to attain unto the "tremendous," if at times unmastered, " majesty" of our modern Rod.

Last of all, I suggest, though the evidence is conflicting, comes fishing by Net. If Tylor, ${ }^{3}$ Calderwood, 4 and others

volume (Tales of Fishes (London, 1919), p. 39) we read of a swordfish, that "when he sounded, he had pulled thirteen hundred feet off my reel, although we were chasing him (in a motor boat) full speed all the time "!

1 See the excellent monograph on "Kite-Fishing," by Henry Balfour, in Essays and Studies, presented to Wm. Ridgeway (Cambridge, I I I3), p. 23, where he regards the invention as ancient and probably proto-Malayan. This hook was usually made of wood and the claw of a bird. Cf. Man, I912, Art. 4, and case 42 in Ethnographical Collection at the British Museum.

2 De Mortillet, pp. 245, 249: "De tous les engins la ligne est le plus simple, et celui qui a du etre le premier employe." He sums up his surview of the world from China to Peru, by "La pêche a la ligne est la péche la plus repandue parmi les nations sauvages."

"Op. cit., "The Net is known to almost all men as far as history can tell." But Darwin, in The Cruise of the Beagle, found the Fuegians without Nets or traps of any kind. Their only methods of fishing were with Spears, and a baited hair line without any hook.

- The Life of the Salmon, p. xv, London, I907: "At once the most primitive and most deadly method of catching fish, which inhabit rivers, is the erection of built barriers and enclosures." Plutarch (De Sol. Anim. 26) has no doubt of the priority of the Line over the Net: "Fishermen when perceiving that most of the fishes scorned the line and hook as stale devices or such as can be discovered, betook themselves to fine force and shut them up with great casting nets, like as the Persians serve their enemies in their wars"

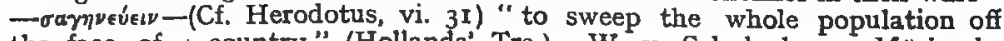
the face of d country" (Hollands" Trs.). W. v. Schulenburg, Mïrkssche 


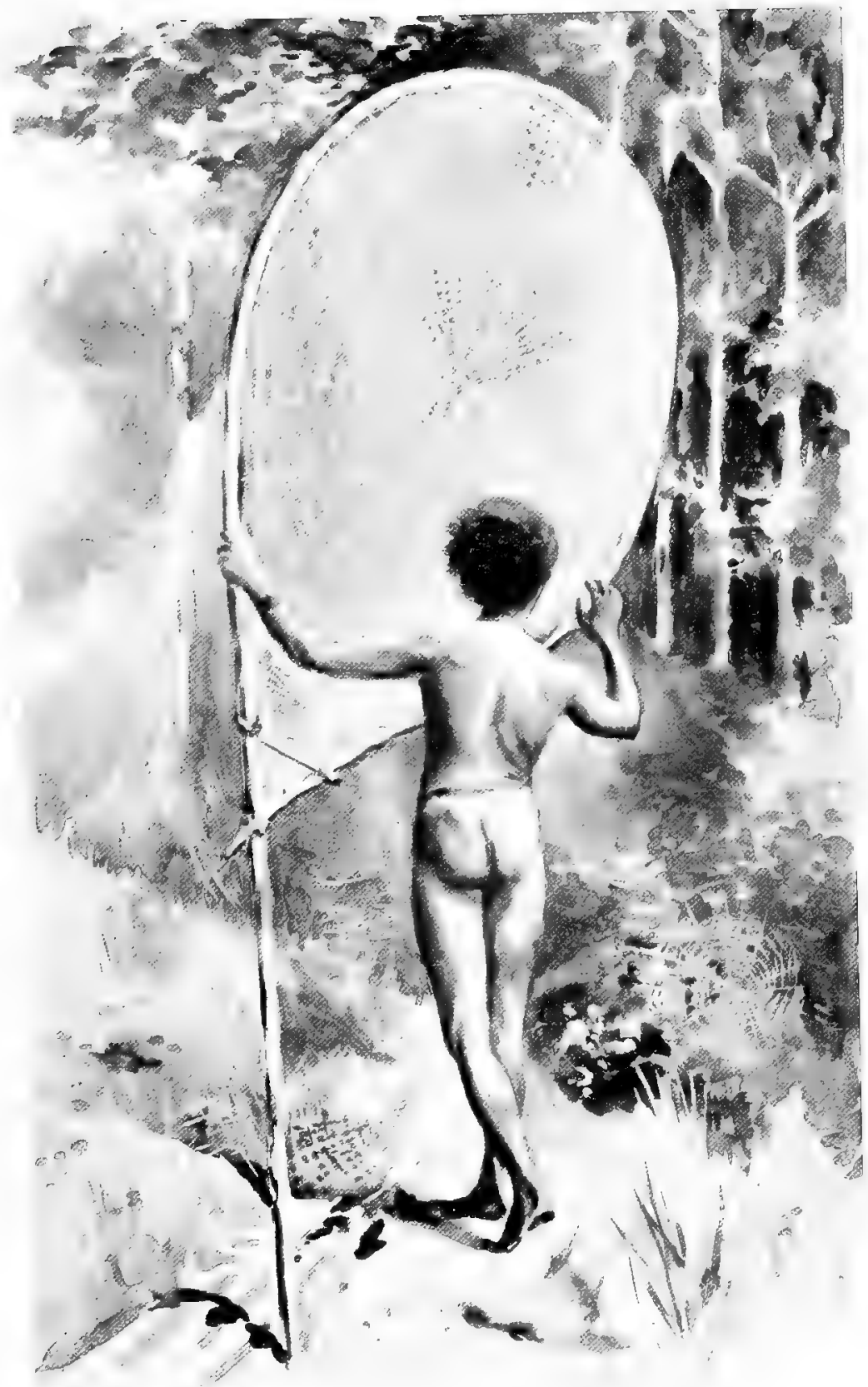

FISHING NET SPUN BY SPIDERS IN NEW GUINEA.

Seen. I, E. 43 . 

are correct in their conjectures that our primitive piscator, when endeavouring to catch by hand fish half stranded or spawning in small pools, blocked any little exit by plaited twigs-wattling, according to C. F. Keary, was one of the earliest prehistoric industries-or stones, that they erected in fact the world's first barrage, then must this ascendant or Scotch cousin of the Net take precedence of the Spear and every other artificial device.

Of the Net's kith and kin are there not some scores specified in the Onomasticon of Julius Pollux, or depicted in M. Dabry de Thiersant's Pisciculture en Chine? The Net was to beget a progeniem to the Angler at any rate vitiosiorem, and (to drag

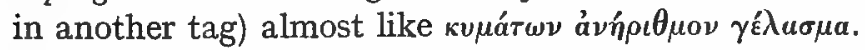

Three of this big family stand out conspicuous by their diversity. (A) The fairy-like Net-perhaps the most interesting because the most incredible-made by Spiders and used by the Papuans.l (B) The "Vimineous Weel" of Oppian. (C) The huge steel trawls, which lately encompassed those ravening sharks of the sea, the German submarines.

How the following device should be classed, I am not sure; it is neither Spear, nor Hook, nor Net. But it deserves to be put on record as an ingenious and successful species of fishing, employed by the Cretans during the War.

According to Mr. J. D. Lawson, Fellow of Pembroke College, Cambridge (to whom I am indebted for the account), the natives, eager to recover the coal that ships while coaling dropped into the sea, set out to fish for it. Since the coal could not swallow the bait, they resolved that the bait should

Fischerei (Berlin, 1903), s. 62, “ Das Fischnetz galt also schon in der Vorgeschichtlichen Zeit, im grauen Altertum für uralt. Mit Recht darf der Fischer sich den ăltesten Gewerben der Menschheit zuzählen."

1 Cf. A. E. Pratt, Two Years among the New Guinea Cannibals (London, I906), p. 266, and 3 photographs. The webs spun by the spiders in the forests are six feet in diameter, with meshes varying from one inch at the outside to about one-eighth at the centre. The diligence of the creatures has been pressed into weaving fishing-nets for the use of man by setting up, where the webs are thickest, long bamboos bent over in a loop at the end. On this most convenient frame the spider in a short time produces a web which resists water as readily as does a duck's back, and holds fish up to a pound satisfactorily. See also Robert W. Williamson (The Mafhu Mountain People of British New Guinea (London, I9I2), p. I93) who differs materially from Pratt as to the formation of the net. The illustration is reproduced by the kind permission of The Illustrated London News Co. 
grip the coal. Having by means of a rude spy-glass located the position of the mineral, they lowered from a boat a cord to which an octopus-the larger the better-was secured. As the fish detested the sensation of suspension, the moment he touched bottom he clutched with all his tentacles any solid object within reach, and while being drawn up clung to it with might and main.

By this method of inverted fishing-whether a survival of "Minoan Culture" or an adaptation from the East, where for many centuries the octopus has been similarly used for catching fish-much coal and much else was retrieved from the sea.

Note.-Since the above was written Th. Mainage has published at Paris Les Religions de la préhistoive. "Rites de Chasse" (ch. viii) includes a section on magic (pp. 326-342) and on religion (pp. 342-9), both dealing with fishing, etc., ancient and modern. The sermon preached among the Hurons to the fish recalls that of St. Anthony of Padua. Mainage, on p. 344, fig. I 88, gives an incised design from Laugerie-Basse, which according to him represents "Pêcheurs armés de filets (?)." The design is as little convincing as the author by his query seems convinced. 


\section{INTRODUCTION}

\section{PART II}

"Except to politicians, a decent definition is a help and a delight." ActiNG on this American dictum I start with two definitions, one of Fishing and Angling, the other of Angling. The first we owe to that past master of the art, Plato. Whether it come within the category of " delight or help," or whether he can endorse the verdict of Theætetus as to its " satisfactory conclusion," each reader must decide.

Plato, using the method of elimination and incidentally more than three pages of print, eventually arrives at the following definition of Fishing and Angling: 1 "Then, now you and I have come to an understanding, not only about the name of the Angler's art, but about the definition of the thing itself. One half of all Art was acquisitive : one half of the acquisitive Art was conquest or taking by force: half of this again was hunting, and half of hunting was hunting animals: of this again the under half was fishing, and half of fishing was striking: a part of striking was fishing with a barb, and one half of this again (being the kind which strikes with a hook and draws the fish from below upwards) is the Art we have been seeking, and which from the nature of the operation is denoted Angling or drawing up."

Theatetus: "The result has been quite satisfactorily brought out."

In search of a more helpful definition I turn to the English Dictionaries. The N.E.D. (New English Dictionary, Oxford)

1 Jowett's Translation, vol. iv. p. 343. The whole passage, which is too long for quotation, is fairly typical of Platonic methods. 
gives Fishing-" to catch, or try to catch fish "- wide enough for all our purpose and for most of our performances! In their definitions of Angling, Angle, etc., the majority of dictionaries disagree, but unite in deriving Angle from the Aryan root, $\mathrm{ANK}=$ to bend, and establishing the fishing term as the cousin of the awkward angles of Euclid and of our youth. The N.E.D. in its definitions of 'Angle' (sb.), of 'Angle' (vb.), of 'Angler,' or of 'Angling,' does not even agree with itself.

Thus we find:

(A) "Angle (sb.), a fish hook: often in later use extended to the line, or tackle, to which it is fastened, and the Rod to which this is attached. See Book of St. Alban's (title of ed. 2), Treatyse perteynynge to Hawkynge, Huntynge, and Fysshynge with an Angle."

(B) "Angle (vb.), to use an angle : to fish with a hook and bait."

(C) "Angler, one who fishes with a hook and line."

(D) "Angling, the action or art of fishing with a rod." 1

If $\mathrm{A}, \mathrm{B}, \mathrm{C}$, which all differ, are accurate, $\mathrm{D}$ can hardly be so. Further from A, B, C, we can deduce no correct definition of D.

Under D the N.E.D. imports as a necessary component part of angling the presence of a rod, but I venture to think on insufficient grounds. In the first quotation cited in support, "Fysshynge, callyd Anglynge with a rodde," the word " rodde," if D hold good, must be redundant or unnecessary. "Rodde" I hold to be an added word of limitation, or description, as in "Fysshynge with an Angle."

But since the dictionaries do hardly help-to some, indeed, they smack of "the heinous crime of word-splitting "-and since the importance (apart from etymological reasons) of possessing an accurate and adequate definition presses, let us prostrate ourselves before another oracle, the Law. But here too success scarcely crowns our quest. The leading case, Barnard v. Roberts and Williams, yields, Delphic-like, little light or leading. ${ }^{2}$

The facts, briefly stated, were: Roberts and IVilliams

1 The italics are mine.

323 Law Times, 439. 
laid in a private river two fishing lines; one end of the lines attached to two pieces of wood driven into the ground made fast the lines, the other end held hooks baited with worms, and a stone to keep the lines under water. "The lines were left by the men, who subsequently were found taking two fish off the hooks, and resetting the lines, of which the keepers deprived them. The charge (under s. 24 of the Larceny Act of I86I) ran of unlawfully, etc., taking fish otherwise than by angling. The Justices of Bangor refused to commit, on the ground that they were angling, and thus under the Act were protected from damages or penalty for such angling."

On appeal both sides cited Izaak Walton and other authors ; both quoted the N.E.D.- - the appellant its definition of 'Angling,' i.e. fishing with a rod, and the respondent that of 'Angle' (vb.), i.e. to fish with hook and bait.

The three Judges, judge-like, disagreed in their reasons but agreed in allowing the appeal, and disagreeing in their conceptions of angling agreed in abstaining from any definition.

"In the kingdom of the blind, the one-eyed is king." Mr. Justice Phillimore was the least non-positive. He even committed himself to the following: "He did not think that a rod must necessarily be part of an angler's outfit, but only a hook and line. He thought the human element must be present, and that it was not sufficient when the tackle was set once and for all, and then left."

It is obvious from the above that, while the dictionaries are but blind guides, the Law (if on this occasion not exactly " a hass ") fails to elucidate what exactly constitutes Angling.

Dr. Henry van Dyke, the author of Little Rivers and other fascinating books connected with fishing, suggests to me "Angling, the art of fishing by hand with a hook and line, with or without a rod." I much prefer this to that of N.E.D., because of its greater accuracy and of its inclusion of that really skilful method, hand-lining. But for general convenience I adopt as the definition of Angling " The action, or art, of fishing with a Rod."

My Fishing from the Earliest Times treats of the Old Stone Men, Egyptians, Assyrians, Chinese, Jews, Greeks, and 
Romans. The amount of space allotted to the last two, compared with that occupied by some of the other nations, may suggest the immortal even if apocryphal chapter of "Snakes in Ireland." "There are none."

To any such criticisms I make answer that for nearly all our knowledge as to the methods and tackle of fishing and varieties of fish we are indebted to the Greeks and Romans, and in a smaller degree to the Egyptians and Chinese.

Reasons of date, data, and dearth of paper prevent my using in this book the material which I had collected on Indian, Persian, and Japanese Fishing.

As regards India, while fishing by net falls well within my adopted date (500 A.D.), that by hook and line-not necessarily Angling - gains entrance by a short head, or a mere century.

Fish (matsya, apparently derived from the root mad and signifying the inebriated) is down to $c$. I000 B.C. only mentioned once ${ }^{1}$ in the Rigveda, X. 68, 8. In the next period-that of the later Vedas and Brāhmanas-fish, but not methods of capture, find frequent mention.

The Net $(j \bar{l} l a)$ is first referred to in the Atharvaveda (not later than 800 B.c.) but not in connection with fishing, while in the Yajurveda (c. 800 B.c.) names for fishermen and a hook -badiša-occur. The I39th Jätaka (c. 400 A.D.) contains the first allusion to fishing with a line and hook.

References in Sanskrit poetry to the iron hook and bait probably imply, though they fail to mention, the Rod. Passages in the epic Mahäbhärata, V. $\operatorname{II06}$ (c. 200 A.D.), in Kāmandaki's aphoristic poetry (c. 300-400 A.D.), in the Pancatantra, I. 208, "when women see a man caught in the bonds of love, they draw him like a fish that has followed the bait," all suggest Angling. ${ }^{2}$

Fish legends, similes, stories-not always redounding to

1 In H. Grassmann's Wörterbuch zum Rig-Veda, twice. One cannot indict a whole sex for inebriety on the strength of a single passage, but fish, despite matsya being masculine in Sanskrit, are always feminine according to the Avesta (vol. v. p. 6I, of Sacred Books of the East, Pahlavi Texts): "Water, Earth, Plants, and Fish are female, and never otherwise."

2 For help and guidance as to India I am greatly in debt to my old Oxford friend, Dr. A. Macdonell, Boden Professor of Sanskrit, and to his two books, History of Sanskrit Literature, p. I43, and Macdonell and Keith, Vedic Indez of Names and Subjects (London, IgI2), vol, ii. p. I73. 
ichthyic wisdom-meet us fairly frequently. Manu ${ }^{l}$ is saved from the Flood by a fish. Buddha ${ }^{2}$ answers questions as to abstention from fish. Wondrous fish occur: e.g. the Kar, " which knows to the scratch of a needle's point by how much the water in the Ocean shall increase, by how much it is diminishing." 3

Stories, such as the recovery by a fish of Sakuntalā's ring and the consequent marriage of King Dushyanta; of Indra, the fearless slayer of the serpent, whose death for defiling the bed of Ahalyâ was compassed by fish ; 4 of Adrikâ's transformation into a fish and her conception in that form of a child by King Uparicaras ; 4 of The Stupid and Two Clever Fishes; 5 of The Frog and The Two Fish, ${ }^{6}$ all these make pleasant if varied reading. But when we come to methods of fishing, all variety vanishes. We are confronted with a damnable monotony, a toujours perdrix. It is almost Net, or Nothing.

This holds true of the piscine tales even in the Arabian Nights, e.g. The Fisherman and the Jinn, and The Fisherman and the 'Efreet. The latter, however, possesses an unique interest: the fisherman here, unlike his Greek and Roman povertystricken brethren, became by means of his miraculous fish, " the wealthiest of the people of his age, and his daughters continued to be the wives of princes "'

Evidence that fishing in India was of old and is now (the fishing caste, I am told, ranks low) not highly regarded can be deduced (inter alia) from its total omission in the Fourteen Sciences and the Sixty-four Arts, which the Vätsyāyana Käma Sütra (not later than the third century A.D.) promulgates for the education of children from five to sixteen. Among the requisite Sciences gymnastics, dancing, the playing of musical glasses, sword-stick, cock quail and ram fighting, teaching parrots and starlings to sing, all these find commendation, but fishing none!

1 The Story of the Flood in the Catapatha Brähmana.

- Sacred Books of the East, xx. 252. Cf. X. 4I.

8 Ibid., xvi. 7. Cf. xxiii. 239 , and v. 65.

I De Gubernatis, Zoological Mythology (London, 1872), vol. ii. 331, f.

¿ The Pancatantra, I., Story I7.

B A Group of Hindoo Stories, by an Aryan (really F. F. Arbuthnot) (London, (88I), p. 35 . 
As with India, so with Persia ancient and modern, toujours le filet! Very many of the earliest prose works in modern Persian came through the Pahlavi from the Sanskrit. Thus the three or four stories-occasionally but wrongly regarded as of Persian origin-about fish and fishing which are contained in the Anwär-i-Suhaili I can be traced to The Fables of Bidpai, or The Pancatantra, ${ }^{2}$ translated from the Arabic version into Persian about 550 A.D.

In modern Persian (c. I000 A.D.) poetry, lines allusive to fishing dot themselves sparsely: ${ }^{3}$ even in them the Net bulks biggest. Hafiz (fourteenth century), however, gives us

"I have fallen into a Sea of Troubles, (presumably tears),

So that my Beloved may catch me with a Hook" (a curl of hair).

A passage in Arabic furnished hope of finding Angling oases in the desert, but when in

"A fish whose jaw the gaff of Death had pierced,"

I found the word (saffiud) rendered gaff given by Richardson's Persian-Arabic Dictionary as " a roasting spit, a poker for the fire," my hope fled, for I quickly realised here an instance of anachronistic translation, or the employment of fishing terms appropriate to modern but inapplicable to ancient methods. 4

I have come to the sad conclusion that the Persians ancient and modern care not in general for fishing or angling, although the Gulf, from which the ancient Sumerians garnered such splendid " harvest of the sea," washes their shores, and from their mountains descend " fishful " streams. I have reached my conclusion for the following reasons:-

(A) There is no word in the language which properly expresses fish-hook. Arabic words, which strictly mean

1 Book I., Story I2 and I5. Book XI., Story 4. Here the fisherman, when asked by the king the sex of a fish, saves the situation and collars 2000 dinar by ejaculating the blessed word, not Mesopotamia, but "Hermaphrodite," which he had once overheard two students casually employ.

"Sir William Jones holds that this collection of Fables "comprises all the wisdom of Eastern nations, and was surpassed in esteem and popularity by few works of Oriental literature."

a No Quatrain of Omar Khayam sings of the craft.

- See Idyll XX. of Theocritus, postea $\mathrm{I} 35$, note I, for another example. 
grappling hooks, have been adopted or adapted. In modern Arabic itself these words are not used for a fish-hook: bâlûgh, a foreign term, prevails.

(B) In Persian, Arabic, and Turkish ${ }^{1}$ the expression to fish, literally translated, equals to hunt fish, and generally describes a man who makes his living by netting, and selling fish.

(C) There is no word for fishing-rod in Wollaston's great English-Persian Dictionary.

(D) Proverbs are usually the offspring and embodiment of the life and occupations of a nation. In both ancient and modern Persian there is, as far as I know, but one proverband that rather contemptful-allusive to fish or fishing. It runs, "Thou shall not make a fish thine enemy," which probably signifies that no foe, however unlikely to injure, can be despised.

(E) In the experiences related to me by the Rev. Dr. St. Clair Tisdall, and by the late Sir Frank Lascelles, Netting ousts Angling.

The former: 2 "'Though I have lived in Persia for many years and have travelled through it from Sea to Sea, from the Persian Gulf to the Caspian, I have never seen a fish-hook in a Persian's hands. In the districts I know best, the Net is the only weapon."

The second, when our Minister at Teheran, on his first holiday went a-fishing. Having caught on a likely stream before supper three or four half-pound trout (I think), he anticipated next day pleasant sport. With the very early morning came not Remorse, but the local Sheikh to do his reverence and to make the customary present. "As I have heard that His Great Excellency worked hard for a few fish last night, my tribesmen have netted the river for the length of a parasang, and I bring you plenty of fish." Tableau ! Hasty flight of Sir Frank to another river, with like results !

Reasons both of date and data prevent my including the

1 Modern Turkish contains (according to Dr. Tisclall) two genuine old Turkish words for fish-hook, (1) Oltah, (2) Z bngah. This is of great interest, for it goes far to show that the Turks, even before leaving Central Asia, were familiar with Angling.

2 To him, a high authority on Persia, not only from the many years spent there but also from his great linguistic accomplishments, I am greatly in debt for much of the foregoing. 
Japanese, perhaps the most alert and adaptive sea-fishers in the world. As their history before 500 A.D. must apparently be classed as legendary, this nation eludes my chronological Net. Data on ancient fishing, if existing, are either unknown ${ }^{1}$ or as being derived from China find place postea. ${ }^{2}$

I set the time limit of my book at roughly 500 A.D., so as to include the last classical or quasi-classical piscatory poems viz. those of Ausonius-notably ad Mosellam-in the fourth and of Sidonius in the fifth century.

This date seems, indeed, a pre-ordained halting-place for three reasons. First, the tackle of our day (though improved almost beyond recognition in rod, winch, artificial bait, etc.) is merely the lineal descendant of the Macedonian described by Elian in the third century A.D. Second, between Ælian and Dame Juliana's Boke no record, with two possible exceptions, of fishing with a fly exists. Third, and more important, we possess no real continuous link between the Angling literature of Rome down to the fifth century and that which sprang up after the invention of printing some thousand years later.

In the intervening centuries, it is true, books and manuscripts were written (mainly by monks) which treated more or less of fishing, but of Angling only incidentally. ${ }^{3}$ They illustrate the customs of fishermen, the natural history of fish, the making and maintaining of vivaria or fish-ponds, rather than instruct or inform on practical Fishing.

The most notable would, could we trace it, be " an old MS. treatise on fishing, found among the remains of the valuable library belonging to the Abbey of St. Bertin, at St. Omer. A paper on this was read, a few years before I855, at a society of antiquaries at Arras. From its style, the MS. was supposed.

1 Mr. Harold Parlett, our Consul at Dairen and an authority on Japan, writes, "I know of no books in Japanese dealing with the history of fishing, and I think it improbable that any exist, unless in MS. It is a subject, which as far as I know, has not yet been studied. I should advise you to dismiss ancient Japanese methods in as few words as possible." I follow his advice.

" On consulting a great Sinologist, he rapped out, "The only thing I know or want to know of Japan is that every art, every craft, it possesses came from China."

${ }_{3}^{3}$ W. J. Turrell, Ancient Angling Authors (London, 19го), p. xi. Ancient, in this most researchful work, might, I venture to suggest, be qualified ty British, for six pages (in the Preface) suffice for all fishing before the tenth century. 
to have been written about Iooo A.D., and to have been divided into twenty-two chapters. The author's main object was to prove that fishers had been singularly favoured by Divine approbation; but appended to the MS. was a full list of all river fish, the baits used for taking them, and the suitable seasons for angling for each sort of fish."

For the existence of this work, vanished now for over sixty years, we have only the authority of Robert Blakey. ${ }^{1}$ But this, if it do pass muster with Dr. Turrell, fails to satisfy Westwood and Satchell, who describe his book on Angling as " a slipshod and negligent work, devoid of all utility, a farrago of quotations incorrectly given, and of so-called original passages, the vagueness and uncertainty of which rob them of all weight and value. Mr. Blakey's volume, it is but fair to add, is redeemed from utter worthlessness by the excellent bibliographical catalogue appended to it by the publisher !" 2

The Geoponika, whether written or redacted by Cassianus Bassus or Cassius Dionysius, or merely translated from a treatise by an ancient Carthaginian author, treats generally of agriculture. The twentieth book, however, deals with fishponds, fishing, and baits : unlike the Roman writers on vivaria, who tell us nothing as to the capture of the fish in them, the writer gives us instructive tips on baits.

One infallible recipe in chap. xviii. for collecting the fishon the lines of Baiting the Swim-from its superstitious naivete compels quotation: "Get three limpets, and having taken out the fish therein, inscribe on the shell the words, 'Ia $\boldsymbol{\alpha} \Sigma \boldsymbol{\alpha} \beta \boldsymbol{\alpha} \omega \boldsymbol{\omega} \theta$, or 'Jehovah, Lord of Hosts'; you will immediately see the fish come to the same place in a surprising manner." 3 The

1 Angling Literature (London, 1856), p. 33.

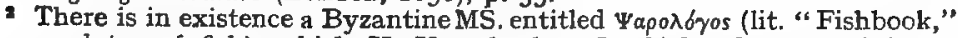
i.e. anecdotes of fish), which $\mathrm{K}$. Krumbacher, Geschichte der byzantinischen Litteratur, 3rd ed. (München, 1897), p. 884, states should be published.

${ }^{3}$ The result of the work done during the last twenty years by German writers, such as W. Christ, Geschichte des griechischen Litteratur, ed. 3 (München, I898), p. $66_{4}$ f. ; E. Oder, in Pauly-Winowa Real Enc. (Stuttgart, I9IO), VII., I22I-I225; and F. Lübker, Reallexikon des klassischen Altertums (Leipzig, I9I4), p. 409, seems to show that our Geoponika is a reduction, c. $95^{\circ}$ A.D., by an unknown hand of an older compilation made in the sixth century by Cassianus Bassus. Behind him in turn are older works of the

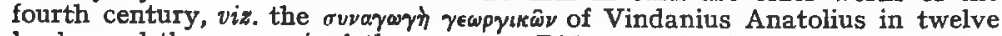
books, and the $\gamma \in \omega p \gamma i k d$ of the younger Didymos of Alexandreia in fifteen 
two Greek words formed the so-called Gnostic formula and occur frequently on amulets, etc. The Geoponika adds immediately, " this name the Ichthyophagi use."

About the fourteenth century a poem entitled De Vetula, attributed to $\mathbf{R}$. de Fournival, got translated or imitated by Jean Lefevre. The fishing portion (68 lines) awakes our interest, as it shows that " more than six hundred years ago, and probably two hundred years before the date of The Boke of St. Albans, most of the modern modes of fishing were practised; for instance, the worm, the fly, the torch and spear, the night line, the eel-basket and fork," etc.

This quotation from Westwood and Satchell might cause a casual reader to suppose that (a) from De Vetula, written only some two centuries before The Boke of St. Albans, we gain our first information "of these modes of fishing," and $(\beta)$ that these were " modern," whereas Oppian had described them all, some thirteen hundred years before The Boke of St. Albans saw light.

With the exception of de Fournival and the elusive MS. of Dom Pichon, 1 which (written about 1420 but only rediscovered about I853) probably stamps this monk as the first to practise artificial hatching, the Continent produced practically nothing till the appearance at Antwerp in I492 of the first printed original book on Fishing, which as regards printing precedes The Boke of St. Albans.

This little Flemish work by an unknown author contains twenty-six chapters of a few lines, gives recipes for artificial baits, unguents, and pastes, and in the last two pages notes the periods when certain fish eat best. As its title sets out, it teaches " how one may catch birds and fish with one's hands, and also otherwise." 2

books. Ultimately we get back to Cassius Dionysius of Utica, who translated the Carthaginian Mazo's work on agriculture (88 B.C.).

1 See infra, P. 291.

2 The date of $\mathrm{I}_{492}$ is suggested by Mr. Alfred Denison, who translated and issued privately twenty-five copies of Dit Boecxken leert hoe men mach voghelen vanghen metten handen. Ende oeck andersins. From the press of Mathys Van der Goes. The marriage of Madame Van der Goes to Godfridus Bach, whose printer's mark also appears in the book, seems to point to 1492 . See, however, M. F. A. G. Campbell, Annales de la Typographie Neerlandaise au xve siecle (La Haye, 1874), p. 80, and Bibl. Pisc., pp. 35, 36. 
The earliest description of fishing in the English language meets us in The Colloquy of Aelfric, A.D. 995, which Skeat first brought to notice and first "Englished " in The Oldest English Treatise on Fishing. ${ }^{1}$ This takes the form of a short dialogue introduced into the Colloquy written by Aelfric, Archbishop of Canterbury, for the purpose of teaching his pupils Latin, and therefore written in Anglo-Saxon with a Latin translation beneath. "It is arranged as a conversation between the master and his pupil ; the latter in turns figuring as huntsman, fisherman, falconer."

The length of the Colloquy, even of the fishing portion, prevents inclusion here, but the pupil's objection to fishing in the sea, "because rowing is troublesome to me," and to going a-whaling, " because I had rather catch a fish I can kill than one that can, with one stroke, kill both me and my comrades," strikes me as well taken and pertinent.

A poem by Piers of Fulham, written about $I_{420}$ (the original MS. of which can be seen at Trinity College, Cambridge) claims next our notice. The author, judging from Hartshorne's rendering, fully justifies the description of him as a somewhat pessimistic angler. He seems to have anticipated De Quincey's " fishing is an unceasing expectation and a perpetual disappointment." He fully appreciated its difficulties and disappointments, but clearly possessed some sportsmanlike instincts, as the following, among other, verses show ${ }^{2}$ :-

"And ete the olde fishe, and leve the yonge, Though they moore towgh be uppon the tonge."

A Latin book Dialogus creaturarum optime moralizatus was published in I480; a translation about I520 styles it The Dialogues of Creatures Moralysed. This very rare work, which I have found fully dealt with from an Angler's point of view only by Dr. Turrell, furnishes the earliest known illustration of an angler fishing with a float.

Next in date, and last to be noticed here, comes the famous

1 The Angler's Note-Book, ist series (1880), p. 76.

2 Cf. Turrell, op. cit., 4. In "and with angle hookys" in Piers, Mr. Marston, op. cit., 2, sees "probably the earliest known reference to angling in English." 
Treatyse of Fysshynge with an Angle, printed at Westminster by Wynkyn de Worde in 1496 as part of the second edition of The Boke of St. Albans. Whether, as has been commonly supposed, Dame Juliana Berners wrote it, or whether any such lady ever existed, are points of controversy, but that The Treatyse was not an immaculate conception, without parents or ancestors, can be reasonably proved by its reference to earlier writers on fishing, and to its "these ben the xii flies ye shall use" being introduced as a precept of practice rather than a revelation of invention.

If few the forbears of what some term " not only the first angling manual in England, but also the first practical work written in any language," its vitality and its prolific progeny admit of no doubt. According to Mr. A. Lang (who accounts for the startling fact by the increased number of people able to read owing to the spread of education) no less than ten editions of The Boke were issued within four years of publication, while Dr. Turrell limits himself to fourteen undated editions between $\mathrm{I}_{500}$ and $\mathrm{I}_{596}$.

Whatever the number of the editions, the need for and the vitality of The Treatyse is demonstrated by the fact that for over a hundred years no new work on Angling was printed in England, and between it and The Compleat Angler-a space of over one hundred and fifty years-there occur but four books on the subject. ${ }^{1}$ To its prolific progeny, the Bibliotheca Piscatoria bears witness 2 in its catalogue of some fifteen hundred authors and of countless books, MSS. etc.

We owe, it is said, this voluminous literature to the geographical position of England, which lends itself very favourably to the pursuit of all kinds of fishing. Can we, also, flatteringly add the other factor of Lacépede's dictum, "Il y a cette différence entre la chasse et la pêche, que cette dernière convient aux peuples les plus civilisés ?"

But the pursuit of fishing did not prevail in early England

1 Cf. M. G. Watkins, Introduction to the Treatyse, etc. (London, I880), p. xi.

It enumerates 3158 distinct editions of 2148 different fishing works published before I883. The Supplement issued by Mr. R. B. Marston in I 901 gives 1200 more. Mr. Eric Parker's delightsome and pocket-companionable An Angler's Gavland, London, I920, gives many happy extracts from the fifteen bundred, and present-day writers. 
or Scotland. A passage in Bede (probably used by Henry of Huntingdon), which has, I think, escaped the many-eyed net of our fishing authors, testifies to its absence in the former.

St. Wilfrid (born 634) on his return from Friesland, where fishing yielded the staple of food, met with such success in his mission to the South Saxons that he not only converted them, " with all the priests of the Idols," but also- " which was a great relief unto them "--taught them the craft of fishing, of which, save eeling, they wotted naught. Collecting under the Saint's order eel-nets where they could, the first adventurers meritis sui patris Divina largitate adjuti ${ }^{1}$ enmeshed three hundred fishes, which they equally divided between the poor, the netowners, and themselves.

The Celtæ, with some exceptions such as the scombercatching Celtiberi, eschewed fish, probably from religious prejudices, which owing to their adoration of the springs, rivers, and waters prevented the eating of their denizens.

Whatever the cause, Dion Cassius expressly comments on the abstinence of the Caledonians, although their seas and rivers abounded with food. ${ }^{2}$ In time the example of the clergy and the ordinance of fast days gradually overcamesave in the case of Eels, which still remain to the Highlander an abomination-their obstinate antipathy. Across St. George's Channel the Irish two centuries ago "had little skill in catching fish." 3

But when the Western Highlanders did go a-fishing, their prayers and promises-prompted by the same principle of gratitude being a sense of favours to come-echo the prayers and promises, Dis mutatis, of the Anthologia Palatina.

The seas differ, but the gods precated are the same. If in the following verses you substitute for "Christ, King of the Elements" Poseidon, King of the Waters, for "brave Peter" ruseful Hermes, and for "Mary fair" Aphrodite, you have the tutelary deities of fishing. The spirit of the prayer and promise of the firstling remain unchanged.

1 In Bede, "Et divina se innante gratia."

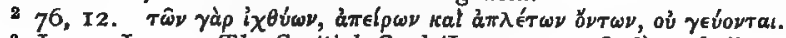

- James Logan, The Scottish Gael (Inverness, 1876), vol. ii. p. I30 f. 
For century after century the fishermen of the Isles have handed down orally to generation after generation the Gaelic prayer with which they set out to sea. ${ }^{1}$

"I will cast down my hook:

The first fish which I bring up

In the name of Christ, King of the Elements,

The poor man shall have for his need:

And the King of the Fishers, the brave Peter,

He will after it give me his blessing.

Columba, tender in every distress,

And Mary fair, the endowed of grace,

Encompass ye us to the fishing bank of ocean,

And still ye to us the crest of the waves!"

The rarity-I have not met its mention-and curious nature of a volume published at Frankfort in I6II, even if more than a century after The Boke of St. Albans, compels some reference.

Conjecturce Halieutice by Raphael Eglinus consists of a long dissertation based on the strange markings of three fishes (pictured on its title-page), two caught in Scandinavia on the same day, November 21,1587 , and the third in Pomerania on May 2I, I596. These markings, supposedly chronological, provide their author with a basis for various prophecies and warnings of the evils to come in Central Europe, especially in Germany.

As neither text nor type peculiarly tempt to perusal, I have not found it easy to disentangle the disasters or allot to each country its individual woe. Deductions from Daniel, the patriarch Joseph, and of course the Apocalypse enable Eglinus to establish definitely to his own satisfaction the future advent, in one or other of the Central Kingdoms, of Antichrist.

Nor, again, is it easy to gather whether a time-limit is set for his appearance, or whether the prophecies apply to twentieth-century events. Alas! also, the data do not enable me with certainty from the very promising entries from Germany, Austria, and Bulgaria to single out the precise

I Alexander Carmichael, Carmina Galica (Edinburgh, Igoo), vol. i. p. 325. 
potentate who best fills the bill, or closest answers to the author's Antichrist. ${ }^{1}$

Space debars from one fascinating branch of my subjectthe superstitions of Fishing. Their far-flung web enclosed the ancient piscator more firmly than his brother venator, or, indeed, any class save only the " medicine men" of Rome.

Nor could their successors disentangle themselves, as witness the recipe given above by Bassus for inscribing on the limpets' shell the Gnostic formula, and Mr. Westwood's words, "There is, in fact, more quaint and many-coloured superstition in a single page of Old lzaak than in all the forty-five chapters of the twentieth Book of the Geoponika. Silent are they touching mummies' dust and dead men's feet-silent on the fifty other weird and ghastly imaginations of the later anglers." 2

And even the modern angler, if he thoroughly examine himself, must confess that some shred of gossamer still adheres. Does he not at times forgo, even if he boast himself incredulous of consequence, some act, such as stepping across a rod, lest it bring bad luck? If particular individuals rise superior, the ordinary fisherman in our present day still avows and still clings to superstitions or omens. Let him in the South of Ireland be asked whither he goes, meet a woman, or see one magpie, and all luck vanishes. ${ }^{3}$ A dead hare (manken) regarded as a devil or witch a century ago brought piscator nigh unto swooning. ${ }^{4}$

Women seem usually fatal to good catches; as one instance out of many we read in Hollinshed's Scottish Chronicle, that " if a woman wade through the one fresh river in the Lewis,

1 S. Bochart, Hierozoicon (Leipzig, I796), p. 868, telling of a fish whose right ear bore the words, There is no God, but God, and left, Apostle of God, and neck, Mahomet, concludes with a parody of Virgil, Buc., iii. Io4.

\section{"Dic quibus in terris inscripti nomina Divum}

Nascantur pisces, et eris mihi magnus Apollo !"

A magnus Apollo to graduate the claims of the different potentates would indeed be a boon. The capture of a fish some two years ago near Zanzibar with Arabic inscriptions-legible only by the faithful-caused immense excitement, as possibly foretelling the speedy end of the world.

${ }^{2}$ Angler's Note-Book, ii. p. II6.

ingler's Note-Book, i. 44.

- Dougal Graham, Ancient and Modern Hist. of Buckhaven (Glasgow, 1883), vol. ii. p. 235. 
there shall no salmon be seen there for a twelvemonth after."

Superstitions of every sort and almost incredible dictate to the ancient and to the modern fisherman what are the good and what the bad days for plying his craft, or setting his sail. Their cousin, imitative magic, plays no small part in deciding his bait.

But enough here of fishing superstitions. Are they not writ large in Pliny, Oppian, Plutarch, in the Folk Lore Records, and larger, geographically, in that masterpiece, The Golden Bough?

The most incredulous, if there were one chance in a hundred of the operation ensuring adeptness in our craft, would willingly sacrifice in conformity with Australian superstition the first joint of his little finger. ${ }^{1}$ Nor, again, if only the most moderate success resulted, would any of us utter a belated plaint at his mother imitating her Fijian sister and throwing, when first a-fishing after childbirth, his navel-string into the sea, and thus " ensuring our growing into good fisherfolk." 2

1 John F. Mann, "Notes on the Aborigines of Australia," Proc. Geograph. Soc. of Australia, i. p. 204.

J. G. Frazer, op. cit., iii. 206-7. 


\section{GREEK AND ROMAN FISHING}

"Noster in arte labor positus, spes omnis in illa." 




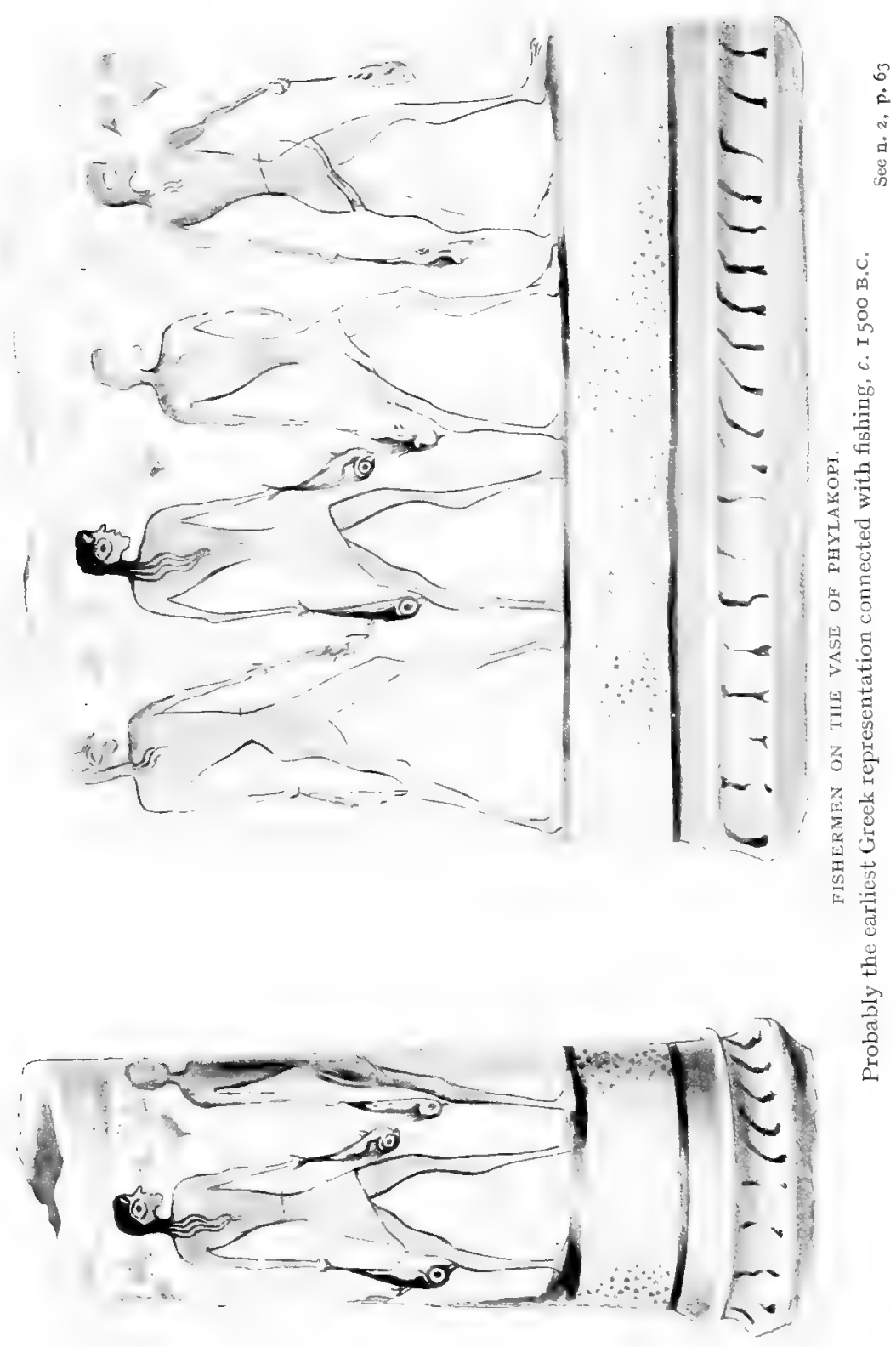




\title{
GREEK AND ROMAN FISHING. ${ }^{1}$
}

\author{
CHAPTER I
}

\section{HOMER-THE POSITION OF FISHERMEN}

IT is difficult to define accurately or trace separately the Lure or the Lore of these two nations, for their methods of fishing were practically the same or dove-tailed one into the other. Since our authors in both languages frequently synchronise, or as in the case of Pliny and Ælian the younger tongue antedates the elder by a century or more, and since this book is based on no zoological system, I shall deal with them for the most part in chronological order.

The opposite page reproduces the figures of the four fishermen from the famous Fishermen's Vase of Phylakopi discovered in Melos some twenty years ago. ${ }^{2}$ If the period assigned to this, viz. c. I500 B.C., be accurate, it seems to be the oldest Greek representation, at any rate in the \#gean area, depicting anything connected with fishing, and antedates the earliest Greek author by four to nine hundred years, in

1 For several reasons I have anachronously placed this section first instead of last.

2 The representation, reproduced by the kind permission of the Society for the Promotion of Hellenic Studies, consists of four men carrying in each hand a fish by the tail. The absence of boots and ornaments is in keeping with their occupation. The fishes with one exception have heads like dolphins, similar to the representation of Poseidon with a tiny dolphin in his hand. The painting is executed in the "black and red " style upon the usual white slip. The figures are drawn firmly and boldly according to the conventional scheme, shoulders to front and legs in profile; the slim proportions of the bodies are common to many Mycenæan works. The most barbaric features of the drawing are the absence of hands, and the monstrous eye in the middle of the cheek. Cf. No. 80 in the British Museum Cat. of Gems, which shows a man clad with the characteristic Mycenæan loin cloth carrying a fish by a short line attached to its gullet. Excavations at Phylakopi in Melos (London, 1904), p. 123, pl. xxii. 
accordance with the varying ages allotted to the Homeric poems. ${ }^{1}$

It is to Homer, whether written by half a dozen different authors or in half a dozen different centuries, ${ }^{2}$ as the oldest Greek writer extant that we naturally turn for information about fishermen and fishing. His evidence is not only the earliest, but also the most trustworthy, according to Athenæus. "Homer treats of the art of fishing with greater accuracy than professional writers on the subject such as Cæcilius, Oppian, etc." 3 -an endorsement from the piscatorial side

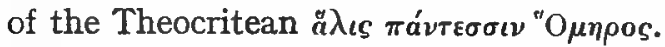

Neither fishermen nor traders in the Iliad and Odyssey possess any real status. While farmers, more especially pastoral farmers, occupy an acknowledged and-next to the chiefs and warriors-the highest position, no fisherman or trader is regarded as a representative unit of the body, politic or social, or as a contributor to the wealth of the tribe or state, a condition with which that of the fisherfolk in ancient Egypt 4 and in China, both in early times and in the present day, is elsewhere compared and contrasted. ${ }^{5}$

1 Equally famous, perhaps even more so, is the representation of a fish found in I882 near Vettersfelde in Lower Lausitz, but now in Berlin. It is the shield-sign of a Scythian chief, made in gold repousse work early in the fifth century B.c. See the publications of A. Furtwangler, Der Goldfund von Vettersfelde (Berlin, r883), (=id. Kleine Schriften (München, I9r2), I. 469 ff. pl. 18); cf. E. H. Minns, Scythians and Greeks (Cambridge, Igr3), p. 236 ff. fig. I 46 . Furtwangler thinks that the fish may have been meant for the Thymus alalonga.

Homer, according to Sir A. Evans, "is at most sub-Mycenæan, his age is more recent than the latest stage of anything that can be called Minoan or Mycenæan," Jour. Hellenic Studies, xxxi. (I9I2) 287. This would seem to place Homer about the twelfth century.

s Deipnosophista, I. ch. 22.

- Herodotus (II. I64) describing the different grades of Egyptian society begins with the priests and ends with the boatmen, among whom he apparently includes the fishermen. Their humble position is confirmed by other evidence; see postea 333. In Laconia fishing was confined to the Helots and Meploikol.

- "With the division of the people of the Empire into four distinct classes-scholars, agriculturists, artisans, and merchants-the men and women who followed the trade of fishing for a livelihood were placed in an anomalous position from not being included in any of the four classes. Thus socially ostracised to a certain extent, they clung to themselves, forming groups or colonies of their own along the coasts or on isolated islands. They lived in a world of their own, knowing nothing of the affairs of their country and caring less. To this day they do not come into direct contact with their countrymen 
"For trader Homer knows no word." 1 As traders he represents no Greeks, although the Taphians approximate closely (Od., I. I86). For this three reasons have been assigned:-

First, the Greeks of Homer's time with the exception of the Phæacians, "who care not for bow or quiver, but for masts, and oars of ships, and gallant barques, wherein rejoicing, they cross the grey sea" (Od., VI. 270), hardly impress us, despite Dr. Leaf's " The whole attitude of both the Poems is one of maritime daring," 2 as adventurous sailors.

They disliked long sea voyages ; they shrank from spending the night on the water; they would go thrice the distance, if they could but keep in touch with land-and naturally enough, when we remember that for the Homeric boat the Ægean was safe for only a few months of the year.

Their food supply made the sea a hateful necessity. "As much as a mother is sweeter than a stepmother, so much is earth dearer than the grey sea" might have been written as appropriately by Homer as by Antipater centuries later. ${ }^{3}$

Whatever trading existed was in the hands not of the Phæacians, but of the Phœnicians, to whose great port Sidon

on the mainland." Wei-Chung W. Yen: Fourth International Fishing Congress at Washington, rgo8. Bulletin of Bureau of Fisheries, No. 664, p. 376 .

1 Professor T. D. Seymour, Life in the Homeric Age (London, I907), p. 284, who might have added that Homer knows no general word either for trade;

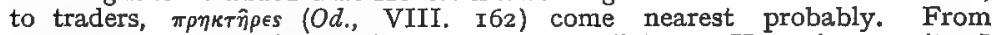
Seymour's work, which sheds much valuable light on Homeric pursuits, I quote and borrow frequently.

"See Class. Journ.; Chicago, XIII. (Igr7), "The Leaf-Ramsay Theory of the Trojan War," where he uses these words in reply to Maury, who holds that the view expounded in Leaf's Tyoy that the War was an economic struggle by the Greeks for trade expansion to the fertile lands of the Euxine and for the extinction of the tolls exacted by the Trojans is untenable, because (inter alia) of their want of nautical enterprise. In favour of Leaf there are, however, mentions (I) of a voyage from Crete to Egypt in five days, and (2) the

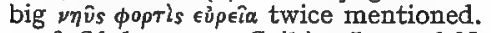

3 Cf. however, Geikie, Love of Nature among the Romans, p. 300, "Subdivided by the waters of the Egean into innumerable islands, where the scattered communities could only keep in touch by boat or ship, Greece naturally became a nursery of seamen. The descriptive and musical epithets applied to the deep in Greek poetry show how much its endless variety of surface and colour, its beauty and its majesty, appealed to the Hellenic imagination. S. H. Butcher, Harvard Lectures (London, I904), p. 49, speaks of the Greeks as "born sailors and traders, who from the dawn of history looked upon the sea as their natural highway." Contrast with this Plato, Laws, iv. 705A,

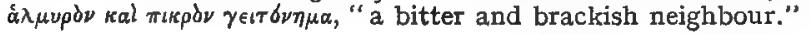


Homer makes reference more than once. ${ }^{1}$ Boldness of navigation, plus guile and gainfulness, characterised thie nation ; their "tricky trading" (cf. the Levantines of our day) ${ }^{2}$ found frequent comment.

A comparison of them with the seamen of Elizabeth's time shows common traits. Both were " the first that ever burst into the silent seas," both committed acts of piracy, both kidnapped and enslaved freely. Lest it be objected that the evidence of Od., XIV. 297 and 340 occurs in a fictitious account by Odysseus of himself and so is itself fictitious, let us call as witness the Hebrew prophet Joel 3: "What have ye to do with Me, O Tyre and Zidon? The children, also, of Judah, and the children of Jerusalem, have ye sold unto the sons of the Grecians."

The second reason lies in the fact that each Homeric house or each hamlet, although perhaps not each town, apparently supplied nearly all its own wants and was practically self-supporting.

The chief crafts existed, as Hesiod shows, but only in a rudimentary stage; workers there were in gold, silver, bronze, wood, leather, pottery, carpentry. Although they were not "adscripti glebæ," the proper pride or narrow jealousy of each settlement was strongly averse from calling in craftsmen from outside. Only apparently those "workers for the people," such as " a prophet, or a healer of ills, or a shipwright, or a godlike minstrel who can delight all by his song," were free to come and go, as they willed, sure of a welcome. "These are the men who are welcome over all the wide earth." 4

1 He never mentions Tyre, the later port. Evans (Scripta Minoa, pp. 56, 8o) and other archæologists now-a-days hold that Homer's \$olvikes, or "red men," are really the "Minoans," and are to be distinguished from the N.86viol or Phœnicians. At what date the latter appeared in the West Mediterranean is still a matter of controversy, but the present trend of opinion is that they only succeeded to the "Minoan" heritage.

'Cf., however, Isaiah xxiii. 8, "whose merchants are princes, whose traffickers are the honourable of the earth." In spite of this, Butcher, op cit., p. 45, writes: "but in Bacon's words, the end and purpose of their life was "the sabbathless pursuit of fortune." "

s Chap. iii. 4-6.

- Od., XVII. 386. 
The third reason was due to nearly all ordinary trade being effected by barter. Payment was in kine, kind, or service. The ox, probably because all round the most important of possessions, constituted the ordinary measure of value: thus a female slave skilled in embroidery fetches four oxen. Laertes gives twenty for Eurycleia, while much-wooed maidens by gifts from their successful suitors "multiply oxen " for their fathers.

Mentes sails to Temesa with a cargo of "shining iron" to exchange for copper. ${ }^{1}$ Then again in Il., VII. $472 \mathrm{ff}$., " the flowing-haired Achæans bought them wine thence, some for bronze and some for gleaming iron, and some with hides, and some with whole kine, and some with captives." Among the fishermen of the Indian Ocean, fish-hooks, on the same principle of importance of possession, " the most important to them of all implements, passed as currency and in time became a true money larin, just as did the hoe in China." 2

"The talents of gold," 3 probably Babylonian shekels, whether Hultsch's heavy or W. Ridgeway's light one, implied, according to some, a money standard of value. But wrongly, because neither gold nor silver came to coinage in Greece or anywhere else till long after Homer's day.

Fishermen seem slowly to have acquired some sort of status. 'A $A$ lev́s, at first meaning a seaman or one connected with the sea, in time denoted also a fisherman. Od., XIX. III, characterises the well-ordered realm of a "blameless king" as one, in which "the black earth bears wheat and barley, and trees are laden with fruit, and sheep bring forth and fail not, and the sea gives store of fish."

Any objection that such a kingdom had no actual existence, but was only invented to heighten the hyperbole of laudation of Penelope's fame, "which goes up to the wide heaven, as doth the fame of a blameless king," concerns us not at all, for the kingdom whether actual or imaginary is held up as worthy of

1 Od., I. I $82 \mathrm{ff}$.

2 W. Ridgeway, The Origin of Metallic Currency (Cambridge, 1892), $27 \mathrm{ff}$.

3 Il., XXIII, 269. 
all praise and admiration. In this our Fish and so our Fishermen have attained some, if small, constituent status.

The period of such attainment cannot be dated, but how and why the status arrived I now try to trace.

Authorities differ widely as to whether the (so-called) Greeks, on leaving Central Asia or whatever their Urheimat, established their first lodgements in Europe or Asia, in Greece Proper or Asia Minor. E. Curtius maintained that the Ionians at any rate, if not all the Greeks, founded their earliest settlements on the coast of Asia Minor, and only later crossed to Greece.

This view finds little favour among most Homeric scholars of the present day, ${ }^{1}$ who reverse the theory. They place the first settlement of the immigrant Greeks in European Greece, whence by peaceable permeation or otherwise they subsequently colonised the coasts of Asia Minor and the Islands.

According to Professor K. Schneider ${ }^{2}$ the Greeks, when swarming from their original Aryan hive and establishing themselves on the coast of Asia Minor and in the Islands of the Egean Sea, carried with them and for a long time closely preserved their original habits of lifeand livelihood. Descended from generations of inland dwellers, eaters of the flesh of wild animals, of sheep, etc., they were ignorant of marine fish as a food. Only when the population increased more rapidly than the crops, did they, profiting by their contact with the Phœnicians, to whom in seamanship ${ }^{3}$ and, according to some writers, in art 4

1 See, however, Hogarth's Ionia and the East, pp. 8, I20. A fish, the Eel, plays an important part in the attempt to determine the original home of the Indo-European family. See S. Feist, Kultur, Ausbreitung und Herkunft der Indogermanen (Berlin, I9I3), pp. I87, 525.

2 Der Fischer in der antiken Litteratur (Aachen, 1892).

3 While the early Greeks learned much with regard to navigation from the Phonicians, none of the Homeric nautical terms have been traced to a Phonician source, as might have been expected in view of the large number of such terms which the English language has borrowed from the Dutch, such as ahoy, boom, skipper, sloop, etc. The French has taken from the English, beaupre, cabine, paquebot, etc. Seymour, p. 322.

4 "The choice of the subjects (in The Shield of Achilles), especially the absence of mythological subjects, the arrangement of the scenes in concentric bands, and the peculiar technique, all point to oriental, i.e. in the main to Phonician and Assyrian influence. In these respects the earliest actual Greek work known to us by description, viz. The Chest of Cypselus (c. 700 B.c.), consisting of cedar wood, ivory, and gold, and richly adorned (according 
they owed much, begin to realise and utilise the wealth of the harvest to be won from the adjacent seas. ${ }^{1}$

Fishing, followed at first mainly by the very poor to procure a food in low esteem, gradually found itself.

In the Iliad and Odyssey no fish appear at banquets or in the houses of the well-to-do: only in connection with the poorest or starving do they obtain mention.

Meleager of Gadara accounted for this fact-previously noted by Aristotle - by the suggestion that Homer represented his characters as abstaining from fish, because as a Syrian by descent he himself was a total abstainer. The curious omission of fish has been held to indicate that Homer either lived before the adoption of fish as food, or, if not, that the social conditions and habits of diet which he delineates are those of generations before such transition. ${ }^{2}$

The decision, if one be possible, lies for Homeric scholars, and not for a mere seeker after piscatoriana. Even to such an one, however, two alternatives seem clear.

First, if Homer did live after the transition occurred, his descriptions of ancient times and customs unconsciously included habits and conditions of a more modern society. ${ }^{3}$

to Pausanias, V. I7) with figures in relief, holds an intermediate place between The Shield of Achilles and the art of the classic period. Hence we infer that the Shield belongs to the earlier time, when (as we also learn from Homer) the Phonicians were the great carriers between the Mediterranean countries and the East" (Monro, Il., XVIII). Professor Jebb (Homer, p. 66) ranks, in the earlier period, Phoenician lower than Phrygian influence, but the latest writer on the subject-F. Poulsen, Der Orient und die friihgriechische Kunst, Leipzig-Berlin, I9I2-makes large claims for the influence of the Phœnicians in art.

1 Under 'Piscator' in Dict. des Antiquites Daremberg and Saglio write: "The configuration of the country generally would naturally induce a large part of the population to seek their livelihood in fishing and fish."

2 The explanation of Athenæus (Bk. I. I6, 22 and 46) is ingenious. Homer never represents fish or birds, or vegetables, or fruit " as being put on the table to eat, lest to mention them would seem like praising gluttony, thinking besides there would be a want of decorum in dwelling on the preparation of such things, which he considered beneath the dignity of Gods and Heroes." The latest explanation-by Professor J. A. Scott, Class. Journ.; Chicago, I9I6-I 7, p. 329 - that "Homer looked upon fish with great disfavour, because as a native of Asia Minor he had been trained to regard fish as an unhealthful and distasteful food to be eaten only as a last resort," would attain nearer " what seems the solution of this vexed question" (Scott's words), if he produced (I) data establishing Homer's country of birth, and (2) evidence far stronger than "Tips to Archæological Travellers" (even though these be written by Sir Wm. Rarnsay) as regards the general "unhealthfulness " of the fish of Asia Minor.

3 Schrader, Reallexikon (Strassburg, I901), p. 244, states that in neither the 
Second, if he lived before such transition-a supposition, which scarcely consists with the presence in Palæolithic débris of copious remains of fish-passages such as Od., XIX. Iog-II4, which ranks " a sea-given store of fish " a constituent of a wellordered realm, and $I l$., XVI. 746, where "This man would satisfy many by searching (or diving) for oysters," are interpolations by later writers.

It is difficult otherwise to reconcile or explain conflicting passages. How, for instance, can the dictum, that "Fish as a food was in the Poems only used by the very poor or starving," be made to harmonise with $I l ., \mathrm{XVI} .746$, just quoted ? 1 If it be confined solely to the Odyssey, a more plausible case may possibly be presented.

Another suggestion, not quite similar, yet not repugnant, is Seymour's. "The Poet represented the life which was familiar to himself and his hearers. Each action, each event might be given by tradition, or might be the product of the poet's imagination, but the details which show the customs of the age, and which furnish the colours of the picture, are taken from the life of the poet's time. His interest is centred in the action of the story, and the introduction of unusual manners and standard of life would only distract the attention of his hearers."

Mackail, perhaps, concludes the whole matter. "The Homeric world is a world imagined by Homer : it is placed in a time, evidently thought of as far distant, though there are

Avesta nor the Rig-Veda is there any mention of fishing, nor in the Aryan period were there any common names for fish, and that throughout the Homeric age, which generally knows fishing as an existent occupation, there still seems to be a recollection of a time when the Greek hero ate fish just as little as he rode, wrote, or cooked soup!

1 It is but fair, however, to add that the Scholiast notes this passage as the only one in the Iliad where fish is mentioned as a food, while Monro makes the ingenious comment that these oysters, or shell fish, are to be regarded not as luxuries, but as a way of satisfying the hunger of a crew at sea. Of oysters this is the only mention in the Homeric Poems. As oyster shells and even unopened oyster shells were found by Dr. Schliemann at Mycenæ, the liking for oysters is not likely to have been lost between the Mycenæan and the Homeric times. The remains of the Homeric (sixth) city at Troy yielded very many cockle shells, but of cockles there seems no mention in the poems.

Numerous representations of fishes are found on Mycenæan and Cretan works of art. 
no exact marks of chronology any more than there are in the Morte d'Arthur." 1

Homer's close knowledge of the many devices for the capture of fish, and his lively interest in the habits of fish quite apart from actual fishing seem inconsistent with Schneider's contention of Greek ichthyic ignorance.

Fish, as we have seen, came gradually to be considered as much a part of natural wealth as the fruits of the ground or herds of cattle. And yet in all the pictures with which Hephæstus adorns the Shield of Achilles, pictures of common ever-present objects, first of the great phenomena of NatureEarth, Sea, Sun, Moon, and Stars-and then of the various events and occupations that make up the round of human lifein all these pictures, which as a series of illustrations of early life and manners are obviously a document of first-rate importance, no form of sea-faring has any place. Ships of war, maritime commerce, and fishing are alike unrepresented. ${ }^{2}$

No satisfactory explanation of this omission has as yet seen the light. The design of The Shield, say some, came from an inland country, such as Assyria. Others that Homer described some foreign work of art fabricated by people who knew not the sea, but Helbig points out that the omission consists with the references to ships and sea-faring elsewhere in Homer. No commerce or occupation, which could be placed side by side with farming in a picture of Greek life, then existed. If Mr. Lang's view-which possesses the pleasant property of incapacity of either proof or disproof-that The Shield was simply an ideal work of art had been more generally borne in mind, we should have been spared endless comment.

In his ascription of The Shield to Assyrian or Phœnician influence Monro finds himself at variance with Sir Arthur Evans. Even if his statement, "the recent progress of archæology has thrown so much light on the condition of Homeric art," be accurate and the deductions from such recent progress be justifiable, the still more recent progress in the same science

1 J. W. Mackail, Lectures on Greek Poetry (London, I9Io), p. 47.

Monro's Note on Iliad, XVIII, 468-608. 
(according to Evans) ousts the Assyrian or Phœnician in favour of a Cretan parentage.

"It is clear that some vanguard of the Aryan Greek immigrants came into contact with this Minoan culture at a time when it was still in its flourishing condition. The evidence of Homer is conclusive. Arms and armour described in the poems are those of the Minoan prime; the fabled Shield of Achilles, like that of Herakles described by Hesiod, with its elaborate scenes and variegated metal work, reflects the masterpieces of the Minoan craftsmen in the full vigour of their art. Even the lyre to which the minstrel sang was a Minoan invention." I

The suggestion that both authorities are really in agreement and that the influence at work may be traced back ultimately to the early Assyrian, i.e. Sumerian, culture, even if Evans holds "that the first quickening impulse came to Crete from Egypt and not from the Oriental side," seems, on present data, untenable.

Till twenty years ago it was generally accepted that no character of Homer ever sailed for recreation, or fished for sport. They were far too near the primitive life to find any joy in such pursuits. Men scarcely ever hunted or fished for mere pleasure. These occupations were not pastimes; they were counted as hard labour. Hunting, fishing, and laying snares for birds in Homer and even in the classical periods had but one aim, food. ${ }^{2}$

The Poet expressly mentions the hardships ( ${ }^{\prime} \lambda$ y $\varepsilon a, O d .$, IX. I2I) of hunters in traversing forest and mountains. Nowhere does he give any indication of sport in hunting or fishing, except perhaps in the case of the wild boar and in the delight of Artemis " taking her pastime in the chase of boars and swift

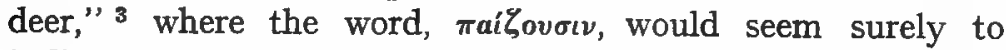
indicate pleasure in sport.

But the recent discovery at Tiryns of a fresco where two

1 Presidential Address to the British Association, I9I6.

Eustathius (on $I l .$, V. 487 ) after stating that by the Homeric heroes fishing

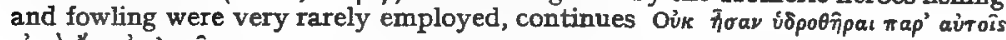

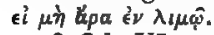

Od., VI. IO2 ff. W. W. Merry ad loc. well compares Soph. El., $566 \mathrm{ff}$. 

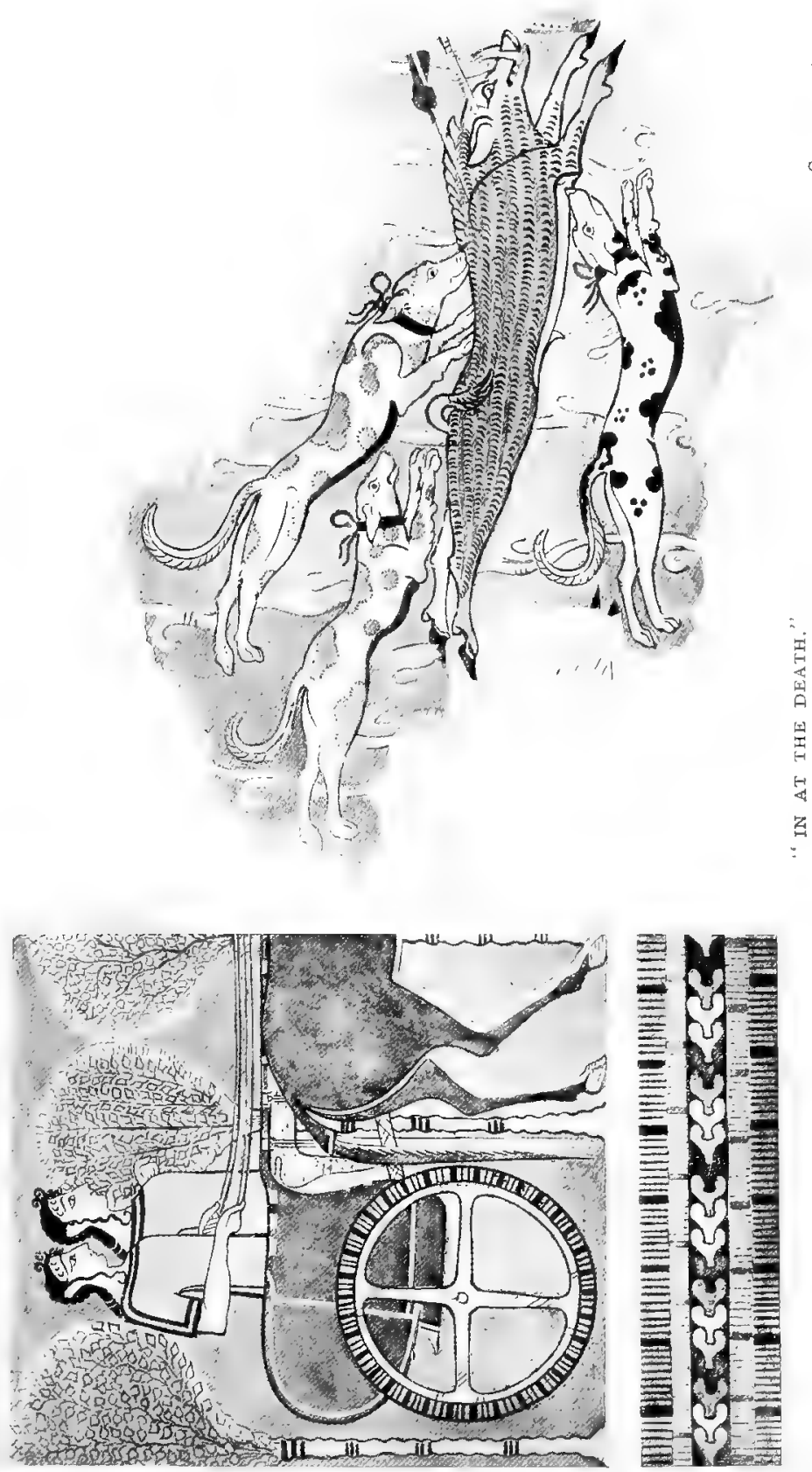

ladies are depicted standing in a car at a boar-hunt 1 -perhaps " in at the death "- certainly makes for considerable qualification, and, if succeeded by similar finds, for complete reversal of the non-sporting theory.

On Circe's Island, Odysseus strikes down " a tall antlered stag" as "he was coming down from his pasture in the woodland to the river, for verily the might of the Sun was sore upon him." He bears the " huge beast " across his neck to the black ship of his companions, who soon devour it. This is the only mention of venison in Homer (Od., X. I58 ff.).

1 G. Rodenwaldt in Tiryns (Athens, I9I2), II, 96 ff. pls, I2 f. 


\section{CHAPTER II}

\section{HOMER-METHODS OF FISHING}

WHETHER Homer lived before or after the adoption of fish as a food, we find in the Iliad and Odyssey several references to fishing with the Spear, the Net, the Hand-line, and the Rod.

It is a point of curious interest that nearly all the references, where methods or weapons of fishing find mention, are made for the purpose of or occur in a simile, which despite the socalled Higher Criticism Mackail says, "In Homer reached perfection." 1 A Homeric comparison, like the parable of the New Testament in its very nature is intended to throw light from the more familiar upon what is less familiar. The poet cannot intend to illustrate the moderately familiar by what is wholly strange. In modern writers the subjects of a simile, apart from those drawn from nature, are sometimes modern or new; in the old they are almost invariably drawn from some well established custom.

If so, it follows that to the Greeks of Homer's time (as was the case with the Egyptians before them) fishing with Spear, Net, Line, and Rod were old and familiar devices. ${ }^{2}$ Which of the first three-Spear, Net, Line-ranks the oldest, has (as

1 Lectures on Greek Poetry, 67 ff. There are nearly three hundred comparisons in Homer's poems : but of detailed similes only some two hundred and twenty, of which the Odyssey contains but forty. Miss Clerke (Familiar Studies in Homer, p. $182 \mathrm{ff}$.) shows that angling is mentioned chiefly in similes, which may, perhaps, indicate that the poet knew that this particular method was not practised in the days in which his poem is placed.

- Among the arguments elaborated by Payne Knight and others to prove that the Iliad and Odyssey were written by different authors and dealt with far different times, one is based on the fact that certain methods of fowling and fishing are only found in the Odyssey. If this argument be pushed to its logical end, it should be easy to prove that the ages of Shakespeare and Ben Jonson, which overlapped, were really far apart, because, while the latter mentions the familiar use of tobacco, the former never once alludes to it. 
shown in my Introduction) been long disputed and seems doubtful of definite settlement.

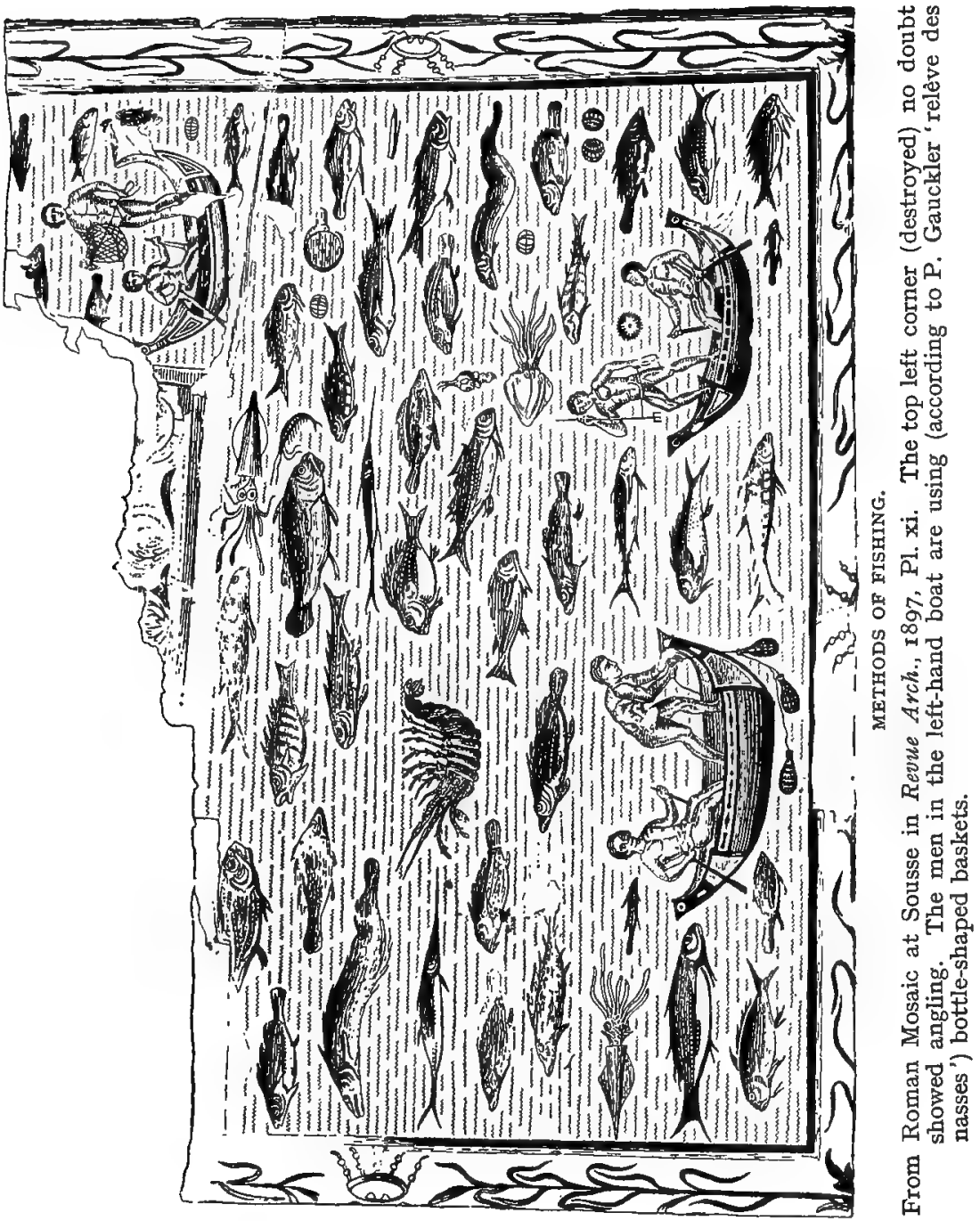

The passages referring to fishing number eight. Of the four methods of fishing mentioned one is with Spear (Od., X. 
I24) two with the Net (Od., XXII. $386 ; I l .$, V. 487), and one with the Rod (Od., XII. 25I).

A. The Spear (Od., X. I24): "And like folk spearing fishes they bare home their hideous meal." This gives a very lively image, because the companions of Odysseus, whose boats had been smashed by the thrown rocks, are in the water, and are being speared like fish by the Læstrygones. ${ }^{1}$

B. The Net (Od., XXII. 383 ff.): "But he" (Odysseus after the slaughter of the suitors) "found all the sort of them fallen in their blood in the dust, like fishes that the fishermen have drawn forth in the meshes of the net into a hollow of the beach from out the grey sea, and all the fish, sore longing for the salt waves, are heaped upon the sand, and the sun shines forth and takes their life away: so now the wooers lay heaped upon each other." 2

In Iliad, V. $487 \mathrm{ff.:} \mathrm{"Only} \mathrm{beware} \mathrm{lest,} \mathrm{as} \mathrm{though} \mathrm{entangled}$ in the mesh of all-ensnaring flax, ye be made unto your foemen a prey and a spoil."

C. The Rod (Od., XII. 25I ff.): "Even, as when a fisher on some headland 3 lets down with a long rod his baits for a snare to the little fishes below, casting into the deep the horn of an ox of the homestead, and as he catches each flings it writhing, so were they" (i.e. the companions of Odysseus) "borne upward to the cliff" (by Scylla).

D. Line and Hook (Iliad, XXIV. 80 ff.): "And she" (Iris on her Zeus-bidden mission) " sped to the bottom like a weight of lead, that mounted on the horn of a field-ox goeth down, bearing death to the ravenous fishes."

E. Iliad, XVI. 406 ff.: "As when a man sits on a jutting rock and drags a sacred fish from the sea with line and

1 The translations from the Odyssey are by Butcher and Lang (London, I88I), and those from the Iliad by Lang, Leaf, and Myers (London, I883).

So too the Egyptians likened the men slain at the battle of Megiddo: "Their champions lay stretched out like fishes on the ground." See J. H. Breasted, Records of Egypt (London, I 906), vol. ii. par. 43 I.

3 Alike, and yet unlike, is

" His rod was made out of a sturdy oak,

His line a cable which in storms ne'er broke;

His hook he baited with a dragon's tail,

And sat upon a rock, and bobbed for whale." 
glittering hook of bronze, so on the bright spear dragged he Thestor," etc. ${ }^{1}$

F. Odyssey, IV. 368 f.: "Who" (the companions of Menelaus) "were ever roaming round the isle, fishing with bent hooks, for hunger was gnawing at their belly."

Odyssey, XII. 330 f. : "They" (the companions of Odysseus) " went wandering with barbed hooks in quest of game, as needs they must, fishes and fowls, whatever might come to their hand, for hunger gnawed at their belly." 2

The Rod finds one express mention-in passage C. Is its use implied in passages $\mathrm{D}$. and $\mathrm{E}$. ? The answer depends greatly on whether the adjectives employed are really descriptive of the qualities and sizes of the fish, or whether they are merely (as often the case in Homer) ornamental or conventional epithets more suited for general than particular use, or are redundant.

Our wonder, if the adjectives are really descriptive, grows by the Rod being only specifically mentioned when "little fishes " are the prey. If the contention of modern fishermenthe value of the rod as an implement increases in proportion to the weight of the fish on the hook-holds good, why does Homer cite the Rod in connection only with "little" fishes, more especially as the prey in the simile (the companions of Odysseus) can hardly be classed as "little"?

1 See Eustathius ad loc. The spear with which Telegonos wounded

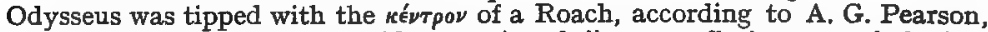
Fragments of Sophocles (Cambridge, I9I7), vol. ii. p. IO5 ff., a propos of the lost

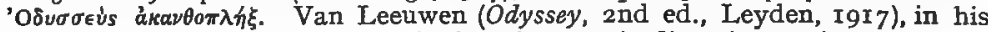
note on $\mathrm{xi}$. 134-7, makes the fish the sting-ray (vadio raice pastinace), which from its deadly character (cf. Pliny, N. H., ix. 67) is to my mind much more probable, despite Liddell and Scott's translation of $\tau \rho v$ y $\omega \nu$ as 'roach' the absolutely harmless Roach! Cf. Epicharmus, Frag. 66 Kaibel, tpuyóves

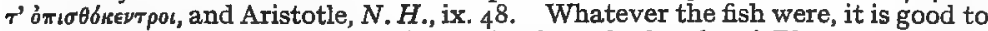
know that it too came to an untimely death at the hands of Phorcys, because of its cannibal propensities. See Eustathius, Od., p. I6 76,45 , commenting on xi. I33. In The Life of Apollonitus of Tyana, vi. 32, Philostratos says Odysseus

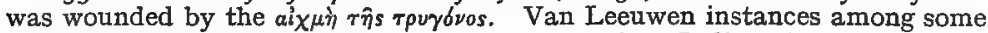
old armour preserved at Bergum the weapon of an Indian pirate, "which is made of the tail of the ray."

2 It is with something of a shock I find such careful translators as Butcher

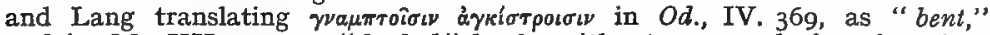
and in Od., XII. 332, as "barbed" hooks, without one word of explanation. These weapons differ in appearance, execution, and date of invention. To evolve the barbed from the bent hook required probably as many generations of men, and centuries of effort, as the development of the bent hook from the primitive gorge. See Introduction. 
Four differing explanations are possible :-

I. That "little" is an ornamental or redundant adjective.

2. That $\dot{\rho} \alpha \dot{\alpha} \beta \delta o s$, which is usually translated rod, i.e. fis hing-rod, is (according to Hayman and others) not a fishingrod, but merely a staff, or spear, shod with horn, and that "little" signifies only fish suitable for food, not large fish, such as dolphins, etc.

3. That the fishermen of Homer (anticipating our professional deep-sea fishermen in Kent and the Channel Islands, who for quickness and certainty, especially in the case of heavy fish, prefer hand-lines to rods), limited the use of the Rod to " little," i.e. not large, fish.1

4. That "little" is partly ornamental, partly intentional, because fish caught close inshore are normally smaller than those caught farther out.

From the adjectives in passages $\mathrm{D}$. and $\mathrm{E}$. can we infer the use of the Rod? Of the adjective in E., Butcher and Lang write: "It is difficult to determine whether iøpós in Homer does not sometimes retain its primitive meaning of "strong " (see Curtius, Etym., No. 6I4); in certain phrases, this may perhaps be accepted, as an archaism. ... On the whole we have not felt so sure of the archaic use as to adopt it in our translation."

Paley, "ispòs means huge, as if a favourite of or dedicated to some sea-god." Was it from this shade of meaning that Theocritus in his Fisherman's Dream ${ }^{2}$ drew his conception

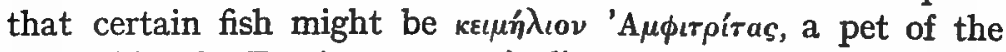
sea-goddess? Faesi seems to incline to Paley's view, but for

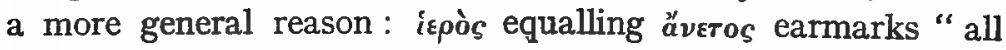
herds and shoals of fish, especially those in the Sea, as consecrate to the Gods."

Granting this, why should one fish be singled out by the epithet when the whole "herd or shoal" is equally ispós?

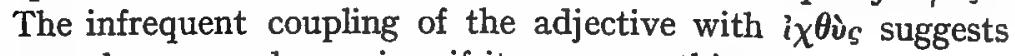
some less general meaning, if it mean anything.

1 There are of course limitations to the "pulley-hauley" of a hand-line; with a $700 \mathrm{lb}$. Tuna a Rod may be a very present help, a windlass even more so. The practice in vogue among the Spanish Tunny fishers is to throw aside the Rod at the moment of hooking and man-handle the fish with the Line.

a Idyll, XXI. 55 . 
Athenæus 1 after trying to answer, "But what is the fish which is called Sacred ?" by citing instances where the Dolphin, Pompilus, Chrysophrys, etc., are so designated, adds a sentence which seems either to be the authority for, or to confirm the authority of Faesi ; " but some understand by the term 'sacred fish ' one let go and dedicated to the God, just as people give the same name to a consecrated ox."

Seymour holds that "the epithet iøpòs as applied to a fish in $\mathrm{Il}_{\mathrm{i}}$, XVI. $40 \%$, has not been satisfactorily explained from ordinary Greek usage: instead of sacred, it seems rather to mean active, vigorous, strong. Cf. the same epithet applied to the picket guard of the Achæans in Il., X. 56." Curtius connects the word with the Sanskrit ishira=vigorous. "Ispòs as active, agile, strong is applied to horses, spies, mind, women, and cows.

Leaf suggests that the word, when applied to night, etc., would have developed the meaning of mighty, mysterious, and so later on sacred. If sacred, the epithet may have arisen out of some sort of tabu or religious feeling against eating fish, in early times often regarded as either uncanny creatures living under water and possessed of superhuman powers, or as divine or semi-divine. ${ }^{2}$

Gradually the dread of fish as creatures $t a b u$ wore off, but survived for long in a hole-and-corner way, e.g. the veneration of $\tau \dot{\varepsilon} \tau \tau \iota \xi$ '̇uá $\iota$ เos, 'the lobster,' at Seriphos, ${ }^{3}$ or the deification of каркívo, ' crabs,' in Lemnos. 4

If ifoòs does mean a big, fine, vigorous fish, to most modern fishermen a Rod would seem implied. This is strengthened by

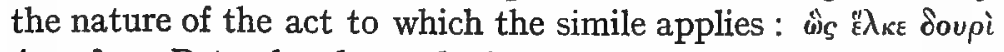
фakıvi, as Patroclus dragged Thestor on the bright spear from the chariot, so the fishermen dragged the fish from the sea.

In $\mathrm{D}$. the case, if any, for the implied use of the Rod is very weak. In this alone of all the references does lead as a weight occur. Here we have no comparison to action such as dragging up a fine fish, but simply to swiftness; the effect of it, the

1 vii. I8-2I.

2 See S. Reinach, Cultes, Mythes, et Religions (Paris I908), iii. 43 ff.

3 EElian, N.H., xiii. 26.

Hesych, s.v. KáBeipoi. 
splash, makes the point of the comparison with which Iris sped on her mission. Nor does the adjective applied to the fish give any aid, for $\dot{\omega} \mu \eta \tau \tau^{\prime}$, if it be not redundant, signifies 'raw-flesh devouring' (rather than 'ravenous') fish, such as shark or sword-fish. ${ }^{1}$

But if the early Greeks and Romans only fished for the pot and not for amusement, the question arises, why should this particular Homeric piscator " be after" sword-fish or shark? Fishing, down to the early Roman times, continued to be more of a distinct trade than was the pursuit of animals and birds. ${ }^{2}$ Hence the Net with quicker and surer returns and not the Rod was the favourite weapon of the fishermen by trade.

In F. (Od., IV. 369, and XII. 330) something in the nature of a line and of a bait of some sort (though not necessarily of a rod) attached to the bent, or barbed, hooks, must be implied. Hunger would assuredly continue to "gnaw at their bellies," if their only food was caught by hooks, pure and simple, for, as Juliana Berners pithily puts it, "Ye can not brynge an hoke into a fyssh mouth without a bayte."

Abstention from fish, however general, did not prevail among Homer's sailors. Athenæus (I. 22) points out that since the hooks used could not have been forged on the Island, and so must have been carried on board the ships, "it is plain sailors were fond of and skilful in catching fish."

Basing my surmise on opvitas in Od., XII. 33I and on the statement of Eustathius ad loc., that hooks were used for capturing sea-birds as well as fish, I suggest that the baits on the hooks were either small fishes (left possibly by the tide in some pool in the rocks), or shellfish, or oysters. These attached to a line (with or without a rod) and thrown into the sea were taken by both sea-fowl and fish. ${ }^{3}$

1 Compare its use four times (in the Iliad only) as applied to birds of prey and to dogs ; also figuratively to Achilles as " savage."

"Later on it is true we do find the Roman " burgher" becoming also an amateur angler, and gentlefolk, including ladies and children, taking freely to the sport. Piscator is generally used in reference to those who were fishermen by trade, whereas venator and auceps may be likewise applied to mere lovers of hunting and fowling (H. Blümner, Die römischen Privatallertümer, Munich, IgII)

A gorge, almost identical with the Neolithic gorge, is used at the present day for catching ducks on the Untersee of Holland. See Introduction. 
But all the preceding points dwarf in interest before the term képas ßoòs á $\gamma$ paúloı, " the horn of a field ox, or ox of the homestead." 1 How does the horn of an ox find itself in this galley? What was its exact use? Where and how was it employed?

Many scholars and fishermen, ancient and modern, have essayed the problem. The reason for the use of the horn passed early out of common knowledge and afforded matter for conjecture from Aristotle downwards.

To enumerate all the theories would necessitate a list almost as long as Homer's catalogue of the ships. The following, the most important, must suffice for our purpose.

(I) Képas was a little pipe or collar of horn protecting the line (which passed through it) just at its junction with the hook, and served the same purpose as a "gimp" on a trolling line.2 "This precaution (according to Arnold) was taken so that the fish might not gnaw through the line "- - precaution very similar to our use of wire between the line and the hook, when fishing for tigerfish, tarpon, shark, etc. ${ }^{3}$

A similar interpretation of the word occurred to Aristotle, who ${ }^{4}$ held that the lower piece of the line was fortified by a little hollow piece of horn, lest the fish should come at the line itself and bite it off. But the use of képas in the second $(O d$.$) passage appears to rule out Aristotle's and Arnold's$ interpretations. The fish here are admittedly, not vare-flesh devouring, which might imply size, but small. Why then this elaborate contrivance as precaution against severance of the line?

The above explanation of the use of képas derives strong support from the method even now employed in the Nile. ${ }^{5}$ The native sportsman, as protection against its being bitten

1 Il., 24. 81, and Od., 12. 253.

2 See Merry and Riddell on Od., XIT. 25I. Döderlein (Il., XXIV. 80), following the Scholiast, also gives this same explanation.

3 T. K. Arnold, Iliad (I852), 20. 80. According to Dugas-Montbel, as quoted here, "To this little tube of horn they attached also a piece of lead to sink the bait, and the horn, being the colour of the sea, had also the advantage of deceiving the fish."

- Plutarch, De Sol. Anim, 24.

s The Field, of January 2nd, I904. 
off, covers a soft woollen line, to which is tethered a live rat, a common bait for a big Nile fish, with a pipe or tube of maize stalk. Here the similarity ends; on the Nile no hook is employed; the sportsman harpoons the fish while hanging on to the rat.

(2) Képas, according to Paley (quoting Spitzner), was a bit of horn fastened to the hook and plummet to disguise their appearance; this, from being nearly the same colour as the sea, served better to deceive the fish.

(3) Képas, according to Trollope and others, was the horn or tube, but in it only the leaden weight was enclosed.

(4) Képas was a kind of tress, made out of the hair of a bull. Plutarch, however, states flatly, "But this is an error." Damm and others insist that the word in this sense is postHomeric, and agree with Plutarch that these tresses, if ever used, would have been of the hair of a horse, and not of a bull. 1

(5) Képas, according to Hayman and others, was simply a prong of horn attached to a staff to pierce and fork out the fish while feeding ; hence the preliminary baits, cídara (similar to baiting a swim on the Thames), are of course not on or attached to the horn. ${ }^{2}$

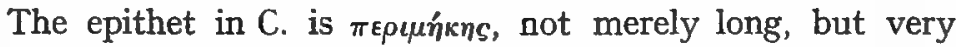
long. The adjective, if not redundant, lends weight to Hayman's theory of spear as against fishing rod. Against it, however, in Od., X. 293, the $\rho \dot{a} \beta \delta \delta$ s, or wand of Circe, which thrice appears (in $0 d ., X .238,3$ I9, 389) minus any adjective, suddenly takes unto itself $\pi \varepsilon \rho \mu \eta \dot{\kappa} \eta s$, very long, without apparent reason for the distinction.

(6) Mr. Minchin's explanation is ingenious, if open to two objections. "As to the ox horn puzzle," he writes to me, "I feel no doubt that the Cherithai (as the Bible calls the Kretans) cut a ring out of the horn of an ox, and then cut a

1 Apollonius Sophista, Lexicon Homericum, (ed. Bekker, Berlin I833), p. 52,

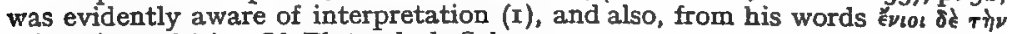
$\tau \rho l \chi a$ répas, of (4). Cf. Plutarch de Sol. an. 24.

2 "The remarks of the Scholiast here (Od., XII. 25I) citing as authority Aristarchus perhaps illustrate fishing tackle as later known. The Homeric tackle was far simpler, a staff shod with a native horn" (Hayman). 
gap, thus making a crescent of horn, to the one end of which they attached their line, which is exactly what the black fellows (in Australia) do to-day with a pearl shell." 1

But against this conjecture weighs the fact that as the grain of the horn runs from butt to point, if the hook be cut from cross-section it would probably break, as the cross-section would be across the grain, and so very frayable. If, however, the hook were cut from a panel removed from the side of the horn and just where the curve comes before the point, the substance of the hook might possibly stand.

Anticipating and dissenting from Mr. Minchin's explanation are Monro's note on Il., XXIV. $80 \mathrm{ff}$., and Professor Tylor's comment in the note. "The main difficulty in the ancient
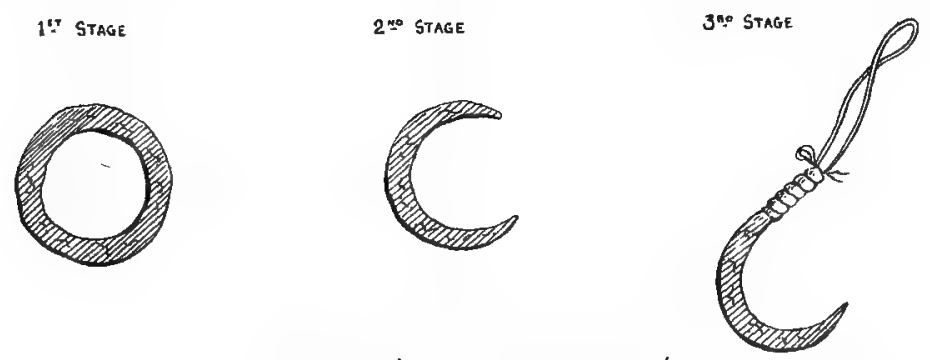

MR. MINCHIN'S EXPLANATION OF Képas.

explanation of the passage is the prominence given to the к'́pas, which is spoken of as if it were the chief feature of the fisherman's apparatus. The question naturally suggests whether the képas might not be the hook itself, made, like so many utensils of primitive times, from the horn of an animal."

On this point Mr. E. B. Tylor writes to Monro as follows : "Fish-hooks of horn are in fact known in pre-historic Europe, but are scarce, and very clumsy. After looking into the matter, I am disposed to think that the Scholiast knew what he was about, and that the old Greeks really used a horn guard, where the modern pike fisher only has his line bound, to prevent the fish biting through. Such a horn guard, if used

1 In The Confessions of a Beachcomber, pp. 266-8 (London, I9I3), the illustrations of pearl-shell fish-hooks in various stages of completion tend to confirm this statement, while the author, Mr. Banfield, inclines to Mr. Minchin's theory as regards the horn of an ox. 
then, would last on in use, anglers being highly conservative, and I shall look out for it."

Maspero, ${ }^{1}$ however, states, "Objects in bone and horn are still among the rarities of our museums : horn is perishable and is eagerly devoured by certain insects, which rapidly destroy it," with which statement may be compared Od., XXI. 395, "lest the worms might have eaten the horns" (of the bow of Odysseus).

Finally the explanation first suggested by Mr. C. E. Haskins ${ }^{2}$ and adopted by Dr. Leaf, that képas was an artificial bait of horn, appears to me as an angler and as having seen in the Pacific, but not used, "bait fish-hooks made of shell all in one piece, of a simple hooked form without any barb," 3 to be perhaps the most likely solution of our problem.

According to Mr. Haskins, $\kappa$ ḱ $\rho a s$ means an artificial bait of horn, probably shaped like a small fish, and hollow at all events at the upper end, into which a $\mu \circ \lambda \dot{v} \beta \delta a \iota v a$ (lead) was inserted to sink it. It had hooks of $\chi a \lambda_{\text {roos }}$ fastened to it and was used by being thrown out, allowed to sink, and then rapidly drawn through the water to attract the fish by its glitter and motion.

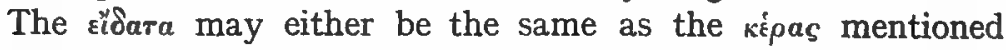
in the next line, or more probably ground bait thrown in to attract fish to the spot, while the use of the present participle, кarà ... $\beta a \dot{a} \lambda \lambda \omega \nu$, seems to imply constant action, i.e. the fisherman throwing in at intervals a handful of ground bait.

While I have not, like Mr. Haskins, " caught many trout with artificial baits made of horn," I can vouch that in England horn minnows still exist and that horn spoons are even now used for pike.

We find in Homer no special variety of fishes, except eels and dolphins. Eels are not ranked in a strict sense as fish; the words are "both eels and fishes" (Il., XXI. 203, 353). Sea calves and seals also find a place. Other fish occur in the picture of Scylla (Od., XII. 95): " and there she fishes (i $\chi$ Өváq) swooping round the rock, for dolphins or sea-dogs, or whatso

1 Maspero, Egyptian Archoology, p. 270.

" "On Homeric Fishing Tackle," Jour. of Philology, XIX., I89r.

sescribed by Mr. Moseley, Notes by a Naturalist on the Challenger, p. 467 . 
greater beast she may anywhere take, whereof the deep-voiced Amphitrite feeds countless flocks."

Seals 1 greedily devour a corpse in the sea (Od., XV. 480). Il., XXI. I22, 203, extend the pleasant practice to fish and eels: "around him eels and fishes swarmed, tearing and gnawing the fat about his kidneys."

It is noteworthy that in Greek and Latin literature the first fish attaining to the dignity of a name is the Eel. ${ }^{2}$

The sea is called ix "fishful," twelve times: the Hellespont only once. Plutarch (Symp., IV. 4) had this probably in mind, when he wrote, " the heroes encamped by the Hellespont used themselves to a spare diet, banishing from their tables all superfluous delicacies to such a degree that they abstained from fish." 'I $\chi \theta$ vó $\varepsilon$ ıs happens but once in connection with a river, the Hyllus $(I l$., XX. 392).

Homer seemingly applies it only where he is impressed, not by the number of fish obvious to the eye or still remaining in, but by the number already taken out of the water. The proportion of salt water ' fishfuls ' to fresh water 'fishfuls 'I3 as against I-would, if not quite accidental, accord with the fact that the early Greeks, whatever be the time at which they became Ichthyophagists, set no high store on fresh-water fish. ${ }^{3}$

1 In Victor Bérard's Les Phéniciens et l'Odyssée (Paris, I9o3), vol. ii. p. 64 ff. (a work, compact of knowledge and of both classical and modern research, which tracks characters and episodes in Homer to and compares them with Egyptian and Phcnician accounts), is found a very interesting dissertation on Proteus, the guardian of the seals of Poseidon and foreteller of the future (Od., IV.). Berard holds that the name was simply a Greek form of the Egyptian word Prouiti, or Prouti, which was one of the ascriptions or titles of the kings of Egypt, as to whose knowledge of or association with magicians (who, like Proteus, were capable of transforming themselves or other objects) he cites alike Maspero and the Old Testament. See, however, for other possibilities, P. Weizsäcker in Roscher, Lex. Myth., iii. 3I 72-3I 78 , who concludes that for us, as for Menelaos or Aristaios, Proteus the shape-shifter is still a very slippery customer.

2 Otto Keller, Die Antike Tievwelt (Leipzig, r913), ii. 357.

3 See infra, p. 20r. 


\section{CHAPTER III}

\section{THE CONTEST BETWEEN HOMER AND HESIOD- HOMER'S DEATH}

THE cause and circumstances of Homer's death remain uncertain and disputed. For them some writers hold fisherfolk responsible.

Midway between (A) the tradition that Homer took so to heart his impotency to read-be it remembered he had been acclaimed "of mortals far the wisest" - the riddle of the fisher boys, that he took also to bed and shortly after died, and $(B)$ the absolute assertion by Herodotus the Grammarian (Vita Homeri) that the poet " died at Ios of disease contracted on his arrival there, and not of grief at failing to understand the riddle of the fishers," lies the account of the death given

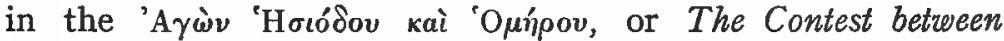
Hesiod and Homer. ${ }^{1}$

The Contest, despite the rather laboured thrusts of the antagonists full of curious if not connected touches, makes the funeral solemnities of King Amphidamas the occasion and Chalcis (not Aulis or Delos) the scene of the encounter.

Victory and prize were adjudged to Hesiod, because he "sang of Tilth and Peace, not of War and Gore." 2

1 The 'A 'yे̀ is found in only a few of the editions of Hesiod. I have followed the text of $\mathrm{C}$. Goettling, $\mathrm{r} 843$. The author Herodotus, who wrote probably about 60 to Ioo A.D., lived of course centuries after Hesiod, who is generally dated some roo to 200 years subsequent to Homer. The account given by Suidas varies in several small details, for instance the riddle is rendered in prose as well as in metre. He definitely states that illness, not the riddle, was accountable for the poet's death.

Since writing this Note, I have come across in the Oxford Homer, vol. v. (19r2), edited by T. W. Allen, the 'A you, the Life of Homer by Plutarch, and by Suidas, all conveniently placed together. Mr. Allen, in the Jour. Hell. Studies, XXXV. (I915), 85-99, has an elaborate article on 'the Date of Hesiod,' which for astronomical and other reasons he now fixes as $846-777$ B.C.

2 "It is difficult to understand how the author could derive from Works 
If left to a jury composed of or even leavened by fishers instead of to the king, the verdict would surely have gone the other way, were it only on the ground that while Homer affords several spirited pictures of fishing, we search in vain all Hesiod's genuine works for any mention, for even any allusion to fishing.

The word fish occurs only in Works and Days, line 277. Even if we allow The Shield of Heracles to be by Hesiod, we find but one passage (lines 2I4-5) relating to fishing, and this with a Net. 1 Hesiod's silence on the subject surprises, for (a) he boasts himself the poet of country life, (b) states that as a youth he fed and led his flocks on the sides and amid the streams of Mount Helicon, and (c) passed the rest of his life on the banks of the river Cephissus. ${ }^{2}$

Homer had previously, on consulting the Pythian Priestess as to the country whence he sprang, received a response, which I render-

"Thy mother's home is Ios, where in time

Thou'lt lie ; but 'ware the young lads' riddling rhyme." 3

But now let the 'A $\gamma \grave{\omega} \nu$ speak. "After the contest the poet sailed unto Ios, and there abode a long time, being already an old man. Sitting one day on the sea-shore, he asked some lads returning from fishing,

"'Fishermen from Arcadia, have we aught?'

and Days a reputation like that enjoyed by Hesiod, especially if we remember that at Thespix, to which the village of Ascra, the birthplace and early home of Hesiod, was subject, agriculture was held degrading to a freeman " (Smith, Dict. Gk.-Rom. Biog, and Myth., s. v. "Hesiod").

1 When Pausanias came to Thespiæ on his Bootian round, the representatives of the Corporation who owned the land told him dogmatically that the Works and Days alone came from the Master's hand, and showed him the ne varietur copy on lead, wanting the proœmium which we read at the head of the poem (Paus., 9. 3I. 4).

2 The passage, attributed by Euthydemus (in his Treatise on Pickled Fish) to Hesiod, which mentions seven fish, does not upset my statement, because the paternity of the work has long been deemed spurious. Even Athenæus brands the'verses as "the work of some cook, rather than that of the great accomplished Hesiod," and concludes from intrinsic evidence, such as the mention of Byzantium, etc., and the Campanians, etc., "when Hesiod was many years more ancient than any of these places or tribes," that they were written by Euthydemus. See Athen., III. 84 .

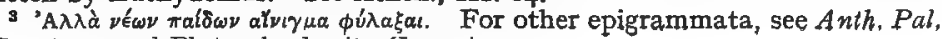
VII, I to 7 , and Plutarch, de vita Homeri, r. 4 . 
To which they made answer,

" 'What caught we, we left ; what caught we not, we carry.' 1

Homer, however, caught not on, until he was told that the key of 'what' was not fish, but lice.2

"Remembering him of the oracle that the end of life was upon him, he makes the epitaph for his own tomb. Arising thence, he slipped in the mud, falling on his rib, and on the third day, so men say, died. And he was buried in Ios."

This is the epitaph-

or

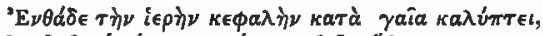

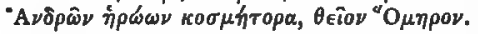

"Here Earth has hid that holy head of thine, Marshal of heroes, Homer the divine." 3

The story of Hesiod after his victory over Homer as set forth in The Contest repays telling.

He journeyed at once to Delphi to give the first fruits of his victory as a votive offering to the Oracle-and here let us note how in early times, certainly down to the time of Xenophon, the Greeks at important events in their lives resorted to some such fane for guidance. ${ }^{4}$

1 From Anth. Pal., IX. 448.

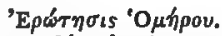

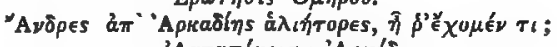

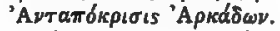

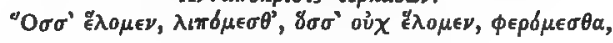

which may perhaps be rendered in rhyme,

"Fishers from Arcady, have we aught?

Our catch, we left ; we bear, what we ne'er caught!"

- It suggests itself to me that in the answer to the riddle there is just possibly a play within a play, or a double latent meaning, for the word $\phi \theta \in \mathrm{s} p$ denotes not only a louse, but also a fish of the Remora kind. Perhaps this humour is too subtle even for a class so noted for "calliditas," or shrewd wit, as Greek fishermen are reputed to have been.

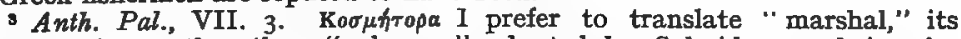
first meaning, rather than "adorner" adopted by Coleridge, as being far stronger, and more fitting for a poet who had " marshalled " on his stage of the Iliad so many heroes. Herodotus states that the people of Ios (not Homer) wrote the epitaph at a subsequent date.

- It was on the advice of Socrates that Xenophon consulted the oracle at Delphi, before he set forth for the campaign in Asia, which forms the story of his Anabasis. Tablets discovered in Epirus in 1877 by C. Carapanos (see podone et ses Ruines, Paris, 1878) give examples of questions addressed to the 
Greeted from the inner shrine as one "held in honour high by the immortal Muses," as one "whose fame shall reach as far as is spread the light of morn" (this use of one of Homer's own and fairest lines ${ }^{1}$ was no doubt intended as the highest possible tribute to his victor), Hesiod is then warned, "But beware of the fair grove of the Nemean Zeus, for there lies thy fate of death."

Alas ! for the poet, who to escape the well-known temple of Nemean Zeus in the Peloponnese hurried off to stay at Oinoë in Locris, never to discover that there too was a place sacred to the same god and called by the same name.

At Oinoë he abode with his hosts, until suspecting that he had debauched their sister (Hesiod seems to have been endowed with superhuman powers, for according to Proclus and Suidas he was a youth twice!), they slew him and threw him into the sea. But on the third day his body was borne back to land by dolphins. On hue and cry for the murderers being raised the brothers seized a fishing boat and set sail for Crete. ${ }^{2}$ But they found not favour in the "pure eyes and perfect witness of all-judging" Zeus, who thundered and sank them. "But the maiden, their sister, after the rape hanged herself." To conclude in the words of the 'A $\gamma$ w'v,

\section{"So much for Hesiod!"}

oracle at Delphi. Agis asks if some mattresses and pillows are likely to be recovered. Another pilgrim enquires whether the god recommends sheepfarming as an investment.

1 Il., vii. $45 \mathrm{I}$.

- Plutarch's account (Sept. Sap. Conviv., ch. I9) varies in many details; notably, ( 1 ) it acquits Hesiod of seduction, (2) the brothers of flight, (3) the maiden of hanging herself. 


\section{CHAPTER IV}

THE DOLPHIN-HERODOTUS-THE ICHTHYOPHAGI-

THE TUNNY

The Shield of Heracles, now rarely attributed to Hesiod the poet nearest in time to Homer, gives us pictures, similar if more ornate in style to those in Homer's "The Shield of Achilles."

The Shield of Heracles would probably not have been written had not Homer's "Shield of Achilles" existed. It differs from the older poem in the presentation of mythological scenes and a scene of fishing, but is perhaps the most complete illustration from fisher life extant before Theocritus.

A sheltering haven from the untamed rage

Of ocean. It was wrought of tin refined

And rounded by the chisel; and it seemed

Like to the dashing wave; and in the midst

Full many dolphins chased the fry, and show'd

As though they swam the waters, to and fro

Darting tumultuous. Two of silver scale

Panting above the wave, the fishes mute

Gorged, that beneath them shook their quivering fins

In brass. But on the crag a fisher sate

Observant : in his grasp he held a net

Like one that, poising, rises to the throw." 1

The painting of the harbour, of the cliffs, of the fishes tossing in tumultuous heaps, and of the chase and capture by dolphins of their prey, all seem to Mr. Hall but a careful elaboration of a

1 Translated by C. A. Elton. In the last two lines occurs the solitary mention by Hesiod of fishing. 
suitable background (as the fields, etc., in the ancient Pastorals torm an artistic background to the shepherds) for the solitary figure.

"But, on the crag a fisher sate

Observant; in his grasp he held a net,

Like one that, poising, rises to the throw."

The occurrence here of the Dolphin, together with the part that it played in the recovery of Hesiod's body, makes this an appropriate place for a brief résumé of the position occupied by this fish in Greek and Roman authors, and of the many pretty legends in which for all time its memory is enshrined. ${ }^{1}$

The myth of the Dolphin-a creature of lightness and swiftness-as the protége of the gods and the helpmate of man stands out as a purely Hellenic conception, and contrasts sharply with that of the Tortoise, unmoving, half-hidden, which according to Eastern belief supports the weight of the world.

In Greek and Latin literature (exclusive of the recipes of the gourmets or the rhapsodies of the opsophagi) no fish wins more frequent mention or higher appreciation than the Dolphin.

And justly so, since, of a nature essentially philanthropic, it delights to be with man, and aid man by willing services. ${ }^{2}$ Pliny, indeed, confesses that he could never reach the end of the stories about their kindly acts, especially towards the young. He notes that they found pleasure not only in the society of man, but also in music, pracipue hydrauli sono, or

1 From the fish (in old English daulphin) came apparently the title of the eldest son of the kings of France from I349 to 1830. According to Littré the name Dauphin, borne by the lords of the Viennois, was the proper name Delphinus (the same word as the name of the fish), whence the province subject to them was called Dauphine. Humbert III., on ceding the province, made it a condition that the title should be perpetuated by being borne by the eldest son of the French king. A. Brachet, An Etymological Dict. of the French Language (Oxford, I883), p. II3, states that the title-peculiar to S. Francefirst appears in II4O : the origin is obscure, though it certainly represents the Delphinus."

2 Lucian (Dialogues of the Sea Gods, VIII) offers an unexpected explanation of this trait. On Poseidon's commending the fish for the rescue of Arion, the Dolphin makes answer: "You need not be surprised to find us doing a good turn to Man: we were men before we were fishes." 


\section{THE DOLPHIN-ICHTHYOPHAGI-THE TUNNY}

"the organ," the only trait, I imagine, common to the fish and to Nero! 1

The helpfulness of the Dolphin shows itself in diverse ways, often on vital occasions. In gratitude for the rescue of Telemachus, Ulysses wore its effigy stamped on signet and on shield. Attracted by Arion's singing, it saves from the waves "the sweet musician," and bears him safe to Tænarum. ${ }^{2}$ Later on, with pleasant disregard of religious bias, it rescues the Christian Saint Callistratus from a watery grave. ${ }^{3}$ It acts as willing, almost as " common " carrier, alike to gods, schoolboys, and damsels in distress. It anticipates our meteorological office, for from the direction of its swim can be predicted the wind of to-morrow.4

Its constant and practical service to fishermen meets wide attestation. Oppian sings it: Pliny proses it: Ællian cribs, and confirms it. 5

From the lagoon of Latera (says our Latin author) multitudes of mugils or grey mullets at stated periods flock to the sea. ${ }^{6}$ The moment the migration begins, crowds collect for the sport, shout their loudest, and summon "Simo" from the vasty deep, or rather the mouth of the lagoon.

The Dolphins, formed in line of battle, swim swiftly in, cut off all escape to sea, and drive before them the frightened fish to the shoals.? While the nets are being drawn the dolphins

1 Pindar (frag. 235 Bergk", I40 68 ff., Schroeder) likens himself to the dolphin,

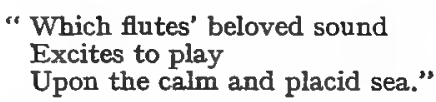

Pliny (Delphin edition, I826, which I use throughout), IX. 8 . Suetonius, Nero $4 \mathrm{I}$.

2 Herodotus, I. 24. Pausanias, III. 25. Plutarch, Sept. Sap. Conviv., I 8. Cf. Lucian's characteristic account, op. cit., VIII.

${ }^{3}$ S. Baring-Gould, The Lives of the Saints (London, I897), vol. x. $3^{85}$.

- Keller, op. cit., 347, confirms this habit of the fish, which, I suggest, is dictated by reason of food.

s Oppian, hab. V. 425 ff. ; Pliny, IX. 9 ; Ellian, de nat. an., II. 8.

n The Mugil, especially Mugil saltator, vies with if it do not surpass the salmon in its poner of leaping. It often (according to Oppian) jumps right over the surrounding nets. Our Dolphin a double duty pays, in (I) driving the fish, and (2) killing the successful saltatores.

7 In Arist., N. H., IX. 48, the Dolphin " seems to be the swiftest of all the creatures, marine or terrestrial," but in N.H., IX. 37, he credits the grey mullet as being "the swiftest of fishes." 
kill, but pause not to eat, such fish as escape the meshes. When at last the catch is saved, then they fall to and devour the fish already killed.

Here let us note an instance of intellectual anticipation of, Trade Unionism. Well aware that their labour has yielded far more than the regulation Trade stroke, and earned more than the Eight Hours' wage, they quietly await settling daynext morning - when they are paid by being stuffed not only with fish, but also with crumbs soaked in wine. ${ }^{1}$

Thus Oppian of another fish-drive,

"The Fishers pick the choicest of the Spoil, Supply their wishes and reward their Toil."

In a story of similar fishing by Mucianus the Dolphins await neither summons by voice as above, or signal by torch (as in Elian, II. 8) but "uncalled and of their own accord" present themselves ready for work.

Trades Unionism among the Dolphins is again not obscurely indicated, ipsis quoque inter se publica est societas. Furthermore, close corporations, not unlike mediæval Guilds or modern Unions, but wotting not of "blackleg" or even " dilutee," surely prevailed, for sum quaque cymba e delphinis socium habet. ${ }^{2}$

Elian's dolphins foreshadow, it would seem, our modern principle of co-operation, when "they draw near demanding the due reward of their joint-undertaking." But their organisation of labour differed from ours in two respects.

First, the willingness and the wage for night and day shift were identical. Second, since they were not blessed as we in the higher civilisation of the twentieth century are by the exalted, if not always successful conceptions of Conferences

1 Pliny, IX. 9: "Sed enixioris operæ, quam in unius diei præmium conscii sibi opperiuntur in posterum: nec piscibus tantum sed et intrita panis e vino satiantur."

2 In Lapland the "sea-swallows" render great aid in the salmon season. For some canse these small marine birds elect to follow the inward and outward course of the fish, and are thus infallible guides to the fishermen, with whom they become so tame that they will light on their fingers, and take, if not "the choicest of the spoil," scraps of fish. No wonder they are termed "The Luck-bringers." See S. Wright, The Romance of the World's Fisheries (London, I908), p. 69 . 
of Conciliation or Compulsory Arbitration, a strike, occasioned either by divergence from the strict terms of the bargain, or by gauche " handling " of the workers-whether for it the sanction of the Ballot or an order of the Shop Steward were a necessary preliminary my researches have not as yet disclosed-a strike, I repeat, could not be called off, but was irreparable, for oùкÉтı

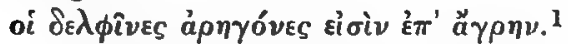

By the Dolphins the economic weapon was evidently brought to greater perfection than by their human brethren. The crude " down tooling " of the Egyptian masons in the fourteenth century B.C., although accompanied by violence such as forcing main gates, etc., was (according to Maspero) quickly settled by the attacked Governor handing over the keys of the granaries, whence with bags-and bellies-full filled they meekly returned to work.

Of another ingratiating characteristic of the Dolphin, its attachment and services to boys, instances are numerous and well attested. ${ }^{2}$ In truth we are compassed about with so great a cloud of witnesses, from the autoptic gospel of the AntiSemite Apion ${ }^{3}$ and of the wide-travelled Pausanias 4 to the

1 Oppian, hal., V. 447. In mediæval times instances of dolphins aiding fishermen are related by Albertus Magnus, De Animalibus, VI. p. 653, and by Rondolet, Libri de piscibus marinis, etc. (Lugduni, 1554-5), XVI. p. 47I. At the present day in Lake Menzalah porpoises shepherd the fish : the Egyptian, however, spares to his helpers their lives, but naught else. The natives of Angola were much more recognisant of service, as an interesting description by an old traveller of a fish drive there evidences: "They use upon this coast to fish with harping irons, and waite upon a great fish which cometh once a day to feed along the shoare which is like a grampus. Hee runneth very near the shoare, and driveth great skuls of fish before him; the negroes runne along and strike their harping irons about him, and kill great store of fish, and leave them in the sand till the fish hath done feeding and then they come and gather up the fish. This fish will many times runne himself aground, but they will presently shore him off again, which is as much as four or five men can doe. They call him Emboa, which is in their speech a Dogge : and will by no means hurt or kill any of them." The Strange Adventures of Andrew Battell of Leigh in Essex. (Haklutus Posthumus or Purchas his pilgrimes (ed. Glasgow, 1905-7), vol. VI. P. 404.)

2 The evidence is collected and discussed by $\mathrm{K}$. Klement, Arion (Wien, 1898), pp. I-64, and by H. Usener, Die Sintfluthsagen (Bonn, 1899), pp. I $38-180$.

Aegyptiaca, book v. frag. 6 (Frag. hist. Gr., III. 5Io f. Müller).

- Pausanias, III. 25. 7, recalls that among the votive offerings at Tænarum " is a bronze statue of the minstrel Arion. Herodotus tells his story from hearsay, but I have actually seen the Dolphin at Poroselene that was mauled by fishermen and testified its gratitude to the boy who healed it. I saw that Dolphin answer to the boy's call, and carry him on his back when he chose to ride." 
gleanings of the industrious A. Gellius, ${ }^{1}$ that I can draw attention to two stories only. These illustrate the relations existing between the Dolphin, and (a) the boy of Bair as set forth by Pliny (IX. 8), and (b) the boy of Iasos by Oppian (V. 468), Athenæus (XIII. 85), and Elian (VI. I5). ${ }^{2}$

In the last two occurs the pretty tale of the fish waiting daily till school ended to take the beloved lad for swims and larks in the sea, but without the refinement found elsewhere of waiting every morning and afternoon to carry him to and from school! To the spectacle in Iasian waters of their play and of their races (" to bring the thorough-bred and the donkey together " à la Admiral Rous, the fish must have been crushingly handicapped !) :

" Drawn by Report to see the strange Amour Admiring Nations crowded to the Shore.

Rapt with delight, surveyed their am'rous Game And owned the Sight superior to the Fame."

But alas! soon was "their am'rous Game" to end.

One day the lad, tired and eager for a bathe, threw himself on his comrade's back, only however to impale himself on the dorsal spike and gradually bleed to death. No sooner did the Dolphin perceive the water tinged with blood, than " with the force of a full-sailed Rhodian ship," he drave straight for land, flung himself and his burden high and dry on the strand, and there, by the side of his beloved dead, abode until death came unto him also.

To testify that these twain "were lovely and pleasant in their lives, and in their death they were not divided," the citizens of Iasos erected a monument, showing the beautiful boy astride the back of the Dolphin, and issued coins bearing the effigies of each, which were sought far as souvenirs by bands of pilgrims attracted thither by the story. In such regard

1 Noctes Attica, 6. 8. I-7.

2 For instances in classical mythology of rescues from drowning, and of corpses brought ashore, see A. B. Cook, Zeus (Cambridge, 19 I 4), i. p. r 7o, and for similar hagiographical instances, see S. Baring-Gould, The Lives of the Saints (London, I873-82), passim. C. Cahier, Caractéristiques des Saints dans l'art populaive (Paris, I867), ii. 69r ff., gives an account full of interest, which is increased by his illustrations of Saints accompanied by fish. 
did the legend continue to be held that even up to the third century B.C. the Iasians struck coins with the device of a youth swimming beside a dolphin, which he clasps with one arm.1

Like Scylla, who "fishes for dolphins and whatso greater beast she may anywhere take," both the Thracians and Byzantines, despite the enormous annual revenues derived by the latter from their fisheries, caught and ate the Dolphin, and for so-doing are branded as impious and barbarian. ${ }^{2}$ The more ancient Byzantine coins show a cow standing on a dolphin, which perhaps symbolises the heifer crossing the Bosporus. ${ }^{3}$

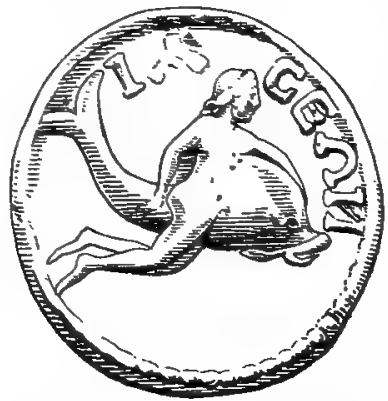

THE DOLPHIN AND THE BOY OF IASOS.

From Coin, British Museum, Cat. Pl. 21. 7.

The ancient literature of the East also portrays Dolphins (Çi çumâras) as the ready helpers of man, in rescuing lives, in drawing ships, etc. ${ }^{4}$ The inhabitants of Isle Sainte Marie, near Madagascar, even now never harm or eat the fish, holding it as sacred, because they believe it rendered signal service to some ancestor. ${ }^{5}$

Herodotus mentions a tribe living round Lake Prasias, who in dwellings and food resemble the Wolga folk, and early Continental and English Lake-dwellers :-

"Platforms supplied by tall piles stand in the middle of the lake, which are approached from the land by a narrow

1 Brit. Mus. Cat., pl. XXI. 7. B. V. Head, Historia Numorum, 620 f. (ed. 2, Oxford, I9I I). In Plutarch's (de Sol. Anim., 36) the lad was thrown from the fish's back by a terrible shower of hail and was drowned.

2 Oppian, hal., V. 52 I ff.

2 B. V. Head, op. cit. p. $266 \mathrm{ff}$. As an emblem of the sea the dolphin is very general, from the rude sculpturings of Etruscan sarcophagi, the later mural adornments at Pompeii, down to the paintings of the walls of the Vatican by Raphael. In all, the striking dissemblancy to the actual dolphin of natural history can be remarked at a glance. In the case of Raphael, however, it must be remembered that the designs are modelled on the classical decorations which were discovered in the Baths of Titus, where the Dolphin had been with propriety introduced as a marine symbol (Moule, Heraldry of Fish, p. 8).

4 De Gubernatis, Zoological Mythology (London, I872), ii. 336.

- Frazer, Totemism and Exogamy (London, I910), ii. 636. W. A. Cork, op. cit., p. 96, states that the Karayas of the Amazon Valley, although eating nearly every other fish, abstain from the Dolphin. 
single stage. At first the piles were fixed by all citizens, but since that time the custom that has prevailed about fixing them is this, every man drives in three for each wife he marries. Now the men all have many wives apiece, and this is the way they live. Each has his own hut (wherein he dwells) on one of the platforms, and each has a trap door, giving access to the lake beneath : their wont is to tie the baby children by the foot with a string, to save them from rolling into the water. They feed their horses and other beasts on fish, which abound in the lake in such a degree that a man has only to open his trap door, and let down a basket by a rope into the water, and then wait a very short time, when he draws it up quite full of fish." 1

Confirming and illustrating Herodotus's account (I. 202) of how a tribe dwelling on the Araxes lived on raw fish, ${ }^{2}$ but depicting more sharply how on fish a whole people were dependent for everything that made up their lives, comes Arrian's description ${ }^{3}$ of the Ichthyophagi of the Persian Gulf.

Denied by the barrenness of their country the ordinary sources of subsistence, they were compelled to use fish for every purpose-food, clothes, houses, etc. These peoples (for the Indian Ichthyophagi are quite distinct from the Arabian) find comment by many authors-e.g. Strabo, Pausanias, Diodorus Siculus. Although by their diet of fish comparatively free from disease, they were noted as short-lived. Alexander the Great, with a view to increasing their span of existence, forbade all the Ichthyophagi an unmixed diet.

Solinus $(56,9)$ testifies as to their extreme swiftness in swimming : non secus quam marince beluce nando in mari valent. Marco Polo (III. 4I) found on the coast of Arabia an interesting survival of the Ichthyophagi. In consequence of the sterility of the soil they fed their cattle, camels, and horses on dried fish, "which being regularly served to them they eat without any signs of dislike. They are dried and stored, and the beasts

1 V. I6, Rawlinson's Translation.

2 See also I. 200, where three Babylonian tribes exist only on fish which they dried in the sun, brayed in a mortar, and strained through a linen sieve.

8 Indica, 26. 
feed on them from year's end to year's end. The cattle will also eat these fish just out of the water."

Not dissimilar is the account given ${ }^{1}$ some twelve centuries earlier of the people of Stobera in India. "They clothe themselves in the skins of very large fishes, and their cattle taste like fish and eat extraordinary things : for they are fed upon fish, just as in Cairo the flocks are fed on figs."

In strong contrast with these Ichthyophagi other races abstained entirely, not as the Egyptians and Jews partially, from fish. Of such were the Syrians, either because they worshipped fish as gods or held them as sacred, ${ }^{2}$ or because (as asserted by Anaximander) of the inhumanity, since mankind originally were born from fish, of devouring one's fathers and mothers. ${ }^{3}$

Surprising, indeed, sounds the statement of Plutarch that among total abstainers in early times were the more religiousminded of the Greeks, among whom later the eating of fish developed into a passionate, almost cat-like, devotion. Invested though the abstentions, total or other, were with divine origin or armed with divine sanction, the root reason of all of them rested, I believe, on the terror of skin-diseases, attributable to a

1 Philostratus, The Life of Apollonius of Tyana, III. 48.

2 Xenophon, Anab., I. 4 ; Cicero, de nat. Deorum, III. 39 ; Ovid, Fasti, II. $473-4$.

3 Very different was the behaviour of the first generation of Man (who according to Philo's Translation of Sanchuniathon, quoted by Eusebius, prap. $e v .$, I. 9, 5), " consecrated the plants shooting out of the earth, judged them gods, worshipped them, but yet lived upon them" (Cf. de Brosses, Culte des Dieux Fétiches). In Plutarch, Symp., VIII. 8. 4, Nestor states that "the priests of Poseidon never eat fish, for Poseidon is called the Generator; and the race of Hellen sacrificed to him as the first father, imagining, as likewise did the Syrians, that Man rose from a liquid substance, and therefore they worship a fish as of the same production and breeding as themselves, being in this matter more happy in their philosophy than Anaximander: for he says that fish and men were not produced in the same substance, but that men were first produced in fishes and, when they were grown up and able to fend for themselves, were thrown out and so lived on the land. Therefore, as fire devours its parents, that is the matter out of which it was first kindled, so Anaximander, asserting that fish were our common parents, condemneth our feeding upon them." The belief in the descent of man from fish exists in the present day among the Ponapians of the Caroline Islands, and elsewhere (J. G. Frazer, Folk Lore in the Old Testament (London, I9I8), i. 40). As regards the changes in our development which make the whole world kin, Empedocles,

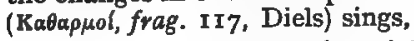

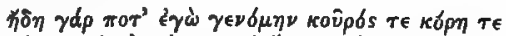

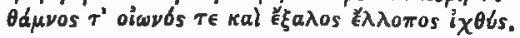


fish diet. ${ }^{1}$ Others, however, hold that the ultimate reason of the tabu lay in the uncanny nature of creatures that can and do live under water, while we can not.

Fishermen rank higher in the time of Herodotus than in the Homeric era. Even the oracles and soothsayers now condescend to avail themselves of their technique and parlance for framing their answers. Thus Amphilytus the Acarnanian encourages Pisistratus before the battle of Pallene with

"The casting net is thrown down, and the fishing net spread wide. And the tunnies shall dart to and fro (therein) in the moonlight." 2

If Pisistratus squared the Acarnanian, as effectively as the Alcmæonidæ (his hereditary foes and the ejectors of his descendants from Athens) absolutely bought the oracle at Delphi, words of greater light and leading than "The Tunnies shall dart to and fro in the moonlight" might have been vouchsafed, for Herodotus relates that Pisistratus fell on the enemy, when they were having their mid-day meal, or asleep after it, or playing dice. To suppose that these words foretold and were understood by Pisistratus to foretell the hour of the subsequent capture of Athens itself presumes a power of mental suggestion, which even Charcot would have envied.

The deliverance may possibly have been particular as regards time, but more probably was, oracle-like, entirely general in terms and time. The words "And the tunnies shall dart up and down in the moonlight" merely continue the fishing analogy of the first line, and refer to the well-known method of catching Tunnies "at the full of the moon," when, allured by the silvery light, they glide and race through the water, and are easily taken.

The mention here of the Tunny makes appropriate some notice of a fish, which looms large in nearly all our authors. Most of them dilate at length on its multitude, migrations, habits, and size. Its economic value as a food asset, then and

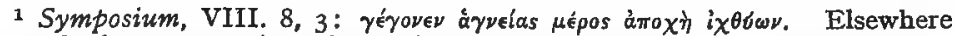
we read of more prosaic and practical reasons why the great majority of the Greeks abstained from certain kinds of fish, e.g. the fear in the case of the loach, of which the Syrian goddess was protectress, lest she gnaw their legs, cover their bodies with sores, and devour their livers.

2 Herodotus, I. 62. 
now, finds ample recognition by writers separated over two thousand years (such as Aristotle and Apostolides), and in its current title of "The Manna of the Mediterranean."

It is curious that the first two fish, the Dolphin and Tunny, on which I have occasion to comment because of the chronological sequence of Hesiod and Herodotus, should have greater

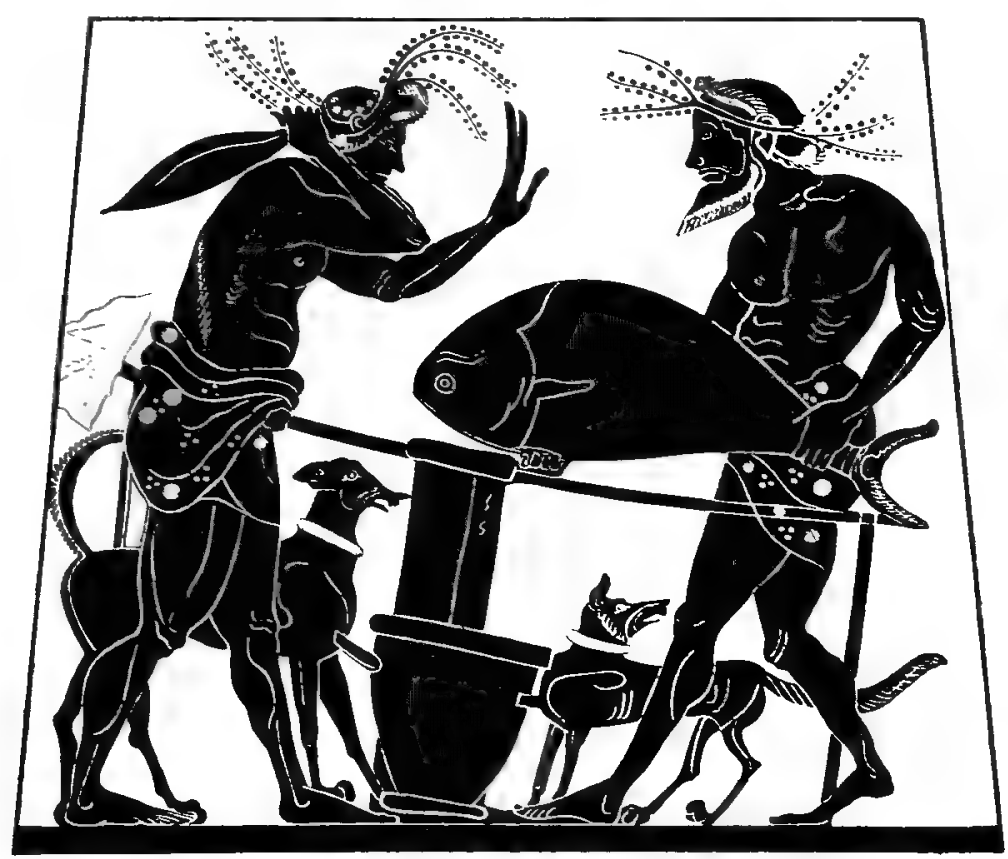

CUTTING UP THE TLNNY.

From Gerhard, Aus. Vas., Pl. 316, 2.

attention paid them and should occupy more space in ancient writers than any other.

The reasons, however, are very dissimilar.

The Dolphin by its engaging habits of aidfulness and of comradeship-to it scarcely anything human seems alienevoked gratitude and liking. The Tunny, apart from the wonder awakened by its multitudes and migrations, compelled an economic interest from its food-producing quantities and qualities. Rhode has excellently summarised the dissemblance: 
"THE MANNA OF THE MEDITERRANEAN" IOI

"Delphinus veterum cordibus atque animis se insinuavit, thynnus gulis atque ventriculis." I

The annual campaign of the Tunny fishing, lasting from May I 5 to Oct. 25, was based on a regular and thorough organisation. All the boats of a given section of the coast acted under the orders of an elected Captain, whose word was law.

Descriptions of fishing for Tunny and Pelamyde-the name given to the young Tunny from his habit of burying himself in the mud ( $\pi \dot{\eta} \lambda \omega \mu \dot{v}_{\epsilon}(v),{ }^{2}$ a derivation often attributed to Aristotle, see $H$. A., VIII. I5, or of herding together ( $\pi^{\prime} \varepsilon \varepsilon \varepsilon \nu$ ä $\mu$ a) according to Plutarch-may be found in Aristotle, $N . H$., IV. Io, and VIII. ${ }_{5}$, in Pliny, H. N., IX. 53, in Elian, de nat. an., XV. 5 and 6, and in Oppian, hal., IV. 53I ff. The story by the last of the Thracians piercing and taking myriads of mutilated Pelamydes from the mud, in which they have for warmth ensconced themselves, merits reading if only for his indignant burst :

"The various Tortures of the bleeding Shoal

Command a Pity from the stoutest Soul." 3

Aristophanes (Hipp., 3I3) compares Cleon to the watch posted on a cliff or height to signal the advent of the Tunnies, a position (as Theocritus (III. 26) and Oppian (hal., IV. 637) show), very similar to that of the "Hooer" in the pilchard fishery of Cornwall at the present day.

These look-outs were frequently artificial. Elian, de nat. an., XV. 5, describes a scaffolding consisting of two fir trees between which many cross pieces were fastened. The long

1 Paulus Rhode, Thynnorum Captura (Lipsiæ, I89o). Had his exhaustive monograph come to hand earlier, this notice would have been worthier, and much time spent on Aristotle, Oppian, etc., have been saved.

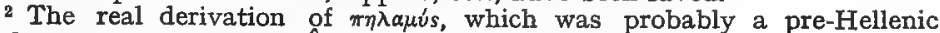
word, seems unknown: see $\hat{E}$. Boisacq, Dictionnaire Etymologique de la langue grecque (Paris, I9r3), p. 779.

${ }^{8}$ Their method was to let down by a rope from the boats blocks of wood (heavily weighted with lead) to which were attached great spikes and hooks, which on reaching the bottom were drawn to and fro, with the result that " here gasping Heads confess the killing Smart, | There bleeds a Tail, which quivers round the Dart." Cf. a fragment from Menander's The Fisherman, frag. I2 in the Frag. comicor. Graec., IV. 77, Meineke, "The muddy sea which nourishes the great Tunny." Sophron's Tunnyfisher seems the earliest mime, where this fish figures. 
ladders still used in Austria and Italy (of which Keller gives an illustration l) and the Turkish dalian of the Bosporus represent the modern scaffold. Oppian (hal., III. $630 \mathrm{ff}$.) and Elian (de nat. an., XV. 5) note the enormous hauls made by the fishermen when "the army" of the Tunnies set out on its migrations, company by company.

The nets used for the capture of Tunny by the Italians (at the present day) are fixed: made of thick cord, without leads, and sometimes as much as 250 fathoms long, and I5 fathoms deep, thus recalling Oppian's "a Town of Nets." 2 Special regard has to be paid now as of old, in fixing their position, to the course frequented by this eminently migratory genus in its annual passage from the Atlantic to the Black Sea and Sea of Azov, a distance of 2800 miles and back again. The same route is always travelled by an ever living stream of undiminished fulness, furnishing food to millions on the Mediterranean.

To the Phœnicians and to the Spaniards of old the Tunny ranked high as a commercial asset. The Tyrian tunny was specially prized ${ }^{3}$; its salsamentum travelled far and wide. Rhode (p. 38) points out, however, that this originally was designed not as a delicacy, but as a preventive against scurvy and other diseases attendant on the long voyages which the far-flung commerce of the Phœnicians demanded.

The older port, Sidon, got its name from its wealth of fish, which in Phœnician was called Sidon, ${ }^{4}$ while Tyrus, one of the earliest inhabitants of the younger port, traditionally invented fishing tackle. ${ }^{5}$ Many Spanish towns, as their coins attest, notably those of Gades and Carteia, owed much of their prosperity, if not their existence, to the salt or pickled fish

1 O. Keller, Die Antike Tierwelt, vol. ii. 388, fig. I22. This work (published at Leipzig a year before the War) unfortunately came into my hands only when I had practically finished my book, and thus I have been precluded from the more copious use of the Fische portion, which I should have desired and which it would certainly have demanded. The seventy pages dealing with fish form a compact treasure-house of ichthyic literature, but owing perhaps to their scope lack piscatorial interest.

2 Faber, Fisheries in the Adriatic, London, I883.

According to Pollux, VI. 63.

- Justin, XVIII. 3, 2.

- Cf. Ezekiel, XXVI. 5, I4. 
trade. Tunny fishing still remains a lucrative industry in the Peninsula. ${ }^{1}$

Pliny bears witness to the full stream of Tunny in IX. 2, where he tells us the multitude of the fish which met the fleet of Alexander the Great under the command of Nearchus on one occasion was so vast, that only by advancing in battle line, as on an enemy, was he able to cut his way through: non voce, non sonitu, non ictu, sed fragore terrentur, nec nisi ruina turbantur. ${ }^{2}$

Faber's account of the watchman, of the alarm caused by throwing in stones near the inlet through which the shoal of fish has just passed, of the raising of the hue and cry to drive it towards the end of the enclosure, the battering of the fish to death with oars, and of other devices might well pass, although written in the nineteenth century, for a description of the Tunny fishing by an author of the first century.

From this fishing Eschylus ${ }^{3}$ drew his vivid image of the destruction of the host of Xerxes at sea-an image placed with more poetic than dramatic aptness in the mouth of the Persian messenger who paints the battle to Atossa. " But the Greeks," he tells her, "kept striking, hacking us with fragments of oars and splinters of wrecks, as if we were Tunnies or a draft of fish."

The comparison strikes as all the more telling, when we remember that one of the most killing methods of capturing the Tunny was and still is by stabbing with pikes and poles the fish, after having driven them into a narrow space.

Imagine the storm of applause, which that bold and glowing picture (in but two lines !) of the common practice and of the wondrous victory must have aroused from an audience who eight years before had either fought at or feared for Salamis, to an author whose conspicuous gallantry both there and at Marathon had earned for him the high honour of a place in the great commemorative fresco in the Stoa Poikile at Athens!

1 Cf. the allusion of Cervantes: dos cursos en la academia de la pesca de los atunos.

Arrian (Ind., XXX. I) and Strabo (XV. I2, p. 726) tell the same story of whales in the Indian Ocean.

3 Persa, 424 ff. 
Phædimus states: "The Tunny is so sensible of the equinoxes and solstices that he teaches even men themselves without the help of any astrological table." 1 Further, that being dim sighted, or as according to Æschylus " casting a squint-eye like a Tunny," the fish always coast the Euxine Sea on the right side and contrariwise when they come forth-“" prudently committing the care of their bodies to their best eye !"

Again, although the fish lack knowledge of arithmetic, they are yet so endowed that "they arrive in such a manner to the perfection of that science," that for mutual love and protection " they always make up their whole fry into the form of a cube and make a solid of the whole number consisting of six equal planes, and swim in such order as to present an equal front in each direction."

"The Tunny more than any other fish delights in the heat of the sun. It will burrow for warmth in the sand in shallow waters near the shore, or will, because it is warm, disport itself on the surface of the sea." 2 With this pleasure inevitably surgit aliquid amari, for about the rising of the Dog-star this fish, as well as the sword fish, became the prey of a piercing parasite, which was nicknamed the " gadfly."

The ordinary weights and sizes to which the Tunny attained are uncertain. The passages in Arist., N. H., VIII. 30, and in Pliny, IX. I7, on account of the doubt whether the span of tail should be two or five cubits are not authoritative. Richter records the capture in 1565 of a fish thirty-two feet long and sixteen feet thick, on whose skin a ship of war was depicted in its entirety. ${ }^{3}$

The power of the skin to expand seems the only limitation of their size and weight, for they take on fat till they burst. 4 No wonder that for beasts of such dimensions the Celtæ used great iron hooks, ${ }^{5}$ which elsewhere were double. ${ }^{6}$ But their

1 Plutarch, de Sol. Anim., ch. 29.

Arist., N. H., VIII. I9.

Ichthyol., II. p. 376 .

- Pliny, N. H., IX. 20, on the say-so of Arist., N.H., VI. I6, "pinguescunt in tantum ut dehiscant."

5 Elian, de nat. an., XIII. I6.

- Oppian, hal., III. 285. 
devices met defeat by these "Fat" (if not somnolent) "Boys" of the Sea, for teste Oppian,

"Oft on the Spikes that arm the indented Chine Rolling averse they sawed the trembling Line."

The Tuna of the Canadian and Californian coasts run very heavy: one of the former caught on a Rod and Line weighed $707 \mathrm{lbs}$. 


\section{CHAPTER V}

ARISTOTLE-THE FIRST "SCALE-READER" ; THE 'FIRST TO DISCOVER THAT IN THE MUREX ITS YEARLY GROWTH IS INDICATED BY THE SHELL-SENSES OF FISH : EXPERIMENTS AS TO HEARING

"Aristotle hath his Oare in every Water"

IF the passage quoted in my Introduction left any doubt that Plato was no admirer of fishing or fishermen, the following, from The Laws, VII. 823 (Jowett's translation), is conclusive proof.

"And, now, let us address young men in the form of a prayer for their welfare: O Friends, may no desire of hunting in the sea, or of catching the creatures in the waters, ever take possession of you, either when you are awake, or when you are asleep, by hooks, with weels, which latter is a very lazy contrivance, and let no desire of catching men, or piracy by sea, enter into your souls."

Then Plato adds : "Only the best of hunting is allowed at all, which is carried on by men with horses, dogs, and men's own persons," and is really hard exercise. "Fishing is not an occupation worthy of a man well born or well brought up, because it demands more of address and ruse than force, and is not for young people, like hunting, the occasion of healthy exercise." 1

1 Byron's view of fishing is not favourable-as his lines in Don Juan, Canto XIII. prove :

Angling, too, that solitary vice,

Whatever Isaak Walton says or sings."

He bore, possibly from failure to catch his boyish Aberdeenshire trout, a grudge against Father Izaak,

"The quaint, old, cruel coxcomb in his gullet

Should have a hook, and a small trout to pull it." 
When expressing astonishment at the variety and extent of Aristotle's knowledge, one of the characters of Athenæus asks from what Proteus or Nereus he could have found out all he writes about fishes and other animals. 1 The curiosity of the questioner was natural. It is, however, probable that Aristotle, from living for several years close to the sea and from his intercourse with fishermen, had amassed a big fund of information about fishes and other aquatic animals.

His knowledge of the Mediterranean fishes not only exceeded that of any ancient writer, but also, if Belon, Rondolet, and Salviani be excepted, that of any writer before Risso and Cuvier. However true may be the criticism of Dr. Günther that Aristotle's "ideas of specific distinction were as vague as those of the fishermen whose nomenclature he adopted," the fact cannot be gainsaid that Aristotle was; and remains, a very great Naturalist as well as a very great Biologist.

To him ${ }^{2}$ by right belongs the distinction, which (except incidentally in Mr. Lones' work ${ }^{3}$ ) I have so far failed to find

Byron closes his note with " But Anglers! No Angler can be a good man." Walton received many a shrewd blow, especially from his contemporary Richard Franck, whose Northern Memories, with its appreciation of the Fly and its depreciation of Izaak's ground-bait, found less favour than the Compleat Angler. His worsting of Walton at Stafford runs, "he stop'd his argument and leaves Gesner to defend it: so huff'd a way." Again, " he stuffs his book with morals from Dubravius-not giving us one precedent of his own experiments, except otherwise when he prefers the trencher to the trolingrod! There are drones that rob the hive, yet flatter the bees that bring them honey."

1 Deipn., VIII. 47. Rabelais would seemingly make Aristotle his own Proteus, for Pantagruel (IV. 3I) discovers him with his lantern at the bottom of the sea spying about, examining, and writing. This lantern has long been coupled with that of the Sea-urchin, but as a few pages later on we find ourselves in the Pays des Lanternois, it is probably a reference to a philosopher's lamp, like that of Diogenes.

2 'The Natural History (of which the text I use is Bekker's) is practically" the only work by Aristotle discussed here. For me, being no "Clerk" although " of Oxenford," it is not, as-

\footnotetext{
"For him was lever have, at his beddes heed,

Twenty bokes, clad in black or reed,

Of Aristotle and his philosophye,

Than robes riche, or fithele, or gay sautrye."
}

'Aristotle's Researches in Natural Science, by Thomas E. Lones (Igr2), from whose book I borrow and to whose kind advice I owe much. At last we have a really admirable translation of Hist. Anim., which is by Prof. D'Arcy Thompson, Oxford, Igro. The notes are those of an expert zoologist, thoroughly familiar with classical literature. 
attributed to him, of being the first writer to note, certainly the first to point out, that its scales make possible a shrewd, in the case of the murex an exact, computation of the age of a fish.

If from lack of the microscope he did not in all particulars antedate, he certainly blazed the trail for the discovery of scale-reading at the close of the eighteenth century by the Dutch microscopist van Leeuwenhoek ${ }^{1}$ and its rediscovery as regards the carp in 1899 by Hoffbauer, ${ }^{2}$ the Gadide and Pleuronectida in $1900-03$ by J. Stuart Thomson, 3 and the Salmonidae about Ig04 by H. W. Johnston and others. ${ }^{4}$

He tells us in The Natural History, I. I, that " what the feather is in a bird, the scale is in a fish " ; in III. II, "5 that " the scales of fish become harder and thicker, and in those which are wasting or aging, become still harder" ; in VIII. 30, that "the old fish are distinguishable by the size" (note this!) "and the hardness of their scales." 6

He then buttresses this discovery of annual growth of scale by another fact resulting from his observation that "the Murex lives for about six years, and the yearly increase is indicated by a distinct interval in the spiral convolution of the shell," " or as Bohn renders the words, "its annual increase is seen in the divisions on the helix of its shell."

In Leeuwenhoek ${ }^{8}$ we read that, in the examination by

1 Select Works, vol. i. p. 69. London, 1798-1801.

2 "Die Altersbestimmung des Karpfen an seiner Schuppe," in the $R$. Jahresber. des Schlesischen Fischerei-Vereins für I 899.

3 "The periodic growth of Scales in Gadidx and Pleuronectidx as an Index of Age," in the Journal of the Marine Biolog. Assoc. (I900-03), VI. $373-375$.

Reports of Scottish Fishery Board, 1904, 1906, 1907.

- Cf. Anim. Gen., V. 3.

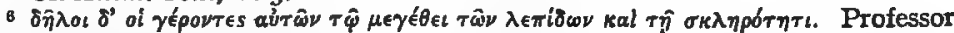
D'Arcy Thompson, in his translation, renders this sentence "the age of a scaly fish may be told by the size and hardness of the scales." It is most probable, though not a certainty, from contextual reasons, from Aristotle's habit of casually harking back, and from Pliny in his translation of it (N. H., IX. 33) applying it generally, that this sentence applies to all fish, and not solely to the Tunny.

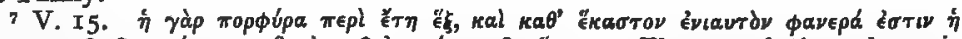

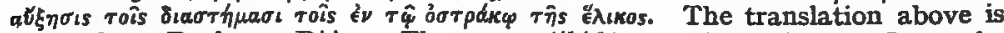
taken from Professor D'Arcy Thompson (ibid.), to whose kindness I owe the following reference and much else in this chapter. Pliny, IX. 60, makes the Murex live seven years.

\& Select Works, I. 69, London, I798-1801. 
a rough self-made microscope of the scales of a large tame carp, he counted the component scale-layers lying one above the other, "as if glued together," and found without exception that a new layer larger than the one of the preceding year is added. The carp, accidentally killed when forty years old, possessed forty such layers in each scale. He adds pathetically-anticipating perhaps Lytton's-

"A Reformer, a creed by posterity learnt

A century after its author is burnt "-

that " many people accused me of telling lies on the matter!" 1

One cannot help being struck with acute astonishment that for over the 2000 years between Aristotle and Leeuwenhoek we obtain, with the exception ${ }^{2}$ of nine words in Pliny (IX. 33), Senectutis indicium squamarum duritia, qua non sunt omnibus similes, cribbed and condensed, as was often his wont, from Aristotle, little, if any, addition to our knowledge of scale-reading.

The ancient authors either ignore or are ignorant of it. Nowhere, not even in that close observer Oppian, that omnivorous reader Athenæus, that pleasant purloiner Ælian, do we read a single line on the subject. But our astonishment, even if we allow for absence of microscope, grows acuter, when we are met in the three most important Ichthyologists before the eighteenth century, Belon, Salviani, and Rondolet, with the same silence.

And this fate of silence apparently prevails even after Leeuwenhoek's book; his discovery seems to have been lost or remained dormant in his pages till a score of years ago.

Had microscopes existed in his day, we may surely surmise that Aristotle would have perfected the system of scalereading, and thus have come down to posterity with his title

1 In Epistola physiologica (Delft, I7I9), IV. p. 40I, he describes how the squamula or scalelets of a herring (twelve years old) were found regularly superimposed, each year's growth on that of the preceding year.

" Athenæus, referring, however, solely to the Murex, "their growth is shown by the rings on their scales," is simply quoting from Aristotie (as Dindorf's text makes plain), whose term of six years he adopts: pavepd $\delta^{\prime} r^{\prime}$

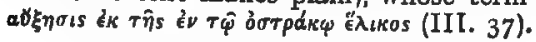


of "The Philosopher of the many Rings" better earned than by his foppish affection for jewellery.

In general opinion, the person most closely approaching the required Proteus or Nereus was his pupil and sometime friend, Alexander the Great. By placing at his disposal several thousand men to collect all kinds of animals and fishes from all parts of the then known world, he enabled him with the aid of the materials thus provided to produce his famous Natural History.

For this identification we have not a scrap of internal evidence, but merely the assertions of much later writers, such as Pliny, Athenæus (who adds that Philip gave him 800 talents to finish the History), and Elian. 1

Apart from want of intrinsic evidence, the fact that the geographical references and the fish mentioned in his Natural History nearly all cluster round Lesbos effectually precludes the idea of Alexander "Hagenbecking " for Aristotle. ${ }^{2}$

Internal evidence and reasons advanced by Professor D'Arcy Thompson ${ }^{3}$ indicate that nearly all the animals and fishes with which Aristotle was practically acquainted belonged to Greece, Western Asia, and Sappho's Lesbos (especially of the lagoon of Pyrrha), where he lived some four years just previous to his Macedonian trip, 343 B.C.

The fishes in his Natural History, mostly given without any attempt at classification or really adequate description, number at least one hundred and ten. He discusses in some instances the anatomical characteristics, food, breeding habits, migrations,

1 Plin., Nat. Hist., VIII. I 7; Athen., Deipn., IX. 58; AEl., Var. Hist., IV. 19.

2 On the other hand, Abu-Shâker, an Arab writer of the thirteeth century, makes Aristotle the material benefactor of Alexander by his present of a box in which a number of wax figures were nailed down. These were intended to represent the various kinds of armed forces that Alexander was likely to encounter. Some held leaden swords curved backwards, some spears pointed head downwards, and some bows with cut strings. All the figures were laid face downwards in the box. Aristotle bade his pupil never to let the key out of his possession, and taught him to recite certain formula whenever he opened the box. This is only another use of magic, for the wax, the words of power, and the position of the figures all indicate that his foes would become prostrate and unable to withstand Alexander. See Budge, Life of Alexander the Great (one vol. ed.), p. xvi.

3 See D'Arcy Thompson, Aristolle as a Biologist, Herbert Spencer Lecture, Clarendon Press, Oxford, I913, p. 13. 
and modes of capture. Of the hundred and ten only some fifty fish can be scientifically identified; of which, all save six come from the sea.

This figure of about one hundred and ten speaks wonders for his industry and knowledge. Even after the lapse of 1800 years separating him from the sixteenth century, the list of Mediterranean fishes compiled by Belon comprises but a hundred or so, and by Rondolet but some one hundred and sixty names. Risso, writing as late as I8Io, furnishes no more than three hundred and fifteen, of which he asserts that eighty-eight had never been previously described.

Not unnaturally, this industry and this knowledge caused our author to be at Athens not only a stumbling-block unto the wise, but "a very wonder unto fools," as the comedians said, who fastened on an occasional lapse, such as his theory that the whole race of shell fish generate without connection.

The Natural History nevertheless will always remain a monument of extraordinary diligence and mental vigour, especially when we bear in mind that he seemingly lacked any antiseptic preparation for the preservation of specimens. His pre-eminence of merit is indicated by the fact that of all the Greek and Latin authors he approximates nearest to some idea of zoological system.

And yet this father of science and this founder of logic makes a direct personal appeal to us as a man very human in his life and tastes. Epicurus, "that most truthful of men," 1 alleges that, when young, Aristotle went the pace, and squandered his patrimony in good living and other pleasant delights. In addition to his love for jewellery and personal adornment we discover him as a great connoisseur of beautiful silver, of which he bequeathed over seventy rare bowls. He ranks in opsophagy as an epicure of the highest order.

It is curious to note that in Aristotle, who apparently was familiar with most, if not all, of the then existent methods, no mention, as far as I can recall, occurs of actual fishing, save his story of the fight and escape of a big Glanis.

$\mathrm{He}$ owed his knowledge largely to his intercourse with 3 Athen., VIII. 5o. 
fishermen and his close acquaintance with the fish marketsa haunting of which in Mediterranean ports was, as in Naples it still is, productive of a liberal education from the numerous specimens displayed and the hundreds of vernacular names applied to them.

Contrast this with our British markets, where, despite our more favourable wealth of sea-harvest, the kinds on sale seldom exceed a score or so, and their vernacular names hardly reach half-a-hundred.

Granting, however, all the advantages accruing from such acquaintance ${ }^{1}$ with fishers and fishmongers, it needed an Aristotle to produce a book of such keen observation and (generally) accurate conclusions as his Natural History : for be it remembered that this, when compared with the vast volume of his other works, is a mere by-product of his industry and intellect, thrown off probably in the few years of his banishment.

Little escaped his ken, or his pen. ${ }^{2}$ At one moment he notes that neither hermaphroditism nor parthenogenesis are uncommon, at the next he deals with the senses in fish. The question whether fish do actually hear or do not hear, remains, comme les pauvres, always with us; it remains like Etna dormant for decades, suddenly to pour forth columns of print which lava-like scar the fair face of many a ream of paper.

Aristotle comes down flat-footed in his verdict: fishes (we read, IV. 8) in spite of having no visible auditory organs undoubtedly do hear; "for they are observed to run away from any loud noises like the rowing of a galley. Indeed some people dwelling near the sea affirm that of all living creatures the fish is the quickest of hearing."

Space forbids my dwelling on the various theories as to

1 Cf. I. V. Carus, Prodomus Faunce Mediterranea, vol. II., Stuttgart, I889-93.

2 Of the closeness of his observation may be instanced (I) the development by the cuttle fish during the breeding season of one of his arms for transference to the mantle-cavity of the female-a function of which Cuvier himself was ignorant, and which was not rediscovered till the latter end of the last

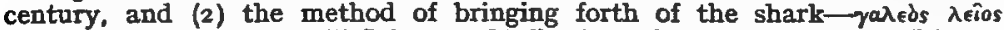
- which was forgotten, till Johannes Müller brought it to light. See D'Arcy Thompson, op. cit., pp. I9-21. 
. whether the undoubted effect of their being disturbed by certain noises is attained by hearing proper, or by vibration acting on the surface part of the fish and communicating instantly with the internal ear.

Day's summary of the question, still regarded after thirty years as fair and conclusive, even if attaching undue importance to the fontanelles, is as follows. "Hearing is developed in fish, and it is very remarkable how any diversity of opinion can exist as to their possessing this sense. The internal auditory apparatus is placed within the cranial cavity: its chief constituent parts are the labyrinth, which is composed of three semi-circular canals, and a vestibule, which latter expands into one or more sacs, where the ear bones or otoliths are lodged. A tympanum and tympanic cavity are absent. They possess fontanelles between the bones, forming the roof of the skull, which being closed by very thin bones or skin permit sounds from the surrounding water to be readily transmitted to the contiguous internal ears. But the chief mode in which hearing is carried on must be due to the surface of the fish being affected by vibration of the water, and the sounds are transmitted directly to the internal ear, or else by means of the air-bladder acting as a sounding drum." 1

It goes against the grain to differ with such a charmful and theme-ful author as Sir Herbert Maxwell. But his conclusion 2 that fish in Loch Ken were disturbed every time a shooting party half to three-quarters of a mile away discharged their guns cannot be reconciled with the experiments made by me in July IgI8 to test the behaviour of trout, when guns were fired, not half a mile away, but quite close to them.

Three of us, all accustomed to watching fish, selected a narrow shallow burn in which the trout ran from fingerlings up to fish three or four years old. Each in turn fired the gun (an ordinary I2 bore C.F.), with the usual shooting charge of powder and No. 5 shot. At the first two trials only was the shot extracted, so as to eliminate any vibration set up by its

1 British Fish: Salmonide (London, 1887), p. 19.

¿ Memories of the Months, Fourth Series (London, 1914), pp. 232-3. 
striking the opposite bank. Two of us lying hidden in the grass observed from different spots.

The gun was fired eight feet, four feet, and three feet above the surface of the stream, which varied in breadth from eight to ten feet, and in depth from sixteen to nineteen inches. It was fired into the air and into the opposite bank (struck from four to two feet above the water) in a direct line above different fishes, lying either singly or in shoals from five to nine inches from the bottom in small pools or runs sixteen to nineteen inches deep. Care was taken to fire up stream, to prevent the trout being startled by the flash of the cartridge.

In no case did the trout take the very least notice, or give any sign of having heard the explosion or felt the concussion of the shot on the opposite bank, composed on three occasions of alluvial soil and on two of rock. Never once did a fish move or go down: in fact, in one of the experiments over a single well-grown trout, the fish was rising again to the natural fly in less than thirty seconds after the discharge of the gun. ${ }^{1}$

Aristotle almost certainly learnt dissection when young. His father belonged to the Asclepiads, an order of priestphysicians who are believed to have practised dissection and taught it to their children. The son's extensive knowledge of the internal parts of mammals, birds, and fishes probably resulted from dissections. Mr. Lones names forty-nine animals and fishes which from the trustworthiness of the definite information imparted were (he holds) certainly dissected. Of these some five are fish.

To the question whether Aristotle ever dissected the human body, the answer after examining the evidence available must, I think, be in the negative, for three reasons. First : after describing the external parts of the human body he states that the internal parts are less known than those of animals, and that we must, in order to describe them, examine the corresponding parts of animals which are most nearly related to man.

Second : his many mistakes-such as in the position of the

1 The experiments conducted by Alfred Ronalds and recorded in his famous Fly-Fisher's Entomology, London, I862, had similar results. 
heart being above the lungs, the emptiness of the occiput, etc. - can hardly be casual slips made by one familiar with human dissection. The passage, however, in Nat. Hist., VII. 3, points distinctly to his having to some degree dissected the foetus.

But this would not conflict with the third and weightiest reason, namely the strong repugnance felt by the Greeks to any mutilation of the body proper and any neglect of speedy burial. The sad appeal of the shade of the unburied Patroclus (Il., XXIII. $7 \mathrm{I} \mathrm{ff}$. ) : " Bury me with all speed that I pass the gates of Hades. Far off the spirits banish me, nor do the phantoms of men outworn suffer me to mingle with them beyond the river," the fervent desire of some of Homer's Heroes that funeral rites should promptly follow their death, ${ }^{1}$ and the agony of Antigone, all these and other instances manifest Greek sentiment. So strong and widespread was this that human dissection would have certainly aroused intense bitterness and probably caused the perpetual banishment of the perpetrator. The suggestion, resting on no evidence, that Aristotle dissected the human body secretly can neither be proved, nor disproved.

The Japanese, till recently, also refrained from dissection of the human body. It was not till the arrival in 1873 of Professor W. Donitz to fill the Chair of Anatomy in the newly established Academy of Medicine in Tokyo that dissection first came to be employed. This new era of medical science started under the happiest circumstances, for frequent hangings, an aftermath of internal strife, provided ample material for its prosecution. ${ }^{2}$

1 "The belief, common later, that the soul of the dead was not admitted immediately to the realm of Hades, but wandered in loneliness on its confines until the body was either burned or buried, is clearly expressed only in this (Patroclus) passage, while possibly in only one other can it be assumed, in all the Homeric poems. The wish for speedy rites sprang from a simpler cause ; men did not want to have the bodies of their friends, or of themselves, torn by wild beasts or vultures: nor does this even begin to show that they had inherited old beliefs with regard to the connection between the soul of the dead and the body, which this soul had once inhabited, leading to a certain treatment of the body. That in earlier times, and perhaps by many Greeks of Homer's age, the soul was thought to maintain a species of connection with the body, and to care for it, cannot be doubted. But caution is necessary that it may not be assumed that the Greeks, who maintained certain customs, inherited also the beliefs on which those customs were originally based" (Seymour, op. cit., p. 462).

2 Professor G. H. Nuttall, in Parasitology (1913), V. 253. 


\section{CHAPTER VI}

CHARACTERISTICS OF FISHERMEN IN GREECE AND ROME -POVERTY "THE BADGE OF ALL OUR TRIBE"DEITIES OF FISHING

"Laud to the Lord, who gives to this, to that denies his wishes, And dooms one toil and catch the prey, another eat the fishes." 1

THIs seems the most convenient, if not quite the chronological, place for examining the position and attributes of fishermen in the poems, epigrams, and eclogues of Greek literature.

Of the two oldest of fisher-folk epigrams or epitaphs, the first is attributed to Sappho, the second to Alcæus of Mitylene. In these rings insistent the same note of hard toil and poverty, which permeates the piscatory eclogues of Theocritus and his followers.

From Sappho " the sole woman of any age or any country who gained and still holds an unchallenged place in the first rank of the world's poets " 2 comes down

"Meniscus, mourning for his only son, The toil-experienced fisher Pelagon, Has placed upon his tomb a net and oar, The badges of a painful life and poor." 3

I cherished high hope of finding in the recently discovered Fragments of Sappho in Part X. of the Oxyrhynchus Papyri,

1 Burton, Arabian Nights.

a Mackail, op. cit., p. 92 . Cf. Strabo's naive but curiously true phrase

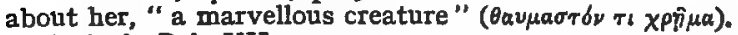

s Anth. Pal., VII. 505:

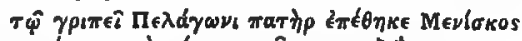

Translated by T. Fawkes.

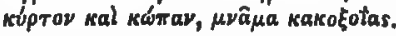


or in the articles on them by Mr. J. M. Edmonds in the Classical Revieve of May IgI4 and June I9I6, a second fisher epigram, or at any rate an allusion to fishing. Alas! the Papyri yield some amatory, but no piscatory verses. Apparently neither Sappho nor Alcæus make any other reference to fishing.

The verses of Alcæus stress poverty even more strongly:

"The fisher Diotimus had at sea

And shore the same abode of poverty-

His trusty boat-and when his days were spent,

Therein self-rowed, to ruthless Dis he went:

For that which did through life his woes beguile, Supplied the old man with a funeral pile." 1

"From fragments of Greek Comedy it is evident that fishers were among the familiar characters on the stage, and were sometimes the protagonists." Examination of the Old, Middle and New Comedians confirm Dr. Hall. ${ }^{2}$

In Epicharmus (B.C. 540-450) the reputed founder of Comedy in Sicily; in Sophron's The Fisherman and the Clown, where the former naturally outwits the country boor ; in Plato the comedian's Phaon, where he may have ridiculed the legend of Sappho's vain love for the Lesbian fisherman; in The Fishes by Archippus, where people were satirised under the names of fishes spelled in the same way as their own; or (to pass from Old to Middle Comedy) in The Fisher-Woman by

1 In Anth. Pal., VII. 305, this epigram is headed in the MS. 'A $\delta \delta$ alov

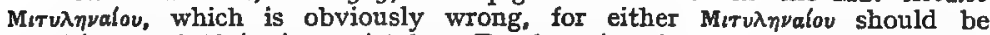

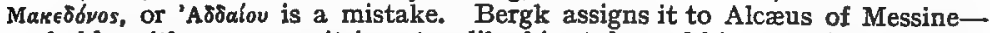
probably with reason, as it is not unlike his style, and his name is more than once confused with Alcæus of Mitylene, the famous lyric poet. (For Alcaus of Messene, see Mackail's Select Epigrams from the Greek Anthology (London, I890), p. 297 f.) Stadtmilller the latest editor of Anth. Pal. conjectures as author Alpheus of Mitylene, but unconvincingly to Mackail and other authorities. Translated by E. W. Peter-The Poets and Poetry of the Ancients, London, 1858 .

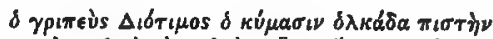

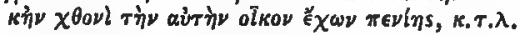

Cf. Etruscus Messenius, Anth. Pal., VII. 38r, 5 f.

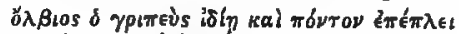

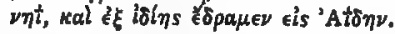

2 For this and other passages quoted or incorporated, I am greatly in debt to Dr. Henry Marion Hall's Idylls of Fishermen, New, York, I912 and I9I 4, and to A. F. Campaux's preface to his De Ecloga Piscatoris qualem! veteribus adumbratam absolvere sibi proposuit Sannazarius, Paris, 1859. 
Antiphanes (in the fragments of which, however, we are confronted by no Sex problem, by no Suffragettism 1) ; and (of the New Comedy authors) in Menander's The Fishermen (where we gather from Pollux that a fisher came on the stage fully equipped for fishing), in all these plays and many more appear fisher folk. ${ }^{2}$

Archippus' drama deserves a moment's notice, because in imitation of Aristophanes' Birds the poet ventured on a chorus composed exclusively of Fishes. Extant fragments of the play (performed probably in 4I3 B.C.) tell of war being declared by the fish against their oppressors the Athenians, who were passionate opsophagists. The principal condition of the Peace Points-whether Fourteen or more our data do not determine-secured the prompt delivery to the Fishes of the head of their chief foe, Melanthios.

If the protocol of this Treaty had attracted the notice of President Wilson, who as a constitutional historian attaches importance to the "broadening down from precedent to precedent," the demands of the Allies for the immediate surrender of our arch-enemy, the Kaiser, might have been more insistent and scarcely less successful.

And so from the first loci classici of fishing in Homer we journey on through the succeeding centuries. In nearly all we encounter fishing and fishermen in literature or play. In the third B.c. we reach the next locus classicus-" The Fisherman's Dream," Idyll XXI. of Theocritus.

"Theocritus is the creator of the literary piscatory, as he is also of the literary bucolic." This dictum would, I think, be rendered more accurate by the substitution of modeller in place of creator. Theocritus, even if we allow for Stesichorus, Epicharmus, and Sophron, stands out the first, not to create but to gather, and by his genius reduce to regular literary shape, the existent poems and songs (Volkslieder) which formed

1 And yet "the eternal feminine" question was to the fore very early, as we see from the old oracle quoted by Herodotus, VI. 77: "But when the female at last shall conquer the male in the battle, Conquer and drive him forth, and glory shall gain among Argives."

Poll., Onomasticon, 10, 52, and Io, 45. In later literature references, etc., to fish are countless : one of the lost plays of Aristophanes bore, indeed, the title of The Eel, according to Keller, op. cit., 357. 
the stock in trade of the Bucoliastæ in Cos, Sicily, and Magna Græcia. ${ }^{1}$

The influence of Theocritus on fishing literature in mime, epigram, or romance is writ large in the pages not only of Moschus, Leonidas of Tarentum, Alciphron, Plautus, Ovid, but also of Sannazaro in the fifteenth, of our Spenser ${ }^{2}$ and his followers in the sixteenth and subsequent centuries, and even of Keats. ${ }^{3}$

\section{This influence shows most widely in the more abundant}

1 This name was applied, according to Athenæus, XIV. Io, from the peculiar poetry made by those who kept cattle.

2 The Faerie Queen, especially Books I., II., III. Of the other writers, I simply cite (A) Piscatorie Eclogs, I633, and in a lesser degree Sicelides, I63I, of Phineas Fletcher, perhaps the most conspicuous writer of fisher Idylls in English, whom Izaak Walton terms " an excellent divine, and an excellent angler, and author of excellent Piscatory Eclogues"; (B) Nereides or Sea Eclogues (of which only one is strictly a fisher eclogue) published anonymously in I $7 \mathrm{I}_{2}$, but to be followed the next year by Dryades, by Diaper (translator with his fellow Fellow of Balliol of Oppian's Halieutica), which Swift commends to Stella as the earliest book of its kind in English, a statement which has been amplified into " the only book of its kind in any literature," for his Muse dives to a new Arcadia set in the coral groves of the deep sea, and thence evokes the characters of his Eclogues-" mermen and nereids who behave exactly like the personages in Virgil and in Sannazaro"; (C) William Browne, Britannia's Pastorals ( $16 \mathrm{I}_{3}-\mathrm{I} 6 \mathrm{I} 6$ ), in which fishing, although but incidentally introduced, is well and truly described, notably the passage in Book I., Song 5, about the capture of the pike; (D) Moses Browne (who endeavoured to show that Angling comes fairly within the range of the Pastoral), the author of the most popular of all English fishing idylls, Angling Sports in Nine Piscatory Eclogues, I729; (E) William Thompson's Hymn to May (I758); (F) John Gay, whose Ruval Sports (I7I3) is, however, more of an angling georgic than a piscatory eclogue.

The eclogue, piscatory or other, was severely criticised by Dryden, who complaining of its affectation that shepherds had always to be in love, roundly stated, "This Phylissing comes from Italy" ; by Pope, who found fault with Theocritus because of his introduction of "fishers and harvesters"; by Dr. Johnson, whose denunciation (in his essay, The Reason why Pastorals Delight) of Sannazaro for his introduction into the eclogue of the sea, which by presenting much less variety than the land must soon exhaust the possibilities of marine imagery, and known only to a few must always remain to the inlanders-the majority of mankind-as unintelligible as a chart, dealt possibly the coup de gráce to the English piscatory. See Hall, op. cit., I83.

3 It is indeed a far cry from Idyll XXI. to Endymion; still here, even though it be no piscatory eclogue, the fisher Glaucus recalls his Sicilian prototype. In Book II. 337 ff., for instance,

"I touched no lute, I sang not, trod no measures;

I was a lonely youth on desert shores";

and again,

"For I would watch all night to see unfold

Heaven's Gate, and Ithon snort his morning gold

Wide o'er the swelling streams, and constantly

My nets would be spread out." 
literary bucolic. Virgil, for instance, admits his model in the opening lines of Eclogue IV. :

\section{Sicelides Musa, paulo maiora canamus ...}

A recent writer straightly asserts that " without Theocritus the Bucolics (save the mark !) of Virgil could never have been conceived, or, if conceived, would have miscarried." 1

Whether or not the offspring of this parentage is not toc savagely depreciated, we note with surprise that Virgil,

" Thou that singest wheat and woodland, tilth and vineyard, hive and horse and herd;

All the charm of all the Muses often flowering in a lonely word,"

a professed imitator of Theocritus, to whom fishermen were as familiar as the waters by which they lived and figured in many of his Idylls, ${ }^{2}$ never mentions fishermen in his Bucolics.

His only (I believe) allusions to them-and the first is merely incidental to an account of the primitive Arts of Man, and how fishing as an Art came in only as the Golden Age went out-are in Georgic, I. I4I-2, Atque alius latum funda iam verberat amnem | Alta petens, pelagoque alius trahit humida lina, and in the Eneid (XII. 5I7 ff.):

Et iuvenem exosum nequiquam bella Menæten, Arcada, piscosæ cui circum flumina Lernæ Ars fuerat, pauperque domus, nec nota potentum Munera, conductaque pater tellure serebat. ${ }^{3}$

Even in these four lines observe how insistently rings out the note of poverty! - the constant characteristic, the almost invariable badge, as we shall soon see, of every professional

1 Moses Browne in the introductory essay to his Angling Sports in Nine Piscatory Eclogwes asserts that Servius allowed only seven of Virgil's Bucolics to be pure pastorals, while Heinsius for similar reasons rejects all but ten of Theocritus's Idylls.

1 I. 39 ff. : III. 25 f. ; IX. 25 ff.; and especially in XXI.

With the execrable taste of his age Sannazaro considered himself bound to produce stall paler shades of those pale shadows, the Eclogues of Virgil, just as their author, the most precedent-loving of poets, rarely ventured to introduce an image or an incident without the authority of some Greek original (W. M. Adams, op. cit., p. 45). Moses Browne (ibid.) declares that it would have been far better if Sannazaro had never written his " sea eclogues, for the exercise of fishing appears so contemptible in him, that any that n rites on a subject, that seems to be of a similar aspect, must suffer disadvantage." 
fisherman in Greek poems, plays, or writers from Homer down to the later Greek Romanticists, ${ }^{1}$ or (as far as I know) in the epigrams from 700 B.C. to 500 A.D., of the Anthologia Palatina. ${ }^{2}$

"The figure of the weather-beaten fisher is a favourite one in the old poets, and we meet it constantly in Art ; in Greek, and in Roman Art especially, it was a very favourite subject." 3

M. Campaux, Mr. Hall, and Herr Bunsmann confirm and amplify this sentence of Blümner's. The thesis of Bunsmann -not easy to obtain, although published in Igro at Münster in Westphalia-seems within its limited scope (he scarcely touches on the methods or craft of fishing) perhaps the best little treatise De Piscatorum in Gracorum atque Romanorum litteris usu.

He sets out to discover and formulate a list of the characteristics most frequently attributed to fishermen. He proceeds to establish each of the dozen selected by buttressing questions from Homer down to Sidonius.

Hospitality, Piety to the Gods and Dead, Shrewd (almost Pawky) Humour, Old Age, Toil and Poverty figure most

1 They must, however, now according to the evidence of the Papyri be dated back some three centuries, i.e. from the usually accepted date of the sixth to about the third century A.D.

As regards some of the Romance writers, the Papyri are a revelation and compel apparently much revision of dates. Thus Chariton (whom "the critics place variously between the fifth and the ninth centuries A.D.") is fixed by Pap., Faylm Towns, as before I50 A.D. Achilles Tatius, whose allotted span, owing to his imitation of Heliodorus (who hitherto has been dated about the end of the fourth century), was run " about the latter half of the fifth or beginning of the sixth century," is now placed by Pap., Oxyrh., 1250, as living before 300 , and thus Heliodorus is removed up to (c.) 250 A.D.

In the Anthologia Palatina there are some 3700 epigrams, etc., dating from 700 B.c. and ending about I 300 A.D. ; none of these, as far as I can recall, contradict the poverty note. I have chosen 500 A.D. as being a convenient date, because it includes all Greek and Græco-Roman writers as distinct from the Byzantine, and includes also the earlier and better prose writers, like Heliodorus and Longus. Epigrams, it is true, continued to be written until the fourteenth century, but there is little, and that of no poetical account, after the tenth, when the popular or "political "verse began, with a few exceptions, to supplant the classical forms.

"H. Blümner, Römische Privataltertümer, p. 329. "It is noteworthy that as Virgil omitted all mention of fishermen in his Bucolics, his imitators have followed his example, and in consequence in classical Latin the fisherman has no place as a pastoral character. The hut and tackle in the Theocritean story of Asphalion was foreign to Virgil's conception of the province of pastoralism" (Hall, op. cit., I9I4, p. 28). 
prominently. I can only notice one or two of the passages cited in support of each characteristic, but the evidence adduced generally carries conviction.

On the Hospitality of fishermen, poor though it were, stress is laid by Greek and Roman writers.

Bunsmann's citation of Petronius (Sat., II4) and Plutarch (Vita Pompeii, 73) as witnesses to credit is, however, far from happy, especially in the case of the former, who recounts that when the boat had been so battered as to be a-wash "procurrere piscatores parvulis expediti navigiis ad pradam rapiendam." The lightning-like change of the fishermen, on realising that their intended victims were ready to defend themselves, from plunderers to helpers, and the non-denial to the shipwrecked folk of the use of their hut for eating some sea-sodden food, scarcely shine as exemplars of high Hospitality. No wonder the guests dragged out a "most miserable night."

Tyrrhenus, the old deaf fisherman in The Ethiopian History (omitted by Bunsmann), embodies a far better instance of the characteristic Hospitality. His glad welcome and the surrender to his guests of "the cosier part of his dwelling" betoken Nature's gentleman. 1

A still better instance meets us in the Greek romance of Apollonius of Tyre, ${ }^{2}$ possibly an imitation of the Heliodorus idyll. The prince, sole survivor of a shipwreck, is found, fed, clad, and afterwards directed by an old fisherman to Pentapolis, where he wins a competition before the king. This romance, which survives in a Latin version of the sixth century, became in the fifteenth and sixteenth centuries widely popular and translated into most European languages. To it, as the scenes and the characters prove, Shakespeare, or possibly Wilkins, must have owed much of his Pericles.

On the question whence originated their Piety to the Gods, whether it sprang from or was only influenced by the fact that their lives were passed amid the unknown but everpresent and awful forces of Nature identified with certain gods,

1 Heliod, Ethiop., V. 18.

- De Apollonio Tyrio, 12. 
or sprang rather from a gratitude proportioned to future benefits, Bunsmann is discreetly non-committal.

But of outward and visible signs of such Piety the Anthologia Palatina is eloquent. Their Piety towards the dead is strikingly attested by Hegesippus, the simplicity of whose style in his eight epigrams in Anth. Pal. betokens an early date. "The fishermen brought up from the sea in their net a half-eaten man, a most mournful relic of some voyage. They sought not for unholy gain, but him and the fishes too they buried under this light coat of sand." 1

Bunsmann furnishes two records of impiety among fishermen. The first occurs in the well-known Baiano procul a lacu recede of Martial (Epigr., IV. 30), where an impious poacher in the very act of landing his fish from the Emperor's lake is stricken with blindness. The second, in Athen., VII. I8, and Ælian, XV. 23, where Epopeus, a fisherman of the island of Icarus, enraged by taking nothing but sacred or tabu Pompili, turned to with his son and devoured them, only themselves in turn to be devoured by a whale. ${ }^{2}$

But the impietas charged from Anth. Pal., VI. 24, is fantastic. The indictment has been drawn owing either to mistranslation of the passage or inability to appreciate the rather heavyhanded humour (frequent in the Greek and Roman writers of the time) of Lucilius, a conjectured author of the Epigram.

Heliodorus lays down at the portals of the temple of "the Syrian goddess" a votive offering of his fishing net worn out, not by catches of fish, but of seaweed "from the beaches of goodly havens." This dedication, as fish were sacred to the goddess and in Syria were forbidden as a food, has been imputed as an affront to the deity, but quite incorrectly. Heliodorus in offering his net intended no disrespect, nor offended any law of the temple. Since its sole catch had been seaweed, his net could plead " pure from the prey of fishery."

1 VII. 276, W. R. Paton's Translation.

2 Cf. Pausanias, III. 2I, 5: "Men fear to fish in the Lake of Poseidon, for they think he who catches fish in it is turned into a fish called The Fisher." In I. 38, 1, we find that only the priests were allowed to fish, because the rivers were sacred to Demeter, and in VII. 22, 4, that the fish at Pharae were sacred to Hermes, and so inviolate. 
The point of the pleasantry is akin to the caustic defence offered on behalf of a Jewish portrait painter, " as none of the pictures are likenesses, he is guiltless of breaking the Second Commandment!"

Ovid's pretty fancy to account for the Syrian abstention doubtless hangs together with the Greek conception of Atargatis and Aphrodite being one and the same. When the Giants revolted against the Gods, Venus fleeing with Cupid reaches, but is stayed by, the Euphrates: thither, Palcestina margine aqua, in answer to her piteous plaints to heaven above and earth below, two fish approach and convey mother and child safely across the flood. 1

"Inde nefas ducunt genus hoc imponere mensis

$\mathrm{Nec}$ violant timidi piscibus ora Syri."

$$
\text { Fasti, II. 473-4. }
$$

But other books, other legends ! for the same author (in Met., V. 33I) tells us that in the battle Venus changes herself into a fish.

Ktesias gives another account. ${ }^{2}$ Derceto by the wiles of Aphrodite "fell in love with a beautiful young man and was brought to bed of a daughter : being ashamed of what she had done, she slew the young man, exposed in the desert the child (who, fed with millk and then with cheese by pilfering pigeons, grew up to become the famous Semiramis) and then cast herself into the lake at Ascalon and was transformed into a fish-whence it came to pass that at this very day the Syrians eat no fishes, but adore them as gods" (Booth's Trans.).

Of the instances of calliditas or shrewd wit of fishermen, the story (supra) of the fisher lads' answer to Homer and the following from Alciphron (I. I6) must suffice, although from Esop, etc., many others can be gleaned. The whole passage is far too long for quotation, but the final retort of the fisher,

1 In gratitude for the part played by certain fish in bringing to the banks of the Euphrates the egg, from which came Aphrodite, Zeus placed fishes among the stars-hence the Pisces. Diognetos of Erythrai ap. Hyg., poet. asty., 2. 30, make these " certain fish" Venus and Cupid. Cf. Myth. Vat., I. 86.

2 Cf. Diod. Sic., II. 20. 
whose request for a battered disused boat has been selfishly refused by its owner, furnishes, according to a German critic, " a perfect gem of the Art of the Sophist, and sounds itself like an insoluble riddle."

To enable the reader to form his own judgment on this particular instance of calliditas, I subjoin the retort: ov

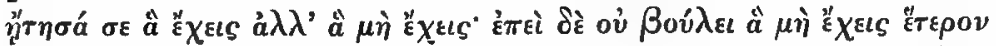

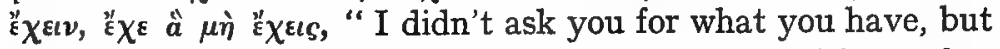
for what you haven't. Since, however, you don't wish another to have what you haven't, what you haven't you can have!"

But apart from this and similar instances of calliditas, the mood of piscatory poetry is generally serious or melancholy, and in keeping with the surroundings; we look in vain for the sunny warmth of Sicilian meadows, where youths pipe and sing gaily.

Like their modern brethren fishermen offered, before setting sail or after returning safe from dangers encountered, gifts to the gods of their craft, of whom first came Poseidon or Neptune, usually represented with a trident 1 ; second, Hermes or Mercury, the most venerated, because of his wily cunning and ready ruses 2 ; third, Pan, a son of Mercury, who taught him all his craft, ${ }^{3}$ and fourth, Priapus. ${ }^{4}$

1 Some recent scholars hold that Poseidon was an early differentiation of Zeus, and that his fish-spear was developed from the three-pronged lightning symbol of that deity as soon as the former became himself specialised into first a river god, and second a sea god. From my friend Mr. A. B. Cook's forthcoming work, $Z$ eus, vol, ii. c. 6, s. 4, I learn that the commonly supposed Trident (in Fschylus, Septem., I. 3I), "the fish-striking tool of the sea-god," is more likely in pre-classical times to have been the three-pronged lightning, symbol of the highest Deity of all, and observable not only in Greece, but also in Asia. Against this view lies the fact that only once in all the Greek art is Poseidon represented with an unmistakable thunder-bolt, and this is on a silver tetradrachm of Messana about $45^{\circ}$ B.C. The name Poseidon merely

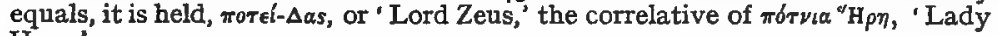
Hera."

2 See Oppian's invocation of him in III. 9-28.

a Ibid. As Pan was worshipped as the god of animals, especially of herds,

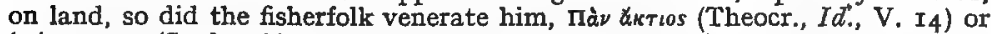
a $\lambda i \pi$ arkкos (Soph., Aj., 695: cf. Anth. Pal., X. IO), as the god of the animals of the sea, and in especial for his service to them in netting Typhon, whose " winds wrought havoc to their boats, and when Auster with Sirocco breath prevailed, caused their catches to go bad." At Athens the god was regarded with gratitude as a powerful benefactor, because of the aid vouchsafed in securing naval victories (Hdt., 6. I05. Simonides frag. 133, Bergk ${ }^{4}$ ).

4 To Janus, however, the credit of being the first to teach the art of Fishing to the Latins is assigned by Alexander Sardus, De Rerum Inventoribus, II. I6. 
It is with a start of surprise that one finds Priapus, far more notorious as the god of propagation and fecundity, among the gods of fisherfolk. Can this be accounted for by some subtle, but inverse connection between the belief in India that the Fish was the symbol of Fecundation, and the God of Fecundation in Greece? Some support for this may lie in the statement of de Gubernatis, that as in the East the fish was a phallic symbol, so now pesce in the Neapolitan dialect means the phallus itself.

His lineage, either the son of Hermes, or his grandson, for among the many putative fathers of Priapus was Pan, may account for the inclusion of Priapus. To Priapus, arriving how he may at goddom, offerings were more freely made than to any other except Hermes. ${ }^{1}$

In addition to these four flourished minor gods. Goddesses too of Fishing (such as Artemis 2), of rivers, of springs, and of the fish therein found devotees. First and foremost, ranked Aphrodite or Venus :

\section{"But she}

Came flushed from the full-flushed wave, and imperial, her foot an the sea,

And the wonderful waters knew her, the winds, and the viewless ways,

And the roses grew rosier, and bluer the sea-blue stream of the bays."

This in common with the belief that Janus invented boats is probably a mistaken inference from the fact that the early as libralis had a head of Janus on one side and the prow of a ship on the other (Roscher, Lex. Myth., II. p. 23).

1 The description in Anth. Pal., X. Io, " Me, Pan, the fishermen have placed on this holy cliff, the watcher here over the fair anchorage of the harbour: and I take care now of the baskets and again of the trawlers off this shore," and in Archias (Anth. Pal., X. 7, and 8) of the fishermen making an image of Priapus to be set up, just where the sea leaves the shore, are only three of very many similar passages. Among the Eleans Apollo was honoured as a God under the title of The Fish-eater (Athen., VIII. 36). In addition to Gods we read of Tritons who were half-men, half-fish, and of a still more wonderful being, an Ichthyocentaurus, whose upper body was of human form, and lower that of a fish, while in place of the hands were horses' hooves!

2 The Phigaleans (in Arkadia) worshipped an old wooden image, called Eurynome, which represented a woman to the hips, a fish below. This curious effigy was kept bound in golden chains and was regarded by the inhabitants as a form of Arternis : see Paus., 8. 4I, 4-6. A large Boeotian vase at Athens shows Artemis with a great fish painted on the front of her dress, a clear indication that she was held locally to be a goddess of fishing (M. Collignon and L. Couve, Catalogue des Vases Peints du Muste National $d^{\prime}$ Athenes (Paris, I902), p. 108 f., No. 462 ; cp. Ib., No. 463). 
To her, seemingly, as many offerings, as many prayers were made as to any god.

Whether she can be identified or not with Atargatis, through Derceto or Astarte, matters little here. ${ }^{1}$ But the image of the goddess, as described by Lucian,2" "In Phœnicia, I saw the image of Derceto, a strange sight truly! For she had the half of a woman, and from the thighs downwards a fish's tail," corresponds closely with an image of Ascalon, ${ }^{3}$

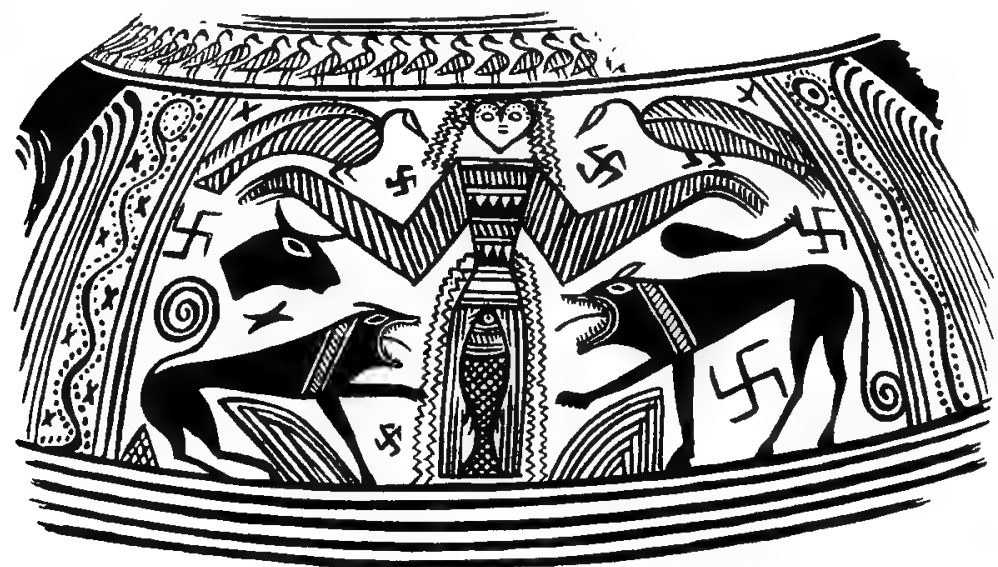

ARTEMIS WITH A LARGE FISH IN FRONT OF HER DRESS.

From Ephemeris Archelogique, PI. 10.

" having the face of a woman, but all the rest of the body a fish."

When in addition we find this same image at Ascalon stated by Herodotus (II. II5) to be that "of the heavenly Aphrodite," the identification of the Greek-Roman goddess appears, at any rate, to have gained wide acceptance. Doubtless Horace had this, ${ }^{4}$ or perhaps some fish-tailed

1 It is probably the wisest course to admit that the unity of an ancient god or goddess was a matter of name, rather than of nature.

${ }^{2}$ De Dea Syr., ii. c. I4. The authorship is a matter of doubt. The author adds, "but the image in the holy city is all woman."

3 Diod. Sic., II. I.

- On Greek and Italian vases, etc., women with fish bodies are occasionally represented. Cf. Keller, op. cit., ii. 349. 
Egyptian goddess, in mind when he penned his famous comparison for an incoherent simile: "Desinit in piscem mulier formosa superne."

Coins of Hierapolis in Cyrrhestica often show Atargatis riding on a lion or enthroned between two lions, 1 sometimes with the legend OEAC CYPIAC, 'of the Syrian goddess.' Strabo (XVI. 27, p. 748) tells us that this city worshipped the Syrian goddess Atargatis, who (Ibid., p. 785) according to Ktesias the historian was called also Derceto. ${ }^{2}$

Another reason for abstention from fish, apart from their sacredness to the goddess, we owe to Antipater of Tarsus. ${ }^{3}$ Gatis, queen of Syria, developed such a passion for fish that she issued a proclamation forbidding their being eaten without

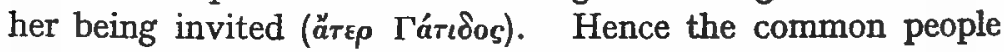
thought her name was Atargatis and abstained wholly from fish.

Mnaseas ${ }^{4}$ assigns to her the deserved and not inappropriate fate of being thrown into her own lake near Ascalon and devoured by fishes. ${ }^{5}$ But against this legend must be placed the fact that Atargatis, in common with many Asian deities and cults translated westward, found sanctuary and high veneration, in her case at Delos. ${ }^{6}$

1 See Brit. Mus. Cat. of Coins, Galatia, pl. I8, 14, or B. V. Head, Historia Numorum ${ }^{2}$ (Oxford, I9I I), p. 777.

${ }^{2}$ For Derketo, standing on a Triton, on coins of Ascalon, see G. F. Hill, Catalogue of The Greek Coins of Palestine (London, I914), pp. Iviii. f., I $3^{\circ} \mathrm{f}$., Pl. XIII. 2I. The dove in the right hand of the goddess is her very usual attribute. The Triton on which she stands expresses her marine nature. Ovid, Met. IV. 44:

Derceti, quam versa squamis velantibus artus

Stagna Palæstini credunt celebrasse figura."

Although Roscher's Dict. of Myth. does not in the long article devoted to Isis specify her as fish-tailed, Isis is distinctly identified with Atargatis of

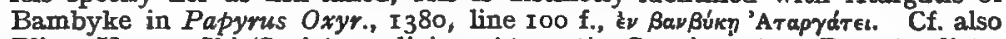
Pliny, V. I9: Ibi (Syria) prodigiosa Atargatis, Gracis autem Derceto dicta, colitur.

${ }^{3}$ De Superstitione, Bk. IV., quoted by Athen., VIII. 37.

- History of Asia, Bk. I., quoted ibid. VIII. 37.

- According to an inscription at Smyrna, H. Dittenberger, Sylloge inscrip. tionum Graecarum. (Lipsiæ, I 900), ii. 284 f., No. 584 , a violator of the sacred fish was forthwith punished by all sorts of misfortunes and finally was eaten up by fish. If one of these fish died, an offering must on the self-same day be burnt on the altar. Cf. Newton, Gk. Inscript., 85 .

- Keller, op. cit., 345 . 
Theocritus in the fragment on Berenice recommends the sacrifice of a certain fish to a goddess. "And if any man that hath his livelihood from the salt sea, and whose nets serve him for ploughs, prays for wealth and luck in fishing, let him sacrifice, at midnight, to this goddess, the sacred fish that men call 'silver white,' for that it is brightest of sheen of all ; then let the fisher set his nets, and he shall draw them full from the sea." 1

If Apollonius of Tyana had been compelled to commend a beauteous fish for sacrifice-an act which his Pythagorean tenets forbade-he must have plumped for the Peacock fish.

Whether he were, teste Hieroclas, as great a sage, as remarkable a worker of miracles, as potent an exorcist as JESUS of Nazareth, or merely, in the words of Eusebius, a rank charlatan, whose magic, "if he possessed any," was the gift of the powers of evil with whom he lived in league is no question to be considered here. Apollonius, at any rate, stands out, not only as one of the most interesting and most discussed personalities of the third century, but also as one of the most travelled.

During his fifty odd Wanderjahre many men had he known, and many cities had he seen of Asia and Africa. In the Hyphasis river of India there exist (we learn from his Life by Philostratus, III. I) Peacock fish (sacred to Aphrodite) to which, if colour or "silver sheen" insure full creels, the Theocritean certainly must yield place, for "their fins are blue, their scales beautifully dappled, their tails, which fold or spread at will, of golden hue!"

But dominant over all other characteristics stands the inevitable and insistent connection of fishermen with Old Age, Toil, and Poverty. Everywhere, in every author, does this note strike loudest; nowhere, have I come across a young fisherman, except Virgil's Menœtes.

These characteristics find their place not only in Greek and Latin literature from and before the "sleepless chase" of

1 For discussion as to which was the "sacred fish," see Plutarch, de Sol. Anim., 32, and Athen., VII. 20. 
Sophocles $\left(\operatorname{Ajax}, 880\right.$ ) to the last Romanticist, ${ }^{1}$ but also in the statuary, pictures, frescoes, mosaics of Greek and Roman Art. Numerous examples can be cited from the museums of Naples, Rome, Paris, and London sustaining the contention that all real fishermen were ever depicted old and careworn. ${ }^{2}$

The fishing boys and women of the Amorini at Pompeii and elsewhere may be adduced as vitiating this statement: but these, it must be borne in mind, are merely artistic representations of Anglers and of dalliance, not of real fishermen toiling for their livelihood. So, too, in the Greek representations where boys, not Putti or Amorini, figure as fishing, it will be found that they are helpers or "fish-boys " of the working fisherman. ${ }^{3}$

The explanations why fishermen are so rendered vary. Perhaps the truest, certainly the concisest, is Alciphron's,

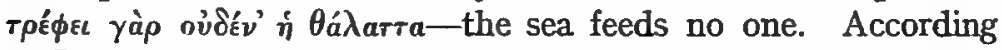
to Bunsmann, fishermen are always represented as old and poor and worn, because their delineators desired by painting the career as blackly as possible to excite sympathy. For this purpose old age and poverty and heavy toil, which appeal unto all, stood ready as their most effective strokes.

According to Hall, the fisher, a common character in all Greek literature, was in early times described with simple truth. Only later, when imitation took the place of originality, did conventionalism render him always as aged, pathetic, superstitious, wretchedly poor, yet patient and content. 4

1 To cite but one of the scores of intermediate authors as regards poverty. Ovid, Met., III. 586-9I,

Pauper et ipse fuit, linoque solebat et hamis

Decipere, et calamo salientis ducere pisces.

Ars illi sua census erat. Cum traderet artem,

"Accipe quas habeo, studii successor et heres,"

Dixit, " opes." Moriensque mihi nihil ille reliquit

Præter aquas: unum hoc possum appellare paternum.

2 The véo raşos in the oracles' warning to Homer, which seem at first sight antagonistic to the above, become in Homer's own words of greeting,

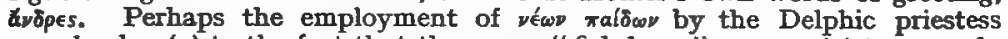
may be due (I) to the fact that they were "fish-boys" proper, (2) to an early and intelligent anticipation of the "juvenescent" tendency, or (3) to the exigency, not unknown to sixth form Hexameter-makers of the present, but (alas! if Oxford and Cambridge be obeyed) not of the future day, of scansion!

Cf. Mus. Borbon., IV. 54, or Baumeister, Denkmäler Klass. Altert. (Munich, $1885)$, i. 552 , f. 588 .

"The happiest, perhaps the only happy, fishermen are those shown at the 
Whatever be the reason, Greek fishermen, whether we read of them in the Epigrams or in the fragments of lost works, all come down as old, patient, half-starved through dint of toil by day and night, sea-worn. Their horny hands grasp better

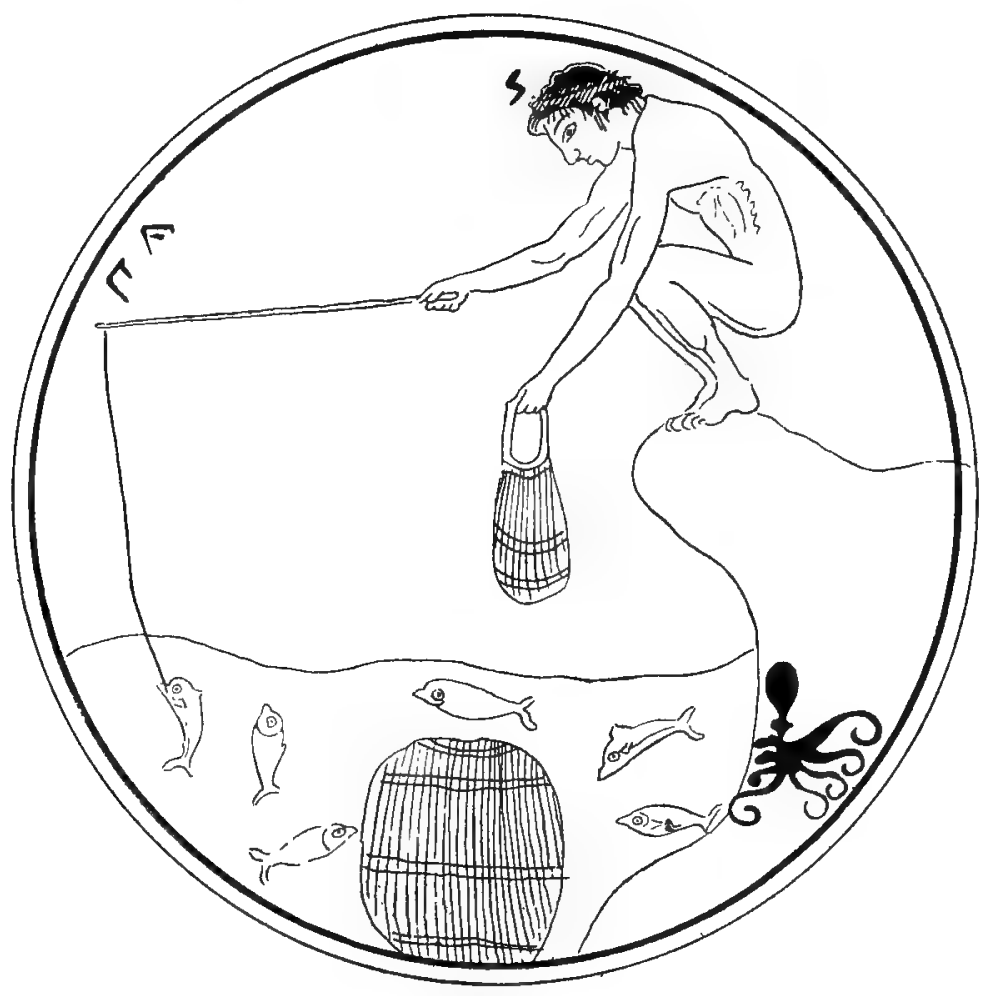

THE HAPPY PISHERMAN, ATTRIBUTED TO THE ARTIST CHACHRYIION.

From P. Hartwig's Die griechischen Meisterschalen, p. 57, pl. 5 .

a trident than hold the delicate pastoral reeds. They play no tunes, they dance no dances, they sing no songs save some rowing chant, as they tug at the oars when homeward bound.

bottom of drinking cups, etc.! In P. Hartwig's (Die griechischen Meistevschalen (Stuttgart-Berlin, 1893), p. 37 ff.) collection of red-figured Greek vases representing fishermen at work, there is an Attic kylix (fifth cent. B.c.) with such a fisherman, who (the idea ran) was only in his element, when the cup was filled with wine. Cf. Theocritus, I. 39 ff., for another old fisherman in the bottom of a herdsman's cup. 


\section{I32 TRAITS OF FISHERMEN--DEITIES OF FISHING}

Meniscus and Diotimus (in Sappho and Alcæus) are aged, lonely, and miserably poor. They are not "white-limbed" like Daphnis in The Herdsman's Offering. They play no flute, nor carry the apples of Love.

So too the circumstances, the life, the recreations of the Shepherd of the Pastoral Idyll of Theocritus are as far removed as can be from those of the Fisherman of the Piscatory Idyll by the same author. The locus is the same. The characters dwell near each other, but how dissimilar their lots ! 


\section{CHAPTER VII}

THEOCRITUS - THE GREEK EPIGRAMMATISTS

But to return to our second locus classicus, 'The Fisherman's Dream ' of Theocritus. ${ }^{1}$ The whole Idyll (XXI.), an exquisite piece of word painting, deserves careful reading as a study of the piscatory genre, but room can only be found for part of it here. ${ }^{2}$

" 'Tis poverty alone, Diophantus, that awakens the arts ; Poverty, the very teacher of labour. Nay, not even sleep is permitted by weary cares to men that live by toil, and if, for a little while, one closes his eyes in the night, cares throng about him and suddenly disquiet his slumber.

"Two fishers, on a time, two old men, together lay down and slept-they had strown the dry sea-moss for a bed in their wattled cabin, and there they lay against the leafy wall. Beside them were strewn the instruments of their toilsome hands, the fishing creels, the rods of reed, the hooks, the sails bedraggled with sea-spoil, the lines, the weels, the lobster pots woven of rushes, the seines, two oars, and an old coble upon props. Beneath their heads was a scanty matting, their clothes, their sailor's caps. Here was all their toil, here all their wealth.

1 Although the Papyrists have as yet unearthed only some six lines of a new poem by Theocritus (discovered by Mr. M. Johnson, and as yet unpublished), in Pap. Oxyrhynchus, XIII. No. 1618, we find parts of Id., V., VII., and XV.

- Translated by Andrew Lang, r889. The question whether Leonidas of Tarentum was, and Theocritus was not, the author of this Idyll is exhaustively treated by R. J. Cholmeley, Theocritus, pp. 54, 55. Whatever conclusion be reached, constant are the references in those Idylls whose authenticity is undoubted to fish and fishing; even in his familiar comparisons Theocritus thinks of the sea. Mr. Lang writes, "There is nothing in Wordsworth more real, more full of the incommunicable sense of Nature, rounding and softening the toilsome days of the aged and poor, than the Theocritean poem of The Fisherman's Dream. It is as true to Nature as the statue of the naked fisherman in the Vatican." 
The threshold had never a door, nor a watch-dog ; all things, all to them seemed superfluity, for poverty was their sentinel. They had no neighbour by them, but ever against their cabin floated up the sea.

"The chariot of the moon had not yet reached the midpoint of her course, but their familiar toil awakened the fishermen; from their eyelids they cast out slumber, and roused their souls with speech."

Asphalion, after complaining that even the nights in summer are too long-for " already have I seen ten thousand dreams, and the dawn is not yet "-is somewhat comforted by the thought that thus " we have time to idle in, for what could a man find to do lying on a leafy bed beside the waves and slumbering not? Nay, the ass is among the thorns, the lantern in the town hall, for they say it is always sleepless." 1

Then he begs his friend to interpret to him the dream he has just dreamt.

"As I was sleeping late, amid the labours of the salt sea, (and truly not too full fed, for we supped early, if thou dost remember, and did not overtax our bellies), I saw myself busy on a rock, and there I sat and watched the fishes and kept spinning the bait with the rods.

"And one of the fishes nibbled, a fat one; for, in sleep, dogs dream of bread, and of fish dream I.2 Well, he was tightly hooked, and the blood was running, and the rod I grasped was bent with his struggle.

1 The meaning is as follows : Asphalion is complaining of wakefulness, and he compares his condition to two things; to a donkey in a furze-bush (as we might say), and to the light of the town-hall, whose sacred flame was perpetual (Snow).

\& Mr. Lang adopts the reading tprov, bread; Ahrens substitutes tipcrov, bear, which seems to fit the context far better, as it keeps up the whole spirit of, "I dreamed of large-sized fish, and a lively fight, just as a sleeping dog dreams of chasing bears." Cf. Tennyson's Locksley Hall-

and his Lucretius-

"Like a dog he hunts in dreams,"

"As the dog

With inward yelp and restless forefoot plies

His function of the woodland,"

passages alike inspired by the lines in which Lucretius (iv. 991 f.) proves that waking instincts are reflected in dreams-

"venantumque canes in molli sæpe quiete jactant crura tamen subito." 
"So with both hands I strained, and had a sore tussle for the monster. How was I ever to land so big a fish with hooks all too slim? Then, just to remind him he was hooked, I gently pricked him, pricked, and slackened; and as he did not run, I took in line. ${ }^{1}$

"My toil was ended with the sight of my prize. I drew up a golden fish, lo, you ! a fish all plated thick with gold. Then fear took hold of me lest he might be some fish beloved of Poseidon, or perchance some jewel of the sea-grey Amphitrite. Gently I unhooked him, lest even the hooks should retain some of the gold of his mouth. Then I dragged him ashore with the ropes, ${ }^{2}$ and swore that never again would I set foot on sea, but abide on land and lord it over the gold.

"This was what awakened me, but for the rest set thy mind to it, my friend, for I am in dismay about the oath I swore."

The Friend: "Nay, never fear, thou art no more sworn

1 This is but one instance of anachronistic translation, or the use of terms, which, if true of our modern line, are inapplicable to ancient angling, for if, as I have shown in the Introduction, all ancient angling was with a tight line, the operation translated as "I took in line" should rather be rendered "I tightened on him." The alternation of easing and tightening is a well-known device. It is a question of the degree of strain involved. If you want to keep a big fish quiet in a confined space or in difficult circumstances, you can generally do so by keeping a very light strain on him, so that, though the line is never absolutely slack, he hardly knows that he is hooked and is often landed without the angler having to yield a foot of his line. Thus the roach-fisher without a reel sometimes lands a $4 \mathrm{lb}$. chub or bream with a foot link of single hair, entirely by this method of suaviter in modo. Thete seems no particular reason why Asphalion should not have been cognisant of these secrets, which three lines in James Thomson's The Seasons, although the fight is, I admit, with a running line, fairly disclose.

"With yielding hand

That feels him still, yet to his furious course Gives way, you, now retiring, following now Across the stream, exhaust his idle rage."

2 To a practical angler this passage is not clear. How is it possible, after you have taken out the hook (the only apparent method of holding the big fish), to fasten round him ropes and drag him ashore, unless he were beached high and dry? Of this we have no evidence beyond a $\nu \in l_{\lambda \kappa} \nu \sigma \alpha$, if used here in its nautical sense " to haul up high and dry." The readings suggested by Wordsworth and others are numerous, but none seem quite satisfactory, even those preferred by J. M. Edmonds, The Greek Bucolic Poets, London, I9I2, and R. J. Cholmeley, op. cit. Perhaps the least improbable text is that given

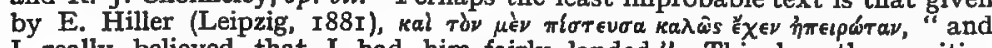
I really believed that I had him fairly landed." This has the positive merit of sticking close to the manuscript reading, and the negative merit of refusing to admit the absurd 'ropes.' 
than thou hast found the golden fish ${ }^{1}$ of thy vision : dreams are but lies. But if thou wilt search these waters, wide awake and not asleep, there is some hope in thy slumbers: seek the fish of flesh, lest thou die of famine with all thy dreams of gold !"

The influence of Theocritus, though becoming less natural and rendered more conventional by the pretty conceits of the later Alexandrian period, ${ }^{2}$ permeates the literature of Greece and Rome for many centuries. In none, perhaps, is this influence more marked than in his pupils Bion and Moschus, and in his younger contemporary, Leonidas of Tarentum.

Three fisher epigrams ${ }^{3}$ by Leonidas suffice as evidence of this. The realism, the pathos, the detailed treatment, the subjects, lowly folk, all alike characterise the Sicilian.

In the first, the fisherman Diophantus on giving up his trade dedicates, according to custom, all the relics of his calling to the patron of his craft. The list of the implements, including a well-bent hook, long rod, and line of horse hair, here and in an epigram by Philippus of Thessalonica (which adds " the

1 Callimachus, whom Theocritus probably knew at Alexandria, calls the " chrysophrys " sacred-

"Or shall I rather say the gold-browed fish,

See Athen., VII. 20.

2 "Theocritus gives nature, not behind the footlights, but beneath the truthful blaze of Sicily's sunlit sky. For it was here that the first vibrations of this spontaneous note were heard in their original purity, before art could distort them with allegory, or echo weaken them with imitation. This is all the more remarkable from the contrast which it offers to what Kingsley calls the 'artificial jingle ' of the Alexandrian school. Simplicity, honesty, truth, and beauty recommend Theocritus as a genuine artist. His imitators, as compared with theirmodel, were like-

\section{'Those many jackdaw-rhymers, who with vain \\ Chattering contend against the Chian Bard,'}

as he himself describes (Id., VII. 47) Homer's imitators." Against this verdict by $\mathrm{H}$. Snow on the Alexandrians must be set the more truthful appreciation of their work by Mackail, op. cit., pp. 178-207, especially p. I84: "They are called artificial poets, as though all poetry were not artificial, and the greatest poetry were not the poetry of the most consummate artifice."

3 Anth. Pal., VI. 4 ; VII. 295; VII. 504. While the last two in the MS.

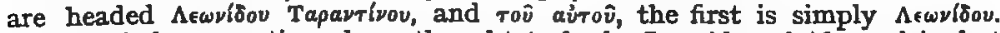
Hence this has sometimes been thought to be by Leonidas of Alexandria, but Professor Mackail informs me that all three epigrams are by the Tarentine, both by evidence of style, and because all three come in groups of epigrams taken from the Anthology of Meleager. 
flint pregnant with fire, that sets alight the tinder "), corresponds in material and order of enumeration fairly closely with Asphalion's in Theocritus.

Of the second I borrow a spirited translation of the last lines,

"Yet-not Arcturus, nor the blasts that blow

Down-rushing, swept this aged man below :

But like a lamp long burning, and whose light

Flickers, self-spent, and is extinguished quite,

In a rush hut he died :- to him this grave

(No wife, no child he had) his brother fishers gave." 1

The third, which should be The Areful Warning, if any warning avail; to boys fishing in the middle of a burn and holding while changing their lure a fish in their teeth (who of us has not done this?), sets a picture of a more violent death, "for the slippery thing went wriggling down his narrow gullet," and choked him on the spot.

The subjoined, somewhat loose, translation is from Blackwood's Magazine, Vol. XXXVIII. ${ }^{2}$

"Parmis, the son of Callignotus-he

Who trolled for fish the margin of the sea, Chief of his craft, whose keen perceptive search, The kichlé, scarus, bait-devouring perch, And such as love the hollow clefts, and those That in the caverns of the deep repose, Could not escape-is dead!

Parmis had lured

A Julis from its rocky haunts, secured Between his teeth the slippery pert, when, lo! It jerked into the gullet of its foe,

2 The following translation by Mr. Andrew Lang is truer :

"Theris the Old, the waves that harvested More keen than birds that labour in the sea, With spear and net, by shore and rocky bed, Not with the well-manned galley laboured he ;

Him not the star of storms, nor sudden sweep Of wind with all his years hath smitten and bent,

But in his hut of reeds he fell asleep. As fades a lamp when all the oil is spent:

This tomb nor wife nor children raised, but we

His fellow-toilers, fishers of the sea."

2 In line $5 \pi \rho \dot{r} r \eta s$, which makes nonsense, should certainly be corrected to $\pi \lambda \omega \tau \hat{\eta} s$. 
Who fell beside his lines and hooks and rod, And the choked fisher sought his last abode. His dust lies here. Stranger, this humble grave An angler to a brother angler gave."

Alciphron, judging from his extant letters, seems the most prolific of the later Piscatory writers. His tribute to the veracity of Sosias, "who is famous for the delicious sauce made of the fish which he entices," reads in such deadly opposition to the common but false impression that fishermen rank next to mining engineers as the biggest liars in the world, that it must be quoted, if only on the principle of "An angler to a brother angler gave."

"He is one of those who duly reverence Truth, and such an one would never even slip into Falsehood."

Lest as an Angler I may be accused of "slipping into Falsehood " in my translation, I subjoin the Greek :

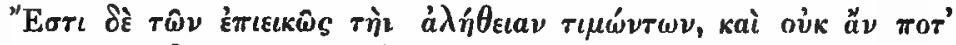

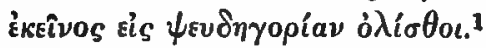

Lucian's Dialogues of the Sea Gods, by their confidential chat, give witty expression to the author's own scepticism towards mythology. "With their imitation of the earlier poets and their amobean form they may be considered as connecting links between Theocritus and others of his group and the eclogues of marine mythology, sometimes classed as piscatory eclogues during the renaissance." 2

If any doubt be as to their being "links," there can be none as to the charm of The Dialogues of (in Macaulay's words) " the last great master of Attic eloquence, and Attic wit," or (he has been perhaps equally well termed) "the first of the moderns."

1 Bk. I. I8.

2 See Hall, op. cit. P. 22 (IgI4), and ibid., p. 35 (IgI2). Lucian, although a Syrian (to which nation fish was from the earliest times a forbidden food), frequently shows himself very conversant with fishes and avails himself of their characteristics: e.g. Menelaus, after witnessing some of the "turns" of that celebrated "lightning-change artist," Proteus, exclaims frankly, "there must be some fraud!" The artist pooh-poohs him and bids him consider the everyday miracle of invisibility wrought by the Polypus, who having " selected his rock and having attached himself by means of his suckers, assimilates himself to it, changing his colour to match that of the rock. Thus there is no contrast of colour to betray his presence: he looks just like a stone " (Dialogues of the Sea Gods, iv. I-3, Fowler's Translation). 
The Fisherman, by the same author, bears no relationship to the Mimes, or Idylls. It takes its title from a scene in which the author sits on a parapet of the Acropolis equipped with the rod of a Piræan fisherman. His bait of gold and figs attracts a swarm of brilliantly coloured fish, Salmo Cynicus, ${ }^{1}$ Flat Sole Plateship, and other philosophers clad in scales.

The Romances, the last prose at times instinct with the genius of ancient Greece, bequeath us many fisherfolk. The famous pastoral Daphnis and Chloe, by Longus, introduces a pretty picture and illustrates the old contrast between the idyllic life of shepherds and the sordid lot of their fishing neighbours.

Daphnis sits with Chloe on a hill near the sea; " while at their meal, which, however, consisted more of kisses than of food, a fisher boat is seen proceeding along the coast." The crew, carrying freshly caught fish to a rich man in the city, " dip their oars, doing what sailors usually do to beguile their toil-the boatswain sings a sea-song, and the rest join in chorus at stated intervals."

As the boat reaches some hollow or crescent-shaped bay, the echo of their song floats up. This only incites Daphnis, who understands the echo, "to store up some of the strains in his memory that he may play them on his pipes, but Chloe, who wots not that such things can be, turns in pretty bewilderment to the boat, to the sea, and to the woods."

The Aethiopica, by Heliodorus of Emesa, has been termed, perhaps with exaggeration, the most elaborate picture of a piscatory kind in ancient Greek. The influence of Theocritus is strongly suggested by the imagery incidental to the description of the cabin, the tackle, and the boat, as well as by the delineation of the character of Tyrrhenus, aged, sea-worn, wretchedly poor, yet content with his lot and hospitable to the stranger. ${ }^{2}$

1 Such in Fowler's Translation, V. 48, is the rendering of $\kappa$ úw, which is quite wrong for two reasons. First, kúwy is almost certainly our dogfish or its cousin. Cf. Aristotle N. H., VI. I I8. Second, the salmon is not found in Greek waters, and so could not be fished for from the Acropolis. Cf. infra, Chapter XIII.

Heliod., Aethiop., 5, r8. Cf. Hall, op. cit., I9I4. 
Agathias gives us one of the very few, perhaps the only, fisher epigram with a love motive. "A fisherman was employed in catching fish. Him did a damsel of property see, and was affected in her heart with desire, and made him the partner of her bed. But he, after a life of poverty, took on himself the swell of all kinds of high bearing, and Fortune with a smile was standing by, and said to Venus, - " This is not your contest, but mine." " 1

Lastly it is of interest to note that one of the few Greek poetesses concerned herself with a love-tale of the sea. Hedyle, who came of a poetic stock (for she was daughter of Moschine the iambist and mother of Hedylus the epigrammatist), penned a poem on Glaucus' love for Scylla. In it she told how the love-sick swain would repair to the cavern of his mistress-

" Bearing a gift of love, a mazy shell, Fresh from the Erythrean rock, and with it too The offspring, yet unfledged, of Alcyon,

To win the obdurate maid. He gave in vain. Even the lone Siren on the neighbouring isle Pitied the lover's tears." 2

1 Anth. Pal., IX. 442. Trs. from the Greek Anthology as selected for Westminster, Eton, etc.

2 Athen., VIl., 48. 


\section{CHAPTER VIII}

\section{THE TWO PLINYS-MARTIAL-WAS THE ROD JOINTED?}

AFTER Theocritus we reach the period which chronologically might perhaps be termed that of the Roman writers, although our two greatest authorities on Fish Lure and Lore wrote in Greek, some three to four centuries after Plautus (c. 254I84 B.C.) had produced his Rudens.

This, the first Latin play, I believe, introducing fishermen on the stage, re-echoes the Greek note of poverty and misery. In Act II., Sc. 2, Trachalio asks, "Shellfish-gatherers, and hookfishers, hungry race of men, how fare ye ?" and receives the answer, "Just as befits fishermen; with hunger, thirst, and expectation." The wretchedness of their calling is made further manifest in Act II., Sc. I.

Descriptions of fishermen are found in Latin adaptations of Greek plays. The Latin mimes, as did the Greek, often display fishermen as characters. The Latin references to actual fishing not only far outnumber the Greek, but also, unlike the Greek, which are almost solely concerned with sea fishing, frequently treat of river and lake fishing. Plautus, Cicero, Horace, Ovid, 1 Juvenal, Tibullus, Pliny the Elder and the Younger, Martial, and Ausonius, by no means conclude the list of our Roman authors.

It may be fairly asked, why I omit any special notice of so valuable and voluminous work as the Natural History of Pliny the Elder.

1 Ovid has, I believe, more piscatory passages than any other poet, except professional writers, such as Oppian. His ten years" banishment to Tomi at the mouth of the Danube and on the shores of the fishful Euxine no doubt added to his love and his mention of Fishing. 


\section{I42 PLINY-MARTIAL-WAS THE ROD JOINTED?}

My reasons are three. First, my book contains numberless references to or quotations from it. Second, none of its thirty-seven Books presents any controversial questions of angling interest-such as "Where is to be found the first mention of the Rod, or Fly ? "-questions which demand for Martial and Elian a full discussion. Third, my notice of Aristotle, on the principle that the greater includes the less, renders any lengthy comment on Pliny almost superfluous.

The Natural History of the latter, at any rate as far as fish and fishing are concerned, for the most part repeats the Natural History of the former, except in such instances as the caudal losses caused by the enmity between the Lupus and the Mugil, and between the Conger and the Murana, where it exactly reverses Aristotle's statement. 1

These and other instances, in addition to his words (IX. 88), "Nigidius auctor est," and (X. I9) "Nigidius tradit," led J. G. Schneider ${ }^{2}$ to conclude that it is open to grave doubt, whether Pliny ever read Aristotle at all in the original Greek. The probabilities, indeed, point to his having used for his Natural History the translation into Latin of Aristotle, which Nigidius Figulus, a friend of Cicero's and (according to Gellius) next to Varro the most learned of the Romans, published with additions apparently of his own. ${ }^{3}$

In Pliny the Younger, and Martial (perhaps Ovid in a lesser degree) one finds what among our classical writers seems the nearest approach to our English sportsman, delighting in his own place, however small, in the country, and in country pursuits. These writers, in spite of living half the year or more in Rome, fall within our conception of country sportsmen.

Most of the others seem more intent on bringing the scent of the hay before the footlights than on making us realise any real joy of fishing. They resemble more the week-enders of

1 Arist., N. H., IX. 13., Pliny, IX. 88. Hardouin suggests that Pliny may have learned this fact from the works of Nigidius Figulus.

9 Cf. J. G. Schneider, Petri Artedi Synonymia Piscium, etc., Lipsiæ, I 789 . This work is an excellent example of the learning and industry of this most versatile editor and commentator: in nearly all points that are matters of doubt or dispute I have followed him.

s Ibid., p. 76 . 
a fishing syndicate than the country gentleman living on his place or river.

Pliny the Younger possesses, in addition to his appreciation of the various joys of country life, a passionate yet exquisite feeling for beauty of scenery, especially for that round Lake Como, to which his letters recur again and again.

I cannot, however, conceive him much of a hunter, despite the abundant game which the Apennine or Laurentine coverts harboured, or much of a piscator, despite his notices of fishing on his favourite lake. A letter (Epist., I. 6) to Tacitus, who had apparently been chaffing him as a sportsman, frankly admits that although he has killed three boars his chief pleasure in the chase consists of sitting quietly beside the nets, to which the game was driven, wrapt in contemplation or jotting down on his tablets the ideas which the solitude and silence demanded by the sport were wont to produce.

As a fisherman he took his pleasure, if not sadly, for the most part vicariously. He joyed more, if I read him aright, in watching from one or other of his villas the boatmen toiling with their nets and lines than in a day's fishing, an impression which seems confirmed by his appreciation of the joy of being able to angle from bed!

Thus we read in Epist., IX. 7: "On the shores of Como I have several villas, but two occupy me most . . . That one feels no wave; this one breaks them. From that, you may look down upon the fishermen below; while from this, you may yourself fish, and lower your hook from your bedroomalmost from your very bed-just as from a little boat." 1

If the site of the present Villa Pliniana is that of the ancient Villa, as from Pliny's description 2 of the close proximity of the spring (which even now preserves the unusual characteristics specified in his letter) we may safely conclude, the feat of throwing your hook from your bedroom is obviously of the easiest.

1 Cf. Martial, Epist., X. 30, 17 ,

"Nec saeta longo quærit in mari prædam.

Sed e cubili lectuloque jactatam

2 Epist., V. 7.

Spectatus-alte lineam trahit piscis." 


\section{I44 PLINY - MARTIAL-WAS THE ROD JOINTED?}

The mediæval writer, Paolo Giovio, dwells at length on the enormous fish to be seen 350 years ago in the depths of Lake Como, and states that trout of Ioo lbs. and over were no uncommon objects. 1

What a prospect of joyous, easeful sport is opened here! No tedious travel of days or weeks to Norway, Canada, or New Zealand; no sleepless roughing it under tent or shack; no diet of canned food; no being "bitten off in chunks" by mosquito or black fly. Think of it, O Angler of high hope, but of sore disappointment-of hard toil and weary waiting ! Think of it! To wake, after sound slumber, in one's own comfortable room: to seize the ready rod, and with one dexterous cast, " almost from your very bed," to be fast in a hundred-pound trout!

\section{"Than which no more in deed, or dream!"}

Martial's abiding love for his birthplace on the picturesque banks of the River Salo in Spain (the delights of which in Ep., XII. I8, and I. 49, he paints with happy enthusiasm to Rome-tied Juvenal and to Licinianus) probably accounts for Angling being mentioned more appreciatively by him than by any other Latin poet.

Angling was one of the favourite amusements of men like Martial, a yeoman (if I may differ from Prof. Mackail 2)-to judge from the frequent references made to his own farm-or at any rate a close observer of the class, which in Ep. 1. 55, he so well describes :

"Hoc petit, esse sui nec magni ruris arator, Sordidaque in parvis otia rebus amat."

1 P. Lund, The Lake of Como (London, I9Io), p. 23, refers to P. Giovio, De Piscibus Romanis, c. $3^{8}$.

' Latin Literature (1906), p. I93. "Martial's gift for occasional verse just enabled him to live up three pair of stairs in the city : in later years he could just afford a tiny country house among the Sabine hills." This three-pair-back theory seems a bit strained, for he often speaks of his Nomentanus ager, a small farm at Nomentum, which yielded excellent wine. Cf. Ep., II. 38 ; VI. 43 ; XIII. II9. He owned, in addition to a house in Rome, apparently another small place at Tibur (IV. 80); so his complaints of being a "pauper" must be understood only in a relative sense. Thither he goes chiefly, he delicately insinuates, for the pleasure of seeing Ovid, who was his neighbour there. Cf. also VII. 93 . 
For in this same epigram and many others the poet is fain

"Ante focum plenas explicuisse plagas,

Et piscem tremula salientem ducere seta."

To him these rank among the chief delights of country life, which life he, though an admirable flâneur, places higher than all else.

$\mathrm{He}$ ends his vivid sketch of it with the passionate burst"Let not the man who loves not this life, love me, and let him go on with his city life-white as his own toga!"1

Martial's charming picture of a Roman homestead, of its life, live-stock, of its pursuits, and of its fishing, ${ }^{2}$ coritrasts vividly with his fawning eulogies of Emperors, and his savage satire on foes. It must be confessed, however, that some of his prettiest appreciations of country life were written in or about the large villas with which his rich patrons had studded, too closely to be really rural, Baiæ and the Bay of Naples.

His pleasure in this part of the coast was increased by the nearness of the baths of Baix, and the Lacus Lucrinus, the home of the famous Roman oyster.

These oysters held, I think, the highest place in Martial's gastronomic affections. Constant his references to them, frequent his assertions or assumptions that they excelled all other. $^{3}$ His well known lament for a beautiful little slave girl, who died when only six, employs as a term of highest praise

1 The client had to be at his patron's house in the morning and attend him, there or anywhere, all day if necessary. It was an act of disrespect to appear before his patron without donning the toga. Cf. Juvenal, VII. I 42, and VIII. 49 ; also I. 96 and IIg, and X. 45 , and Martial, Ep., X. Io. In prose the most caustic description of the client-and-patron institution may be found in Lucian, Nigrinus, 20-26. In Ep., XII, I8, to poor Juvenal dancing attendance in Rome on his patron and sweating in the requisite toga he recounts the many delights of his home in Spain: among them "ignota est toga," a blazing fire of oak cut from the adjoining coppice, and lastly the venator or keeper, whose attractions in lines 22-3 do not appeal to the modern sportsman. I draw attention to these lines, because they reflect quite casually, but quite clearly, the decadent vices of the age: remember, they are not quotations from some obscure, if obscene, versifier, but were written (and published l) by the second poet to the first poet of that generation. It has been pointed out that in the epigrams of Martial with which Juvenal is connected some obscenity usually creeps in. Cf. Ep., VII. 9 I.

${ }^{2} E$ p., III., 58, 26,

"Sed tendit avidis rete subdolum turdis

Tremulave captum linea trahit piscem"

- Cf. Ep. VI. II, 5, and III., 60 3, and XII., 48, 4. 


\section{I46 PLINY-MARTIAL-WAS THE ROD JOINTED ?}

Concha Lucrini delicatior stagni, rendered by Paley " more delicate" (in complexion) "than the mother-of-pearl in the shell of the Lucrine oyster." I

Others hold that concha is meant for the oyster itself. One author, basing himself on the varying praises of the particular beauties of the child, rhapsodises thus: "Oysters" so tender, so juicy, so succulent, so delicious, that the poet could find no fitter comparison for a charming young girl!" But in the words of Jeffrey of the Edinburgh Review, "This will never do." To twist the verse into a comparison of pleasure derived from the sense of taste rather than of beaty from the sense of sight passes the inadmissible, and unless Martial could eat, or in Charles Lamb's word on a gift of game, " incorporate" the pretty child, reaches the ludicrous.

Martial shows up as a sportsman. Proud of a good day, he knows-and tells us - what it is to be "blank" (" ecce redit sporta piscator inani," Ep., X. 37, I7). That he is no "River Hog " and quite eligible for some select club on the Test or Itchen appears from his throwing back into his native river any mullet which looked less than three pounds. ${ }^{3}$

The interest attaching to his Epigrams lies not only in the evidence they afford of his and his friends' love for things

1 Ep., V. 37, 3.

2 Pliny (XXXII., 2I) and other writers show that epicures, then as now, were divided as to which was the best oyster. Mucianus awards the palm over all the other oysters to those from Cyzicus: "Cyzicena majora Lucrinis, dulciora Britannicis, suaviora Medulis, acriora Lepticis, pleniora Lucensibus, sicciora Coryphantenis, teneriora Istricis, candidiora Circeiensibus," but Pliny in "Sed his neque dulciora neque teneriora esse ulla, compertum est," evidently plumps for those of Circeii in Latium. The British oysters came chiefly from Rutupia (in Kent), now Richborough, not far from our Whitstable of oyster fame. The castle and camps of Rutupiæ and Regulbum were built by the Romans to command and secure the entrance to the Thames by the arm of the sea, which then separated Kent from the Isle of Thanet. These oysters find mention in Juvenal (IV. I4I), " Rutupinoque edita fundo Ostrea callebat primo deprendere morsu." Dalecampius says of them, "Præstantissima nutriunt." " Our modern rule that no oyster should be eaten in a month whose name lacks an $/$ probably descends from the Medireval

"Mensibus erratis vos ostrea manducatis."

3 Ep., X. 37, 7 and 8,

"Ad sua captivum quam saxa remittere mullum,

Visus erit libris qui minor esse tribus."

This is an attempt to show how large and plentiful the mullets were in Spain, and is just hospitable swagger, for Pliny, $N_{.} H .$, IX. 30 , states that a mullet rarely exceeded two pounds. 
piscatorial, but also in the probability that in them we meet with the first recorded mention of $(a)$ a Jointed Rod, and (b) Fishing with a Fly. The former claim turns on the couplet,

"Aut crescente levis traheretur harundine praeda,

Pinguis et implicitas virga teneret aves."

$$
\text { Ep., IX., 54, } 3 .
$$

For levis there are two other, though less well supported, readings, viz. vadis and velis. Is harundo (literally a ' reed,' then a ' rod,' but used impartially to describe both the weapon of the fowler and of the fisher) in these lines a fowler's reed, or a fisher's rod? The answer, if indeed any be possible, depends on the precise meaning to be attached to crescente, having regard to the context and the whole epigram.

Crescente, which some dictionaries, ignoring its use in a similar connection in Silius Italicus, VII. 674-77, " sublimem calamo sequitur crescente volucrem," render jointed, can only here, I suggest, be properly translated by lengthening, or increasing. But whether this process of increasing was effected by real joints cannot be clearly ascertained.

In his solitary note on crescente Valpy (Delphin edition, 1823) vouchsafes the bald and not informative comment: "Vero mihi videtur intelligenda esse virga quæ crescat in locis palustribus."

The following explanation is interesting, but to my mind indecisive, even though it claims the authority of "the old commentators." I Crescente-. "L'oiseleur caché sous un arbre rappelait les oiseaux en imitant leur chant: puis, quand les oiseaux étaient sur l'arbre, il allongeait le roseau enduit de glu, qu'il tenait à la main et les oiseaux venaient s'y prendre. Le poëte dit que le roseau croissait, parcequ'à mesure que l'oiseleur se hissait sur ses pieds, la baguette engluée semblait croître en effet. Telle est la manière dont les commentateurs anciens interprètent ce distique."

Much again depends on whether we read vadis (shallows) or levis (swift); vadis would incline the balance heavily, but not absolutely, to the rod, not to the reed. We get no help

1 Nisard edition of Martial, Paris, 1865. 
from Friedländer, who contents himself with a mere reference to Martial, $E p$., XIV. 2I8, quoted below.

Paley is of doubtful or little avail. He holds that harundo means the fowler's reed. The implement was so contrived that a smaller reed, tipped with birdlime (viscum), 1 made from the cherries of the mistletoe, was suddenly protruded (perhaps blown) through a thicker reed against a bird on its perch, and that to this lengthening crescente refers. Cf. Ep., XIV. 218.

"Non tantum calamis, sed cantu fallitur ales, Callida dum tacita crescit harundo manu."

The fowler attracted the attention of the bird as he approached it, by imitating its note. ${ }^{2}$

Propertius refers to fowling (Vertumnus, V. 2, 33), and in Petronius (Sat., Io9, 7) we find "volucres, quas textis harundinibus peritus artifex tetigit." 3 Textis here, which Mr. Heseltine renders 'jointed,' would seem to show Paley's suggestion, that the first cane was hollow, while the second was "protruded" through it, to be wrong.

Rich explains this method of fowling as follows. The sportsman first hung the cage with his call bird on the bough

1 Cf. Virgil, Geor., I. I39. Also Oppian, Cyneg., I. 65 f., where, as tools of the fowler, are specified, "long cords, and moist honey-coloured bird-lime, and reeds which tread their track through the air." Cf. also Ovid, Met., XV. 477, "nec volucrem viscata fallite virga."

\& Cantu seems to refer more naturally to the song of the call bird (Oppian, hal., IV. I20 ff.), rather than to that of the fowler, but $\mathrm{cf}$. Cato (the poet of the third century A.D.), in Disticha, I. 27, "Fistula dulce canit volucrem dum decipit auceps"; and Tibullus, II. 5, 3r, "Fistula cui semper decrescit harundinis ordo." In addition to catching birds by rods and birdlime, a common practice according to Aristophanes was to confine doves, etc., with limbs tied up or with eyes covered, in a net, and thus allure other doves, etc., to the snare. Illex was the technical name for the decoy bird. For this purpose use was made both of kindred and of hostile species, such as the owl and falcon. The latter was also trained to catch the bird, which had been decoyed within its reach. Cf. Martial, Ep., XIV. 2I8. Aristophanes, Aves, $1082 \mathrm{f}$.

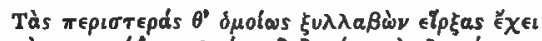

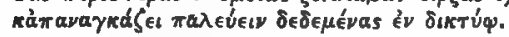

Ibid., 526 ff., trans. B. H. Kennedy :

"And the cunning fowlers for you set

Snare and springs, twig, trap, gin, cage, and net."

Plautus. Asin., I. 3,67 f.:

" Edis nobis area est, auceps sum ego.

Esca est meretrix, lectus illex est, amatores aves."

- Cf. Petronius, Sat., 40, 6, and Bion, Id., 4, 5 . 
of a tree, under which, or at some convenient distance from it, he contrived to conceal himself. When a bird, attracted by the singing of its companion, perched on the branches, he quietly inserted his rod amongst the boughs until it reached his prey, which stuck to the lime and was thus drawn to the ground. When the tree was very high, the rod was made in separate joints, like our fishing rod, so that he could lengthen it out until it reached the object of his pursuit, whence it is termed crescens or texta.

If the example given by Rich (from a terra-cotta lamp) be faithfully rendered, the joints in the rod are easily discernible. ${ }^{1}$

But all question as to the existence of a jointed fowling rod is now settled past peradventure by P1. 24, Fig. 686, in the Brit. Mus. Cat.

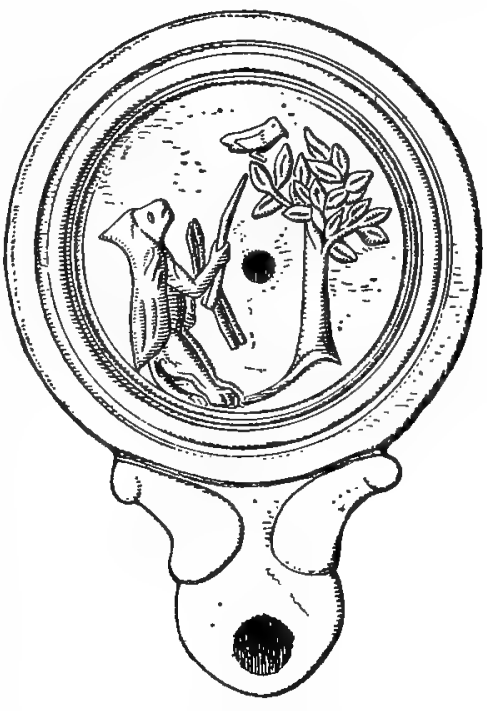

THE FOWLER.

From Brit. Mus. Cat. of Lamps,

Pl. 24, Fig. 686. of Gr. and Rom. Lamps, I9I4. This shows an animal dressed in a hooded cloak, holding in his right hand a length of fowling rod, and in his left two spare lengths, trying to reach a tree on which sits a bird. Mr. Walters, the editor of the catalogue, kindly informs me that Fig. 686 can no longer be regarded as that of The Fox and the Grapes. Similar lamps shown in S. Loeschcke's recent Lampen aus Vindonissa, e.g. Pl. I2, No. 473, confirm the evidence of the Brit. Mus. lamp in every detail.

Not a few editors, on the other hand, retain vadis in Martial's

1 A. Rich, Dict. of Rom. and Gk. Antiquities, London, I874, s.v. 'Arundo.' I have been unable to trace this lamp in either Birch or Passeri. Daremberg and Saglio, op. cit., seem to collect most of the information on the subject, s.v. "Venatio,' V. p. 694. The above and other methods of aucupium, "bird. catching," prevail to a devastating extent in Italy at the present day. 


\section{I50 PLINY-MARTIAL-WAS THE ROD JOINTED ?}

epigram, instead of levis, as evidently did Hay, the Scotch poet, in translating the couplet,

"Could I a trout, now, with my angle get,

Or cover a young partridge with my net."

Much can be said for the view that line three applies to fishing. So much, indeed, that were it not for one, apparently fatal, omission, we might confidently proclaim the first definite mention of a jointed rod. To this omission, conclusive to my mind of the meaning of harundo, I have so far found no allusion.

Let us suppose that the first line of the couplet does refer to fishing. The poet would like to give some birds or fish, or both, to his friend Carus, but bewails his inability to send anything better than some chickens. He does explain fully why he cannot send birds, but he omits entirely any reason, or even any hint, as to what prevents him sending fish. We are not allowed to imagine that the weather was too bad, for the whistling ploughman imitating the magpie in his call, the starlings, the linnets, all negative that.

The whole epigram seems to refer to fowling. The application, even if vadis for levis be adopted, would not necessarily be altered. Are there not wild duck and snipe to be caught in the shallows (vadis) as well as fish, and probably by other means than birdlime, though with the use of a rod?

If levis, or even vadis be read, two arguments lean heavily against harundo being the fisher's Rod. The first, in a poem dealing entirely with birds this somewhat obscure reference to fish would be extremely abrupt ; the second, the line following " harundine præda " runs, " Pinguis $e t$ " (not " aut " as before) "implicitas virga teneret aves," " and (not or) the sticky reedline," etc.

Save for this omission and the trend of the whole context, a strong argument might be easily advanced for fishing in the apparent redundancy of harundo and virga. But these two words may refer to two different weapons of capture, or, what is more probable, to two different ways of catching birds-the first, by a long reed with a noose, and the second by a branch with birdlime. 1

1 The best reeds for fowling purposes (harundo aucupatoria) came from 
To conclude, whether harundo here be a weapon for capture of birds or of fish, it is now established beyond any doubt or contradiction that there was used in and probably long before Martial's time ${ }^{1}$ a Reed Rod, capable of extension, either by protruding a smaller cane through a larger one, or else, perhaps, by an action somewhat similar to a chimney-sweep's, with jointed rods fastened together in the hand, when prolonging his brush.

If such a Reed Rod was found of service to the fowler for reaching a bird on a high branch, is it not extremely probable, is it not almost certain, that in spite of no express mention of such use the fisherman also employed a similar jointed rod for the purpose-common alike to his primitive predecessor and his more advanced successor-of getting the bait over any obstacles which lay between him and the water, and for increasing both the reach of his arm and the length of his throw ? 2

Whether the Rod of the piscator was similar to that of the aucupator or not, we do find these two pursuits, with but one verb for both, coupled in two of Tibullus's beautiful lines on Hope (II. 6, 23). His Hope is very reminiscent of St. Paul's Charity or Love, which " beareth all things, believeth all things, hopeth all things, endureth all things. Love never faileth."

" Hæc laqueo volucres, hæc captat harundine pisces

Cum tenues hamos abdidit ante cibus."

" 'Tis Hope, that taketh birds with the Snare, fish with the Rod with fine Hooks well hidden in the bait."

Panormus, those for fishing (harundo piscatoria) from Abaris in Lower Egypt. Pliny, XVI. 66. For a legal decision as to the selling, etc., of reeds, see Digesta Justiniani, VII. 1, 9, 5 .

1 Possibly in the time of Aristophanes,

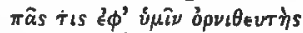

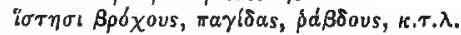
Aves, 526 f.

In the seventh century B.c. the Chinese mention the $C h$ 'ih $K a n$ or the " glu tinous line for catching birds." Cf. Apuleius, Met., XI. 8.

2 The epitaph in Corpus Inscript. Lat., ii. 2335, is of interest :

d. [M.] Quintus Marius Optatus

heu iuvenis tumulo qualis iacet a[bditus isto,]

qui pisces iaculo capiebat missile dextra,

aucupium calamo præter studiosus agebat . . .

Cf. Carm. Lat. Epig., no. $4 \mathbf{1 2}$. 


\section{CHAPTER IX}

\section{THE FIRST MENTION OF A FLY}

THE first mention of fishing with a fly occurs apparently in Martial's lines, " Namque quis nescit, | Avidum vorata decipi scarum musca?" which have been translated :-

"Who has not seen the scarus rise, Decoyed, and killed by fraudful flies ?" 1

These lines are of surpassing interest. In them we may possess the very first mention of a fishing fly, whether natural or artificial, in all the records written or depicted of the whole world.

If the reference be to an artificial fly, it certainly antedates by some two centuries the passage of $Æ$ lian (XV.I), which has hitherto been universally acclaimed the first mention of such a fly. If on the other hand the reference be to a natural fly, it antedates by the same period of time the first mention of the natural fly, or rather winged insect ( $\kappa \omega \dot{\nu} \omega \psi)$, to be found also in Flian (XIV. 22).

And here, pray, observe the cold calm of the classical commentator! This passage, which, as I have said, may be the very first historical document testifying to the use of the fly, the very first tiny beginning of the immense literature consecrated to the fly, the very first starting point in the fly fisher's journey of sore travail to farther knowledge, this passage so pregnant of possibilities and so provocative of comment, has never, I believe, been suggested by any editor as possibly the locus classicus of fly fishing, far prior to the generally adopted passage of Ælian.

Even if we make great allowance for the wrath of the

$$
{ }^{1} E_{p,}, V_{15} \text { I8, } 7 \mathrm{f} .
$$


literary angler at the careless indifference with which these lines appear from his standpoint to be treated, the comments by the editors of Martial must be classed, in other respects also, as unsatisfactory and jejune.

Paley and Stone, for instance, confine themselves to telling us that "scarus is some unknown but highly prized fish, which was caught by an inferior one used as bait." That is all! nothing more! Their " unknown" stamps their indifference, or ichthyic ignorance. " Further, they never even hint that in this passage commentators have suggested two readings, musco-' moss,' and musca-'fly.' They simply adopt musco without hinting at any difficulty arising from such adoption.

Friedländer adopts musca. His only note consists of, "Vorato-musco wollte Brodæus lesen wegen der von Athenæus, VII., p. 3I9 f., aus Aristoteles angeführten Stelle 2 . . ."

The majority of editors ${ }^{3}$ prefer, and probably rightly, the reading musca for many reasons, the chief being that all the manuscripts of Martial without a single exception give musca. The upholders of musco, in their endeavour to enforce that mere conjecture by quoting from Athenæus, "The Scarus flourishes on his food of sea-weed," 4 and supporting it by Pliny, "The Scarus is said to be the only fish that ruminates and is herbivorous" (and here note that as Pliny--like Athenæus-was taking his information from Arist., N. H., VIII. 2, he should have translated фuкious by algis, not by herbis), make the mistake of translating фuкiov by muscus. They ignore,

1 See infra, p. 155, note 6 .

2 See infra, p. I 55 , note 5 .

9 Schneidewin, Ed. I., I842, and Ed. II., I852, reads musca, as does Lindsay, I903. Paley and Stone (I888) musco; W. Gilbert (Leipzig, I886 and r896) reads musca, and in his apparatus criticus remarks "vorata d. sc. musca cum libris Scrin. Schn. Gib.-vorato d. sc. musco Brodæus Schn."

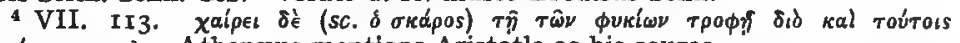

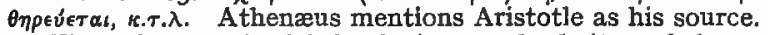

The references by ichthyologists to the bait used for catching the Scarus seem infrequent: I at least have only come across the following. "The fishing requires some experience: fishermen allege that there is necessary $u n$ individu vivant pour amorcer les autres, yet here we call to mind what Flian and Oppian say as to the great number of fish attracted by following a female attached to the line." See Cuvier and Valenciennes, H. N. des Poissons, vol. XIV., p. I50, Paris, I839.

- IX. 29. Scarus solus piscium dicitur ruminare herbisque vesci, non aliis piscibus. See also Oppian, II. $645-65^{\circ}$. 


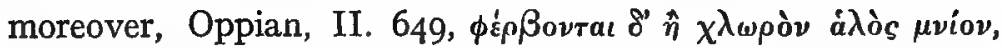

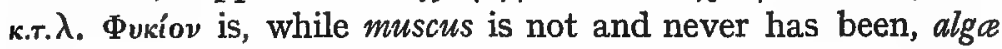
or true seaweed ; muscus is ' moss.' 1

Nor do these Olympian editors, who sit beside their proofsheets, and whose notes are ever hurled far below them in the valley, condescend to explain to us poor gropers after light how moss to a sea-fish like the Scarus can be of value as food.

Most fishermen will tell you that freshwater fish do eat moss; that they themselves have seen them in the act of eating such moss on the Thames; that roach in especial are particularly fond of this moss, which is used in summer months as a bait with great success; this moss they call by various names, ' silk weed,' 'flannel weed,' ' blanket weed,' and 'crow-silk.' Now all these so-called mosses are not mosses at all, but belong to the family Conferve, which are freshwater green alga: so even in rivers we find that moss is not used as bait. ${ }^{2}$

That not only the Scari but other fish, e.g. the Melanuri, feed on seaweed and that they are taken by baits composed of seaweed, many writers besides Athenæus and Pliny duly record. Theocritus (Id., XXI. Io) speaks of "baits of seaweed." Oppian, ${ }^{3}$ describing the manner of catching the salpe by baiting a place with stones covered with seaweed, states that when the fish have gathered round this in numbers, " then prepares he (the fisher) the snare of the weel." Elian $^{4}$ asserts that among the marine plants, on which he says fish feed, are $\beta$ pía...

1 The Oxford Dict. gives, "Alga, a seaweed: in plural, one of the great divisions of the Cryptogamic plants including seaweeds, and kindred freshwater plants, and a few ærial species," and "Moss, any of the small herbaceous Cryptogamous plants constituting the class Musci, some of which form the characteristic vegetation of bogs, while others grow in crowded masses covering the surface of the ground, stones, trees, etc." As " applied to seaweed rare "; I might venture to add either poetical, as in Tennyson's Mermaid, " in hueless moss under the sea," or loose and unscientific.

${ }^{2}$ Compare J. Britten and R. Holland, Dict. of English Plant Names (London, I884), III, 576. Wright in his Dialect Dictionary, "Crow-silk, Confervæ, and other Algæ, especially $C$. vivulavis."

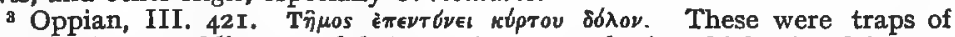
wickerwork, resembling our lobster pots or weels, in which the fish were caught as they flocked to suck at the seaweed, with which the stones (placed inside the traps to sink them) were covered. Cf. $\$$ Elian, XII. 43, who states that for this sort of fishing fishermen made use of qúkovs $\theta a \lambda a \sigma \sigma i o v$.

4 N. H., XIII., 3. Cf. also ibid., I, 2, 
кaì фuкía ă $\lambda \lambda a$, the difference between which seems according to Aristotle merely one of size.

If a poll of writers on Fishing and of practical Pisciculturists were taken to-day, a large majority would vote that sea-fish do not eat seaweed, but feed on the larva, and other minute insects in or on the various alga or seaweeds. But against this opinion is arrayed the authority of Darwin and Wallace, who state that various species of Scarus do browse, and do graze on seaweed, and some of them exclusively on coral. ${ }^{1}$

The Skaros (according to Aristotle) was the only fish which seemed to ruminate, ${ }^{2}$ whose food was seaweed, ${ }^{3}$ and teeth, set in deep saw-edged jaws, were not sharp and interlocking, like those of all other fish, but resembled those of a parrot, as its beak resembled that of a parrot.4

From the seeming to ruminate of Aristotle we reach in later writers like Oppian, I. I34 ff., and Ovid, Hal., IIg, the positive assertion that the scarus did ruminate. ${ }^{5}$

Is it not possible, if a mere angler may hazard a suggestion on scientific points, that the belief of modern writers and pisciculturists is not far out, and that while some of the Scari do browse and graze exclusively on coral, and some sometimes on seaweed, they do this to obtain as food only the minute larva, which their so-called rumination helps them to separate from the seaweed or coral ? 6

A second very practical argument against the reading musco suggests itself. Let us allow that some sea fish do eat not only alge but moss: even then, why should our Scarus

1 Voyage of the Beagle, ch. 20: "Two species of fish of the genus scarus, which are common here (Keeling Island), exclusively feed on coral," Sir R. Owen, "The anterior teeth are soldered together and adapted to the habits and exigences of a tribe of fishes which browse on the lithophytes, that clothe the bottom of the sea, just as ruminant quadrupeds crop the herbage of the dry land."

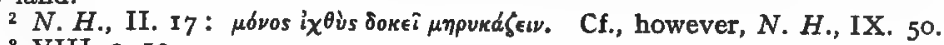

3 VIII. 2, I3.

- Arist., N. H., II. 13. Pliny, XI. 6I. "Piscium omnibus (dentes) serrati, præter scarum : huic uni aquatilium plani."

s In VII. I I3, we again find Athenæus misrepresenting Aristotle.

" "This idea of rumination," according to Mr. Lones, op. cit., p. 237, " by the parrot wrasse (Scarus cretensis), which is clearly the Skaros of the Ancients, probably arose from its grazing or cropping off marine plants, and grinding them down, assisted by its having a strongly walled stomach" (cf. the functions of the gizzard of a fowl) with which, out of the myriads of 
" be deceived" by the small amount possible of attachment to a little hook, of seaweed or moss or their larva? This is infinitesimal when compared with the greater masses, giving immeasurably ampler supply of larva, growing in the sea.

Were it not for the incitement or excitement caused by the fly's movements or novelty, hardly a salmon, I venture to think, would rise to a fly; but to our scarus, since algœ and moss (if the latter exist in the sea of sufficient length) are familiar growths and constantly set in motion by the action of the water, both these incitements are surely lacking.

Even if neither of these arguments carries weight, the objection brought forward by Gilbert appears to me to put the reading musco out of court: "Suppose Martial knew what Athenæus and others state as regards this peculiar habit of the scarus, surely this was not the place, where the Scarus is introduced only as a representative of all fish, to air his knowledge-least of all in words such as "quis nescit.'

In conclusion, if musca be the right reading, we can, I think, definitely assert :

A. That this passage contains the very earliest mention of a fly being used for the taking of fish :

B. That from Martial's employment of it as an illustration, and from his not drawing attention to the novelty or oddness of such use, and especially from the words "quis nescit," which imply a general knowledge, fly fishing had been long invented, and was a method common among anglers :

C. That this solitary passage is inconclusive as to whether the fly was simply a natural one attached to a hook, and used perhaps as now in dapping, ${ }^{1}$ or an artificial one.

fishes, the scarus and his tribe alone are endowed. On p. I62, "The stomach of a skaros is without a cæcum, and appears to be of far simpler form than that of most fishes."

A trout often appears to ruminate, working its jaws quietly for a considerable time-perhaps this is merely to settle its last mouthful comfortably and to its liking. According to Banfield, in Dunk and other islands off Northern Australia, a fish, very similar to only even more brilliant in hues than the Pseudoscarus vivulatus, is able by the strength of its teeth (some sixty or seventy, set incisorlike) to pull from the rocks limpets (its chief food), which when steadfast can resist a pulling force of nearly 2000 times their own weight! It swallows molluscs and cockles whole, and by its wonderful gizzard grinds them fine. See Confessions of a Beachcomber (London, 1913), p. 156.

1 "Dapping," to which I miss allusion even in Dr. Turrell's excellent 
To my mind, however, the scale dips deeply in favour of the artificial fly for the following reasons.

I. The trend and purpose of the whole passage, especially when we note carefully the preceding verse and a half, "Odi dolosas munerum et malas artes. I Imitantur hamos dona," is to inveigh against fraudful gifts, typical of which fraudful flies are singled out-in fact, against all presents which are not what they appear. Mr. A. B. Cook writes: "I quite agree with your view that the passage gains much, if all three lines are made to refer to an artificial fly with a hook concealed in it. Indeed, that is pretty obviously the meaning."

2. The difficulty which the ancients would have experienced in impaling, etc., on one of their hooks a natural fly would have been greater than dressing an artificial one. The smallest hook in the Greek-Roman Collection at the British Museum (found at Amathus in Cyprus I894) measures over $\frac{1}{4}$ in. breadth at the bend.1 If we allow that owing to oxidation the metal may have coarsened and swollen, the task of impaling, and further of fastening a natural fly securely enough to withstand the buffets of even wavelets of the sea (for N.B. the Scarus is

Ancient Angling Authors, is so often regarded as a more or less modern method that, even at the risk of a portentous note, I must record my reasons for differing in toto from this view. Walton certainly employed it in the seventeenth century. Pursuing the device further back, it is distinctly enjoined in the earliest fishing treatise in English, the earlier version of The Boke of St. Albans (i.e. a MS. of about $I_{45^{\circ}}$ printed from a MS. in the possession of A. Denison, Esq., with Preface and Glossary by T. Satchell, London, I883), and seems, although not clearly described, surely specified as follows: In " How many maner of Anglynges that ther bene . . The IIIIth with a mener for the troute with owte plumbe or floote the same maner of Roche and Darse with a lyne of I or II herys batyd with a flye. The Vth is with a dubbed hooke for the troute and graylyng ..." This passage draws a decided distinction between baiting with a fly and a dubbed hook, or artificial fly. But no lead (plumbe) or float was to be used, therefore the method intended seems without doubt "dapping," which warrants, to my mind, the assumption that this device is as old as the earliest instructions in English. This older form of the Treatise seems, it is true, to have differed slightly from the version used for $T$ he Boke of St. Albans in 1495 . T. Satchell held that they both had a common origin in the " bokes of credence," which are mentioned in the latter, and may, he suggests, have been French, but of this I am doubtful, principally because the French and English traditions appear to me to have marked points of difference.

1 The two smallest perfect hooks scale about No. Io and No. I I respectively in the old, and 5 and 4 in the new numbering. They are considerably smaller than the Kahun (XII Dynasty) hook, which Petrie believes to be the smallest known in ancient Egypt. Cf. his Tools and Weapons (London, 19I7), p. $37 \mathrm{f}$. But the Kahun hooks scale Nos. 9 and 6 respectively. 


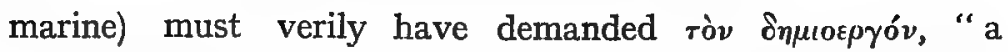
craftsman of the people, welcome over all the wide earth." I

For these reasons the kudos of the first mention of an artificial fly belongs, in my opinion, to Martial rather than to Elian.

1 Od., XVII. $3^{83}$ and $3^{86}$. 


\section{CHAPTER $\mathrm{X}$}

\section{THE SCARUS-THE EARLIEST ACCLIMATISATION OF FISH -THE FIRST NOTICE "FISHING PROHIBITED"}

From the wealth of copious yet conflicting accounts of this famous fish in Greek and Roman writers, a large monograph might be produced. ${ }^{1}$ I restrict myself to a short notice of the acclimatisation of the fish, and of the controversies on its value, as (A) a Dainty, and (B) a Diet.

The original habitat of the Scarus was in the seas off Asia Minor, especially in the Carpathian Sea. During the Augustan age it was rarely taken in Italian waters, and then only when driven thither by storms. Thus Horace complains that neither Lucrine oysters nor Rhombi come his way,

$$
\text { " aut scari, }
$$

Si quos Eois intonata fluctibus

Hiems ad hoc vertat mare."

$$
\text { (Ep., II. } 50 \text { ff.) }
$$

Pliny (IX. 29), after attributing to the Scarus the unique characteristic of being herbivorous and never feeding on other fish and asserting that of its own accord it never passes from the Carpathian Sea beyond Cape Troas, goes on to tell us that

1 " Il est peu de poissons et même d'animaux qui aient été, pour les premiers peuples civilisés de l'Europe, l'objet de plus de recherches, d'attention, et d'éloges que le Scare " (Lacépède). On the family of the Labrida (of which the Scarus forms a genus) the same author asserts that Nature has not conferred either strength or power, but they have received as their share of her favours, agreeable proportions, great activity of fin, and adornment with all the colours of the rainbow. Of the two cousins of the Scarus, the Turdus and the Julis, his eulogy can not be omitted: "Le feu du diamant, du rubis, de la topaz, de l'émeraude, du saphir, de l'améthyste, du grenat scintille sur leures écailles polies: et brille sur leure surface en gouttes, en croissants, en raies, en bandes, en anneaux, en ceintures, en zones, en ondes; il se mêle à l'éclat de l'or et d'argent qui y resplendit sur de grandes places, les teintes obscures, les aires pales, et pour ainsi dire décolorées." Nicander of Thyatira (cp. Athen. 7. II3) states that there were two kinds of Scarus, one alósos of many diverse colours, the other 'ovías of a dull grey tint. 
in the time of Tiberius (or Octavius, according to Macrobius) vast quantities at the Emperor's command were collected by an Admiral of the Fleet and planted along the Ostian and Campanian shores.

Careful protection by land and sea rendered poaching almost impossible. For the period of five years any scarus caught in the nets had, under heavy penalties, to be returned straightway to the water. The enforcement of these wise regulations effected such mighty thriving of the fish, that "postea frequentes inveniuntur Italiæ in litore, non antea ibi capti; admovitque sibi gula sapores piscibus satis et novum incolam mari dedit."

This operation commands our comment, not merely on account of its big success, but because it is the earliest and (as far as I can discover) the only instance in all ancient literature, certainly in Greek and Latin, of the acclimatisation of fish (not eggs) in the sea, and on a large scale.

I do not include, though I do not forget, the large lucrative planting of oysters in the Lucrine lake by Sergius Orata centuries before. ${ }^{1}$ Later on we shall read of the Romans carrying eggs, naturally fertilised, from one water to another, and of the Chinese 2 transporting vast quantities of similar eggs considerable distances.

But their methods and operations differed from the Emperor's. Pliny expressly states that the Admiral planted fish, not eggs of fish, in the sea, not in fresh water, and in a new habitat hundreds of miles from the old.

To this planting or involuntary colonisation, Petroniusseemingly, despite controversy, the "Elegantiæ Arbiter," or the not altogether Admirable Crichton, of Tacitus-probablyalludes:

" ultimus ab oris

Attractus scarus atque arata Syrtis

Si quid naufragio dedit, probatur." 3

Poets and gourmets have vied in singing the praises of the fish as the daintiest of dishes-" according to the Greeks to do

1 Pliny, IX. 79.

2 See J. B. Du Halde, Description gégraphique... de l'Empire de la Chine. ... (Paris, I 735), vol. i. p. 36 .

s Petron., Sat., 93, 2. 
justice to its flesh was not easy: to speak of its trail, as it deserved, was impossible, and to throw away even its excrement was a sin." Confirmatory of Badham reads the pronouncement of magnus ille et subtilis helluo, "that great and exquisite gourmet" Archestratus, who from the grandiloquence and gravity of his Epic was evidently of opinion omne cum fidibus helluoni! 1

Epicharmus the comedian in his Hebe's Wedding (frag. 54, Kaibel),

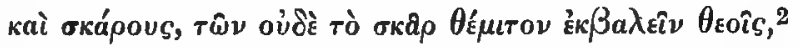

"Not even their trail is it lawful for the gods to throw away,"

summarises the wild infatuation of the Greeks for the scarus, while from Ennius ${ }^{3}$ some centuries later is extorted,

"Quid scarus? præterii cerebrum Jovis pæne supremi :

Nestoris ad patriam hic capitur magnusque bonusque."

1 Archestratus is constantly quoted and always praised by Athenæus as " excellent," "experienced," etc. Archestratus the Syracusan in his workvariously termed " Gastronomy," " Hedypathy," "Deipnology," " Cookery " -begins his epic poem, "Here to all Greece I open wisdom's store " ! (Yonge's trans.). From delivering his precepts in the style and with the gravity of the old gnomic poets, Archestratus was dubbed "the Hesiod or Theognis of opsophagists." The comic poets have many a gibe at him, e.g. Dionysius of

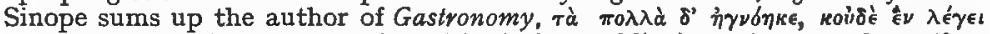
(Thesmophorus, frag. I. 26, Meineke)! Before publishing this work, the author travelled far and wide to make himself master of every dish that could be served at table. Known to us almost entirely as a supreme bon vivant, and as the earliest (except Terpsion) and certainly greatest Mrs. Glasse of the Greeks, his accuracy of description of the various fishes used for the table was so consistent, that we find even so high an authority as Aristotle making use of it in his Natural History. Archestratus in his travels concerned himself not at all as to the manners or morals of the countries visited, "as it is impossible to change these," and held little or no intercourse with any but those, e.g. chefs, who could advance the pleasures of taste. Whatever the cause, whether too many sauces or too little nutritive food, he was so small and lean that the scales are supposed to have returned his weight as not even one obol! (Cf. Hayward, The Art of Dining). Hayward himself must have appreciated the limitation of guests, which Archestratus imposes for a proper dinner

"I write these precepts for immortal Greece,
That round a table delicately spread,
Or three, or four, may sit in choice repast
Or five at most. Who otherwise shall dine,
Are like a troop marauding for their prey."

(I. Disraeli's trans.)

The sentiment, if not the number, coincides with the Latin proverb"Septem convivium, novem convicium."

2 I follow Wilamowitz in $\sigma \kappa \alpha \hat{\rho} \rho$ for $\sigma \kappa \omega \hat{\rho}$, the usual reading, partly because Epicharmus being a Dorian would use the Doric form, partly because being a comedian he is probably playing on the words $\sigma \kappa a ̂ \rho$ and $\sigma k \alpha$ óps.

3 Hedyphagetica (frag. 529, Baehrens). Suidas state that the Persians

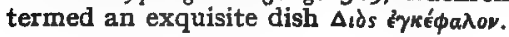


Although Pliny (IX. 29) definitely asserts " Nunc scaro datur principatus," we find Martial within a few years dismissing the fish as of poor flavour-its only redeeming point the trail, which is excellent,

" Hic scarus, æquoreis qui venit obesus ab undis, Visceribus bonus est, cetera vile sapit."

In the curious and rare Ichtyophagia (the omission of the second ' $h$ ' of the theta may be a printer's error) by the learned Doctor Ludovicus Nonnius, published at Antwerp in I6I6-a treasure-house from which I quote much and take morean attempt is made to explain these diametrically opposed estimates. Nonnius asserts that as among the common herd only those fish which have fat flesh find favour or yield good flavour, and as the Scarus possesses a drier and more flaky flesh, " a plebis illis palatis spernebatur."

This deals a nasty knock to poor Martial, who plumed himself on his taste as a gourmet, acquired (he fails to add) at the banquets and entertainments of his patrician friends or wealthy patrons.

Medical controversy, rarely absent, as to wholesomeness for once hardly exists. Galen, Diphilus, Xenocrates all agree as to the Scarus, although the last warns us that it is "hard

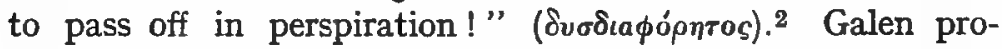
nounces fish who haunt the rocks the most wholesome ${ }^{3}$ : of these, the Scarus is by far the best. Diphilus the Siphnian on the whole agrees, but condemns it as dangerous when fresh (!) because it hunts and feeds on the poisonous sea-hare and so frequently causes cholera morbus. 4

But according to Elian, IX. 5I, the Mullet ( $\left.\tau \rho^{i} \gamma \lambda \eta\right)$ was held by the initiates of the Eleusinian Mysteries in the greatest honour, for one or other of two curious reasons: the first,

1 Another reading is adesus. Cf. Xenocrates, de Alimento ex Aquatilibus, c. I4, of the scarus, which was fresh-caught and not vivarium-kept, being $\pi 0 \lambda \lambda \sigma_{0 i s}$

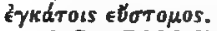

2 See Liddell and Scott.

3 VI. 718 (Kühn).

- Athen., VIII. 5I. 
because it brings forth its young thrice a year ${ }^{1}$, and second, because it eats the sea-hare, who bears death to man. ${ }^{2}$

Nonnius (p. 8I) informs us that the followers of Pythagoras

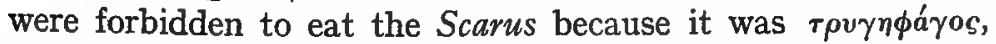
i.e. an eater of grain or grapes, whence or how obtained he vouchsafes not to inform us. ${ }^{3}$ It is of interest to read in Faber (op. cit., p. 27) that the common seal (Phoca vitulina) is believed at the present time to go ashore in the Ombla Valley in quest of grapes during the vintage, and is also said to commit great havoc in the vineyards of Sardinia and Sicily!

But for once Nonnius naps! Although, according to tradition, Pythagoras proscribed all fish, three kinds only are expressly and by name forbidden (in Symbols I8, I9, 60), viz. the Melanurus, the Erythinius, and the Sepia; nothing is said about the Scarus.

I presume that the error arose from Nonnius confusing a passage in Plutarch (Symp., VIII. 8, 3.) where a propos of

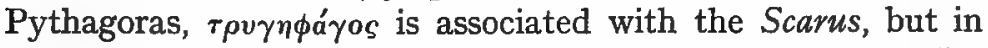
exactly the opposite sense, "for we can not call the Mullet corn-destroying, or the Scarus grape-eating," etc.

Again our Nonnius! By a passage from Pliny, XXXII. 3, he attempts to clear the Scarus and throw the blame for cholera on the Mullet.

But Pliny distinctly states that alone of all animals the fish

1 Cf. Oppian, I. 590.

2 IElian, XVI. I9, writes that these sea-hares were so poisonous, that if a man touched one thrown up on the shore with his hand, he shortly died, unless medicine was at once administered. So poisonous indeed are they, that " if you touch them with but your walking stick, there is the same danger which

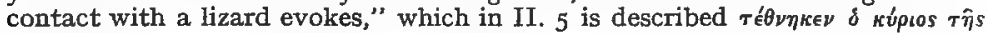
$\lambda$ '́rou! Nero, to "mak siccar" (like Kirkpatrick with the Red Comyn), employed the sea-hare as a dainty for friends whose deaths he earnestly desired. Cf. Philostratus, Life of Apollonius of Tyana, VI. 32.

3 Nonnius, always the alert defender of his favourite fish, ingeniously suggests that the scarus of Pythagoras was not our famous scarus, because as this fish, even during the Augustan period, was extremely rare in Italian waters, there seems little necessity for its being banned by the "Hyperborean Apollo of the Crotoniates " in B.C. 540-510. Numa, apparently influenced by Pythagorean precepts, forbade (according to Cassius Hemina, Pliny, XXXII. Io) all scaleless fish being offered to the gods. Festus, p. 253, a. 20, however, states that in such offerings it was allowable to present all fish with scales, except the Scarus, which was sacrificiable, and most acceptable to the god of the peasants, Hercules, whose " swinish gluttony | Crams and blasphemes his feeder." For squaram, Müller suggests scarum, while Lindsay prints squatum, the skate. 
called the Mullet, when he can annex no other food, eats the sea-hare without fatal consequences, after which he " tenerescit tantum et ingratior 1 viliorque fit." These Mullet, sold by fraudulent fishermen as Scari, caused the indictment of Diphilus. Rondolet bears witness that near Massilia similar sales took place " ab imperitis piscatoribus," but surely " too skilled" would be the better epithet. It is but fair to add that Athen., VIII. 5I, asserts that the Scarus also eats the sea-hare.

For this long discursus, the repute of the Scarus, the disputes of epicures and of doctors whether it be a dainty, or a sound diet, and the exclusive properties attributed to it by Greek and Roman writers must be my excuse.

Summarising these last, we find that the Scarus, in addition to being the most passionate in his love 2 , alone of all fishes,

(A) Is not a cannibal, but a vegetarian (Pliny, IX, 29). Oppian claims for the mugil-grey mullet-that it is the only non-carnivorous fish (II. 642-3). Couch gives as his considered opinion, "Mugil capito is the only fish of which I am able to express my belief that it usually selects for its food nothing that has life." Modern authorities have established that the scarus feeds on molluscs also.

(B) Seems to ruminate or does ruminate. ${ }^{3}$

(C) Belongs to,

"The only kind that dare

To form shrill sounds, and strike the trembling air." 4

(D) Sleeps at night. ${ }^{5}$

"Scarus alone their faded eyelids close

In grateful intervals of soft repose."

1 Mayhoff would read inertior.

(Oppian, II. 66r ff.)

2 正lian, I. 2.

s Aristotle and Pliny, supra: Oppian, I. 135-7; Ellian, II. 54.

- Aristotle (according to Athen., VIII. 3) states that the scarus and seahog are the only fishes that have any kind of voice, but in reality he (IV. 9) mentions five others, among which is the cuckoo-fish, who "whistle and grunt" (see Pliny, XI. I 12 : Oppian, I. I34-5). Athenæus errs, for Aristotle (N. H., IV. 9, 8) asserts that the Dolphin when out of the water "groans and cries"; while Pliny (IX. 7) says of the Dolphin, "Pro voce gemitus humano similis." Aristotle expressly differentiates between the five mentioned fish and the Dolphin-for the former possess no lungs, windpipe, or pharynx, and so can produce no voice, only " sound," while " the dolphin has a voice and therefore utters vocal and vowel sounds, for it is furnished with a lung and a windpipe."

5 Someone may throw at me the sentence of Seleucus of Tarsus, who in the 
But Aristotle (and, of course, Pliny) hold that most, perhaps all, fish do sleep, even if their eyelids are not closed : at any rate Tunnies and all flatfish do, while Pliny (X. 97) goes as far as asserting that "Dolphins and whales can be heard to snore!"

(E) Has plain, not sharp or jagged, teeth. 1

(F) Never deserts his fellow fish. If he have swallowed a bait, his friends flock around him and liberate him by biting the line in two. If he be caught in trap or weel, they approaching very delicately give the prisoner the choice of $(a)$ gripping with his teeth a tail " by which he is dragged through the mesh of twigs," or (b) of pushing through his own tail, which they (outside) seize, and pull him through the weel backwardsthus avoiding damage from the twigs to the eyes of the captive. ${ }^{2}$

This devotion to his imprisoned fellow was turned to good account by fishermen. Fastening a hook in the jaw of and trailing a net behind a female scarus (preferably alive) they secured large catches by dropping the lead, which reversed the net and enmeshed the would-be rescuers. With the seed of the coriander Scari are taken " with a vengeance!" 3

Ælian (I. 4) concludes a similar story, probably purloined from Oppian, for he was an adept in picking up unconsidered and unacknowledged trifles, with, "These things do they, as men do : but to do loving-kindness are they born, not taught " ; which demonstrates that the invaluable Scarus provides men, not only with a menu, but also a moral !

only English translation of Athenæus (by C. D. Yonge) is made to say (VII. I I3), "The Scarus is the only fish which never sleeps." If Yonge had been faithful to the text (Schweighäuser's) which he expressly states he had adopted, he would have omitted the ov, because it is in brackets and the editor expressly puts against it the note " Deest vulgo negativa particula," and his accompanying Latin translation is " unum hunc ex omnibus piscibus dormire." Kaibel (Leipzig, $\mathrm{x} 887$ ) also brackets the ov, while Dindorf ( 1827$)$ has no ov, bracketed or other.

1 Aristotle, N.H., II. I3; Pliny, XI. 6r. Another instance of the carelessness of Athenæus-induced perhaps by his omnivorous reading-is to be found in the first line of VII. II3, "The Scarus, Aristotle says, has sharp or jagged teeth," whereas a reference to $N$. H., II. I3, discloses that all fish except the scarus have sharp or jagged teeth, a statement which is confirmed by Rondolet.

Cf. Opp., IV. 40-64; Pliny, XXXII. 5 ; and Ovid, Hal., 9 ff.

s 死lian, N.H., 12, 42 . 
If we cannot absolutely claim for Martial the first mention of the jointed Fishing Rod and the natural or artificial Fly, we are safe in acclaiming him the author of the first notice, "Fishing strictly prohibited," or " Chasse défendue," in his

"Baiano procul a lacu recede,

Piscator : fuge, ne nocens recedas."

(IV. 30.)

This epigram turnishes Bunsmann with one of the only three acts of Impietas which he can allege against the blameless race of fishermen. Martial here solemnly warns a fellow craftsman against fishing in the lake of Baiæ, because (I) the fish there are sacred to the Emperor Domitian, (2) a previous intruder was smitten blind in the very act of landing his fish, so that-and here comes a touch of the true angler- " he could not see his spoil."

The pretty compliment, veiled in the words " sacred fish," ranks Domitian as a god, because, as at many temples of the gods fish were held sacred, so at his Baian abode the fish had been shown by divine action to be sacred. But the fulsome bluntness of "than whom in the whole world there is none mightier " mars the effect. Lest, however, his friend might think that "Not twice in this world shall the Gods do thus," or deem the superhuman sanction played out, Martial adjures him to throw to the fish some plain hookless food, and "dum potes, innocens recede."

These Baian fish were evidently not as sophisticated or as discriminating as their neighbours, the Melanuri, which greedily snatch food thrown into the sea, but to any bit whatsoever containing a hook they approach neither delicately, nor at all.1

In case some reader, fired by the fame of Theocritus or Martial, imagine an easy affluence by writing Fisher Eclogues or Fisher Epigrams, I refer him to Martial's other warning, where he states that a written copy of one of his books could be bought for about fourpence halfpenny (considerably cheaper than a printed one now) and that with a profit to the bookseller ! 2 
The seeming naiveté of Martial's appeal to a buyer and of his recommendation that the book, which describes presents, would be for a man like himself not too flush of coin, an admirable present to send at the Saturnalia, incites me to give the whole, if fishless, passage.

The hint of how to get rid of their surplus stock or " remainders " at Christmas may avail our present poetasters in these days of economy and war taxes. "The whole collection of Xenia" (distichs describing certain kinds of viands so-called) " in this thin book will cost you four sesterces to buy. Is four too much? You may get it (in a cheaper form) for two, and even that will leave a profit to the bookseller. This book itself, which describes presents, may be sent as a present at the Saturnalia, if you have not much money to spare, like myself."

Manuscript books at Rome cost even less than printed books do now. This seeming inconsistency was effected by a large number of slaves writing rapidly at the dictation of one person, and so multiplying copies very cheaply and easily.

By such means, no doubt, was published Acta Diurna, the fly sheet or daily newspaper of Rome. Composed originally of the reports of lawsuits, births, deaths, marriages, and the almost equally numerous divorces, it came to contain in the time of Julius Cæsar the debates and Acta of the Senate, and later the news collected and conveyed by constant couriers from all parts of the Empire. ${ }^{1}$

1 Cf. Suetonius, Augustus, c. 83 . 


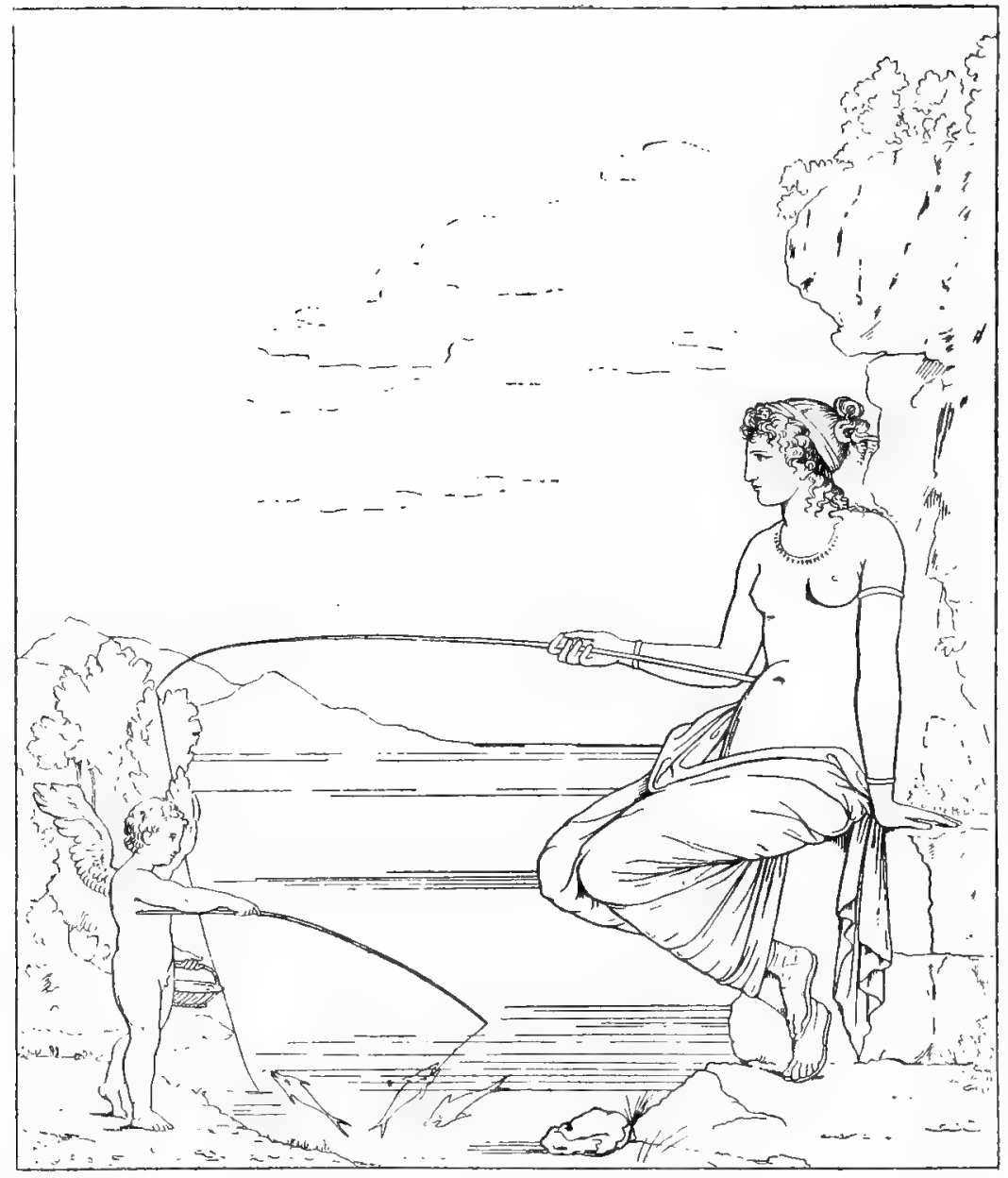

VENUS AND CUPID ANGLING.

From the Real Museo Borbonico, vol. iv. pl. 4 . 


\section{CHAPTER XI}

PLUTARCH : THE CHARGE AGAINST HIM OF CONTEMNING FISHING QUITE FALSE-CLEOPATRA'S FISHINGOPPIAN-THE TORPEDO FOR GOUT-ATHEN EUS

Our next two authors, Plutarch (a little later than Martial) and Oppian (c. I7o A.D.), both wrote in Greek.

Plutarch for centuries has been misrepresented and maligned as an opponent and contemptuous disdainer of fishing, but quite inaccurately. I am not of the class of writers who invest Nero with a halo, or canonise Clytæmnestra. I am no Knight of the Round Table on a quest to redeem lost characters, but I feel it a duty and a pleasure on behalf of Plutarch to fling down the glove and challenge his traducers to a duel à outrance.

Modern English writers,

$$
\begin{aligned}
& \text { " to the listening earth } \\
& \text { Repeat the story," }
\end{aligned}
$$

but not, like the Moon, the story of " the birth" of their error. Inevitably in their pages crop up Burton's words, " Plutarch, in his book $D e$ Sol. Anim., speaks against all fishing as a filthy, base, illiberal employment, having neither wit nor perspicacity in it, nor worth the labour." 1

1 The Anatomy of Melancholy (London, I806), I. 406. If Burton, " that universal plunderer" has cribbed from Dame Juliana Berners her eloquent eulogy on the secondary pleasures of angling, this book, in turn, till its resurrection in the eighteenth century was ruthlessly pillaged without acknowledgment. Warton, Milion, 2nd edition, p. 94, suggests that Milton seems to have borrowed the subject of $L^{\prime}$ Allegro and II Penseroso, together with some thoughts and expressions, from a poem prefixed to the book, while a writer in The Angler's Note Book, March 3I, I880, believes that "Walton probably drew the inspiration of his Angler's song from the wonderful storehouse of this quaint and original author." 
Holland translates the passage, "for the cowardice, blockishness, stupidity, want of shifts and means in fishs, either offensive or defensive, causes the taking of them to be dishonest, discommendable, unlovely, and illiberal." I subjoin. the Greek so that each reader may make his choice of or a translation of his own. ${ }^{1}$

These words do, it is true, occur in Phutarch's de Sol. Anim., 9. But the chapter merely gives a fanciful report of an imaginary debate before a jury empanelled to determine whether land or water animals are the more crafty. The words embody, not the opinion, matured or other, of the author, but one of the charges in the opening speech of Aristotimus, who appears on behalf of the superior sagacity of the terrestrials as against the aquatics.

From a sentence in the mouth of a special pleader Plutarch has been branded for centuries, at any rate since the time of Burton's book (162I), as the foe of fishing and the maligner of the craft. And with as much reason you might make Plato responsible for an opinion alien to his nature but advanced by one of his dialecticians, or saddle Father Izaak with some heresy of Venator's.

An attempt to account for so learned and on the whole so fair an author as Burton being led into a charge, the inaccuracy of which even cursory perusal of chapter nine evinces, may, if fishless, yet interest some of my readers. One of the blemishes ascribed to the Anatomy is the burdening of the text with too profuse quotations, ransacked from not only classical and patristic writers, but also (literally) from "Jews, Turks, and Infidels."

Making full allowance for Burton's encyclopædic knowledge, whence, and how, were these all amassed? Hearne, the Oxford historian, helps towards an answer in his statement that Mr. John Rouse, of Bodley's Library, for many years provided his friend of Christ Church with choice books and quotations. Is it too much to surmise that the passages "provided" by

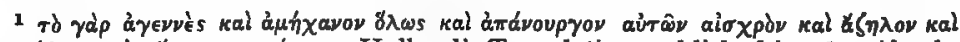

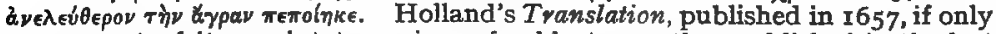
on account of its quaint turns is preferable to another published in the last century. 
the helpful service of Rouse 1-a trait fortunately still characteristic of his Bodley successors-included the sentence of damnation, which, even if verified, was, from being torn out of its context, certainly misunderstood and ill-digested ?

One ought to be chary of attributing motives, much more so reasons; but the only apparent reason for the numerous repetitions of Burton's slander must have been the line of least resistance or least exercise, which deterred writer after writer from taking the trouble to consult the original context and thus discovering by whom and how the words were spoken. I have so far failed to find a single defender of Plutarch on this count or any plea for reversal of a verdict based on evidence wrongfully accepted. ${ }^{2}$

Indignation at the injustice of the charge waxes all the hotter, when one remembers that the person indicted is the very self-same Plutarch who stands out as our authority for much unique lore on fish, fishing, and tackle. $\mathrm{He}$, and no other, consoles the victims of an Emperor's decree of banishment by pointing out the happiness of their lot in being far removed from the intrigues, the vices, the dust, the noise of Rome to a fair Ægean island, where the sea breaks peacefully on the rocks below, and-an additional assuagement- " where there is plenty of fishing to be had!"'

Could a man who contemned and denounced fishing so vigorously put into the mouth even of the pleader for the superior craftiness of fish, unless he himself had angled and possessed the true angling spirit, the following sentences, as true and as useful to-day as when written nineteen centuries ago ?

"For the first and foremost, the cane of which the angle Rod is made, fishers wish not to have big and thick, and yet they need such an one as is tough and strong, for to pluck and hold the fishes, which commonly do mightily fling and struggle when they be caught, but they choose rather that which is small

' Milton wrote (1646) a Latin Ode on sending a book to the Bodleian, in which he addresses Roivius as,

"Aeternorum operum custos fidelis

Quæstorque gazæ nobilioris."

2 Two years after this was written, I find that Mr. G. W. Bethune in his edition of The Complete Angler (New York, I89t), p. 6, notes the Aristotimus point, but goes no farther in defence of Plutarch. 
and slimmer, for fear lest if it catch a broad shadow, it might move the doubt and suspicion that is naturally in fishes.

"Moreover, the line they make not with many water knots" (happy anglers!), " but desire to have it as plain and even as possibly may be, without any roughness, for that this giveth as it were some denuntiation unto them of fraud and deceit. They take order likewise that the hairs which reach to the hook should seem as white as possibly they can devise, for the whiter they be the less are they seen in the water for their conformity and likeness in colour to it." 1

We anglers seem of a verity " nae gleg at the uptak." After some 1650 years we find John Whitney, in the preface to The Genteel Recreation: or the Pleasure of Angling, ascribing with modesty as to personal prowess, but quiet pride as to discovery, his success very largely to the use of "fine Tackling " which in the poem (!) he further, if in barbarous verse, enforces,

"Fineness in Angling's th' Anglers nearest Rule :

For Prudence must still regulate in all." 2

The sentence in his Preface is apposite to many a Preface, whether in prose or verse. "As to the verse there is fault and folly enough, but grant Poetical License, if in pleasing nobody I have pleased myself, and that's all the reward I desire," for alas! to many of us writers self-pleasing must be the sole reward of our desert, if not of our desire.

Misrepresentation as a despiser of fishing and fishermen has clutched another victim, Dr. Johnson, of all people! As Plutarch hasbeen branded for an opinion not his own, so Johnson has been held guilty of the famous libel-." A worm at one end and a fool at the other." The popular belief is all false. According to Boswell, he was very appreciative-an attitude not always Johnsonian-of Walton's work.

Again, it was no other than he ${ }^{3}$ who urged Moses Browne to bring out in $175^{\circ}$ a new edition-the fifth and last was

1 De Sol. Anim., 24. (Holland's Translation.)

2 London, I700. Dr. Turrell, op. cit., p. I 57 , believes Whitney to have been the first to recommend the use of the floating fly-not for the purpose of circumventing the wily trout, but to prevent the fly being gobbled by the minnows.

a Cf. R. B. Marston, Walton and some Earlier Writers on Angling, 1894, an informative and yet delightful volume. 
published in 1676-of The Compleat Angler, of which his criticism, " a mighty pretty book," hardly indicates contempt for its subject, or author, whose life he once meant writing.

On Voltaire also the Worm-Fool libel has also been saddled, but wrongly. To another Frenchman, Martial Guyet, it has been attributed, but not convincingly.

In Notes and Queries, $3^{\text {rd }}$ series, X. $47^{2}$, can be found the lines:

"Messieurs, je suis pêcheur, et pêcheur de la ligne,

J'en fait ici l'aveu. Ce cas semble peu digne

De vos graves esprits : car on l'a dit souvent

La ligne, avec sa canne, c'est un long instrument

Dont le plus mince bout tient un petit reptile,

Et dont l'autre est tenu par un grand imbécile !"

"These lines were written by Guyet, who if he were Martial Guyet died nearly one hundred years before the great lexicographer was born." I Even before Guyet the libel seems to have become hackneyed, "car on l'a dit souvent."

Plutarch's works figure so frequently in these pages that I will not here specially dwell on or quote from them, except "once more the tale to tell " of Antony and Cleopatra's fishing as given in his Life of Antony, 29, 2.

Antony (who "fishes, drinks, and wastes the lamps of night in revel "), when with Cleopatra on the Nile had, of course, if Beaumont and Fletcher's lines hold, not been half as successful as his mistress :

"She was used to take delight, with her'fair hand To angle in the Nile, where the glad fish,

As if they knew who 'twas sought to deceive them, Contended to be taken." 2

To shine in her eyes, he secretly commanded his diver to attach fish to his hook. Cleopatra, becoming aware of the trick, signalled her diver to go down (or as some others relate, bribed Antony's own servants) to affix to his hook, a salted fish

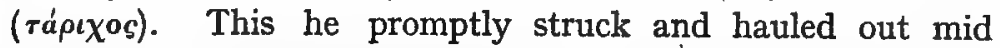

1 As to the various Guyets, see 6th series, III. 87, 5th series, V. 352, and Lawrence B. Philip's Dict. of Biog. Reference, which gives "Martial Guyet, French poet and translator, I 7 th century."

2 The False One, Act I., Scene 2. 
laughter and ridicule. "Leave," cried Cleopatra, "leave the fishing rod to us ; your game is Cities, Provinces, and Kingdoms." 1

Shakespeare makes Cleopatra's diver attach the salted fish :

"Cleo : Give me mine angle, we'll to the river : there,

My music playing far off, I will betray

Tawny finn'd fishes; my bended hook shall pierce

Their slimy jaws, and as I draw them up,

I'll think them every one an Antony,

And say 'Ah, ha! you're caught.'

"Charmian:

'Twas merry when

You wager'd on your angling ; when your diver

Did hang a salt-fish on his hook, which he

With fervency drew up.

"Cleo:

That time !- $\mathrm{O}$ times ! -

I laughed him out of patience, and that night

I laugh'd him into patience ; and next morn,

Ere the ninth hour, I drunk him to his bed."

We owe most of our knowledge as to the technical methods, the varying minutiæ, and the numerous materials employed by the Greeks and Latins in Fishing and Angling, to Oppian, to Elian, Pliny the Elder, and Plutarch.

"Bearing somewhat the same relationship to Eclogues of Fishermen that Virgil's Georgics do to those of Shepherds, were the Greek verse treatises on fish and fishing. No fewer than six didactic Epics of the sort were composed, but only that of Oppian is extant in complete form. ${ }^{2}$ It is written in hexameter,

1 Shakespeare, Antony and Cleopatra, Act II. Sc. 5. Weigall, The Life and Times of Cleopatra, pp. 245-6, makes the locus the harbour of Alexandria, not the Nile, and the modus, Antony's diver affixing fresh fish to his hook. Cleopatra, guessing Antony's ruse, assembled next day a party of notables to applaud the angler, but instructed a slave to dive from the other side of the vessel and the instant the hook touched the water attach to it a pickled Pontic fish. Cleopatram " ridentem dicere verum quid vetat?"

2 A century or so before Oppian, Demostratus, a Roman Senator, wrote also 'A quoted by ancient writers, is now not extant. From the extracts given by Ilian (XIII. 2I, XV. 4 and I9) we gather that Demostratus, who wrote in Greek, had even more than a Greek love of the marvellous and cared nothing for the sober scientific study of his subject. It is noteworthy that an alternative title of his work was $\lambda 6$ you a $\lambda$ seurikol, or, say, Fishing Yarns. 
and combines material based on observations with much extraordinary information gathered from floating material. In the last part of the treatise, the accounts given of the methods of capturing fish by men on various coasts lend a few pictures akin to independent Idylls.

" Most of the poem, however, is very like Pliny's Natural History, put into verse. These didactic poems, as a whole, have little relationship with the Piscatory Eclogue, other than that implied in the fact that they are written in verse and tell much about the practices of fishers."

This grudging estimate of Oppian by Mr. Hall contrasts strangely with the terms of highest eulogy which authors of all ages have bestowed on him. Scaliger calls him " a divine and incomparable poet." Sir Thomas Browne bewails with wonder that "Oppian's elegant lines are so much neglected: surely we hereby reject one of the best epic poets." Scaliger remarks that no author makes more frequent use than Oppian of similes, which he praises warmly for their strength and beauty, for their brilliancy and effect.

In my humble opinion they occur far too frequently and regularly. If we do not come across one at least in every hundred lines, the effect is agreeable disappointment. The subjects of comparison, moreover, are conventional and limited.

But Oppian's poems were held in the very highest favour, not only by our stingy stepmother, Posterity, but by his contemporaries. The Emperor (whether he were Antoninus -of all the Emperors 1 perhaps the keenest fishermanCaracalla, or Severus is not clear, as Oppian's exact date is still unsettled ${ }^{2}$ ), on hearing the author recite his verses revoked the decree of banishment on Oppian's father (to Malta), and paid the poet a golden stater, or more than a guinea a verse. ${ }^{3}$

1 Suetonius, Augustus, c. 83, classes fishing as one of Octavian's chief relaxations.

2 W. Christ, Geschichte der griechischen Litteratur, ed. 3 (München, I898), p. 629, decides for Marcus Aurelius.

3 As there are 3506 hexameters, the reward was over 3506 guineas sterling, which, without allowing for the increase in value of money between the second century and the twentieth, contrasts remarkably with the fourpence halfpenny a volume of Martial. According to Suidas, however, Oppian received from the Emperor 20,000 staters, which would be a far larger reward than Octavia bestowed on Virgil for his EEneid. It has been suggested that this largesse 
With this very liberal payment by piece or verse-work may be contrasted the treatment meted out to the great Persian poet Firdausi by the Emperor Mahmud.

The most romantic of the versions of the story makes the latter promise a miskal (or something less than $\frac{1}{4}$ oz.) for every couplet of the former's epic, Shah Nameh. On the poem's arrival at Court, joy reigned till discovery that it contained some 60,000 couplets.

Aghast at the amount, Mahmud or his Chancellor of Exchequer took advantage of some ambiguity in the terms and, despite the protests of Firdausi that the largesse was promised in gold, made payment in silver. It chanced that the treasure arrived while the author was in the public baths at Tús ; furious at the fraud, he gave 20,000 to the bathkeeper, 20,000 to the refreshment seller, and 20,000 to the camel driver who had brought the bags of bullion.

Many years after, the Emperor, either repenting him of his broken word or moved by reports of the great poverty in which the poet had long lived, dispatched the sum in gold, or, as some say, indigo. Alas! as the convoy entered Tús by the Rudbar gate, by that of the Razan was Firdausi being borne to his grave. 1

At the death of Oppian in his thirtieth year, the citizens of his native place in Cilicia erected a statue to his memory. It bore the most laudatory of inscriptions, of which the last two lines have been Englished - "All" (i.e. preceding poets)

"All the inspired him their chief allowed And all to him their humbler laurels bowed,"

was not paid on all the verses of the Halieutica, but only on those in which Oppian records the prowess and sport of the Emperor in "The Virginia Water" of the Cæsars-where we learn from Eutropius (VII. I4) that Nero fished with golden nets drawn by purple ropes. If so the total would be a mere fraction of either the 3506 guineas or of the 16,000 guineas. Great doubt exists as to whether or not there were two poets named Oppian; and if there were, to which does the anonymous Greek Life of Oppian refer, and which of the two was the author of Ixeutica, for possibly it was to the author of this poem that the Imperial payment of gold was made. See W. H. Drummond's paper in Royal Irish Academy, 1818. Also A. Ausfeld, De Oppiano et scriptis sub eius nomine traditis, Gotha, 1876.

1 Cf. Prof. E. Browne, Literary History of Persia, vol. II., pp. 128-138, and Sir Gore Ouseley's Biographies of Persian Poets, for the various Firdausi versions. 
- to which halting and involved translation we at least neither bow laurels nor doff hats.

The Halientica is divided into five books. The first two treat of the natural history of fishes, the other three of the art of fishing. Despite this proportion of space, fish rather than fishermen are the heroes of the scenes. The work displays considerable knowledge of zoology, coupled with absurd fables, which are adduced as grave matters of fact.

In the fulness with which he enumerates the various kinds of fish, and methods of fishing, the technique, the weapons, the materials appropriate to each, Oppian stands pre-eminent among our authors. Nor need we wonder at this fullness of treatment. He was wedded heart and soul to all pertaining to fish, or fishing, which he calls the "lovely art."

The kinds of fish mentioned by this " poeta doctissimus" I number, according to Bishop Hieronymus, one hundred and fiftythree. This figure is verified by Ritter, who adds that " Pliny's long list contains only twenty-three more, i.e. one hundred and seventy-six in all, " a total which hardly warrants the naturalist's triumphal outburst, "In the sea and in the ocean, vast as it is, there exists by Hercules! nothing that is unknown to us, and a truly marvellous feat it is that we are best acquainted with those things which Nature has concealed in the deep." 2

From the only English translation of the Halieutica (made in I722 by Diaper and Jones, Fellows of Balliol) I take a few passages illustrating the character and methods of Oppianic fishing. ${ }^{3}$

The latter at once arrest our attention by their modernity. They are practically ours. Apostolides in his work describing fishing in modern Greece states that "les quatre engins

1 "De quibus Oppianus Cilix est, poeta doctissimus, I53 esse genera piscium, quæ omnia capta sunt ab Apostolis, et nihil remansit incaptum, dum et nobiles et ignobiles, divites et pauperes, et omne genus hominum de mari hujus sæculi extrahitur ad salutem." Comment. in Ezechiel. Cf. Ritter, op. cit., p. 376 .

2 N. H., XXXII. 53.

3 The great objection to this translation, owing probably to the difficulty of expressing-certainly of compressing-the "intractable" subject matter in the rhymed verse adopted by the translators, is its weary verbiage: for instance, one passage of three lines in the translation needs twelve, and another of nine needs thirty! Diaper was the author of Nereides, or Sea-Eclogues. 
d'Oppien, les filets, les hameçons, les harpons et les nasses," with the addition of " les claies de roseau, d'importation romaine sans doute," are the weapons of Hellas in the present day. The tricks of Oppian prevail in the Peloponnese: to-day, as nearly two millenniums back, the Scarus and the Mullet are caught by using the female as decoy.

The procedure of taking the Octopus (which Aristotle pictures for us in IV. 8), "when clinging so tightly to the rocks that it cannot be pulled off, but remains attached, even when the knife is employed to sever it : and yet if one employ fleabane

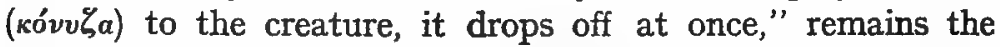
same in Greece to-day. Apostolides writes (p. 50), "Comme on voit, non seulement le procédé de pêche aux poulpes a persisté jusqu'à nos jours, mais la plante (Conyse) qu'on emploie à cet effet porte encore le même nom."

But as Canning called into existence a new world to redress the balance of power in the old, so too the Attic fisherman to dislodge the Octopus has, Raleigh-like, imported to the aid of his old herb, American tobacco.1

The devices for fishing, which in Oppian, I. 54-5, are-

"The slender-woven Net, Viminious Weel, ${ }^{2}$

The Taper Angle, Line and Barbed Steel

Are all the Tools his constant Toil employs,

On arms like this, the Fishing Swain relies,"

are amplified in III. $73 \mathrm{ff}$. in number and detail.

1 N. C. Apastolides, La Pêche en Grice (Athènes, rgo7), p. 3r. The selection of Aristotle as the prototype of philosophical inveighers against Tobacco by Thomas Corneille (Act I., Sc. I, of Le Festin de Pierre),

" Quoi qu'en dise Aristote, et sa digne cabale,

Le tabac est divin, il n'est rien qui l'égale,"

is hardly happy, for, as the weed nicotine only reached Europe some nineteen centuries after the philosopher's death, his "dise" equals vien !

${ }^{2}$ With $\delta \delta \nu a \xi$ and $\kappa u ́ p \tau o s$, cf. the $\pi \lambda \in \kappa \tau \delta \nu ~ \delta \phi \alpha \sigma \mu \alpha$ in Archestratus (frag. xv. 6). See Pp. I 47 and $I_{76} \mathrm{ff}$. of Paulus Brandt's Parodorum epicorum Gracorum et Archestrati Reliquia, Leipzig, 1888 . Brandt argues that the expression describes a nassa, qua retis loco piscatores utebantur, and on the analogy of the Dalmatian fishermen (cf. Brehm, Thierleben, IV., vol. II. p. 533) who, when the sea is not quite calm, drop from the bow of the boat pebbles dipped in oil to make smooth the surface, and so more easily detect the fish,

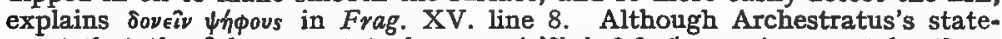
ment that the fish are not to be seen $\left(0 \delta^{\prime} \delta^{\prime} \sigma_{\iota} \delta \in \hat{\nu} \nu \tilde{\sigma} \sigma \sigma o t \sigma \nu\right)$, except by those

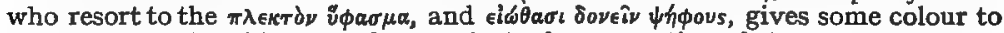
Brandt's ingenious identification, the lack of any mention of the essential factor in such a calming operation, the oil, seems to rule it out. 
"' By those who curious have their art defined,

Four sorts of fishers are distinct assigned.

The first in Hooks delight: here some prepare

The Angle's Taper Length, and Twisted hair.

Others the tougher threads of flax entwine,

But firmer hands sustain the sturdy Line.

A third prevails by more compendious ways,

While numerous Hooks one common Line displays."

We then pass to fishing by Nets, Mazy Weel, and Spears or Tridents. A spirited passage, spoilt in the translation by superfluous verbiage, sings of nocturnal fishing with spears and an attracting light. The method probably obtained the world over, certainly in China, Rome, and Greece, where Plato (Soph., 220 D.) classes it under the heading $\pi v \rho \varepsilon v \tau \iota$ í next to Angling. In Scotland it prevailed extensively, if illegally, as Burning the Water, or Leistering, a Norse term, and practice which Thor himself did not disdain. A passage from a lost comedy-The Trident-perhaps by Philippides, shows a fisher armed with a three-pronged fork and hornlantern off a-Tunnying. ${ }^{1}$

The lines ring as true to-day as when Oppian ${ }^{2}$ penned thern.

"Erected torches blaze around the Boat,

And dart their pitchy Rays ...

Admiring shoals the gaudy flames surround,

And meet the triple spear's descending wound,"

while if fishing were legally permitted only to those who came up to his ideal of what an angler should be (III. 29-3I),

"First be the Fisher's limbs compact and sound,

With solid flesh, and well braced sinews bound,

Let due proportion every part commend,

Nor Leanness shrink too much, or Fat distend,"

1 IV. 640. Cf. Oppian, cyneg., 4, I 40 ff. for a similar description.

- This method, originating from the curiosity of fish and their desire (in Shelley's words) " to worship the delusive flame," is especially successful in rivers at the spawning season. In the Rhodian Laws-a code for the government of mariners and fishermen originally promulgated by Tiberius-occurs a special proviso, $r e$ fishing by means of torches, forbidding fishermen to display lights at sea, lest thereby they should deceive other vessels. It has been suggested, prettily, but I fear not practically, that leistering was learnt from the hunting habit and natural endowments of the Halcyon or Kingfisher; just as to the brilliancy of its colours and splendour of its flash the fish are attracted, so to the brightness of the torches and the shimmer of their rays come the salmon, etc. 
rents the world over would speedily abate, and many a river would know its tenant no more.

For reading "at lairge" Oppian is admirable. At one moment you are enjoying a vivid and passably accurate account (III. I49 ff.) of how the Cramp or Torpedo Fish

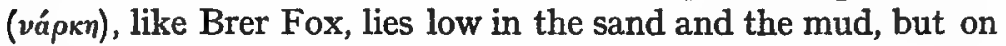
a sudden " ejects his poisoned charms" with such effect that soon

" On every joint an Icy Stiffness steals, The flowing spirit binds and blood congeals." 1

A fish stupefied by the shock is likened (II. 8I ff.) unto a man who in dreams tries to escape from the threatening phantoms, only to find his knees bound and his limbs incapable of flight.

At another moment our poet (in I. 2I7 ff.) is reproving the incredulity of those who doubt the fact that a sucker fish can stop a ship under full sail, by sticking to its keel ! 2

The peculiar powers of the Torpedo Fish command some comment. Ancient authors galore, to whom, in the absence of the more powerful electric Eel of Central America, the vápk $\eta$ must have appeared an amazing creature, have written and differed about it. Aristotle had early noted that it caught its prey by means of a stupefying apparatus in its mouth, or rather at the back of its head. Claudian asks (Carm. Min. Corp., XLIV. (XLVI.) I f.) :

"Quis non indomitam miræ Torpedinis artem

Audiit et merito signatas nomine vires?"

Plato compares Socrates to the fish from his capability of electrifying his audience in the strict, but not in the corrupt

1 Cicero, de Nat. deor., II. 50, I27.

2 Perhaps the best prose description of the power of the Echineis is to be found in Cassiodorus, Var., I. 35. Pliny, XXXII. I, solemnly asserts that the death of the Emperor Caligula was presaged by a Remora stopping his great galley, alone out of all the accompanying fleet, on his voyage to Antium. Not only did the Remora stop a ship, but according to Pliny, it could, from its power of checking the natural actions of the body under excitement, hasten or stay an accouchement as well as a lawsuit: hence plaintiffs seldom ventured into the fish market, because the mere sight of a Remora at such a juncture was most inauspicious! (Pliny, IX. 4I, and XXXII. I). Cf. Aristotle, $H$. A.,

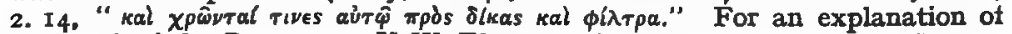
the myth of the Remora, see V. W. Ekman, "On Dead Water," in the Reports of Nansen's Polar Expedition, Christiania, I904. 


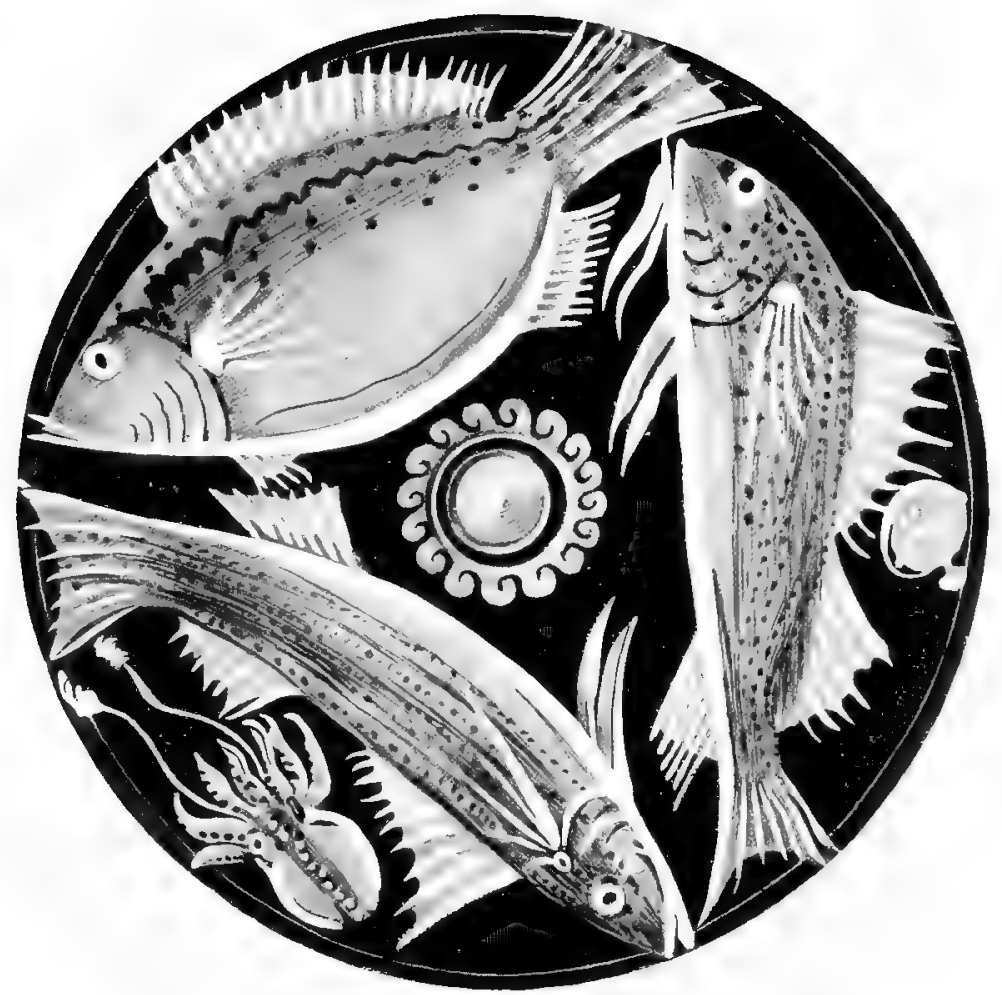

CAMPANIAN FISH-PLATE IVITH PATTERN OF TORPEDO FISH.

Note the small well in centre for sauces. 

present-day sense of the word, as some writers imagine. The comparison to the fish in Meno $80 \mathrm{~A}$ illustrates the benumbing effect of the Socratic method on the thought and talk (riv

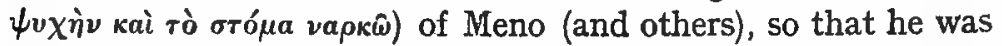

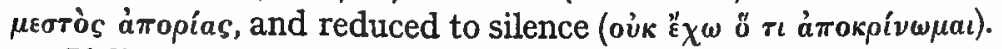

If limited to the electric fire which flashed from his eyes, the comparison is complimentary to the philosopher, but, if applied to the whole face, is, even if true, quite the reverse. The thirty odd busts still extant of Socrates hand down to us an ugly, flat face with pig's-eyes, all characteristic of the Torpedo narke. 1

Ælian (IX. I4) indulges in wondrous stories gleaned from his mother and viris peritis of the permeation of the electric shock. Did one but touch the net in which the fish was taken, lo! he was cramp-bound. If some enquiring observer placed a pregnant torpedo in a vase of sea-water, his fate, did but a drop fall on leg or arm, was similar, but the fish, even though this virtue had gone out of her, in due season became a mother!

According to Mr. Lones, Oppian, Elian, to whom (V. 37) we owe the specific for immunity when handling the fish, viz. " the liquor of Cyrene," Theophrastus, all exaggerate the powers of the Torpedo.

A most interesting account is given in Athenæus (VII. 95), who avers that the shock was not produced by all parts of the fish's body, but by certain parts only, and that Diphilus of Laodicea had proved this by a long series of experiments. ${ }^{2}$ According to Galen and Dioscorides the shock, whence or however obtained, relieved chronic headache, while a contemporary of the latter recommends a person suffering from gout in the feet to stand "bare-legged" on the shore, and apply the Torpedo.

As the German and Austrian watering places are still under a cloud, we may yet see on the shores of Italy bands of gouty

1 For a profoundly interesting study of the extant portrait-busts of Socrates, see A. Hekler, Greek and Roman Portraits (London, I912), p. xi. f., with plates 19, 20, 2 I.

The Torpedo was one of the food fishes of the ancients, and is represented with other fish on several of the Campanian-ware fish plates to be seen at the British Museum, e.g. Cat. Vases, vol. iv., p. 121, F. 268, which shows the small well in the centre of the plate used for fish sauce. 
and passionate pilgrims standing bare-legged, awaiting the cure of the vápкn!

Complaints of gout are rife, even among our fish-affecting epigrammatists. From Hedylus, a singer rather of wine than of fish, we trace the lineage of the disease, " of -Bacchus the limb-loosener, and of Venus the limb-loosener, is sprung a daughter, a limb-loosener, the Gout "' 1

As to spawning, every author from Herodotus down to Izaak Walton has evolved various but mostly inaccurate theories. Oppian (I. 479 ff.) lays down that, as the passion of Love overcomes fish, the bodies of the male and female meet in the water and "exude mingled slime," which swallowed by the female produces conception. To this (I. $554 \mathrm{ff}$.) he allows an exception in the case of the murcence. These mate with land serpents, "who for a time lay aside their venom ": a monstrous connection which finds affirmation by Sostratus ${ }^{2}$ and by Pliny. ${ }^{3}$

The touching charm of the passage ${ }^{4}$ about the Naucrates ductor or pilot fish (whence its name of $\left.\eta^{\prime} \gamma \eta \tau \dot{\eta} \rho\right)$, which for some reason in more modern times has transferred its affection and services from the whale to the shark, compels quotation:

"Bold in the front the little pilot glides, Averts each danger, every motion guides ;

With grateful joy the willing whales attend, Observe the leader and revere the friend; True to the little chief obsequious roll, And soothe in friendship's charms their savage soul. Between the distant eyeballs of the whale The watchful pilot waves his faithful tail, With signs expressive points the doubtful way, The bulky tyrants doubt not to obey, Implicit trust repose in him alone, And hear and see with senses not their own; To him the important reins of life resign, And every self-preserving care decline." 5

1 Anth. Pal., XI. 4I4.

3. Oppian, V. 66 ff.
Cf. Pliny, IX. 68; Elian, II. 13 ; Plutarch, De Sol. Anim., 31. With this pilot fish must be mentioned that other, so famous in New Zealand waters, " Pelorus Jack." A cetacean of the Dolphin tribe, he regularly met the coastal steamers between Wellington and Nelson. The old Maori chief, Kipa Hemi, 
Some of Oppian's best bits contain animated portraits of sea-fights. The combatants are as intensely personified as Homer's Greeks and Trojans in their hand-to-hand fight on the banks of the Scamander. But unlike the Heroes, the belligerents of Oppian pull each other to pieces without any responsibility on their part, or shock to moral sense on ours:

"Unwise we blame the rage of warring fish

Who urged by hunger must supply the wish ;

While cruel man, to whom his ready food

Kind Earth affords, yet thirsts for human blood."

In proportion as fish, which according to the earliest authors was despised or disregarded, grew in favour with the Greeks, the frequency of its mention in Greek literature increased apace.

The Deipnosophista by Athenæus, to which belongs the distinction of being one of the earliest collections of $A n a$, is a curious sort of philosophers' feast. It quotes from nearly every writer on nearly every topic; it discusses almost every conceivable subject, especially gastronomy. It weighs the qualities of all things edible. Comments on fish, taken from plays, histories, treatises, etc., are plentifully, if incongruously, scattered. ${ }^{1}$

Everything goes in this work; grammatical problems are mixed up with gastronomic; the discursiveness of Athenæus races from grave to gay, grim death to any story, however apparently disconnected.

His tale of the Pinna (III. 46), a bivalve shell-fish, and the Pinnothere (a small crab who inhabits the shell of the Pinna) resembles many of the fables current among the West Indian negroes as regards the cleverness of the Crab. As soon as the small fish, on which the Pinna subsists, have swum within the shell side, the Pinnothere nips the Pinna as a signal to him to close his shell and secure them.

Plutarch (De Sol. Anim., 30) shows that the habit was not entirely altruistic, for "this being done, they feed together claimed that this fish, Kai Kai-a-wayo, was not only the embodiment of his tribal Mana and his family guardian angel, but had guided his ancestor eleven generations before in his exploring of Cook Sound, etc.

1 See W. Smith, Dict. Gk.-Rom. Biog. and Myth., s.v. 'Athenæus." 
upon the common prey." From the Pinna which haunts the bottom of the sea came "the most transparent pearls, very pure and very large." 1

The enormous industry of Athenæus, who (VIII. I5) speaking of the materials he had amassed for this one book, casually states that he himself " had read and made extracts from 800 plays of the Middle Comedy alone," and in it cites nearly 800 authors, and over I200 separate books, has undoubtedly preserved to us many valuable passages of the ample literature and numerous plays in which fishermen once figured. My many quotations from and references to his Deipnosophistice make it unnecessary to deal with this author 2 at greater length.

1 Athen., III. 46. From Faber, op. cit., p. 94, we learn that "the pinnotherus finds refuse in the shells of living bivalves, living on the small animalculæ contained in the constant stream of water, which flows in and out of these molluscs. The fancy of the ancients has attributed the status existing between the two species as arising from a friendly alliance, protection and board afforded on the one hand, and watching against and warning of the approach of an enemy on the other. These observations descend from so early a date that we find the pinna and the crab among the Egyptian hieroglyphs, bearing the interpretation of the duty of paterfamilias to provide for his offspring."

The rendering of passages from Athenæus (Deipn.) and from Pliny (N.H.) are usually Bohn's. 


\section{CHAPTER XII}

ELIAN-THE MACEDONIAN INVENTION, OR THE FIRST MENTION OF AN ARTIFICIAL FLY

"They knew 'e stole ; 'e knew they knowed;

They did not tell, or make a fuss,

But winked at Elian down the road,

And 'e winked back-the same as us!" 1

ELIAN (I70-230 A.D.), who, though born in Italy and brought up in the Latin tongue, acquired so complete a command of Greek that he could speak it as well as an Athenian gentleman (hence his sobriquet $\mu \varepsilon \lambda i \gamma \lambda \omega \tau \tau o s)$, composed his works in Greek.

His Natural History ${ }^{2}$ soon became a standard work on Zoology, although in arrangement it is very defective: for instance, he skips from elephants (XI. I5) to dragons in the very next chapter, and from the livers of mice in II. 56 to the uses of oxen in II. 57. This treatment of things, $\pi$ ocki $\lambda a$

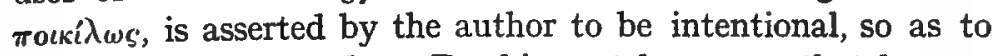
avoid boring the reader. For his part he avows that he prefers observing the habits of animals and fish, listening to the nightingale, or studying the migration of cranes, to heaping up riches ! 3

Whether as a Naturalist $\mathbb{E l i a n}$ possesses any value, whether his work is " scrappy and gossiping, and largely collected from older and more logical writers," 4 or "from the industry

1 After Kipling.

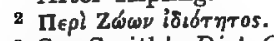

s See Smith's Dict. Gk. and Rom. Biog. and Myth., s.v. ' Elian.'

- Perizonius has proved that XElian transferred large portions of the Deipnosophiste of Athenæus to his Varia Historia, a robbery which must have been committed almost in the lifetime of the pillaged author: that I85 


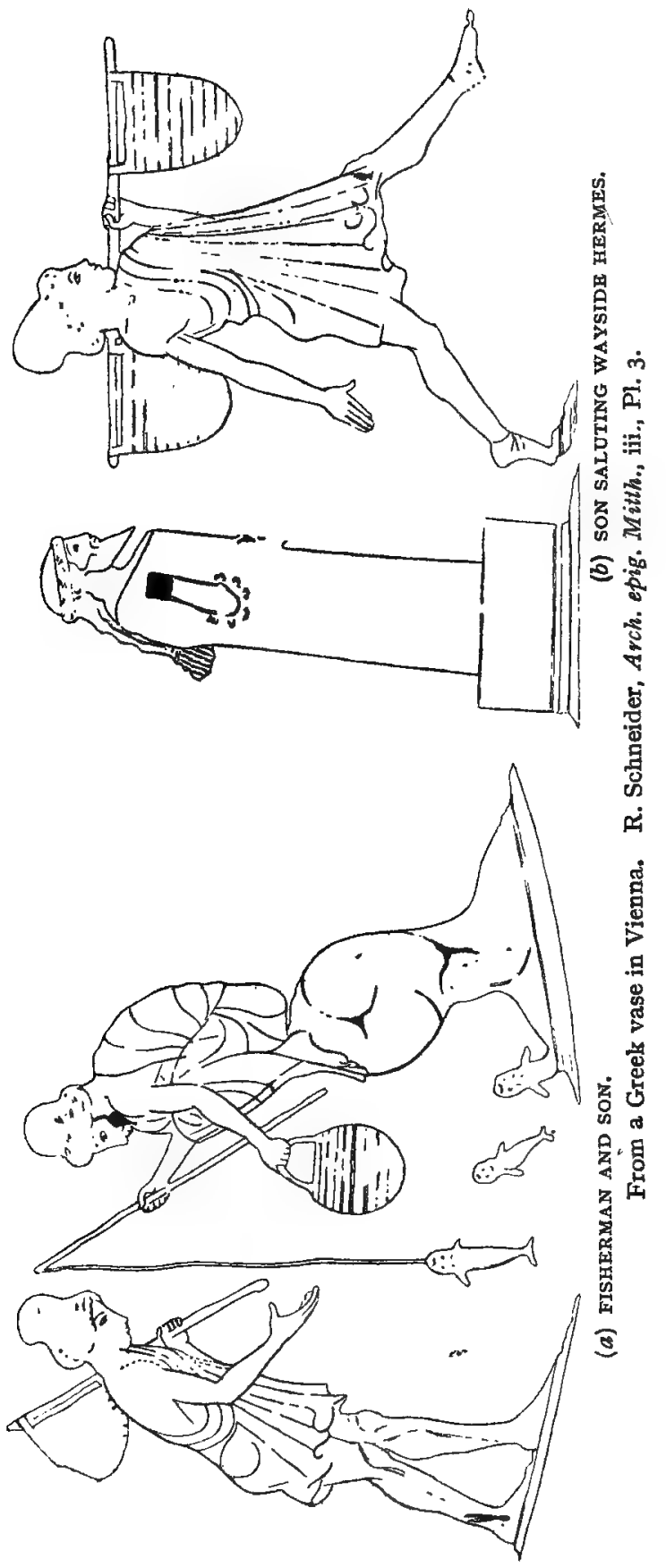


displayed, despite deficiency in arrangement, a valuable collection in Natural History," to us fishermen matters little, for unto him has been ascribed the great glory of being the first author of all ages and of all countries specifically to mention and roughly describe an Artificial Fly.

And not only is he the first, but also (with possibly one exception) the only author during fourteen hundred years, who makes any reference to any such fly. ${ }^{1}$ From Elian until the Treatyse of Fysshynge with an Angle we find no mention of, or allusion to, the Artificial Fly, but that it was. well known as a method of angling is easily deduced from the authoress's abrupt introduction of the subject, "There ben the xij flies or dubbes with which ye shall angle." 2

The usually accurate Bibliotheca Piscatoria of Westwood and Satchell states under heading of ' Elian,' that Stephen Oliver (Mr. Chatto), in his Scenes and Recollections of Fly Fishing, first pointed out this remarkable passage. Now the first edition of Oliver's book is dated I834; so, if the Bibliotheca Piscatoria be correct, Ælian's statement apparently remained unknown to Anglers for nearly eighteen centuries.

I purposely set out a translation of the whole passage in Elian, XV. I, because short extracts are usually given, and because these vary greatly on a very important point. I adopt with some alterations the translation by Mr. O. Lambert in his Angling Literature in England (188I).

"I have heard of a Macedonian way of catching fish, and it is this : between Berœa and Thessalonica runs a river called the Astræus, and in it there are fish with speckled skins; what the natives of the country call them you had better ask the Macedonians. These fish feed on a fly peculiar to the country,

Elian extended such transference to his Natuval History also, his story of the Pinna, and others would seemingly demonstrate. Sir J. E. Sandys, $A$ History of Classical Scholarship, ed. 2 (Cambridge, I go6), i. 336, goes so far as to say: " $\mathrm{He}$ is the author of seventeen books On Animals, mainiy borrowed from Alexander of Myndos (first century A.D.)."

1 Dr. W. J. Turrell, op. cit., XI., states that a Latin poem written by Richard de Fournival, about the thirteenth century, alludes incidentally to fishing, and from this it appears that the fly and the worm were among the lures then used by anglers, but does not state expressly whether Fournival's fly was natural or artificial.

a Cf. H. Mayer, Sport with Rod and Line, Barnet and Phillips, New York. 
which hovers on the river. It is not like flies found elsewhere, nor does it resemble a wasp in appearance, nor in shape would one justly describe it as a midge or a bee, yet it has something of each of these. In boldness it is like a fly, in size you might call it a midge, it imitates the colour of a wasp, and it hums like a bee. The natives generally call it the Hippouros.

"These flies seek their food over the river, but do not escape the observation of the fish swimming below. When then the fish observes a fly on the surface, it swims quietly up, afraid to stir the water above, lest it should scare away its prey; then coming up by its shadow, it opens its mouth gently and gulps down the fly, like a wolf carrying off a sheep from the fold or an eagle a goose from the farmyard; having done this it goes below the rippling water.

"Now though the fishermen know of this, they do not use these flies at all for bait for fish; for if a man's hand touch them, they lose their natural colour, their wings wither, and they become unfit food for the fish. For this reason they have nothing to do with them, hating them for their bad character ; but they have planned a snare for the fish, and get the better of them by their fisherman's craft.

"They fasten red (crimson red) wool round a hook, and fix on to the wool two feathers which grow under a cock's wattles, and which in colour are like wax. Their rod is six feet long, and their line is the same length. Then they throw their snare, and the fish, attracted and maddened by the colour, comes straight at it, thinking from the pretty sight to get a dainty mouthful; when, however, it opens its jaws, it is caught by the hook and enjoys a bitter repast, a captive."

The lines which describe the making up of the fly- $\tau \hat{\varphi}$

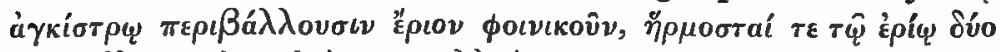

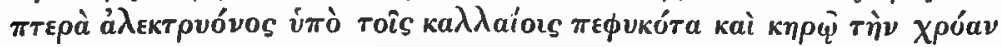
$\pi \rho о \sigma \varepsilon i \kappa a \sigma \mu \varepsilon^{\prime} a^{1}{ }^{1}$-are translated in Westwood and Satchell's Bibl. Pisc., and by Mr. Lambert quite differently.

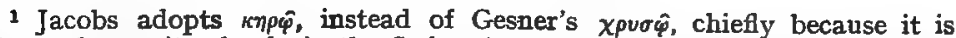
written thus quite clearly in the Codex Augustanus. It also seems to fit the context better. 
In the Bibl. Pisc. :

"Round the hook they twist scarlet wool, and two wings are secured on this wool from the feathers which grow under the wattles of a cock, brought up to the proper colour with wax."

\section{In Lambert:}

"They fasten red wool round a hook and fit on the wool two feathers which grow under a cock's wattles, and which in colour are like wax."

It is asserted in the Bibl. Pisc. that the whole passage is therein "for the first time, accurately, translated," but this proud boast must take a back seat, for Mr. Lambert translates with far nearer accuracy. One grave error springs from mistranslation in the former of $\pi \rho о \sigma \varepsilon к к а \sigma \mu \varepsilon v a$ as "brought up to," instead of "like," a meaning very common in Greek writers of the second and third century.

But, apart from the question which of the two be the better. rendering, no doubt whatever can exist which of the flies described would be found the better, if not the only, killer. Application of wax to the hackles of a cock would certainly cause the fibre to stick together, entirely destroy their free play in the water, and render them useless as wings.

This passage, ever since its rediscovery by Oliver in I834, has been acclaimed by most writers on Fishing as (A) being the first instance in literature, or for that matter in art, of the Artificial Fly, and as (B) ascribing to the Macedonians the credit of a " new invention" in Angling.

It is undoubtedly the first and only express mention of a specially made-up Artificial Fly down to 500 A.D., and probably even down to Dame Juliana's Book (c. I500). But I suggest and believe that this passage is intended, not as a description of a " new invention," or of a striking departure from old methods of Angling. It merely instances the Macedonian's adaptability to his environment, and his imitative skill in dressing from his wools and feathers a fly to resemble as closely as possible the natural fly on which the fish were feeding, a practice very common among anglers of the present day.

So far from the Artificial Fly being a " new invention," it 
seems to me to have been for a long time in more or less regular use. The materials necessary or employed for dressing flies are set forth in two other places by Ælian in this same work. The Macedonian fly is described at length and in special detail, probably because it marked an advance in making up a fly.

I have not been able so far to find the passages in Bk. III. 43, and Bk. XV. Io, mentioned (except in Bliumner's genera] list of fishing weapons under "Fischfang" 1 ) or alluded to in connection with fly-making, much less brought into the prominence which their special pertinence of a surety deserves and demands.

This omission may be due to previous writers being content with the authority and researches of Oliver and of Westwood and Satchell, and on the line of least exertion not pursuing the subject any further even in the pages of Ælian himself. If they had so pursued, they would have discovered in the first passage in Bk. XII. 43, which is separated by only three books, and in the second passage in Bk. XV. Io, which is separated by only nine chapters from the locus classicus in Bk. XV. I, strong reasons for qualifying their statement as to the Macedonian "invention."

In Bk. XII. 43, Fishing is divided into four kinds-by

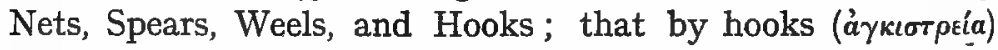
is adjudged "the most skilful, and the most becoming for free

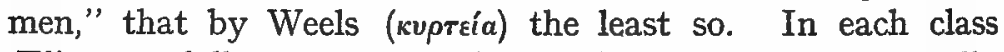
Elian carefully enumerates the articles necessary or generally used.

The list of those necessary for fishing with hooks, or Angling, recounts " natural horsehair, white, and black, and flamecoloured, and half-grey ; but of the dyed hair, they select only those that are grey, or of true sea-purple, for the rest, they say, are pretty poor. They use, too, the straight bristles of swine, and thread, and much copper and lead, and cords." Now follow the important words-" and feathers, chiefly white, or black, or various. They use two wools, red and blue." a

1 Die römischen Privataltertümer (Munich, I9I I), pp. 529-30.

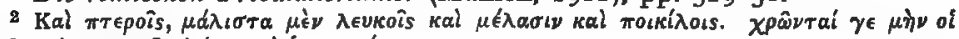

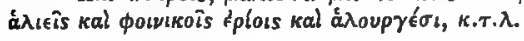


Further requirements are "corks, and wood, and iron, and of things they need, are reeds well-grown, and nets, and soaked rushes, a shaved wand, and a dog-wood Rod, and the horns and hide of a she-goat." The equipment is as ample as amazing. What use, in the name of every fishing Deity, unless the author is referring to Oppian's method, did the Angler make of the " horns and hide of a she-goat"?

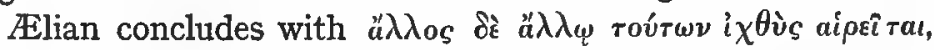
which antedates the tale of the millionaire, who, reproached with having brought a thousand times too many flies, ejaculated, "with some of these, if I can't get a salmon, maybe I'll strike a sucker"!

In XV. Io, which deals with the capture of pelamyde or young tunny fish, one of the crew sitting at the stern lets down on either side of the ship lines with hooks. On each hook he ties a bait (perhaps not a bait in our modern technical sense, but rather a lure) wrapped in wool of Laconian red, and to each hook attaches the feather of a seamew. ${ }^{1}$

Let us set aside, because of Ælian's haphazard method of arrangement, any argument which might otherwise fairly be adduced from the following facts. (A) He expressly sets forth in XII. 43 (three books before he mentions the Macedonian device) red and other wools and feathers as part of the ordinary tackle of an Angler-most probably in river or lake, for here, unlike XV. ro, where the prey is a sea-fish, we have no mention of a ship, oars, etc. (B) When he does mention the Macedonian device, he does not announce it in any way as a new invention or a striking departure from the old methods of fishing, but quite simply, in the words: "I have heard of the Macedonian way of fishing, and it is this."

Setting aside, I repeat, any arguments thus to be deduced, we are face to face with the hard and curious fact, that in all three passages the materials, out of which the lures are constructed, are the same; they are wools of various colours, and feathers taken from birds, in XV. I, from a cock, in XV. Io, from a seamew.

Any assertion or suggestion that these wools and feathers

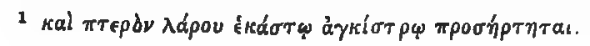


were used, and are specially stated to have been used for tying only the Macedonian fly, and that this special statement of such uses is meant expressly to differentiate the Macedonian from all other ways of fishing, and thus constitutes the first mention of an Artificial Fly, I counter by a couple of queries.

Why in XII. 43, and XV. Io, are these self-same wools and feathers set out among the necessary ordinary requisite tackle of a fisherman, if they were not used for dressing a fly, perhaps more primitive but still Artificial? And, if they were not so used, to what other fishing purpose can they be fairly applied ?

Again, let us for a moment grant that the Macedonian device was the absolutely new invention or the striking departure from all preceding angling methods, which, had artificial flies not previously been well known, it most certainly would have been. In this case, surely Elian, meticulous in his examination and classification of the tackle, etc., needed for each of the four stated kinds of fishing, would have employed, when about to tell of this invention, words calling more instant attention to and far worthier of this great revolution than the simple, "I have heard of the Macedonian way of fishing, and it is this" !

As supporting my contention, a further point must be noted. In the list of tackle in XII. 43, wools and feathers are mentioned in a general manner, but in XV. I, their use is particularised and elaborated. Similarly in the first passage the making and material of Rods are given, but in the second (and here only) the particular length of rod is stated.

It is on these passages (XII. 43, and XV. ro) and on their natural implication, that I chiefly found my conclusion that (A) the practice of making up and fishing with some kind of artificial fly had been in more or less general use for a long time previous to the Macedonian device, and (B) that the device is quoted merely as an instance of a special, local, and improved adaptation of such usage-in a word as le dernier cri in flies! !

If in Martial (Ep., V. I8. 8) musco, not musca, should be

1 If Sandys (antea, I85, note 4) be right about Elian's work being " mainly borrowed from Alexander of Myndos," first century A.D., the artificial fly was probably well known in Martial's time. 
read, then to Ælian would belong the credit of being the first to mention not only the use of the artificial fly, but also the use of the natural fly.

In XIV. 22, we read of the Thymalus (a kind of grayling), which alone of all fishes gives out after capture no fishy smell, but rather so fragrant an odour that one would almost swear that in his hand he held a freshly gathered bunch of thyme (" that herb so beloved by bees "), instead of a fish. Flian then lays down that, while it is easy to catch this fish in nets, it is impossible to do so with a hook baited with anything except the $\kappa(\dot{v} \nu \omega \psi$, i.e. the gnat, or more probably from the vivid description by one who has evidently suffered, the mosquito, "that horrid insect, a foe to man, both day and night, alike with his bite and his buzz." 1

Here then, in XIV. 22, we get, if the conjecture musco should be held to deprive Martial of his priority, the first mention of angling with a natural fly.

The difficulty, obvious at once to the practical angler, of how the ancients (or even the moderns with all the elaborate perfections of Redditch) could manufacture a hook little enough to impale a mosquito did not escape Aldrovandi. ${ }^{2}$ But the $\kappa \omega ́ \nu \omega \psi$, said to spring from the $\sigma \kappa \dot{\omega} \lambda \eta \kappa \varepsilon$, i.e., larvce found in the sediment of vinegar, was apparently even smaller than his brother mosquito, the 's $\mu \pi i_{\text {is. }}{ }^{3}$

As only with great care, and even then only on very fine wire, can the smallest modern hook, No. 00o, be coaxed to impale a big gnat, the problem before the Ancients of impaling with a hook one, and this not even the largest, of the mosquito

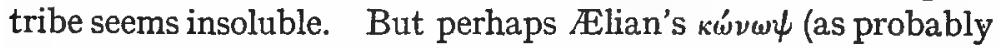
also his i $i \pi$ oupos) was far larger than its descendant of the present day, or perhaps our author has substituted by mistake the mosquito for some larger but similar gnat.

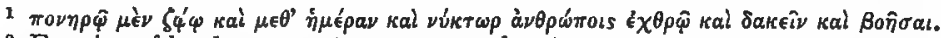

2 For size of hooks, see antea, P. I57 and note I.

3 Cf. Arist., $N . H$., V. Ig. The $\sigma \kappa \omega \lambda \eta \xi$ of Aristotle is an immature product of generation which grows and finally becomes a pupa, or (so Aristotle believed) an egg giving birth to the perfect animal. 


\section{CHAPTER XIII}

\section{AUSONIUS-SALMO, SALAR AND FARIO-FIRST MENTION OF THE PIKE}

Ausonius (c. 3I0-c. 393 A.D.) is practically the last Latin writer within my time-limit (A.D. 500) who has allusions of interest to Fishing. In the fifth century, however, Sidonius, whose fishing and hunting interest apparently equalled his diocesan-his 'Nolo Episcopari' was, if fruitless, at once exceptional and genuine, for the see of Clermont had to be forced on his acceptance-tells us in a letter and in his poems of the catching of fish, especially by night lines in a lake on his wife's property in the Auvergne. ${ }^{1}$

The tenth Idyll of Ausonius ("Ad Mosellam," a great favourite with Izaak Walton), ranks, according to Mackail, " the writer not merely as the last or all but last of Latin, but also as the first of French poets." It demands mention, quite apart from the vividness of its pictures, because it is the only fisher poem of any length in classical Latin, and because in it occurs the first mention of the Salar and the Fario.

Of the Salmo Pliny three hundred years previously was the first to speak. ${ }^{2}$ The Greeks knew not the Salmon: at any

1 Ep., II, 2 ; Carmina, XIX. and XXI. Fortunately for Sidonius, Clermont was in the Auvergne, so he could be at once piscator and episcopus.

2 1X. 32. "In Aquitania salmo fluvialis marinis omnibus prefertur." To make this clear piscibus should be understood after omnibus. The salmon is the fish most frequently found in the débris of the French caves, many of which are in Aquitania, so Palæolithic and Plinian man at any rate ate tooth to tooth in their preference. See Introduction. It is somewhat amazing, considering their opsophagy and the excellence of the fish, that down to 500 A.D. no Greek, and no Latin writer, except Pliny, Ausonius, and Sidonius, Ep. II. 2, mentions the Salmonide. I cannot forgo Ausonius's epithetmouth-filling yet appropriate-for us, who dwell in "this blessed Isle, this England," Aquilonigenasque Britannos. 
rate, no opsophagist or other author notices the fish. Their silence is natural; the high temperature of the water forbids its frequenting the Mediterranean or its inflowing rivers. ${ }^{1}$

The length of the whole poem ( 483 lines) prevents entire quotation, although the touch and movement all through display fully the instinct and feeling for sport.

Pictures of the scenery along the banks of the Moselle are followed by the enumeration and characterisation of the fish in its waters rendered after the manner of the didactic epic. The poem furnishes a lively description of the fishermen of the Moselle, made from actual observation. Men in boats drag nets in mid-stream; men watch the corks of little nets in shallower water; men perched on banks or on rocks armed with rods scan the floats bobbing on the water, or jerk in the prey. But we search for fly-fishing in vain.

"And now, where the bank gives easy access, a host of spoilers are searching all the waters. ${ }^{2}$ Alas! poor fish, ill sheltered by thine inmost stream! One of them trails his wet lines far out in mid-river, and sweeps off the shoals caught in his knotty seine; where the stream glides with placid course, another spreads his drag-nets buoyed on their cork-floats.

" A third, leaning over the waters beneath the rock, lowers the arching top of his supple rod, as he casts the hooks sheathed in deadly baits. The unwary rovers of the deep rush on them with gaping mouth-too late, their wide jaws feel through and through the stings of the hidden barb-they writhe-the surface tells the tale, and the rod ducks to the jerky twitch of the quivering horse-hair. Enough-with one whizzing stroke the boy snatches his prey slant-wise from the water;

1 Salmon appear but infrequently in representations, but Plate 8 in C. W. King's Roman Antiquities at Lydney Park, Gloncestershire, London, I 879 , shows in colours a mosaic dedicated to the god Nodons by Flavius Senilis, an officer in command of the fleet stationed off the Severn: this mosaic includes a number of salmon. King, $i b$. Plate $r_{3}, 2$, is a diadem of beaten bronze representing a fisherman with a pointed cap in the act of hooking with undoubtedly a tight line a fine salmon: cf. A. B. Cook's discussion of these finds in Folk-Lore, 1906, XVI. 37 ff. Nodons was in fact, like Nuada, a fish god, indeed a Celtic understudy for Neptune. If salmon figure little in representations, they bulk large in laws, and in commissariats for campaigns, e.g. 3000 dried salmon were ordered by Edw. II, in his war with Bruce.

2 From Professor R. C. Jebbs' Translation, p. I 76 (line $240 \mathrm{ff}$.). 


\section{I96 AUSONIUS-SALMO-FIRST MENTION OF PIKE}

the blow vibrates on the breeze, as when a lash snaps in the air with a crack, and the wind whistles to the shock.

"The finny captives bound on the dry rocks, in terror at the sunlight's deadly rays; the force which stood to them in their native stream languishes under our sky, and wastes their life in struggles to respire. ${ }^{1}$ Now, only a dull throb shudders through the feeble frame, the sluggish tail flaps in the last throes, the jaws gape, but the breath which they inhale returns from the gills in the gaspings of death: as, when a breeze fans the fires of the forge, the linen valve of the bellows plays against its beechen sides, now opening, and now shutting, to admit or to confine the wind.

"Some fish have I seen who, in the last agony, gathered their forces, sprang aloft, and plunged head foremost into the river beneath, regaining the waters for which they had ceased to hope. Impatient of this loss, the thoughtless boy dashes in after them from above and strikes out in wild pursuit. Even thus Glaucus of Anthedon, the old man of the Bcotian Sea, when, after tasting Circe's deadly herbs, he ate of the grass which dying fish had nibbled, ${ }^{2}$ passes, a strange denizen, into the Carpathian deep. Armed with hook and net, a fisherman in the depths of that realm whose upper waters he had been wont to plunder, Glaucus glided along, the pirate of those helpless tribes."

Whether the Salar and the Fario of the Idyll are, or are not, identical with the burn trout or salmon trout of modern days affords a problem for ichthyologists, not for me.

Ausonius is the first to mention not only the Salar and Fario ${ }^{3}$ but also our Pike-Esox lucius. ${ }^{4}$

1 Cf. Plutarch, Symp., IV. 4. "The place where we live is to fish no less than Hell : for no sooner come they unto it, but dead they immediately be." Holland's Translation.

2 For the story of Glaucus, see Esch., Frag. 28; Paus, IX. 22, 6 and 7 ; Virgil, En., VI. 36; and Athen., VII. 47, 8. Ausonius follows the version according to which Glaucus had been metamorphosed by Circe, and then on tasting the herb regained his human form as the "Old Man of the Sea." Ovid, Met., XIII. 898 ff.

${ }^{3}$ Mosella, 88. "Purpureisque Salar stellatus tergora guttis," and ibid., I29 f., "Qui necdum Salmo, necdum Salar, ambiguusque Amborum medio, sario, intercepte sub avo."

4 Mosella, 122 ff. Polemius Silvius, Index Dierum Festorum, more than half a century later, seems the second-such is the infrequency of mention. 
" Lucius obscuras ulva cænoque lacunas

Obsidet; hic nullos mensarum lectus ad usus

Fervet fumosis olido nidore popinis,"

which Badham has loosely translated :

"The wary luce, midst wrack and rushes hid,

The scourge and terror of the scaly brood,

Unknown at friendship's hospitable board,

Smokes midst the smoking tavern's coarsest food."

The striking silence as to a fish so far-spread in his habitat and so notable in his habits as Esox lucius in all preceding Greek and Latin literature must excuse a semi-excursus.

Cuvier writes: "We are necessarily astonished that the Ancients have left us no document, so to speak, on a fish so abundant in Europe as the Pike . . . a fish which the Greeks must have known. The word Esox occurs only once (Pliny, IX. I7) as an example of a large fish ${ }^{1}$ comparable to the Tunny in form. In spite of Hardouin, I do not see that Esox of the Rhine is the Pike, or believe with Ducange that it is the Salmon. The name Luccio or Luzzo, by which we still call the Pike in this country, gives force to the supposition that the Latins of the time of Ausonius called it Lucius." 2

The astonishment at the absence of all reference to the Pike would be greatly increased, if the authors, or really Valenciennes, had lived to read later writers. Parkyn (op. cit., p. I3I) cites the fish among those represented by the craftsmen of both Palæolithic and Neolithic Art in the caves of France and Spain. G. de Mortillet (op. cit., p. 220) claims that the remains of Pike in the Palæolithic age occur not infrequently. F. Keller (op. cit., vol. I. 537, 544) notes their presence in Neolithic finds at Moosseedorf, etc. Meek, Migration of Fish, p. I8 (London, I9I7), states that the Pike " occupied the European region in Oligocene and Miocene times, and that the remains of Pike are found in the Pleistocene of Breslau."

1 C. Mayhoff here prints J. Hardouin's conjecture isox, which was based

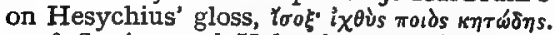

2 Cuvier and Valenciennes Histoire Naturelle des Poissons, vol. XVIII., pp. 279-80 (Paris, 1846 ). See Introduction. If the Pike be late in literature, in heraldry it makes amends, for there is no earlier example of fish borne in English heraldry than is afforded by the Pike in the arms of the family of Lucy, or Lucius-a play on words not confined to heraldry but to be found in Shakespeare, Puttenham, and others. See Moule, op. cit., p. 49. 


\section{I98 AUSONIUS-SALMO-FIRST MENTION OF PIKE}

Attempts have been made to explain the absence of this fish previous to Ausonius by identifying Esox lucius with (A) the Oxyrhynchus, and (B) the Lupus. These seem to me unsuccessful. ${ }^{1}$

Petrus Bellonius among the early writers upholds the first identification. In his Observations de Plusieurs Singularitëz, Book II. ch. 32 (published I553), "Le fleuve du Nil nourrit plusieurs autres poissons, lesquelz toutes fois ie ne veul specifier en ce lieu, sinon entăt que le Brochet y est frequent, et que nous avons difficulté de luy trouver une appellation antique, ie veul mŏstrer qu'il fut ancieňement appellé Oxyrynchus."

His effort breaks down for three reasons. First, Ælian says that the Oxyrhynchus, - a fish supposed to have sprung from the blood of the dead Osiris, or to be the impiscation (if the word may be coined) of Osiris-although caught in the Nile (X. 46, I, I2.), dwells mainly, or according to Plutarch, de Iside et Osiride, 7, altogether in the sea, whereas our Esox cannot endure sea-water. Second, the sharp pointed form of beak (whence the name) cannot possibly represent the broad gooselike mouthpiece of our Pike. Third, the size of the Oxyrhynchus, often 8 cubits or I 2 feet in length, ${ }^{2}$ proscribes the Pike.

Against the identification suggested by Franciscus Philadelphus of Esox lucius with Lupus two reasons lean heavily: (A) the etymological impossibility of $\lambda$ úros (because of the wolflike nature of the Pike ${ }^{3}$ ) changing into Lucius, and (B) the Lupus is always in Greek called $\lambda a ́ \beta \beta a \xi$, never $\lambda$ úkos. $^{4}$

1 For the attempt to identify the Esox with the Huso made by a French writer, apud Vincentium, XVII. 53, and with the Salmon by other writers, see J. G. Schneider, op. cit., pp. 24 and 126.

2 王lian, $N$. H., XVII, 32.

3 The epigram on Pope Lucius III. (II 8 I to II 85 A.D.), who was banished from Rome for his tyranny and exactions, is, both as a comparison and a contrast, apt.

"Lucius est piscis rex atque tyrannus aquarum:

A quo discordat Lucius iste parum.

Devorat ille homines, his piscibus insidiatur :

Esurit hic semper, ille aliquando satur.

Amborum vitam si laus æquata notaret,

Plus rationis habet qui ratione caret."

- Athen., VII. 86 ; "The $\lambda \alpha \beta \rho \alpha \xi$ has his name from his voracity, $\lambda \alpha \beta \rho \delta \tau \eta s "$ (cf. Opp., II. I30). It is said also in shrewdness he is superior to other fish, being very ingenious in devising means to save himself, wherefore Aristophanes the comedian writes:

"Labrax, the wisest of all fish that be." 
The story of how the Lupus comes to his death by the Prawn can be read in Oppian ${ }^{1}$ and in $\mathbb{E}$ Elian. ${ }^{2}$ The fish, ever voracious, takes the prawns into his mouth by the thousand; these, unable to resist or retreat, jump about and puncture his throat and jaws so seriously that he soon dies of poison and suffocation.

Pliny (IX. I7), it has been claimed, under the word Esox intends our Esox lucius; but Cuvier maintains, and rightly, that his Esox signifies some very large fish, perhaps a Tunny.

Sulpicius Severus, a presbyter who lived in Aquitania (c. 365-425 A.D.) and penned an enthusiastic Life of S. Martin of Tour, ${ }^{3}$ writes: " ad primum jactum reti permodico immanem Esocem extraxit." It is not for me to discuss or decry this amazing statement of a very small net holding this monstrous Esox. But as the growth of a Pike under the most favourable circumstances is probably not more than $2 \mathrm{lbs}$. a year for twelve years when usually it lessens materially, I do suggest that the adjective immanem is hardly applicable (unless St. Martin's biographer, perhaps also a fisherman, has lapsed unconsciously into a "fish story") to a fish of about 20 or 30 lbs., and so would seem to confirm Cuvier. 4

Pike, Carp, and Grayling were not apparently indigenous in England. They were introduced from the Continent at some undetermined date by one of the earlier religious orders for the better keeping of Fast Days, which as enjoined by the Church, even in Queen Elizabeth's time, amounted to no less than $\mathrm{I}_{45}$ in number. ${ }^{5}$

1 Op. cit. II. I27 ff.

2 Op. cit. I. 3 o.

3 De Virtute B. Martini, III. I3.

4 The biggest Pike ever caught in the United Kingdom seems to be the 72 -pounder mentioned by Colonel Thornton in his "Sporting Tour." Walton's ring-decorated fish (see Gesner), three hundred years or so old, was no doubt heavier, if it were genuine. At any rate a Pike of 40-50 lbs. is very exceptional.

5 The value of the herring (Clupea havengus) was unknown to the Greeks and Romans, and so remained generally till the Middle Ages. "Ignorance, presumably of the real nature of the Cetaceans betrayed our forefathers into breaking Lent, for under the impression that the whale, porpoise, and seal were fish, they ate them on fast days. High prices, moreover, were paid for such meats, and porpoise pudding was a dish of State as late as the sixteenth century" (P. Robinson, Fisheries Exhibition Literature, Pt. III. p. 42). Some laxity may, I think, be pardoned, for the very name " porpoise" (in Guernsey pourpeis)-derived apparently from porc-peis (porcum +piscem)-implies that the creature was regarded as a "pig-fish." 
The Pike, though known in the thirteenth century, was very scarce. Its price (as fixed by Edward I.) doubled that of the salmon, and exceeded ten times over that of either the turbot or cod. Even as late as the Reformation a large pike fetched as much as a February lamb, and a very small pickerel more than a fat capon. This ratio of prices recalls the rebuke administered by Cato the Censor to those prodigal Romans who were willing to pay more for a dish of fish than for a whole ox.

In view of the necessity for fish on the fast days, which claimed nearly half the year, the situation of twenty Sees (two Archbishoprics and eighteen Bishoprics) out of twentyseven on what were then salmon rivers can hardly have been a geographical accident.

The Carp must also have been a scarce fish in Tudor England. Dame Juliana Berners writes, "Ther be fewe in Englande." Holinshed, a propos of its scarcity in the Thames, states, "It is not long since that kind of fish is brought over into England." Leonard Mascall, however, in his Book of Fishinge (1596), credits a Mr. Mascall of Plumstead in Essex with the introduction of carp.

A hackneyed couplet, frequently quoted for the purpose of establishing the date at which carp and pike were introduced, but so full of mistakes as to be worthless, runs thus:

"Turkies, Carps, Hops, Pickerell, and Beer,

Came into England all in one year."

Since another version brackets "Reformation, hops, bays, and beer," the year intended is obviously ${ }^{5} 532$.

A Pike, or rather the head of a fish so-called, served at supper is said to have caused the end of Theodoric the Goth. In it he imagined he saw the face and head of Symmachus, whom he had just put to death; straightway he became so terrorstricken that within three days he had joined his victim. 



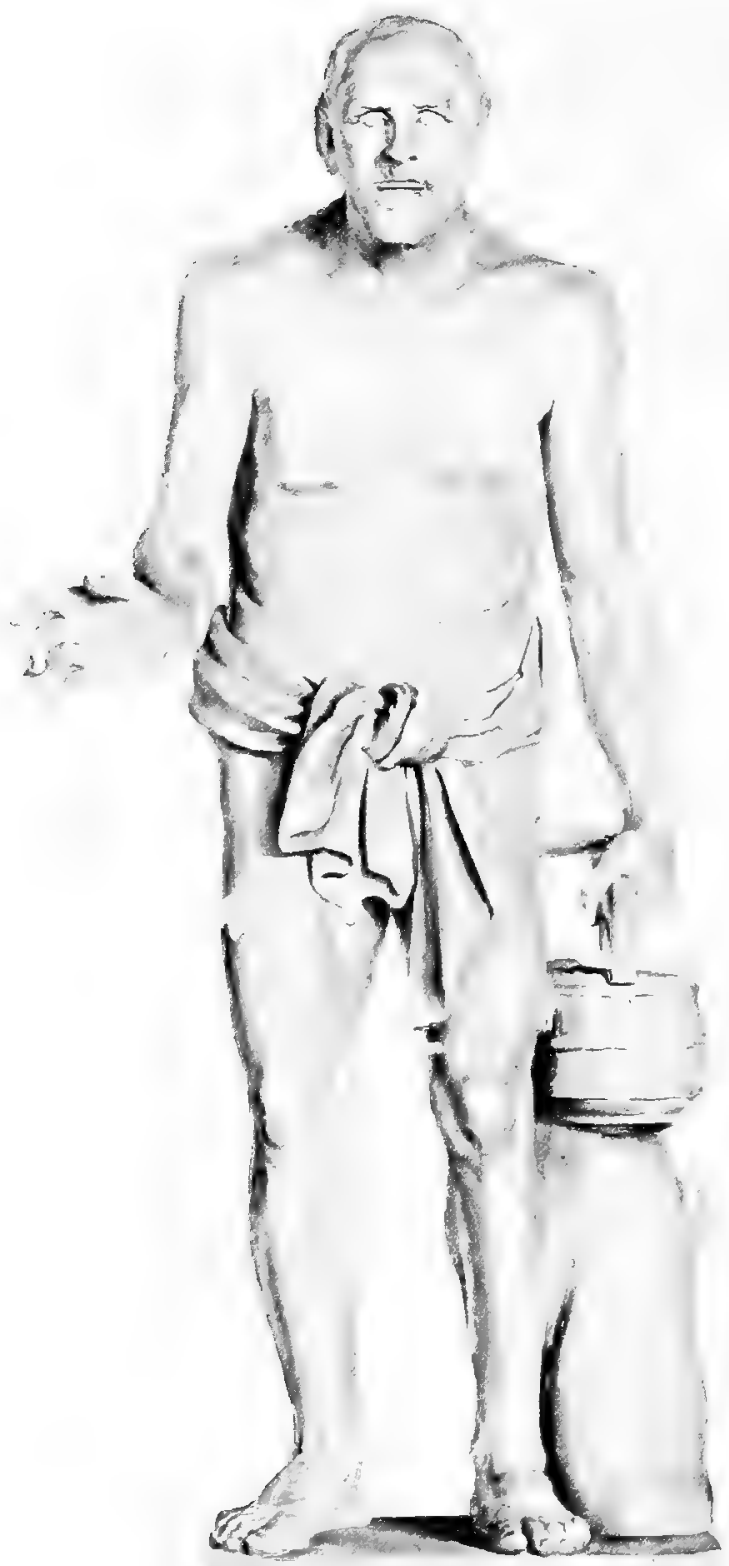

THE NAKED FISHERMAN OF THE VATICAN. 


\section{CHAPTER XIV}

INFATUATION FOR FISH-EXTRAVAGANT PRICES-COSTLY ENTERTAINMENTS - VITELIIUS - CLEOPATRA - APICIUS-COOKS-SAUCES

LEAVING now the Lore of fishing among the Greeks and Romans, let us turn, before examining the nature and number of their Lures, to their estimation of Fish as a food.

We found, it will be remembered, that the Homeric poems make no mention of fish being served at a banquet of the heroes, or even appearing on the tables of people of position. Only poor or starving folk ate fish. Although fish became later an insensate luxury, the Greeks at first apparently abstained from all fish caught in fresh water, except the eels of Lake Copais, then as now far-famed. ${ }^{1}$

This abstention from fresh-water fish originated (according to Plutarch) in the belief that every spring and every stream was sacred to some god or nymph, to catch whose property or progeny-the fish in them-would be an act of impiety. ${ }^{2}$ This sounds like a laboured explanation of a fact really due to other causes. One of these is brought out clearly in Geikie. When noticing the difference which existed between the Greek and the Roman interest in and feeling for the sea, he, or rather Professor Mackail, attributes it largely to a question of food supply. ${ }^{3}$ 880.

1 Cf. Chapter IV. Also Plutarch, Symp., VIII. 8, and Aristoph., $A c h$,,

2 Akin to this we have the special prohibition-unique as far as I knowwhereby priests at the temple of Leptis abstained from eating sea fish, because Poseidon was god of the sea, and owner and protector of its denizens. Plutarch, De solert. an., 35, II. At other of his temples, e.g. in Laconia, the fate awaiting a violator of the sacred fish was that common to poachers of similar holy waters, death.

${ }^{3}$ The Love of Nature among the Romans (London, I912), p. 300, n. I. 
Greece proper, from its comparative sterility and poverty of water, was very limited in its capacity to grow crops or rear herds. It compulsorily fell back largely on fish. And principally sea-fish, because of their superior palatability, and because of the inadequacy, owing to scarcity of lakes and perennial rivers, of fresh-water fish.

Whatever be the cause of the early abstention, three points arouse our interest. (A) The passages in Greek writers (previous to \&lian) that describe angling in Greek fresh waters, reach but a scant half-dozen, while those that depict fishing in such waters-sacred lakes, temple stewponds, and eeling in Lake Copaïs excepted-can probably be reckoned on both hands. ${ }^{1}$

(B) The Palatine Anthology (at least in the period from 700 B.C. to 500 A.D.) contains no reference (as far as I know) to aught but sea-fishing.

(C) The Greek comedians, Athenæus, the Greek opsophagic authors all almost always reserve their appreciations for food

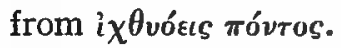

The statement that the Romans abstained, like the Maeatæ or Celts ${ }^{2}$ of North Britain, from fresh-water fish from similar, or any motives, cannot be established. It goes far beyond the evidence at our command, although some aversion may be possibly deduced from Ovid (Fast., VI. I73 f.), and as regards shell-fish from Varro. Unlike the Greeks, however, they certainly in a very short period became great consumers of fish from the Tiber, the Po, the Italian Lakes, and afterwards from the Danube, Rhine, etc., but in their estimation, as in that of the Greeks, fish from the sea ever held the higher place. ${ }^{3}$

- Passages which at first sight seem to conflict with this summary can often be ruled out from (A) geographical reasons, where (I) the fishing occurs in

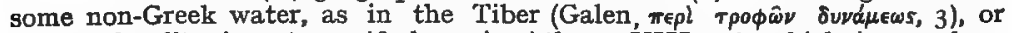
(2) the locality is not specified, as in Athen., VIII. 56, which is merely a quotation from a treatise of Mnesitheus, concerned with all kinds of fish from a digestive point of view; and (B) from the brackish nature of water.

${ }^{2}$ Dio. Cass. $76,12,2$, speaks of the Scottish Seas as swarming and crammed with fish.

3 Damm, p. 465 , asserts that the order of eating of fish among the Greeks was (I) Fish from the sea, and then, but much later, (2) Fish from the rapids of a river. Daremberg and Saglio: "Pour les Grecs le poisson d'eau douce 
If cost be a true criterion, this preference for salt-water fish continued as late as the fourth century. In Diocletian's Edict, 301 A.D., fixing the price of food, etc., throughout the Empire, the maximum allowed for best quality sea-fish was nearly double that of best quality river-fish.1

In both Greece and Rome fish became luxuries of the most expensive kind. Seas and rivers were scoured far and wide. No price was thought too extravagant for a mullet, a sturgeon, or a turbot; three mullets of historical celebrity even fetched in Rome the almost incredible sum of $£ 240 !^{2}$

In spite of many laws and decrees made at Athens and at Rome (where the Censor often interfered ${ }^{3}$ in cases of extravagance in dress, living, etc.) the prices, owing to the ingenuity of the sellers and the wild competition of the buyers, rose constantly higher. The plaint of Cato the Censor that things could not be well with a community, where " a fish fetched more than a bull," was uttered in and of a generation, which in comparison with its successors looks frugal, even niggardly.

Pliny records (N. H., IX. 3I) " octo milibus nummum unum mullum mercatum fuisse" -one mullet equalled $£ 64$, or the price of nine bulls! He also says (N. H., IX. 30) that mullets were plentiful and cheap when under $2 \mathrm{lb}$., "a weight they rarely exceeded." Martial (Ep., XIV. 97) confirms this in

comptait à peine dans la consommation du poisson de mer : seules les anguilles du lac Copaiis avaient quelque renom. Mais la pêche maritime eut toujours beaucoup plus d'importance." Pliny, XXXII. 10: Pisces marinos in usu fuisse protinus a condita Roma. Philemon the comedian makes the cook in his play, "The Soldier" (cited by Athen., VII. 32), bewail having for the feast mere,

$$
\text { " river fish, eaters of mud; }
$$

If I had had a scare or bluebacked fish from Attic waters I should have been accounted an immortal!"

1 See infra, p. 287.

a Suetonius (Tib., 34), "Tresque mullos triginta milibus nummum." A thousand sesterces, in the time of Augustus, equalled $£^{8} I_{7} s$. I $d$., but later only $£ 7$ I $5 s$. I $d$. For convenience I take rooo sesterces as roughly equivalent to about $f^{8}$ os. od.

- An amusing instance of official interference is recorded in Apuleius, Metamorhp. I, I8. Lucius, the hero of the story, tries to buy some fish for dinner from a fishmonger at Hypata in Thessaly, who demanded roo nummi (denarii): after much haggling, 2o denarii's worth is bought and being taken home, when the local adile intervenes, seizes the parcel on account of the extravagant charge, and destroys the fish in the presence of the seller. The result, which Lucius bewails, was loss of both dinner, and denarii / 


\section{FISH MANIA-VITELLIUS-APICIUS-COOKS}

his "Do not dishonour your gold serving-dish by a small mullet: none less than two pounds is worthy of it." In proportion as they exceeded this, they grew in value.

One would imagine that Nature had fallen in with the caprice of the Romans, for the fish seems to have grown larger in the decline of the Empire, as if to humour the extravagance of this degenerate people. Horace thought he had pretty well stigmatised the frantic folly of his glutton by a mullet of 3 lbs. (Sat., II. 2, 33) ; but the next reign furnished one of $4 \frac{1}{2}$ lbs., which presented to and sold at auction by the Emperor Tiberius was bought by Octavius for $£ 40$ (Seneca, Ep., XCV. 42), while in Juvenal, IV. I5 f., we have one of 6 lbs. ${ }^{1}$

How long the passion for these big mullets lasted it is impossible to tell, but Macrobius, speaking with indignation of one purchased by Asinius Celer in the reign of Claudius for $£ 56$ (in Pliny, $N . H ., I X .3 I, I$ find the price was $£ 64$ !), declares that in his time (fifth century A.D.) such mad prices had vanished.

Alongside of Pliny's caustic comment ${ }^{2}$ that the price of a victorious Triumph equalled that of a cook, or a fish, can be set the lament of the Greek comedians that for some fish one had to pay ioov $\hat{\imath} \sigma \varphi$, i.e. for weight avoirdupois you handed over a similar weight in money or, as Mayor neatly renders it, " $f$ for $\mathrm{lb}$." This gibe at the public mania sprang from bitter personal experience. At Rome, too, we read " of those who sell rare fish for their weight in money."

'Does not Martial's savage outburst on a glutton who had sold a slave for $£$ ro to procure a dinner, which was not really a good one because nearly all the money was spent on a mullet-

"Non est hic, improbe, non est

Piscis : homo est ; hominem, Calliodore, comes," apply with greater force to " the men-eaters" who purchased mullets for $£ 40$ or $£ 60$ each ? 3

1 See Mayor's Juvenal and Gifford's Trans., IV. I5. In Pliny, IX. 3I, Mutianus speaks of a mullet which was caught in the Red Sea, weighing 80 lbs. The comment of I. D. Lewis (on Juv., IV. I5 f.) that this fish " is utterly fabulous," is not the voice of one crying in the wilderness.

" IX. 3I, "at nunc coci triumphorum pretiis parantur, et coquorum pisces."

- Ep., X. 3I f. 
Juvenal's scathing invective on Crispinus-who had bought a mullet of $6 \mathrm{lbs}$. for $£ 48$-runs :

"What! you, Crispinus, brought to Rome erewhile, Lapt in the rushes of your native Nile,

Buy scales at such a price! You might, I guess, Have bought the fisherman himself for less ; Bought, in some countries, manors at this rate, And, in Apulia, an immense estate." 1

The folly of the Roman nobles and millionaires did not exhaust itself in buying fish at insane prices, or squandering their fortunes on Vivaria and similar extravagances. They touched a yet lower depth of infamy by taking their cognomen from fish.

Thus Columella contrasts the custom of their ancestors of taking a cognomen from some great victory, e.g. Numantinus or Isauricus, with that of their decadent successors such as Licinius Murana or Sergius Orata. ${ }^{2}$

The Greek Comic Poets and Satirists castigate with bitter sarcasms and jeers the frenzied, almost cat-like devotion to fish.

Even Diogenes the Cynic came to an untimely end by eating with eager haste a polypus raw. ${ }^{3}$ Philoxenus the Poet, when warned by his doctor, after " he had bought a polypus two cubits long, dressed it, and ate it up himself all but the head," that he had but six hours left to live and to arrange his affairs, bequeathed his poems and the prizes of his poems to the Nine Muses:

"Such is my Will! But since old Charon's voice Keeps crying out 'Now cross': and deadly Fate, Whom none can disobey, calls me away, That I may go below with all my goods, Bring me the fragments of that polypus." 4

The moralists of the Empire bewail " the costly follies of the patricians." Juvenal, Martial, and other Roman Satirists

1 Sat., IV. 23 ff. (Gifford's Trs.).

- VIII. x6. Cf. also Varro, De Re Rust., Bk. III. 3, Io; Elian, VIII. 4 ; and Macrobius, Sat., III. xv, I ff.

3 Athen., VIII. 26.

- Ibid. V1II. 26. 
lampoon the gluttony and extravagance connected with opsophagy, or the eating of fish. This limitation of the word is explained by Plutarch (Symp., IV. 4), " fish alone above all the rest of the dainties is called oै $\psi$ ov, because it is more excellent than all the rest," and characteristically defended by Athen., VII. 4. ${ }^{1}$

The banquets of the Greeks ${ }^{2}$ seem to have outdone even those of Imperial Rome. Both must have weighed heavy, alike on table and on chest.

At these, writes Badham, " although all flesh was there, although quadrupeds mustered strong, and a whole heaven of poultry, still it was the flesh of fishes that ever bore away the palm; they were the soul of the supper, and the number of kinds brought together at one repast was surprisingly great. From the poetic bills of fare preserved by Athenæus I have verified twenty-six species of fish in one Attic supper, and not less than forty at another ${ }^{3}$ On the fish course being brought in, the appearance of the banqueting hall soon became more splendid: hardware made way for solid silver: gold breadbaskets were now handed round: the flower of youth of both sexes entered bearing bits of pumice, drugs against drunkenness, and trays full of chaplets of Violets and Amaranth, while others hung up that mystic flower, the present of the

1 Xenophon, in speaking of a man as " an opsophagist and the biggest dolt possible," evidently does not subscribe to the pleasant theory that fishfood increases the grey matter of our brain. Holland's translation of Plutarch is not complimentary: " hence it is we call those gluttons who love belly. cheer so well opsophagists."

2 In charity to the Greeks may I hazard the plea (the rules of even the Law Courts are now sensibly relaxed) that their delight in Brobdingnagian meals may have originated in the days when their gods walked with men on earth, or grew up later as the sincerest form of flattery ? No one in Homer keeps his eye more skinned or his nose more active than a god, when hecatombs " are about." The Olympians flit constantly to IEthiopia and are impatient of any business, mundane or heavenly, which interferes with a trip thither, when with the keen scent (or vision ?) of vultures, they smell (or see ?) hecatombs in preparation in the heart of the Dark Continent, where the inhabitants, as a scholiast tells us, kept a feast for twelve days, one for every god! See A. Shewan's Homeric Games at an Ancient St. Andrews (Edinburgh, r9II), p. II6-a most delightful and destructive skit at the expense of The Highe Criticism of Homer!

The greatest number of fish which I can count at any feast mentioned in Athenæus (in Bk. IV. I3) amounts to only thirty-two! Badham (p. 587) omits to state that the whole poem is nothing but a parody, chiefly of Homer, by Matron, and is not a "Bill of fare of an Attic supper " in any sense. 
God of Love to the God of Silence, to intimate that henceforth all things said or done at the feast were to be kept, inviolable and $s u b$ rosa, under which flower by the rain of myriads of petals all the guests literally soon were." 1

The amount of money spent on suppers and entertainments at Rome staggers conception. The figures recorded by even serious historians seem beyond all belief: for instance, the ordinary expense of Lucullus for a supper in the Hall of Apollo is given at 50,000 drachma, or $£ I 600$.

At one of the suppers to which it was the custom of Nero to invite himself-his meals, Suetonius (Nero, 27) tells us, were prolonged from midday to midnight or vice-versa-no less than $€ 32,000$ was expended on chaplets, and at another still more on roses alone. But it must be remembered that the Italian rose bloomed only for one day-witness the lines, "Una dies aperit, conficit una dies," and "Quam longa una dies, ætas tam longa rosarum." 2 The cost of an entertainment by his brother in honour of the Emperor Vitellius on his entrance to Rome was nearly $\AA^{80,000 !}$

But of Vitellius himself let Suetonius ${ }^{3}$ speak: "He was chiefly addicted to the vices of luxury and cruelty. He always

1 Sammonicus Serenus, a savant of the early third century A.D., states that the acipenser was brought to table to the accompaniment of flutes by servants crowned with flowers. Cf. Macrob. III. I6, 7 f. Cf. Athen. VII. 44, and Elian, VIII. 28.

In describing this imaginary Attic supper, Badham certainly lets himself go. The allusion to "the present of the God of Love" he may have taken from an anonymous epigram in Burmann's Anthologia (I 773), Bk. V. 2 I 7 .

\footnotetext{
“ Est rosa flos Veneris; cuius quo furta laterent Harpocrati matris dona dicavit Amor.

Inde rosam mensis hospes suspendit amicis,

Convivæ ut sub ea dicta tacenda sciant."
}

These lines, of which several variants exist (notably that of the Rose Cellar in the Rathskeller of Bremen), are founded on the legend that Cupid bribed the God of Silence with his mother's flower not to divulge the amours of Venus. Hence a host hung a rose over his table as a sign that nothing there said was to be repeated. A quaint and touching legend runs that in the beginning all roses were white, but when Venus walking one day among the fiowers was pricked by one of their thorns, these roses "drew their colour from the blood of the goddess," and remained encarmined for ever. Cf. Natal. Com. Mythol., V. x3. See also A. de Gubernatis, La Mythologie des Plantes (Paris, 1882), II. 323, and R. Folkard, Plant Lore, Legends, and Lyrics (London, I884), $516 \mathrm{ff}$.

3 Cf. Ausonius, Id., XIV. 39, and 43.

${ }^{3}$ Suet., Vitell. 13. 
made three meals a day, sometimes four-breakfast, dinner, supper, and a drunken revel afterwards. This load of food he bore well enough, from a custom to which he had inured himself, of frequently vomiting !" No wonder Seneca lashes the gluttons of Rome with "Vomunt ut edant, edunt ut vomant!" I For each of these meals he would make different appointments at the houses of his friends for the same day. None ever entertained him at less expense than 400,000 sesterces (or $\$ 3200$ ). But the most famous entertainmentgiven in his honour by his brother-commandeered no less than 2,000 choice fishes, and 7000 birds.

Yet even this supper he himself outdid at a feast to celebrate the first use of a dish fashioned expressly for him, and from its extraordinary size yclept "The Shield of Minerva." In this dish ${ }^{2}$ costing $f_{100,000}$ and capable of feeding one hundred and thirty guests " were tossed together the livers of charfish, the brains of pheasants and peacocks, the tongues of flamingos, and the entrails (or rather the milt) of lampreys, brought in ships of war from the Carpathian Sea, or the Spanish Straits." 3

In order "satiare inexplebiles libidines," etc., Vitellius is believed to have squandered in a few months 4 no less than seven million two hundred and sixty-five thousand pounds $(£ 7,265,000) ! 5$

No wonder that Caligula, perhaps the biggest spendthrift of the Cæsars, laid down the maxim that " a man ought to be either an economist, or an Emperor!"

The fabulous sums spent on entertainments by the Greeks and Romans were equalled, even surpassed by the Persians, the Sybarites, the Egyptians, and other nations. But the cost, though prodigious, of Cleopatra's four-day entertainment to Antony and his captains (in the menu of which fishes from

1 For Vitellius's habit, see Dion., 65. 2.

$=$ Adrian had the good taste to melt it down.

- Thomson's translation. The mania for expensive bowls obtained in either nation: the philosopher Aristotle owned 70, while $\mathbb{E s o p}$, the tragic actor, paid $\$ 8000$ for a single ewer. The histrionic, as Esop and Roscius show, was a most lucrative profession. Cf. Pliny, XXXV. 46.

- According to Dion., 65.4, and Tacitus, Hist., II. 95.

5 Tac., loc. cit., " noviens milies sestertium paucissimis mensibus intervertisse creditur sagina." 
the Nile and the Red Sea figured conspicuously), pales before that of a supper given in honour of Xerxes and his captains by Antipater of Thasos, i.e. 400 (presumably Attic) talents or some $£ 100,000 !$ No wonder Herodotus mournfully adds, "Wherever Xerxes took two meals, dinner and supper, that city was utterly ruined!" 1

Nor at the feasts, which the invader of Media made "for a great multitude every day," was it a case of taking up of the fragments that remained but twelve basketsful, because, as Posidonius (in the I4th book of his History) continues, "besides the food that was consumed and the heaps of fragments which were left, every guest carried away with him entire joints of beasts, and birds, and fishes, which had never been carved, all ready dressed, ${ }^{2}$ in sufficient quantities to fill a waggon. And after this they were presented with a quantity of sweatmeats," etc.

The prize, however, for mad lavishness must be adjudged even in a race of such strenuous competitors, to " that most admirable of all monarchs," Ptolemy Philadelphus. It is "Eclipse first, the rest nowhere," if the description of the coronation feast given by Callixenus in his History of Alexandria be faithfully rendered by Athenæus. ${ }^{3}$

The imagination of the average reader before reaching the last chapters will have been fatigued and appalled by the picture of overwhelming wealth and magnificence, but as Ptolemy, after a reign of grandiose and continuous expenditure, left at his death $£ 200,000,000$ in the treasury, the cost of the whole entertainment must have been as nought compared with his revenue.

M. Gavius Apicius, after squandering half a million sterling on the indulging his passion for creating new dishes and new combinations of food from materials collected in Europe, Asia, and Africa, one day balanced his accounts. Finding

1 Herodot., VII. II8-120, Athen., IV. 27.

2 See Athenæus (V.46), who is so struck that he quotes the passage twice! The culinary accommodations must have been "prodeegeous!" At the birthday feast of a mere Persian grandee, an ox and an ass, and other animals that were his, even a horse and a camel, were roasted whole in stoves (or ovens). Herodot., I. I33.

v. 25-35. 
that but barely $f^{80,000}$ remained, and despairing of being able to satisfy the cravings of his hunger from such a miserable pittance he poisoned himself. $\mathrm{He}$ is possibly the author of a Treatise (in ten books!) of recipes for new dishes and new sauces for fish; for one of the latter more than twenty-five ingredients were necessary. ${ }^{1}$

The importance attached to cooks and cooking finds a cloud of witnesses in Greek and Roman writers. Athenæus in especial recites their triumphs and their bombastic boasts. So high was the chef's position and so excellent was the cuisine in Greece that we find the Roman ambassadors, who in the sixth century B.C. were sent to investigate the working of Solon's Laws, bringing home a special report on Cooking !

To these Attic cordons bleus in succeeding generations not only Italy but Persia were glad to send pupils, and pay exorbitant fees for tuition. The Attic cook gave himself the same airs of superiority over his Roman brother, as the French chef over the Anglican-him " of a hundred sects but only one sauce." Carême, the chef of Talleyrand (the author of this mot), never abated his claim that to the success of the Congress of Vienna he contributed no less than his master. ${ }^{2}$ His salary, however, does not begin to compare with that of Antony's cook, £3000 a year and "perquisites" galore.

1 “' The Treatise we now possess is a sort of Cook-Confectioners' Manual, containing a multitude of recipes for preparing and cooking all kinds of flesh, fish, and fowl. From the solecisms of style it is probable that it was compiled at a late period by one who prefixed the name of Apicius in order to attract attention and insure the circulation of his book." -Smith's Dict. Gk. Rom. Biog. and Myth.

Teuffel and Schwabe, History of Roman Literature (trans. G. C. W. Warr, London, I892), II. 28 f., point out that Colius Apicius, the traditional author of the work de re coquinaria, should rather be Colii Apicius, i.e. " the Apicius of Cœlius," Apicius being the title and Coelius the writer. The book was founded on Greek originals.

In Seneca (ad. Helv., Io), "sestertium milies in culinam consumpsit." See Martial, III. 22, who flays Apicius with biting scorn in his-

\footnotetext{
"Dederas, Apici, bis trecenties ventri, Sed adhuc supererat centiens tibi laxum. Hoc tu gravatus ut famem et sitim ferre Summa venenum potione perduxti.

Nil est, Apici, tibi gulosius factum."
}

For C. Matius the earliest (in the time of Augustus) and for other Latin writers on Cookery, see Columella, XXI. 4 and 44 .

2 See A. Hayward, Art of Dining. 
Anaxandrides 1 compares the beauteous work of portrait painters unfavourably with the beauty of a dish of fish. Xenarchus ${ }^{2}$ contrasts poets with fishmongers, much to the detriment of the former:

"Poets are nonsense: for they never say

A single thing that's new. But all they do

Is to clothe old ideas in language new,

Turning the same things o'er again

And upside down. But as for fishmongers,

They're an inventive race and yield to none," etc.

Hegesippus's summing up, " But the whole race of cooks is conceited and arrogant," finds confirmation in dozens of instances. Two grandiloquent boasts may serve: "I have known many a guest who has, for my sake, eaten up his whole estate," and

\section{"I am in truth a God, I bring the dead By mere scent of my food, to life again."}

Self-laudation is no monopoly of Greece, or Sicily, whence came perhaps the most famous of the tribe. In our own Beaumont and Fletcher's play-The Bloody Brother-a chef vaunts,

“ For fish I'll make you a standing lake of white broth, And pikes shall come ploughing up the plums before them, Arion on a dolphin playing Lachrymæ."

Lucian, in his witty Dialogue, ${ }^{3}$ makes Hermes act as auctioneer at the sale of the different creeds as personified by their founders or by philosophers, and dilate on the exceptional merits of the lot then under the hammer, "because he will teach you how long a gnat will live, and what sort of soul an oyster possesses." Mr. Lambert states that Ausonius wrote

1 Anaxandrides, Odysseus, frag. I ap. Athen., VI. II. See also Athen., VI. 4-I2; VII. 35-4I; Livy, XXXIX. 6: "Tum coquus, vilissimum antiquis mancipium et æstimatione et usu, in pretio esse, et quod ministerium fuerat, ars haberi coepta"; and Martial, XIV. 220.

2 Porphyra, frag. I. ap. Athen., VI. 6.

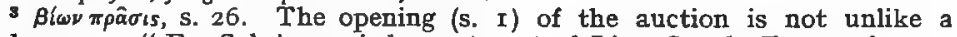
modern one: "For Sale! a varied assortment of Live Creeds, Tenets of every description. Cash on delivery, or credit on suitable security!" While lot (in 5. 26)-The Peripatetic-fetches $£^{80}$ os. od., the great Diogenes (in s. I I) is knocked down for threepence! Fowler's Trs. 
a poem on the oyster! To be more accurate, he wrote two, ${ }^{1}$ and lengthy ones to boot!

The Emperor Domitian (Juvenal, IV.) ordered a special sitting of the Senate to deliberate and advise on a matter of such grave State importance as the best method of cooking a turbot.

Greek and Roman writers frequently poke fun at the gourmets who asserted that they could instantly tell from the flavour whence the fish came: from what sea, and what part of that sea, from what river, and even from which side of that river. ${ }^{2}$

Either these ancient connoisseurs were blessed with a more exquisite and developed sense of taste than we moderns, or the whole pose was an intolerable affectation, for "they drenched their subtly-conceived dishes with garum, alec, and other sauces, which were so strong and composite that it would have been hardly possible to distinguish a fresh fish from a putrid cat-except by the bones!" 3

This assertion is none too strong, if the receipts for these sauces be duly pondered. Mention of garum, which gets its name from being made originally from the salted blood and entrails of a fish called garon or garos by the Greeks, is in classical writers very general: we find it even in Eschylus and Sophocles. 4

1 Ausonius, Epist., 5 and 15. But, after all, our own Keats, addressing his favourite Moon, did not hesitate to write:

$$
\text { To the poor patient oyster!" }
$$

$$
\text { (Endymion, III. } 66 \text { f.) }
$$

2 Pliny, IX. 79: "Is (Sergius Orata) primus ... adiudicavit quando eadem aquatilium genera aliubi atque aliubi meliora, sicut lupi pisces in Tiberi amne inter duos pontes ... et alia genera similiter, ne culinarum censura peragatur." See Horace, Sat., II. 2, 3 I ff. Also Columella, R.R., VIII. 16, 4: "Fastidire docuit fluvialem lupum, nisi quem Tiberis adverso torrente defatigasset" ; and also Juvenal IV. I39 ff. :

"Nulli maior fuit usus edendi

Tempestate mea: Circeis nata forent an

Lucrinum ad saxum Rutupinove edita fundo

Ostrea, callebat primo deprendere morsu,

Et semel aspecti litus dicebat echini."

More of the same sort is to be read in Macrob., Sat., III. I6, I6-18.

3 Robinson, op. cit., p. 45.

- Esch., Proteus frag., 211; Nauck ${ }^{2}$, and Soph., Triptolemos, frag. 606 Jebb, ap. Poll. 6. 65 and Äthen., II. 75. 
The various sauces known in Latin are too numerous to recite. 1 The two best, although the authorities are far from unanimous, seem to have been made out of the gills and entrails of the Mackerel and Tunny. The components of one recipe justify Robinson. In addition to other odds and ends, its outstanding feature was the gore and entrails of the Tunny, crammed in a vessel hermetically closed, and only drawn off when decomposition was complete! No wonder Plato the Comedian complains ..." drenching them in putrid garum they will suffocate me."

Alec, like garum, once the name of a fish (possibly the anchovy), came to signify only the sauce made from it, and subsequently from other cheap fish. It differed from garum chiefly from being thicker, and judging from the recipes probably nastier. You took first the dregs and fæculence remaining after the garum liquor had been decanted: to them, add turbid brine, sodden bodies of the fish, etc., and then you have the semi-solid compound, from which alec was derived, not inaptly yclept " Putrilago." 2

If, as Badham (p. 69) asserts but not convincingly, garum a double duty served, as a sauce and as a liqueur, the price of the latter was exorbitant, over $£ 3$ a gallon. ${ }^{3}$ Martial ( $E p$., XIII. I02) in

\section{"Expirantis adhuc scombri de sanguine primo Accipe fastosum, munera cara, garum,"}

calls attention to the expensive nature of his present, for

1 Pauly-Winowa, Real-Enc., VII. $84^{\mathrm{I}-9}$, has nine columns on the subject, ending with a bibliography!

2 Horace, Sat., II. 4, 73; Martial, III. 77, 5; and V. II., 94. The greatest delicacy of all these mixtures, the so-called Garum Sociorum, exported all over the Empire from Carteia, New Carthage, etc., was compounded of the intestines of the Spanish Mackerel. The absence of beard in the Mackerel is accounted for by this fish being convicted of treason against the reigning Monarch, and condemned to perpetual loss of beard. Keller, op. cit., 326 , omits a reference to this Fischeprozess, but cites the habit of writers-especially Bucolic-explaining any natural curiosity by putting into poetic or other shape a legend or Volkslied dealing with the point, e.g. Essop's fable why the Camel lacks horns.

3 Pliny, XXXI. 43: "singulis milibus nummum permutantibus congios fere binos." Ibid,, 44: "transiit deinde in luxuriam creveruntque genera ad infinitum, sicuti garum ad colorem mulsi veteris, adeoque suavitatem dilutum, ut bibi possit." Cf. Martial, Ep., XIII. 82. 2: "Nobile nunc sitio luxuriosa garum, and Calius Aurelianus " (De Chronicis, II.; De Paralysi), on the liquor extracted from the Scomber. 
garum made from the scomber was in Pliny's words "laudatissimum," while the " $\lambda \mu \eta$, or muria, fabricated from the intestines and nothing else of the tunny was cheap and inferior.

Apart from their gastronomic popularity, the medical efficacy of the various gara as pæaned by Pliny must, like the Waverley Pen, have " come as a boon and a blessing to men," in the wide range of their cures. ${ }^{1}$ For ulcers of the mouth and ears, one mirifice prodest. On the application of other gara, " dumb-foundered flee away" burns, blains, dysenteries, bites of dogs, maximeque crocodili, etc. Chapter 44 might indeed easily pass as the leaflet of an advance agent for a patent pill.

With the knowledge and use of the various internal parts of fish, it is strange to find Caviare, made out of the roe of the Sturgeon, first in a recipe of the ninth century. Soft and hard roes then, as now, were generally exported, but as a separate article it became known only in Byzantine times. ${ }^{2}$

With the hungry desire for fish among all classes and with the deep pockets of the rich enabling them to go to any extreme price, is it any wonder that the trade of a fishmonger at Athens and Rome was most lucrative? Several fishmongers acquired large fortunes and high position. The Athenians even raised to the rank of citizens the sons of Chærephilus, for the adequate reason that he sold such excellent pickled fish ! 3

At Athens, and probably at Rome, there existed a Society or Corporation of Fishmongers, akin to our own Fishmongers' Company, one of the many trade guilds of mediæval times. Its power and political pull often defeated or evaded the stringent regulations, which from time to time fixed the price of fish. In early times fish were sold by the fishermen themselves, as soon as the Fish-Market at Rome had been opened by the ringing of its bell.

1 Cf. XXXI. 44, and XXXII. 25.

2 If O.Keller, op. cit., $33^{8}$, be right in his authorities, Blakey's, " the praise of Caviare is frequent," is far astray. Despite the view of Hullmann's Handelsgesch. d. Gr., 149, Athenæus deals merely with garum and oxygarum, while the classical cookery books maintain a uniform silence.

s Athen., III. 90 . 


\section{CHAPTER XV}

FISH IN SACRIFICES-PICKLED FISH-VIVARIA OF OYSTERS, ETC.-ARCHIMEDES

The Feast Day, Ludi, of the Tiber fishermen was celebrated on the Campus Martius in June under the management of the Prcetor Urbanus with much ceremony. Ovid ${ }^{1}$ sings :

"Festa dies illis qui lina madentia ducunt,

Quique tegunt parvis æra recurva cibis."

The custom of offering to the Gods fish (although rarer than that of animals) certainly and widely prevailed. Proof can be piled on proof-pace a passage from Plutarch and pace the contention that the practice is not purely Hellenicfrom the pages of both Greek and Roman authors.

Take, for instance, the statement of Agatharchides of Knidos: that the largest eels from Lake Copais were sacrificed by the Bœotians, who crowned them like human victims, and after sprinkling them with meal offered prayers over them. ${ }^{2}$ Or the story in Posidonius the Stoic of Sarpedon celebrating his victory by " sacrificing to Neptune, who puts armies to flight, enormous quantities of fish." 3 Theocritus in his fragmentary Berenice, $\mathbb{E}$ lian, ${ }^{4}$ and Antigonus on the offering of the Tunny all confirm the custom. ${ }^{5}$

1 Fasti, VI. $239 \mathrm{ff}$.

2 Agatharchides, frag. I $a p$. Athen., VII. 5o. In these days of the Science of Comparative Curiosity and International Meddling the answer of the Boeotian to a foreigner asking how so singular a victim and sacrifice originated rings out pleasantly refreshing: "I only know one thing: it is right to maintain the customs of one's ancestors, and it is not right to explain them to foreigners!"

3 Athen., VIII. 8.

- Elian, XV. 6.

- Athen., VII. 50, and Paulus Rhode, Thynnorum Captura (Lipsiæ, I89o), p. 7I. Most of the major deities-e.g. Diana, Apollo, Mercury, Juno, Neptune, 
Plutarch (Symp., VIII. 3) would seem indeed the only exception: he straightly asserts, according to Nonnius and others, that " no fish is fitting for offering or sacrifice." 1

This is but another instance of Plutarch's being saddled with responsibility for some expression or opinion uttered by one of his characters, as is clearly shown by the words: "Sylla, commending the discourse, added with regard to the Pythagoreans that they tasted especially the flesh sacrificed to the gods, but that no fish is fit for offering or sacrifices."

P. Stengel holds that fish, with the curious exception of the Eel, were not sacrificed to the gods in early days, because they neither possessed blood which could be poured forth at the altar, nor could they be offered up alive as could be an enemy, a sacrifice which found special favour in divine eyes. ${ }^{2}$

This statement, unless explained in some manner, contrasts queerly with the passage in Plutarch's Life of Numa Pompilius, where the king is taught by Picus and Faunus, reinforced subsequently by Jupiter himself, to make a lustration " as a charm against thunder and lightning, composed of Onions, Hair, and Pilchards!'” Lest these curious constituents arouse your mirth and infect you with doubt as to their efficacy, hearken unto Plutarch's further words, "which is used even unto this day!"

From this account (wittily versed by Ovid) ${ }^{3}$ we discover Jupiter, resentful at being brought down to earth by the magic of Picus and Faunus, ordering the charm to consist " of Heads "- " Of onions," replied Numa. " Human "-_ Hairs," said Numa, desirous to fence against the dreadful injunction,

Ceres, and Venus-claimed a particular sacrificiable fish or fishes. Sometimes fishes were offered to two or more gods, $e . g$. the mullet to Ceres and Proserpine. Cf. J. G. Stuck, Sacrorum et sacrificiorum gentil. descriptio, ii. p. 72 .

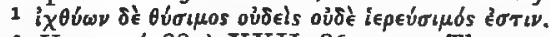

2 Hermes (I 887), XXII. 86. Ioo. The reason here stated for the Eel being sacrificiable was because it could be brought alive to the altar and its blood poured out on it. Stengel's argument, especially in association with his remark that sacrifices of fish were as scarce as those of game, is not convincing, for why should not other fishes be kept alive in water till the hour of oblation? The belief in the sanctity of the Eel pertains even unto our day, for in the spring at Bergas (between the Dardanelles and Lapsaki) they are or were pefore the War inviolate.

Fasti., III. 339 ff. 
and interrupting the god. "Living," said Jupiter-." Pilchards," broke in Numa.

Whether fish were but rarely sacrificed or not, Festus I at any rate makes clear that at the Ludi on June 7 th, and possibly the Volcanalia in September (although at the latter the oblations were mostly animal), Raman fishermen did offer up fish, " quod id genus pisciculorum vivorum datur ei Deo pro animis humanis."

Offerings of fish may be (as $O$. Keller suggests) a relic of Totemism resting on the belief that the spirits of men after death pass into fish.

The suggestion gains force when we remember that Anaximander ${ }^{2}$ and others taught that men lived once as fishes, but later came on land and threw off their scales ; and that the early religious conceptions of Latium were so debased as readily to engender or harbour such a conception. On the other hand, it must be admitted that not a single clear and convincing case of Totemism has hitherto been adduced from the Græco-Italic area.

In these oblations and in Varro's " Populus pro se in ignem animalia mittit," 3-an animal in place of a man be it remarked - can be detected a mitigated survival of the widespread custom of human sacrifice in propitiation of a deity. ${ }^{4}$ On much the same lines grew up the custom, as civilisation progressed, of burning the weapons of, instead of killing, the captured foe, after a battle. The immolation of prisoners formed a sacrifice not so much of revenge, as one in honour of the slain on the side of the victors: such at least is the conclusion suggested to me by the words of Festus, " humanum sacrificium dicebant, quod mortui causa fiebat." 5

As offerings at Rome had dwindled from men down to animals, or small fish, or eventually even salt or pickled fish,

1 Festus, p. 274, 35 ff. W. Lindsay.

2 Plutarch, Symp., VIII. 8. 4.

De Lingua Latina, 6. 20 (in his description of the Volcanalia).

4 F. Boehm, De symbolis Pythagoreis (Berlin, 1905), p. 19, would connect the fish-offering of the Volcanalia with the belief that the soul took the form of a fish. G. Wissowa, Religion und Kultus der Römeri: (München, I9I 2), p. 229, m. I3.

'Cf., however, Keller, op. cit., 348. 
or fish mixed with wheat, so among the Israelites the scapegoat had become the vicarious victim offered up to Jehovah "for the sins of all the people," and among the Assyrians the oblation had even shrunk to little fishes, made of ivory or metal.

Fish, in addition to being worshipped as gods or held so sacred that eating them was prohibited, were frequently used by the Priests or by the Augurs for divinatory purposes. In accordance with their swimming or not, and in what direction, with their leaps into the air, how, whence, and whither effected, with their reception, or refusal, or smashing with their tails of particular foods, were framed the oracular deliverances or priestly predictions, as Plutarch and others show. ${ }^{1}$

Thus at the spring of Limyra in Lycia, if the fish seized food thrown to them greedily, the omen was favourable; if they flapped at it with their tails, the reverse. ${ }^{2}$ In Lydia (according to Varro ${ }^{3}$ ) from their movements, when rising to the surface at the sound of a flute, the watching seer deduced and delivered his answer. Divination was not limited to certain holy waters; when in the war between Augustus and Sextus Pompeius a fish darted from the sea and threw itself at the feet of the former, the ready augur found no difficulty in acclaiming him as the future "Ruler of the Waves." 4

Ichthyic soothsaying held its ground among the Greeks of the Byzantine empire. One prediction 5-when a boiled fish shall spring out of the pot, then the last hour of Constantinople will have struck-is of present-day importance. But whether the fish has filled his saltatory rôle, and if so whether the doom of the city has sounded, lie for decision at the moment of writing on the lap of the Big Four in Paris.

The belief that fish could and did foretell events lingered long in England; thus the deaths of Henry II. and of Cromwell

1 Pliny, IX. 22, and XXXII. 8. 府lian, VIII. 5; XII. 1, Athen. VIII. 8 Plutarch, $D e$ soll. Anim. ch. 23. Hesych. s.v. Soura.

2 Pliny, XXXI. I8.

s De Re Rust., III. I7, 4 .

- Suetonius, Augustus, 96. The subject of oracular fish is dealt with by A. Bouché-Leclercq, Histoire de la divination (Paris, I879), i. p. I5I f., and also by W. R. Halliday, Greek Divination, p. I68, n. 3 .

B O. Keller, op. cit., 347 . 
were foreshadowed by the fighting of fish among themselves in the vivaria belonging to Henry II. and Cromwell. ${ }^{1}$

As is but natural in hot countries, the trade in salted and pickled fish, the rápı ${ }^{\circ}$ s of the Greeks, the salsamentum of the Romans, grew to great importance. ${ }^{2}$

This sweet-sour comestible was among both nations early, universal, and pushed to the extreme of madness. ${ }^{3}$ In such high esteem was it held that it came to be looked on as an offering meet for the gods. Cato and others testify to the exorbitant prices commanded by Pontic and kindred salsamentum, of which a small flask fetched more than one hundred sheep! Of every kind-and they were as diverse as the countries and towns that furnished them-we find champions ready to go to the stake to prove the superiority of their own pet choice.

Of some towns it was the chief, if not the only, commerce. As modern towns frequently bear for their arms or on their seal some device connected with their history or trade, so ancient seaports which produced salsamentum often stamped their coins with the figures of fish, etc.

Thus Olbia, one of the most important markets for salt or pickled fish, bears on its money an eagle taking a fish, ${ }^{4}$ while a

1 The cause, sympathy with their owners, mentioned by Robinson, $o p$. cit., 88-9, hardly recommends itself.

- The Greek term, rapi $\chi \eta$, was applied to Conserves de viande et poissonbut chiefly the latter. Salted fish was a food far commoner among the Latins than among the Greeks (Daremberg and Saglio). Sausages-Isicia or Insicia-were made from fish as well as meat. Of both there were, according to Apicius (Bk. II.), many preparations, those from fish being in great demand.

8 Nonnius, op.cit., p. I55. Apart from fashionable mania, the salsamentum was used for very practical purposes, e.g. as food for the Athenian soldier on campaign. Cf. Aristoph., Ach., IIOI, 2. From the frequent notices and quotations in Athenæus, Euthydemus the Athenian seems to have been the most prolific author on pickled fish. On him and his three treatises, see Pauly-Winowa, Real. Enc., VI. I505.

- $A$ propos of the fish-trade of Olbia, Koehler (in the Mem. de l'Acad. des Sciences de St. Petersburg, VIme série, tome I, p. 347, St. Petersburg, I832, as quoted by E. H. Minns, Scythians and Greeks, Cambridge, I9I3, p. 440) concludes that preserved fish of every quality, from jars of precious pickle, corresponding to our caviare or anchovy, to dried lumps answering to our stockfish were all sent to Greece, and later to Rome, from the mouths of Dnêpr and the sea of Azov. As regards some of the small copper coins of Olbia, Mr. G. F. Hill, $A$ Handbook of Greek and Roman Coins (London, I899), p. 3, writes: "If these are coins, they differ from the ordinary Greek coin only in the fact that, instead of putting a fish type on a flan of ordinary shape, the whole coin was made in the shape of a fish. Another explanation is suggested by the fact 
copper coin of Carteia ${ }^{1}$ depicts an angler, possibly Mercurya god of fishing. Sinope, and many other places, have left similar numismatic representations. Of most interest from a monetary point of view are the Greek diobols of Tarentum. Those bearing the figure of Taras on his dolphin passed as current token in the fish market. ${ }^{2}$

Famous for the beauty of their execution were some of the Syracusan coins, representing the head of Arethusa surrounded by dolphins. The accounts of the legend vary. Shortly, the

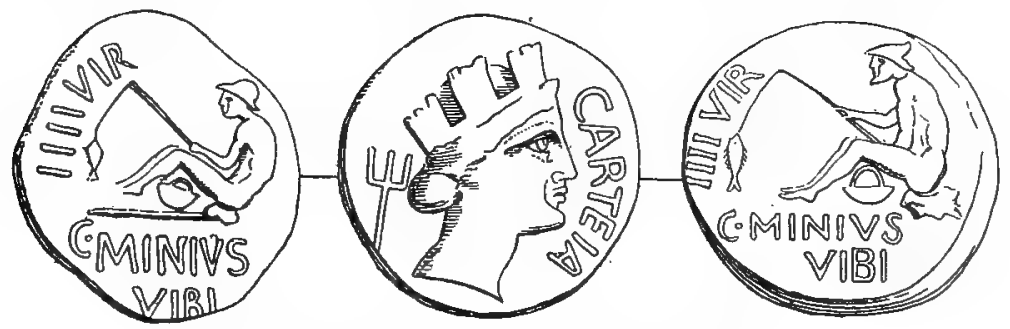

TWO MEN FISHING, FROM COINS OF CARTEIA.

From A. Heiss, 49, 20-21. See N. I.

lovely maid of the train of Artemis fled the embraces of her lover Alpheus,

"Arethusa arose

From her couch of snows

In the Acroceraunian Mountains,"

and prevailed on Oceanus to open a way through his waves till

that a pig of metal was sometimes called $\delta \in \lambda \phi / s$. These fish-shaped pieces may be the degenerate representatives of similar-shaped pigs of bronze." He refers to Ardaillon, Les Mines du Laurin, p. III, who compares the French saumon with the meaning of "a pig of metal."

1 In Pitra, op. cit., pp. 508-5r2, will be found a list of $\mathbf{I}_{5} 6$ coins, gems, etc., illustrating the connection of various fishes with deities and places. For the coins of Carteia, see A. Heiss, Description générale des monnaies antiques de l'Espagne, Paris, I870, p. 331 f., pl. 49, I9-2I (=my Fig. supra). The salsamentum of this town was in special request; its boasted excellence might be perhaps accounted for by Strabo's statement that the diet of the Tunnies off Carteia consisted of acorns which grew in that sea, just as land acorns with an occasional truffle achieve, according to gourmets, for the Spanish pig the primacy of hams. Alas! for such conjecture, science shows that the Tunny throve on Fucus vesiculosus, not acorns. Cf. Keller, op. cit. $3^{8} 3$.

2 B. V. Head, Historia Mumorum, Oxford, I9I I, p. 67: "These little coins formed the staple of the common currency in the Tarentine fish-markets, as well as in the rural districts subject to Tarentum, and even beyond its territories-in Apulia and Samnium for instance." 
reaching seeming safety in the Isle of Ortygia, close to Syracuse, she welled forth in the midst of the salt sea a fountain of sweet pure water. Alpheus, not to be outdone, got himself transformed into a river to emerge also at Ortygia and to mix his stream with the spring of the nymph.

Around her head or amidst her hair on Syracusan coins dart dolphins (some hold eels, which were sacred to Artemis), symbolic of the sea, to show that the sweetness of the fountain was still untainted by the surrounding salt of the ocean.1 Sweet the water may have been, but Athenæus (II. I6) characterises it as "of invincible hardness." These coins are the work of those great masters, Cimon, Euaenetus, and an unknown third, the 'New Artist' of Sir Arthur Evans. ${ }^{2}$ On an electrum coin of Syracuse an octopus is well delineated, while the obverse shows a veiled female head in profile. $^{3}$

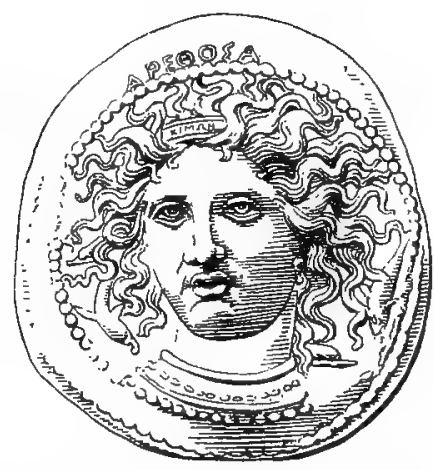

ARETHUSA, FROM A TETRADRACHM OF SYRACUSE BY CIMON.

From G. F. Hill's Handbook of Coins, Pl. 6, Fig. 6.

The octopus, judging by the fact that at Mycenæ in one tomb alone Dr. Schliemann excavated fifty-three golden models of it, and by the many gold ornaments of which the fish forms the chief or only figure, was undoubtedly a very frequent and favourite subject for the craftsmen of the 'Minoan' age,

1 Some authorities (Preller, Griech. Myth., I. I9I) believe the head to be that of Artemis, not only the protectress of Arethusa, but also the goddess of rivers and springs, and of the fish therein-one of her emblems was a fish. Some coins show her or Arethusa's head with seaweed plaited in the hair, or the hair plaited in a sort of fish-net surrounded by little fish. The whole island of Ortygia was absolutely dedicated to Artemis-no plough could cut a furrow, no net ensnare a fish, without instantly encountering a sea of troubles. See Keller, op. cit., p. 343. The sacred fish were seen by Diodorus (V. 3) as late as Octavian's reign.

2 For an admirable account of Syracusan coin-types during the 'fine" period (4I 3-346 B.C.), see G. F. Hill, Coins of Ancient Sicily (London, I 903), p. $97 \mathrm{ff}$., with frontispiece and pls. 6-7. On the widespread representation of the Tunny on vases and coins-Carthaginian, Pontic, etc.-see Rhode, op. cit., pp. 73-77.

see G, F, Hill, op, cit., $\mathrm{Pl}, 7, \mathbf{2}$. 
although it did not bulk so big in early Mediterranean religion as L. Siret would make out. ${ }^{1}$

The taxes or duties derived from fish or fishing furnished the peculiar of the Temples at Delos, Ephesus, and elsewhere : at Byzantium and some other places they went to the city. After the Roman conquests these imposts were paid not to the cities (Cyzicus and other places were the exceptions), but to the State, and were gathered by the intermediary " publicans." 2

With stories before him, such as those of the suppers recorded by the dozen in Athenæus, and given to and by the Emperor Vitellius, for which the fish were brought in ships of war from the Carpathian Sea and the Straits of Spain, it is no wonder that a modern author is driven to conclude that the ancients thought more of the edible than the sporting qualities of the fish. They ransacked the habitable globe for side-dishes, but did not trouble themselves about the precepts of Mrs. Glasse.

Apart from this ransacking of the globe, the Romans developed, as the demand for fish by rich and poor alike grew ever greater, the Egyptian and Assyrian vivarium to a marvellous extent.

Built at first (as Columella avers ${ }^{3}$ ) simply for the purpose of supplying fresh fish for the table, they found such favour that no self-respecting Roman could afford to be without his vivarium. With the rich they were the occasion of most costly ostentation and extravagant expenditure.

Whether Sergius Aurata (or Orata) took or not his cognomen 4 from the fish Aurata, all writers identify him as the first to build a vivarium for oysters. From their sale, from the income derived from the vapour baths (pensiles balineas), of which he was also the pioneer, and from the villas erected on his property, close to Baix, the baths, and the oysters, he amassed an

' L. Siret, Questions de chronologie et ethnographie ibériques (Paris, 1913), Index. s.v. 'Poulpe."

${ }^{2}$ Cf. Tacitus, Annals, XII. 63.

- De Re Rustica, VIII. I6, "Our ancestors shut up saltwater fishes also in fresh waters. For that ancient rustic progeny of Romulus and Numa valued themselves mightily upon this and thought it a great matter, that, if a rural life were compared with a city life, it did not come short in any part of riches whatsoever."

" "Orata," according to Festus, p. 196, 26 ff. Lindsay, " genus piscis appellatur a colore auri, quod rustici orum dicebant." 
enormous fortune. He posed as the Pontiff of the Palate; his was the final decision, from which lay no appeal, as to which sea or which part of what river produced the best of the various fishes.

From the not unnatural bias of owner and founder he adjudged the Lucrine oysters finest of all. Pliny's words (IX. 79) that, when Orata " ennobled " the Lucrine, British oysters had not yet reached Rome convey a gratifying compliment to our insular pride, somewhat dashed by Pliny plumping for the Circeian. 1

Oysters throve with travelling and a change to new waters. ${ }^{2}$ The Brundisian oyster when planted in Lake Lucrinus not only kept its own flavour, but took on that of its new home.

Apicius, not our gourmet M. Gabius, but an initialless successor, would have proved an admirable QuartermasterGeneral.3 When "Trajan was in Parthia at a distance of many days' journey from the sea, he sent him oysters, which he kept fresh by a clever contrivance of his own invention; real oysters not like the sham anchovies which the cook of Nicomedes, king of the Bithynians, made for him," when far inland and yearning for oysters.

In a comedy by Euphron, ${ }^{4}$ a chef sings his teacher's marvellous skill :-

"I am the pupil of Soterides

Who when his king was distant from the sea

Full twelve days' journey and in winter's depth

Fed him with rich anchovies to his wish

And made the guests to marvel.

B.

How was that?

A. He took a female turnip, shred it fine

Into the figure of the delicate fish."

1 See ante, p. I46. If he praise our oysters, he straightly condemns the pearls from them, as being "small and discoloured ;" wherefore (IX. 57) Julius Cæsar, when he presented a thorax to Venus Genetrix, had it made of British " pearls," a very poor requital to a goddess, who, if Suetonius is to be trusted, had so often stood him in good stead, both as a distant ancestress, and in other connections! Some really fine pearls have been found in Scotland and Wales : the best known of these, got at Conway in the eighteenth century, was presented to Catherine of Braganza, and is still preserved in the Crown jewels. Wright, op. cit., p. 220.

2 Pliny, XXXII. 2 r.

Athen., I. I3 ; cf. Suidas, s.v. oั $\sigma \tau \rho \in \alpha$.

* Euphron, incert. fab. frag. I, quoted by Athen., I. I3. 
No wonder the king spake to his admiring guests thus :-

"A cook is quite as useful as a poet,

And quite as wise, as these anchovies show it."

To Fulvius Herpinus or Lippinus belongs the credit of being the first-just before the Civil War-to fatten the Cochlea, or sea-snail, in a vivarium. By careful collecting from Africa and Illyrica and skilful feeding, his cockles became renowned for size and number. ${ }^{1}$

In the period between the taking of Carthage and the reign of Vespasian, the taste in fish became a perfect passion ; for its gratification Proconsuls enriched, like our Clives from India, beyond the dreams of avarice by the spoils of Asia and Africa, incurred the most lavish expense. Thus Licinius Muræna, Quintus Hortensius, Lucius Philippus constructed immense basins, ${ }^{2}$ which they filled with rare species. Lucullus, like the Persian king at Athos, but with unlike motive, caused even a mountain to be pierced to introduce sea-water into his fishponds, and for the achievement was dubbed by Pompey, "Togatus Xerxes." 3

But in many cases the huge outlay was repaid with interest. Varro ${ }^{4}$ avers that Hirrius (who first before all others designed and carried out the vivarium for Murana) received twelve million sesterces in rent from his properties, and employed the entire sum in the care of his fishes! At the death of Lucullus the fish in his stew-ponds realised over $£ 32,000$.

The rich Patricians were not satisfied with a single pond ; their fish preserves were divided into compartments where they kept different kinds. In case any reader, like the Third Fisherman in Shakespeare's Pericles,

$$
\text { "Marvel how the fishes live in the sea," }
$$

1 Cf. Varro, De Re Rust., 3. I2, I, and Plin., 9. 82.

2 Petronius, 120, 88, expelluntur aquae saxis, mare nascitur arvis.

3 Lucullus, enriched by the vast booty captured from Mithridates and Tigranes, was the first who taught luxury to the Romans (Athen, VI. Iog). Polybius $(3 \mathrm{r}, 24)$ writes that $\mathrm{M}$. Porcius Cato denounced the introduction of foreign extravagances into Rome, citing as instances that for a jar of pickled fish from Pontus 300 drachme had been paid, and that the price of a beautiful boy exceeded that of a field.

- De Re Rustica, III. 17 . 
I hasten to endorse the

First Fisherman: "Why as men do on land; the great ones eat up the little ones,"

and to add that the fish confined in these separate ponds found in the waters their business and livelihood from the testacece purposely planted.

This passion for piscince gradually impoverished the Mediterranean and other seas. Fish in the Tyrrhenian Sea had no time to come to maturity, because as Columella complains, "Maria ipsa Neptunumque clauserunt!" I While Varro and Columella give careful directions as to the making and keeping of practical fish stews, they keep silence as to methods of capturing the inhabitants.

I have come across no notice of vivaria among the Greeks : 2 their kinsman in Sicily erected at least one magnificent example. Diodorus Siculus (XI. 2) tells us that the Agrigentines (probably by the labour of the Carthaginian prisoners) " sunk a fishpond, with great costs and expenses, seven furlongs in compass, and twenty cubits in depth : in this water, brought both from fountains and rivers, fish were planted which soon supplied them with an ample stock both for food and pleasure."

To the great Archimedes is due the unique achievement of a vivarium on board ship. It is impossible here to set forth all the glories of this wonderful vessel, intended for the corn traffic between Egypt and Sicily, and propelled by means of huge sweeps-every sweep worked by a team of twenty men (Ėkoøópos).

Her Gymnasium, her three Baths, her Flower Garden, her

2 De Re Rustica, VIII. I6. Cf. also Juvenal, V. 94 ff.-

"quando omne peractum est

Et iam defecit nostrum mare, dum gula sævit,

Retibus assiduis penitus scrutante macello

and Seneca, Ep., 89, 22-

Proxima, nec patimur Tyrrhenum crescere piscem,"

"quorum profunda et insatiabilis gula hinc maria scrutatur, hinc terras."

2 The explanation for this by Nonnius, op. cit., p. 75-that the Greek coasts, from being surrounded on all sides by seas, yielded ample supplies of fish, while the Romans, "whose seas were not so near," were not as fortunate and were compelled to be more instant in pisciculture-is a statement at the best doubtful, and certainly not supported by the existence of vivaria in Sicily, lapped on every side by seas. 
trellised Vineyard, her Temple to Venus, her Library with its floor of mosaics exhibiting a series of subjects taken from the Iliad, and, lastly, in the bow by the side of the huge reservoir of 2I, 000 gallons, her water-tight well, made of planks lined with lead, and filled with sea-water, in which a great number of fish were always kept-if all these wonders of a ship, launched over 2200 years ago, do not cause us to think a little, and to abate our boasts over our Imperators and Olympics, then to the cocksure conceit of the twentieth century naught is of avail, not even the account given by Moschion. ${ }^{1}$

Disregarding the practical directions of Varro (whom Schneider ${ }^{2}$ stamps, with regard to fish, etc., as a mere plagiarist of Greek authors), of Columella, and in a lesser degree of Pliny how to construct and conduct paying stew-ponds, and turning a deaf ear to Varro's warning that " to build, stock, and keep them up was most costly," the Romans thought no money, no time, too much to expend on vivaria. ${ }^{3}$ Possession and cultivation of fish in vivaria, which were sometimes made in the dining-room, became the one delight of these "Tritones Piscinarum," as Cicero dubs two of his friends.

The primary cause for their existence, a ready supply of fresh fish in a hot climate, was forgotten. Other owners resembled Hortensius, who (according to Varro) " not only was never entertained by his fish at table, but was scarcely ever easy, unless engaged in entertaining or fattening them." The death of " his friend," the Murcena, between whom and himself such a close attachment existed, almost broke his heart. ${ }^{4}$

1 The existence of such gigantic craft has been called in question, but is proved by an inscription from the temple of the Paphian Aphrodite in Cyprus,

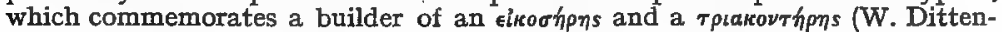
berger, Orientis Grceci Inscriptiones Selectce (Lipziæ, r903), I. 64, no. 39). See also, L. Whibley, A Companion to Greek Studies (Cambridge, 19I6), P. 584 f. Athen., V. 40-44. Caligula built two ships for cruising and fishing up and down the Campanian coast: their poops blazed with jewels. They were fitted up with ample baths, galleries, and saloons, while a great variety of vines and fruit trees were cultivated. Suetonius, $\mathrm{Cal}$. 37. Divers have discovered at the bottom of Lake Nemi two imperial house-boats of enormous size, the timbers of which are decked with bronze reliefs of magnificent workmanship. See V. Malfatti, Le navi romane del lago di Nemi, I905.

2 op. cit., p. 246 .

Cf. Tibullus, II. 3. 45 .

"Claudit et indomitum moles mare, lentus ut intra Neglegat hibernas piscis adesse minas."

- Pliny, IX. 8I. 
Macrobius testifies that Crassus, " first among all the greatest men of Rome, mourned a murcena" (probably it of the earrings and necklace of precious stones) "found dead in his vivarium even as a daughter." It was on the occasion of Domitius twitting him with "Did you not weep when your fish died?" that Crassus got back with " Did you not bury three wives and never weep at all ?" 1

Of Hortensius Varro continues: ${ }^{2}$ " His mullet give him infinitely more concern than my mules and asses do; for while I, with one lad, support all my thrifty stud on a little barley, etc., the fish-servants of Hortensius are not to be counted. He has fishermen in fine weather toiling to procure them food; when the weather is too boisterous for fishing, then a whole troup of butchers and dealers in provisions send in their estimates for keeping his alumni fat. Hortensius so looks after his mullet as to forget his men; a sick slave has less chance of getting a draught of cold water in a fever than these favoured fish of being kept cool in their stews in Midsummer."

The fish often answered to their names when called by their master, or their keeper. The latter, nomenclator, made a very handsome income from the admiring crowds, who flocked to see the fish perform their exercises with wagging tails or heads bedecked with rich jewels. ${ }^{3}$

1 Plutarch, De Sol. Anim., 23.

2 De Re Rustica, III. I7. This abstinence on the part of Hortensius from eating his "mulli barbati" is the more to be appreciated, when we remember that, according to Sophron, the savoth of the "barbati" was far pleasanter than that of any other mullet. Athen., VII. I26.

3 Martial, Ep., IV. 30, 4 .

"Qui norunt dominum manumque lambunt

Illam, qua nihil est in orbe maius.

Quid quod nomen habent et ad magistri

Vocem quisque sui venit citatus ?"

and Martial, X. 30, 22 .

\footnotetext{
" Natat ad magistrum delicata muræna,
}

Nomenculator mugilem citat notum,

Et adesse jussi prodeunt senes mulli.'

Cicero, Ep. ad Att., XX. I, "Our leading people think that they attain unto Heaven if they own in their ponds bearded mullets, who will come to them to be stroked." Cf. Lucian (De Dea Syria, 45-48). \#lian, VIII. 4, confirms these statements, and in 12. 30, tells of a spring in Caria sacred to Zeus, in which were kept eels decked with earrings and chains of gold, while Pliny, XXXII. 8, writes that at the Temple of Venus at Hierapolis, of which Lucian speaks as an eye-witness, "adveniunt pisces exornati auro." This practice is, and has been, world wide. "Fishes though little have long ears," is an old 
Antonia, to whom the lands and villa of Hortensius descended, even stripped herself of her earrings to put them on a murcena. This lady, apart from this anecdote, was no ordinary person. We find her passing from the positive of celebrated renown for her beauty, her virtue, her chastity (no mean feat in that day !), through the comparative of being the mother of Germanicus Cæsar and Claudius, and the grandmother of Caligula (which last, in slang parlance, "wanted a bit of doing ! "), unto the superlative of deathless fame in Pliny's "Nunquam exspuisse" (never spat!). I

The savage use, to which Vedius Pollio put his vivaria, can be learnt from the pages of Pliny ${ }^{2}$ and Seneca. ${ }^{3}$ A slave, for breaking a crystal decanter at a banquet given to Augustus, was ordered to be thrown instantly into a piscina, there to be eaten alive by the nibbling voracious Murana. Escaping from his guards he threw himself at the Emperor's feet, "beseeching nothing else except that he should die otherwise than as food for fish " 4. Cæsar moved " novitate crudelitatis" (he little knew that this was his host's cheery custom) commanded the crystals of Pollio to be smashed on the spot, the slave to be freed, and all the fishponds to be filled up.

As conducive to la joie de vivre of the other slaves, the command was commendable, for the bite of the Murcena's serrated teeth, according to Nicander's Theriaca-that "nullius fidei farrago"- - owing to its mating with the viper, dealt poisonous death and destruction to the fishermen driven by its pursuit " headlong from their boats," and was only curable by a mixture made of ashes from its own burnt head! So dreaded was this fish-curious is it not, to read, although from

Chinese proverb. " In Japan fish are summoned to dinner by melodious gongs. In India, I have seen them called out of the muddy depths of the river at Dohlpore by the ringing of a handbell, while carp in Belgium answer at once to the whistle of the monks who feed them, and in far away Otaheite, the chiefs have pet eels, whom they whistle to the surface" (Robinson, op. cit., p. I4). Cf. Athen., VIII. 3, " and I myself and very likely many of you too have seen eels having golden and silver earrings, taking food from any one whofoffered it to them." The Egyptians similarly adorned their crocodiles with gold earrings. Herod. 2. 69.

1 VII. 18.

2 IX. 39.

- De Ira, III. $4^{\circ}$.

- For eels devouring the flesh of a corpse, see Iliad, 203 and 353. 
its savage nature no other could inhabit the same vivarium, the many stories of its tameness and docility ? - that one of the direst of imprecations ran that in the underworld your enemy's lungs should be mangled by Murane ! 1

In times preceding these infatuated extravagant ages, the purpose for which vivaria were first created was steadfastly kept in mind and wonderfully advanced by practical pisciculturists. From being a mere pond for keeping fish alive till needed for the table, vivaria developed in the course of time into spawning grounds.

The pisciculturists went even farther. They turned lakes and rivers into natural oivaria by depositing in them not only adult fish, but the spawn of all such species as are in the habit, although born at sea, of pushing some distance up estuaries and streams. Columella instances specially the rivers Velinus, Sabatinus, Ciminus, and Volsinius as examples of the great success of this experiment in fish propagation. ${ }^{2}$

Comacchio on the Adriatic, from its extraordinary advantages of position and of fish-food, can hardly have escaped being utilised for similar purposes by the Romans. For many

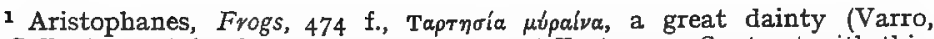
ap. Gell., 6. I6. 5), is of course meant to suggest Tartarus. Contrast with this, the popularity of the fish, as attested by its frequent mention, especially in Plautus, and by the fact which Helbig (Camp. Wandgemälde (Leipzig, 1868), Index, p. 496, s.v. "Murāne") brings out, that on the mural decorations of Pompeii no fish finds more frequent representation.

${ }^{2}$ De Re Rustica, VIII. r6, "Quamobrem non solum piscinas, quas ipsi construxerant, frequentabant sed etiam quos rerum natura lacus fecerat convectis marinis seminibus replebant. Et lupos auratasque procreaverunt ac siqua sint alia piscium genera dulcis undæ tolerantia."

"What fish Columella meant by Aurata is not settled : it is certainly not the "goldfish," as some translate, for they are not sea-fish. Facciolati, after saying that the name came from the fish having golden eyebrows, goes on that " some folk deny that he can be identified with the "gilthead " or " dory." Perhaps the fish is one of the Sparida group, which pass at certain seasons of the year from the Mediterranean into salt-water fish marshes, as observed by Aristotle, and confirmed by M. Duhamel. Or can it be the smelt ?

Faber, pp. 37,38, " of fresh-water fishes, twenty-one species, among them the fresh-water Perch, are also common to the sea: amongst the sea fishes, the flounder frequents brackish water, and sometimes enters the rivers: others only occasionally frequent the lagoons and brackish waters, among them the Gilthead," a statement incidentally confirmed by Martial (Ep. X.III. 90) in his helluous pronunciamento, that practically the only really good $A$ urata was that whose haunt was the Lucrine lake, and whose whole world was its oyster! of which fish Martial (XIII. 90) seems only appreciative,

". . cui solus erit concha Lucrina cibus." 
centuries, at any rate, its valli or breeding grounds have been renowned. Ariosto sings its speciality:

" La Città che in mezzo alle piscose

Paludi del Pò, téme ambe le foci."

Tasso hands it down as the place where the fish-

"finds itself within a prison swamp

Nor can escape, for that seraglio

Is aye to entrance wide, to exit barred."

At the present day over twelve hundred tons of fish, eight hundred of them eels, are annually captured at Comacchio.1

Since the above was printed, new and interesting evidence of the importance of fish, not only as an economic, but also as a hygienic, factor in the nation's prosperity has been furnished by Prof. J. A. Thomson in his lecture before the Royal Institution, January 6, I92I.

He traced a connection between the decline of Greece and a shortage of little fishes. There was strong reason to believe that one of the causes for the decay of "the glory that was Greece" was that malaria was brought into the State.

The little creature, which caused malaria, lived on the mosquito by whom it was carried. The mosquito spent its larval life in the fresh waters. Little fish were the enemy of the mosquito-particularly the fish known as "millions"which consumed the pest at a great rate.

The professor suggested, therefore, that what had happened in Greece was that there had not been enough little fish to keep the mosquitos in check. Because of this, malaria had been brought into the country, and that plague helped, if it did not cause, the destruction of the wonderful civilisation of Greece.

1 Faber, op. cit., 86. Cf. Revue Contemporaine, June 30 and July I5, I854. where the fisheries at Comacchio are described at length. 


\section{CHAPTER XVI}

LEGAL REGULATIONS OF ROME AS REGARDS FISHING

PREvious instances of taking fish belonging to another have so far only been attended by divine or superhuman punishment. I venture now a few sentences on what were the Roman (I have discovered no Greek) legal regulations-for there does not appear to have existed at Rome any special law on Fishingand how the rights of fisheries and fishers were protected.

From the evidence available it is clear-

(I) That among Res Nullius, or things belonging to no one, were fish and wild animals in a state of nature. The Digest, 4I. I. I, lays down that "omnia animalia, quæ terra, mari, cælo capiuntur, id est feræ bestiæ, volucres, et pisces, capientum fiunt.'

(2) That they became the property of the person who first "reduces them into possession," i.e. captures them.

(3) That the sea and public rivers were not capable of individual ownership.

(4) That no citizen could be prevented from fishing in the sea and such rivers by any person. To this rule there are several exceptions; for instance, $(a)$ a cove of the sea bordering on a man's land--perhaps if enclosed with stakes, etc.-could be exclusively occupied for fishing (Digest, 47. 10, ss. I3 and I4); (b) a right of fishing in a recess or backwater of a public river could be acquired by prescription, and would then be protected by a possessory Interdict against any one who tried to fish this water (Ibid., 44. 3. 7).

It is hard to define precisely what constituted a public river and what a private river. Under the term "public" came all rivers of any size, not merely those that were tidal. 
Whether a river was public depended not only on its size, but also on the "opinion of those dwelling around it." No river, periodically dry in summer, could be accounted public (Digest, 43. I2, ss. I-4).

All streams not public, many lakes, and all piscina, etc., were private property, from which the owner could prevent any one taking fish. The legal remedy for such exclusion, based on the ground of trespass, was Interdict-a procedure very similar to that of Scotland, whose law is mainly modelled on that of Rome.

The further legal question-were the fish in such piscince res nullius or were they such individual property as to make any one taking them without permission liable for theft-was answered by the jurist Nerva in Digest, 4I. 2. 3, s. I4, who held that they were individual property-" pisces quos in piscinas coiecerimus a nobis possideri."

Thus the owner of vivaria could proceed against a poacher by ( $\mathrm{r}$ ) an interdict for trespass, and (2) a prosecution for theft, in case of a fish being caught with the intention of taking it away. On the other hand, a person prevented from fishing or navigating by another could only proceed by an action of Injuria, personal affront (Digest, 43. 8. I7, ss. 8 and 9; 4I. I. 3०; 43. I4, s. 7).

Although I purposely limit myself to a very slight sketch of Roman regulations, the case reported by Pliny (N. H., IX. 85) seems, alike from legal and piscatorial interest, worthy of reproduction and examination.

As the Anthias is one of the shyest of fishes, special precautions and plenty of patience were necessary for a good catch. Thus fishermen wore clothes of the same colour as their boats. They sailed without fishing over the same stretch of sea. They merely went on "baiting the swim" on each tack, day after day, till some spirit, bolder than the rest, could be induced to take the bait. Still more days elapse before the fish, which has by this time been well identified, is followed by any of his mates. Eventually example proves so infectious that shoals innumerable, of which the Elder Brethren even eat from the fisherman's hands, surround the boat. 
Now is the accepted hour for " the fisherman to throw out a little beyond his finger tips a hook concealed in bait," and (to prevent alarm) smuggle the fish out gently, one by one, by a very slight jerk. His mate receives the fish on pieces of cloth, so that no floundering about or other noise may scare their comrades. On no account must " the betrayer of the others" be captured, lest instantly the shoal take to flight and be no more seen.

But " there is a story that a fisherman, having quarrelled with his mate, threw out a hook to one of the leading fishes, which he easily spotted and with malicious intent captured. The fish was, however, recognised in the market by his mate, against whom he had conceived this malice: accordingly an action for damages (damni formulam editam) was brought, which the defendant, as Mucianus adds, was condemned to pay."

Now, as shown above, (I) a fish is "res nullius," (2) a fish becomes the property of him who first " reduces it into possession," (3) the sea, with some exceptions which do not apply here, is not capable of individual ownership.

If "the betrayer of his kind" was till malicious capture admittedly and of set purpose left free in the sea, how could it have been reduced into possession, how could any title in it have been acquired, and, lastly-granted some kind of possession-by what actio or legal formula could such possession have been enforced?

These points were to me a stumbling-block, till Professor Courtney Kenny of Cambridge kindly came to my aid. As the extension here of Mansuefactio is apparently unique, and would possibly have been repudiated by jurists after Mucian's time, we seem to be faced by a novel point, which on account of its intricacy and interest will appeal to people learned in the Roman Law.

The Professor's letter runs: "Ownership in the Anthias must have been created by that form of Occupatio of a res nullius, which consists, not by the physical detention by angling, or by a piscina, but in mere mansuefactio. This form is familiar for birds (Dig., 4I. 2. 3. I5: and for English Law, 
Bracton, 2. I. 4) : but for fishes I know of no other passage than the one cited by you. Perhaps jurists, not so early as Mucian, would have declined to admit that there had been a true occupatio of this Anthias. The partner, who sold this fish, which was partnership property, would be called on to account for it, and pay over, in damages, his partner's share of the price by the contractual action Pro Socio. He might, in addition, be made to pay a penalty for his wrong-doing in the delictual Actio Furti. For, though there was a legal primâ-facie presumption (Dig., I7.2.5I) in favour of the honesty of any partner in the sales of partnership-property, we are here expressly told that he acted 'maleficii voluntate,' i.e. his contrectatio of the fish was 'fraudulosa,' and therefore a Furtum. The defrauded partner might well have brought both actions at once (Dig., I7. 2. 45), but Pliny speaks only of his having brought the last named one." 



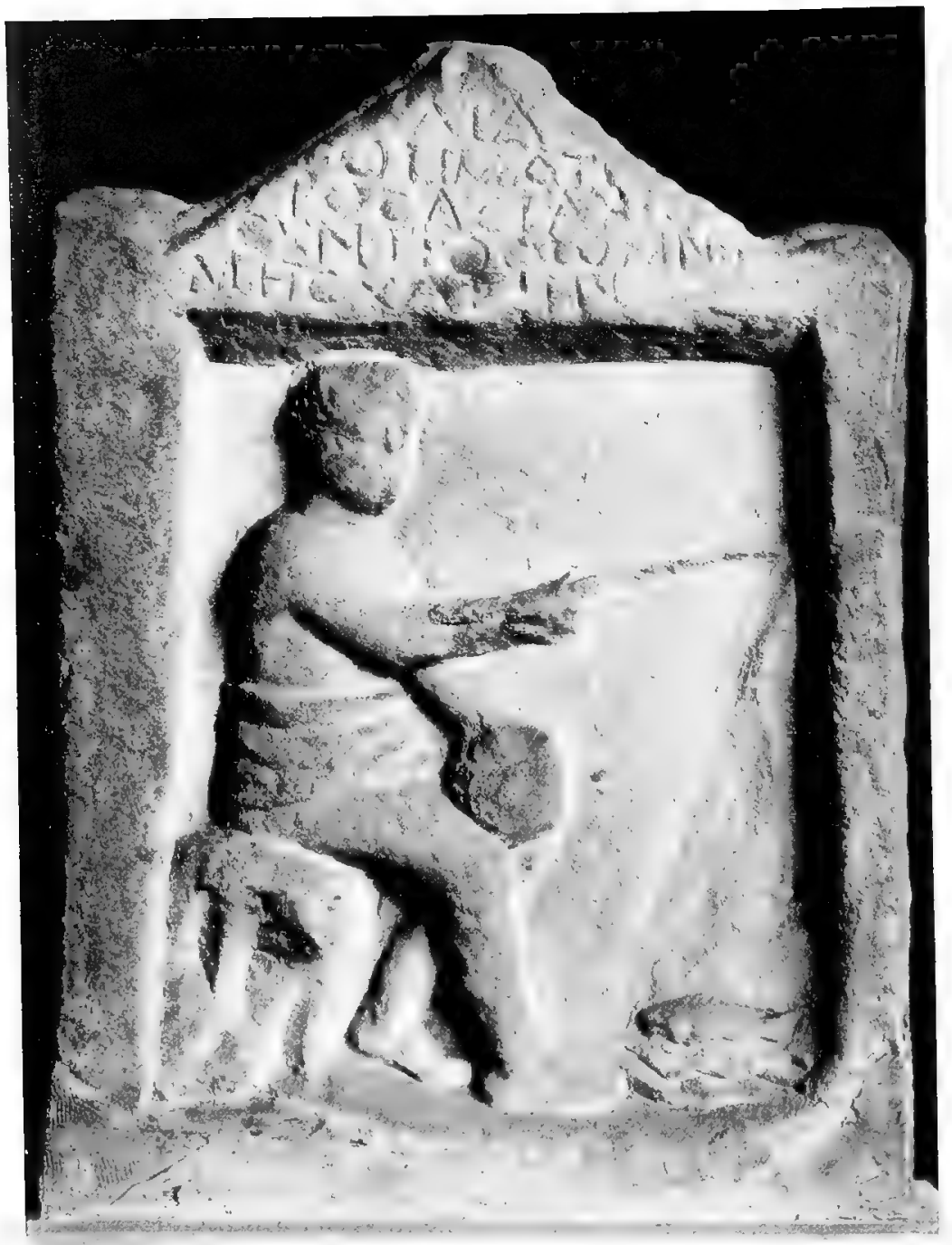

A GREEK ANGLER.

From the Agathemeros Relicf, c. 3rd century B.C. 


\section{CHAPTER XVII}

TACKLE-CURIOUS METHODS OF FISHING FOR THE SARGUS BY DRESSING IN A SHE-GOAT'S SKIN-FOR THE SKATE BY DANCING AND MUSIC-FOR THE SILURUS BY A YOKE OF OXEN-FOR THE EEL WITH THE GUTS OF A SHEEP. WHAT WAS THE SILURUS? WILD THEORIES AS TO THE PROPAGATION OF EELS

"Unseen, Eurotas, southward steal, Unknown, Alpheus, westward glide, You never heard the ringing Reel, The music of the waterside."

(A. LANG.)

THE tackle, implements, and some curious modes of fishing apparently peculiar to, or handed down to us only from, Greek and Roman sources call for consideration and comment.

Nets, we have seen, were of all sorts and kinds in shape, make, and size. Their number and nature as disclosed by Julius Pollux, Plutarch, and Elian indicate that the art of netting was well nigh perfected. Oppian, after enumerating many varieties and telling how the enormous

"Nets, like a city, to the floods descend And bulwarks, gates, and noble streets extend,"

excuses himself from further amplification :

"A thousand names a fisher might rehearse

Of nets, intractable in smoother verse." I

1 Trans., by Diaper and Jones (London, 1722-see supra, p. 177), which

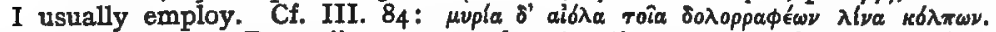
Fishing nets from Pompeii, even now almost entire, are to be found in Italian Museums. The best times for hauling up the nets were (according to Arist., 
Confirmation comes from Alciphron's 1 statement that scarce a fathom of the harbour of Ephesus but held a Net: on one occasion the sole haul, after much moiling and toiling, was the putrid carcase of a camel ! 2

What and whence the Rod? It was certainly short: only from 6 to 8 feet (Elian, XV. I) -a length which is in the main confirmed, if assuming the height of some of the fishermen represented on vases, etc., in the Greek and Roman rooms of the British Museum to be as high as six feet, you then measure the rod. On the other hand, the sitting youth in the Agathemeros relief (Brit. Mus. Cat. Sculpture, I. 3I7, No. 648) measures $24 \mathrm{~cm}$., the Rod $8 \mathrm{~cm}$., the line $15 \mathrm{~cm} .^{3}$

As we do not possess any relic of the Homeric rod, the length of the only one mentioned in either the Iliad or the Odyssey must be a matter of conjecture, especially as this is styled $\pi \varepsilon \rho \mu \eta^{\prime} \kappa \eta$, or " very long " one. 4

The ordinary Rods were made of cane, hence Harundo and Calamus, which was imported usually from Abaris in Lower Egypt, or of some light elastic wood. For large and powerful fish, where something stronger was required, Ælian tells us that Tuncus Marinus and Ferula were preferred.

If the Rod were tapered, it was tapered probably by Nature not by art, at least so the Agathemeros relief, all the pictures of Venus and Cupid angling, and of many Amorini from Herculaneum would suggest. The question whether the Rods were jointed has been discussed in my chapter on the crescens harundo of Martial.

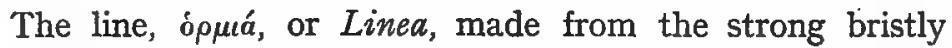

$N . H .$, VIII. I9) " just about sunrise and sunset. Fishermen speak of these as "nick-of-time" (Epaiol) hauls. The fact is that at these times fishes are particularly weak-sighted" (D'Arcy Thompson, Trs.). Pliny, IX. 23, practically copies Aristotle.

1 Alciphr., Epist., I. I7.

2 A terra-cotta relief of the type known as "Median," c. 460 B.c., in Brit. Mus. Cat. of Terra-cottas, No. B. 372, Pl. 20, shows a fisherman holding two fishes, or a fish and a purse, and as if in the act of pulling in a net. This a very early exemplar of Greek Netting.

s Cf. the rod of Heracles on a black-figured vase published by C. Lenormant and J. de Witte, Élite des Monuments Céramographiques, Vol. III, Plate 14. The Rod is $8 \mathrm{~cm}$, and the Line is $6 \mathrm{~cm}$.

4Od., 12, 25I. Cf. the same phrase in Od., Io, 293, for Circe's magic wand. 
hairs of animals (seta) but most generally of horsehair, ${ }^{1}$ of flax, of sparton out of the genista, perhaps of byssus, but never

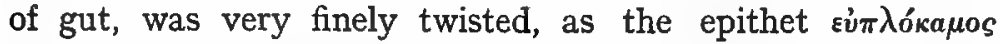
shows. It was usually as long as the rod itself, although in the Agathemeros relief we find it nearly double the length. The colours of the line were grey, black, brown-sometimes red or purple. It was made tight to the top of the Rod and not let down to the butt, or running. ${ }^{2}$

Plutarch prescribes that the hairs next to the hook should for deception's sake be taken from a white horse, and adds advice, as pertinent now as then, that there "should not be too many knots in the line!" 3

To the line was fastened the hook (hamus) which was of one or two sharp barbs. 4 From Herculaneum, 5 Pompeii, and elsewhere have been collected hooks which vary extremely in form, size, and method of adjustment. ${ }^{6}$ Although sometimes of bone, they are mostly manufactured from iron or bronze.

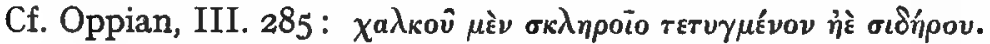

It strikes us moderns as strange to have the epithet hard applied to bronze and not to iron, till we are informed that the

1 Plutarch, de Sol., 24, commends those of a stallion as longest and strongest, of a gelding next, and of a mare least, because of the weakness of the hairs due to her urination.

2 Elian, N. H., XII. 43. See Introduction.

s Plutarch, de Sol., 24.

4 It is of great interest to note that according to Iangdon (see Jewish Chapter), probably in Sumerian, and certainly in Hebrew, the word equalling hook, in its primary sense equals thorn, which strongly suggests, if it do not absolutely prove, that the ancients employed, as do even now the catchers of flat fish in Essex, and the Indians in Arizona, a thorn as their primitive hook. In Latin hamus signifies hook and thorn. Cf. Ovid (Nux., II3-II6).

5 Waldstein and Shoobridge, Herculaneum (London, I908), p. 95. "The only industry which has left much trace is fishing; hooks, cords, floats, and nets were found in much abundance."

- See antea, P. I57, and note 1 . According to Petrie, Tools and Weapons (London, I9I7), p. 37 f.: " The European fish-hooks do not appear before the fonderia age: in Greece and Roman Italy hooks are common." G. Lafaye, in Daremberg and Saglio, op. cit., III. 8. s.v. " hamus," gives figure 3696, a simple bronze hook, figure 3697 , a small double hook in the Museum at Naples, figure 3698 , a quadruple hook (four bronze barbs attached to the angles of a square plate of lead), and figure 3699 , a bronze hamus catenatus. H. B. Walters-Catalogue of the Bronzes, Greek, Roman, and Etruscan in British Museum (London, 1899), Nos. 38 and 39 -describes, but does not figure, two hooks of the Mycenæan period from Rhodes, 2 inches and $27 / 8$ inches long, which are dated about ${ }^{4} 5^{\circ}$ B.c. Petrie, loc. cit., states that the "usual pattern of the Greek-Romans is, as figured in No, IOo, while Ior and Ioz are the limits of size." 
ancient bronze was made of tin and copper, not zinc and copper, as is our softer alloy, and was so hard that, Pliny tells us, it could be worked to represent the finest hair of a woman's head.

The Pompeian hooks were almost exclusively adapted for sea fishing, and are thus generally large in size, long in shank, and flattened at the top to facilitate attachment to the line.

Plutarch's statement that some hooks were straight, as distinct from the usual recurved sort, may possibly be indicative of a survival of the palæolithic gorge. Some of the Roman hooks are double-barbed, some are fixed back to back like eel-hooks, and fastened to wire to prevent erosion by the teeth. In the pursuit of large fish such as the Amia, hooks of a serpentine curve are recommended, "as these great fish manage to get loose from straight ones!"

To the hook was fastened the bait (esca), usually worms, flies, and other insects. For large fish the bait was often cooked, because the scent was believed to offer an additional attraction. By a clever contrivance of small pieces of lead equally balanced and carefully attached the lure was made to have the appearance of natural movement.

The Reel on a fishing Rod was certainly unknown to Ancient Nations. Wilkinson figures something resembling a Reel being employed when spearing hippopotami. 1

The Amia (mentioned by Pliny, IX. I9, alone of all the Latin writers) is according to Oppian ${ }^{2}$ a little smaller than the tunny, which reaches large proportions. Later, ${ }^{3}$ he recounts how the Amia furnishes sad labour and trouble to the fishermen from his habit, the moment he feels the hook, of instantly rising, of swallowing more line, and then of biting through the middle, "or even the topmost hairs of it."
1 op. cit., Pl. $37^{8}$.
2 Bk. II. $55^{6}$.
3 Bk. III. I38-148. 
But successful cunning to avoid capture was no monopoly of the Amia. Ovid, Oppian, Pliny, Plutarch, Elian, recount numerous devices which certain fish employ to nullify net or hook. I subjoin three of the chief tricks used to defeat the hamus.

The Mugil, whose greed is only saved by its guile, despite his fore-knowledge of danger has madly grabbed the bait, but keeps thrashing it with his tail, till at last he shakes it free of the hook. "At mugil cauda pendentem everberat escam Excussamque legit." 1

The Anthias on the first prick of the hook turns over on to his back and quickly severs the line with his dorsal fin, or spike, "of the shape and keenness of a knife." 2

The Scolopendra, according to Aristotle, "after swallowing the hook, turns itself inside out until it ejects it, and then it again turns itself outside in," and (in Pliny's words) vomits up everything inside him till he has ejected the hook, and "deinde resorbet!" 3

Lines with floating corks and lead attached close to the hooks, partly to facilitate the throwing of the line, and partly, combined with a sliding cork, to regulate the position of the bait, were in regular use. Ground fishing, when the lure is leaded and thrown with or without rod, was well known and widely exercised.

Pastes and scents were also employed, either like myrrh dissolved in wine to intoxicate (see the accompanying drawing, which is, I believe, unique), ${ }^{4}$ or, like the cyclamen, or sow-

1 Ovid, $\mathrm{Hal}, 3^{8}$ f. ; cf. Oppian, III. 482 ff.

2 Pliny, N. H., XXXII. 5 ; Ovid, Hal., 44 ff. ; Plutarch, De Sol. Anim., 25. This trick is also characteristic of the Armado of the Parana river, but its enormous strength enables it also either to jerk the paddle of the fisher away, or to capsize the boat. Cf. S. Wright, The Romance of the World's Fisheries (London, I908), p. 208.

${ }^{3}$ Pliny, IX. 67, taken totidem verbis from Aristotle, N. H., II. I7, and IX. 5 I.

- The fisherman on the Mosaic from the Hall of the Mystz in Melos (R. C. Bosanquet, in the Jour. of Hellenic Studies (1898), xviii. 60 ff., P1. I) appears to have been using a glass bottle half-filled with wine as a lure. The inscription MONON MH $\Upsilon \triangle \Omega P$ is generally taken to be late Greek for "Everything here except water" (which will be supplied by the next rainfall). But the words might be legitimately rendered: "Only let no water be used "a natural exclamation from the devotees of the wine-god! Prof. Bosanquet, despite his fine sense of humour, has missed the double entendre. 
bread, to poison the fish. ${ }^{1}$ From Oppian's description of the workings of the poison, IV. $658 \mathrm{ff}$., we take the lines :

"Soon as the deadly Cyclamen invades

The ill-starred fishes in their deep-sunk glades,

... the slowly working bane

Creeps o'er each sense and poisons every vein, Then pours concentred mischief on the brain,

Some drugged, like men o'ercome with recent wine,

Reel to and fro, and stagger thro' the brine;

Some in quick circlets whirl : some 'gainst the rocks

Dash, and are stunned by repercussive shocks ;

Some with quenched orbs, or filmy eyeballs thick,

Rush on the nets and in the meshes stick,

In coma steeped their fins more feebly ply,

Some in titanic spasms gasp and die.

Soon as the plashings cease and stillness reigns,

The jocund crew collect, and count their gains."

In the simile-inevitable in Oppian-which ends the passage our author may indicate, though he does not name, the Germanic tribes (for over Rome in his day as over Europe in ours hung the barbarian menace) when he condemned the abhorred habit practised by the enemy of poisoning the springs and wells :

$$
\text { ..." the brave defendants sink }
$$

In thirsty pangs, or perish if they drink."

In the number of methods, in the variety of devices, the fishermen of Oppian and Ælian are not behind their modern successors; it is indeed the reverse of

"John P. Robinson he

Guessed they did not know everything down in Judee." 2

We moderns are, in fact, merely the heirs to a piscatorial estate, which by scientific improvement or intensive culture

1 For the poisoning of the Tunny, cf. Aristot., N.H., VIII. Cakes made of cyclamen and clay were let down near the lurking places of the fish, according to Oppian.

2 With one method of fishing the ancients (in common with nearly all the moderns) were unfamiliar. The locus is off Catalina Island, etc.: the modus is by kites with line and bait attached, to which last, moving over and on the surface of the water, the Tuna seems irresistibly attracted. See antea, p. 4r, note 3 . 


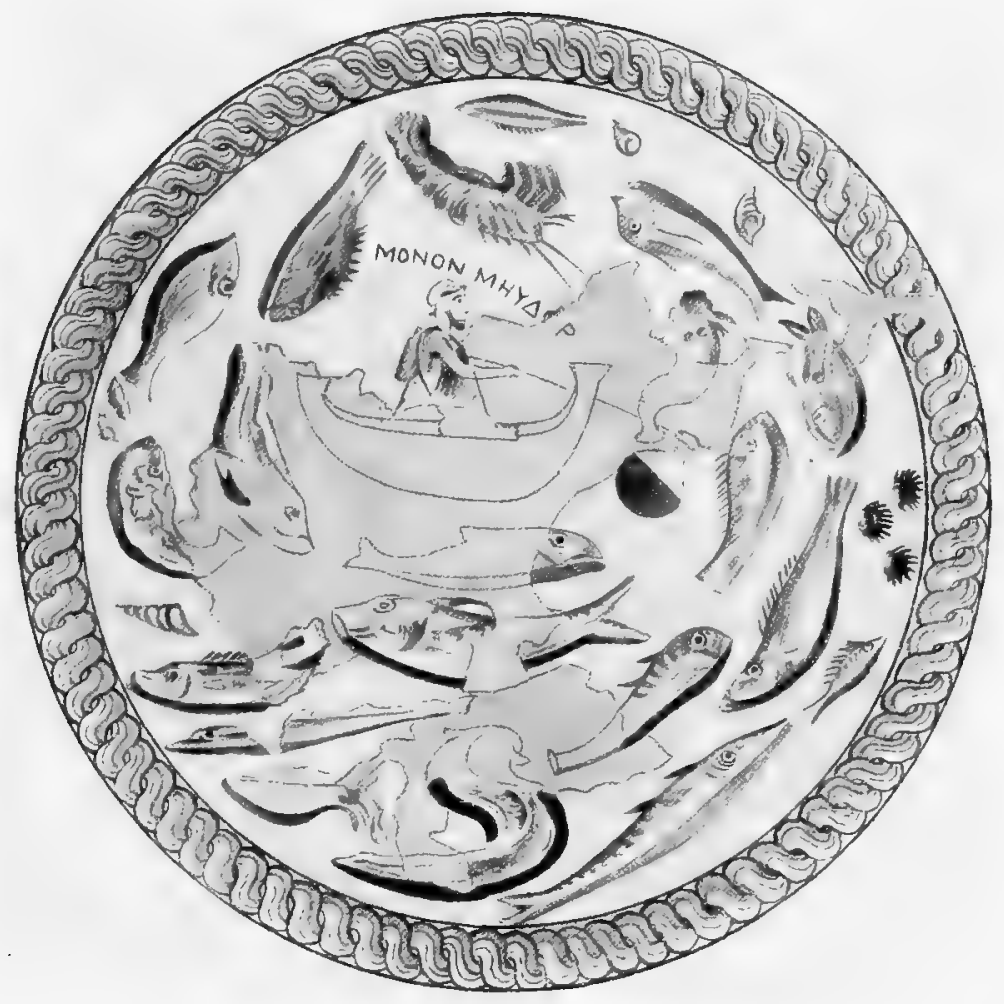

ANGLING WITII WINF.

From a Mosaic at Melos. 

we have rendered more serviceable and better adapted to the requirements of fish more harried, and consequently more highly educated.

The old devices, the old recipes were never entirely lost. ${ }^{1}$ They continued to be handed down through the Middle Ages, and may be found in most of the collections of household recipes, such as those of Baptista Porta, Conrad Heresbach, and others. They naturally in the course of some thousand years got rather split up, or fell into abeyance; it was not, in fact, till the seventeenth century that fairly full collections of them began to reappear.

But except just to mention " tickling," an ancient device in both Oppian and Elian, we have room here only for four methods, all very quaint, either unknown or uncommon among twentieth-century fishers.

The first, that by which the goat-herd annexes the Sargus, according to Oppian.2

In hot weather it was, and still is, in Sicily the wont of the goat-herds to drive their flocks to some cool shallow of the sea. "Once upon a time" one of them noticed that the sargi came round the goats in vast shoals. The reason for this-whether grasped in a moment by one great brain, or evolved by two or three generations of speculating herdsmen-was discovered to be the attraction of the male sargus by the smell of the female goat.

So the reasoning goat-herd slays his nanny, puts himself inside her skin, and to perfect, I presume, the resemblance of the deception, "adjusts on his brows the horns!" Then he gently glides into the shallow, "scatters the food full shower" among the sargi hot on their amorous mission and, well! for the number that were slain by "The Sturdy Rod his latent Hand extends" I refer you to the fourth book of the Halieutica!

Ichthyologists declare that the male sargus is very uxorious, and has at least one hundred wives always in close-herded attendance on him. As the words " unhappy lovers " indicate

1 Cf. Apostolides, op. cit., p. 3 r.

2 Bk. IV. 308 ff. Cf. AElian, I. 23. 
that the sargi were present not a few, these multiplied by one hundred must have yielded quite a decent creel. ${ }^{1}$

The second method owes its success to the love for music and for watching the dance, which Aristotle and Elian assert to be characteristic of several fishes, but especially of the skate. The recipe of this method, far pleasanter, certainly less odoriferous than that of the last, demands I Boat, I Violin, I big Net, 2 Men, one of whom fiddles, while the other dances as he unwinds the net. Attracted to the spot, and, like Wagner-devotees, so entirely absorbed by the melody as to be unconscious of all else, the skates fall easy and numerous victims to the slowly drawn net.

This method seems " the limit." It certainly trenched on even Badham's credulity. He states that he would not have cited this statement of \#Elian's, unless it had been " singularly countenanced and confirmed by no less a person than the great French ichthyologist, Rondolet," whose mere name in this musical context must presumably carry conviction, for (as is not unusual with Badham) no reference is given. ${ }^{2}$

The third method, employed by the Mysians for capturing the Silurus in big rivers like the Danube and the Volga, is set

1 Cf. Oppian, IV. 375 ff. I. Walton, citing the Sargus as an example of "the lustful fish," quotes Dubartas, "because none can express it better than he does," whose last two lines, as examples of this perfect expression, I cannot resist,

"Goes courting She-Goats on the grassie shore

Horning their husbands, that had horns before."

" But in confirmation of "this statement of Elian," Badham, had he taken the trouble, could have found several others by that and other authors. Thus IElian, XVII. 18, of the Sea-roach. Ibid., VI. 3I, of the Crab, which on hearing the flute and singing would not only quit the sea, but follow the retreating singer to dry land, and capture I Filian, VI. 32, of the Thrissa states that it was caught by singing to it, and by the noise of shell clappers which induced the fish to dance itself into the Nets and boats. Cf. also Athenæus, VII. I37, where the Trichias is so delighted with singing and dancing, that when it hears music it leaps out of the sea and is enticed on land 1 Cf. also Herodotus, I. $\mathrm{r}_{4} \mathrm{I}$, for the story of Cyrus likening the Ionians to dancing fish. Not only were there fish that delighted in music and singing, like the dolphin (Pliny, IX. 8, musicæ arti, mulcetur symphoniæ cantu, sed præcipue hydrauli sono), but according to Philostephanus there were others, that themselves made music, like the Poecilic, who "sang like thrushes"" (cf. Pliny, XI. II2). Of singing fish Pausanias, VIII. 21. 2, says, " among the fish in the Aroanius are the so-called spotted fish: they say that they sing like a thrush. I saw them after they were caught, but I did not hear them utter a sound, though I tarried by the river till sunset, when they were said to sing most." 
forth by Ælian (XIV. 25) in words which describe with such charming naivete the perfection of the Silurian palate, eye, and possibly nose, enabling it to discriminate instantly between "the lungs of a wild " and other " bull," 1 that we may venture upon quoting the whole passage :

"An Istrian fisherman drives a pair of oxen near the riverbank, not, however, for the purpose of ploughing. . . . If a pair of horses are at hand, the fisherman makes use of horses ; and with the yoke on his shoulders, down he goes and takes his station at a spot which he thinks will make a convenient seat for himself, and be a good place for sport. He fastens one end of the fishing-rope, which is stout and capable of standing a good tug, to the middle of the yoke, and supplies the oxen, or the horses, as the case may be, with sufficient food, and the animals take their fill.

"To the other end of the rope he fastens a strong and terribly sharp hook, baited with the lungs of a wild bull; this he throws into the water as a lure-a very sweet lure-to the Istrian silurus, having previously fastened a piece of lead of sufficient size to the rope above the place where the hook is bound on, to serve as a support for the pull. ${ }^{2}$

"When the fish perceives the bait of bull's-flesh, he immediately rushes at the prey, and, meeting with that he so dearly loves, opens wide his great jaws and greedily swallows the dreadful bait; then the glutton, at first turning himself round with pleasure, soon finds that he has been pierced unawares with the aforesaid hook, and being eager to escape from the calamity shakes the rope with the greatest violence.

"The fisherman observes this, and is filled with delight ; he jumps from his seat, and, now in the character of a fisherman, now in that of a ploughman, like an actor who changes his mask in a play, he urges on his oxen or horses, and a mighty

1 The head of the ox was Thor's bait when fishing for the monstrous Midhgardh serpent. See D. P. Chantepie de la Saussaye, The Religion of the Teutons (Boston, I902), p. 242. C. A. Parker, The Ancient Crosses of Gosforth, Cumberland (London, I896), p. 74 ff., describes and figures a relief representing Thor's fishing. In this we see the line (below the boat) with an ox's head, surrounding which are several enormous fishes.

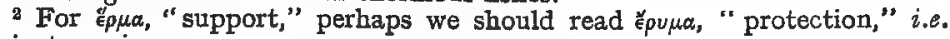
against erosion. 
contest takes place between the monster and the yoked animals ; for the creature, foster-child of the Ister, draws downward with all his might, while the yoked animals pull the rope in an opposite direction. The fish can make no headway. Beaten by the united efforts of the team, he gives in, and is hauled on to the bank."

Siluri, according to common report, have been caught weighing over $400 \mathrm{lbs}$. and of more than twelve feet in length.

There is good ground for us moderns patting ourselves on the back, when we realise that owing to the many improvements effected in our tackle, and not least in the Rod, an angler off Catalina has often landed a heavier fish than a yoke of oxen on the banks of the Ister, e.g. Mr. A. N. Howard (in I9I6) caught the record Black Sea Bass in Californian waters, weighing 493 lbs.

Even this big fellow is quite a dwarf beside the Tuna of 7 Io lbs. taken in Canadian waters by Mr. Laurence Mitchell, ${ }^{1}$ which still holds, I believe, the record of the world as the very largest fish ever taken on a rod.

I myself have seen a sword fish of over 300 lbs. killed on a rod off Santa Catalina. When in I909 out for Tarpon in Kingston Harbour, Jamaica, I had the good luck to secure after a fight of two and a half hours, and after being towed almost down to Port Royal and back, a distance of some five miles, a shark weighing II6 lbs., with a rod only 8 foot long, with a light salmon line, with a No. 4 hook, and with a bit of piano wire, faute de mieux, attached to prevent erosion. ${ }^{2}$

From the time of the earliest authors the identification of the Silurus has been a vexed question.

Aristotle writing of the Glanis, a large fresh-water fish (his only account of actual fishing, it may be remembered, is a fight

1 See Forest and Stream, Nov. 7, I914.

2 The shark finds great favour among the negroes; "you can swallow him in de dark," is a commendation based on the absence of small tricky bones, such as the shad's. But to the best black gourmets, the fish only attains its highest perfection in soup, after being buried for two weeks ! The cook of the friend with whom I was staying in Jamaica only consented to cutting up my shark, on condition that if a gold watch was found in its belly, that was to be her perquisite-a condition postulated, I eventually discovered, because on a similar occasion one hundred years before, her grandmother did discover a gold watch. Alas for her ! two ship-bolts of iron were her only treasure-trove. 
with a Glanis), ${ }^{1}$ attributes to it characteristics and habits, which Pliny totidem sententiis, if not verbis, transfers to the Silurus, although he thrice mentions the Glanis. Flian, in addition to XIV. 25, declares in XII. I4, that the Glanis is a species of, and very like, the Silurus, while Athenæus treats them as separate fish.

As late as the time of Scaliger, the problem gave rise to discussion which led to no elucidation of what fish exactly corresponds to the classical Silurus. Perhaps the sentence of Albertus Magnus, ${ }^{2}$ " a river fish which was called by the Greeks Glanis, but by us Silurus," seemed, although only a conjectural compromise, as near as we could get to the identity.

Agassiz, however, reluctant to accept Cuvier's identification of the Glanis with the Silurus glanis, came to the conclusion (after examining six specimens of a Siluroid new to Ichthyologists, which he obtained from the Acheloüs in Western Greece) that from agreement in the form of the anal fin, the position of the gall bladder, the connected spawn, etc., they were the same as Aristotle's Glanis. To this Siluroid Agassiz gave the name Glanis aristotelis : it is, perhaps, better known as Parasilurus aristotelis. ${ }^{3}$

If the Silurus be the Scheid of Germany, his strength, habits, and ferocity, as set forth in our authors are indeed very credible. From Aristotle we learn that this "river fish" is easy to hook (as we should suspect from its rapacity, which has been tersely summarised in "pisces pisci præda at huic omnes "), but from its huge powers and hard teeth very hard to hold.

The passage in Pliny, IX. 75, which he extracts from Aristotle 4_" Silurus mas solus omnium edita custodit ova, sæpe et quinquagenis diebus, ne absumantur $a b$ aliis" -has by a wrong rendering accorded to the male Silurus the proud distinction of being the only male fish that guards its eggs. This is absurd, for other instances, e.g. Chromis simonis, exist.

1 N. H., VI. I3.

2 De Anim., VIII. 3, p. 262.

a Theodore Gill, "The Remarkable Story of a Greek Fish," Washington Univ. Bull., Jan. I907, PP 5-15.

i N. H., VI. I3. 
Where fish, however, pay any regard whatever to their ova, it is usually, but not always, on the father that the duty falls. "Omnium" in Pliny is to be read not with "solus " but with " edita ova." This reading advances the quite different claim that the Silurus is the only male that includes in its watch and ward not merely its own but promiscuously also the eggs of other fish. Perhaps the same start of surprise awaits him, on the pentecostal and last day of his vigil, as that of the hen when she first beholds a mixed brood of chickens and ducklings emerging from under her breast.

Pliny reveals some fabulous uses of the Silurus. In XXXII. 28 , fresh caught Siluri are an excellent tonic for the voice. In 46 , by the smoke and scent of a burnt Silurus, especially one hailing from Africa (!), the pangs of child-birth are said to be greatly eased. In 40, for curing "ignes sacros" or the malady of St. Anthony's fire, the application of the bellies of living frogs, or of ashes from a Silurus, were two of the nostrums recommended.

The fourth and last method, for the capture of Eels, given by Ælian, ${ }^{1}$ although almost certainly cribbed from Oppian, ${ }^{2}$ but with a local habitation and a name carefully thrown in to suggest originality, reads much as follows :

The eeler from a high bank of the "river Eretaenus, where the eels are the largest and by far the fattest of all eels," lets down at a turn of the stream some cubits' length of the intestines of a sheep. An eel, seizing a bit of it at the nether end, tries to drag the whole away, on which the fisher applies the other end (which is fixed to a long tubular reed serving the place of a fishing rod) to his mouth, and blows into the sheep's gut. This presently swells; the fish receiving the air in his mouth swells too, and unable to extricate his teeth is lugged out, adhering to the inflated intestines. ${ }^{3}$

"Gin these be joys of artful eeling, oh! gie me Essex

1 XIV. 8.

Hal., IV. $45^{\circ} \mathrm{ff}$.

" "Bobbing for eels," with a bunch of worms on worsted is of like principle, but lacks the pneumatic touch. The eels seem to get their teeth caught in the worsted, and are pulled out before they can let go. See antea, p. 42, for the garfish of the Solomon Islands being caught from a kite by a hookless spider's web. 
Flats," with their " sniggling for eels with a needle," or "banding " for fish with whitethorn hooks!

In addition to this pneumatic method of Elian others were employed for taking eels. Stirring up the mud, in which they were wont to lurk was a common device; hence the proverb

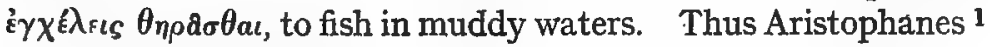
makes the sausage seller, whom the Whigs of Athens had hired to outbawl the demagogue Cleon, shout, "Yes, it is with you as with the eel-catchers; when the lake is still, they do not take anything, but if they stir up the mud, they do; so it is with you, when you disturb the State." 2

Even at the risk of being likened to Mr. Bouncer of Oxford fame, who in every answer of his Divinity paper dragged in his sole and cuff-attached bit of Old Testament knowledge with " and here it may not seem inappropriate to subjoin a list of the Kings of Israel and Judah," I venture some comments on the Eel.

The frequent allusions in our authors to the Eel, (A) as a sacred fish, (B) as the delight of the epicure, and (C) as a propagator of its species in a variety of surprisingly erroneous ways, must be my excuse.

(A) It was held as a god, or at least as a sacred creature, by the Egyptians, ${ }^{3}$ as sacred to Artemis in the spring of Arethusa, ${ }^{4}$ and semi-sacred by the Bœotians. ${ }^{6}$

Antiphanes ${ }^{6}$ ridicules the Egyptians for the sacred honour paid to the fish, wrongly termed by the Greeks the Eel. Contrasting the value of the gods with the high prices paid for the fish at Athens he gibes; "they say that the Egyptians are clever in that they rank the Eel equal to a god, but in reality it is held in esteem and value far higher than gods, for them we can propitiate with a prayer or two, while to get even a smell

1 Equites, $864 \mathrm{ff}$.

2 Fishing by "stirring up the mud," is known in India. The agents employed for the trampling in the pools are elephants ranged in close order: the beasts enter thoroughly into the sport. Cf. G. P. Sanderson, Thirteen Years among the Wild Beasts in India.

S Herodotus, II, 72, who-states that it was sacred to the Nile.

- Elian, VIII. 4; Plutarch, Mor., 976^. See Chapter XVI. ante.

6 Athenzus, VII. 50.

- Antiphan., Lykon frag. I, I ff., ap. Athen, 755. 
of an Eel at Athens we have to spend twelve drachma or more!" Anaxandrides' 1 makes a Greek say to an Egyptian :

"You count the Eel a mighty deity, And we a mighty dainty!"

Juvenal in Satire XV. (written probably after his return from semi-exile in Egypt) lashes with ridicule the compatriots of his butt Crispinus. The enumeration of their animal and vegetable gods is a fine specimen of dignified humour. By piscem in line 7 , may be indicated the Oxyrhynchus, the Lepidotus, or the Phagrus, the so-called Eel-three sacred fishes of the Nile.

" Illic æluros, hic piscem fluminis, illic

Oppida tota canem venerantur, nemo Dianam."

(B) As a delicacy, the Eel by the Greeks was rated very high. But the reverse held good at Rome. Unlike its cousin the Murana it gets little commendation by the Latin comedians -Terence's in Adelphi, 377-38I, is the solitary exception I can recall-and by the gourmets. Apicius deemed it worthy of but one recipe. ${ }^{2}$

"Vos anguilla manet longæ cognata colubræ" (Juvenal, V. IO3) is often quoted as stamping the low position of the Eel at Rome, but in reality, as the whole context bears out, this particular " cousin of the snake" was condemned not because of its kinship, but because it was Cloaca-bred and drain-fed. ${ }^{3}$

1 Anaxandr., II $\delta$ גets, frag. I, 5 f.; ap. Athen., 7, 55.

2 Contrast with the Greeks and Romans the abstention from the Muranidas by the Egyptians, Jews, Mussulmans, and Highlanders; in the case of the last, however, the abstention was due to no religious injunction but to physical loathing.

Fuller on the derivation of the Isle of Ely is too quaint to omit: "When the priests of this part of the country would still retain their wives in spite of what Pope and monks could do to the contrary, their wives and children were miraculously turned into eels, whence it had the name of Ely. I consider it a lie." That Ely is derived from the abundance of Eels taken there has the ancient authority of Liber Eliensis (II. 53). J.'B. Johnston, The Place-Names of England and Wales (London, I9I5), p. 250, takes Ely to mean the "eelisland." He adds, however, that Skeat regarded Elge, Bede's spelling of the name, as " eel-region," the second element in the compound, ge, being a very rare and early Old English word for " district" (cf. German, Gau). Isaac Taylor, Names and Histories (London, I 896), s.v. Ely, states that rents were there paid in Eels.

3 Care must be taken to distinguish between the Eel, $z \gamma \chi \notin \lambda \nu s$, of the Greeks, Anguilla of the Romans, and the so-called Lamprey, púpava, or Murcena. 
The passage in Menander's, ${ }^{1}$ Drunkenness which makes one of the characters declaim that, were he a god, he would never allow a loin of beef to load his altars, unless an Eel were also sacrificed, testifies to the preference for the Eel to meat. Numerous are the pæans of praise rendered by Greek writers to the superlative excellence of the fish.

The Eel is dight "the King of fish" 2; he, or rather she, was " the white-skinned Nymph" 3 ; was "chief of the fifty Virgins of Lake Copais" " ; was a very "Goddess,"

"Then there came

Those natives of the Lakes, the eels, Bœotian goddesses, all clothed in beet," 5

(with which, or majoram, on beech leaves, Aristophanes ${ }^{8}$ tells us they were often served) ; and, the very last word in laudation, was "the Helen of the Feast" 7

Whether this was applied because the fish was the personification of all delicate dainties, as Helen was the fairest of all the fair, or because every guest strove like Paris to supplant his neighbour and keep her all to himself, the reader must choose. Athenæus certainly leans to the latter view. ${ }^{8}$

Philetærus ${ }^{9}$ would seem to have no doubt in identifying what is the sting of death and what is the victory of the grave,

"For when you're dead, you cannot then eat eels."

To the sense of smell as well as that of taste the Muranida

Although both belong to the large family of Muranide, the Murcna is usually a much smaller fish, seldom over $2 \frac{1}{2}$ feet long. In shape and general appearance it closely resembles the Eel, but can be differentiated by its teeth and certain spots over the body. It becomes very corpulent, so much so that in late life it is unable to keep its back under water: it is easier to flay, and whiter of flesh than its relative. Apart from its mating with the viper, and its tendency (teste Columella) to go mad, its chief characteristics are greed and fierceness of attack. The second book of Oppian has two really spirited pictures of its fight with, and conquest of, the Cuttle fish, and of its rush at, but eventual defeat by, the Lobster. At Athens the Eel, at Rome the Muræna, was the favourite.

\footnotetext{
1 Menand. Mé $\theta \eta$, frag. I. Ir ff., ap. Athen., 8, 67.

2 Archestratos, $a p$. Athen., 7, 53.

3 Eubul. Echo. frag. I, I f., ap. Athen. 7, 56.

4 Aristoph., $A c h$., 883. See F. M. Blaydes's note on $880 \mathrm{ff}$.

5 Eubul., Ion, frag. 2, 3 f., ap. Athen., 7, 56.

- Aristoph., Ach., 894. Pax, IoI4.

7 Bk. 7, 53.

8 Bk. VII. 53.

" Philetær., Oinopion, frag. I, 4 ap. Athen., 7, I2.
} 
appealed strongly, to judge by the eulogy that their bodies when being cooked exhaled an odour fragrant enough to restore the sense of smell in the nose of a dead man! while, if boiled in fine brine, they "changed the human nature into the divine!" 1

The luxurious and lazy Sybarites, who felt they had broken their bones if they but saw another digging, and suffered not a cock in the whole country, lest he should mar their slumber, were so passionately addicted to Eels that all persons catching or selling them were exempt from taxes and tribute. ${ }^{2}$

(C) The propagation of Eels: This has given birth to more theories-all of them till some twenty years ago quite erroneous -than any other ichthyic question. From Aristotle downwards nearly every zoologist, nearly every writer on fish, has advanced his view as to how and whence eels are bred. ${ }^{3}$

Only a few of them, and they all divergent, can find space here. Aristotle held that Eels had never been found with milt or roe, that when opened they did not seem to possess generative organs, and that apparently they came from the so-called entrails of the earth, seemingly referring to certain worms formed spontaneously in mud and the like. 4

Oppian (I. 5 I3 ff.) -

"Strange the formation of the eely race

That know no sex, yet love the close embrace.

Their folded lengths they round each other twine,

Twist amorous knots, and slimy bodies joyn ;

Till the close strife brings off a frothy juice,

The seed that must the wiggling kind produce.

1 Badham, op. cit., 392.

2 Athenæus, XII. I5 and 2o. If the fish found favour helluously, medically condemnation attended it. Hippocrates warns against its use; Seneca, Nat. Qu., III. I9, 3, terms it "gravis cibus." If to the gastronomic virtues of the Mur anide both Greeks and Latins were more than kind, to other characteristics they were far indeed from blind-e.g. their slipperiness, etc, was proverbial. See Lucian, A nach., I, and Plautus, $P$ seud., II. 4, 57. Further, did the fish but hap in a dream, then good-bye to all hopes and desires, which slipped away, as surely as Alice's "slithy toves did gyre and gimble in the wabe." See Artemidorus, Oneirocritica, II. I4. The phallic character of the fish prevalent in ancient times continues in modern Italy, e.g. the proverbs ( $\mathrm{I}$ ) about holding an Eel by his tail, and (2) that when it has taken the hook, it must go where it is drawn. De Gubernatis, op. cit., II. 34 I.

For the many classical theories on Eel procreation see Schneider, op, cit., pp. 36 ff.

Aristotle, H. A., IV. II. 
Regardless they their future offspring leave,

But porous sands the spumy drops receive.

That genial bed impregnates all the heap,

And little eelets soon begin to creep."

Pliny, after making the assertion (taken, as usual, from Aristotle) that among fish the females are larger, and often the more numerous, goes on, an echo once more of " His Master's Voice," to deny to the Eel sex, either masculine or feminine ; according to him, Eels when they had lived their day, rubbed themselves against the rocks, and their scrapings came to life : " they have no other mode of procreation." 1

Von Helmont attributed the birth of Eels to the dews of May mornings! other authors deduced their parentage from the hairs of horses! others again from the gills of fish! while the great Izaak Walton insisted on spontaneous generation! 2

To solve the insoluble, recourse was, as usual, had to the gods : thus Jupiter and a white-armed goddess yclept Anguilla ${ }^{3}$ (the Latin for Eel) were accounted parents of the countless " cousins to the snake."

Theory was piled upon theory, false conclusions were drawn from falser data. Even as late as 1862 appeared an author, not one whit less certain of the truth of his discovery based " on a series of observations extending over sixty years," or one whit less active in asserting it, than any of his numerous predecessors.

In The Origin of the Silver Eel, Mr. D. Cairncross propounded the following assertion: "The progenitor of the silver Eel is a small beetle: of this I feel fully satisfied in my own mind, from a rigid and extensive comparison of its structure and

1 Pliny, IX. 23 and 74 , and X. 87 . In IX. $3^{8}$ he asserts that Eels alone of all fish do not float when dead. Aristotle, who (N.H., VIII. 2$)$ is, as usual, his authority, confines himself to noting this characteristic as not possessed " by the majority of fish," and accounts for it by the smallness of stomach, lack of water in it, and want of fat; he states, however, that when fat they do float.

2 Accuracy as to procreation was not Father Izaak's strong point, as his theory that pike were bred from pickerel weed shows. It was on this point that Richard Franck, author of Northern Memoirs (written in 1658, but unpublished till I694), with the invincible contempt of the fly-fisher for the baitfisher, so jumped on Walton, that " he hufféd away." See Sir H. Maxwell, op. cit., IV. 123 .

3 Robinson, op. cit., 73. This seems a bit of bogus mythology. Perhaps Natalis Comes may be responsible. 
habits with those of other insects." 1 "The beetle in the act of parturition " is represented on the frontispiece !

The fact that this beetle is evidently a dead one would not, as the Bibliotheca Piscatoria rather wickedly puts it, even if known to the writer, cause him to alter his opinion one jot!

It was only in 1896 -strange, indeed, that a problem which so many keen intellects had attacked should remain unelucidated for over two thousand years !-that the mode of reproduction and development of the Eel was first surmised, and then for the most part ascertained by Professor Grassi and Dr. Galandruccio. But not till Ig04 were most of the surmises of the Italian investigators placed beyond question, and the mode of reproduction, etc., established beyond doubt by Johann Schmidt of Copenhagen.

The now accepted view (stated shortly) is as follows: freshwater Eels approach maturity when about six years old, and then change their colour from browny-yellow to silver, whence "Silver Eels." In this bridal attire and with eyes enlarged, they find their way from the rivers to the sea, and far out into deep waters of the ocean. The pace at which they travel on their way to the sea cannot be computed exactly, but two marked Eels have been caught whose record was nineteen kilometres in two days. Meek ${ }^{2}$ states that neither the exact locality nor the approximate depth of the spawning is as yet known, but that there can be no doubt that the spawning region lies deep and far out in the Atlantic beyond the Continental shelf.

The Times, Sept. 25, I920, announces that Dr. J. Schmidt has just discovered the spawning place of fresh-water Eels to be not far S. of Bermuda, or about $27 \mathrm{deg}$. N. and $60 \mathrm{deg}$. W., much farther $W$. than he anticipated. Of the many marvels of the ichthyic world this is, perhaps, the greatest. It taxes, it transcends, our powers adequately to conceive the hereditary instinct or gauge the enduring strength which impels fish-as yet

$I$ It is curious to find that a similar belief was held in Sardinia : according to Jacoby, the water beetle (Dytiscus roeselii) is there believed to be the progenitor of the Eel, and is accordingly called the "Mother of the Eels" (Turrell, op. cit., p. 37).

2 Migrations of Fishes, London, Tgr6. 
sexually undeveloped - of only moderate size to traverse 3000 or 4000 miles of an ocean full of foes, and to seek, especially to find, the only area which contains the requisite depth, temperature, and currents favouring the procreation and the return home of their minute but parentless progeny.

The conclusion is now clear that the Eels of Europe at any rate have a spawning area in common; the two Italian doctors were wrong in supposing that Eels spawned in the Mediterranean. In such ocean depths certainly below, probably far below, the one hundred fathoms ${ }^{1}$ line the generative organs of the Eels develope, and in due though protracted time the females spawn. ${ }^{2}$

Their eggs float for a time; the young, when hatched out, pass through a metamorphosis and are known in one stage as Leptocephalus brevirostris. This larval form, which is flat and transparent and has a very small head, drifts with the ocean currents towards the coasts of Europe, where it passes through a series of metamorphoses into the Elver or young Eel, which in March and April swims up English rivers. The fecundity of the Eel, were it not for the system of check and countercheck devised by Nature, would in time become a danger; for the ovary of a female thirty-two inches in length has been estimated to contain no fewer than $10,700,000$ eggs $!^{3}$

But however legitimate or illegitimate their methods may seem, all praise should be rendered to our ancient anglers. Especially so, when we call to mind that, as they possessed not running lines, reels, gut, nor probably landing nets, the playing of large fish must have required more delicate manipulation and the landing presented far greater difficulties than to us, armed as we are with all these and many other appliances.

$1 \mathrm{~J}$. Schmidt found the youngest known stages of Leptocephalus, the larval stage of eels, to the west of the Azores, where the water is over 2000 fathoms deep: they were one-third of an inch in length and so were probably not long hatched.

2 It is believed that no Eels return to the rivers, and that they die not long after procreation. "They commence the long journey, which ends in maturity, reproduction, and death." Presidential Address, British Association, Cardiff, I 920 .

3 There is in the Natural History Museum at South Kensington an excellent collection of specimens, illustrative of the development of the Eel. 


\section{CHAPTER XVIII}

\section{THE NINE FISH MOST HIGHLY PRIZED}

I subjoIn a list of the nine fish which found most favour in Greece and Rome. This, although necessarily rough and tentative, can (I believe), be justified by an examination of our authors. ${ }^{1}$ To anyone who on the strength of one author may be dissatisfied with the place allotted to a particular fish, I would point out that since the oracles of taste vary with the ages, it is essential to hold in mind the exact date at which a passage was written.

Then, again, the Greek saw not eye to eye, or ate not tooth to tooth, with the Roman. The verdict of the opsophagists or, as these often differed, of the plain people of one century not infrequently reversed that of the last.

As with us at the present day it is hardly feasible to adjudge definitely to what fish belongs the primacy of palate, so was it with the ancients. In the case of the Greeks the task is impossible. Every one of our nine can boast at least half a dozen champions. Then, again, as regards the epoch of individual supremacy we are without any guiding statement, such as Pliny's that in his time the Scarus was reckoned the king of fish. ${ }^{2}$

1 Any apparent resemblance in this list, or in this book, to Badham's book is easily accounted for by the fact that both derive much from the same source, he without any, I with due acknowledgment to the little known volume by Nonnius (Antwerp, I6I6), which itself draws largely from Athenæus, Xenocrates, etc. The sequence of sentences, turns of expression, choice of epithets in Badham sometimes so strongly suggest Nonnius, that it is a case of yet another miracle of unconscious absorption-from a rare book written in Latin $23^{8}$ years previously! - or of-well, \&lianism. I hesitated for a long time from even hinting such unacknowledged extraction by an author to whom two generations have owed much pleasure and more knowledge. Were it not for the inadequacy of his references and for his bursting, Wegg-like, into poetry, which doubles the length and sometimes obscures the sense of the original Greek or Latin, Badham would be delightful reading.

2 Bk. IX. 29. 

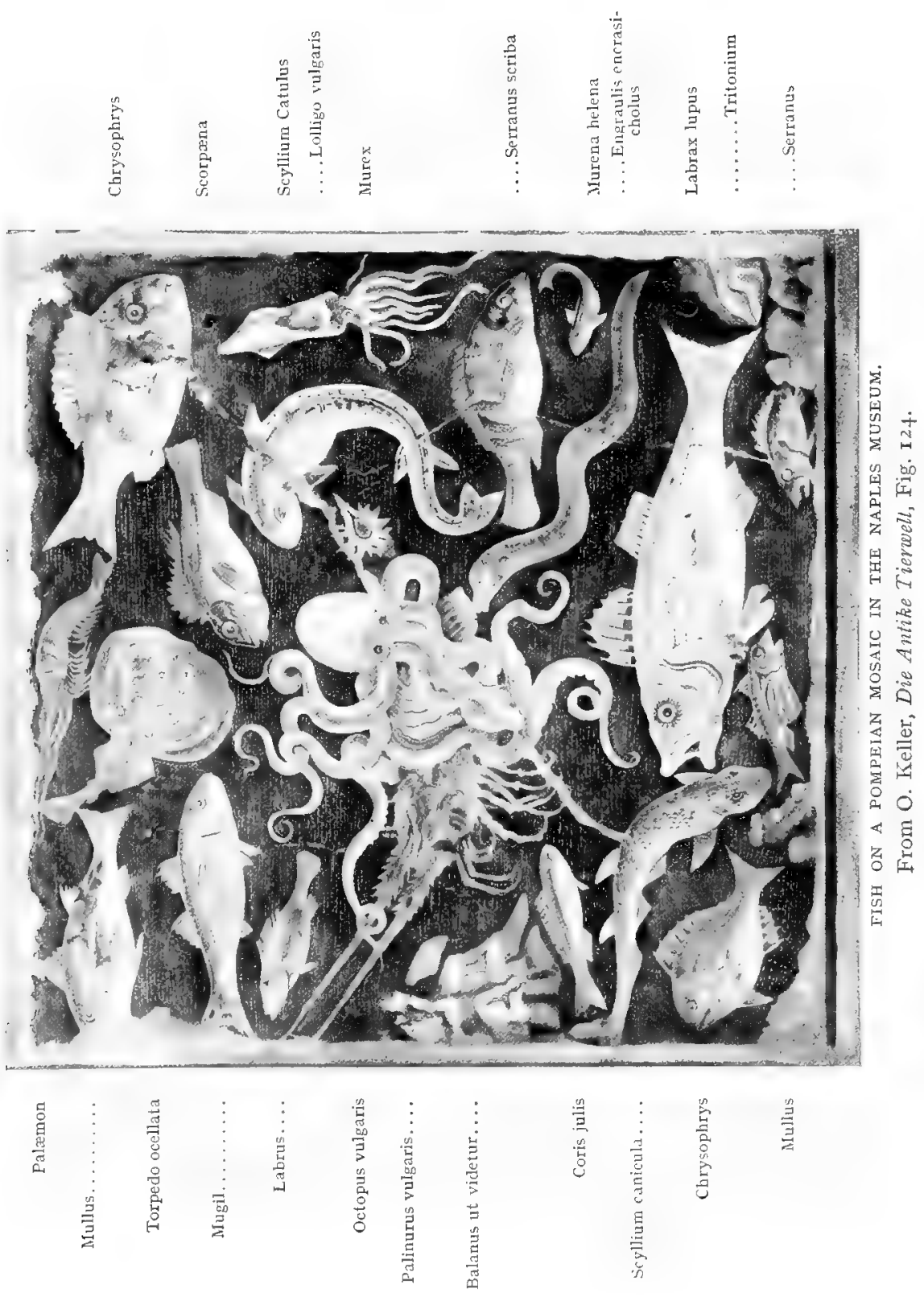

For these reasons, discount as we may the personal predilections of an author like Ennius, of a gourmet like Apicius, of a bon vivant like Vitellius, any list is perforce approximate, not absolute. It must be governed by the dictum of the great

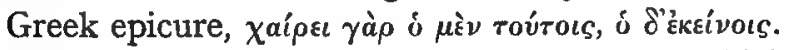

But if our opsophagists disagreed as to which was the best fish, they were fairly unanimous as to which part of a fish was best. Setting aside the peculiar partiality of the Greeks for the head of the Conger, the part near the tail afforded the most savour, and found the most favour with ancient (and modern) gourmets.

Three reasons for this preference have been suggested :

(A) That from Xenocrates. After laying down that fish roasted are more nutritious than fish boiled, that sea fish are easy of digestion and by their formation of blood impart a good colour to the skin, that fish from lakes and rivers are generally bad for the stomach, form thick juices, and are difficult of evacuation, this great physician affirms emphatically that the part near the tail of all kinds of fish (Nonnius excepts the Tunny) are the most wholesome, on account of it being most frequently exercised. ${ }^{1}$

(B) That from Pliny. Writing of the Murcena, he says that it is quite clear that in its tail abides its anima ("life' or ' being '), because a blow on that part swiftly kills it, while one on the head is more tedious in effect. ${ }^{2}$

(C) That alleged in Scandinavia. To the Norseman the most delicate part of the salmon was its tail. His choice, now-a-days by no means exceptional, was explained by a pretty piece of ætiological tradition. Loki, fleeing from the pursuit of the gods whose anger he had provoked, had the wit and the time to transform himself into a salmon. Then and in this guise would he have surely escaped, had not Thor caught him by the tail, " and this is the reason why salmon have had the tails so fine and so thin ever since." 3

1 Cf. Blakey, op. cit., p. 73.

2 N. H., XXXII. 5 .

a In Krause, op. cit., 237, Loki, originally god of Fire, changes into a salmon from his predilection for the red colour of the fish! The Icelandic Eddas attribute the invention of the Net to Loki. 
In my list, which excludes the Echineis, despite its being according to Cassiodorus 1 " that honey of flesh, that dainty of the deep," in precedence comes I the Mullus, 2 the Scarus, 3 the Acipenser, 4 the Rhombus, 5 the Lupus, 6 the Asellus, 7 the Eel and the Murana, 8 the кátroos, 9 the Sole.

r. Mullus (M. barbatus), the "Red Mullet." The passages already quoted as regards the huge prices sometimes given for it establish the extreme esteem with which this fish was regarded. But if need be, witness after witness to credit can easily be called. Perhaps, as regards the Latins, Nonnius will suffice: "Inter omnes pisces prærogativa quadam omniumque consensu Mullus sibi imperium occupavit, nec alius unquam majori in honore aut gratia apud Romanos fuit." 2

Among the Greeks, if, as seems acknowledged, the $\tau \rho i \gamma \lambda \eta$ corresponds to the Mullet, its place must be accounted high from the number of its devotees. Matron ${ }^{3}$ goes into raptures even over its mere head when steeped in brine, irrespective of whether it came from an autumn (as recommended by Aristotle) or a spring fish (the choice of Xenocrates).

The acme of epicurean hospitality was reached with serving the Mullet, not dead swimming in sauce, but alive swimming in a globe of glass, to be handed round among the guests. All eyes gloated as its gay hues gradually grew dimmer, till at last with death they faded into one dull colour.

Seneca lashes with his bitterest irony the custom, and the company. They are no longer content to satisfy their teeth and their stomach-no, they must also gratify their eyes. "No one now sits with a dying friend. None can bring himself to witness the death, however much desired! of his father. The last hours of brother or kinsman find no soul with him. To the death of the Mullet have they all flocked with one accord." 4

2. For the Scarus (S. cretensis), the "Parrot Wrasse," see Chapter X.

3. The Acipenser, a Latin name, adopted by some Greek

1 Var. epist., III. $4^{8 .}$

2 Op. cit., p. 93.

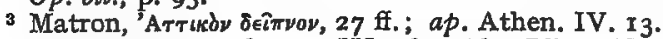

- Cf. Seneca, Nat. Qucest., III, I8. Also Pliny, N: H., IX. 3 ०. 
writers, which is often, if not convincingly, identified with the Sturio, the "Sturgeon," and by Archestratus $\mathbf{l}$ is affirmed

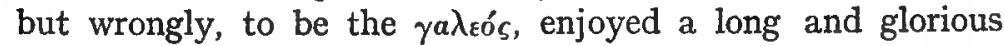
reign of supremacy from the early times of the Republic down to Vespasian. For it alone, with perhaps one exception, was reserved the high honour of being served at a banquet to the music of flutes and pipes, crowned itself, borne by slaves likewise crowned. 2

Its praise and its price (Varro styles it multinummus) seem alike exorbitant. We find the name of Gallonius the glutton-auctioneer, the first to bring the fish into fashion, occurring again and again.3 On Ovid's (Hal. 134) "Tuque peregrinis acipenser nobilissimus " may be piled passage upon passage. Plautus in a fragment of his Bacaria ${ }^{4}$ asks :

"Quis est mortalis tanta fortuna affectus umquam

Qua ego nunc sum? quoius hæc ventri portatur pompa:

Vel nunc qui mihi in mari acipenser latuit antehac,

Quoius ego latus in latebras reddam meis dentibus et manibus."

Cicero-no fish story-teller he-makes at least four references to it. In De Fato, frag. 5, he sets forth the tale of the Acipenser ("piscis ... in primis nobilis") presented to Scipio, to whom, as he persisted in inviting all and every one who saluted him, Pontius anxiously whispered, "Do you know what you are about? Lo! this is a fish fit only for a few choice palates!"

As to its decline from its high estate, Pliny's definite assertion (IX. 27), "Apud antiquos piscium nobilissimus habitus acipenser ... nullo nunc in honore est," finds corroboration by Martial, XIII. gr :

"Ad Palatinas acipensem mittite mensas;

Ambrosias ornent munera rara dapes." 5

1 Archestrat., ap. Athen, VII. 44.

2 Cf. Macrobius, Sat., II. I2, and Athenæus, VII. 44.

- Horace, Sat. II. 2, 46.

- Macrobius, Sat., III. I6, I.

5 Pliny claims for the Acipenser that he "unus omnium squamis ad os versis contra aquam nando meat." The reading of the last four words is however much disputed. C. Mayhoff prints contra quam in nando meant. Plutarch, De Sol. Anim., 28, of the Elops, "it always swims with the wind and tide, not minding the erection or opening of the scales, which do not lie towards the tail as in other fish." 
The Elops or Helops has been deemed to be the Acipenser, 1

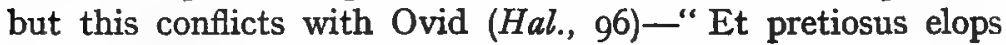
nostris incognitus undis "- -with Columella (VIII. I6), and with Pliny (XXXII. 54).

Whatever the Elops, Varro and Epicharmus testify to its extortionate price, while Pliny lets us know that by many of the cognoscenti its flavour was deemed to be the very best of all.

The capture of this rare and elusive fish-its usual habitat was off Pamphylia-became the occasion of great rejoicing; the crew of the successful boat were crowned with wreaths, and welcomed by the music of the flute-players. ${ }^{2}$ It is noteworthy that the Acipenser does not occur in the pages either of Varro or of Columella, while the Elops does.

4. The Rhombus, whether it were $R$. maximus, the " Turbot," or $R$. lavis, the "Brill," has been long in dispute.

Juvenal describes his celebrated Rhombus with "erectas in terga sudes" (IV. I28) ; " erectas" may be conceded to the licence of a poet as regards the back fin of a Turbot, but not of a Brill, which is yielding and rather wavy. Then, again, Diphilus declares that its flesh is soft, Xenocrates that it is firm, and improves with keeping. Now the flesh of the Brill is soft: that of the Turbot much firmer. Rhombus (unmentioned by Aristotle) probably stood for both Turbot

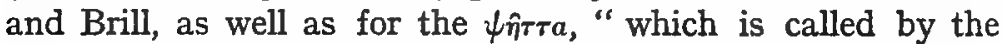
Romans the Rhombus." 3

The fish, which derives its name from its supposed likeness to the geometrical figure, was in poetry but not in popularity ${ }^{4}$ more celebrated than that other famous flat fish, the Sole. As a dainty the Sturgeon was in vogue long before the Rhombus, perhaps because, as Horace (Sat., II. 2. 49) suggests, it was introduced by a man of fashion:

"... Quid? tunc rhombos minus æquora alebant ?

Tutus erat rhombus, tutoque ciconia nido,

Donec vos auctor docuit prætorius."

1 Athen., VII. 44; and Pliny, IX. 27.

2 死lian, VIII. 28.

Cf. Athenæus, VII 139.

- Cf., however, Alciphron, I. 7, where among presents from fishermen, it takes premier place. 
It ran often to immense size. Martial's fish (XIII. 8I), although "latior patella," can hold no candle to the one presented to Domitian. ${ }^{1}$

That Emperor, though deeming himself and insisting on his subjects acclaiming him, of god-like attributes, was not equal to solving the knotty question of how to cook and to serve his fish rohole, "Derat pisci patinæ mensura"--if its proportions were in the same street with a Rhombus vouched for by Rondolet, viz. three metres long, two broad, and one thick, the fact excites no wonder-so he straightway summoned a special meeting of the Senate. ${ }^{2}$

Discover, Montanus advises, a new Prometheus capable of modelling the amplest trencher instantly, but, since to a god like Domitian (he flatteringly adds), offerings of huge fish will frequently be made-

"But, Cæsar, thus forewarned make no campaign, Unless some potters follow in your train."

5. The Lupus 3-Labrax lupus_-" common Bass" at Athens enjoyed the choicest preference. Aristophanes absolutely refused to be disturbed while feasting on a Milesian Labrax.

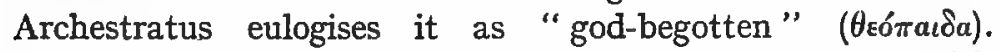
During the early Roman Republic it indeed ranked (with the Asellus) only second to the Acipenser. 4

The fish throve best and grew fattest in sewage; hence those "from between the two bridges" of the Tiber were famed

1 Juv., IV. $37 \mathrm{ff}$.

2 With this meeting compare that summoned post-haste by Nero in the Revolution (which led to his death), when to anxious and breathless senators he imparted the important news that he had just effected an improvement of the hydraulic organ, by which the notes were made to sound louder and

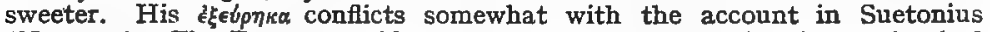
(Nero, 4I). The Emperor evidently had a bent and a liking for mechanical invention, for according to C. M. Cobern, New Archaological Discoveries, etc., I9I7, in one of his palaces were elevators which ran from the ground to the top floor, and a circular dining-room which revolved with the sun.

a The part played by fish in recovering episcopal keys and rings has been dwelt on elsewhere. Sad it is that in the case of St. Lupus the role is performed not by his namesake fish, but by a barbel, in whose belly was found, just previous to the return of the bishop to his See of Sens the selfsame ring which on being exiled by Clothaire II. he had cast into the moat. Let us, disregarding all geographical habitats, trust that Barbel was here an ichthyic inexactitude for Lupus. Cf. S. Baring Gould, The Lives of the Saints, Vol. X. 7, Edinburgh, I9I4.

"Pliny, IX. 28. 
far and near ; see Horace, Sat., II. 2, 3I ; Macrobius, Sat., II. I2 ; and Juvenal, V. I03-8. The latter's " et solitus mediæ cryptam penetrare Suburæ" was rendered quite clear only in I743, when the remains of the Cloaca leading from the lowlying ground to the Tiber were excavated. From this greedy scavenging he is christened by Lucilius (Sat. 4, frag., I27, Baehrens) " the platter-licker" (catillo)-

"Hunc pontes Tiberinus duo inter captus catillo." 1

The -Doctors once more are at variance. The Court, unanimous that (in Walton's phrase) "its savour was excellent," only by a majority (Galen and Celsus J.J.) upheld its nutritive powers, Hicesius $\mathrm{J}$. dissenting. Rondolet against the volume of authority affirms that the Lupus of the sea is of better quality than that of the river. Pliny ${ }^{2}$ dubs the Lupus "lanatus "- not from his woolly appearance, or woolly taste, but from the whiteness of his flesh-laudatissimus. But by the time of Domitian it has fallen from its proudest place.

Its Aristophanic title of " the wisest of fish " was earned by its cunning in escape from net or hook; its method in the case of the former is vouched for by Cassiodorus, ${ }^{3}$ and of the latter by Ovid. ${ }^{4}$

\section{"quassatque caput, dum vulnere sævus}

Laxato cadat hamus et ora patentia linquat."

Pliny, commenting on the marvellous friendships and hatreds which exist among fish, instances the astounding combination of both in the lupus and the mugil (grey mullet), " who burn with mutual hate for some, yet live in concord for other, months of the year"--despite the cheery custom, hereditary in the lupus, of nibbling off the tail of the mugil; all, however, live, "quibus caudae sic amputentur." 5

1 Cf. Macrobius, Sat., II, I2: "Lucilius . . . eum .. . quasi ligurritorem catillonem appellat, scilicet qui proxime ripas stercus insectaretur." $A$ propos of 'Catillo,' there is a quaint remark in the Gloss. Salom., "Nomen piscis a catino dictus ob cuius suavitatem homines catinum corrodunt "- the fish was so delicious it made one fairly bite the dish !

2 IX. 28.

3 Epist., XI. 40.

- Hal., $4 \mathrm{I}$ f.

5 N. H., IX., 88; Arist., H. A., IX. 3. 
"THE PLATTER-LICKER"-ASELLUS ?-COD 261

6. The Asellus has been identified as the Gadus merlangus, the "Cod;" and as the Merluccius vulgaris, the "Hake," by Scaliger and Rondolet, and by Hardouin with some doubt.

It cannot be the Cod (although Dorion speaks ${ }^{1}$ of " the övos which some call the ráosos "), because hardly any of the Gadida, except the Hake, frequent the Mediterranean on account of the temperature of the water. Nor can the Asellus be the Hake, because, while the latter is taken all the year round, Pliny ${ }^{2}$ and $\mathbb{E l i a n}{ }^{2}$ distinctly state that the $A$ sellus hides in the heat of summer.

This assertion, if the ofvog be the same as the Asellus, tallies with, probably indeed derives from, Aristotle's remark that it is the only fish that hides itself in a hole in the ground in the hot weather, when the Dogstar rages. ${ }^{3}$ The fish, Varro informs us, is called Asellus from the ashen colour of its scales, resembling that of the coat of an ass. 4

If there be doubt as to its classification scientifically, there is none gastronomically. Laberius and Cornelius Nepos ranked it only second to the Acipenser. Ovid (Hal. I3I) enters a demurrer against the name given in :

"Et tam deformi non dignus nomine asellus."

Galen warmly commends the fish for its quality of flesh, and great nutritive power ; in these respects, indeed, he places the Mullet, the Lupus, and Sole far below. Xenocrates, whose dictum usually differs from his successor, depreciates it, as does "nobilis ille helluo" Archestratus, whose palate pronounced the flesh "spongy."

A sovereign remedy for fever and ague are " the small stones found in the head of the Asellus, when the moon is full, and attached in linen to the patient's body!" 5

7. The Murcena-M. serpens or helena-(frequently but quite erroneously called the "Lamprey"), with whose taming,

1 Dorion, ap. Athen., VII. 99. Dorion was the author of a treatise much used by Athenæus.

${ }^{2}$ IX. $25 ; N . H .$, IX. 36.

3 Athen., VII. 99. Cf. Oppian, I. I5I

4 De Ling. Lat., 5.

5 Pliny, XXXII. $3^{8 .}$ 
teaching, and fighting I have dealt, was on the menu a most welcome and eagerly anticipated item. ${ }^{1}$

Of the Murcenida, at Athens the Eel, at Rome the Murana was, as the last chapter shows, the greater favourite. Archestratus, it is true, commands men of taste to buy at all hazards the Murcena of "the Straights" 2; but the Latin authors sing its praise frequently and fervently.

The comparative want of appreciation of the Eel at Rome may have been merely masculine, and evolved from the Latin boy (pratextatus) regarding "this cousin of the snake" not as a dainty for his palate, but as a scourge for his body! Early association counts for much in later life: so his back's memory of a flogging with a whip made of eel-skins, twisted tightly together, may have caused the male adult to approach delicately, or not at all, the fish with his freeborn palate. 3

At the tripatinium, which marked the height of delight at a supper, 4 the Murcena gave the choicest morsel. Horace, Martial, and others not only sing its fame, but give its proper dressing. To Martial's taste that from Sicily ranked first, but Varro-was it because these, as Suidas asserts, were the largest?-votes for the Spanish fish.

While Apicius (X. 8) hands down various recipes for the proper frying and boiling of the other parts, he distinctly discards, on account of its reputed poisonous properties, the head of the Murana. But among the Greeks direction follows direction for cooking the Conger's " exquisite head." Philemon rhapsodises over-

1 The Lamprey, Pride, and Murcena are different fish. They are all engraved in Nash's book, who lays down that the Murcena is not the lampreyas indeed a representation (from Herculaneum) of the former done with great exactness serves to establish. See T. D. Fosbroke, Encyl. of Antiq. (London, I843), p. I033, and p. 402 , figure 3.

Ap. Athen., VII. 9I.

3 The toga pratexta was worn by the higher magistrates, certain priests, and free-born children. Isidorus, in Gloss." "Anguilla est qua coercentur in scholis pueri," and Pliny, N. H., IX., 39, "eoque verberari solitos tradit Verrius prætextatos." Under the old law pratextati were unamerceable; non in cere, sed in cute solvebant! Our Saxon forbears adopted the whip of eels : see Fosbroke, op. cit., p. 303. Rabelais (II. 30) continues the tradition"Whereupon his master gave him such a sound thrashing with an eel-skin, that his own would have been worth nought for bagpipes."

4 Pliny, N. H. 35; 46; quoting from Fenestella. 
" noble conger

From Sicyon's bay, the conger which the God

Of the deep sea doth bear aloft to Heaven

Fit banquet for his brethren." 1

8. The кámpos-by some identified with the Aper, by some translated the "Sea-Hog." Neither scientifically, nor in my list can I place this fish; it was apparently unknown to the Romans.

Of the fish as Caper, except in Ennius," "Caproque apud Ambracienses," and Pliny, XI. II2, " et is qui caper vocatur," Latin literature is silent. Nor do these two quotations aid, because the first occurs in the poet's imitation or translation of Archestratus (Apul., Apol., p. 384), while Pliny simply transliterates Aristotle's кám $\rho$ os. ${ }^{3}$

Of its right to be near the top of the list, the words of Nonnius bear high proof: "Among the fishes which the Greeks sought with mad desire, and at any cost to procure, was first and foremost the кámpos, which, though called Aper, was unknown to the Romans."

Archestratus 4 outdoes even himself in his eulogy of this fish, for he straightly enjoins any one lucky enough to be in Ambracia,

"Buy it at once, and let it not escape you,

Not if you buy it at its weight in gold ;

Else will the indignation of the gods

O'erpower you : for 'tis the Flower of Nectar."

The immediate sequel to these lines is of interest. The poet, transported from earth to heaven at the thought of his favourite dainty, describes it in wording which recalls the most solemn rites of Hellenic religion. There were certain foods reserved for communicants. There were mysteries which none but advanced initiates might witness. There were objects of peculiar sanctity borne by virginal ministrants. There

1 Philemon, $a p$. Athen., 7. 32.

2 Hedyphagetica. The reading is most uncertain.

3 In N.H., II. I3, and IV. 9. This cannot be our boar-fish which is marine, whereas Aristotle talks of it being in the river Acheloüs. It may possibly be another name for the Glanis.

"In Athen., 7. 72. 
were divinatory pebbles shaken in the glittering caldron of Apollo. These sacred associations are all suggested by the language of our enthusiast :

"It is not meet for every man to taste,

Nor see it with his eyes. Nay, he must hold

The hollow woven-work of marsh-grown wicker

And rattle pebbles in his glittering count."

But the words, though reminiscent of actual cult, have a double entendre and are meant to bear a more mundane meaning. In plain prose, then, "it needs a wealthy man with capacious cash-box (literally a basket, fiscus) and a rattling big bankaccount (pebbles to reckon L. S. D.) to afford such a luxury as this!"

Not far behind it among Greek epicures came the Glaucus, possibly the sea-grayling, of whose "most precious head" Anaxandrides is enamoured, and Antiphanes and Julius Pollux write with appreciative gusto. But are not all things about the Glaucus written in the seventh book of the Deipnosophistce, chapters 45,46 , and 47 ?

9. The Buglossus, or Lingulaca (Solea vulgaris, the "Sole" I), alike at Rome and at Athens the most prized, if not the most lauded in verse, of the Flatfish, held rank as high as any, actually far higher than its so-called cousin, the Passer.

Although Xenocrates and Galen differ as to the firmness or reverse of its flesh-I wonder whether the latter got hold of a Lemon Sole !- the ancient agrees with the modern faculty in accounting it "very nourishing, and of most pleasant flavour." 2 It then as now was almost always the first fish ordered, "as soon as men be sick or ill at ease" in Plutarch's time and words.

1 See Stephanus, Thesaurus Graca Linguce, ii. 347 C-D.

2 Badham (plagiarising Blaikie), on p. 364 -in "Galen, Xenocrates, Diphilus speak disparagingly of the Sole," is inaccurate. Xenocrates terms its flesh indigestible. Galen states that it is quite the reverse, and commends it highly as a diet. Diphilus does not hesitate to declare that the Sole affords abundant nourishment and is most pleasing to the taste. Cf. Nonnius, p. 89. In the case of a Sole with its customarily modest dimensions it is not easy to hearken unto the command, which was laid down in the twelfth century for the benefit of Robert, the so-called King of England, "Anglorum Regi scripsit schola tota Salerni," by "the Schoole of Salernes most learned and 
From likeness to a tongue sprang its first Greek and Latin

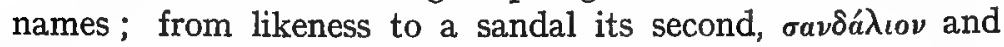
solea. Thus we find Matron ${ }^{1}$ establishing, or merely perpetuating, the pretty myth that these fish, possibly from some adhesive power-and is it heresy to suggest their breadth ?served the Goddesses of Ocean as sandals or shoes :

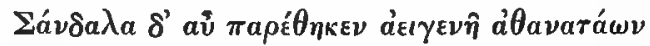

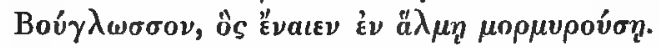

As Yonge renders them-

"And next (the goddesses such sandals wear)

Of mighty soles, a firm and well-matched pair,"

the verses have the double demerit of being uncomplimentary to Aphrodite et $\mathrm{Cie}$, and of reading into Matron an allusion unwarranted by his lines. ${ }^{2}$

A not dissimilar use of the Sole is instanced in Polynesian theology. Ina the daughter of Vaitooringa attempted flight to the sacred island. Fish after fish essayed to bear her thither, but unequal to the burden dropped her in the shallow water. At last she besought the Sole, who managed to carry her as far as the breakers. Here, again unshipped, she lost her divine temper, and stamped with such fierceness on the head of the unfortunate helper of distressful maids that its under eye was squeezed right through to the upper side. "Hence the Sole is now obliged to swim flat on one side of its face, having no eye." 3

Plautus puns or makes play on Solea, which means, first, a shoe or sandal (as does $\sigma a v \delta a ́ \lambda \iota v$ ), and, second, the fish, and sculponea, a kind of wooden shoe (which Cato ${ }^{4}$ remembers

juditious Directorie, of Methodicall Instructions for the guide and governing the health of Man ":

"Si pisces molles sunt, magno corpore tolles.
Si pisces duri, parvi sunt plus valituri."

Cf. Regimen Sanitatis Salerni, London, I6I7, but better still Sir A. Croke's ed., Oxford, I 830 .

1 In Athen., 4, 13 , line $76 \mathrm{ff}$.

2 It is noteworthy that two of the Nymphs on the "Nereid Monument" are supported by fish (A. H. Smith, $A$ Catalogue of Sculpture in the British Museum (London, I900), ii. 35, Nos. 9I0, 9I I).

${ }^{3}$ Cf. Robinson, op. cit., 82.

- De Re Rust., 59. 
being worn only by country folk) often employed for striking a person. 1

Then comes the other play on Lingulaca, which in its first sense equals a chatterbox, and in its second the fish.

Lysidamus : Soleas, Chalinus : Qui, quæso, potius quam sculponeas,

Quibus battuatur tibi os, senex nequissime?

Olympio: Vin' lingulacas? Lysidamus: Quid opust, quando uxor domi est?

Ea lingulaca est nobis, nam numquam tacet. ${ }^{2}$

To render the double punning of these lines has been a task too hard even for the excellent Loeb Library. But Badham, perhaps poeta nascitur, but here non fit, comes to the fore:

"Fresh tongues for sale, who'll buy, who'll buy?

Come, Sir, will you ? No, friend, not I;

Of tongue enow at home I've got

In my old wife, Dame Polyglot."

The Cestreus, or Mugil. My inclination to include this fish among "The Nine Fish most highly prized" was checked in part by Faber's placing it only in Class II., and in part by the possible reproach, seeing that the glories of its cousin the Mullus had been fully recounted, of "too much one family." But as the fish possesses traits very individual, if not always engaging, and as Athenæus devotes to its gastronomic and other properties no less than four chapters, ${ }^{3}$ I cannot pass by it without some comment.

Its edible qualities vary with the place of its capture. While the Mugil of Abdera, Sinope, and other clear-watered places achieved high praise, its more frequent but muddytasting brother of the lagoons formed the staple of one kind of rápıxos. Their predilection for lagoons and brackish water-evidenced by writers as far apart as Aristotle and Apostolides (Ig00 A.D.)-came about possibly from the fish " breeding best where rivers run into the sea," or can be accounted for by the belief that "Some of the grey mullet

1 Terence, Eun., V. 7, 4 .

2 Plautus, Casin. II. 8, 59 ff.

A Deipn, VII. 77-80; cf. Pausanias, IV. 34. 
species are not produced by copulation, but grow spontaneously from mud and sand." 1

Apart from characteristics already mentioned, e.g. its greed and guile, its hereditary feud with the Lupus, its being " the swiftest of fishes" (which attribute, nevertheless, saved it not from being the prey of the slowest, if not the shrewdest of fishes, the Pastinaca or string-ray, ${ }^{2}$ ) we find various points of interest noted by ancient writers :

(A) "Whilst rain is wholesome for most fishes, it is, on the contrary, unwholesome for the Cestreus, for rain and snow superinduce blindness." 3

(B) The passionate desire of the Cestreus, when about to spawn, "renders it so unguarded" that, if a male or female be caught, fastened to a line, allowed to swim to sea, and then gently drawn back to land, shoals of the opposite sex will follow the captive close up to the shore and fill the awaiting nets. ${ }^{4}$ This method of fishing, which prevails at Elis at the present day, is but one, as Apostolides indicates, of the many survivals in modern Greece of the ancient craft. ${ }^{5}$

(C) The Mugil, together with three others, possesses by far the best sense of hearing, " and so it is that they frequent shallow water." 6

(D) The Mugil, anticipating the ostrich, hid its head when frightened and fancied that the whole of its body was concealed. Unlike the ostrich, however, it has long got cured of its "ridiculous character" 7, for, as Cuvier remarks, this trait in modern times has not been observed.

(E) The Mugil, although vouched for as the greediest and most insatiable of feeders, attained paradoxically the sobriquet of Niorıs, or the Faster.

The epithet probably gained currency from the stomach of the fish (like that of most salmon caught in fresh water) rarely

1 Arist., N. H., V. Io and II.

2 Pliny, IX. 67.

3 Arist., N. $H$. VIII., I9.

4 Oppian, Hal., IV. I20-145 ; Arist., op. cit., V. 5.

5 OP. cit., p. 45.

- Pliny, X. 89, and Ælian, IX. 7 .

7 Pliny, IX. 26. 
being found to contain food. This perhaps may be accounted for by the great length of its gut, throughout which the filmy garbage and vegetable matter forming its chief diet are inconspicuously disposed. "The Cestreus is fasting" even became a proverb and was applied to men who lived with strict regard to justice, because-as Athenæus explains-the fish is never carnivorous. ${ }^{1}$

(F) The use in cases of adultery of the Cestreus in Greece and the Mugil at Rome, if not singular among fish, is striking ; for it survived into the civilised age of Catullus (" percurrent raphanique mugilesque," 2) and of Juvenal (" Quosdam mœechos et mugilis intrat," 3 ). Indeed, traces of the same barbaric custom still exist among certain tribes on the West Coast of Africa.

Gifford writes: " the being clystered (as Holyday expresses it) by a Mugil was allowed by no written law, but it seems to have been an old and approved method of gratifying private vengeance. Isidorus thinks that the fish was selected for this purpose on account of its anti-venereal properties, but he confounds the Mugilis with the Mullet." 4

From The Fisheries of the Adriatic, a most elaborate Report by Faber on the kinds and market values of the fishes of that sea, I give the class allotted to the fish of my list. It must once more be impressed on the reader that these eight fish (for of course Faber does not deal with the кámpos), were the most renowned in Greece and Rome. Of these, five onlythe Mullet, Acipenser, Rhombus, Lupus, and Sole-are in Class I.; the Asellus and Murcena in II. ; the Scarus, and it could not be lower, in III. 5

The classification disappoints and depresses, especially in the case of the vaunted and lovable Scarus. It tempts, however, to an insoluble sum in proportion. If about these and

1 Aristophanes, and half a dozen other comedians cited by Athen., VII. 78.

2 XV.x9.

3 Sat., X. 3I7.

4 Further details must be sought in Robinson Ellis, $A$ Commentary on Catullus (Oxford, 1876 ), p. 46, and Schneider, op. cit, 69.

s Although these five must be reckoned in the first class everywhere, none of the five or other Mediterranean fishes can compare in taste with their northern representatives. 
other less esteemed fish the books extant and known to have been lost are almost as countless as the smile of Ocean, how many volumes would an Englishman or an American-given the same fish-mania and the same literary facility as the Greeks-require to do justice to his wealth of first-class edible fish? Verily the Library of Alexandria, with its room for 400,000 volumes, would scarce suffice. 


\section{CHAPTER XIX}

FISH IN MYTHS, SYMBOLS, DIET, AND MEDICINE

ALTHOUGH the salutary warning-Terminat hora diem: terminet auctor opus -forbids us prolonging the Greek-Roman section, already disproportionate in space, yet the part played by fish (A) in myths, (B) in symbols or emblems, Pagan or Christian, (C) in medicine, and (D) in diet necessarily demands some notice. And as our authorities are, in the main, writers in Greek and Latin, this section seems the appropriate place for what must, although the literature on the subject is superabundant, be summary and restricted comment.

By the Solar Mythologists, the fish (no creature, however small, escapes the mesh of their net) has been made to take a prominent rôle. The fair-haired and silvery moon in the ocean of light is simply the little gold-fish; the little silver-fish which announces the rainy season is merely the deluge. The goldfish and the luminous pike, like the moon, seem to expand and contract, and in this form, as expanding or contracting, the god Vishnu or Hari (perhaps meaning "fair-haired" or "golden ") refers now to the sun, now to the moon, Vishnu being held to have taken the form of the gold-fish.

"The epic exploits of fishes," to borrow de Gubernatis's term, would include the myths of Adrikâ, the fish nymph who became the mother of Matsyas, the king of fishes; of the Puranic fishes, symbolical and natural; of the fishes of the Eddas, with the scaly transformations of Loki, and hundreds of similar legends. ${ }^{1}$

1 A. de Gubernatis, Zoological Mythology (London, 1872), II. 329 ff. The latest luminary among the Solar Mythologists is L. Frobenius, Sonnenkultus, whose lengthy chapter in vol. I. on the world-wide Fish-Myth and its solar significance may be consulted by the leisurely. 
The vagaries of Solar Mythology can be safely neglected. But the story, derived perhaps from Semitic sources, of fish incarnation and of the adventures of Manu, is deserving of fuller consideration.

According to one variant of the legend, Vishnu, in the form of a small fish, approached Manu to beg protection against the larger fish; whereupon he was placed securely in a water-jar, but in a single night outgrew the jar. Manu then tried a pond, and next the Ganges, but similar increases in size compelled him to remove the fish to the sea. Upon this the god made himself known, warned the sage of the coming of the Flood within seven 'days, and bade him build a ship and furnish it more or less on the lines of the Jewish Ark, only among the passengers were to be seven Sages!

In accordance with his promise, Vishnu, still in fish shape, reappeared on the subsidence of the waters, and with a rope attached to his horn towed the Ark to the Northern Mountain, where it grounded. 1

Instances of impiscation (so to speak) appear not infrequently in my pages. Oannes, with head and tail of fish, but also with human face and feet; Dagon, "Sea-monster, upward man and downward fish"; Atargatis, or Derceto, "with face of woman but body of fish "; Venus, turning herself and Cupid -and also, as one account adds, her lover Mars_-into fishes to escape the pursuit of the Giants; - all these can be grouped with other myths.

These tell us that Asia was saved by a fish and is supported by a tortoise, that Polynesia was brought up, itself a fish, on a fish-hook out of the primæval ocean, or that America was rescued from the depths of diluvian chaos by a turtle. Well may Robinson conclude, "Since in the beginning there were only Light and Water, the eldest of the Zoological Myths is the Fish Myth." 2

According to de Gubernatis, ${ }^{3}$ " the ancient systems of mythology have not ceased to exist: they have been merely diffused

1 Cf., however, "The Story of the Deluge," in the Catapatha Brăhmana.

2 P. Robinson, op. cit. (p. 18), to which I owe much, here and elsewhere.

o op.cit., p. xi. 


\section{FISH IN MYTHS, SYMBOLS, DIET, MEDICINE}

and transformed. The nomen is changed ; the numen remains. Although from loss of celestial reference and significance its splendour is minished, its vitality is enormous." We find, however, that the mythic motives or original principles common to India and Hellas (as well as Scandinavia, etc.) are most conspicuous among the Greeks. India, indeed, seems absolutely wanting in some which in Europe manifest extraordinary vitality and expansion.

But in any comparative enumeration, strict regard must be paid to the fact that the fauna of a myth commonly varies with its geography; as an instance of this, the epos, which in Europe recounts the cunning of the fox, in India dilates on the craft of the serpent.

The fish myth proved no exception. It passed from nation to nation gradually down the ages, till we find the Greeks, borrowers sometimes unconsciously, sometimes of set purpose, perpetuating it widely in connection with deities and subdeities.

Thus came it about that to several of the greater gods of the Greek, and afterwards of the Roman, Pantheon appertained a particular fish (or fishes). These not only enjoyed their gods' protection, but also the double distinction of being at once an attribute represented with them and a sacrifice offered to them.

The association of certain gods with certain fishes is not always obvious. While the linking of Amphitrite with the Dolphin, or of Poseidon with the Tunny is easily explained by legends of hoary tradition, it needs all the ingenuity of Eustathius to decipher the connection between Artemis and the Maine. 1

In time, as their coins indicate, fish became associated with various coast towns, which owed their prosperity to fishing. Good examples descend from Olbia, Carteia, and Cyzicus on the Propontis. The early electrum coinage of the last shows the badge of this or that magistrate invariably accompanied by a Tunny, the badge of the state. ${ }^{2}$ Very remarkable ${ }^{3}$ is

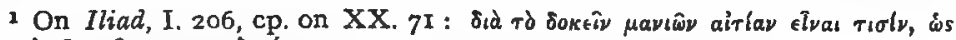
olov Eimeîv roîs $\sigma \in \lambda \eta v i a$ So $\mu$ évols.

2 Brit. Mus. Cat. Coins, Mysia, p. 18 ff. Nos. I ff. pl. 3, 8 ff.

s Brit. Mus. Cat. Coins, Mysia, p. 18, No. I, pl. 3, zo 
an electrum stater with a Tunny upright between two sacrificial fillets, which may signify that this tunny was closely connected with some deity or was itself of a sacro-sanct character.

Even more remarkable is a coin of Abdera in Hispania Bætica. This carries on its obverse a laureat head of Tiberius: on its reverse a four-pillared temple, two of the columns of which are in the form of fish. This unique representation has never been fully explained. ${ }^{1}$

It is surely a happy coincidence that on some mintages of Imperial date the fish occurs together with the head of some
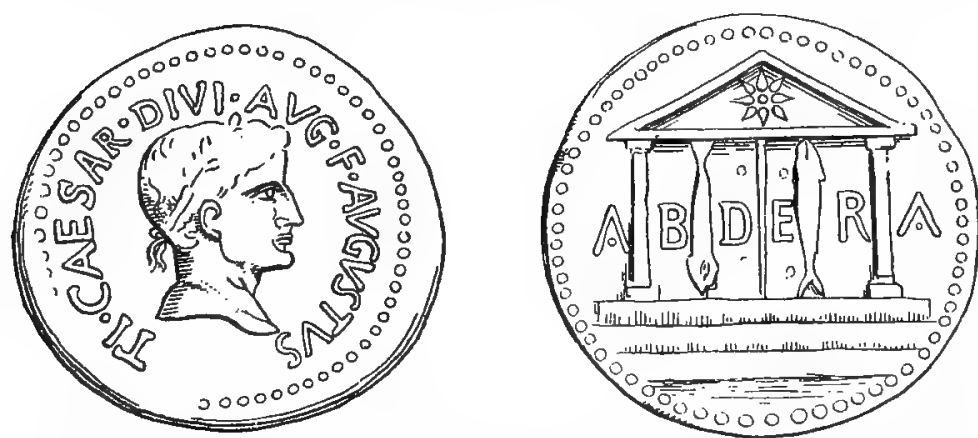

LAUREAT HEAD OF TIBERIUS AND TEMPLE WITH TWO COLUMNS IN SHAPE OF FISH, FROM A COIN OF ABDERA.

From A. Heiss, Pl. 45, 9.

self-styled deities, such as that choice couple, Nero and Domitian. On sundry pieces struck by Nero, the octopuslike and predatory Sepia not inappropriately finds place; but monstrously incongruous seem the coins which associate the man-serving and man-saving Dolphin with the self-serving and man-slaying Domitian. ${ }^{2}$

With the Jews, although its emblematic employment was scanty, the fish occasionally figured, e.g. as a sign of Judah. In the Talmud it appears more frequently, and as symbolic of some moral quality-e.g. of innocence. ${ }^{3}$ In Japan the carp

1 A. Heiss, op. cit., pl. 45, 9.

: See Cohen, Monnaies Domitian, Nos. 227, 229, 236, and Pitra, op. cit., pp. 508-5I2. Although writing some sixty years ago he enumerates no less than $\times 56$ illustrations from coins and representations of fish association.

8 For the fish-symbol in Judaism there is a good collection of facts in I. Scheftelowitz, "Das Fisch-Symbol in Judentum und Christentum," in the Archiv. für Religionswirsenschaft (I9II), XIV. I-53, 32I-392. 


\section{FISH IN MYTHS, SYMBOLS, DIET, MEDICINE}

has been for centuries the emblem of the Samurai, because of its accredited power to withstand opposition and to swim against the current of the stream.

On the advent of Christianity, numerous become the allusions in Patristic and other literature. From the repetition by Father after Father of Aqua viva piscis Christus, of piscatio duplex, Ecclesia presens et futura, and of similar sentences, the application approaches perilously near the commonplace.

Nor was its scope morally limited. St. Augustine, St. Cyprian, and others allegorise fish and fishing in both good and bad senses.

Thus, piscis pia fides qua vivit inter fuctus nec frangitur ; piscis fides invisibilium; rete Christus; sagana Ecclesia; Christus est piscis assus discipulis, serpens Judcis, can be matched by pisces immundi, peccatores: piscis maris, damones; piscator Diabolus; rete, deceptio Diaboli; and sagana, cor mulieris, which last, from a technical point of view, hardly stamps Bishop Humbertus as a proficient in our craft.

From the identification-Christus est piscis ${ }^{1}$ - is no long step to the symbolic use of the very letters which spell the Greek word for fish : thus from IX $\theta Y \Sigma=I-c h-t h-u-s$, is estab-

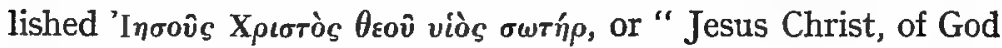
Son, Saviour."

This symbolic adoption in connection with their God was far from original. A fish, at first the symbol of Vishnu, was adopted by the Buddhists, and from them by the Christians of Turkestan.2 This adoption and adaptation of a Pagan symbol was but one of the many instances where Christian policy or Christian practice took over and continued heathen customs, institutions, and vestments. ${ }^{3}$

1 Pitra, op. cit., has several plates bearing on this. Of the coloured, pl. I shows an eucharistic table with a fish and bread upon it, and at each side seven baskets full of the latter, while in pl. 3 a fish swims bearing on his head a basket with sacred loaves, both illustrative of the miracle. See also pp. $565-6$.

2 Keller, op. cit., p. 352. The latest and best monograph on the fishsymbol in Christianity is that of F. J. Dölger, Das Fisch-symbol in frühchristlicher Zeit (Freiburg, rgro), whose conclusions are summarised in the Archiv für Religionswissenschaft (rgr2), XV. 297 f.

Cf, the many fascinating works of Dr. J. Rendel Harris, e.g. The Cult of the Heavenly Twins and Boanerges. Also Lowrie, Avt and Archaology: and Miss M. Hamilton, Greek Saints and their Festivals. 
Such seems to have been the trend, possibly from pursuing a policy of compromise, more probably from following the line of least resistance, of most religious changes or revivals. But while the attributes of many of the Greek gods were, at least in certain of their attributes, assimilated to Syrian and Eastern divinities, and while the Roman pantheon made room for various Egyptian new-comers, the Jew's conception of his Deity remained practically unaffected and uninfected.

A fish frequently figures on the tombs of the early Christians in the catacombs at Rome: sometimes it bears on its back a bowl with wine and wafers of bread. Many tombs contain small fish of wood or ivory. Such fish served, we are told, as emblems and acrostics, pointing out to his co-religionists the burial place of a Christian without betraying the fact to the persecutors.

This explanation lacks confirmation, and carries little conviction, for two (among other) reasons. First: critical statistics show that fish as symbols in Christian art figured frequently both before and after Constantine. Second: fish as indicative of a burial place would by their very presence quickly defeat the object aimed at. They would indicate, as surely as pointers game, the secret grave, for the persecutors of the Christians, as history shows, were not all exactly fools.

Some authors trace back not a few of the signs 1 and usages adopted and perpetuated by the Christians to the worship of Venus, of which, when in conjunction with a fish, the underlying idea was the adoration-nearly universal—of fecundity. Two instances, which I give for what they are worth, must suffice.

As regards Lent, A. de Gubernatis contends that Aphrodite or Venus, the goddess of Love ${ }^{2}$, frequently represented the Spring. Hence it is that in Lent, appointed by the Church to be observed in Spring, and again on Friday (or the day of Freya)

1 See C. Cahier, Caractéristiques des Saints dans l'art populaive (Paris, 1867). Vol. II. 69I fi., for illustrations of Saints accompanied by fishes.

2 Op. cit., II. 340. "The gemini pisces, the two fishes joined in one, were sacred to her, and the joke of the poisson d'Auril ... is a jest of phallical origin, and has a scandalous significance." 


\section{FISH IN MYTHS, SYMBOLS, DIET, MEDICINE}

we are enjoined to eat fish, of which, it must be remembered, Aphrodite was a patron goddess.

As regards Maunday Thursday, Robinson writes: "One of the annual Church disbursements up to the end of the sixteenth century was for herrings, 'red and white.' Let us hope that those who in pious observation of Christian ordinances thus charged themselves with phosphorus were not aware that they were simply perpetuating the worship of Venus. 1 Friday, again, is dies Veneris, and fish, her own symbol, is therefore appropriate for the day."

Of the making and explaining of symbols in early and mediæval times there is no end. The monkish mind, perhaps owing to environment and fasting, found this a congenial and pleasant pursuit.

Among the books on this subject, Mundus Symbolicus, although, or perhaps because, published in I68I, attracts me most, not merely by its fulness of information and of quotation from classical, Patristic, and mediæval literature-it is a good competitor with Burton's Anatomy for Collectanea-but also by the number and naiveté of its lemmata, or appropriate apophthegms, which appeal alike to one's ignorance and one's humour. Of 737 pages of the volume before me 43 concern themselves solely with fish, and provide delightful browsing. ${ }^{2}$

The object and practice of Picinelli, from whose $I l$ Mondo Simbolico Erath makes the Latin translation, is to examine into the habits, real or alleged, of each fish, and deduce, as was the frequent custom of books in the sixteenth and seventeenth centuries, from its delinquencies or virtues a moral lesson or lessons.

Thus the lemma, "Fallacis fructus amoris," not inaptly summarises the amatory character of the Sargus, as indicated

1 P. Robinson, International Fisheries Exhibition (London, 1883), Part III. p. 43. "The representations of the Virgin in a canopy or vesica piscis are supposed to have a specially Christian significance: if they have any at all, it is a very heathenish one."

2 Mundus Symbolicus, a rare folio, of which two editions, I68I and I694, exist, is a translation of $I l$ Mondo Simbolico (written by Picinelli Filippi, and published at Milan 1653, 1669, and 1680), made by Aug. Erath. Cf. Tresor des livres rares et precieux, tom. v. (Dresde, 1859-69), P. 282. The Bodleian possesses only the 1694 edition of Mundus Symbolicus, while apparently the British Museum lacks both. 
in my chapter on Tackle. Nor, again, is the author far astray with his lemma for the Monachus or Monk fish (a name derived from the hood on its head) - " Habitum non virtutem"--which recalls the mediæval jeer, "The cowl makyth not the Monk," and Oscar Wilde's description-half-echoing Browning-of the pike as "some mitred old bishop in partibus:" Of the Monk fish-also Bishop fish-a well intended representation can be found in the pages of the learned Gesner.

Under Salmo, when suffering from leeches or gill-maggots, the author provides us not only with the lemma, "Haret ubique" and the appropriate, if not quite original, reflection of St. Bernard that conscience is like the leech which ceaseth not night nor day from making its presence felt, but also with a vivid description of a kelt dying- " donec toto corpore tabescat."

Any connection between a salmon and a swallow (hirundo) for a moment seemed a new ichthyic revelation! The context, however, and not least St. Bernard's pointing of the moral, led to the discovery of the misprint of hirundibus for hirundinibus (' leeches').

With one more passage I regretfully leave Picinelli, or rather Erath. The collocation of the rose and fish held in the hand of Cupid, which Alciatus " non sine mysterio instruxisset," occasioned " the erudite" and anonymous epigram (p. 67I) showing that Love resembles the rose and the fish. This apparent incongruity finds explanation thuswise: while each has prickly points, the first fades in a day and the second is incapable of being tamed-a comparison which, if unique, ignores the Egyptian and Roman powers of domestication. ${ }^{1}$

"Symbola adulantum cernis, Rosa, Piscis amorum, ${ }^{2}$ Non sane unius Symbola certa mali.

Nam Rosa verna suis non est sine sentibus, idem

Piscis habet spinas intus et ipse suas.

Pulchra Rosa est, verum illa brevi fit marcida, piscis

Est ferus, esse aliqua nec cicur arte potest."

1 The bronze statuette found at Hartsbourg showing the Germanic god Chrodo, standing on a fish, while holding in his uplifted left hand a wheel, and in his lowered right a basket of fruit and vegetables, is not at all on all fours. Cf. Montfaucon, Antiquity Explained, trans. D. Humphreys (London, I92I), II. $26 \mathrm{I}, \mathrm{pl} .56,3$.

${ }^{2}$ The construction of 'Rosa, Piscis' is not discernible. Perhaps ('Rosa Piscis ') would be less obscure. 
One lemma " Pingit et delectat" is not the author's happiest effort. That attached to the only illustration of a man fishing -Tenet et tenetur-tersely depicts the happy angler.

Many instances illustrating the importance attached to fish, both in diet and in medicine, are to be found scattered through my pages. I would, however, wager that in addition to these multiplied even one thousandfold, there would yet remain in the pages of medical ${ }^{1}$ and other writers (even if we stop as early as Aëtius) matter sufficient for a large Monograph. ${ }^{2}$

In one book alone of Pliny's (XXXII.) fish are recommended as remedies, internal or external, no less than (according to my rough reckoning) 342 times !

If Hippocrates, "the father of Medicine," in the fifth century B.c. (c. 460-359) laid the foundation, Galen some six centuries later (I 3 I-20I A.D.) crowned the edifice of that science. The cry and the practice of the former, "Back to Nature," was energetically enjoined and brilliantly defended against the inevitable reactions of the Alexandrian and other schools by the latter, who acclaims his predecessor as " divine."

In his insistent teaching "Ensue Health," as the one and only thing alike for patients and physicians, Galen ${ }^{3}$ might well have adopted the last line of Ariphron's glorious pæan to Health :

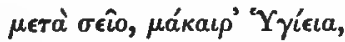

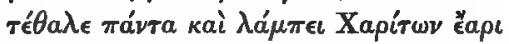

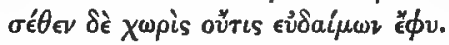

In his own case success crowned his efforts. He boldly boasts that he did not desire to be esteemed a physician, if from his twenty-eighth year to old age he had not lived in perfect health, except for some slight fevers, of which he soon

1. To Galen alone 499 works are attributed.

- For a list of practitioners, medical authors, and quacks before Pliny, and the enormous fees sometimes paid them, see $N . H .$, XXIX. I, 7. Not inappropriate, and probably not infrequent, when we read of their number and their disagreements, was the epitaph-Turba se medicorum perisse. This attribution of death to too many doctors is accredited to Hadrian, but is

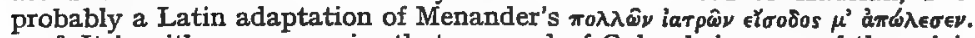

3 It is with some surprise that we read of Galen being one of the original Deipnosophiste (I. 2), and with more still that we find the omnivorous and omniscient Athenæus quoting but once from this most prolific author, and that a passage which lays down, let us trust from the experience of his patients that Falernian wine over twenty years old causes headaches. 
rid himself. 1 Perhaps a secondary motive was not absent, viz. the desire to avoid the taunt so often levelled at medical men :

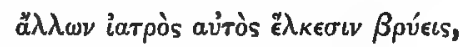

which Urquhart in his Rabelais translates,

"He boasts of healing poor and rich,

Yet is himself all over itch!"

As regards fish as a diet in health and sickness, quot medici, tot sententice seems hardly exaggeration. Their wondrous unanimity as regards the food-properties of the Eel amazes, for with fish it was usually a case " where doctors disagree."

The "Father of Medicine," in denouncing its use (especially in pulmonary cases) was followed by nearly all medical writers, some of whom, however, were not slow, when otherwise differing from him, to assert that he killed more folk than he saved by his practice of leaving Nature to effect its cure. Paulus Jovius sums up historically the medical attitude towards Eels : " abhorred in all places and at all times, all physicians do detest them, especially about the solstice."

As Galen's dictum 2 that fish afford the most desirable food for "the idle, the old, the sick, and the silly" embraces the majority-if we allow Carlyle's " mostly fools "- of mankind, it would be idle to pursue the dietetic side, were it not for the distinguos (to use the old Schoolman's term) as to which fishes fell within or without the Mysian's category.

Diphilus (with Philotimus and others) speaks disparagingly of some, but highly recommends others. Habitat alone, he urged, formed the deciding line between the clean and unclean. His Treatise on Food for the Well and $I l l^{3}$ divides sea-fish into (A) those which keep near the rocks-these, in his words, " are easily digested, juicy, purgative, light, but not very nutritious " -and (B) those which haunt deep water-these are "much

1 Empedocles, albeit no doctor, is said to have delivered Selinus in Sicily from malaria by drainage, etc., and so roughly anticipated the triumphs of Ross and Gorgas over the mosquito by some 2400 years. See Diog. Laert." VIII. 7o, s.v. "Empedocles."

₹ De Alim. Fac., 3, 28. Cf. De Attenuante victus ratione, vol. vi. ed. Chartier, which confirms and amplifies the above.

3 Athen., op. cit., VIII., chs. $51-56$, which discuss various fishes from a health point of view. 
less digestible, very nutritious, but upsetting to the internal economy."

Alexander Aphrodisiensis attributes the superiority of Class A to the fact that, as the water round the rocks is in perpetual motion, its denizens continuously exercise themselves. ${ }^{1}$ Galen, for a somewhat similar reason, appraises as the lowest in nutriment the inhabitants of marshes, lakes, and muddy waters, because of their lack of swimming exercise and their impure food.

A further subdivision commends itself to Rhazes. All fishes rough of scale, mucilaginous and white-coloured are best; those of a black and red shade must be avoided.2 $\mathrm{A}$ special distinguo extends to the part of fish, as Xenocrates plumps for the tails, on account of their being most exercised! Bonsuetus, centuries after Galen, echoes him :

"All fish that standing pools and lakes frequent Do ever yield bad juyce and nourishment." 3

But however divided the ancient practitioners were in their estimate of the digestibility of a fish diet, or of particular fishes, in their ichthyic remedies internal or external they credulously and enthusiastically coincided. Hence rained piscine prescriptions in every form, fresh, salt, cooked, calcined : every part and tissue, flesh, bones, skin, trail, brains, gills, viscera, and teeth-each and all were regarded as specifics against some human disease or infirmity. ${ }^{4}$

All ailments practically find a cure in the ichthyic panaceas or nostrums which render old medical tomes boresome from repetition, and yet at times diverting. In regular prescriptions and old wife recipes alike, fish play a prominent part.

Have you been bitten by a mad dog, and need a theriac? Dioscorides' recommendation, ${ }^{5}$ as amplified by Pliny, is

1 Guastiones Medica et Problemata Physica.

2 Blakey, op. cit., 73.

- Cf. Burton, op. cit., I, 97, whose trs. is given above.

- The belief in fish as curatives of not only human but also animal ailments still lingers. In this very year, I920, we read in The Field, Aug. I4, of a Ross-shire crofter begging for a live trout to push down the throat of a cow, that had just calved but was suffering from hæmorrhage. In consequence, or in spite of the trout, the cow recovered.

s Do Materia Medica, II. 33; I. I81, ed. (Kühn). 
"pickled fish applied topically, even where the wound has not been cauterised with hot iron; this will be found sufficiently effectual as a remedy"!

Do you suffer from toothache? Then you must have omitted to rub your teeth once a year in the brains of a dogfish, boiled in oil and kept for the purpose!

If, however, this and other remedies disappoint you, Dioscorides ${ }^{1}$ and Celsus ${ }^{2}$ come to your aid with the sting of the pastinaca, which, applied with hellebore or resin, extracts the teeth painlessly! As a dead certainty, if the ichthyic kingdom fail to give relief, " attach two frogs to the exterior of your jaw"!

Health, perfect health, should be the lot of every woman who follows the Plinian precepts in Book XXXII. 46 .

Is she helpless from hysteria? "Lint, greased with a dolphin's fat, and then ignited," produces an anti-excitant; or, if the case yield not to treatment instantly, "the flesh of the strombus, left to putrefy in vinegar" is an excellent alternative!

If an easy delivery be desired, "first"-the prescription smacks of Mrs. Glasse-" catch your torpedo-fish at the time that the moon is in Libra, keep it in the open air for three days," and then, as soon as it is introduced into the patient's room, the trick is done! Pregnancy, on the other hand, proves often abortive, if the woman "happens to step over castoreum or over the beaver itself," or misuses a Remora.

For dyeing the hair black calcined echineis with lard, or horse-leeches boiled in vinegar, are cheap and trustworthy recipes. For depilatories your choice is wide. The blood, gall, and liver of the Tunny, fresh or pickled; or merely the liver, pounded, but preserved with cedar-resin in a leaden box ${ }^{3}$; the Pulmo marinus, the Sea-hare, according to

1 De Materia Medica, II. 22, I, I76 (Kühn). Cf. P. A. Matthiole, Commentarii in libros sex Pedanii Dioscordis Anazarbei (Venetiis, I554), Bk. II. c. xix.

2 VI. 9.

3alpe the midwife recommends this prescription to disguise the age of boys on sale for slaves (Pliny, XXXII. 47). At the end of the chapter the author seems to awake from his trance of trustfulness, in the words, "in the case of every depilatory, the hairs should always be removed before it is applied !" 
Dioscorides (De mat. med., ii. 2o), the Scolopendra (ibid., ii. I6) ; or " the brains of the Torpedo applied with alum on the sixteenth day of the moon!"

Two more panaceas-needful and desirable now, as thenand I move to pastures new, or rather contiguous. The first : a mixture " of a live frog in a dog's food " will, on Salpe's authority, for ever deliver us from the yapping and barking which so often makes night hideous.

The second-naïvest and quaintest (if I may employ without cruelty these over-driven adjectives): "Democritus assures us that if the tongue be extracted from a live frog, with no part of the body adhering to it, and it is then applied--the frog must first be placed in the water(!)-to a woman while asleep, just at the spot where the heart is felt to beat, she will of a certainty answer truthfully any question put to her !" 1

If Hippocrates blamed his predecessors for their scanty use of drugs, he would scarcely, unless suddenly clothed with a shirt of credulity, have approved of the plethora of prescriptions and panaceas prevalent in later centuries. Truly applicable would then have been the inscription suggested for a pharmacy; "Hic venditur galbanum, elaterium, opium, et omne quod in um desinit, nisi remedium." 2

But credulity clogged such great minds as Hippocrates and Galen. Even they included astrology in the therapeutic art, and indict practitioners who only used that " science" despitefully, or eschewed it, as " men-killers."

Quite apart, however, from the recognised prose treatises by iatric writers such as Galen, Diphilus, and Xenocrates, there must have existed a very ample literature in Greek verse. One collection alone, Poetce Bucolici et Didactici (Didot, Paris, 1872 ), reveals under the heading of Carminum Medicorum Reliquice the names of some dozen authors who deal chieflyMarcellus Sidetes indeed exclusively-with the medicinal properties of fish.

1 Pliny, XXXII. I8. Belief in the efficacy of fish-nostrums continues unto this day: in the Middle Ages it permeated all classes, and all Europe, e.g. Charles IX. of France would never, if he could help it, drink unless a fragment of the tusk of the narwhal, or so-called sea-unicorn, were in the cup to counteract a possible poison.

Badham, op. cit., 83 . 
Cursory skipping of these fragments compels, even if one's acquaintance with ancient medical writers be slight, ready assent to the opinion of the learned editor (p. 74) that originality was not the dominant characteristic of their begetters. They are apparently, with two exceptions, but metrical plagiarisms or excerpts-not quite as bad as Tate and Brady's Translations of the Psalms-from the works of Galen and others.

The first exception, the medical oath (öpros iarpexós) startles our modern conceptions. The practitioner swears that he will administer none of the poisons, some of the deadliest of which, as we have seen, were piscine. ${ }^{1}$

The second is a fragment from a medical work by Marcellus Sidetes. In the days of Hadrian and Antoninus Pius, despite the stirring times described by historians, Life (to alter the well-known verse) must verily have been a watch and a vision -or rather a yawn-between a sleep and a sleep to many a reader, for no less than forty-two volumes were necessary to contain the hygienic hexameters of our author. But more astonishing even than the leisure required for their perusal, the whole forty-two (according to Suidas) were held in such high esteem that by command of the Emperors they were placed in all the public libraries of Rome.

In our fragment, Remedies from Fish, Marcellus, after prefacing that by long study he has acquainted himself with their medicinal effects, sets out a list of healing fish. He adds here and there some leading specific. To one of these he prettily makes us privy, e.g. the application of a burnt mullet, mixed with honey, in cases of carbuncle.

But our author must not be written down as a one-ideaed fish-quack; for that Nature works cures (if not miracles) by the agencies of earth, and of "broad-wayed air," as well as of the sea, is a firm tenet of his faith. ${ }^{2}$

1 The influence of fish, wherever important, in commerce is noteworthy. They furnished, as we have seen, designs for a mint or cognomina for Roman Nobles. An interesting and probably very ancient instance occurs in the oath taken this very year (I920) by the Stipendiary Magistrate of Douglas, Isle of Man: "I swear to do justice between party and party, as indifferently as the herring's backbone doth lie in the midst of the fish."

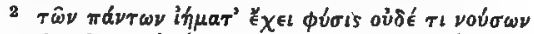

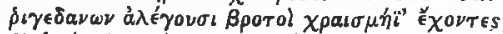

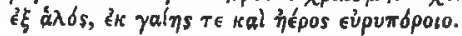


Among the Greeks and Latins aphrodisiacs and antaphrodisiacs, i.e. incentives to, or prophylactics against love, were accounted of potency, and meet with frequent mention. Each kingdom of Nature, animal, mineral, vegetable, piscine, was impressed to compass these purposes.

The list submitted by Pliny-a weighty natural historian, mark you ! - of those drawn from the first would be scouted by any modern Obeah or Ju-ju man, however powerful, as taxing too severely the credulity of his ignorant clientele. Even Haitian superstition would reject its obvious absurdities. "The ashes of a spotted lizard"-here even the compiler is compelled to caution "si verum est '- "held in the left hand stimulate, but in the right kill desire," ranks far from being the most incredible of the prescriptions. 1

The Ancients specialised not only in gods, but also in fishes which made, or made not, for passion. We, however, while enjoying a hundred sects, have brutally boiled down our aphrodisiacs to one, stout and oysters!

The salacious properties of many fishes-inherited or acquired, according to ancient legends, from their mother or protectress, Aphrodite-furnish the theme of classical authors, grave and gay; e.g. ' Ef Epicharmus in Hebe's Wedding-at wedding feasts fish were an absolute essential; of Varro, ${ }^{2}$ tunc nuptice videbant ostream Lucrinam; of Plautus, ${ }^{3}$ where at the marriage of Olympio the old man in love orders the purchase of stimulating fish.

"Emito sepiolas, lopadas, loligunculas."

Even Pythagoras, according to Lilius Giraldus, believed that cupidity could be aroused, not by fish, which were apparently banned to his disciples, but by Urtica marina. ${ }^{4}$

Pliny's list of proved aphrodisiacs and antaphrodisiacs includes among the former "the eye-tooth of a crocodile attached to the arm," and among the latter " the skin from the left side of the forehead of the hippopotamus attached fast to the body in lambskin." 5

' $N . H .$, XXX. 49. Cf. Elian, op. cit. passim, for aphrodisiacs.

¿ Fragment, Varro Sexagesis, ap. Man. Marc., p. 319 . 15 ff., Lindsay.

a Cas., II. 8, 57; cf. also $A$ ul., at the wedding of Euclid's daughter.

- See ibid., Rudens, II. I, 9.

b $N$. $H$., XXXII. $5^{\circ}$. 


\section{CHAPTER XX}

\section{DIOCLETIAN'S EDICT, 3OI A.D.-PRICES OF FISH AND OTHER ARTICLES THEN AND NOW}

STRUCK with Adam's words with regard to the Edict of Diocletian, 30I A.D.- " if we could fix the value of the denarius at this epoch, the prices of fish then would prove an interesting subject for comparison with those now (I883) current at Billingsgate" - I set to work to ascertain how great had been the depreciation of and what was the exact value of the denarius at the opening of the fourth century.

Much labour would have been saved, had I earlier come across Abbott's The Common People of Ancient Rome, but I found some compensation in the solution of my sum coinciding approximately with his estimate of the denarius $={ }^{\circ} 4352$ cent. ${ }^{1}$

The Edict of Diocletian ${ }^{2}$ contains, as Mr. Abbott (to whose book I am indebted for very much that follows) indicates, many points of great economic interest to us at the present time.

First-sentences of the Introduction (probably from intrinsic evidence written by the Emperor himself) might well pass for a diatribe in to-day's paper against a Beef or other Trust. Fortunate it is for these that the newspaper man possesses not the power of life and death wielded by Diocletian.

1 London, Igr2. Note, however, that Hultsch in Pauly-Winowa, Realenc. (Stuttgart, I903), V. 2 II, says: 'Damit war aus dem Silber-D., der noch unter Severus einen Metallwert von etwa 30 Pfennig gehabt hatte . . . eine kleine Scheidemünze zum Curswerte von I, 8 Pfennig oder Weniger geworden." On this showing the denarius had sunk to I

2 Fragments of the Edict in Latin and in Greek have been coming to light for the last two centuries from Egypt, Greece and Asia Minor-not the least important being found by W. M. Leake; see his Edict of Diocletian, 1826 . See also Mommsen's Inscriptionum Latinarum, vol. III. Pp. I926-I953, the text of which was published by $\mathrm{H}$. Blïmner with a commentary in $\mathrm{I} 893$ in his Der Maximaltarif des Diocletian. A convenient account of this famous Edict, together with a full bibliography, is given by H. Blümner in Pauly. Winowa, Real. Enc. (Stuttgart), V. pp. 1948-1957. 


\section{DIOCLETIAN'S EDICT-PRICES THEN AND NOW}

The Emperor, having decided that the prices promulgated shall be observed in "all our domain," goes on, "it is our pleasure that if any shall have boldly come into conflict with this formal statute, he shall put his life in peril. In the same peril also shall he be placed, who, drawn by avarice in his desire to buy, shall have conspired against these statutes. Nor shall he be esteemed innocent of the same crime who, having articles necessary for daily life and use, shall have decided that they can be held back, since the punishment ought to be even heavier for him who causes need, than for him who violates laws."

Second-the prices are maximum prices, not for commodities only, but also for wages.

Third-although the number of slaves owned had decreased since Augustan days, the scale of wages was still distinctly affected by slaves being hired out by their owners for day or job work.

Fourth - the absence of power being applied to manufacture, of the assemblage of men in a common workshop, and of the use of any other machines than the hand loom, or the mill for grinding corn.

Fifth-for the urban workman in the fourth century (as Mr. Abbott, p. I76, demonstrates), conditions of life must have been almost intolerable. It is indeed hard to understand how he managed to keep body and soul together, when almost all the nutritious articles of food were beyond his reach. "The taste of meat, fish, butter, and eggs must have been almost unknown to him, and even the coarse bread and vegetables on which he lived were probably limited in amount. The peasant proprietor who raised his own cattle and grain would not find the burden so hard."

Sixth-the failure within a dozen years of the Emperor's bold attempt to reduce the cost of living. Lactantius, ${ }^{1}$ writing in 3I3-I4, sums up the result of this interference with economic check and countercheck - "for the veriest trifles much blood was shed, and out of fear nothing was offered for sale, and the scarcity grew much worse, until after the death

1 Lactantius, de mortibus persecutorum. 7 . 
of many persons the law was repealed from necessity." Sixty years later the Emperor Julian made a similar but smaller attempt to control prices, but the corn speculators of Antioch so entirely worsted him that he had to acknowledge defeat.

By the courtesy of the Secretary of the Fishmongers' Company I was furnished, with some average wholesale prices for I9I3, the last year unaffected by the war. The consumer, it must be remembered, is compelled, in general, to pay the retailer one-third per $\mathrm{lb}$. more to defray handling, rent, etc.

The following sea fish were sold in London, per lb., as

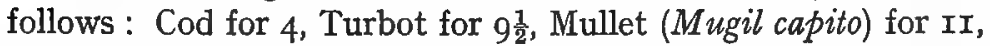
Sole for I7 pence. In the Edict the price of fresh sea fish is lumped at from $4 \frac{1}{2}$ to 7 pence, so we have no datum for comparison of individual prices. In the case of the Mugil capito, however, we are enabled to contrast its price, i.e. II pence, with that in Egypt, c. I200 B.C., i.e. ${ }_{20}^{9}$ of a penny. ${ }^{1}$

A comparison with America in I 906 shows that the average price of fresh sea fish was from $4 d$. to $7 d$. per lb., or practically the same as in Diocletian's time, while that of river fishfresh-per lb. was 6 to $7 \frac{1}{2}$ as against $3 \frac{3}{4}$ pence in the Edict. ${ }^{2}$

Salt fish, per 1b. in 301 A.D. cost $4 \frac{1}{4} d$., in U.S.A. $4 d$. to $7 \frac{1}{2} d$.

Oysters (by the Ioo), Is. Iod., (in London) $4 /-$ to I4/-.

The figures show that prices of other commodities in the Edict vary extremely, but for sea fish are not far apart.

From the articles of raw material and manufactured wares, which number in the Edict over eight hundred, and from the wages, etc., I subjoin some items and prices on account of their general interest. ${ }^{3}$

\section{Price in-}

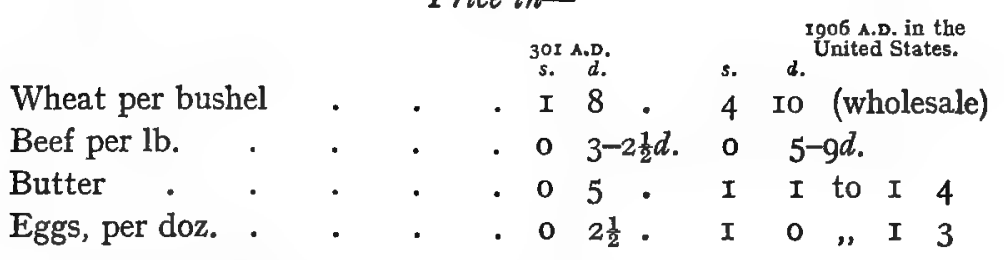

1 See p. 337 , postea.

2 The lower price of river as compared with sea fish seems additional evidence that the preference for the latter, well attested in the earlier days of Athens and of Rome, still continued.

From p. I74 ff. of Abbott, who gives the prices in cents. 


\section{Wages per Day.}

s. A.D.

Unskilled Workman o $5 \frac{1}{4}$ receives keep.

Carpenter - . O I0 $\frac{1}{2}$ " , Painter
1906 A.D.in the United

Stales.

$5 /-$ to $9 /-$ (8 hours)

Io/- to $16 /-\quad$,

II/ to I6/- ,

I add a few other prices, without attempting in these years of the ever-climbing wave of cost to give the corresponding modern quotations.

Fowl

Snails (per score)

Asparagus (25 to the bunch)

Apples (best, Io)

Barber

Tailor (for cutting out and finishing best over garment) . . . . . . . . 0 . 0 I $1 \frac{1}{4}$ Elementary Teacher (per pupil per month) . . $\begin{array}{llll} & 0 & 0 & \text { ro } \frac{1}{4}\end{array}$ Writing $6 \quad$ s. $d$.

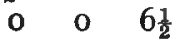
Greek, Latin, or Geometry (per pupil per month) • $\begin{array}{lll}0 & 3 & 7\end{array}$ Advocate for presenting a case . . . . . $\begin{array}{llll}0 & 0 & 4\end{array}$

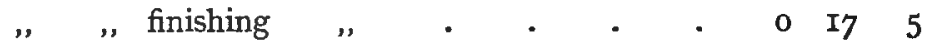
Watcher of Clothes in public baths (for each patron) $\quad$ o $\quad 0 \quad 4 \frac{1}{2}$ Patricians' shoes (per pair) . • . . . 0229 Boots (Women's) ", . . . . . . . 0 o I I ". (Soldiers', without nails) . . . . . 0 I I0 $\frac{1}{2}$ Transportation (I person, I mile) . . . . . $0004 \frac{1}{2}$ Waggon (I mile) White Silk (per lb.) . . . . . . . Io Io 0 Genuine Purple Silk (per lb.) . . . . I30 1о 0 Washed Tarentine Wool (per lb.) . . . . 03 I Ordinary washed Wool from $5 \frac{1}{2}$ to $I I d$. 


\section{CHAPTER XXI}

\section{DIFFERENCE BETWEEN ROMAN AND MODERN PISCICULTURE}

WITH the opinion held by some, that the method of breeding fish employed by the Romans was practically the same as that of the modern Pisciculturists, Badham ' seems to agree, when he remarks: "The plan of stocking rivers with fish $a b$ ovo has been, after the lapse of many centuries, revived by two Vosges fishermen, Gehin and Rémy," and "they have thus re-established a very ancient practice, and succeeded in stocking the streams of France."

But this is a total misconception. It can only have arisen from ignorance either of what is found in Latin writers, such as Columella, or of what is the nature of the method used by Rémy and, with great improvements, by present Pisciculturists.

Shortly, the Roman method collected from the bottom of a river or a marsh eggs, already fertilised in the natural manner by fish, and removed them to other lakes or vivaria.

Rémy and his successors catch and strip the females of their eggs; which are pressed out into a pan. They then extrude the milt of the male on to the eggs, in a proportion, differing according to what fish are being spawned, of one male to one or more female. They next place the eggs on perforated wire or other trays fixed in long boxes, over and under which water of a regulated temperature passes. ${ }^{2}$

Op. cit.. p. $4^{8}$.

2 In the case of Trout, the ova can be successfully transported to South Africa or even to New Zealand, as the period of incubation is a long one. After hatching, the alevins, fry, or young fish can be utilised to stock fish ponds, or other waters. 
The erroneous view of those of Badham's school needs correction. By tracing historically the various and not generally known discoveries which led to our modern practice of fish-breeding I hope to prove that the process of the Romans differed from ours. For this reason I subjoin a short résumé showing why and how Pisciculture as we term it and know it came about. 1

The same demand for fish, the same dearth of fish, which compelled the enactment in mediæval Europe of stringent laws protecting fish, spawn, and fry, caused in ancient China and Imperial Rome the breeding of fish in lakes and vivaria by non-natural methods, and in Europe from the fourteenth to the nineteenth century the quest of an unnatural or artificial method.

Laws aimed at repairing the dearth of fish-a very serious economic matter when all Europe observed frequent fast days-caused by destruction of spawn and of fish during the breeding seasons by human and animal agencies, were made in England as early as the reign of our Ethelred II., who in 996 forbade the sale of any young fish. ${ }^{2}$ Malcolm II. of Scotland fixed the times and conditions under which salmon fishing was permitted. Under Robert $I$. the willow of the bow-nets had to be two inches apart, so as to allow a passage for the grilse. In I4II Robert III. punished with death anyone taking a salmon in the close season. The Kings of France were not idle. Many ordinances fix the meshes of the nets and the length of saleable fish.

The first known attempts at fish-breeding were made by the Chinese and Romans. M. Haime asserts that "we have no positive data as to the epoch in which the Chinese began their experiments, although everything shows that they reach back to the most remote antiquity." The address of Mr. Wei-Ching Haime.

$1 \mathrm{Cf}$. an article in the Revue des deux Mondes, for June, I854, by M. Jules

2 According to Magna Carta, c. 33, " all kydells [dams or weirs] for the future shall be removed altogether from the Thames and the Medway, and throughout all England, except on the sea-shore."

It was for over $5^{00}$ years held that this was a measure intended to safeguard the passage of fish, but W. S. McKechnie, Magna Carta (Glasgow, I $9 \mathrm{r}_{4}$ ) pp. $303 \mathrm{ff}$., $343 \mathrm{ff}$., has shown that it aimed at removing hindrances to navigation, not to ascending fish. 
W. Yen dates the epoch as probably that of Tao Chu Kung, who lived in the fifth century B.c. ${ }^{1}$

In Rome considerable trade was done in the sale of young fish for stocking waters. In China the commerce in fish eggs was on a vast scale and extremely lucrative. The Jesuit missionary Du Halde writes, " Le gain va souvent au centuple de la dépense, car le Peuple se nourrit en partie de Poissons."

The method, however, of both the Chinese and the Romans was to gather eggs, already naturally fertilised, lying at the bottom of, or adhering to weeds in, the water. The Chinese went farther by employing special traps of hurdles and mats to bar the rivers and catch the eggs deposited on these.

During the long interval between the Roman Empire and the eighteenth century, we note little or no progress in the rearing of fish, although preserves became numerous in Italy and France. Kings and nobles were zealous and jealous in making and maintaining artificial ponds. Charlemagne the Great personally ordered the repairing of old and digging of new ponds. By sales from their vivaria, and by heavy royalties from their fisheries the religious communities amassed large revenues.

Towards the end of the Middle Ages new methods to counter the scarcity universally prevalent, despite the teaching in the thirteenth century of Peter qf Vescenza, were eagerly sought. Dom Pinchon, a monk of the Abbey of Réome, seems the first to have conceived the idea of artificially fecundating the eggs of trout. He pressed out in turn the milt of a male and the eggs of a female into water, which he then agitated with his finger. He placed the resulting eggs in a wooden box, with a layer of fine sand on the bottom, and a willow grating above and at the two ends. The box till the moment of hatching was immersed in water flowing with a gentle stream.

The process-described in a manuscript dated I420, but not published till about I850-naturally led to no practical results. Consequently Pinchon's claim to be the father of

1 Op. cit., 376, but see Chinese chapter.

2 History of the Chinese Empire (Paris, I735), vol. I. p. 36. 
modern Pisciculture-a term first used some three hundred years after his death—can hardly be sustained. His discoveries interest only from a historical point of view.

The middle of the eighteenth century witnessed an improvement on Pinchon's plan. In Sweden (where the care taken to protect fish even prohibited the ringing of bells at the spawning season) the bream, perch, and mullet attach their eggs either to rocks, or twigs of pine.

Lund shut up males and females for three or four days in three boxes, furnished with twigs of pine, etc. (on which the fish spawned), and pierced with little holes to allow the entrance of water. He succeeded at his first attempt in raising from 50 female bream, 3,I00,000 fry; from Ioo perch, 3,215,000 fry ; and from roo mullet, 4,000,000 fry.

Jacobi of Westphalia, the first real inventor of practical fecundation by artificial means, experimented on trout and salmon for sixteen years before attaining definite success.

He pressed in turn the eggs and milt into a vase half filled with water which he kept gently stirred with his hand. The fertilised eggs were at once placed in a grated box inside a larger chest, in which Jacobi had inserted at the sides and at the top fine metallic gratings to allow the easy flow in and out of water over the sand or gravel lying at the bottom. The apparatus was set in a trench by the side of a brook, or, better still, in an artificial channel into which springs were led. The young fish after hatching lived for three or four weeks on their umbilical sac, and were then passed into a reservoir.

By these simple means Jacobi, who for his services was granted by England a pension for life, solved the problem of protecting fertilised eggs against their enemies, and yet of leaving them in surroundings not unlike those of Nature. The experiment, as far as it went, succeeded admirably.

In Great Britain I Shaw, Andrew, Young, Knox, and Boccius, and in Germany, Blooch, and others carried on, at various times and with varying methods and measures of

1 Leonard Mascall, owing to his recipes for preserving spawn in his Booke of Fishing I590, "must be looked upon as the pioneer of fish-culture in England," according to Mr. R. B. Marston, op. cit., 35. 
success. In France little or nothing was done, except by Quatrefages, till we reach the two peasants, Rémy and Gehin, whose labours laid firm the foundation on which all subsequent Pisciculturists have built.

In 1849 the Academy of Sciences learned that a prize had been granted in 1845 by the Society of the Vosges to two fishermen of La Bresse, Rémy and Gehin, for having fertilised and artificially hatched eggs from trout, and for having raised some five to six thousand trout from one to three years old, which continued to thrive in the waters in which they were confined.

On investigation by the Academy, it was found that Rémy and Gehin (who came in later) had been led from conclusions based entirely on their own observations (for " they are quite unlettered and ignorant of the progress of the Natural Sciences ") to employ with success methods rather similar, but superior, to those of Jacobi.

They had enormously decreased the high mortality by their greatest and probably unique achievement, i.e. provision for the fry of a natural food. This was produced by the simultaneous rearing of a smaller and non-cannibal species, and by the collection in the enclosed streams or made waterways into which the young trout were liberated of hundreds of frogs, whose spawn afforded an excellent subsistence.

Jacobi's and Rémy's discovery was the parent of our modern Pisciculture. The gear and apparatus, especially in America, have been transformed. The methods of stripping, of hatching, of feeding are enormously improved, with mortality in eggs and fry incredibly reduced.

From this account of their discoveries and from the nature of the methods now in use, it is obvious that the suggestion of Badham and others that the method of breeding fish employed by modern Pisciculturists was practically that of the Romans must go by the board. 


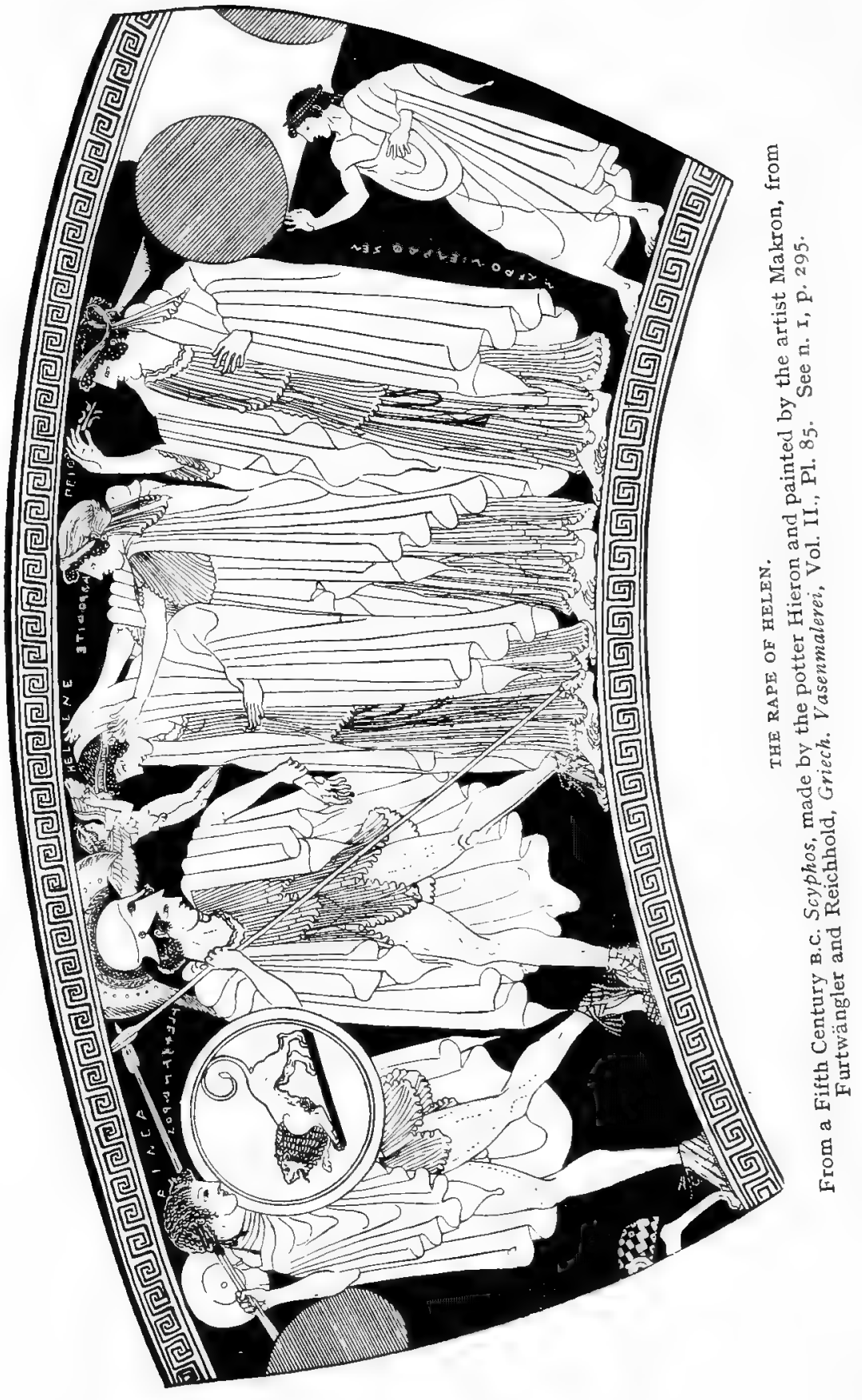




\section{CHAPTER XXII}

\section{THE RING OF HELEN}

In the countries dealt with in this book I give instances where Fish and Fishing have, according to myth or tradition, played a prominent part in human affairs, and have been the cause, direct or indirect, of important events.

Thus in Greece and Rome, to fish is assigned the responsibility for-

(A) The death of Homer, from his inability to solve the riddle of the lads. ${ }^{2}$

(B) The death of Theodoric, who recognised in the head of a pike which he was eating the head of his murdered victim, Symmachus. ${ }^{3}$

(C) No less an event than the Trojan War, which, according to the windbag Ptolemy Hephæstion, happened on this wise.

In the belly of a huge fish named $\mathrm{Pan}$ (from its resemblance to that god) was found a gem (asterites), which when exposed to the sun shot forth flames and became a powerful love philtre. Helen, on acquiring this, had it engraved with a figure of the Pan fish, and when desirous of making a special impression wore it as a signet ring.

Thus, when Paris visited Sparta the charm blazed from her finger with the result of the immediate conquest of Paris, the flight from Menelaus, and the Ten Years' War!

But, despite Homer, it was discovered (!) afterwards that

1. From a splendid vase-painting representing the two sides of a magnificent scyphos made by the potter Hieron and painted by the artist Makron. The original (now in Boston) is of the finest fifth-century (B.c.) art. See Furtwängler and Reichhold, Griechische Vasensnalevei (München, Igog), vol. II. 125 ff., pl. 85 .

2 See Chapter III.

- See antea, p. 200. 


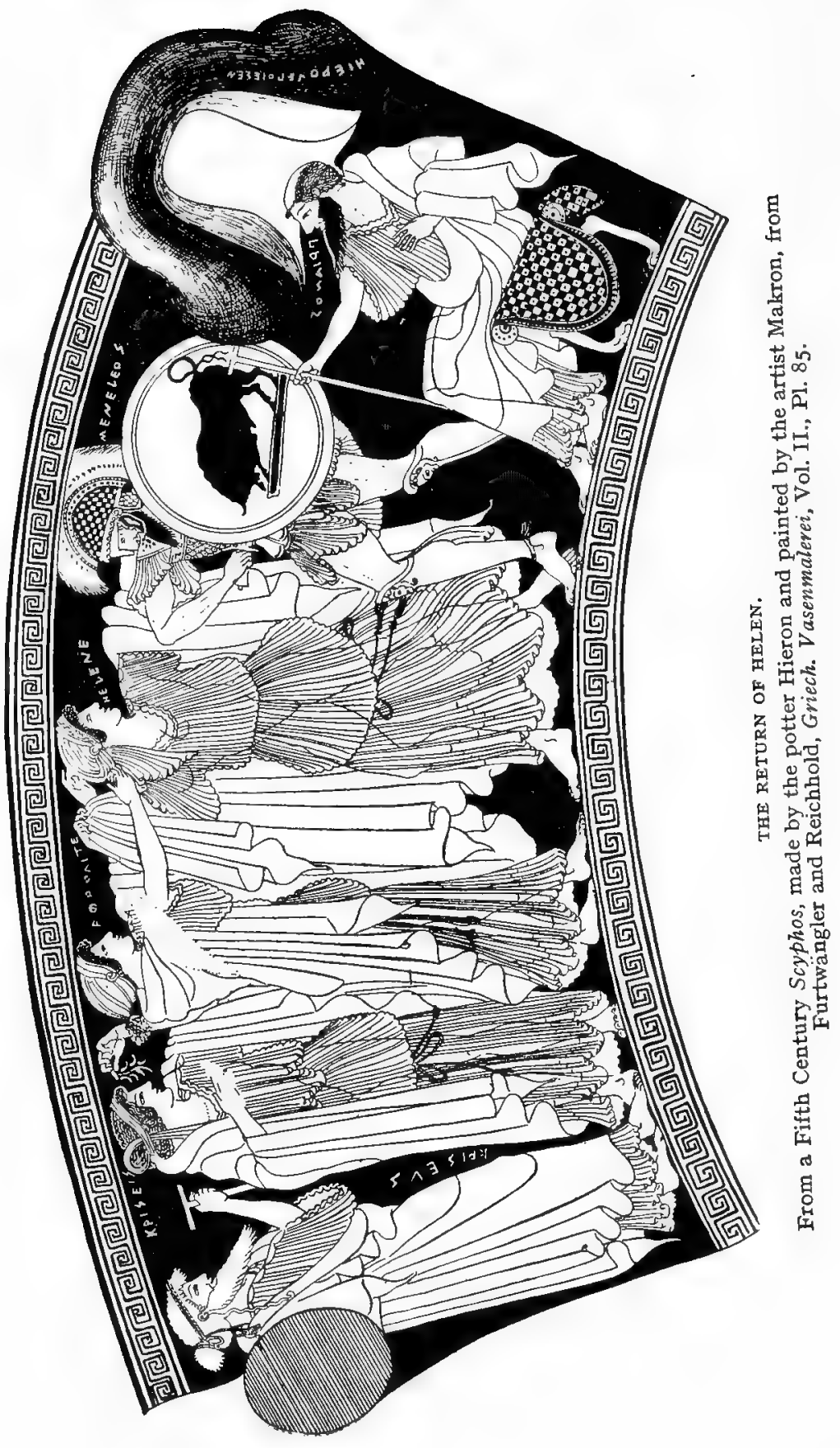


Helen was not in Ilium at any time during the siege, and that what the Trojans harboured was not her real self, but only

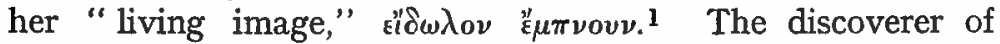
this interesting fact was (so ran the slander) Stesichorus. Struck with blindness after writing an attack on Helen, he recovered his sight by composing a Palinodia. ${ }^{2}$ The ghost of Achilles, when raised by that most famous medium of antiquity, Apollonius of Tyana, denied positively that Helen was in Ilium. ${ }^{3}$

If Mr. J. A. Symonds be right, "We fought for fame and Priam"s wealth," and for naught else, then she "with the star-like sorrows of immortal eyes " was neither causa causans nor any cause of the Fall of Troy. Perhaps " Priam's wealth " is but an intelligent anticipation of Mr. Leaf's theory that the War was fought for "The Freedom of the Sea " (Euxine), and, incidentally, the capture of another nation's profits.

3 Eurip., Hel., 34 .

2 Plat., Phardi., 243A ; Isokr., Hel., 65; Pausaniäs, III. I9, r3.

3 Op. cit., IV. I6. In his palinode, of which a few lines (frag. 32, Bergk ${ }^{4}$ ) are extant, Stesichorus asserts that it was not Helen herself, but only her semblance or wraith, which Paris carried off to Troy. Greeks and Trojans slew one another for a mere phantom, while the real Helen never left Sparta. Hdt., 2, II2 ff., gives a rather different turn to the story. According to him, Helen eloped from Sparta with Paris, but was driven back by a storm to Egypt, where Paris told lies and was punished by Proteus. Euripides in his Helena combines the two versions. Iike Stesichorus, he makes the truant a mere phantom, an 'eloping angel,' Like Herodotus, he sends the real Helen to Egypt. Menelaus, who, escorting the phantom home from Troy, arrives in Egypt, is there confronted with the real Helen and is sadly puzzled. Just as he begins to think himself a bigamist, the misty Helen evaporates ! 



\section{EGYPTIAN FISHING}




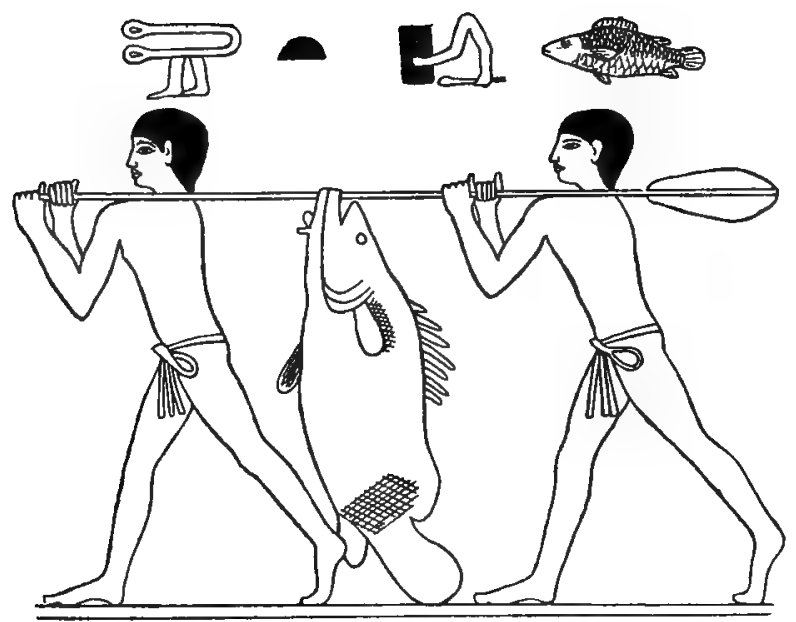

MEN CARRYING A LARGE FISH.

From Petrie's Medum, Pl. XII. See n. I, p. zoI.

\section{NOTE}

Conflicting chronologies prevent the definite dating of the earlier Egyptian monarchs: verily a thousand years are but as yesterday in the sight of Manetho, Mariette et cie. Thus it is that the reign of Menes, the first historical king, has no permanent abiding place in the 3167 years between 5867 and 2700 B.C. Discrepancy in dates is not confined to the older or later computators, such as Champollion-Figeac, Wilkinson, Lepsius, and Petrie, but has infected quite recent writers, like Borchardt and Albright, who in IgI7 and in I9I9 respectively place Menes c. 4500, and c. 2900 B.C.

If the authorities disagree as to the dates of the Old, Middle, and New Kingdoms (the divisions used in my pages), they agree fairly well on what Dynasties are comprised in each of these. So whether a reader adhere to 5867 or to 2700 B.C. for Menes, the Old Kingdom still comprises Dynasties I. to XI. ; the Middle Kingdom Dynasties XII. to XVI.; the New Kingdom Dynasty XVII. to Alexander the Great or 332 B.C., at which stage the Ptolemies came on the scene. 


\title{
EGYPTIAN FISHING ${ }^{1}$
}

\section{CHAPTER XXIII}

\author{
"THE NILE IS EGYPT"
}

This terse epigram seems foreshadowed by Homer, who calls

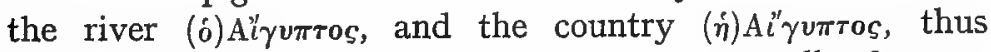
indicating correctly that Egypt is only the Nile valley. ${ }^{2}$

The all importance of the river to the country meets early and general recognition. In a hymn ${ }^{3}$ it is lauded as " the creator of all things good": solemn rituals from the earliest down to Mohammedan times implored "a good Nile" : temples in its honour existed at Memphis, Heliopolis, and Nilopolis: at Silsileh ceremonies and sacrifices, ${ }^{4}$ from time immemorial, welcomed its annual rise ; magnificent festivals were universal throughout the land. ${ }^{5}$ Petrie.

1 The illustration is reproduced by the kind permission of Prof. Flinders

1 The data for this essay had been collected and half of it written, when I heard of an article on Ancient Egyptian Fishing by Mr. Oric Bates, in Havvard African Studies, Cambridge, Massachusetts, I9I7. While somewhat disappointed of not being the first to write in English on the subject, I was quickly reconciled by the fact that the task had fallen to an experienced Egyptologist, whose monograph, while making necessary the recasting of this chapter, bequeathed to me some new, if not always convincing theories, and much technical and other data, the frequent use of which I gladly acknowledge.

2 Od., IV. 477 , and XVII. 448 . In Th. 338 of Hesiod, who, though not a contemporary, flourished shortly after Homer, $\delta$ Neînos first appears. The Egyptians called it $H a p i$, but in the vernacular language $Y$ etor, or $Y e-o r=$ the River, or Yaro=the great River.

8 Papyrus Salliey, II. On the other hand, another hymn speaks of the unkindness of the Nile in bringing about the destruction of fish, but it is the river at its lowest (first half of June) that is meant. See Records of the Past, being English translations of ancient monuments of Egypt and Western Asia (ed. S. Birch, vols. I.-XII. I873-8I), IV. 3, and ibid., new series (A. H. Sayce), III. 5 I.

${ }_{4}$ The yearly sacrifice of a virgin at Memphis may be doubted-at least for the Christian age of Egypt, to which Arab writers wish to attribute it.

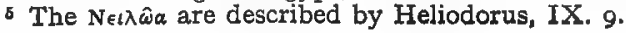


To Egypt, river or country, goes out the undying reverence of all Anglers. Whether Egyptian or the Sumerian civilisation were the older; which of the two have left the earlier signs of a written language 1; whether the Egyptian surpassed the Assyrian empire in extent or magnificence-about all these points " disquisitions" (in Walton's word) have not ceased.

But to Egypt belongs the glory of holding in future and happy thrall world-wide subjects, who salute, or rather should salute (had previous writers not been reticent on the point) her (and not Assyria) as the historical mistress and foundress of the art of Angling.

In my Assyrian and Jewish chapters I stress the remarkable absence, despite the close and long connections of these nations with the land of the Nile, of anything graven or written which indicates knowledge of the Rod. In Egypt two instances of Angling are depicted: the first ${ }^{2}$ probably (to judge by his place on the register) by a servant or fishing-ghillie as early as c. 2000 B.C., the second by a magnate some 600 years later. ${ }^{3}$

The argument of silence--because a thing is not depicted or mentioned it therefore never existed-often pushes itself unjustifiably. May not absence of the Rod be an instance? Had Mesopotamia (it may be further urged) been endowed with the atmospherical dryness of Egypt and the consequent preservative qualities of its soil instead of a widely-spread marsh-engendered humidity, would not scenes of Angling there probably meet our eyes? Humidity may account for great losses in Mesopotamia, but its toll in the Delta of Egypt was also heavy. This large area has yielded, compared with the Upper Kingdom, inappreciable returns.

But even if the country of the Two Rivers had possessed the same climatic conditions as the Upper Kingdom, it could never have become to the same extent the historical storehouse for posterity of the works and records of ancient Man.

1 J. H Breasted, A History of the Ancient Egyptians, 1908, p. 47, declares that the Egyptians discovered true alphabetical letters 2500 years before any other people, and the calendar as early as $424 \mathrm{I}$ B.C.

2 P. E. Newberry, Beni Hasan (London, r893), Plate XXIX. Cf. Lepsius, Denk. Abt., 2, Bl. 127; J. G. Wilkinson, Manners and Customs of the Ancient Egyptians (London, I878), p. I 16, pl. 37 r.

Itid., loc. cit., pl. $37^{\circ}$. 
Difference in religious belief, for one thing, precluded. The Sumerians, the first settlers recognised by history in the plains of Shinar, conceived (as did their successors the Babylonians and Assyrians) the next world to be a forbidding place of darkness and dust beneath the earth, to which all, both good and bad, descended. Hence burial under the court of a house or the floor of a room, often without any tomb or coffin, or much equipment for the life beyond the grave, was sufficient.

In belief and equipment the Egyptians differed toto orbe. For them after death. was preordained a life to obtain which the body must be preserved from destruction; otherwise it hastened to dissolution and second death, i.e. annihilation. To avoid this fate, they resorted to permanent tombs, embalmment, and mummification.

But as the Double, or $K a$, of the departed (unlike the Soul, or $B a$, which fared forth to follow the gods) never quitted the place where the mummy rested, daily offerings of food and drink for its sustenance had to be placed in the chapel chamber of the richer tombs. Sooner or later came the time when for reasons of expense, or other, the dead of former generations found themselves neglected, and the $K a$ was reduced to seeking his food in the refuse of the town. To obviate such a desecration, and ensure that the offerings consecrated on the day of burial might for all time preserve their virtue, the mourners hit upon the idea of drawing and describing them on the walls of the chapel.

Furthermore to make homelike and familiar his new abode, or the "Eternal House" (in contrast to which the houses of the living were but wayside inns) elaborate precautions were taken. We find depicted on the walls of the chapel the lord of the domain, surrounded by sights and pursuits familiar to him when alive. "The Master in his tomb," writes Maspero, "superintends the preliminary operations necessary to raise the food by which he is to be nourished in the form of funerary offerings: scenes and implements of sowing, harvesting, hunting, fishing meet his eye."

From these representations of actual life, intended for the comfort of the dead, we, the living, are enabled not only to 
reconstruct in part the manner and social economy of the Ancient Egyptians, but also to gather, aided by excavated tackle, fairly accurate knowledge of their various devices for catching fish. And so to the religious conception which fostered the adornment of the tombs the gratitude of all fishermen is due, and should be deep.

If the god Hapi, who is represented with the girdle of a fisherman round his loins, and bearing lotus flowers, fowl, and fish, was hymned by the people as "the Creator of all things good," to the Father of Rivers 1 the Father of History renders tribute for his gift of one " thing good " which furnished to all, bar kings and priests, a stable and staple food, fish.

Its economic importance can hardly be over-rated. Testimony as to its cheapness and abundance is not wanting. Of such is the wail of the poorer folk that the price of corn might be that of fish. ${ }^{2}$ Not less impressive rings the plaint of wandering Israel-even heaven-sent manna apparently palls ! - "we remember the fish we did eat in Egypt for naught." The Egyptians accounted the fish plague, next to the death of the firstborn, as direst in result.

Confirmatory witnesses are Diodorus Siculus, who notes the great number and the many varieties of fish found in the Nile, ${ }^{3}$ and Elian, who neatly and truly characterises the aftermath of the annual inundation as "a harvest of fish." 4 Evidence, again, of "a plenty" of fish, its pursuit, and its copious consumption fronts us in the prehistoric kitchenmiddens and in the bone or horn harpoons of pre-dynastic graves. Later, the frequent tomb fishing-scenes and some textual notices attest absence of dearth.

The numerous slate palettes in the pre-dynastic graves furnish Mr. Bates with further proof, and with a new theory,

1 The Nile is the second longest river in the world (Perthes, Taschen Atlas). The Egyptians believed that it sprang from four sources at the twelfth gate of the nether world, at a place described in ch. I 46 of the Book of the Dead, and that it came to light at the two whirlpools of the first cataract.

2 Brugsch., Dict. Supplem., I9I 5. Cf. Stele de l'an VIII. de Rameses II., by Ahmed Bey Kamal (Rec. trav., etc., vol. 3o, pp. 2I6-2I7). The King, as an instance of how well his workmen are provided for, cites the fact that special fishermen are allotted to them.

s I. 36 .

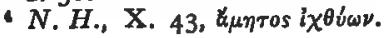


which seems to me, if ingenious, too ingenuous and too farfetched.

The palettes, ${ }^{1}$ almost invariably presenting the profile of only those fishes, birds, or beasts that historic men pursued for food, were intended (by the aid of colours extracted from the malachite, galena, etc., crushed upon them) to establish an unpalpable, but, in human eyes, very serviceable connection between the fisher and his prey.

One method of such connection consists in creating a likeness of the intended quarry. Such a likeness, by the belief that the simulacrum is actively en rapport with that which it represents, bestows on the possessor power over the original. "Cases," Bates correctly adds, " of this sort are the commonplaces of imitative magic." Usually a hunting or fishing amulet which simulates the form of the quarry was worn by the owner, or attached to his gear.

The palettes themselves played the part of mere paintstones, but their supposed resident power might very efficaciously be transferred to its proprietor by means of the paint ground upon it.

"Persons who go in pursuit of the crocodile," says Pliny, " anoint themselves with its fat." 2 In the same way as the crocodile-hunter thus assimilates himself to his quarry by a direct contagion, so the owner of the palette could possess himself of the power in the slate likeness by painting himself with the " medicine" ground upon it.

The validity, or otherwise, of the suggestion must be determined by expert mythologists. The theory, to my mind, appears too far-fetched, and breaks down from the introduction of an additional agency.

The fisher wearing an amulet or attaching a charm to his tackle, and the fat-anointed crocodile hunter both supposedly have direct connection with his quest.

But Bates's solution demands four agents at work, the fisher, the prey, the portrayed profile of the latter, and the palette; from these the fisher extracts the desired power by 
decorating himself with the paint made out of a fifth agency, the galena, etc. Here exists no direct contagion as with the crocodile hunter, or direct connection as with the amuletwearing piscator. That such early men as the pre-dynastics, though possessed of no insignificant a culture, should reason by causation at a fifth remove, seems lacking in probability, especially in a matter of primitive semi-religious belief, which is ever slow, ever resentful of change. 


\section{CHAPTER XXIV}

\section{TACKLE}

"I tell you that the fisherman suffers more than any other. Consider, is he not toiling on the River? He is mixed up with the crocodiles: should the clumps of papyrus give way, then he shouts for help." 1

Now let us see by what implements and devices this "plenty of fish " was made to pay toll.

The documentary evidence on Egyptian fishing is so slight and fragmentary that were it not for extant implements and representations of fishing scenes its technical history could not be reconstructed even partially. The implements carry us back to about the beginning of the pre-dynastic age, and constitute our principal source of information regarding Nilotic fishing.

But from the beginning of the Old Kingdom until the Roman period the material remains dwindle, while the tomb scenes increase in importance. Later-perhaps in part owing to the changes in the interests of the Egyptian artist--the implements themselves again become of prime significance. ${ }^{2}$

It is impossible in Egypt, or elsewhere, to allot definite priority to Spear (or Harpoon), Net, Hook and Line, or Rod. The fact that all four methods were $c .2000$ B.c. in synchronous use establishes merely a date a quo, a date which indicates (if a first appearance really prove anything) that Egypt in Angling by over a thousand years precedes China, where the earliest mention occurs, c. 900 B.c. ${ }^{3}$

The Spear and the Harpoon, with their cousin the Bident,

1 The Scribe on the Praise of Learning. Cf. Maspero, Le Genre epistolaire chez les Égyptiens (1872), p. 48.

2 Bates, p. I99.

see Chinese Chapter. 
concern us first. Of the Trident there seems to be neither example or representation. Priority of use may possibly be

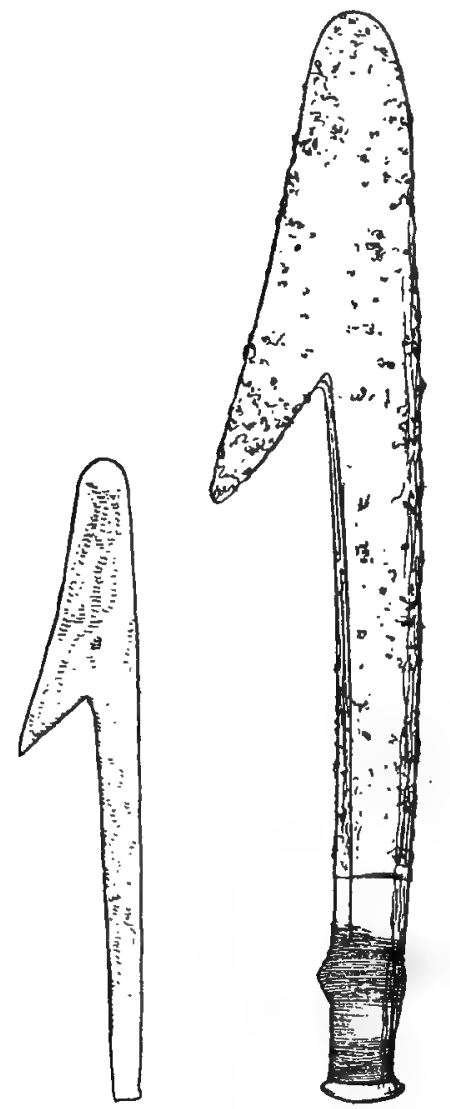

EARLY HARPOON,

See note I. conceded to the Spear in Palæolithic times. The fact that in Egypt we are dealing with an age, the Copper, separated from the Palæolithic by the New Stone era, prevents even a guess as to priority on the Nile. Egypt, it is true, bequeaths us the oldest historical as apart from archæological data, but these are merely great-greatgrandchildren of the débris data of France, and comparatively modern.

Then again, in Europe the Harpoon was rarely combined with objects of the Copper Age, in Egypt frequently.

The Harpoon has been divided by Bates, but, I think, somewhat needlessly, into two types.

(I) A spear barbed unilaterally or bilaterally.

(2) A similar Spear which has its head so socketed as to come free from the shaft when the object has been struck, the quarry being thereafter retrieved by means of a line made fast to the head itself.

One of the simplest specimens is, perhaps, that figured by Reisner, 1 while two by Petrie ${ }^{2}$ are, though probably predynastic, of more elaborate workmanship.

1 The Archaological Survey of Nubia for I907-8 (Cairo, I91o), Plate LXV., b. 5 .

2. Naqada and Ballas (London, 1896), Plate LXV. 7 ; and Ancient Egypt (I9I5), Part I. p. I3, f. 3. 



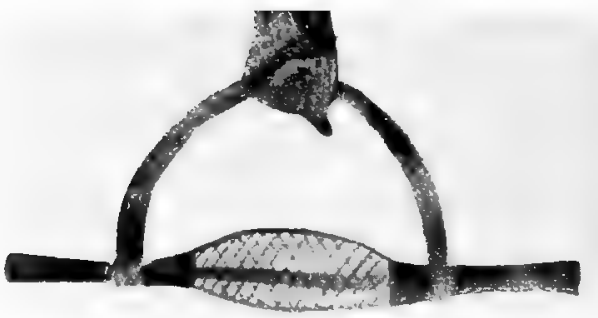

AN EGYPTIAN REEL.

From F. Ll. Griffith, Beni Hasan, Pt. 4, Pl. I3, 3.

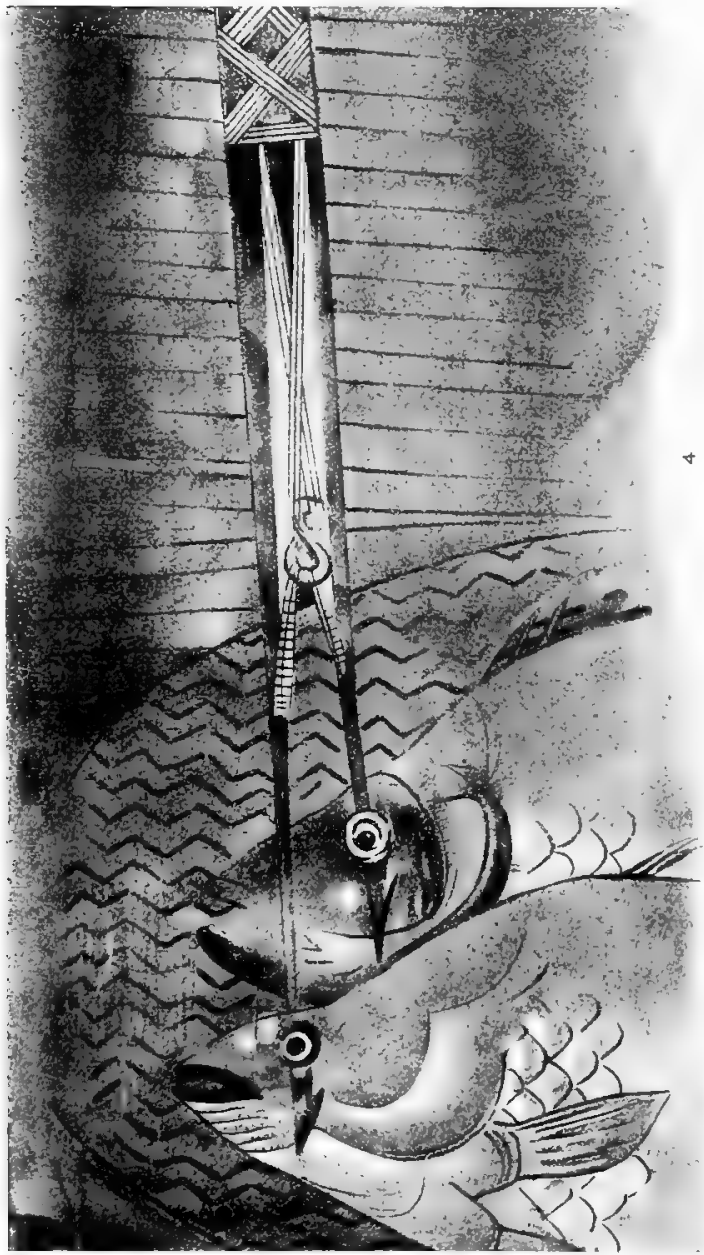

SPEARING FISH.

From F. Ll. Griffith, Ben Hasan, Pt. 4, Pl. 13, 3. 
To the latter the earliest Harpoons in Egypt appear to be the three-toothed bone Harpoons of the first prehistoric age. The representation of launching the Harpoon at fish is one of the commonest in tombs from the Vth to the XVIIIth Dynasties. The truth seems to be that the Harpoon as a means of livelihood ceased in the second prehistoric age, but as an instrument of sport lasted much later, though in the latest paintings it may be only a religious archaism. ${ }^{1}$

Seventy years have failed to displace substantially Wilkinson's statements: fish-spearing from bank or papyrus punt was the sportsman's method: the spear or bident, ${ }^{2}$ about nine to twelve feet long, was thrust at passing fish : to it a long line (held in the left hand) was usually fastened for the purpose of recovering the weapon and the fish, if struck. Sometimes the weapon was feathered like an arrow (the author was possibly misled by or is alluding to the hieroglyph 质), or was just like a common spear.

If the statement be correct that "the bilaterally barbed Harpoon is almost unknown before the Middle Kingdom times," 3 we are faced by the remarkable fact of a weapon found again and again in the Magdalenian epoch of Palæolithic Man-each reader can supply his own conjecture how many millenniums before-being absent in a culture familiar with Copper Age hooks and harpoons.

But hold what view we may as to the original priority of implement, examples of Spear-Harpoons are found in Egypt, at any rate, much earlier than those of either the Net or the Hook.

An illustration or two will serve to confirm the sporting use of the Harpoon, as advanced by Wilkinson and Petrie.

The first, a fine representation, depicts, in fig. 3, probably Khenemhetep standing in a papyrus boat in the act of spearing

1 Tools and Weapons (London, I9I7), p. 37.

2 Bates holds (244) that the bident was only used by the nobles, and never by the professional fisherman, who employed nets, lines, traps, etc., but never the bident. He sees an analogy in the throwing sticks used by the nobles in the Old Kingdom fowling scenes, "whereas the peasants appear to have taken birds only by traps or clap nets."

s Bates, p. 239. 


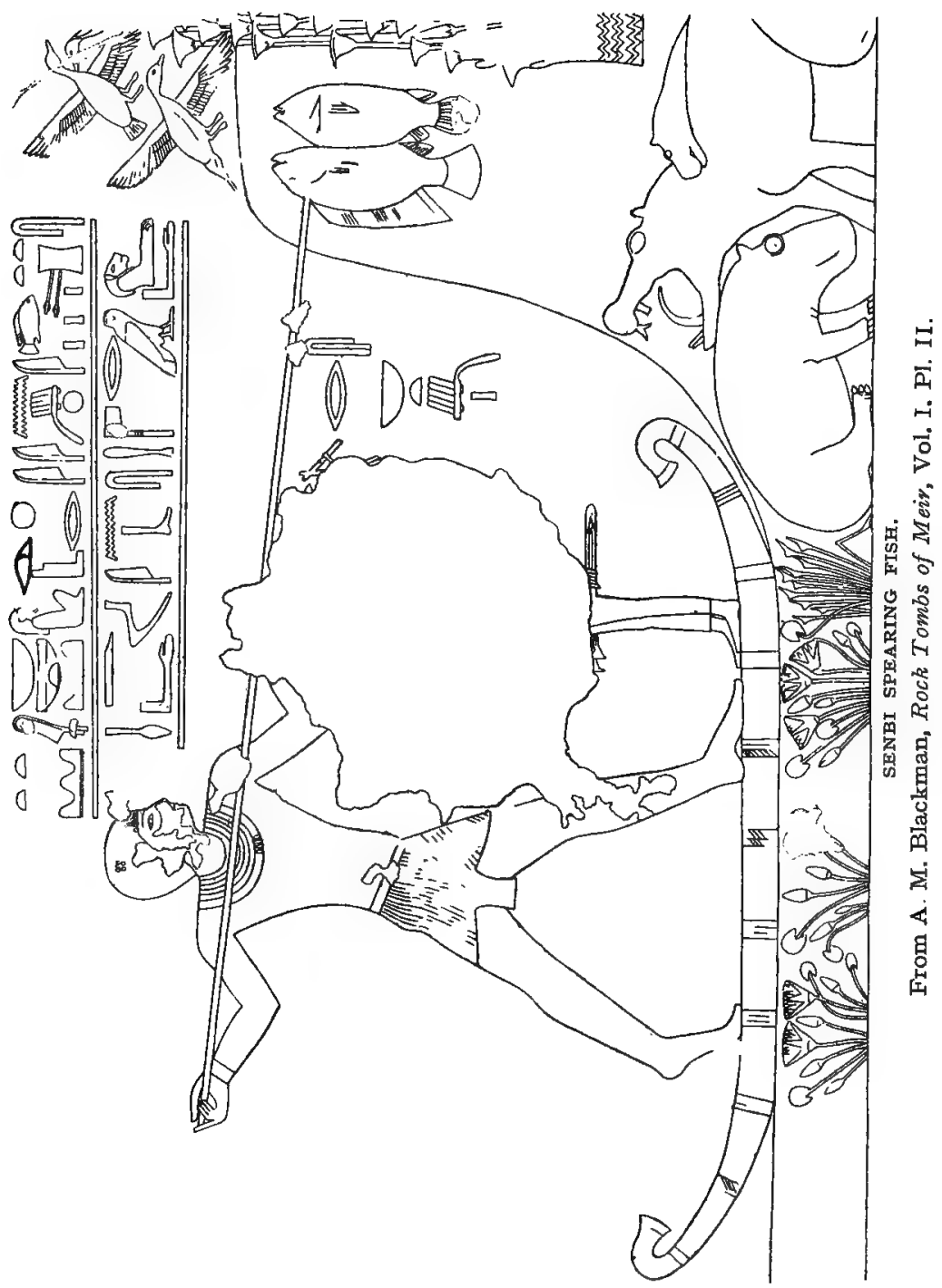


two large fish; beside him stands an attendant holding a bident Harpoon and a Reel unfixed.

In fig. 4 (an enlargement in colour of the preceding plate) the barbed heads transfix the heads of two big fish : an attendant holds a spare harpoon and a reel of cord evidently meant to revolve in its handle. ${ }^{1}$

In the second 2 "Senbi, accompanied by his wife Meres, stands in a skiff constructed of reeds spearing fish. The subject is depicted over and over again in the tomb-chapels, but here it is imbued with new life. How realistic are the monster hippopotami who bellow, and display their gleaming white tusks, as Senbi comes skimming over the water in his frail canoe! The inscription over Senbi fishing runs as follows: "Spearing fish by him who is honoured by Osiris, Lord of the Western Desert, the Nomarch, the Superintendent of the Priests, Senbi the Justified.' '

Before passing to the Hook, a few words as to the Reel. Although Wilkinson would limit its use to Hippopotami, as in Khenemhotep's scene, may we not fairly deduce its employment also in the spearing of large fish ?

The surprise sometimes expressed as to the absence of any evidence that the Reel did duty with the Rod is quite superfluous. The Line of the Nile, and, indeed, of all Europe till the seventeenth century, was the tight, not the running Line. ${ }^{3}$ A possibility, but not a probability, of a Reel being used by a man catching a catfish with line and hook has been detected in Plate I4I of the famous tomb of Ti, which shows the right hand carrying what may be merely a club, or more likely a stick for the line to be wound on, when not in use.4

From the beginning of the Middle Kingdom onward the Reel, of which a fine example comes from Beni Hasan, 5

${ }^{1}$ F. Ll. Griffith, Beni Hasan, Pt. IV. p. 3, Pl. XIII. fig. 3, 4. See also Newberry, op. cit., Pl. XXXIV.

2 A. M. Blackman, The Rock Tombs of Meir (London, 19I4), vol. i. 28. Cf. also Steindorff's Das Grab des Ti (Leipzig, I913), Pl. II3.

${ }^{3}$ Cf. Introduction.

4 Steindorff, Ibid.

- F. LI. Griffith, Beni Hasan, Pt. 4 (London, I900), Pl. XIII, 4. For kind permission to reproduce this and the next illustration I have to thank the Egypt Exploration Society. 
appears to have found employment against Hippo. From the stick on whch the hanks of cord were wound, perhaps, came its invention. I The most developed form shows merely an axle run through holes in the ends of a semi-circular handle. The ends of the axle were set in handles, which to some extent facilitated the process of winding up. ${ }^{2}$

The pursuit of the Hippo originated, like that of the fox in England, from economic causes, viz. the destruction wrought on crops, not on flocks and poultry. The beast in pre-dynastic times existed in Lower Egypt, but by the end of the Old Kingdom seems to have retreated to Upper Ethiopia. Pliny, however, speaking of its ravages at night on the fields indicates its survival above Sais. ${ }^{3}$

Diodorus Siculus, 4 after surmising that if the Hippo were more prolific things would go hard with the Egyptian farmer, furnishes the details, but not the locus of a hunt. "It is hunted by many persons together, each being armed with iron darts." With the substitution of copper harpoons for iron darts, the description applies almost verbatim to some of the hunting scenes of the Old Kingdom. ${ }^{5}$

The Hook.-At the end of the pre-dynastic or beginning of the First Dynastic period the Hook, fashioned in no rude method, and wrought of no primitive material, but of copper, makes its appearance.

From this it is clear that Egypt (a) can lay no claim to have invented this method, and $(b)$ had travelled many stages on the long road of piscatorial invention. The complete absence in the Nile Valley of hooks of bone, flint, or shell which occur in so many neolithic centres in other parts of the world adds confirmatory evidence.

1 Cf. the $\varnothing$ hieroglyphs in Griffith's Hievoglyphs (London, r898), P1. 9, fig. I80, and text, p. 44. The more elaborate form is shown by Paget-Pirie, The Tomb of Ptah-hetep, bound in Quibell's Ramesseum, London, 1898.

2 Bates, p. 242.

8 N. H., XXVIII. 831. Perhaps he derived his information from the not-trustworthy Theriaca of Nicander, $566 \mathrm{ff}$.

4. I. 35. He visited Egypt c. 20 B.c.

- P. 243. From Newberry's Beni Hasan, there come, curiously enough, only two representations of Hippos and not one of a Hippo hunt. From

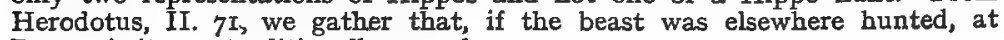
Papremis it was traditionally sacred. 
In Egypt no records of the progenitor of this copper Hook survive. No family tree helps us, as elsewhere, to surmise whether the thorn, the flint, or the shell constituted the material of the first hook, for no non-metallic prototype has come to light. The numerous bone and ivory points, all more or less like the slender rod or pin of ivory shown in El Amrah and Abydos, ${ }^{1}$ may, perhaps, indicate the gorges used by fishermen in pre-dynastic times. The absence, however, in the above example of any indentation in the middle, round which the line was frequently attached, tends (in my view) rather to negative the suggestion.

The earliest hooks were of simple shape. The point was barbless. The head, which in all cases lay in the plane of the hook, was formed by doubling over the end of the shank against the outside of the latter, so as to form a stop or an eye, which might, or might not, have been an open one. ${ }^{2}$ Their length (varying from 2 to $6 \mathrm{cms}$.), if contrasted with the bronze hooks of the Swiss Lakes, is short in proportion to their width from the outside of the point to the outside of the shank. ${ }^{3}$

The XIIth Dynasty displays a few barbed hooks alongside barbless ones. One of the latter, belonging to Petrie, excites our interest, for the string of its attachment (some nine inches in length) is composed of double stout twist, while another proves itself the ancestor-in fact itself is-the Limerick hook with a single barb.

By the XVIIIth Dynasty barbed hooks, usually of bronze, largely predominate. Instead of being headed up in the older fashion they show the end of the shank expanded, so as to form a small flange in a plane at right angles to that of the hook. A line bent on the shank below this flange (even if slight), and drawn hard up against it had the advantage of chafing less than when made fast to a hook of the earlier type. The New Kingdom hooks, which continue scarcely altered in

1 Mac Iver and Mace (London, I902), Pl. VII. I.

2 'T. E. Peet, The Cemeteries of Abydos (London, I9I4), Pt. 2, Pl. XXXIX. 3.

3 For twenty-five figures of hooks, see Bates, Pl. XI. For others curiously shaped, probably Vth Dynasty, see Lepsius, Denkmäler, etc. (Berlin, I849), II. p. 96 . 
Roman times, are well designed, but their barbs are less intelligently placed than are those of the Middle Kingdom. ${ }^{1}$

But even in Roman times several types of hook, fairly well distributed in the Northern Mediterranean, seem unknown in Egypt; for instance, double hooks, barbed or barbless, of the Bronze Age in Switzerland, hooks with a split eye or an eye made by twisting the end of the shank round itself (as found in Crete) and many others are yet to seek. ${ }^{2}$

The cluster or gang hook early confronts us in the tomb of Gem-Ni-Kai. ${ }^{3}$ The fisherman here extends his index finger to feel the faintest bite: below the water the line ends in a cluster of five hooks, one of which holds a large fish.

The ancient monuments sometimes portray fishing from a boat with hand-lines. Those of the Old Kingdom as often as not depict the fisher as an elderly peasant, presumably no longer equal to the brisker business of hauling a heavy seine.

Occasionally two lines are employed, as in the scene which Blackman" describes: "A small reed skiff, containing two men, one of whom, lolling at ease in the stern, has just secured a catch upon one of his lines, while his companion, standing upright in the bow, is pulling his loaded net out of the water."

Another instance of hand-lining comes from Beni Hasan. ${ }^{6}$ The same register contains a representation which is not only the earliest (c. 2000 B.C.) of fishing with a Rod known in the whole world, but is also (with the exception of that from the tomb of Kenamūn at Thebes ${ }^{6}$ ) the only depictment, I believe, of the Rod till we reach Greece about the sixth century B.c.

Unless the passion for sport pure and simple dominated rich and poor alike, we can fairly surmise that Angling yielded good results. The man in the Beni Hasan illustration, whether a fishing ghillie, or a professional fisherman belonging to the

1 Petrie, Kahun, Gurob, and Hawara, p. 34.

2 Bates, p. 249.

a F. von Bissing, Die Mastaba des Gem-Ni-Kai (Berlin, I905), vol. I., Pl. IV. fig. 2.

Op. cit., vol. III., P1. VI

- P. E. Newberry, Beni Hasan (London, I893), Part I, Pl. 29. Cf. Wilkinson, op cit., vol. I., P1. 37 I.

- Ibid., $\mathrm{Pl} .37^{\circ}$. This faces my introduction. 


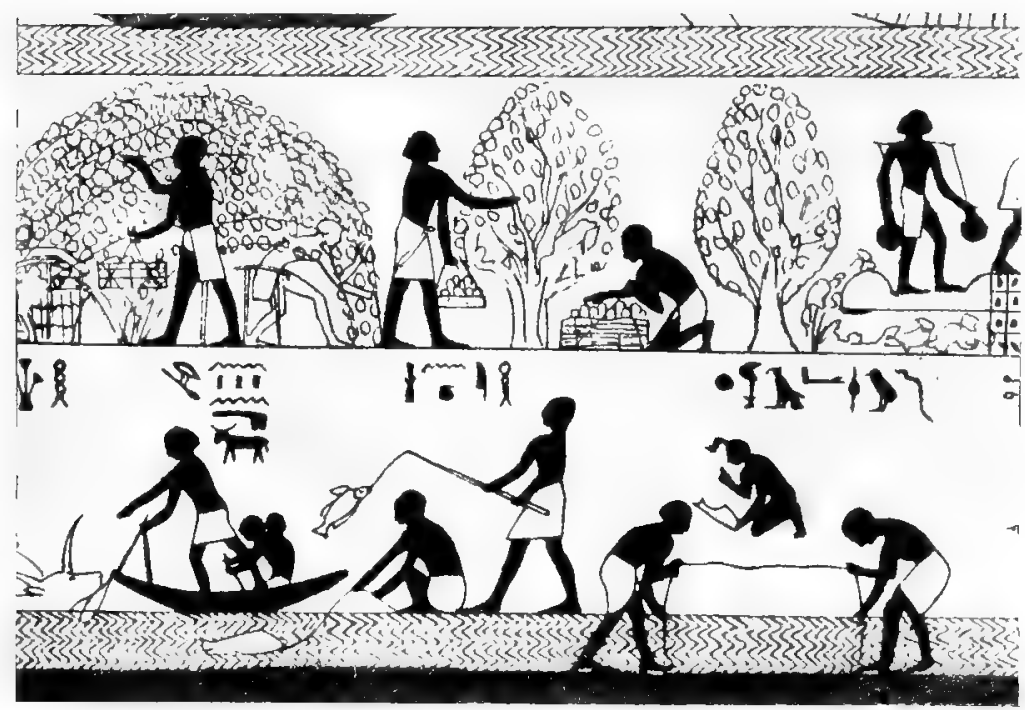

THE EARLIEST REPRESENTATION OF ANGLING, C. 2000 B.C. From P. E. Newberry, Beni Hasan, Ft. I, Pl. 29. 

province which the tomb's owner governed, or a peasant fishing on his own, is not merely posing for his picture.

The Theban illustration (some six hundred years later) squares with Wilkinson's statement "sometimes the angler/ posted himself in a shady spot by the water's edge, and, having ordered his servants to spread a mat upon the ground, sat upon it as he threw his line: some, with higher ideas of comfort, used a chair, as stout gentlemen now do in punts upon retired parts of the Thames." The beat of our piscator, whose fishing $X_{\text {lines should be closely studied, was probably not on " a retired }}$ part" of the Nile, but on one of his own vivaria, which, as in Assyria and Italy, ensured a supply of fresh fish in hot weather.

The lengths of the Rod and of the Line, if we may compute them by the height of the Anglers, assimilate fairly well to the eight cubits or six feet of Ælian's Macedonian weapon some two millennia later.

Figures of fish caught by the mouth indicate baits, but no data enable us to identify their nature. Wilkinson's statement "in all cases they adopted a ground bait, without any float" leaves itself open to question. In the Beni Hasan scene of Angling, which he entitles Fishing with Ground Bait, neither the hieroglyph attached nor anything else shows that, although in this instance no float appears, the bait was resting at the bottom, and not moving in the stream. The tombs generally may have led him to conclude that floats were unknown, but a netting scene in the Tomb of Ti shows a large float, presumably indicating the exact spot occupied by the trap in the water. 1

The ancient Egyptian, if he employed the practice of his modern successor, used scraps of meat, lumps of dough, minnows, and bits of fish. ${ }^{2}$ In connection with the last two a very curious passage in the Book of the Dead runs, "I have not caught fish with bait made of fish of their kind." 3

1 Steindorff, op cit., Pl. IIo. Bates, p. 240, holds that "floats attached to Harpoon lines were probably in common use ": the infrequency-to say the least of it-of their representation lends but a slender support to his suggestion.

2 Klunziger, Upper Egypt (I878), p. 305, states that the townsfolk hand-lined with these baits, but that the fish-eating Bedouins still employed the Spear.

3 Budge, Trans. Book of the Dead, vol. II. p. 362 . 
Such was the plea by the soul of the dead man not to be punished for what seemingly was a heinous sin. It is hard to discover where the enormity of the crime arises. 1 As most fishes are cannibals, the bait here presents one of their natural foods. In the case of an artificial bait, which from the fish's point of view amounts to cheating and deception, the punishment presumably fitted the crime, for which no prayer could atone, no pardon be possible!

Perhaps this conception indirectly caused and still causes the abstention from such lures as the artificial fly, which the native even now generally rejects. The implied prohibition, if the whole passage be not metaphorical, probably sprang from and is a relic of Totemism, which widely prevailed in early times.

The Net : the first examples, owing to their more perishable materials, naturally post-date those of the Harpoon and the Hook, but occur in representations far earlier than either. The suggestion that a part of a Net figures in the hieroglyph of the scenes from the Royal Tombs at Abydos ${ }^{2}$, and so denotes its appearance in the Ist Dynasty, carries no conviction.

Close inspection shows the object to be a bag, or piece of cloth. The Net's delineation by an artist at the end of the IIIrd or very beginning of the IVth lies not open to cavil. ${ }^{3}$

Peculiar importance pertains to this scene, because it is the first portrayal of the Net in Egypt, and possibly the very first representation connected with fishing the whole world over. It, moreover, as an illustration merely of fish, antedates (if avoiding the Scylla of Petrie's and the Charybdis of Albright's chronologies we steer by Lepsius's chart) the famous Sumerian scene of Gilgamesh carrying fish, by some four centuries. 4

The tomb of Zau furnishes one or two representations of

1 Yet compare the Scriptural prohibition, "Thou shalt not seethe a kid in his mother's milk," which appears to have been one of the commandments included in the earliest Decalogue. Sir J. G. Frazer discusses this curious injunction in Folklove in the Old Testament, vol. III. p. III ff.

2 Vol. I. pl. IO, f. II.

s Petrie, Medum (1892), Pl. XI. A good example (Vth Dynasty) of a Net heaped up in a boat is found in N. de G. Davies, Ptahhelep (London, I goI), Pl. VI., in the right-hand column of the hieroglyphs. c. 2800 B.C.

See my Assyrian Chapter, p. 368 . The Gilgamesh representation dates 
special interest. Apart from that of Zau himself " dressed in sporting attire" and spearing fish from a papyrus skiff, the artist in another has let himself go more freely.

Not content to show what is happening above the surface of the pool, he breaks through all embarrassing congruities in order to display the crowded scene below, without which his subject would not have been completely set forth. The waters extend also to the left, where seven fishermen haul into a boat a drag-net full of fish, which include, as in the tomb of Aba, eight different species. Hippopotami and crocodiles do not fail to appear: even the humble frog, who sits among the water reeds, is remembered. I

Netting obtained more widely than its depictments, in proportion to those of Harpooning and Angling, indicate. Representations of the latter methods occur nearly always in the durable tomb-chapels of the rich, who from their ampler leisure more often ensued sport, while the professional fisherman, like his Greek and Roman brother, came of the tribe whose badge was poverty. Then, too, it must be remembered that the Netsmen mainly inhabited the Delta, which from reasons of humidity has yielded fewer pictures of life.

Practically every kind of Net known to the ancient world found employment in Lower Egypt, as the list drawn up by Julius Pollux, by birth himself a Deltan, makes clear. The representations give us many Nets. The hand, the double-hand, the cast (most rarely), the stake, the seine, etc., all find place. Weights of stone, but none of lead (according to Bates), meet our eyes in the monuments. ${ }^{2}$

Netting needles range from pre-dynastic to Roman times. The first, of a very simple type, are merely flat pieces of bone, pointed at each end, and pierced in the middle. ${ }^{3}$ Net-making and Net-mending scenes are not absent. In one of the latter the artist, of naturalistic turn, shows an old fisherman mending

1 N. de G. Davies, The Rock Tombs of Deir el Gebrawi (I902), Pt. II. Pl. V.

2 p. 259. The reason assigned is not convincing: "No lead weights are depicted on the monuments, for by the time they were introduced the artist was devoting himself to mythological and religious scenes." Petrie, Kahun, Gurob, and Hawara, p. 34, however, assigns some weights of lead from Kahun to XVIIIth Dyn.

3 Cf. Petrie, Abydos (London, 1902), pl. 4r. 
a hand-net, and gripping the end with his toes, while a lad, preparing twine, rubs his spindle on his thigh. ${ }^{1}$

Actual specimens of Net twine prepared from flaxen and other vegetable fibres were discovered at Kahun in balls of two-strand and of three-strand string of the XIIth Dynasty. Fragments of Nets " having $\frac{1}{2}$ to $\frac{3}{4}$ inch ( $\mathrm{I}^{\cdot} 2$ to $\mathrm{I}^{\circ} 9 \mathrm{~cm}$.) mesh, the smallest being $\frac{1}{8}$ inch (say $0.3 \mathrm{~cm}$.) square," came to hand at the same locality. ${ }^{2}$

Kahun yielded also some fragments of later, probably XVIIIth Dynasty, Nets, with meshes from 0.5 to ${ }^{\circ} 5 \mathrm{~cm}$. and made of coarser twine than the earlier examples, ${ }^{3}$ whose fineness of mesh tallies with the small size of some of the ancient needles.

Weels or wicker fisher traps (especially in the Old Kingdom) come down to us either small (about I m. 50 long), simply constructed, and capable of manipulation by two men, or very large, of more complex fashioning internally, and requiring several men to handle. 4

Whether the Egyptians employed poisons, like most of the Mediterranean nations, I have not discovered. As examples, they are impossible of survival ; for depictment of their actual use not even the boldest Nilotic Cubist would have been adequate, unless he imitated the Athenian artist by hieroglyphing "These be poisons "! Dyn.

1 J. J. Tylor, The Tomb of Paheri (London, 189́5), Pl. VI., probably XVIIIth

Petrie, Kahun, p. 28.

3 Ibid., p. 34.

4 Illustrations of both kinds can be found in Steindorf's Das Grab des Ti, Pls. CX. and CXI. 

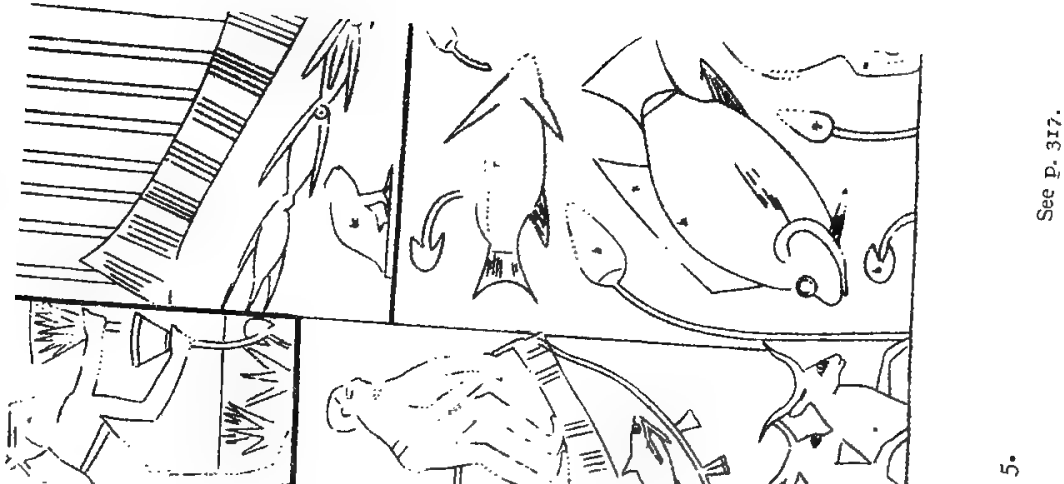

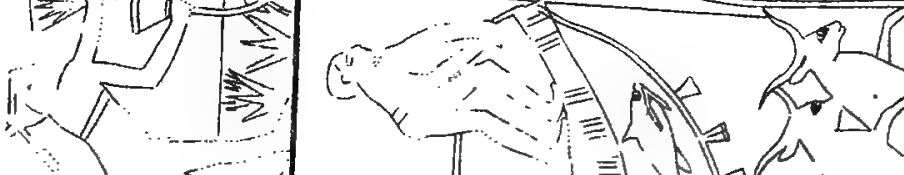

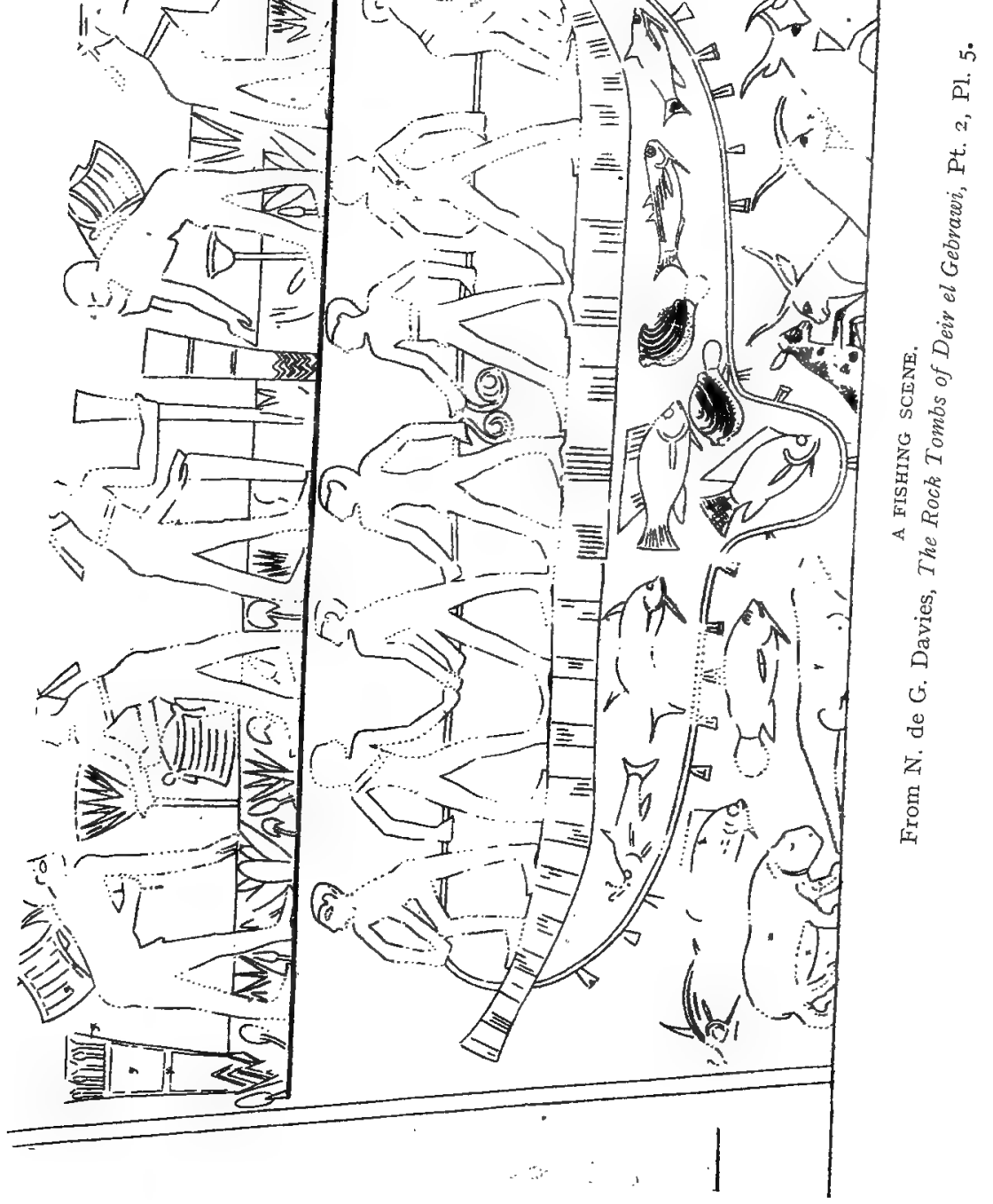





\section{CHAPTER XXV}

\section{ABSTENTION FROM FISH}

THE statement, "the Nile contains all sorts and kinds of fish," 1 must in an age of scientific enumeration be taken with several grains of salt. The total for the whole country, riverine and marsh, reaches but seventy-one species, of which only two, Mormurops anguillaris and Haplochilus schalleri, are peculiar to Egypt. ${ }^{2}$ A score or so find representation in ancient times; but identification is far from easy, and is in some cases, e.g. the Mullets, only possible generically.

In scenes of the return of Hatshepsu's expedition from the land of Punt the drawings of the fishes are so characteristic that Prof. Doenitz has been enabled to determine their species, and identify them as belonging to the Red Sea. The powers of observation in the artists accompanying the ships demonstrate careful training. But I cannot, since the eyes of the Solea are similar, endorse the eulogism bestowed in the case of a sole, unless it were a freak, "one eye is drawn larger than the other, showing a fine observation of Nature!" 3

The priests, the King, and the commonalty in some cases eschewed fish.

Priestly abstention was by no means uncommon, as some of the temples of Poseidon ${ }^{4}$ demonstrate. In Egypt the observance was strict, at Askalon the reverse. Plutarch, ${ }^{5}$

1 Diodorus Siculus, I. 36.

2 Cf. G. A. Boulenger, Fishes of the Nile (London, I907), and Pierre Montet, Les Poissons employés dans l'Ecriture Hieroglyphique. Bulletin de l'Institut Français d'Archéologie Orientale. Tome XI., 19I3.

${ }^{3}$ Egypt, Pt. II. P. 226. Bædeker, Leipsic, 1892.

Antea, p. 20 r.

5 De Iside et Osiride, c. 8. 
confirming and amplifying Herodotus, ${ }^{1}$ writes :- " The priests indeed entirely abstain from all sorts: therefore on the ninth day of the first month (Thoth), when all the rest of the Egyptians are obliged by their religion to eat a fried fish before the doors of their houses, they only burn them, not tasting them at all, assigning as their reasons two, the second of which -indeed, the most manifest and obvious--is that fish is neither a dainty, nor even a necessary kind of food." 2

But by the priests of Atargatis, to whose subjects ichthyophagia was under pain of blains, boils, and other dire diseases absolutely forbidden, fish boiled and roasted were daily offered, and by them daily eaten. ${ }^{3}$

The religious ceremony in Thoth may have been merely a later aspect of a taboo once possibly universal among the class from which the priesthood largely drew, or may, perhaps, have been prompted by the desire of obtaining a good fish harvest. Apart from the uneconomic depletion of food entailed by the prescribed eating, the killing of " the children " or possessions of the deity seems hardly the best way to secure fruition of such desire.

If, however, the feast survived as a relic of Totemism, the ceremony may possibly come within Robertson-Smith's conception of the origin of all religious communion or sacraments, i.e. a renewal of the connection between the god of the Totem tribe with his people at a meal, where " the Totem itself is sacrificed at an annual feast, with special and solemn ritual." 4

In the same way, eating of fish by the priests at Askalon may have originated from the idea of bringing the deity and his servants into closer relationship, and may have been continued to impress their religious superiority on the mass of the people, who were forbidden such food, and thus any direct connection with their god. Although the practice was different, the object of both priesthoods-enhancement of their religious

1 II. 37 .

2 From the Trans. of S. Squire.

3 Mnaseas, as quoted by Athenæus, VIII. 37.

4 W. Robertson-Smith, The Religion of the Semites (Edinburgh, I889), p. 276. 
prestige-was identical. Where the people abstained, they ate; where the people ate, they abstained.

The Kings as High Priests seem, down to Ptolemaic times, to have eschewed fish absolutely. The Stele of Piankhi, at any rate, indicates their practice c. 700 B.c. To this Nubian conqueror of Egypt came the petty Kings of the Delta to offer submission; but "they, whose legs from fear were as the legs of women, entered not into the King's house, because they were unclean and eaters of fish, which is an abomination for the Court: but King Namlot, he entered, because he was pure, and ate not fish." I

The reason for this insistence by a Nubian lay perhaps in the fact that Piankhi had as monarch of Egypt just been affiliated to the Sun-god, who not only created righteousness, but lived and fed upon it. A curious prayer or semi-threat by one of the dead survives. If he be not allowed to face his enemy in the great council of the gods, the Sun-god should or would come down from Heaven and live on fish in the Nile, while Hapi, the god of the river, should or would ascend to Heaven and feed on righteousness. The granting of his prayer or the fulfilment of his threat would reverse the whole scheme of creation. ${ }^{2}$

The word translated by abomination signifies generally something dirty. The epithet, if the Deltaic kings resembled the Deltaic fishermen, is not inappropriate. Many representations of the XVIIIth and XIXth Dynasties render the latter, in contradistinction to their brothers of the river proper, with scrubby beards, uncouth of aspect and scant of dressa characteristic which Diodorus Siculus notes, when describing their habitations as mere cabins of reeds.

But in fairness it must be remembered that since nearly all history and representations reach us from Upper Egypt, these portraits may merely typify the contempt or dislike felt by the richer and more civilised Nilotic for his Deltaic

1 J. H. Breasted, Records of Ancient Egypt (Chicago, 1906-7), vol, IV., par. 882.

${ }^{2}$ See Hastings' Ency. of Religion and Ethics, vol. X. pp. 796 and 482, and Zeitschrift für ägyptische Sprache, vol, 49, p. 5I (Leipzig, I9II). 
brethren, ${ }^{1}$ in whom some writers profess to discern an indigenous and less progressive race.

Were the records and art of Buto, for example, a capital once ranking in importance and opulence with Thebes, available, another story and another picture might confront us. Owing in the main to humidity, our conceptions are perforce coloured by the traditions of Upper Egypt, and thus at times liable to deception.

Is it, for instance, likely that the priests and denizens of the Delta, where maritime commerce principally furnished their prosperity, regarded the sea with the same loathing and dread that the riverine priests and writers express? Can we really imagine the priests of Alexandria not eating salt because it was "Typho's foam," or not speaking to pilots because they do business on the great waters, or embellishing their temples with figures (like those at Sais) of an infant, an old man, a hawk, a fish, and a sea-horse?

The meaning of these figures, according to Plutarch, ${ }^{2}$ " is plainly this: $\mathrm{O}$ ! ye who are coming into or going out of the world, God hateth impudence, for by the hawk is intended God, by the fish hatred on account of the sea, as has been before observed, and by the sea-horse impudence, the creature being said first to slay his sire, and then force his mother."

How and when did the abstention from fish arise? Was it originally a tabu observed by all, kings, priests, nobles, and commons ? 3 Did the last come gradually to disregard or

1 Their brawling in boats and carousing in drink are depicted. Cf. N. de G. Davies, Tombs of $\mathrm{El} \mathrm{Gebrawi,} \mathrm{Pt.} \mathrm{II.} \mathrm{(London,} \mathrm{r902),} \mathrm{Pl.} \mathrm{V.,} \mathrm{and} \mathrm{Newberry,}$ Beni Hasan, Pt. II., Pl. IV., and Davies, Ptahhetep, Pt. II., Pl. XIV., and Pt. I., Pl. XXI. In the XXth Dynasty the chastity of their wives was not a striking characteristic.

2 Op. cit., XXXII.

a Fish hieroglyphs are regarded by some as general determinatives for words meaning "shame," "evil," etc. (cf. Plutarch, op. cit., 32), and by others as merely phonetic determinatives (cf. Montet, op. cit., p. 48). That fish were regarded as either enemies or emblems of enemies of the gods and of the kings would seem to be borne out by the ceremony annually performed at Edfu, where the festival calendar contains the following: "Fish are thrown on the ground, and all the priests hack and hew them with knives, saying 'Cut ye wounds on your bodies, kill ye one another: $R$ a triumphs over his enemies, Horus of Edfu over all evil ones." "The text assures us that " the meaning of the ceremony is to achieve the destruction of the enemies of the gods and king." Cf. Erman, Handbook of Egyptian Religion, trs. by Griffith (London, I907), p. 216. 
were they forced by food pressure to rebel against it ? Did the nobles in the Old and Middle Kingdoms occasionally wobble in their diet? All these questions meet with no adequate answer.

An answer to the first, i.e. the date and reason of the abstention, as yet baffles even the richness of the fertile preservative sands of Egypt, since adequate data must stretch back to pre-dynastic periods.

One fact stands out. The lower classes very early eschewed the $t a b u$ and ensued after fish. Their example was followed later by the upper classes, " with whom fish became a favourite dish : the epicure knew each variety, and in which water the most dainty were to be caught. It was, therefore, a most foolish invention of later Egyptian theology to declare that fish were unclean to the orthodox, and so much to be avoided that a true believer might have no fellowship with those that did." 1

Robertson-Smith declares that the doctrine-the highest degree of holiness can only be attained by abstinence-resulted from the political fusion in Egypt of numerous local cults in one national religion, with a national priesthood that represented imperial ideas. ${ }^{2}$

The statement, " countless pictures of offerings to the gods and the dead survive, but never a fish among them " has in the light of subsequent discoveries to be revised. One strong reason at any rate existed in its favour. In the Pyramid texts carved on the sepulchral chambers of the Pharaohs of the VIth Dynasty the hieroglyph of the fish was deliberately suppressed, which goes far to prove that fish were regarded as impure for kings. Furthermore, in the thousands of lines which contain spells for the future benefit of these dead Kings not one figure of a fish occurs.

On the other hand, evidence exists of practices in apparent conflict with the above facts. Newberry, ${ }^{3}$ provides two

1 Erman, Egyptian Life, Eng. Trs. (London, 1894), p. 239, basing himself on Mariette's statement in Monuments divers recueillis en Egypte, pp. I5 152 .

2 Op. cit., p. 284

3 El Bersheh, Pt. I. (London, n. d.), P1. XXIII. 
Middle Kingdom instances of fish being brought to the owner of the tomb, and Maspero ${ }^{1}$ one of the New Kingdom.

Then, again, how about the famous representations of fish, both upon an altar and also on the face of an altar, in Capart's work? 2 These basalt statues (he holds) exhibit the King making offerings of fish; others regard them merely as the King marching at the head of the Nile gods, and himself representing the great river, "the giver of all things good."

Donations of fish were frequently made to the temples by the Kings. Rameses III., for instance (as the Harris Papyrus discloses) presented thousands and thousands, labelled " dressed, cut up, and from the canal." 3 These gifts were not for the priests, but (probably) for their employés or the populace.

We read (in the Hammamat Stele) of " the officers of the Court Fishermen" attendant on Rameses IV. Their task, unlike that of a similar corps in the Chinese court whose duty (inter alia) was to manage the arrangements for the Emperor's sport, principally consisted in securing " a plenty of fish" for the enormous entourage and servants of the monarch.

But the Pharaohs till Cleopatra were, as far as I can gather, personally as free from the sin of fishery, as the net offered to the Syrian goddess in the epigram of Heliodorus. ${ }^{4}$

The problem as to fish being offered or not to the gods or the dead may possibly be solved, if we bear in mind that while fish are never mentioned in the longer versions of the offering texts of the Old Kingdoms, and are not represented in the pictures of the food provided for the dead before the XIIth Dynasty, after that date some occasional instances to the contrary do occur.

1 Tombeau de Nakhti (Mém. de la Mission française au Caire, vol. V. fasc. 3., Paris, I893), Fig. 4, p. 480.

2 Les Monuments des Hycsos, Bruxelles, I9I4. Connected with these and somewhat confirming Capart appear to be two life-size figures of Amenemhat III., in one of which the king is seated between two goddesses holding fish.

3 These offerings (I 5,500 dressed, 2,200 white fish, etc.) are named under the heading, "Oblations of the festivals which the King founded for his Father Amon-Re." But in the summary of the good deeds wrought for the gods by Rameses III.- " I founded for them divine offerings of barley, wheat, wine, incense, fruit, cattle and fowl "- observe the complete silence as to fish, because these offerings were to the gods, not to the temples. Cf. Breasted, Ancient Records, IV., paragraphs 237,243 , and 363 .

- Antea, p. I23. 
Figures (even of food, as I have shown) drawn in the tombs were supposed to retain their original powers. To avoid their contact with the dead by walking into his chamber, figures of human beings, of animals including snakes, of birds, but not of insects, were, at any rate in the VIth and XIIth Dynasties, frequently mutilated. 1

A prayer ${ }^{2}$ shows how real was the fear: "Let not decay caused by any reptile make an end of me, and let them not come against me in their various forms." The danger to the royal Ka from a fish swimming, or from the fish Clarias macracanthus walking from its habitat in the Upper Nile into the tomb chapel, beggars description!

The apparent anomaly, that while scenes of fishing occur in the tombs as often as those of fowling and hunting, and that while the latter frequently, the former never, figure in the offerings, is (according to Lacau ${ }^{3}$ ) quite easy of explanation. When a man dies, he is identified with and taken to Osiris, to whom, like the other gods, no fish was meet for offerings, whereas the scenes, which depicted them, were representations of what a man had done or known in his lifetime.

Additional doubts whether the ban against fish-offerings met with exceptions, are caused by the discovery of models of fish buried in the XIXth Dynasty foundation-deposits along with those of fowl, beef, etc. ${ }^{4}$ Perhaps the modelling differentiates the instance. If fish were neither meet nor permissible offerings to the gods, how came it that some deities were venerated in connection with fish?

The evidence of Strabo that the Lates niloticus was at Latopolis, ${ }^{5}$ a city named in the fish's honour, revered in conjunction with a goddess whom he terms Athena, may, like that of many another globe-trotter, perhaps, be discounted.

But when we find in the scattered stones of that temple

1 Mutilation was not invariable, even in the XIIth Dynasty, as Beni Hasan discloses.

2 In the Book of the Dead, Chapter I54.

3 P. Lacau, Suppressions et modifications des signes dans les textes funebraires, Zeitschrift für ägyptische Sprache, vol. 5I (I9I3), $42 \mathrm{fH}$.

4 Petrie, Six Temples at Thebes (London, I897), Pl. XVI., f. I 5, fish from foundation deposit of Taussert, and Pl. XVIII, from Siptah.

s XVII. I, 47. Latopolis is now Esneh. 
various sorts of fish, one enclosed in a royal cartouche ${ }^{1}$ and at the same place a Ptolemaic-Roman cemetery, containing great numbers of Lates, mummified by art or Nature, ${ }^{2}$ and when further we find at Gurob, near the old Moeris Canal, cemeteries of the same fish unassociated with human remains, and dating from the XVIIIth or XIXth Dynasty, when we find all these, ${ }^{3}$ we are driven, as was the negro when faced with another, but logical, dilemma, to " purtend brains, at any rate scrat heads."

Nor is our " purtending or scratting" ended, when attempts, based on the finding in the fish cemetery at Gurob of a small head of a goddess, are made to connect the Athena of Strabo with Hathor, to whom Keller ${ }^{4}$ alleges that the Oxyrhynchus (often found embalmed at Thebes) was sacred. So, again, our clarity of ideas is not increased, when we read that Hatmehyt was the patron goddess of Mendes, the capital of the XVI Nome (which of all the Nomes alone possessed a fish for its emblem) and that this fish is regularly represented above the head of Hat-mehyt.

But one fact stands out as adverse to the identification of any god as a god of fish or connected with fishing. In the magico-religious welter of god-creating and god-adopting characteristic of the later Egyptians, who locally worshipped beasts, birds, reptiles, and insects, the first commandment given to Israel was faithfully observed, in that they made not unto themselves a graven or other image of any deity " of the likeness of any fish that is in the water under the earth." 5

1 Wilkinson, op. cit., III. 343 , f. 586 .

2 See Proc. Soc. Biblical Archeology, XXI. p. 82, for a picture of a bronze mummy-case containing remains of a small Lates.

${ }^{8}$ L. Loat, Saqqara Mastabas, I. Gurob. Plates 7, 8, 9, and Petrie and Currelly, Ehnasya, 1905, p. 35.

4 Op. cit., p. 346.

5 See Bates, p. 234 , ff. 


\section{CHAPTER XXVI}

\section{SACRED FISH}

APART from the mythological fishes, the $A b d u$ and the $A n t$, which were supposed to accompany the boat of the Sun, we find others held sacred or worshipped in different Nomes or cities.

Before considering these, I draw attention to the cut of a representation from Gamhud, ${ }^{1}$ and to the account by $\mathrm{E}$. Mahler of a Stele, attributed to Thotmes III., now in the Museum at Buda-Pesth. ${ }^{2}$

Both are remarkable; for in both Fish takes the place of the usual Bird-Soul. As the Buda-Pesth Stele is unpublished, we have to depend on Mahler's account. He tells us that in the ancient beliefs and myths of Egypt the fish was a symbol of eternity, and guided the boat which bore the dead to the waters of the blessed.

The Gamhud illustration, attributed to the Ptolemies, who held fast to the tradition that the parts of Osiris were eaten by three fishes, one of which was the Oxyrhynchus, has a distinct interest, because here for the first time the Oxyrhynchus figures as a substitute for the Bird-Soul.

The Buda-Pesth Stele probably deduces from Gurob, where there is, or rather twenty years ago was, a fish cemetery excavated by Petrie. Here, too, was a temple built by Thotmes III., and a smaller one erected in his honour.

The idea of the dead man may well have been " $I$ have embalmed thousands and thousands of fish. Now then, one of you, in return do your best to secure for me immortality."

1 Ahmed Bey Kamal, Annales du Service des Antiquités de l'Égypt, 1908, IX. 23 f., Pl. r.

'Actes du IV' Congres International d'Histoire des Religions, I9I3, p. 97 f. 
Herodotus 1 states that only two fishes are venerated, the Lepidotus and the Phagrus. The Father of History is not open in this case to the charge of exaggeration, for with these the Oxyrhynchus, and (according to Strabo) the Lates niloticus, and (according to Wilkinson) the Mcotes should be included.

Various reasons are assigned for the veneration, local if not national, of these particular fishes. Wilkinson suggests, with

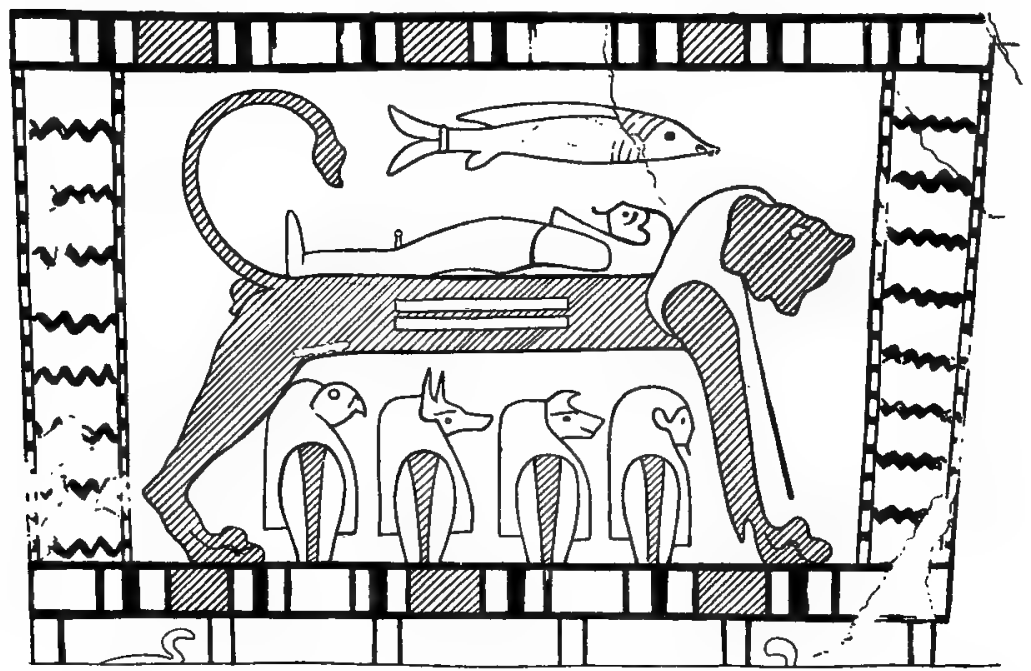

THE OXYRHYNCHUS TAKING THE PART OF THE USUAL BIRD-SOUL.

From Ahmed Bey Kamal, Annales du Service des Antiquités de l'Egypt.

a touch of ironical humour-" the reason of their sanctity (i.e. the Oxyrhynchus and Phagrus) was owing to their being unwholesome : the best way of preventing their being eaten was to assign them a placeamong the sacred animals of the country!"

Some writers detect in their sanctity a remnant of local Totemism, a word which in blessedness equals and in length of inadequate definition surpasses Mesopotamia. ${ }^{2}$

1 II. 72.

- For a description, not a definition of Totemism, see Robertson Smith, loc: cit., or J. G. Frazer's four volumes on Totemism and Exogamy. The Oxford Dictionary for once is not very helpful in, "Totemism, the use of Totems, with a clan division, and the social, marriage, and religious customs connected with it." 
But Robinson, disagreeing with Robertson Smith and Frazer in their conception of Totemism, denies that these fish were totems in any proper sense. Primitive man performs an act of positive sacrifice when he devotes to the religious tribal idea the best fish of the waters, and thenceforth abstains from eating them; whereas the Egyptians shabbily denied themselves only the refuse. They made that sacred which they could not eat. All the evidence tends to the suspicion that the gods were put off by the priests with the very worst of the fish. If a species were poisonous or belonged to a class that was unwholesome, it was straightway declared sacred. ${ }^{1}$

Speaking from my own experience and purely on palatal grounds, had I been High Priest I should have banned nearly all Nile fishes for their insipidity and muddiness. Tastes, of course, differ. The Lates is passable, but the Oxyrhynchus attracts no opsophagist devotees, which is probably the fault of "The Creator of all things good" in either the temperature of his water or the character of their food, since a cousin, $O$. mormyrus, geographically not far removed, is ranked by epicures as delicious. ${ }^{2}$

The reason assigned by the priests to Plutarch for the abstention from and local veneration of the Oxyrhynchus, Phagrus, and Lepidotus possesses, whatever its truth, the charm of an antiquity reaching back to the dawn of goddom.

After the slaying of Osiris by Typho, Isis made unwearied search for his body. But she could never recover his private part, for it had been flung into the Nile, and eaten by the Lepidotus, the Phagrus, and the Oxyrhynchus: " fish which of all others, for this reason, the Egyptians have in more especial avoidance. But Isis made its effigies, and so consecrated the phallos, for which the Egyptians to this day observe a festival." 3

The same author vouches for the veneration of the Oxyrhynchus, as shown by the people of the city named after that fish ; "they will not touch any kind of fish that have been taken with an angle, for they are afraid lest perhaps the hook may be

1 Op. cit., p. 37.

2 The Mormyri, which number some roo species, are peculiar to Africa.

3 De Iside et Osiride, I8. 
defiled by having at some time or other been employed in catching their favourite fish." 1 Ælian goes farther: "were but one of these fish taken in a net, the townsmen would let the whole catch free." 2

Holy Wars, even if unpreached by a tarbushed Kaiser, came to pass in Plutarch's day; " within our memory, because the people of Kynopolis presumed to eat their fish, the Oxyrhyncites ${ }^{3}$ in revenge seized on all the dogs, or sacred animals of their enemies that came in their way, offering them in sacrifice, and eating their flesh in like manner as they did that of their other victims: this drew on a war between the two cities, wherein both sides, after doing each other much mischief, were at last severely punished by the Romans." 4

To another religious war, between the Ombites and the Tentyrites, we owe the great Satire XV. of Juvenal, when banished to Egypt at the age of eighty. ${ }^{5}$ The poem ranks high, not only for its mordant irony but also for its description of the origin of civil society, " a description infinitely superior to anything that Lucretius or Horace has delivered on the subject," according to the not always laudatory Gifford.

"Who knows not to what monstrous gods, my friend,

The mad inhabitants of Egypt bend?

The snake-devouring ibis, These enshrine,

Those think the crocodile alone divine."

"Those" were the Ombites, "These" the Tentyrites, who hated the crocodile worshipped at Ombos : hence

" Blind bigotry, at first, the evil wrought,

For each despised the other's gods, and thought

Its own the true, the genuine-in a word

The only deities to be adored." 6

1 Plut., 8.

2 N.H., X. 46.

3 The Mormyri, to which the Oxyrhynchus belongs, figure on the walls, and in bronzes, $O$. kannum and $O$. caschive being most frequent; but the Bana (Petrociphalus bane) and Grathonemus aprinoides also occur. The best delineations are found in the tombs of $\mathrm{Ti}$ and of Gizeh.-G. A. Boulenger, Fishes of the Nile, London, I907.

- Plut., Ibid., ch. 72.

- The banishment is disputed by Franke and others. Cf., however, Sat., XV. 45. "Aegyptus, sed luxuria, quantum ipse notavi."

- From Gifford's Translation. 
The Phagrus had the distinction of being venerated in Egypt and Greece, whose writers, bothered by none of our scientific hesitation, regarded him not as one of the Mormyri, but as the Eel. They scoffed alike at his deification and his devotees. 1

The Phagrus, and the Moeotes, which is Wilkinson's addition to the four other sacred fish, were probably the same under different names. Ælian, indeed, states that the former, worshipped at Syene, was called the Mcotes by the people of Elephantine (quite close to Syene), and attributes its sanctity to its annual appearance always heralding the rise of the Nile, ${ }^{2}$ a property of prescience transferred by Plutarch to the Mceotes. ${ }^{3}$

We know so little about the locus of the Lepidotus (Barbus bynni) cult that Wilkinson's assertion, "its worship extended over most parts of Egypt," needs confirmatory data.

The Crocodile, like the Lates, was worshipped here and there, but elsewhere keenly hunted. Of the first Thebes and Lake Mœris furnish types. Each place (according to Herodotus) harboured one crocodile in particular, very tame and tractable. ${ }^{4}$ They adorned his ears, as Antonina her Murcena, "with earrings of molten stone or gold, and put bracelets on his forepaws, giving him daily a set portion of bread, with a certain number of victims : when he dies, they embalm and bury him in a sacred place." 5

Of the various methods for catching the crocodile our author sets forth one which we all must agree as "worthy of mention." "They bait a hook with a chine of pork, and let the meat be carried out into the middle of the stream, while the hunter on the bank holds a living pig which he belabours. The crocodile hears its cries and making for the sound encounters the pork, which he instantly swallows down. The men on the shore haul and, when they have got him to land, the first thing the hunter does is to plaster his eyes with mud.

1 Cf. Athenæus, VII. 55, for the jests of Antiphanes, etc.

2 N. H., X. I9.

ap. cit., 7 .

- Plato bears witness to the skill of the Egyptians in taming fish, and animals, even the shy wild gazelle. Polit. 532 .

- Herodotus, II. 69, 70. Rawlinson's Trans. 
This once accomplished, the animal is despatched with ease, otherwise " (it may surprise you) " he gives great trouble." 1

Both the Phagrus and the Crocodile possessed foreknowledge as to the rise of the river, the first as to time, the latter as to extent, for " in what place soever the female lays her eggs, that may be concluded to be the utmost extent to which the Nile will spread that year." 2

Blackman ${ }^{3}$ praises the art of a scene, as (although the crocodile is but roughly blocked out) one ranking with the finest specimens of ancient Egyptian bas-reliefs: " not even the Old Kingdom mastabas at Sakhara can produce anything to surpass it for vigour and beauty of technique." 4

1 The story of the trochilus, with which alone out of all birds and beasts our author states the crocodile lives in amity, because the little bird enters its mouth (when on land) and frees it from myriads of devouring leeches, is too well known for reference, were it not for the dispute $(a)$ as to whether the birdPluvianus egyptius-performs any service except uttering a shrill cry on the approach of man and thus warning the crocodile, and $(b)$ whether for leeches, we should not substitute gnats. Cf. W. Houghton, N. $H$. of the Ancients (London), pp. 238-244. The account of the connection between the bird and the beast given by Plutarch is far prettier and more spirited than that of Herodotus.

2 Plutarch, ibid., 75. The beasts enjoyed both a hereditary transmission of holiness and a subtle discrimination as to the build of a boat, for fishermen who embark in one made of papyrus enjoy security from their attentions, " they having either a fear or else a veneration for this sort of boat" because Isis in her search for the remains of Osiris used such a means of conveyance. Plutarch, ibid., I8.

${ }^{3}$ Op. cit., II. p. I4, Pl. 2, Register 3.

- Crocodiles and Papyri seem a curious juxtaposition I Some time ago Dr. Grenfell was excavating ground likely to yield important finds. Bad luck dogged his digging: only preserved crocodiles came to light. One day a labourer, incensed at work wasted on the beasts, jabbed his pick into the latest specimen, whose head disgorged a roll of papyrus. Similar headsmashings were fruitful of results, most of which belong to the Hearst Collection. 


\section{CHAPTER XXVII}

FISHERIES-ATTEMPTED CORRELATION OF THE PRICE OF FISH THEN AND NOW-SPAWNING

"When a (fisherman) father casts his net, his fate is in the hands of God. In truth there is no calling which is not better than it." I

THE classification of Egyptian society made by Herodotus ${ }^{2}$ merits mention if only on account of its unexpected gradations; (A) Priests, (B) Warriors, (C) Cowherds, (D) Swineherds, (E) Tradesmen, (F) Interpreters, (G) Boatmen. The position allotted to the cowherd and swineherd before the tradesman, if startling to modern eyes, characterises most early societies. "For trader," as Seymour shows, "Homer knows no word." 3 Fishermen, although unnamed but presumably included under boatmen, figure last, a rank consonant with that assigned by the Scribe above.

If their life was socially of the lowest and their toil of the hardest, they must have earned a modest living, even though no tacksman millionaire finds record. We may fairly assume a general and constant demand for fish from (A) the revenues yielded by fisheries, and $(B)$ the taxes paid by fishermen.

Of (A) Lake Mœris affords a striking instance. When the water retired from the lake to the Nile, the daily sale realised one talent of silver (reckoned by Wilkinson at $£$ I93 r5s. od.), and when the current set the other way one-third of that sum, but in all some $£ 45,000$ yearly. 4 We learn that the proceeds

1 Maspero, Du genre epistolaire ahez les Egyptiens, p. 65 f.

2 II. I64. Cf., however, II. 47. It is not quite clear whether the order of the list is intentional. If so, it is certainly justifiable from the point of view of primitive or early society.

See p. 65, antea.

- Herod., II, I49. 


\section{4}

\section{FISHERIES-PRICE OF FISH-SPAWNING}

of these fisheries formed the dowries or allowances for the scents, etc., ${ }^{1}$ of the Queens.

Later on they also received as appanage the revenues of Anthylla famous for its wines, so they fared not badly for pin money. Herodotus ${ }^{2}$ informs us that the town " is assigned expressly to the wife of the ruler of Egypt to keep her in shoes. Such has been the custom ever since Egypt fell under Persian rule," an origin not improbable from Plato's statement that one district was allotted for toilette purposes to the Persian Queens and called "The Queen's Girdle."

(B) The taxes (or revenues) obtained in the Ptolemaic times,

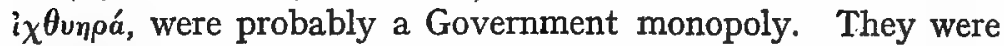
divided into $(a)$ a tax on fishermen of one quarter of the value of

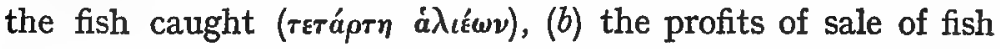
at prices higher than those paid for them direct to the fisherman.

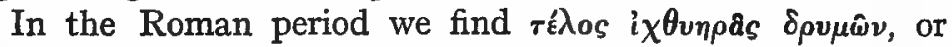
a rent from marshes deep enough at the time of the inundation to contain fish and shallow enough at other times to grow papyri and marsh plants. Leases for fishing and selling papyri, etc., brought good returns. But these returns must be distinguished from other revenues derived from the industry, e.g. the fisheries of Lake Mœris, and from a tax paid by the fishermen, both of which seem to correspond with the Ptolemaic " fourth part." On the other hand the фópos, no doubt, was a tax paid by fishermen for the right of fishing, or for the use of boats in waters owned by the temples. ${ }^{3}$

The Net, in the marsh country, was not only the most lucrative "engine of encirclement," but also a double duty paid. In other parts the inhabitants passed their nights upon lofty towers to escape the gnats, but in the marsh land (Herodotus continues), "where are no towers, each man possesses

1 Diodorus Siculus, I. 52. Twenty-two different kinds of fish existed in the royal fish ponds of Mœris. Keller, op. cit., $33^{\circ}$.

2 II. 98.

8 See Grenfell and Hunt, Tebtunis Papyri, II. 180-I, and I. 49-50. Also Wilcken, Griechische Ostraka, I. I37 ff. The craft employed were usually primitive rafts or canoes made of papyrus canes bound together with cords of the same plant. Theophrastus, Hist. Plantarum, IV. 8, 2, alludes to them. Pliny, N.H., VII. 57, speaks of Nile boats made of papyrus, rushes and reeds, while Lucan, IV. $x_{36}$, refers to them in

"Conseritur bibula Memphitis cymba papyro." 
a net instead. 1 By day it serves to catch fish, while at night he spreads it over the bed in which he is to rest and creeping in goes to sleep underneath." While struck by the resemblance to Goldsmith's article of furniture,

"A bed by night, a chest of drawers by day,"

we are forced once more to "scrat head," and very hard. Imagination reels before the mesh of a Net, capable alike of catching a marketable fish and denying a gnat!

Fish intended for immediate use were usually dressed on the boat and quickly dispatched to market; the rest of the catch was opened ashore, split, salted, and hung to dry in the sun. Pictures 2 of all these operations, and examples of splitting knives, survive. Splitting in the earlier eras, for some reason, ran, not sheer down the back, but always rather to one side or other.

Promptness of curing in a hot climate like Egypt was all important. Diodorus, indeed, tells us that practically all fish were at once pickled or salted, a statement confirmed by Julius Pollux's mention of the Egyptian tariché, especially that from Canopus, being exported ${ }^{3}$ far and wide, certainly to Palestine, whither " the Egyptian fish came in baskets or barrels." 4

Prices of wheat, honey, fish and other wares occur in Spiegelberg's work, ${ }^{5}$ but no attempt is made by him (as far as I know) to correlate the prices in ancient and modern Egypt.

I essay the task more as a jeu d'esprit than for any result of economic value, by means of the Mugil capito. This grey mullet has been identified with the ancient ' $A d$, a fish which figures frequently in the representations, e.g. in the Tomb of $\mathrm{Ti}$, of Ptah-hotep, ${ }^{6}$ and of Naqada. ${ }^{7}$ Its habit of ascending the

1 II. 95.

2 See Alan H. Gardiner, The Tomb of Amenemhat (London, I9I 5), Pl. II, and Petrie, Medum, Pl. XII.

anomasticon, VI. 48. A primitive method of curing prevailed in the last century among the Yapoos -" the fisher then bites out a large piece of the fish's belly, takes out the inside, and hangs the fish on a stick by the fire in his canoe." See Darwin, Voyages of Adventure, etc. (London, r 839), p. 428.

4 Mish., Makhshivin, VI. 3. The Greeks and Copts of the present day, whose enjoined fasts are frequent, rarely split their fish before packing them in large earthen pots.

5 Rechnungen aus den Zeit Setis, I. 87 ff.

- Quibell, The Ramesseum (London, I898), Pl. XXXIIl.

7 J. de Morgan, Ethnographie Préhistorique (Paris, I897), I93. 
Nile from the sea was known and noted by ancient authorities. Strabo, after stating that it, the Dolphin, and the Shad were the only fish so to do, informs us that the Mullet in his upward journey carefully consorted with the Schalls, or Catfish, whose strong spikes afforded it protection against the crocodiles. 1

We find at the end of the XXth Dynasty, say I200 B.C., that 300 of Ireth fish, Ioo of Shena", and $800^{\circ} A d$ (each lot) fetched I kite of silver-the kite being $\frac{1}{10}$ of a deben of $9 \mathrm{I}$ grammes. Although in the XVIIIth Dynasty gold had been just twice as valuable as silver, at this time silver stood to gold in a ratio of I $\frac{2}{3}$ to $I$.

Thus Ioo Shena', 300 Ireth (both of which are as yet unidentified) and 800 ' $A d$ fish were (each lot) worth $\frac{91}{10} \times \frac{3}{5}$, i.e. 5.46 grammes of gold.

Now one sovereign weighs 123.27447 grains, and as $\frac{11}{12}$ of this is gold it contains II3'OoI6 grains of gold. As a gramme equals $15^{\circ} 432$ grains, the value of $5^{\circ} 4^{6}$ grammes of gold thus works out at about I4 shillings and II pence to the nearest farthing. The whole calculation, however, depends on the assumption that the kite is known to be exactly 9'I grammes.

This, the latest estimate of its probable weight, can only be an estimate, for the Egyptians of the XVIIIth Dynasty, at any rate, did not make weights to a minute fraction of a gramme. A calculation therefore to the nearest farthing is somewhat meaningless, unless the weight of the kite is determined to be 9.10, and not 9.09 or 9.1I grammes. Since the weight is certainly not known to two places of decimals, it is doubtful if it can be regarded as correct to the first place. Hence I4s. II $d$. is not absolutely a more accurate estimate than $I 5 /-.^{2}$

Assuming for convenience that the kite was worth $15 /$, we could have purchased at the end of the XXth Dynasty 800 ' $A d$ fish for this sum. One fish would thus cost $\frac{I 5 \times I 2}{800}=\frac{9}{40}$ of a penny: but since the Egyptian Mugil capito, as sold in

1 Cuvier and Valenciennes, $O p$. cit., XI. p. 62.

- In Ridgeway, The Origin of Metallic Currency, etc. (Cambridge, I892). p. 240, is illustrated a fine Kite weight from which one Kite would equal about I 40 grains, corresponding to $9 \cdot 08$ grammes. 
the big markets, averages (I am informed) $\frac{1}{2} \mathrm{Ib}$., the conclusion of the whole matter is that in the era mentioned I lb., or two fish, cost $\frac{9}{20}$, or 45 of a penny. In pre-war days the average marketable price worked out at 2.954 pence per $\mathrm{lb}$., so the Egyptian Mugil in I9I3 cost about $6 \frac{1}{2}$ times more than c. I200 B.C., while the English Mugil in I9I3, which (according to figures kindly furnished me by the Fishmongers Company) averaged Io to I2 pence per lb., cost about 24 times more.

The Egyptian correlation of $6 \frac{1}{2}$ to I cannot, it is true, be definitely established until we have data proving that the kite was exactly 9.I grammes, nor can it be accurately applied to other commodities, but it may help us to a rough approximation of what some of their prices were in the XXth Dynasty. ${ }^{1}$

The depreciation of money between the XVIIIth and XXth Dynasties, heavy as it seems, was as nothing to that which ensued in subsequent centuries. Examples of this can be observed in the fall of the Gallienus tetradrachm from about half a crown to one halfpenny in less than a century. Again under Macrianus (260 A.D.) the coinage was so bad and so worthless that the banks closed their doors, but were compelled by the king to open and continue "his divine coinage." At the time of Diocletian's Edict on maximum prices (30I A.D.) a denarius (4 drachme) was reckoned at 50000 of a litra of gold, but in Egypt after Constantine's reign it fell much lower, e.g. 432,000 denarii equalled I pound.

From the Papyrus Oxyrh. I223 we find the solidus computed at $2,020 \times 10,000=20,200,000$, (!) denarii at the end of the fourth century. ${ }^{2}$

Billon Denarii, i.e. made out of copper and very little silver, ceased to be coined at Alexandria after A.D. 297, and got utterly depreciated.

We get little farther in our quest of correlation of prices

1 The information as to the average prices and weights of the Mugil capito, on which the above calculations were grounded, was obtained from the Department of Supplies in Egypt. "In the markets of Alexandria the weight of the grey mullet varies from 8 to 3 to the oke $\left(2^{\circ} 75 \mathrm{lbs}\right.$.), say $5 \frac{1}{2}$ to $14 \frac{1}{2} \mathrm{oz}$. each. The pre-war retail price was for large fish, 3 or 4 to the oke, 8 Piastres; for small, 8 to the oke, 5 Piastres." The prices in August, I920, had increased to 20 and I6 Piastres respectively, or nearly two-thirds more.

2 Cf. Pap. Oxyrh. 1 430 , Introd. 
even with other passages; in Pap. Fayum Towns (A.D. Ioo), of 12 drachma for fish; in Pap. Petrie III. I07 (e), 6, 24 drachma for fish (third century B.C.) ; and in a Papyrus not yet (I9I8) published, 4 obols and 5 obols for a "male" Cestreus, or Mugil capito.

With salt fish, again, we have no certain leading. For 2 dipla or double jars of this comestible the price was 2 drachma, but then their size is uncertain. ${ }^{1}$ So again it doth not vantage us much to read of 240 drachme being given in A.D. 255 for

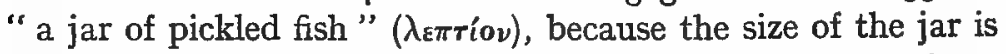
still undetermined." Nor does " 56 drachme for Ioo pieces of salt fish" (third century A.D.) solve the problem because, although a " piece of salt fish " probably implied some definite weight, we have no data for discovering to what this amounted. ${ }^{3}$ Nor again can we deduce anything definite from the statement

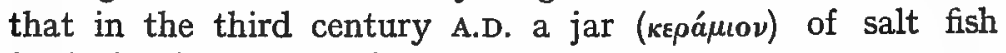
fetched I drachma I $\frac{1}{2}$ obols.

The superior derision with which some writers regard the simple. if inaccurate account, given by Herodotus of the spawning of the Egyptian fish betokens their ignorance of the parable of the beam and the mote.

If Herodotus erred, what (and this I keep reiterating, on the Kipling principle of "lest we forget ") about the theorists for 2300 years as to the procreation of Eels ?

Aristotle with his "Entrails of the earth," Oppian with his " Slime of their bodies," Helmont with his "May Dew," others with their "Horse-hair," and Walton with his "Spontaneous Generation " are they as correct zoologists as the Father of History ? With him procreation resulted from a semi-direct if inaccurate connection, but May Dews and Horse-hairs, etc., etc., what do they or what could they do in the galley of contact?

After which outburst I pass to Herodotus.4

" Gregarious fish are not found in any numbers in the rivers ; they frequent the lagunes, whence, at the season of breeding, they proceed in shoals towards the sea. The males lead the

1 Pap. Oxyy., III. 520, 2 I, A.D. I43.

- Berliner Eriechische Urkunden, I. I4, col. IV. I8.

agyptian Exploration Fund Annual Report, 1906-7, p. 9.

- Bk. II. 93 . 
way, and drop their milt as they go, while the females, following close behind, eagerly swallow it down. From this they conceive, and when, after passing some time in the sea, they begin to be in spawn, the whole shoal sets off on its return to its ancient haunts. Now, however, it is no longer the males, but the females, which take the lead: they swim in front in a body, and do exactly as the males did before, dropping little by little their grains of spawn as they go, while the males in their rear devour the grains, each one of which is a fish. A portion of the spawn escapes and is not swallowed by the males, and hence come the fishes which grow afterwards to maturity. . . .

"When the Nile begins to rise, the hollows in the land and the marshy spots near the river are flooded before any other places by the percolation of the water through the river-banks ; and these, almost as soon as they become pools, are found to be full of numbers of little fishes. I think that I understand how it is this comes to pass. On the subsidence of the Nile the year before, though the fish retired with the retreating waters, they had first deposited their spawn in the mud upon the banks: and so, when at the usual season the water returns, small fry are rapidly engendered out of the spawn of the preceding year. So much concerning the fish."

And was the great zoologist Aristotle 1 more accurate in his suggestion as to spawning? "Some surmise that the female becomes impregnated by swallowing the seminal fluid of the male. And there can be no doubt that this proceeding on the part of the female is often witnessed, for at the breeding season the female follows the males and perform the act and strike the males with their mouths under the belly, and the males are thereby induced to part with the sperm sooner and more plentifully."

The Pahlavi texts tell us that at spawning time or season of excitement fish in pairs travel to and fro a mile in running water. In this coming and going they rub their bodies together, and a kind of sweat drops out between, and both become pregnant. 


\section{CHAPTER XXVIII}

\section{FISHING WITH THE HAIR OF THE DEAD}

THIS chapter owes its birth to a passage of intrinsic interest but gruesome nature.

Before quoting or dealing with it, I may be allowed a few words as to my running it to ground and the curiosity it excited among Angling scholars.

Some years ago I read in an article that " fishing with the

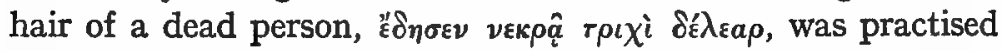
by the Egyptians, as is shown by discoveries during the last thirty years." No authority, no reference was given. "Thirty years" opened up a search too extensive to waste on an anonymous statement.

Even so this fishing with an unknown gut, dead men's hair, kept worrying me. Aristotle and others had written of the use of horse-hair, but none of my friends or I had ever come across this Egyptian tackle. A great authority suggested that it was possibly taken from a body of which the hair continued to grow after death, and thus possessed much value because of length and strength.

Instantly floated before us visions of obtaining by a new Rape of the Lock this most desirable gut. Two nefarious courses were discussed. First, to rifle the coffin of Edward I., which when last opened in Dean Stanley's time revealed (teste the Verger) long hair still growing. Second, to raid the tomb of the Countess of Abergavenny (née Isabella Despencer) in Tewkesbury Abbey, in which (to use Canon Ernest Smith's words) " at the restoration of the Abbey in 1875 was disclosed bright auburn hair, apparently as fresh and as plentiful, as when the body was buried four and a half centuries ago." 1

1 Aristotle (H. A., III. I I, states that the hair does grow in dead bodies. Since his time many descriptions of remarkable growth after death have been 


\section{GROWTH OF HAIR-GUNNAR'S BOWSTRING 34I}

Do the Sagas or other ancient Scandinavian literature, in which descriptions of fishing frequently figure, allude to such use of dead men's hair? Two of the foremost Scandinavian scholars could recall none. The Kalevala - the great Finnish epic-yielded no help.

Nearest comes the account of "Gunnar's Slaying" in Story of the Burnt Njal.1 After his bowstring has been cut by his foe, Gunnar said unto his wife, Hallgerda, 'Give me two locks of thy hair, and ye two, my mother and thou, twist them together into a bowstring for me.' 'Does aught lie on it?' she says. 'My life lies on it,' he said; 'for they will never come to close quarters with me, if I can keep them off with my bow.' 'Well,' she says. 'Now will I call to thy mind that slap in the face thou gavest me,' and refused him her hair.

Gunnar, just ere he falls, sings :

$$
\begin{aligned}
& \text { "Now my helpmeet, wimple hooded, } \\
& \text { Hurries all my fame to earth. } \\
& \text { Woman, fond of Frodi's flour } \\
& \text { Wends her hand, as she is wont." } 2
\end{aligned}
$$

The passage containing the Greek words quoted in the article was eventually discovered on p. 82 of Fayum Towns and their Papyri, by Grenfell, Hunt, and Hogarth.

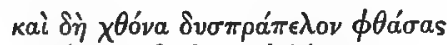

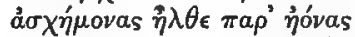

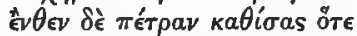

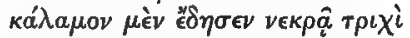

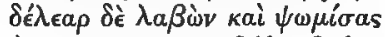

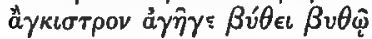

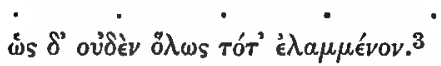

published, and many people believe that such growth does take place. Erasmus Wilson pronounces that "the lengthening of the hairs observed in a dead person is merely the result of the contraction of the skin towards their bulb."

1 Blakey, op. cit., 207, states an engraving was found at Herculaneum " representing a little Cupid fishing with the ringlets of her (sic) hair for lovers." So far I have failed to track this hermaphroditic representation, nor is Sir C. Waldstein aware of its existence.

2 Translated by Dasent. Frodi's flour $=$ gold.

a Professor Grenfell tells me that öre here has no connection, unless the main verb came in line $I 6$, where there is a lacuna, but the traces do not

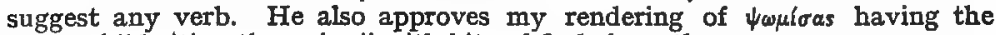
sense of "baiting the swim " with bits of Hlesh from the corpses. 
I subjoin a translation :-

"And so hastening over the rugged ground he came unto the unsightly shores, and there seated on a rock tied the rod with dead hair, and taking bait and feeding with little morsels, drew the hook along (or up and down) in the deep pool. But

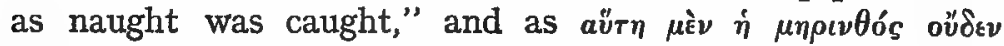
है $\sigma \pi \alpha \sigma \varepsilon v_{3}^{1}$ both in its literal and proverbial sense held true, he returned to the place whence he came, the place of corpses.

The Editors' introduction to the Papyrus runs: "The matter of the poem is hardly less remarkable than the manner in which it was written down. The subject is the adventures of a man whose name is not given. After some talk, the hero proceeds to a place which is full of corpses being devoured by dogs. He then makes his way to the sea-coast and proceeds to sit down on a rock, and fish with Rod and Line. He did not, however, succeed in catching anything: we then revert to the corpses, the gruesome picture of which is further elaborated. The language and style of the composition, the literary qualities of which are poor enough, clearly show its late date, not posterior to the second century."

I am indebted to Professor Grenfell for further information. "The Papyrus," he writes me, "is certainly a poem describing the descent of some one to the under-world. An Austrian, A. Swoboda, 2 wrote an article to show that it belonged to a Naassene ${ }^{3}$ psalm describing the descent of Christ to Hades. The beginning of a poem on this subject, in the same metre as the Papyrus, is known from Hippolytus, Refutatio Hereticorum. The second column of the Papyrus seems to be an address to a Deity, and would fit in with Swoboda's theory.

"The composition being, in any case of a mystical and imaginative character, I do not think the description of the fishing incident is to be regarded as in any way real, and, from the fisher's point of view, it is not to be taken literally. No parallel for the use of dead men's hair in fishing has ever been suggested. In none of the Papyri are there any details about

1 Aristophanes, Thesm., 928. Cf. also Wasps, 174-6.

2 Wiener Studien, XXVII. (I905), pp. 299, ff.

- Or early Gnostics, also called Ophites, who honoured serpents. 


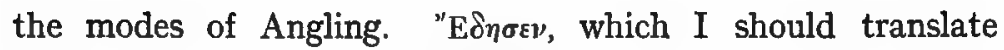
tied, has been generally supposed to refer to the angler's line, and considering the composition is poetical, this seems the natural interpretation."

This coupled with the Introduction to the Papyrus appears to shatter the statement that fishing with the hair of a dead person was practised in ancient Egypt. But although in such a mystic adventure as a Descent to Hades all is possible and all is pardonable, the passage can hardly from its extremely abrupt and casual mention of hair be regarded as heralding in the use of this substance as a quite new adjunct to fishing. It partakes of the nature of a simile.

If it be true that an ancient simile was intended to throw light from the more familiar on the less familiar, but never to illustrate the moderately familiar by the wholly strange, one might, despite the absence of all reference to such tackle in the representations or in classical writers, possibly argue that lines made of the hair of the dead were known and were used by the Egyptians. The substitution of the hair of a dead person for the hair of a horse may be but a bold and not ineffective attempt to heighten the mysticism of the picture.

Apart from the pleasant gain which the quest and the running down of this hare in "a mare's nest " (to mix metaphors boldly) entailed, one's only real satisfaction is that the Egyptian angler, notwithstanding his gruesome gut and loathsome bait, caught NoTHING ! 


\section{CHAPTER XXIX}

\section{THE RING OF POLYCRATES}

IN accordance with my custom of ending the Fishing of each nation by a story in which fish play directly or indirectly an important part, I searched for an Egyptian tale or legend. The serpent Apep in the $\mathrm{Ra}$ myth is merely a variant of similar beasts figuring in the Bel and Andromeda legends: his story, moreover, lacks the stir of battle of the former, or the human interest of the latter. 1 The absence of any such legend is due doubtless to the bad esteem in which fish were held by the priests, who in the early days, at any rate, wrote the history of the country.

As Maspero in his Contes Populaires de l'ancienne Egypte (which by the by differs in The Two Brothers from the account given by Plutarch) failed to provide provender, I perforce fall back on a story, which, if Egean in locale, is Egyptian in effect, the tale of the ring of Polycrates.

This has been used by Cicero and other ancient writers to point the moral of calling no man happy until his death, and by modern to adorn many a tale of good luck, but since its historical importance has often been neglected, I venture to recall shortly what Herodotus sets forth. ${ }^{2}$

1 But as one of the earliest instances of imitative magic the story is notable. In the tale of Overthrowing Apep, based on the XXXIXth Chapter of The Book of the Dead, the priestly directions for destroying this enemy of $\mathrm{Ra}$, or the Sun, run as follows: "Thou shalt say a prayer over a figure of Apep, which hath been drawn upon a sheet of papyrus, and over a wax figure of Apep upon which his name has been cut: and thou shalt lay them on the fire, so that it may consume the enemy of Ra." Six figures in all, presumably " to mak siccar," are to be placed on the fire at stated hours of the day and night. Cf. Theocritus, Id., II. 27 ff., where the slighted damsel prays, "Even as I melt this wax, with the god to aid, so speedily may he (her lover) by love be molten."

2 III. $4^{\circ} \mathrm{ff}$. 
Polycrates, Tyrant of Samos, was so proverbial for a good fortune, which had never met with check or disaster, that Amasis, King of Egypt, fearing the effects of the $\phi \theta$ óvor of the Gods on Polycrates and consequently on their newly-formed alliance, advised him to propitiate them by getting rid of one of his most valued possessions. Accordingly the Tyrant cast into the sea ${ }^{1}$ his seal-ring of extraordinary beauty, which in a few days was found in the belly of a fish and restored to him.

This last shock of happy fortune was too much for Amasis, who broke off his alliance and thus left Polycrates free to aid Cambyses in his invasion and conquest of Egypt. It is fair to add, even at the expense of this pretty fish story, that Grote (IV. 323) holds that Polycrates himself broke off the Egyptian to effect the more powerful Persian alliance.

1 Some recent scholars have suggested that in the stories of Polycrates throwing his ring into the sea, and of Theseus proving his parentage by a like sacrifice, we should detect traces of an early custom, by which the maritime king married the sea-goddess-a custom perpetuated in the symbolical union between the Doges of Venice and the Adriatic. This ingenious hypothesis was first worked out by S. Reinach, "Le Mariage avec la mer," in Revue archeologique (1905), ii. I ff. (=id. Cultes, Mythes, et Religions, Paris, I906), i. 266 ff.).

Nore.-For kind advice at " parlous times" I am indebted to my friends, Dr. Alan H. Gardiner and Miss M. A. Murray. The latter has doubled the debt by reading my proofs. 

ASSYRIAN FISHING 




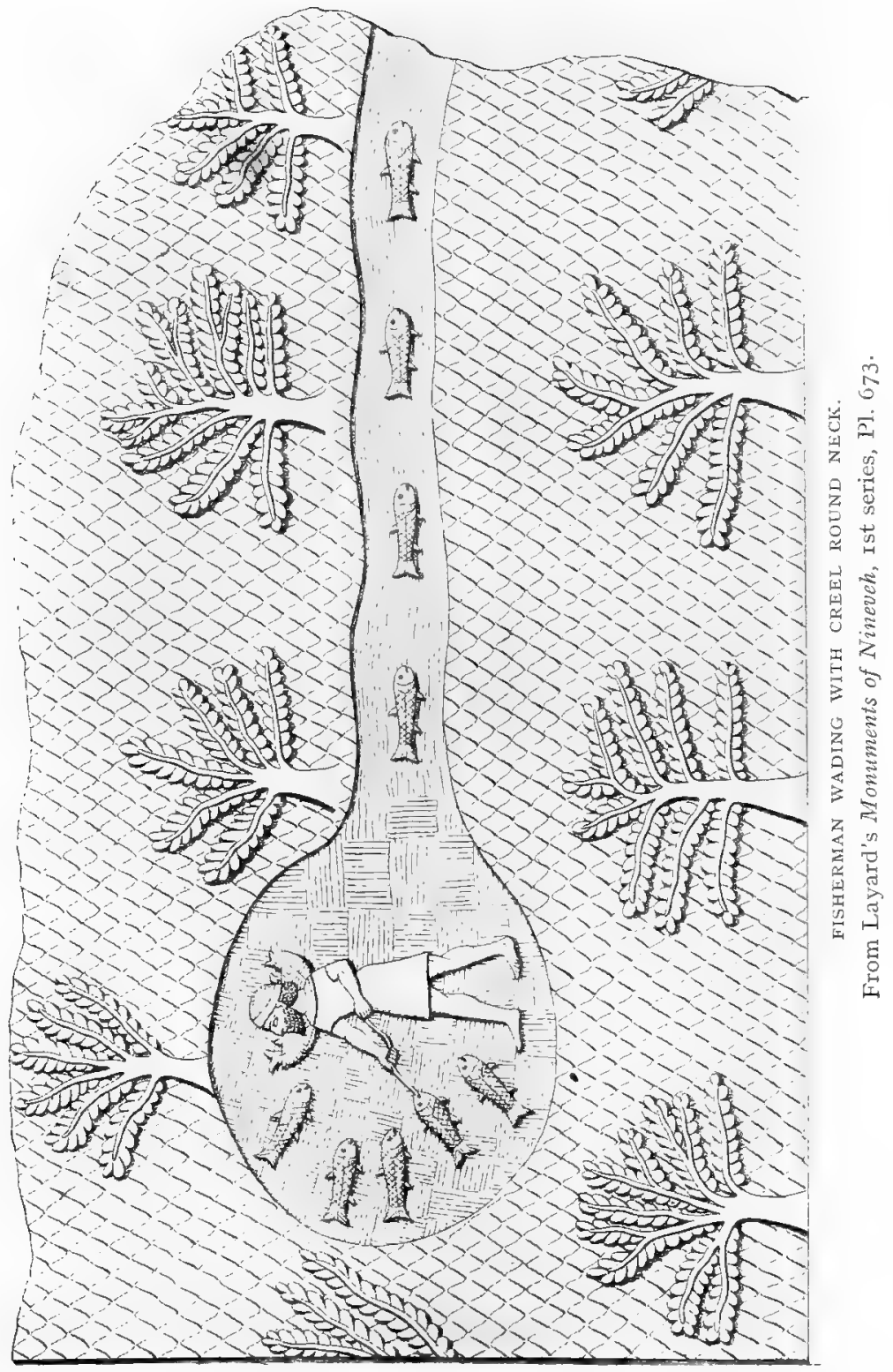




\section{ASSYRIAN FISHING ${ }^{1}$}

\section{CHAPTER XXX}

NO ROD, ALTHOUGH CLOSE INTERCOURSE WITH EGYPT

THERE is no delineation or suggestion of the Rod, or of Angling on any sculpture or any seal, Sumerian, Babylonian, or Assyrian. ${ }^{2}$

The omission does not preclude the existence or use of the Rod. If it did exist, and were used, we are surprised that there should not survive amongst the thousands of things mentioned and the many pursuits represented a single indication of it. Our wonder, indeed, grows stronger when we call to mind that the Assyrians :

(a) Were a people much given to sport of all kinds:

(b) Were keenly addicted to the eating of fish, which was not, as in Israel or Egypt, half-banned by a prophet, or wholebarred to a priesthood by custom, totemistic or other :

(c) Did attach very real importance to the maintenance of an ample supply of fish. Their dams and vivaria, the adjuncts of every important temple or every self-respecting township, and their enforcement of Fish Regulations, attest the economic value :

(d) Do mention and do represent other kinds of fishing, e.g. with the hand-line and the net. The latter, for both fowling

1 The term Assyrian in this chapter usually includes the Sumerians and Babylonians.

" Lest Forlong's sentence (Rivers of Life (London, r883), II. 89), “ A beautiful Assyrian cylinder exhibits the worship of the Fish God; there we see the mitred Man-God with Rod and basket," etc., be quoted in opposition, I would point out that this so-called Rod is merely a cut sapling, like the one in the hands of Heracles, but without a sign of any line, which in the Greek vase in the British Museum is obviously attached. Cf. Elite des monuments Ceramographiques, vol. III., Plate I. 
and fishing, often finds place in their, and Israelitish, metaphors. Examples occur in the story of the defeat of Marduk and Tiamat, "They (the enemies) were cast into the net," and in the prayer of Eannatum to the god Enki that, if the citizens of Umma in future break the recent treaty, he will destroy them in his net. But in the legend of the taking of $\mathrm{Zu}$, the stealer of the destiny-tablets, the net of the Sun-god is certainly a fowling one :

(e) Did possess near at hand, and had not to import (as the Romans from Africa) ample material for the Rod in reeds, which were abundant near Babylon and were utilised in the construction of furniture, light boats, and fences. In the lists of private property these reeds-employed for household not angling purposes-figure not infrequently:

( $f$ ) Were for hundreds of years closely associated in intercourse and trade with the Egyptians, whose use of the Rod can be carried back to about the XIIth Dynasty, c. 2000, or, according to Petrie's chronology, c. 3500 B.c.

Before discussing the date of the first contact or connection between the two countries, it is advisable shortly to distinguish between the three peoples whom I group under the term Assyrians, and roughly apportion the periods of the four thousand odd years of Assyrian history during which each was predominant.

The first, the Sumerians, occupied before-perhaps long before-the close of the fourth millennium the land on the lower plain of the Tigris and Euphrates and on the sea coast, as it then was. ${ }^{1}$ They possessed an advanced civilisation, with an organised government, many large cities, and considerable agricultural and industrial development.

Whence their emigration, to what family, Mongol or other, they belong, is not clear. It is settled they were not Semites, like the Babylonians and Assyrians. Their language (preserved

1 From the find (made during the war by a Sikh regiment on the Tigris above Samara) of an alabaster vase (now in the Ashmolean Museum), which from archæological reasons must be placed among the very earliest remnants of Sumerian civilisation, it is evident that-given the discovery was in situthe frontiers of the Sumerian Empire must have extended much farther north than has been hitherto generally supposed. Owing to the deposits of the two rivers, the sea has receded some hundred and twenty miles. 
in liturgies, etc., ${ }^{1}$ down even to the time of the Persian conquest) and their writing, adopted by the Babylonians and Assyrians, which runs, unlike the Hebrew, from left to right, ${ }^{2}$ disprove Sumerian descent from Shem.

It is impossible at present to fix a definite period for their immigration. The dates assigned vary from 7000 to 4000 B.C. The statement, however, that "Aryans, Turanians, Semites were all in a nomadic condition, when the early Sumerian settlers in Lower Babylonia betook themselves to agriculture, builded great cities, and established a stable government," seems hardly exaggerated, even though it postulates a very ancient era.

The second, the Semitic Babylonians, starting possibly from South Arabia by way of the Syrian coast, reached the lower part of the Tigris and Euphrates about 3800 B.c. ${ }^{3}$ It was not, however, until some thousand years afterwards, that they effected a conquest of the Sumerians.

Like other defeated peoples, such as the Canaanites with the Jews, the Irish with the English, "Hibernis ipsis Hiberniores," they grafted their policy on that of their victors, and perpetuated many of their racial characteristics and customs, as well as their religion. "The Semitic invaders seem to have been completely converted. In fact Babylonian religion has scarcely anything characteristically Semitic in it." 4

The third, the Assyrians proper, an offshoot from Babylonia, are found (before 2300 B.c.) pushing their way north along the Tigris, on whose western bank they founded their first city and earliest capital-Asur. Wars between them and Babylonia mark the history of centuries. Their definite suzerainty over

1 The Sumerians made extensive use of music, especially in their religious ceremonies; they were the founders, according to Langdon, of liturgical music, which unfortunately it is impossible to reconstruct, as the notes themselves have not survived.

2 The Sumerian language was not well adapted to express peculiarly Semitic sounds.

a Petrie (Egypt and Israel (London, I9II), p. 15): "The Turanian race akin to the modern Mongols, known as Sumerians, had civilised the Euphrates valley for some thousands of years and produced a strong commercial and mathematical culture. The wandering Semite had at last been drawn into this settled system of life."

S. Langdon, Babylonian Magic, Bologna, IgI4. 
that country was only established by Tiglathpileser III., c. 730 B.C.

Passing now to the dates of the connection between this Empire and Egypt, the first assigned is :

(a) Early dynastic, say about 4400 B.C., which would probably correspond to the early Sumerian periods. Some authorities indeed hold that Egypt was invaded by Babylonians, or was culturally permeated by the "proto-Babylonians," or Sumerians. Of invasion we possess no proof, or even strong suggestion; of cultural permeation, to which Hommel, in especial, attributes the whole primeval culture of Egypt, some elements and some signs are possibly noticeable, but even these are Semitic, not Sumerian, ${ }^{1}$ while their total compares insignificantly with those of native origin. ${ }^{2}$

Of these signs, the use by the Egyptians of the cylinder seal, of which the Royal tombs of the first Dynasty afford examples, stands out as the most important. As this characterised Sumer and Babylonia at all times, while it fell into disuse in the country of the Pharaohs, the seal was inferred to be an original product of Sumer, whence it reached Egypt in late pre-dynastic or early dynastic times.

But (as King ${ }^{3}$ continues) "Recent research-such as Naville's at Abydos, and Reisner's at Naga-ed-Dêr-leaves small room for the theory that early Egyptian culture was subjected to any strong foreign influence in early dynastic times; thus the theory of the invasion by Semitic tribes must be given up." Maspero maintains that as far back as

1 The carved ivory handle of a flint knife in the Louvre proves (according to Petrie) that the art of slate-palettes in Egypt originated from Elamite civilisation, which flourished before its rise. It must be of pre-historic age, yet shows a well-developed art with Mesopotamian or Elamite affinities earlier than the sculptured slate-palettes and maceheads. M. G. Bénédite (Monuments Pict.) holds that in this knife-handle we have the most tangible evidence yet found of a connection in very early times between the Egyptian and Mesopotamian civilisations. King (Jour. Egypt. Archoology, vol. IV. p. 64) suggests that there was a connection with Babylonian-Elamite seals from Susa.

2 Thus the general conception of pictographic writing might perhaps be borrowed from the Euphrates valley, but not a single sign taken from the Babylonian script can be found (W. Max Muller, Encly. Bibl., P. 1233). Dr. Alan Gardiner, on the origin of the Semitic and Greek alphabets, concludes that the evidence does point to the alphabet being Semitic in origin and based upon acrophonic picture signs (Journal of Egyptian Archaology, vol. III., p. I).

3 History of Sumer and Akkad (London, rgro), p. 322. 
the IVth or Vth Dynasties there were overland relations between Egypt and Chaldea. ${ }^{1}$

(b) Petrie 2 places the beginning of the invasion of Egypt by the Semites about 3400 B.C. When referring to a painting of one of these Princes of the Desert named Absha coming into Egypt, he writes that " though rooo years before Abram" (whom he himself dates about 2roo B.C.) " he was one of the same race: it is therefore invaluable as an historical type of the great Semitic invasion." Evidence from Egyptian sources seems to show that before and after the conquest by the Hyksos, Semitic invasions occurred after the VIth Dynasty and again c. 2250 B.C.

Petrie, on the strength of the cylinder of Khendy and the tablet of Khenzerm-two Babylonians "who rose to the throne of Egypt"-concludes that an invasion from SyroMesopotamia took place in the XIVth Dynasty, say 2800 B.C.

(c) It is not, however, till the XVIIIth Dynasty, c. I400 B.C., that we reach firm ground for fixing the first point of direct historical contact between Babylonia and Egypt.

Authority for this dating is found in the famous tablets brought to light in 1887 at Tel-el-Amarna, which include letters from the rulers of Babylonia and Assyria to Amenhotep III. and his son Akhenaton. Apart from the historical value of their presumptive indication of an earlier intercourse, the discovery discloses three points of great interest.

First, the fact that these were written in Babylonian shows that this language had already become the lingua franca of the civilised world. Second, a more human personal note, the probability from the red dots (still visible) made by some Egyptian with a reed for the purpose of marking the divisions of the foreign words, that the acquisition of this lingua franca was advisable, perhaps necessary, to qualification for a clerkship or an embassy. Third, that Babylonian literature had found its way among the nations which used its language.

Of this we have conclusive evidence in two documents.

1 Egyptian Archaology (1902), p. 366.

2 Historical Studies (London, I910), II. p. 22. Others would make the invasion about 2466 . 


\section{NO ROD-CLOSE INTERCOURSE WITH EGYPT}

The first concerns the goddess Ereshkigal, the other transmits the legend of Adapa. ${ }^{1}$

From the Bekten stele we deduce a close intercourse between the two countries about the XIXth Dynasty, for we read of Rameses II. ${ }^{2}$ being in Mesopotamia " according to his wont, year by year," and receiving tributes and presents from the chiefs of the countries round about.

The connection between Assyria (proper) and Egypt rests on ample evidence. Fish, or "beasts of the sea," passed as presents, perhaps as trade. On the Broken Column of TiglathPileser I. (Cylinder IV. 29-30) we read, "And a great beast of the River, a great beast of the Sea, the king of Musre" (probably Egypt) "sent (unto him)."

The Select Papyri (pl. 75, I, 7) tell of certain fish being brought, perhaps as a staple of trade, from the Puharuta or Euphrates to Egypt, and (in pl. 96, I, 7) of another fish or fishy substance called Rura, being imported from the land of the great waters, Mesopotamia. ${ }^{3}$

1 The Babylonian legend of Adapa is thus known to have circulated in Palestine and Egypt before the Hebrew Exodus. The story of Adapa is thought by some to have influenced the Hebrew version of the story of Adam and Eve and the loss of Paradise. See the excellent discussion in T. Skinner, Genesis (in the International Critical Commentary (I9I2), $P_{.}$9I ff), and Langdon, The Sumerian Epic of Paradise (University of Pennsylvania, Publications of the Babylonia Section, I9I5), vol. X., pp. 38-49.

2 Rameses II. was held in high esteem as a rain-maker-perhaps rain-god -as is evidenced by the sacrifices offered by the Hittites that their princess should on her journey to Egypt to marry Rameses enjoy fair weather, despite that it was the season of the winter storms. In consequence of this power over the elements, the Hittite chiefs strongly advocated friendship with Egypt, as otherwise Rameses II. would probably stop rain and cause a famine in their country (Breasted, Ancient Records, III. 423, 426).

${ }_{3}$ Layard, Nineveh (London, 1849), vol. II. p. $43^{8}$. 



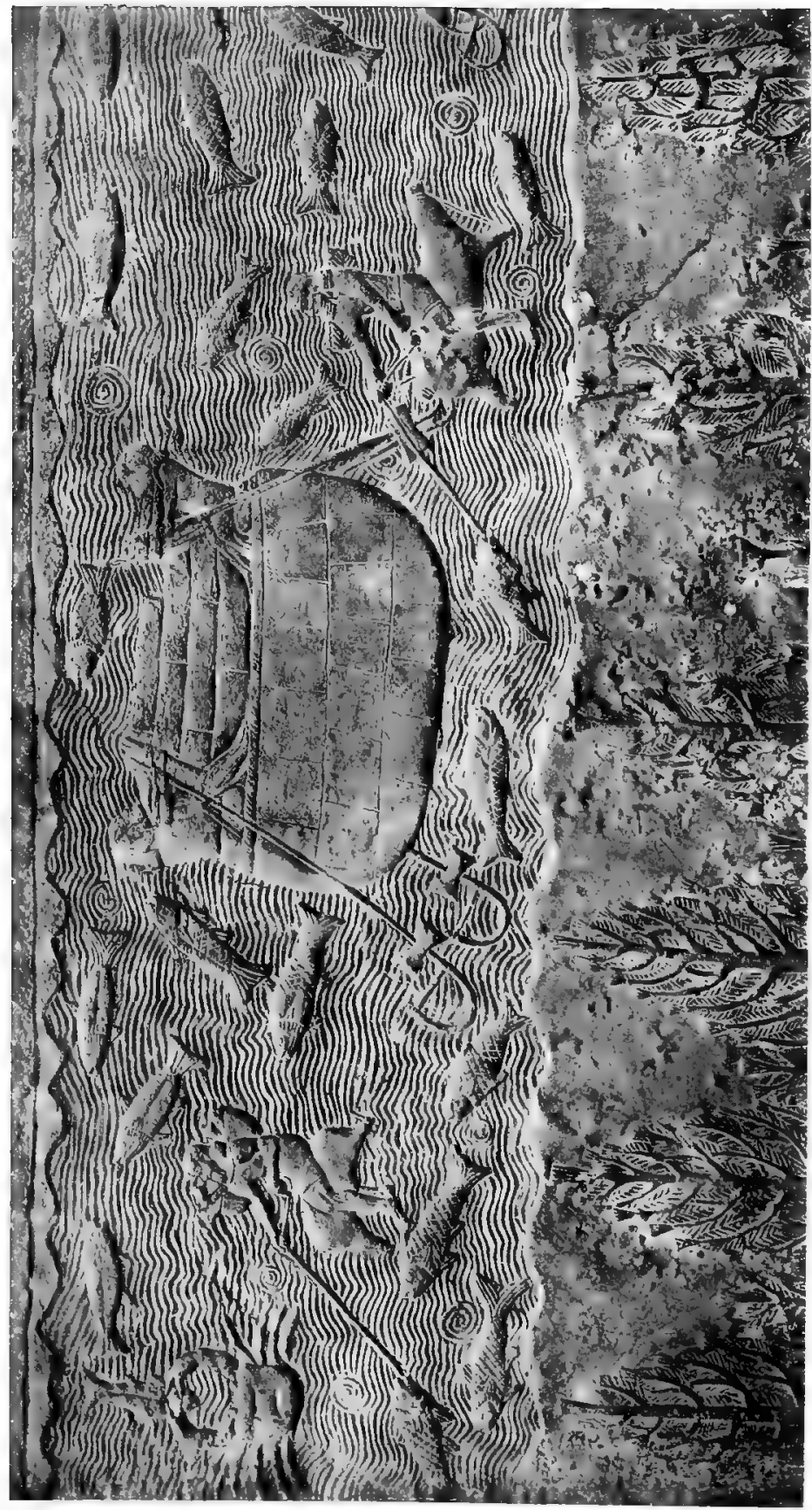




\section{CHAPTER XXXI}

\section{FISHING METHODS}

THE relevance to fish and fishing of all the preceding matter, except the last two sentences, may be challenged : a moment's consideration, however, shows that it is apposite.

The object of introducing these historical facts is to demonstrate (I) the existence of an intercourse between Assyria and Egypt for certainly fourteen hundred, possibly three thousand, years, (2) to show cause for our astonishment at the absence of the Rod from all Mesopotamian representation or records, and at the non-adoption of a weapon which for centuries found favour with the Egyptians.

In my Jewish chapter I comment at length on the absence of any mention of or allusion to the Rod in Israelitish literature and on the unconvincing reasons advanced for this absence. Angling may have been unsuited to the Semitic temperament, because it yielded less lucrative returns than the Net.

Even if we grant that the ruling or only passion of this temperament was for fishing " in plenty," why, we are driven to ask, did both nations condescend to fishing with hand-lines, which are not much more productive than the Rod? If handlining was prompted by some instinct of sport, why was Angling, the higher development of this instinct, not also reached?

Of the four implements of Fishing, the Spear, the Rod, the Line and Hook, and the Net, the Assyrians seem to have

1 "Fishing, fishing everywhere" is the key-note of the picture; the crab in the top left-hand corner is also well into his fish. The picture facing p. 349 comes from the Assyrian sculptures in British Museum : in Mansell's collection, No. $43^{\circ}$. 
been acquainted only with the last two, Line and Hook, and Net.

Examples of the former method occur in Monuments of Nineveh (Ist Series). In Plate $39 \mathrm{~B}$, a man sitting on a terrace by a river is depicted in the act of landing a fish ; in Plate $67 \mathrm{~B}$, a man is wading in a river with what seems to be identical with a creel. The first was excavated, and subsequently re-buried at Nimroud, the latter (also re-buried) at Kouyunjik. The second picture excites a livelier interest, for two men well into their fish are shown in the water astride the inflated skins of a goat - a method of crossing the Tigris as habitual then as in the present year of our century. ${ }^{1}$

Despite Rawlinson's sentence, " of early Chaldean (i.e. Sumerian) there are found made of bronze materials chains, nails, and fish-hooks," 2 no specimen of a fish-hook, bronze or other, has been as yet obtained in Mesopotamia. It is impossible thus to determine whether the hooks were straight like those recorded by Plutarch, bent like those of the Odyssey, or barbed. Cros, however, claims that Lagash excavations yielded " copper fish hooks." Rev. d'A ssyr., vi. 48.

Representations also fail to help, probably because a hook, plain and simple, hardly commends itself as a subject for artistic treatment. Nor does the primitive Assyrian sculptor, however distrustful of the imagination of the observer, go as far as to depict " by conventional device" a hook inside the mouth of the fish which is being taken!

In the Assyrian language there is apparently no word for fish-hook. From the resemblance between the Hebrew word hooh, which means both thorn and fish-hook, and the Assyrian word hâhu, which, it is alleged, means thorn, it has been

1 We sometimes find with an army crossing a river, as delineated in the sculptures, each soldier with the skin beneath his belly and paddling with his legs and arms, but retaining in his mouth one of the legs of the skin, into which he blows as into a bagpipe. The act of paddling across a big river, like the Euphrates, would of itself need all his breath; but King points out that the sculptor, in the spirit of primitive art, which, diffident of its own powers of portrayal or distrusting the imagination of the beholder, seeks to make its object clear by conventional devices, wishes to indicate that the skins are not solid bodies, and can find no better way of showing it than by making his swimmers continue blowing out the skins.

2 Five Great Monarchies (London, I862-67), vol. I. p. 99. 
conjectured that in the latter word we have the Assyrian term for fish-hook. Professor S. Langdon, who in a letter to me advances this conjecture, goes even farther-" in fact hâh hu is our only direct evidence for the practice of fishing with hook and line in Assyria."

Basing himself on a similar Hebraic resemblance, he would make the Assyrian sinnitān, " two reins," come from a supposed sinnitu, a possible feminine of sinnu, which occurs perhaps in the sense of "thorn," and carry the same meaning as the Hebrew sên, which probably equals "thorn," while its plural sinnoth does stand for " fish-hooks."

He believes that in the word, abarshu, which Esarhaddon employs, "I snatched him (Abdi-Milkuti, King of Sidon) as a fish from the sea," and again, of a chief of the Lebanon range who had rebelled and fled, "I caught him from the mountains like a bird," we have evidence of a technical word for pulling or jerking out a fish with a line held in the hand, or perhaps attached to a Rod, because "snatch" would hardly be the appropriate term for the slower action involved in the drawing in of a net. I

Whether in the first simile the suggestion is philologically valid is a point for Assyrian scholars to determine. The adequate rendering or explaining of Sumerian words by Assyrian ones is often difficult and doubtful, for while the latter language is a great help to understanding the former, the Assyrian, especially the later Assyrian, equivalent does not entirely correspond to what would be expected from a literal analysis of the Sumerian word. The second simile, I hold, alludes to the Net of the fowler, with which the representations show the Assyrians to have been familiar.

' In each case Esarhaddon " cut off his head." Both heads were sent to Nineveh for exhibition. Asur-bani-pal was a greater specialist in heads than his father: the head of any foe whom he particularly hated or feared, such as Teumann of Elam, was preserved by some method, and hung conspicuously in the famed gardens of the palace. A sculptured representation hands down the scene to us. The king reclines on an elevated couch under an arbour of vines: his favourite queen is seated on a throne at the foot of the couch: both are raising wine cups to their lips: many attendants ply the inevitable fly-flappers, while at a distance musicians are ranged. Birds play and flutter among the palm and cypress trees; from one dangles Teumann's head on which the eyes of the king are gloating. Such is the picture drawn by de Razogin, Ancient Assyria (London, 1888). 
While there may be doubt whether we possess any Assyrian word signifying hooks, there can be none as to their existence and their employment.

From the absence of any, even conjectural, word for or representation of a float, we can only infer that ground bait fishing was the chief, perhaps the sole, line method in vogue.

$I$ can find no evidence that the Assyrians availed themselves of the spear, the trident, drugs or poison, but as the first two figure in Egyptian, Jewish, and Roman records, and appear to be the common property of all early peoples, the probability is that they were known and used in the Two Rivers.

The fish of these resembled the fish of the Nile in their alleged refusal to rise to a fly, but our soldiers have caught on the fly hundreds of "salmon" of good weight up to Ir2 lbs. One (hand-lined) scaled I7o lbs., and one (speared) ran up to 2I5 lbs. This "salmon" is a kind of mahseer, the noblest of the carp family, 1 or, according to Mr. Tate Regan, a barbel, probably the species Barbus esocinus described by Heckel as coming from the Tigris. ${ }^{2}$

The second method was by Netting, which to judge from its repeated occurrence either as a pursuit or in metaphor was universal, and prevailed far more extensively than line fishing, especially in Sumeria. The only Sumerian word, according to Dr. Langdon, for fishing, $h a-d i b$ (one of the oldest words in the world for the act or occupation), signifies or is akin to a word signifying "to surround," i.e. with a net, as does the Babylonian term bâru. If this be the case, Netting probably constituted their universal, possibly their only fishing.

In the eastern division of Assyria proper lie the main tributaries of the Tigris, such as the Zāb and the Diyālā, rising among the Kurdish mountains. As Netting was naturally more restricted in this area than in the Persian Gulf, line fishing possibly obtained more widely here than in the South.

At any rate it is from the Sumerian excavations that we derive a well-known example of metaphorical Net fishing.

1 See The Fishing Gazetle, January 6, 1917.

2 See The Field, March 15, I9I9. The fish is said to attain a weight of over 300 lbs. 


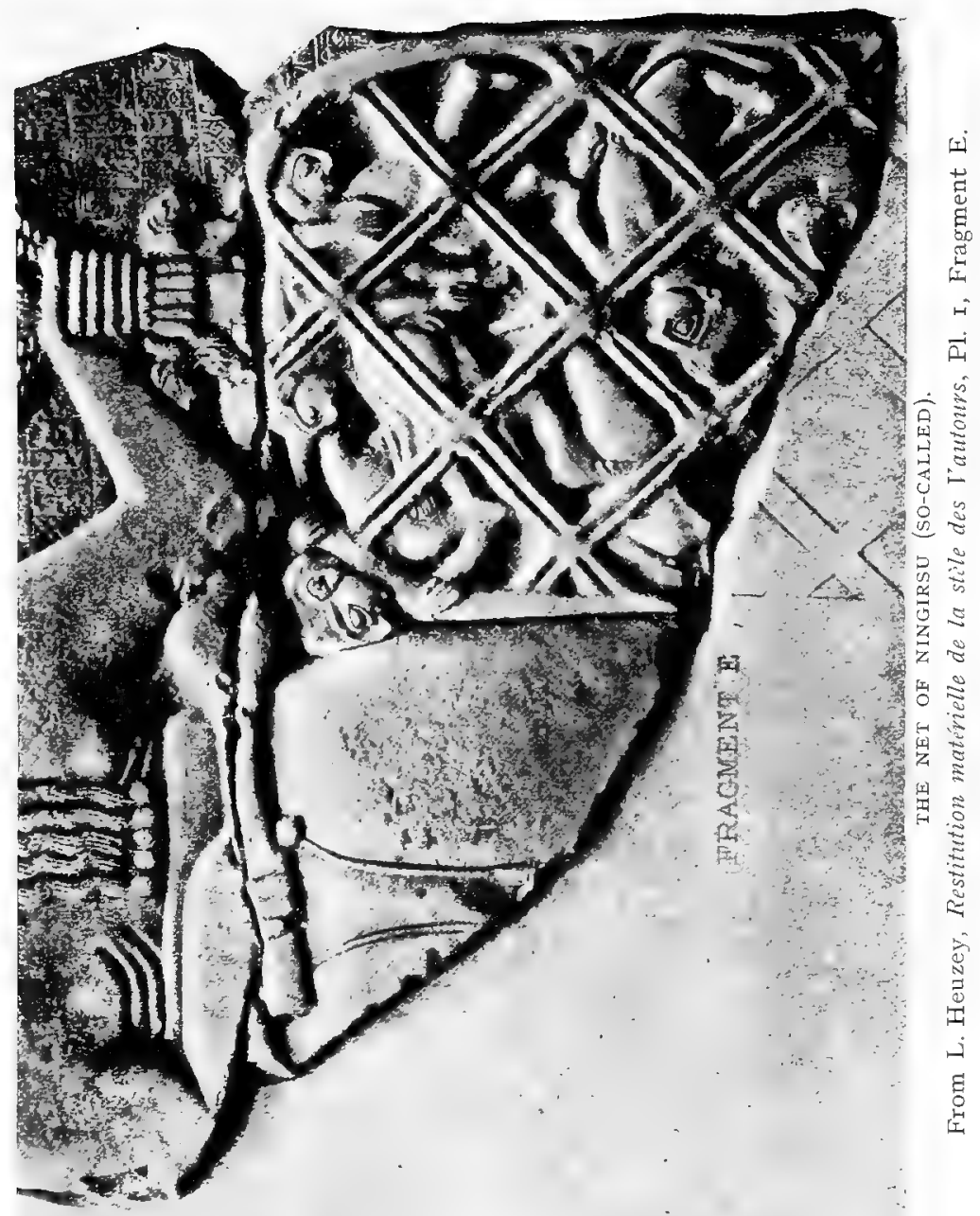



This is to be found in what till lately has been held to be a fine representation 1 of Ningirsu, the god of the Sumerian Telloh or Babylonian Lagash, triumphing over his enemies.

The Net full of prisoners symbolises the capture of the enemies of the city. To indicate the impossibility of escape (Jastrow continues), " a prisoner who has thrust his head out of one of the meshes is being beaten back by a weapon in the hands of the god." 2 King further elaborates the scene; "The god grasps in his right hand a heavy mace which he lets fall upon the Net in front of him containing captives, whose bodies may be seen writhing and struggling like fish in the broad meshes. On the relief, the cords of the Net are symmetrically arranged: the rounded corners at the top show it as a Net formed of ropes and cordage." 3 But later Sumerian scholars deny that Ningirsu has anything to do with the Net or even figures in the scene. On the Stèle des Vautours the person represented is not a god, but a king, Eannatum, with captured soldiers enclosed in the Net (Shusgal). What is more, the king in the accompanying inscription, not only designates the Net as that of Enlil, the earth god, but also of Ninharsag, the mother goddess, of Enki, the water god, of Siu, the moon god, and of Shamash, the sun god. All the greater gods were supposed to carry nets: Ningirsu must certainly have possessed one, but neither he or it are depicted here.

1 See Planche I. of Restitution de la Stele des Vautours, by Leon Heuzey.

2 Civilisation of Babylonia and Assyria (Philadelphia, I9I5), p. 387.

a $A$ History of Sumer and Akkad, op. cit. (I9I0), p. I $3 \mathrm{I}$. The scene is shown in the Plate which fronts this section. 


\section{CHAPTER XXXII}

\section{THE EARLIEST RECORDED CONTRACT OF FISHING}

ONE of the very earliest-the earliest as far as I have foundrecorded contract concerning fishing occurs in the second year of Darius II., 422 B.C. It runs thus ${ }^{1}$ :-

"Ribat son of Bel-ERIba the sLave of ENIIL-NadinSHUMI SPOKE OF HIS OWN FREE WILL TO ENLIL-NADIN-SHUMI SON OF MURASHU IN THE FOLIOWING MANNER: 'THE FISHPOND BETWEEN THE VILLAGE AHSHANU AND THE FARM OF BEL-ABU-UZUR IN THE FIELD OF THE MASTER OF THE MERCHANTS and the fishpond in the field of the PREfect and the FISHPOND BY THE VILLAGE OF BIT-NATUN-EL, GIVE ME FOR YEARIY PAYMENT. EACH YEAR I WILI GIVE ONE HALF TALENT OF PURE SILVER, AND FROM THE DAY ON WHICH THE FISHPONDS ARE GIVEN TO ME FOR FISHING, DAILY WILL I SUPPLY FISH FOR THY TABLE.' AND THEN ENLIL-NADIN-SHUMI HEARD HIM, AND HE GAVE HIM FISHPONDS FOR A YEARLY TRIBUTE OF HAIF A TALENT OF SILVER.

"SIGNED IN THE PRESENCE OF TWO JUDGES, BEFORE SIX WITNESSES, AND A SCRIBE."

The Tablet is impressed with five seals. ${ }^{2}$

The next recorded fishing contract deals with netting in Babylonian waters. It is dated the 25th day of Elul in the fifth year of Darius II., or 4I9 B.C. B. Meissner's translation of the document may be rendered as follows ${ }^{3}$ :-

1 A. Ungnad, Hundert Ausgewählte Rechtsurkunden, No. 56.

2 Two contracts (in 5th year of Darius II.) contain provisions that in case " of any fish being lifted," i.e. stolen, the keeper has to pay a fine of Io shekels, and in second case to compensate owner. Revue d'Assyriologie, vol. IV., pp. $182-x 8_{3}$, by V. Scheil.

- Orientalistiche Litevaturzeitung (Berlin, I914), p. 482. This was published by Clay in Publications of the Babylonian Section of the University of Pennsylvania, vol. II., Part I., No. 208. We find a receipt in the XXth century B.c. 
“Makimni-Anni the son of Bel-Ab-usur, Bi'-ILIya the SON OF . . . \& IshiYa, NATIN THE SON OF TABSHalaM, aND ZADABYAMA THE SON OF KHINNI-BEI, OF THEIR OWN FREE WILL SPOKE AS FOLLOWS TO RIBAT, THE SON OF BEL-ERIBA, THE SERVANT OF RIMUT-NINURTA: 'GIVE FIVE NETS AND WE WILL DELIVER TO YOU FIVE HUNDRED FISH OF GOOD QUALITY (TUKGKUNU) BY THE I5TH DAY OF THE MONTH TISHRI IN THE 5TH YEAR!' THEN RIBAT HEARKENED UNTO THEM AND GAVE THEM FIVE NETS. ${ }^{1}$ ON THE I5TH OF TISRI THEY SHALI DELIVER THE FIVE HUNDRED FISH OF GOOD QUALITY. IF THEY DO NOT DELIVER THE FIVE HUNDRED FISH OF GOOD QUALITY ON THE APPOINTED DAY FOR THEIR DELIVERY, THEN ON THE 2OTH DAY OF TISHRI SHALL THEY DELIVER A THOUSAND FISH. EACH ONE GOES BAIL FOR THE OTHER IN RESPECT OF MAKING UP THE NUMBER OF THE FISH. FOR THE FIVE HUNDRED FISH, BEL-IBNI, THE SON OF APLA, ALSO GOES BAIL."

The parties to the contract are Ribat, the steward of the rich Babylonian banker Rimut-Ninurta, and five Aramaic fishermen. In consideration of Ribat's furnishing five nets, they bind themselves to deliver by the I5th of Tishri (about September), i.e. within twenty days from the making of the contract, five hundred fish. On failure to do so, the time is extended by five days, but the number of the fish is then increased to one thousand. Each of the five fishermen "goes bail " for delivery of five hundred, or if need be, of a thousand fish, but an outsider, Bel-ibni, son of Apla, cautiously limits his bail or guarantee to the first figure.

These documents possess many points of interest.

(A) They are not only the very earliest, but I suggest the only extant fishing contracts (proper) prior to the third century A.D. In Egypt, during the Ptolemaic period, fishermen,

for salt used for fish supplied by a grocer, sealed by the official controller. C1. M. Shorr, Urkunden des Altbabylonischen Civil und Processrechts, No. 256.

I In the Neo-Babylonian period the word, which makes its first appearance in this contract, employed for net appears to have been salitu or litu. The word is written sa-li-tum, and the first syllable (sa) may be either part of the word, or else the determinative riksu, which is written before things made of cordage. If the word be read salitu, it may perhaps be derived from the root, salhi, to immerse. The rendering of the word as net is not quite certain, but, as will be seen from the translation of the text, the context points to this meaning. It is clearly some sort of tackle used by fishermen, and the most obvious meaning would be net. 
it is true, had to pay to the Government a quarter of the value

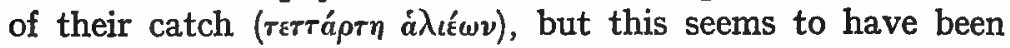
a regular tax. Later on we find fishermen paying to the priests of Lake Moeris a pópos (not to be confounded with $i \chi \theta v \eta \rho \grave{\alpha} \delta \rho v \mu \hat{\omega} v$, or state tax) which presumably included the purchase of the right to fish, as well as the hire of boats. But this was in the nature of a royalty or rent, was a continuous obligation, and proportioned to the catch, whereas in our second document the time is limited, and the payment fixed, not proportioned. 1

(B) The second contract demonstrates that the custom of additional guarantors is no mere modern institution.

(C) It also tends to show that the system, previously known as employed by Babylonian landlords, of letting their farms to tenants for a fixed proportion of the crops, extended occasionally to their waters as well.

1 See antea, 333 f., and Tebtunis Papyri, vol. II. pp. I80-18I. B. P. Grenfell and A. S. Hunt, I907. 


\section{CHAPTER XXXIII}

\section{FISH-GODS-DAGON}

I FIND no trace in Assyria of Ichthyolatry, or of certain fish being accounted sacred, or forbidden as food. The nearest approach to abstention occurs in the warning that on the 9th day of Iyyar to partake of fish was almost certain to bring on an attack of sickness, just as in Syria ichthyophagy was held to entail ulcers and wasting diseases. ${ }^{1}$

Despite the Dagon or Oannes traditions, I am not convinced that in the crowded pantheon of Babylon or Assyria there can be found a fish-god proper, or god of fishing, i.e. a deity similar to those of Greece and Rome with a temple and established priesthood, to whom fishermen made prayer and offerings either for boons received or favours to come.

If the word, fish-god, is limited strictly to those images, half-man, half-fish, which are to be found on seal Cylinders, ${ }^{2}$ or sculptured or depicted in the outer halls or walls of some deity's temple, there is certainly-even if the images at Nineveh were importations from the Mediterranean coast and not indigenous-considerable proof of their existence. But if the word connotes the attributes of a special temple, a priesthood, and sacrifices, such as we find in connection with the Philistinian Dagon at Ashdod, I suggest there is no proof whatever. The fact seems to be that in early Sumeria the fish-god or man-fish was a symbol of Ea, the god of water, and probably derived from Aquarius. 3

The Assyrian colonists carried north with them the pantheon

1 See antea, p. 99, n. I.

2 See W. Hayes Ward, Seal Cylinders of Western Asia (Washington, I9ro), p. 2 I 7 , figs. $658,659,660,66$ I.

${ }^{3}$ Ward, op. cit., p. $2 \mathrm{I}_{4}$, in fig. 249 , gives apparent confirmation. 
of the Babylonians, composed in part of the local deities of Sumeria, and in part of their own translated from their original habitat; but from the start they modified the hierarchy and changed materially the individual attributes of the gods. ${ }^{1}$

Thus we find that mighty Assyrian hunter, Tiglath-Pileser I., in his record of the beasts he had taken, e.g. four elephants caught alive, or had slain in the desert, which included "four wild oxen mighty and terrible, ten elephants, one hundred and twenty lions on foot, and eight hundred speared from his chariot," ascribing his success to the help of the gods Ninurta and Nergal.

These gods were closely associated with battle and sport, but to both other characteristics were attributed at various epochs of their godhood. It has been suggested that the evolution of the fish-god Dagon from the Babylonian deity Dagān followed on such lines, but sufficient data for an identification of the two do not survive.

From the sculptures discovered at Kouyunjik and at Nimroud (now in the British Museum), and from an Assyrian cylinder, ${ }^{2}$ Layard is able, although all three vary somewhat in details, to describe this so-called fish-god, be it Oannes or Dagon, ${ }^{3}$ as "combining the human shape with that of the

1 In noting the attributes ascribed to various gods, we are confronted by the problem as to what suggested to the Babylonian his precise differentiation in their characters. These betray their origin: they are the personification of natural forces: in other words, the gods and many of the stories told of them are the only explanation the Babylonian could give, after centuries of observation, of the forces and changes in the natural world. In company with other primitive peoples he explained them as the work of beings very similar but superior to himself. See King, Babylonian Religion (London, 1889). This inevitable tendency of anthropomorphism was tersely expressed by Xenophanes of Colophon (frag. I5):-

"If oxen, horses, lions had but hands

To paint withal or carve, as men can do,

Then horses like to horses, kine to kine,

Had painted shapes of gods and made their bodies

Such as the frame that they themselves possessed."

"For the Nimroud sculpture, see Monuments of Nineveh, op. cit., and Series, Plate 6, while for the agate cylinder, see Nineveh and Babylon (London, I 853 ), p. 343, where in a note Layard writes, "It is remarkable that on this cylinder the all-seeing eye takes the place of the winged human figure and the globe in the emblem above the sacred tree."

- For the data and authorities available in 1855 and examination into Oannes and Dagon, see J. B. Pitra, Spicilegium Solesmense, III., pp. 500, 501 , 503. 
fish. The head of the fish formed a mitre above that of the man, whilst its scaly limbs, back, and fan-like tail fell as a cloak behind, leaving the human limbs and feet exposed." But in identifying this mythic form with Oannes, he terms it merely " the sacred man-fish," not deity.

There were to be seen in the temple of Belus, according to Berosus, sculptured representations of men with two wings, or two faces, with the legs and horns of goats, ${ }^{2}$ or the hoofs of horses ; also bulls with the heads of men, and horses with the heads of dogs. ${ }^{3}$

I venture to suggest that the mystic fish-form of Dagon or Oannes is of the same nature and in the same category as the man with the legs and horns of goats, or with the hoofs of horses: but these mythic goat or horse forms were not elevated into goat-gods

1 Nineveh and Babylon, op, cit., pp. 343,350 . See also Le Mythe de Dagon, by Ménant; Revue de l'Hist. des Religions

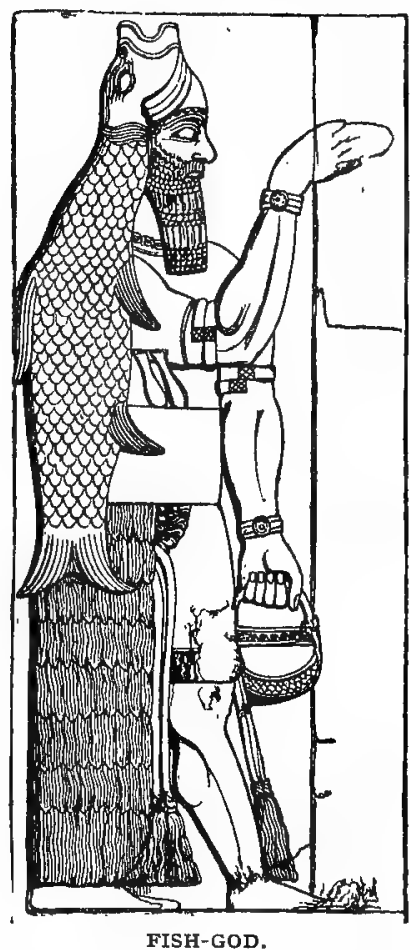

From Layard's Nineveh and Babylon. (Paris, I885), vol. II. p. 295 ff., where a great variety of Assyrian fish-men may be found. Forlong (op. cit., I. 23I) instances a cornelian cylinder in the Ouseley collection depicting Oannes or the Babylonian god or demi-god, attended by two gods of fecundity, on whom the Sun-god with a fish tail looks down benignantly. Forlong's obsession detects in every representation, Indian or Irish, Assyrian or Australasian, some emblem of fecundity, while his ever-present " King Charles's head" is some phallic symbol. We are almost reminded of the witty quatrain current some years back :

"Diodorus Siculus

Made himself ridiculous

By insisting that thimbles

Were all phallic symbols!"

2 The goat-fish god dates as far back as Gudea, c. 2700 B.c. He was like the man-fish or fish-god, a symbol of Ea, the god of water, and probably derives from Capricorn. See Ward, p. $2 I_{4}$, fig. 649 ; and p. 249, figs. 745. 747 .

3 Cf. Ezekiel, VIII. Io, " Every form of creeping things and abominable beasts pourtrayed upon the wall round about." 
or horse-gods. The idea of the deification of the fish-forms, whether that of a man issuing from a fish or of a man whose upper half was human but lower piscine, may, perhaps, have sprung from the undoubted worship by the Philistines at Ashdod and elsewhere of the god called Dagon, and partly to the original description of him in the A.V., but now corrected in the R.V.

Dagon, it will be remembered (I Samuel v. 4), after being confronted with the ark of the Lord in the morning, was found fallen: "the head of Dagon and both the palms of his hands lay cut upon the threshold, only the fishy part (A.V.) or stump (R.V.) of Dagon was left unto him." From this passage Milton undoubtedly drew his conception of-

"Dagon his name ; sea-monster, upward man And downward fish." 1

It is possible that the theory of his having from his navel down the form of a fish, and from his navel up the form of a man-a theory which is unknown to the Targum, Josephus, or the Talmud, and perhaps is as late as the twelfth century A.D. ${ }^{2}$ -merely transfers by the help of etymology the description given by Lucian of the goddess Derceto, worshipped on the same coast-line by the Syrians, who were more partial to fish deities than the Assyrians. ${ }^{3}$

This Dagon has been mistakenly connected with Odacon, the last of the five sea-monsters who arose from the Erythræan Sea. His body (according to Berosus) was like that of a fish, but under the head of the fish was that of a man, to whose tail were added women's feet, whose voice was human, and whose language was articulate. During the day he instructed the Sumerians in letters and in all arts and sciences, more

1 Paradise Lost, I., 462.

2 There was a Babylonian god Dagan whose name appears in conjunction with Anu and often with Ninurta (Ninib). Whether the Philistine Dagon is the same as the Babylonian Dagan cannot with our present knowledge be determined. The long and profound influence of Babylonia in Palestine in early times makes it quite possible that Dagon, like Anath, came thence. Ency. Bibl., p. 984. No evidence suggests Dagan as a Babylonian fish-god.

Some authorities now hold that Dagan came to Babylonia with the Amoritic invasion towards the latter half of the third millennium.

3 For Derceto, see antea, p. 124, and for Atargatis, antea, pp. 127-8. 
especially in the building of temples, but at night he plunged again into the sea. 1

Authorities disagree whether Dagon derives his name from the Hebrew Dāg, signifying fish, or dāgān, sheaf or agriculture. Sanchouniathon early held, as do most modern writers, the latter view. Reichardt errs in his conjecture that the representation in De Sarzec (p. I89) shows the deity holding in his hand ears of corn, instead of what really is a palm branch of the conventional type. ${ }^{2}$

Cylinder seals depict ${ }^{3}$ river gods, some with streams rising from their shoulders, or flowing from their laps, or from vases in their laps, and containing fish, and others half men and half fish. Mythological beings with fish headdress occur not only on seals but on the Ninevite reliefs, etc., where it has been suggested that they do represent Dagan.

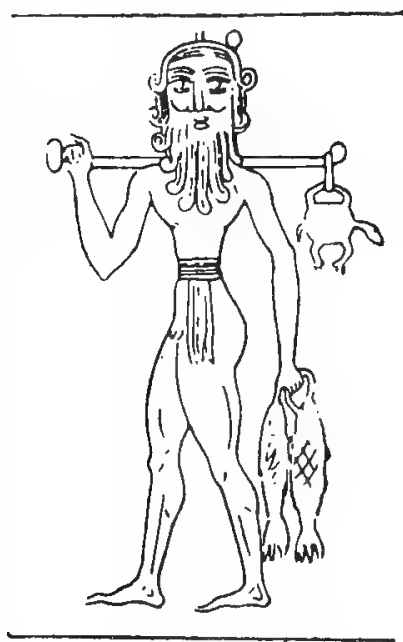

GILGAMESH CARRYING FISH.

From La Revue d'Assyyiologie, VI. 57

The delineation of fish on vases, etc., 4 and of a fish in a

1 Oannes of Berosus is identified with Enki (otherwise Ea) by Langdon, Poime Sumerien, etc. (Paris, I919), p. I7. Tradition generally makes the earliest founders or teachers of civilisation come from the sea. Manco Capac and Mama Ocllo, the children of the sun god, rose, however, not from the sea, but from Lake Titicaca, when they brought to the ancient Peruvians government, law, a moral code, art, and science. Their descendants styled themselves Incas.

${ }^{2}$ See G. F. Hill, Some Palestinian Cults in the Greek and Roman Age, in Proceedings of the British Academy (London, I9I I-I2), vol. V. p. 9.

a Cf. Heuzey, Sceau de Goudéa (Paris, 1909), p. 6 ; also W. Hayes Ward, Seal Cylinders of Western Asia (Washington, I9IO), figs, 288-289; see also figs. I99, 66I. The large number of seals, almost entirely cylinder, which have been found in the excavations is probably owing to every Assyrian of any means always carrying one hung on him. The use to which they were put was precisely similar to that of our signet ring. An Assyrian, instead of signing a document, ran his cylinder over the damp clay tablet on which the deed he was attesting had been inscribed. No two cylinder seals were absolutely alike, and thus this method of signature worked very well. The work on the cylinders is always intaglio; the subjects represented are very various, including emblems of the gods, animals, fish, etc.

4 Récherches Archéologiques, vol. XIII. of Delegation en Perse, by Pottier, Paris, I9I2, figs. II7, 204, etc. 
stream of water on a small fragment from Telloh, are of early Sumerian art. The representation of Gilgamesh carrying fish dates from at least 2800 B.C., or some thirteen hundred years previous to the Phylokapi Vase (the most ancient Greek representation of men similarly engaged) and so furnishes a comparison, and from the differences in delineation of face, arms, and eyes a contrast of singular interest. 1

1 L. Heuzey, Revue d'Assyriologie, VI. 57, and Hayes Ward, op. cit., p. 74 , fig. I99. 


\section{CHAPTER XXXIV}

\section{THE LEGENDS OF ADAPA, AND OF THE FLOOD}

EA (originally the primal deity of the Sumerian city of Eridu and eventually the god of the waters on and beneath the Earth) formed with Anu, the god of Heaven, and Enlil, the god of the Earth, from the earliest period the great triad at the head of the Babylonian pantheon. The representation of Ea took the form of a sea-monster with a body of a big fish, full of stars, and claws for the base of his feet. 1

$\mathrm{Ea}$ is ordinarily known from the pretty legend woven round his mortal son Adapa, and the command in obedience to which Adapa firmly but unconsciously made refusal of the gift of immortality.

The latter, to supply his father's household, went a-fishing in the sea one day-fish food was evidently not the " abomination " to the Sumerian that it was to the Egyptian gods - but suddenly Shūtu the South Wind came on to blow, upset his sailing boat, and ducked him under the water, or, as Adapa puts it, "made me descend to the house of my lord," i.e. Ea, god of the Sea. ${ }^{2}$ In anger Adapa caught the South Wind and broke her wings. ${ }^{3}$ But for this assault he was haled to

1 Cf. Langdon, op. cit., 72. Ea or " Enki est généralement représenté sous la forme d'un animal ayant la tête, le cou, et les épaules d'un bélier, et qui rampe sur les pattes de devant : le reste du corps est celui d'un poisson."

3 See the Nippur Poem, op. cit., p. 84, note 3.

- From Karl Frank, Babylonische Beschwörtunge Reliefs, p. 8o. The South Wind was specially dreaded, because it caused destructive floods in the lowlying regions of the Euphrates valley. In Langdon's Sumerian Epic of Paradise (op.cit., 19I 5), p. 4r, we find that "Adapa sailed to catch fish, the trade of Eridu," a pretty and simple touch identifying the god with his worshippers, and his pursuit with their trade; and one which supports the theory that to the Babylonian his god, in early times, was a being very similar to himself, if more powerful. 
appear in heaven before Anu, who had noticed, or had learnt through his messenger, 1 that the South Wind had ceased, according to the earlier or Eridean account, to blow for seven days.

Before setting out Adapa was bidden by Ea to put on

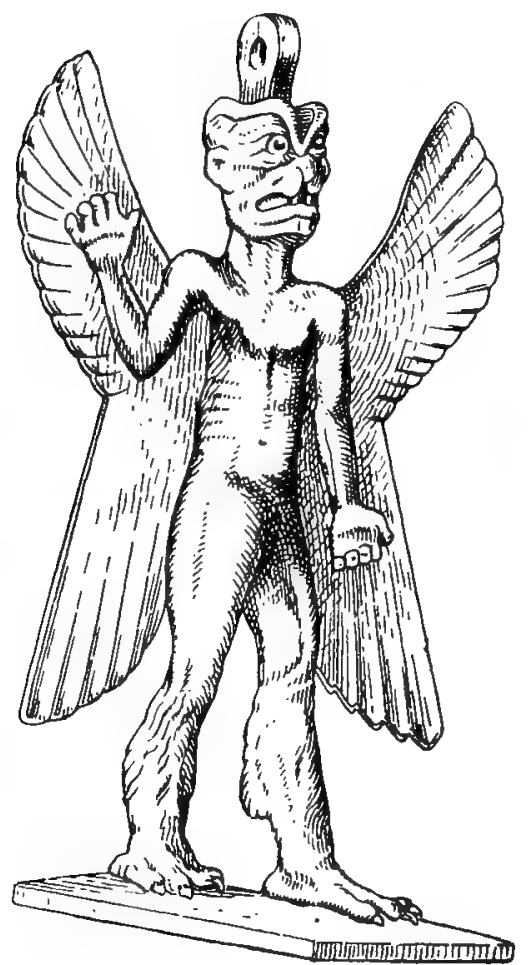

THE DEMON OF THE SOUTH-WEST WIND.

From Karl Frank, Babylonische Beschwörtunge Reliefs, p. 8o. garments of mourning to propitiate the two gods, Tammuz and Gishzida, guarding the portals of heaven, but was warned not to touch at any hazard what he purposely misnamed the "Bread of Death," or the "Water of Death," which would be offered unto him. ${ }^{2}$ He could, however, accept the garment and the oil when likewise presented.

At the interview the guardian gods interceded so successfully with Anu that his wrath waned; he granted a pardon, and decided that as Adapa had seen the interior of heaven, he should be added to the company of the gods.

He therefore commanded that the "Bread of Life" and the "Water of Life" should be brought forth; but Adapa would neither eat nor drink of them, although he put on the proffered garment and anointed himself with the poured-out oil. And Anu, when he saw that Adapa had not partaken of the "Bread of

1 See the Nippur Poem.

- Ea's command sprang from the fear of losing the worship, etc. of his devotee, when once he had acquired immortality by eating and drinking of the Bread and Water of Life. 
Life," or of the "Water of Life," asked him, saying, " Come, Adapa, why dost thou neither eat nor drink?" And Adapa answered that he had refused to eat or drink, because Ea his lord had so commanded him.

Whereon comes the conclusion of the whole matter, and the loss of immortality in the last words of Anu, "And now thou canst not live!" 1

Ea was regarded not only as the god of the sea, but of wisdom, somewhat perhaps on the lines of myths common to Greece, India, and elsewhere, which tell us that always by the way of the sea came civilisation. The great civilisations of the world have in fact been developed round the shores of the great seas-the Indian Ocean, the Mediterranean, the Atlantic.

The Assyrian legends credit Ea for the most part with goodwill and beneficent acts towards mankind. ${ }^{2}$

Prominent among these stands out his revelation, by means of a dream, to Utnapishti of the all-destroying flood, which the gods, wroth at the sins of mankind, had ordained, and his command forthwith to build a ship, whose size and shape, etc., are given with much precision, e.g. it was coated inside and out with bitumen and divided into cells. On this Utnapishti and his family and servants embarked, after bringing on board all the gold and silver they could collect, and "seeds of life of all kinds," and beasts, both domestic and wild. ${ }^{3}$

The Sumerian original of the Babylonian Deluge story, which has now been recovered, corresponds with the main features of the later version.

1 Adapa stands out as a pathetic and cruelly-punished figure. In this, one of the prettiest of the clumsy legends by which mankind tried to explain the loss of eternal life, Ea forbids for selfish reasons his eating or drinking of the Bread or Water of Life, while Anu's offer of immortality springs from his desire to deprive Ea, whom he suspects of having betrayed to Adapa the celestial secrets of magical science, of his devotee and fish-gatherer.

${ }^{2}$ Keller, op. cit., p. 347 , is astray in stating that Ea was regarded " als Fischgott.", As god of the waters, he was the protector of the fish therein, but apart from this, there is no evidence that he was termed, even with a wide use of the word, a Fish God.

${ }^{3}$ For the omission of fish from the cargo of Noah's ark, Whiston in his philosophic $A$ New Theory of the Deluge (London, I737), accounts by the fact, that fish, living in a cooler, more equable element, were correcter in their lives than beasts and birds, who from the heat or cold on land engendered by the sun or its absence were prone to excesses of passion or exercises of sin, and so were saved! 


\section{LEGENDS OF ADAPA AND OF THE FLOOD}

In both a flood is sent to destroy mankind, but in the first the intention of the gods is revealed in time to a pious Sumerian, possibly a priest king, Ziudsuddu, the Sumerian equivalent of the abbreviated Semitic name Utnapishti. He escapes from the flood in a great boat, which floats away on the waters. When the storm after seven days ${ }^{1}$ has abated and the sun at last struggled out, Ziudsuddu makes a thanksgiving sacrifice of an ox and a sheep. We find him in the end reconciled with the great gods, who, as in the Babylonian version, give him immortality.

From the incompleteness of the text it is impossible to determine whether in the Sumerian version the episode of the birds occurs; the probability is that it did not. As is but natural, the earlier story is simpler and more primitive in style than the Babylonian.2

In the Gilgamesh account of the Flood, which in general resembles the story as given by Berosus, the absence of the raven, in the Bible the return of the dove with an olive leaf in her mouth, proclaims the abating of the waters, while the Algonkins allot the rôle, on the failure of the raven, to the muskrat. But, in the Indian legend it is a fish, not a god, which not only conveys to Manu the beneficent warning of the coming deluge but also saves him eventually by drawing his ship to a northern mountain. ${ }^{3}$

1 The length of the flood varies greatly from the above seven days, to eight months and nine days of the Nippur Poem, to the nine months and nine days of Le Poeme Sumerien, during which Tagtug is afloat, and to the one year and ten days which is the total duration in the Bible.

See Poebel, Historical Texts (Publications of the Babylonian Section of the University of Pennsylvania), vol. IV., Part I., pp. 9 ff. In Langdon's Le Pozme Sumérien (Paris, I9I9) is to be found much, which is not written in the later account of Adapa and of the Flood, and of Paradise, and many details which are different. In it there is no woman, no temptress, no serpent. But it does record that the survivor of the Flood was placed in a garden and apparently forbidden to eat of the fruit of a tree, growing in the centre of the garden. He does eat, however, and thereby loses immortality.

3 The myth of the Deluge is practically world-wide, except in Africa (including Egypt), "where native legends of a great flood are conspicuously absent-indeed, no clear case of one has yet been reported." J. G. Frazer, Folklove in the Old Testament (London, I918), vol. I. P. 40. Maspero seems quite wide of the mark in treating the semi-ritual myth of the Destruction of Man as " a dry deluge myth," Dawn of Civilization (London, I894), pp. $164 \mathrm{ft}$. For various accounts of the Deluge, see Hastings, Encyclopardia of Religion and Ethics, article Deluge (Edinburgh, I9II). 


\section{CHAPTER XXXV}

\section{FISH-VIVARIA-THE FIRST INSTANCE OF POACHING}

WE find in two important sources of our knowledge of Assyria (proper) references to beasts or fishes of the sea and of the river.

The first occurs in The Broken Column of Tiglath-Pileser I., in whose reign Assyria attained to high prosperity. This king, the first of that country to leave behind a detailed record of his achievements, was, as we have seen, a mighty hunter. After recounting his many military campaigns he adds in Column IV. a list of the beasts and fish which he had taken in his hunting expeditions. The text runs :-

I. The gods Ninurta and Nergal, who loved his priesthood, (the task) of hunting in the field,

2. Entrusted unto him, and in ships of the land of Arvad

3. he sailed, and he slew a mighty dolphin in the sea. ${ }^{1}$

Then follows a catalogue raisonné of his famous $\mathrm{Zoo}$, in which were collected the elephants, lions, mountain-goats, stags, dromedaries, which he captured himself or obtained (antedating Hagenbeck) "through merchants whom he had sent out," and other numerous "wild beasts and fowl of the Heaven that fly, the work of his hands, their names together with (the number of) the beasts which my ( ) did not record .. . have I recorded." In addition to these, of

1 Annals of the Kings of Assyria, by Budge and King (Ig03), p. 138 . 'Dolphin' is the translation of Nakhivi, doubtless from the same root, which in Arabic is Nakhara, to spout, and occurs in the same sense in Syriac and Ethiopic. In view of the evidence of Pliny and other authors as to the former existence of the whale in the Mediterranean, I suggested to Professor King an alternative rendering of nakhiri as 'whale,' and he informed me he accepts my suggestion as the more probable of the two. 
which "he caused their herds to bring forth young," we find-

29. "A great pagatu, a crocodile, a hippopotamus (?), and beasts of the Great Sea,

3o. the king of Musrê sent unto him and caused the people of his land to behold.'

We cannot determine what one of the subjects of this gift, "a great pagûtu," exactly was. Tum-su-hu may possibly be the equivalent of the Egyptian emsah, Arabic timsâh, i.e. a crocodile. If so, Musrê must indicate Egypt. ${ }^{1}$

The Annals of Așur-Nasirpal form our second document of knowledge. The walls of his palace, lined with sculptures in relief, represent his exploits in the field of battle and in the chase. Details are most carefully and elaborately carved; the designs mark the acme of Assyrian art.

In Column III. he records ${ }^{2}$

"SOME MEN I TOOK ALIVE AND IMPALED THEM ON STAKES OVER AGAINST THEIR CITIES. ${ }^{3}$

At THAT TIME I MARCHED INTO THE DISTRICT OF LEBANON, AND UNTO THE GREAT SEA.

In the Great Sea I washed My weapons and I made OFFERING UNTO THE GODS.

THE TRIBUTE OF THE KINGS OF THE SEA FROM THE LANDS OF THE MEN OF TYRE AND SIDON AND ARVAD, WHICH LIETH IN THE MIDST OF THE SEA, SILVER AND GOLD AND A GREAT PAGUTU AND A SMALL PAGUTU AND IVORY AND A DOLPHIN, A CREATURE OF THE SEA, I RECEIVED AS TRIBUTE FROM THEM, AND THEY EMBRACED MY FEET."

This "washing," or as it has otherwise been rendered "dipping," of a weapon in the sea is not to be taken, as it

1 Another translation (R. Asiatic Proc., XIX. pp. 124-5) renders these lines " creatures of the Great Sea which the King of Egypt had sent as a gift, and entrusted to the care of men of his own country," either as carriers or permanent attendants. But see p. 53 of the Introduction to The Annals of the Kings of Assyria, op. cit. Dr. St. Clair Tisdall writes: "If Nam-su-hu (Budge and King's translation) be right, it is evidently the Egyptian name ' $m s u h u=$ crocodile, with the plural $N a$ prefixed. Egypt in Arabic is still Misy."

2 Op. cit., Introduction, pp. $372 \mathrm{ff}$.

3 The Assyrians, probably from having no admixture of the softer Sumerian blood, from living in a less enervating climate, and from Hittite influence, stand out as more virile, fiercer fighters, and crueller foes than the Babylonians. 
sometimes is, in a sense suggesting fishing by a harpoon or spear, or as typical of victory, but rather as a symbolical act of homage and propitiation to the unknown deities of the deep.

A later Assyrian king, Asurbanipal, no doubt from the value which the test of use in his many hunting expeditions afforded, regarded the dog from a point of view very different from that apparently taken by some of his subjects.

To judge by an old Assyrian prayer, "From the dog, the snake, and the scorpion, and whatever is baneful may Merodach preserve us," the general feeling was that of fear.

But five clay models preserve for us representations of some of the king's favourite hounds, with their names inscribed upon them. The appropriateness of their names betrays their master's familiarity with canine traits, as we detect from Chaser of the Wicked, Conqueror of the Foe, Biter of his Enemy, Mighty in his help, He crossed the road and did his bidding ! 1

At Harrān (according to al-Nadim), dogs were considered sacred and had offerings made unto them, a statement which is strengthened by the divine title at Harrān of My Lord with the Dogs, which seemingly points to Marduk and his four dogs, the name of one of which, Iltebu, "the Howler," is as characteristic to-day as it was five thousand years ago.

In the Bible it is curious to note the low position of the dog. It is rarely spoken of with approval. Possibly the existence and proclivities of the numerous packs of pariah dogs account for the fact. Tobit seems the only person who makes his dog his companion, and then only when on journeys. ${ }^{2}$

Over two hundred kinds of fish are enumerated in the catalogue of Asurbanipal's library at Nineveh : the attachment of the fish determinative constitutes our authority. No writer, even Dr. Boulenger, has classified or identified the fishes of Assyrian representations as thoroughly as Montet and others have those of the hieroglyphs.

1 W. Hayes Ward, op. cit., p. 418, states the dog appears in cylinders very early-chiefly as guardian of the flock. Cf. Figures 39I, 393, 394, 395. $\mathrm{He}$ is seen in the late Babylonian: cf. Figs. 549, 551, 552, and later still in hunting scenes, Figs. 630, 1064, 1076 and 1094, which last shows in a very spirited manner four dogs in a fight with two lions. The dog running away is fairly "making tracks!"

2 C. Tobit v. I6, and xi. 4 . 
The task would seem more formidable, for two reasons : first, the short time that cuneiform as compared with hieroglyph writing has been deciphered, and the wider study which Egyptian excavation has attracted; and second, the Assyrian artist treated his subjects more generally and more conventionally than his confrères in Egypt. Although in the sea and river scenes fish and shells are introduced, scarcely any distinctions mark particular ichthyic species. Contrast with this the representations of the return of Hatasu's expedition from the land of Punt or Arabia. Here the artists depict the fishes so characteristically that Doenitz has identified them as belonging to the Red Sea, and even determined the species of each.

We can recognise in the rivers, crabs, sometimes with a fish caught in their claws, eels (or water-snakes), and small turtles. When the sculptor wished to indicate the sea, he made these fish larger, and to emphasise his point added others, which are only inhabitants of salt water, e.g. the star-fish. ${ }^{1}$

Within the last five years identification ${ }^{2}$ of Mesopotamian fish has been carried further by Dr. Harri Holma of Helsingfors, ${ }^{3}$ and by Professor Langdon. ${ }^{4}$

From the latter I take the following list :-

"I. The buradu, of the skate and ray type. This flat fish is the most common of all species in Southern Babylonia from the earliest historical period. The Sumerians knew it as the suhuru fish, and speak of it as 'bearded,' referring to a kind of skate fish with long hairs about the mouth. They mention also the 'goat-skate,' and the 'lower lipped skate.' Dr. Holma's statement (p. 96) that the suhuru cannot be the skate, turbot, or plaice, because these have no beards, has been contraverted, since fish of the skate type often have long feelers at the mouth resembling a beard.

" 2 . The kuppa, said to be the rhombus maximus.

1 Layard Monuments of Nineveh (op. cit.), vol. II. p. 438.

2 The identification, which is avowedly more of a philological than a scientifically zoological nature, is in the cases of Nos. 2 and 3 a "terminological inexactitude," for as Dr. Boulenger's lists show, neither the turbot nor the sole occur in the Persian Gulf. Cf. Proc. Zoological Society, 1887, p. 653; I889, p. 236 , and I892, p. I34. I9I2).

'Monograph, Kleine Beiträge zum assyrischen Lexicon (Helsingfors,

- Sumerian Grammar (London, 19I7), p. 6o. 


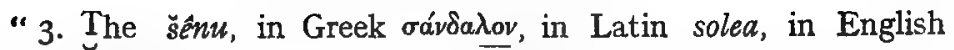
'sole.' Šênu means 'sandal ' in Babylonian.

" 4. Sêlibu, or 'fox fish,' perhaps so-called from its slyness; probably Alopecias vulpes.

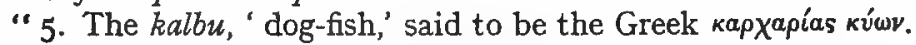

" 6. The piazu, ' pig-fish,' Galeus canis, ' sea sow.'

“7. The puhadu, ' lamb fish,' perhaps Pelecus cultratus.

" 8. The balgu, a fish well known in all periods, and said to be the same as the widely spread Mongolian balyq, the ordinary word for fish in Turkish; in some parts the sword fish, in others the 'bull head."

" 9. The qarshu, probably the 'shark, or a fish of prey of the Persian Gulf.

“' ro. The gallabu, ' barber,' not yet identified.

" Ir. The simunu, 'swallow fish,' by some identified with the ' flying fish.'

"I2. The zingur, supposed to be the 'sturgeon.'"

Other fish names, especially Sumerian, remained unidentified till (in May, I9I8), Langdon translated the only hymn (yet published) to Ninâ, the Fish Goddess, and spouse of Tammuz. Among its twelve fish we get the 'electric fish ' (query the vá $\rho \kappa \eta$ ), the 'nun fish,' the 'fire fish of the sea,' and the 'swallow fish.' The touching lines bewailing the death of Tammuz are, alas! imperfect. I

Fish abounded in the Two Rivers. Euphrates fish were so plentiful that they could be caught simply in one's hand, apparently without any "tickling." 2 The coast folk could not cope with their catches. ${ }^{3}$ Wicker traps, automatically opened and shut by the tides, yielded their " harvest of ocean."

Sluice gates were far commoner in Assyria than in Palestine. The numerous rivers, and scientific system of irrigation which from earliest ages threaded Sumeria and later on Western Assyria, account for the frequency.

According to Sir W. Willcocks, "The granary of the ancient

1 Proc. of Soc. of Biblical Archaology (London, May, I918), p. 83. 2 Lewysohn's (Zool. d. Talmud, 248 , as quoted by Keller, op. cit., p. 330)
"Euphrat heisst etymologisch der fischreiche " is far from generally accepted. The river in Babylonian is Purattu, pronounced by the Persians Ufratus, which became when borrowed by the Greeks, Euphrates. So far from meaning rich in fish, Langdon traces the name to the Sumerian buranna, burnuna, meaning great basin.

a Diod. Sic., III. 22. 
is destined to be that of the modern world." The success of the irrigation works, at Hit and elsewhere, may verify his prediction. 1

Vivaria, or fish-dams, known only late in Palestine, were early and generally constructed in Mesopotamia. As adjuncts of Sumerian temples, they can be traced as far back as 2500 B.C. No decent-sized township eventually lacked, or could afford to lack, these piscine with their ever-ready supply of fresh fish.

The keeper, or fisherman, attached to the temples (according to Langdon) seems to have been called Essad, a term which subsequently came to mean Tax Gatherer. It is open to doubt whether the latter meaning can, as has been suggested, be derived from or connected with the former on account of his extraction of a toll for fish caught by the public in the stewponds of the priests, or of a percentage, in lieu of pay, of the fish caught by him for use in the temples.

How real was the importance attached to fish, and how recognised its value as a food, can be discerned from early Sumerian documents. The excavations of Telloh furnish an elaborate description of the new temple built by Gudea in honour of Ningirsu. We read that with this god went also other deities, such as his musician, his singer, his cultivator of lands, and his guardian of fishponds. ${ }^{2}$

Then, again, among the officials who were deprived of office by Urukagina, on account of the profits illegally secured by farming out the public revenue, we come across the Inspectors of Fisheries. The drastic reforms and the thorough cleansing of the bureaucracy initiated by this monarch sprang from his desire to improve the condition of his poorer subjects, who for years had suffered from the oppression of the rich or the venality of public functionaries. How general and how numerous vivaria had early become shows in the plaint that "if a poor man built himself a fishpond, his fish was taken; he received neither payment nor redress."

1 See General Marshall's Report on Mesopotamian Campaign in The Times, Feb. 2I, I9I9.

2 History of Sumer and Akkad (London, 1910), p. 268. 
A document of the twenty-first century brings to light further evidence of the economic importance of fish and of the rights of fishing, and what to us modern fishermen is of intenser interest - the first case on record of Poaching !

This occurred in the reign of Samsu-iluna, the successor to the great Hammurabi. The latter's Code of laws of 287 sections was considered on its discovery some twenty years ago to be a Digest of Babylonian decisions, but the recent finding of a clay tablet, clearly the prototype of the Code, proves its Sumerian origin.

It not only illuminates vividly the social and economic conditions of Babylon, but established for generations the status, the rights, the duties flowing from contracts or arising from injury.

Its scope is curiously wide. It includes, for instance, provisions to meet such rare cases as injuries which resulted in the miscarriage of women. The similarity of enactment in these cases and in divorces demonstrates inter alia how marked was the Code's influence on the Mosaic legislation some seven centuries later.

Every one of Hammurabi's subjects could by its help acquire a clearer conception of his individual property. The letter or rescript of Sansu-iluna shows that rights of fishing were acknowledged, and enforceable.

The Rescript runs :-

"Unto Sin-Idinnam, Kar-Sippar, and the Judges of Sippar say, Thus SaIth Samsu-Iluna. They have Reported (UNTO ME) THAT THE SHIPS OF THE FISHERMEN GO DOWN UNTO THE District of Rabīm and to THE District of ShaKaním AND CATCH FISH. I AM THEREFORE SENDING (UNTO THEE) AN official of the Palace Gate. When he shall Reach theE, THE SHIPS OF THE FISHERMEN WHICH ARE IN THE DISTRICT OF SHaKanim (SHALt THOU ... 1) AND THOU SHALT NOT AGAIN SEND THE SHIPS OF THE FISHERMEN DOWN INTO THE DISTRICT OF RABİM OR THE DISTRICT OF ShaKaNIM. ${ }^{2}$

1 The hiatus probably may be filled by the word "recall," or "bring away." King.

Letters of Hammurabi (London, I898-1900), vol. III. pp. I2I-3, L. W. 
This letter confirms what had previously been only surmised, viz. that the inhabitants of certain districts had enjoyed the exclusive right of fishing in their home waters. "It has already been inferred," King continues, "that the duty of repairing the banks of rivers and canals, and of clearing the waterways, fell upon the owners of property along the banks, and it was no doubt as a compensation for this enforced service (or corvée) that the fishing in these waters was preserved."

Mesopotamia and Armenia did not lack in fish of unusual, even fatal, properties. Thus of certain fishes near Babylon Flian tells us ${ }^{1}$ on the authority of Theophrastus, when the irrigation streams were without water, they remained in any small hole which was moist or held a little water, and were able to find a living in the herbage which grew in the dry channels, etc. Pliny (IX. 83) gives a somewhat similar story but a more detailed description of these fish, which " have heads like sea-frogs, the remaining parts like gudgeons, but the gills like other fish." Emerging from their water holes, they travel on land for food, moving along with their fins, aided by a rapid movement of their tail. If pursued, they retreat to their holes and make a stand.

He notices too the stay-at-homeness of the fish in the Tigris and of those in the lake Arethusa. Though the river flows in and out of the lake, the denizens of the one are never to be found in the other. We discern the reason for such estranged relations in his previous sentence, " the waters of the lake support all weighty substances and exhale nitrous vapours." 2 Ktesias mentions a spring in Armenia, the fishes of which are quite black and, if eaten, prove instantly fatal. ${ }^{3}$

The only spring of sweet-smelling water " in toto orbe," Chabura, lies in Mesopotamia. The reason (according to legend) for its possessing this unique property was because in it the Queen of Heaven, Juno, or presumably her Babylonian counterpart, was wont to bathe. ${ }^{4}$ But Pliny fails to indicate whether the unique scent was an effort of Nature to supply a bath meet for the Queen of Heaven, or was merely a 
by-product of her lavation. Possibly the fish of Chabura (like the thyme fish) exhaled a " most sweet scent," and so effected " the sweet smelling." But probably to preserve their power, " they will come to feed from men's hands." 1

I have adduced sufficient proof that fish were plentiful in Mesopotamia. Additional testimony has needlessly been sought in Professor Sayce's now fairly accepted suggestion that the ideogram for Nineveh implies the House of the Waters or of Fish. ${ }^{2}$

Another explanation of Nineveh as The Lady of the Waters deduces from Ninâ (said to be a daughter of $\mathrm{Ea}$ and a fish goddess) lengthening into Nineveh. But the term The Lady, i.e. The Lady par excellence, in Assyrian especially applies to Bêlit the spouse of Asur, who became generally identified with Ishtar of Nineveh. ${ }^{3}$

If The Lady of the Waters translate correctly the ideogram of Nineveh, the term may have sprung from a temple to this reputed Fish Goddess standing in that city. But even if the existence of such a temple can be inferred, its original site probably lay in Sumerian Lagash, not in Nineveh.

1 N. H., XXXII. 7 .

Hibbert Lecture (London, 1887), p. 57.

- On the ancient goddess NinA, see Langdon, Tammuz and Ishtar (London, 1914). There is no known representation of Nina. Of Belit, or Ishtar, many exist; of Ishtar arma ferens that on a seal in Tammuz and Ishtar, Plate I., No. I. is perhaps the best. 


\section{CHAPTER XXXVI}

FISH IN OFFERINGS, AUGURIES, ETC.

The Sumerian records leave no possibility of doubt as to offerings of fish being made to the deities, not exclusively or specially to a deity of fish. They show Eannatum in early days offering at Telloh certain fish to various gods to secure their aid that the treaty which he had just concluded with the city of Umma might be maintained for all time unbroken.

Similar offerings present themselves all through the history of Assyria. Numerous tablets detailing the nature of the enjoined offerings include fish, and as numerous receipts by the temples acknowledge offerings of fish. ${ }^{1}$ In the course of time votive offerings in ivory and bronze, etc., according to King, took the place of actual fish. ${ }^{2}$

The striking resemblance of the institution of the ScapeGoat in Palestine to the ancient Mashhulduppu or Babylonian Scape-Goat, both in object and high ceremonial ritual, is noted in my Jewish chapter. ${ }^{3}$ But we cannot for one moment assume that sacrifices and oblations in Assyria evolved from perhaps the earliest primitive, i.e. human, sacrifice, or followed the same lines as those of Israel or of Rome. In the first nation human sacrifice probably prevailed in the earlier times to a wide extent, and in the second (as Varro indicates) "Populus pro se ignem animalia mittit," and even "pisciculum pro animis humanis" became a not unusual and cheaper alternative. 4

1 See Nikolski, Documents de la plus ancienne époque chaldenne, Nos. 265 and 269 ; this last tablet (c. 2900 B.c.) records the delivery of large numbers of fish of various kinds by fishermen for two great festivals.

Cf. antea, p. 217 , as regards Rome.

s Postea, p. 427.

- See Greek-Roman section, Chapter XVI. 
On the other hand, we possess, in historic and pre-historic Assyria, no trustworthy evidence of human sacrifice. Sayce, it is true, in 1875 published two texts, which, as he translated, demonstrated that human sacrifice did prevail. These, refuted by Ball, are not accepted as even a proper translation of the passage, much less a proof of the practice.

Jastrow has recently returned to the charge. He suggests that, "His eldest son shall he burn at the Khamm of Adad," and other passages, establish that at one time children were offered in sacrifice, very much on the same lines as the later Judæan immolation of their children to Moloch, as when King Ahaz (2 Kings xvi. 3) "made his son to pass through the fire " in the Tophet just outside the gates of Jerusalem. But Jastrow finds even less favour now than Sayce did forty years ago. 1

Campbell Thompson, after remarking that the existence of human sacrifice among either the Babylonian or Assyrian is not easy of satisfactory proof, concludes, "The fact is that human sacrifice goes out in proportion as civilisation comes in, and probably by the time men are ready to commit their religious ritual to writing, human sacrifice has ceased to be a regular and periodic rite: as the Assyrians were the highest civilised of all the Semites before our era, so in all probability fewest traces of this custom exist in their records."

A semi-religious practice, not dissimilar in object to that of the Scape-Goat, can be discerned, if not as a vehicle for carrying away all the sins of the people, yet as a method of ridding the individual by the agency of some beast or fish of the affliction which lay upon him.

In one of the so-called Penitential Psalms or incantations, which the tablets from the library of Asur-bani-pal bequeath us, the prayerful desire to be free of suffering finds utterance in :-

"Let me cast off my evil that the birds may fly up to Heaven with it,

That the fish may carry off my affliction."

2 Op. cit., P. 358. 
This whole passage ought, however, to be regarded not as a Penitential Psalm so much as " a ceremony for cleansing a man from tabu, when he wishes to see something in a dream. It finds close connection with the Levitical charm, originating from sympathetic magic, e.g. for cleansing the leper or leprous house," i.e. by the two doves, as in Leviticus xiv. . $^{1}$

Langdon asserts that in the Sumero-Babylonian religion each individual in normal conditions was guided by a divine

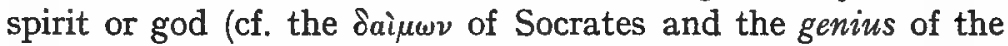
Romans). When a man was possessed by the powers of evil he was estranged from his personal god, because some demon had attacked or driven out the protecting deity from his body. In this ancient period there seems to be no moral element whatever in the case. If a man became tabu (which the eating of fish in other countries than Assyria would involve), or possessed by some dangerous unclean power, which made him unholy and filled him with bodily or mental distress, this state came about solely because at some unguarded moment a demon had expelled the indwelling god.

The demon had to be exorcised by some method of atonement, of which the most important element was in Sumerian magic water, in Hebrew blood. "In view of the great influence which Babylonian magic appears to have exerted upon the Hebrew rituals, it is curious it did not succeed in banishing this gross Semitic practice. Blood of animals does not occur as a cleansing element in Babylonia," an omission due apparently to the culture of the Sumerians " not permitting such crude ideas, and to their teaching those Semites with whom they came in contact a cleaner form of magic." 2

In addition to the demons or spirits described above we find others, which could and, unless the proper rites were paid to the dead, did affect the living. The greatest misfortune which could befall a man was to be deprived of proper burial. ${ }^{3}$ His

1 Semitic Magic (London, I908), pp. I8r, 186.

2 Babylonian Magic (Bologna, I9I4), pp. $237-8$.

3 "In Israel not to be buried was a terrible disgrace which one could hardly wish for one's enemy: the spirits of the unburied wandered restlessly about. Burial alone so bound the spirit to the body that it had rest and could harm no one." Cheyne's assertion in Encyl. Bibl. (op. cit.), p. I04I, seems to me 
shade, ran the common belief, could not reach Arallū, but wandered disconsolately about the earth. When driven by pangs of hunger it perforce ate the offal or leavings of the street. As the Egyptians, to ensure the continued existence of the dead and his $k a$, provided sepulchral offerings (the depictments of which included fish ${ }^{1}$ ), so did the Babylonians, not only for a similar but also for the additional purpose of preserving themselves from torments.

To leave a body unburied was not unattended with danger to the living. The shade of the dead man might bewitch any person it met and cause him grievous sickness. The wandering shade of a man was called ekimmu, i.e. spectre. Only sorcerers possessed the power of casting a spell whereby the ekimmu might be made to harass a man. On the other hand, the spectre sometimes settled on a man of its own accord, in the hope that its victim would be driven to give it burial to free himself from its clutches. ${ }^{2}$

The Babylonian conception of the condition of the dead was an utterly joyless one. Arallī, or the House of the Dead, was dark and gloomy. Its dwellers never beheld the light of the sun, but sat in unchanging gloom. The Babylonians possessed no hope of a joyous life beyond the grave, nor did they imagine a paradise in which the deceased would live a life similar to that on earth.

The nature of the under-world can be gathered from the description given to Gilgamesh by the spirit of Enkidu risen

hardly warranted, at any rate by the O.T. passages which he adduces in support of this statement, in attributing to Israel the idea of the unburied dead being condemned to miserable wandering. For the Greek conception see inter alia the Antigone of Sophocles.

I See Egyptian Book of the Drad (London, I9Io), ch. LIII., with reference to the deceased being obliged, from lack of proper food in the under-world, to eat filth-" Let me not be obliged to eat thereof in place of the sepulchral offerings." To provide food for the dead, asphodel was planted near tombs (Odyssey, XI. 539 and 573) by the Greeks. From Hesiod (Op. 4r) we learn that the roots of the asphodel were eaten as a common vegetable, as was the mallow. Merry states that in the Greek islands, where customs linger longer than on the mainland, this " kind of squill is still planted on graves." If the Homeric 'mead of asphodel' turns out, as some editors maintain, to have had a strictly utilitarian significance, how many poets and poetasters have mistaken 'greens " for "greenery!'

King, Babylonian Religion (op. cit.), p. 45, and Babylonian Magic and Sorcery (London, I896). pp. II $\mathrm{ff}$, where the incantation appropriate for exorcising demons is set out. 
from the grave (sometimes cited as an instance of necromancy), " the place where was the worm that devoured, and where all was cloaked in dust." 1 The Hymn of the Descent of Ishtar into Hell goes farther :

"To the land whence none return, the place of darkness,

To the house wherein he who enters is excluded from the light, To the place where dust is their bread and mud their food."'

The very curious bronze of the Le Clerq collection in Paris, in which ichthyic garments and gods of the under-world, Arallū, occur, must be my excuse for this too lengthy and almost fishless digression on the Babylonian dead. It shows several figures, two clad in garments of the form of a fish, with their scales very visible.

Two explanations of the bronze have been offered. The first, hitherto generally accepted, suggests that the figures are representations of the gods of the under-world, or of the dead waiting on a sick person, together with some demons of the under-world and two priests wearing fishlike raiment. ${ }^{3}$

My friend Professor Langdon has furnished me with another explanation, more detailed and more interesting.

This so-called representation of a scene in the lower world from a bronze talisman has been misunderstood. The obverse has three registers. In the upper register are depicted the seven devils, all with animal heads, in attitude of ferocious attack upon a human soul. The middle register represents a sick man who is supposed to be possessed by the seven devils. He lies upon a bed. At his head and feet stand two priests each arrayed to appear like fish : these are symbolic of Ea, god of the sea and patron of all magic. They clothed themselves in a

1 Gilgamesh here learns how infinitely better is 'the condition of those to whom the rites of burial have been paid, compared with that of those who have been unburied. R. F. Harper, Assyrian and Babylonian Literaturs (New York, I9oI), $363 \mathrm{ff}$.

"The Hebrew conception of Sheol coincides in regarding it as " a land whence none return," Job vii. 9-Io; as " a place of darkness," Job x. 21-22 ; as a place of "dust," Psalm xxx. 9, and Job xvii. I6.

8 Priests dressed as fish or with some fish-like raiments often attend the Sacred Tree (see Ward, op. cit., Nos. 687,688,689). These are held by some to be genii of the deep. In Ward, No. 690, two fish-men are guarding the Tree of Life. 
fishlike robe to signify that they derived their divinations and incantations from the sacred water, of which $\mathrm{Ea}$ was the god.

In the lower register are drawings of cult utensils, such as holy water bowls, censers, etc., and of the fever demon Labartu, who has been driven from the body of the man and is in flight by boat. The reverse of this bronze has in deep relief one of the seven devils who is in the act of peering over the upper edge of the bronze, and gazing upon the scene of atonement and magical healing below.

The cuneiform texts prescribe that fumigation, either for cleansing a person or exorcising a demon, may be performed by the wizard, with or without a censer, a bowl, or lighted torch. ${ }^{1}$

Apart from its permeation of Israel in legislation as indicated in connection with Hammurabi's Code, the influence of Assyria stands out in other ways clearly. The semi-similarity of treatment of the Deluge has already been noticed, while the rendering in the stories of Sargon and Moses of a widespread legend 2 differs only in such points of detail as the substitution of the Nile or (according to Arabic tradition) of a fish-pond for the Euphrates, and of the irrigator Akki as the discoverer of the chest of reeds for Pharaoh's daughter. ${ }^{3}$

1 Compare the exorcism by Tobias of Sara's demon in Tobit. Langdon, Babylonian Magic and Sorcery (op. cit.), p. 223, commenting on the difficulty, which Semitic philology does not clear up, as to whether a wizard is one who cuts himself (as Robertson Smith and most scholars suppose), or whether he is one who casts his spell by whispering or ventriloquy, holds that "from the Sumerian word and the Sumerian ideogram of the word uhdugga which means one who whispers as he casts saliva, we can settle at once the most primitive method of sorcery known to us."

$2 \mathrm{Cf}$. with those of Moses and Sargon the stories of Gilgamesh King of Babylon (Flian, XII. 22), of Semiramis Queen of Assyria (Diodorus Siculus, ii. 4), and of Karna in the Indian Epic of Mahabharata (Cheyne's Traditions and Beliefs of Ancient Israel (London, I907), p. 519. " It has been conjectured," writes Frazer (op. cit.), II. p. $454 \mathrm{ff}$, "that in stories like that of the exposure of Moses in the water (in this case, unlike most others, all supernatural elements are absent) we have a reminiscence of the old custom as practised by the Celta on the Rhine, and according to Speke by some Central African tribes in the last century, of testing the legitimacy of children by throwing them into the water to sink or swim; the infants which sank were rejected as bastards. In the light of this conjecture it may be significant that in several of these stories the birth of the child is represented as supernatural, which in this connection cynics are apt to regard as a delicate synonym for illegitimate." On p. 454 he touches on the question whether Moses, the son of Amram by his (Amram's) paternal aunt, was thus the offspring of an incestuous marriage, and therefore exposed on the Nile.

${ }^{3}$ See Rogers, Cuneiform Parallels to the Old Testament (London, I912), pp. I 35 ff. 
"My lowly mother conceived me, in secret she brought me forth : She set me in a basket of rushes, with bitumen she closed my door:

She cast me into the river, which rose not over me :

The river bore me up, unto Akki the irrigator it carried me.

And for . . . four years I ruled the kingdom."

The assertion that the Old Testament is fairly saturated with Babylonian culture and folklore, and that even in the days of the New Testament we have not passed beyond the sphere of its impression hardly overshoots the mark, when the similarity of these and other instances is borne in mind.

The earliest point of contact between Babylon and Palestine is recorded in Genesis xiv. I, which makes Abraham the contemporary of "Amraphel King of Shinar," who most probably can now be identified with Hammurabi in the light of the recent discoveries of Kugler. ${ }^{1}$

The first connection of Israel with Assyria proper occurs in the reign of Shalmaneser II., in whose Monolith Inscription figures, as one of the allies of Benhadad I. of Damascus, the name of Ahâbbu Sir'lai, generally identified with Ahab, King of Israel.

Fish are discovered playing a part in auguries and divinations very similar to their róle in Rome. Augury in both nations was regarded with deep veneration. It reached in Assyria a very high plane. It was practised as a recognised science by

1 From Astronomy many Assyrian dates have been ascertained. Kugler by stellar researches has settled the vexed question of the date of Hammurabi, and probably that of Abram, at about 2 I2O B.C., which unites within one year the latest conclusions of King, Jastrow, and Rogers, and so establishes an important degree of accord among Assyriologists on events subsequent to 2200 B.c. as regards which they have hitherto been wide apart. Then again modern astronomers have worked out that there was a total eclipse of the sun at Nineveh on June $I_{5}, 76_{3}$ B.c. The importance of the fixing of this date can as regards Assyrian chronology hardly be exaggerated. The Assyrians, rejecting the Babylonian system of counting time, invented a system of their own, by naming the year after certain officers or terms of office, not unlike the system of the Archonates at Athens, and the Consulates at Rome. These were termed limus: a list of these functionaries during four centuries has come down to us. In the time of one of them, Pur Sagali, there is a mention of the eclipse of the sun. As this eclipse has now been fixed for the year 763 B.c., we possess an automatic date for every year after of the limus. 
a large and organised body of the priesthood under the direct control and patronage of the King.

All strange occurrences in heaven or earth were referred to the seers. Almost every event of common life was believed by the pious Babylonian to require prophetic decision whether it boded well or ill.

Among the reforms undertaken by Urukagina was that of the college of the diviners, for he tells us that "he, who hitherto received one shekel for his work, took money no more."

In the letters of Hammurabi these diviners were recognised as a regular Guild. Knowledge of the tablets of recorded answers, which, suiting the individual circumstances of each interrogator, had for generations been stored in the library, enabled them to render an interpretation of practically all events. Their forecasts had resort not only to astrology, but to other means, such as the observations of the movements of fish, of the flight of birds, and of the entrails and livers of sheep and other sacrificial animals, all of which were the subject of minute inspection.

The Babylonians in seeking to determine the future watched carefully the movements, etc., of fish. Although the greater part of the known divination tablets regarding fish omens are in a sad state of preservation, the following will serve as an example: "If fish in a river keep in a school and steadily face up stream, in that place will be peaceful habitation," a deliverance hardly fraught with comfort at times of flood or drought!

Then again the passage (in Ezekiel xxi. 2I-22), "The King of Babylon stood at the parting of the way, at the head of the two ways, to use divination: he shook the arrows to and fro, he consulted the teraphim, he looked in the liver," etc., is of great interest, as evidence that the Babylonians employed both Belomancy or divination by arrows, and Hepatoscopy or inspection of the liver.

Belomancy was practised by other nations, 1 notably in

1 Apollo to the Greeks was at once archer-god and god of divination. The word à $\gamma \in i \lambda \epsilon$, " he gave as his oracular response," means literally " he

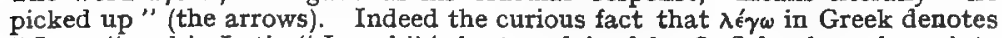
"I say" and in Latin "I read " is best explained by $O$. Schrader, who points 
Arabia (as witness Mohammed's command against the use of arrows, " an abomination of Satan's work !') ' more frequently than in Babylonia. There it attained but secondary importance. The general method required the shaking or shuffling before the image or the sacred place of the deity of a set of arrows. In the temple of Mecca the three important arrows were named, The Commanding, The Forbidding, The Waiting.

Hepatoscopy: the liver among the Assyrians, the Jews, ${ }^{2}$ the Greeks, and the Etruscans, ${ }^{3}$ contested with the heart the honour of being the central organ of life. Its convulsive movements, when taken from the sacrificed victim, gave warnings of the future. So sacred was the liver held in Israel, that eating it was forbidden : it had to be returned to the Giver of Life. ${ }^{4}$

Fish were early utilised for the calendar of the year. The signs of the Zodiac showing Pisces, possibly derived from connection with the god of water, and Scorpio, possibly representing one of the Crustacea, date back to c. 3000 B.c.5

out that it meant originally "I pick up " or " collect" (the arrows of divination) and so both read and declare the will of heaven. See O. Schrader, Prehistoric Antiquities of the Aryan Peoples, trans. F. B. Jevons (London, I890), p. 279.

1 Koran, Sur. v. 92.

2 Proverbs, vii. 23.

s See, e.g. C. Thulin, Die Götter des Martianus Capella und der Bronseleber von Piacenza, Gieszen, I906.

4 Ency. Bibl., p. III8.

- According to Langdon, Tammuz and Ishtar (op. cit.), p. 47, "Nina, a water deity, was identified at an early date with the constellation, Scorpio; for this reason her brother Ningirsu, also a water deity, was identified with one of the stars of Scorpio." 


\section{CHAPTER XXXVII}

\section{THE FIGHT BETWEEN MARDUK AND TIĀMAT}

Following my usual course of ending the chapter on each nation with a legend or story, in which fish or ichthyic monsters figure as direct or indirect agents of some important event, I subjoin the only myth in Assyrian literature which comes within this category, viz. the famous fight between Marduk and Tiamat, the monstrous creature of the deep.

Tiāmat, with her consort Apsū, had revolted against the gods and brought into being a brood of monsters to destroy them. So formidable seemed her forces that all appeals by Anshar, the leader of the gods, to Anu, and then to Ea, were made in vain. No god would "face the music," till Marduk was prevailed upon to become their champion. Nor does this grand refusal seem unnatural, when we read of Tiāmat's dimensions.

"Fifty Kasbu, or more correctly Biru (i.e. 300 miles), was her length, one Kasbu (six miles) was her breadth, half a rod was her mouth;" and the rest of her body of proportionate bulk! I Nor again is it unnatural that at-

"The lashing of the water with her tail, All the Gods in heaven were afraid."

1 The Biru or Kasbu represented the distance walked by an ordinary man in one Sumerian hour, which, as they divided their whole day into twelve, equals two of our hours. The prehistoric Sumerians, like other nations, reckoned the year by the Moon, not by the Sun. The historic calendarmakers endeavoured to bridge the hiatus and correlate the solar with the lunar year by inserting an intercalary month. They combined the decimal and the sexagesimal in their scheme of numbers-hence, though curiously, their multiplication was always by six, not ten. Cf. W. Zimmern, Zeit und

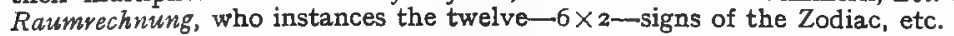


How pigmy in comparison with Tiamat appears the decadent sea-dragon mentioned by Ignatius, on whose gut, r2o feet long, in the library of Constantinople were written in letters of gold the Iliad and the Odyssey!

Allied with Tiämat in her fight were-

" Spawned sea-serpents,

Sharp of teeth and cruel of fang."

"With poison instead of blood she has filled their bodies, And mighty tempests, and the fishman, ${ }^{1}$ and the ram, ${ }^{2}$ They bear merciless weapons without fear of the fight."

Beowulf in his famous battle with the Dragon stands out as nobler and braver than Marduk, inasmuch as he, a man, to free his country from the Dragon's toll of death and ravage, of his own volition seeks out the monster. He " attacks alone, for being altogether fearless he scorned to take an army against the foe," whereas Marduk-the god-was compelled to the duel, since he was unable to enlist a single god. Beowulf " counted not the worm's warring for aught," whereas Marduk among his preparations,

"Made a net to enclose the inward parts of Tiāmat

And the four winds he set so that nothing of her might escape."

The protagonists (literally protagonists, for behind Marduk cowered the shrinking gods, and behind Tiammat her spouse and her spawned monsters) on meeting consume time, quite in the grand Homeric manner, by launching taunts and reproaches at each other.

Eventually Marduk, after spreading out his net to catch her, seems to have anticipated the gassing tactics of the Huns by many millenniums, and owing to the absence of a mask with even greater success, for-

"The evil wind, that was behind, he let loose in her face, 3

As Tiāmat opened her mouth to its full extent.

He drove in the evil wind, while she had not yet shut her lips.

1 Aquarius.

- Capricorn.

- Similarly in the Gigantomachy as figured on the Siphnian Treasury at Delphi, Folus, god of the winds, helps the deities against the giants by deflating two bags of wind. He is represented by an Ionian sculptor as 


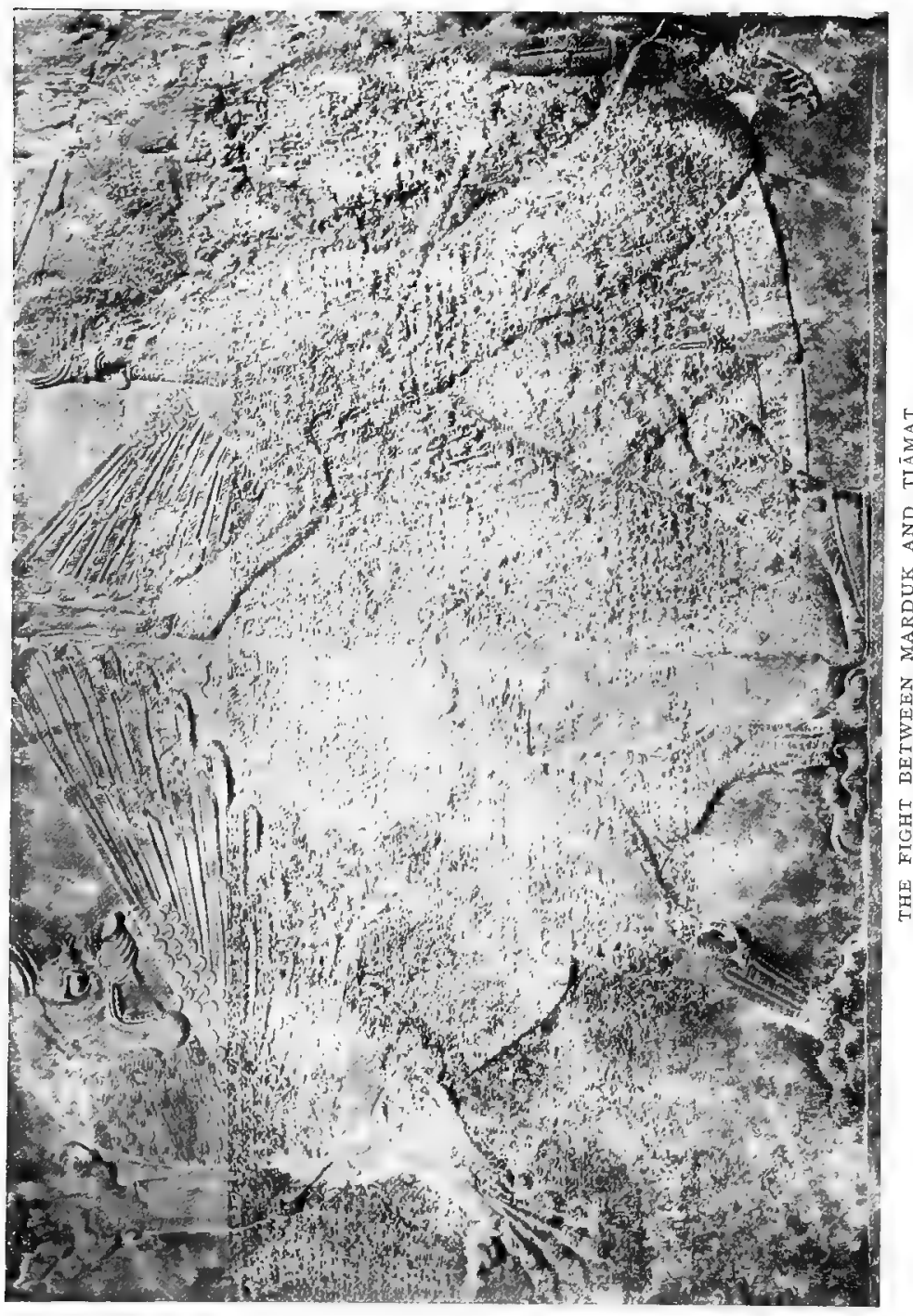



The terrible winds filled her belly,

And her courage was taken from her and her mouth she opened wide.

His spear he seized, and broke through her belly, He severed her inward parts, he pierced her heart."

Then for a while Marduk rested but, arising,

" He split her body up like a flat fish into two halves.

One half of her he set in place as a covering for the heavens. He fixed a bolt, he stationed watchmen, And bade them not to let her waters come forth."

Finally to their hero and saviour the gods accord a triumphant welcome, and

"Presents and gifts they brought unto him." 1

working his wind-bags with all the concentration of a Hun working his machine-gun. See G. Perrot-C. Chipiez, Histoive de l'Avt dans l'antiquite (Paris, I903), VIII. 368 and 375, fig. I72.

1 Cf. Babylonian Religion (op. cit.), Pp. 62-85. 



\section{JEWISH FISHING}






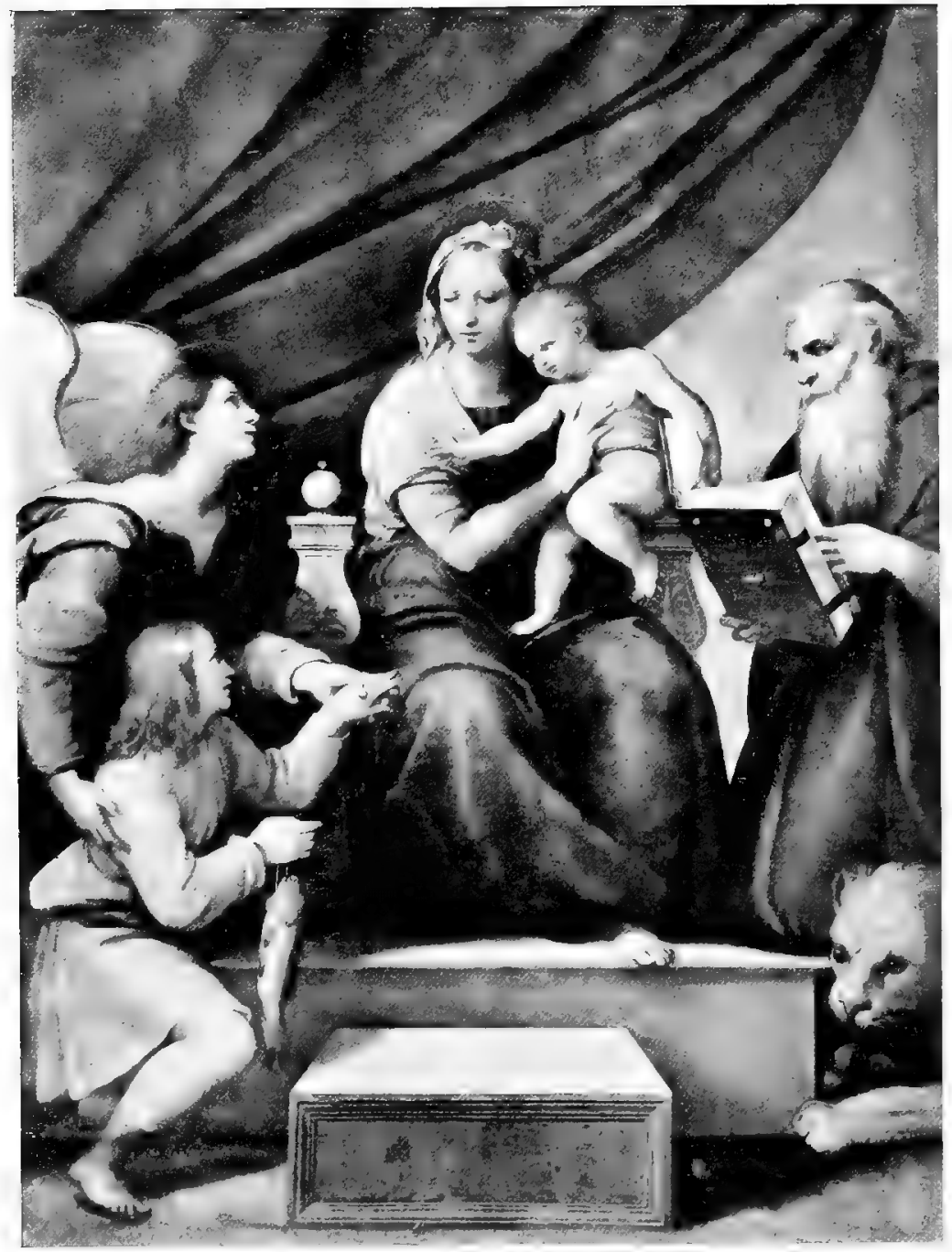

tobias, IN La Madonna del Pesce, BY RAPHAEL. 


\section{JEWISH FISHING ${ }^{1}$}

\section{CHAPTER XXXVIII}

ROD NOT EMPLOYED IN SPITE OF CLOSE INTERCOURSE WITH EGYPT-REASONS SUGGESTED FOR ABSENCE

THE absence of any mention of Angling in Israel, and in Assyria causes wonder and surprise, especially when we remember that the relations of both nations in trade and intercourse with Egypt, where Rod fishing did obtain, appear when at peace constant and close. ${ }^{2}$

In the Assyrian chapter the vexed question of the earliest date assignable for the invasion or cultural permeation of Egypt by Sumerian or Semitic influences has been considered, and the conflicting views stated.

A fair consensus of agreement holds that the Hyksos sprang from Semitic stock; but the dates suggested for their conquest of Egypt vary from 2540 down to I845 B.c. ${ }^{3}$

However this may be, the definite association with Egypt of that branch of the Semitic tribes destined in Jacob's lifetime (Gen. xlvii. 27) to be known as Israelites, ${ }^{4}$ begins with the advent of Abram into that country.

1 Throughout my pages the words, Jews and Jewish, are generally used in the popular sense, and not as merely signifying members of the tribe of Judah. To my friend Dr. A. R. S. Kennedy, Professor of Hebrew at Edinburgh University, my thanks are due for advice and for reading the proof-sheets of my section on the Jews.

2 In this chapter the word Assyrian generally stands for Sumerian, Babylonian, and Ássyrian proper.

B Remains of the Hyksos kings are far-scattered; e.g. an alabaster vaselid of very fine work, bearing the name of Khian, was discovered in the palace of Cnossos in Crete, while a granite lion bearing the king's cartouche on his breast, unearthed many years ago at Bagdad, is to be seen in the British Museum. J. H. Breasted, History of Egypt, p. 2 I8 (London, 1906).

4 The verse is not conclusive that they were called Israelites during their 
King, Rogers, and Jastrow in their later works have seemingly adopted the date arrived at by Kugler from stellar researches for the first Babylonian Dynasty. If Abram were, as is now thought; the contemporary of Hammurabi, his flitting must have occurred between 2 I20 and 2080 B.C., but since Egyptian chronology beyond the fifteenth century is fluid, and no early positive synchronisms with Babylon survive, we cannot definitely designate any particular king in Egypt as the contemporary of either Hammurabi or Abram.

The Bible is our main authority for the continuance of the association. The stories of Jacob, of Joseph (in whose title Abrek I some detect a Babylonian influence and a connection with that of Abara-rakku, the designation of one of the five great officers of state), and of Moses, are but episodes of an intercourse which, if we begin with Abram and end with Onias, lasted (with intervals of war and invasion) for some 2000 years.

Evidence of intercourse crops up again and again throughout the four centuries of the Jewish Monarchy. Thus we read (I Kings iii. I) of the marriage of Solomon with the daughter of Pharaoh. From Solomon's reign onward till the birth of Christ and long afterwards, the connection between Egypt and Israel, friendly or hostile, never fails. The flight of Jeroboam to Shishak (I Kings xi. 40) and the giving of presents, probably tribute, by Hosea to the King of Egypt (2 Kings xvii. 4) present but two instances.

Papyri recently discovered prove the settlement near Assouan of a considerable Jewish, or rather, more correctly, Palestinian colony from (say) 500-400 B.c. This, like the similar but older community at Tahpanhes, exhibits a mart of wide and keen trading. The papyri "show that the Aramaic-the common language of Syria-was regularly used at Syene (Assouan), and we readily see how five cities in the land of Egypt speak the language of Canaan and swear to Yahweh

sojourn in Goshen. The name used by the older sources is Ibrim, probably identical with the Egyptian word Aperu or Apriu.

1 This is probably a shortening of the Sumero-Babylonian Abarrakku, equalling seer. $H$. de Genouillac was the first to connect the word with the Hebrew Abrek, in his Tablettes Sumbriennes Archaiques. 


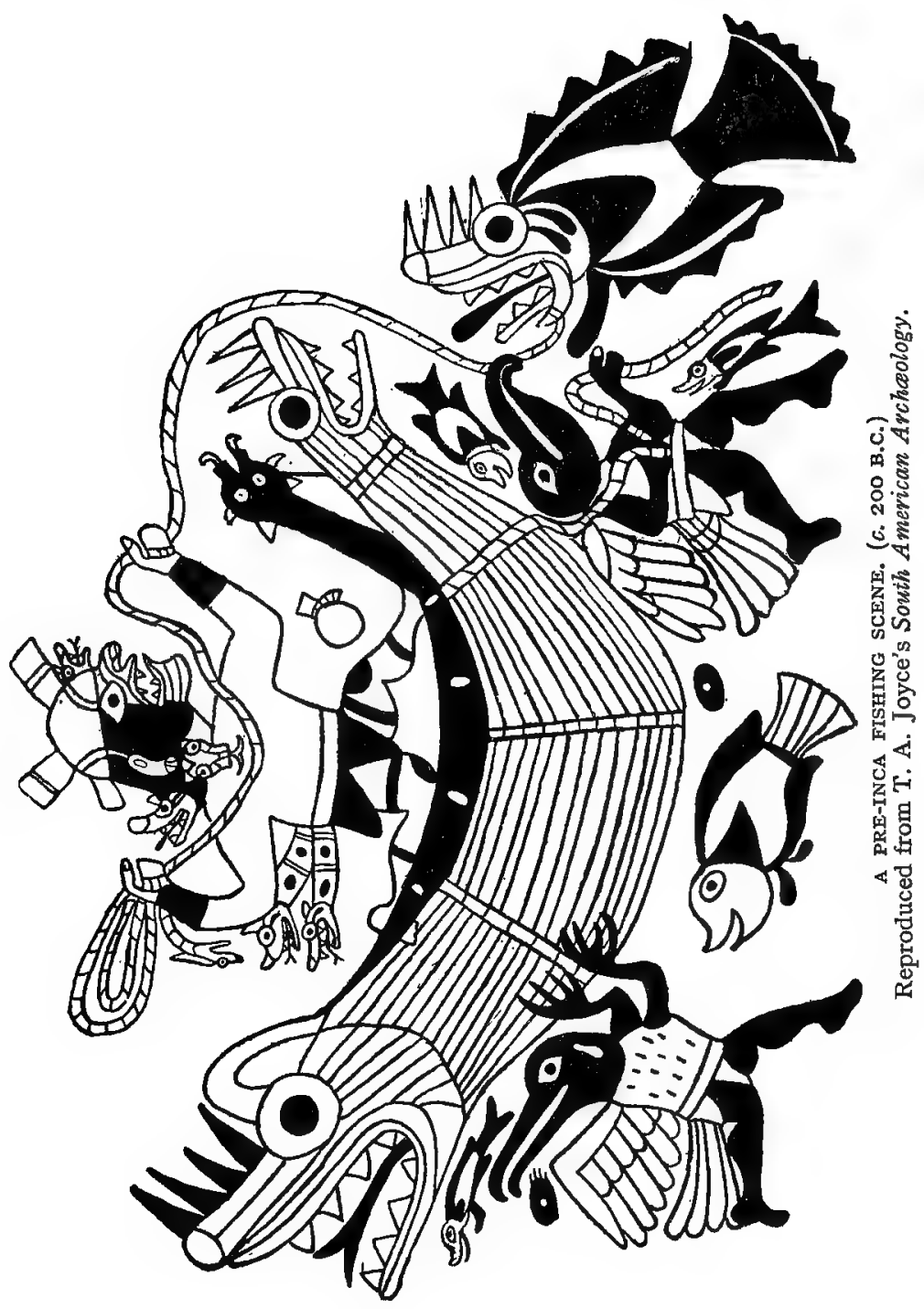


of Hosts (Isaiah xix. I8) as the oath in these papyri is by Yahu." 1

After the destruction of Jerusalem by Antiochus Epiphanes, the petition by Onias to Ptolemy Philometor for permission to erect a central temple for the benefit of the many thousands of his compatriots resident in Egypt concludes the historical evidence that $I$ call as to the continuance of the EgyptianIsraelitish connection. Its survival for centuries after the birth of our Lord is a matter of common knowledge.

The existence of this connection rests not merely on historical evidence. Recent excavations in Southern Palestine tell the same tale, or even carry it still farther back, to pre-Israelite Canaan. Thus, after referring to the tale of Sinuhe (c. I970 B.c.), Professor G. Barton writes, "There was apparently considerable trade with Egypt at this time. Men from Palestine often went there for this purpose. Such traders are pictured in an Egyptian tomb of this period. Trade with Egypt is also shown to have existed by the discovery of Egyptian scarabs of the time of the Middle Kingdom in the excavations at Gaza, Jericho, and Megiddo. As Egypt was nearer, and commerce with it easier, its art affects the arts of Palestine more than the art of Babylon." 2

R. A. Macalister ${ }^{3}$ writes: "Meanwhile the oldest foreign civilisation of whose influence definite relics have come to light within the land of Palestine is that of Egypt under the XIIth Dynasty." The assertion that " almost every spadeful of earth which is turned over in Southern Palestine brings to light more evidence of Egyptian influence" seems hardly an exaggeration. 4

But, it may be asked, what has all this got to do with fishing? Of itself and in itself apparently nothing.

1 See p. 94, Flinders Petrie, Isyael and Egypt, of which in this section I frequently avail myself. Inscriptions of $i$. XXVIth Dynasty, or c. 600 B.C. disclose that there was an actual priesthood dedicated to the god YHW, which word is clearly spelt out.

2 Archoology and the Bible, p. Iog (London, I916).

The Civilisation of Palestine, p. 33 .

- The Biblical World, Feb., I9ro, p. ro5. Inscriptions of Sinai (published in I9I3 by the Egypt Exploration Fund) furnish much evidence as regards the intercourse between Egypt and Israel. For the trade between Solomon and Egypt, see I Kings x. 28, etc. 
The introduction, however, of the historical facts cannot be branded as irrelevant. They demonstrate a constant association for over two millenniums with Egypt, and the deep influence of Egyptian civilisation and methods of life on Jewish policy.

And yet, notwithstanding such intercourse and such cultural influence, we can nowhere in the literature of the Bible or of the Rabbis discern either a direct mention, or (as I hope to show) an implied allusion to the use of the Rod, which as a weapon both for market and sport from c. 2000 B.C. found favour in Egypt. ${ }^{1}$

The same holds true of the Land of the Two Rivers; in no Assyrian sculpture, on no Assyrian seal, can we detect any delineation or any suggestion of angling, although instances of other kinds of fishing occur frequently. ${ }^{2}$

In no book of the Old or of the New Testament can be found any direct mention of the Rod. In the Talmud-a vast work of teaching and discussion-the same silence prevails. The authoritative Talmudische Archäologie (by S. Krauss, Igro) gives us fishful places such as Lake Tiberias, and many points of ichthyic or piscatorial interest such as the hook, the line, salted fish, garum, etc., but contains no reference to the Rod. ${ }^{3}$ Mr. Breslar, it is true, has recently girded up his loins to establish that in the Bible and the Talmud can be found at any rate the implied use of the Rod, but to a practical angler quite unconvincingly. 4

1 See Plates $37^{\circ}$ and $37 \mathrm{r}$ in Wilkinson, and antea, p. $3 \mathbf{r} 4$.

2 See antea, pp. 355-9.

3 In Singer, Jewish Ency., V. p. 404. "Fishing implements such as hook and line, sometimes secured on shore to need no further attention (Shab. I8A), and nets of various constructions " are practically all that are given.

- After acknowledging (Notes and Quevies, Dec. 2, 1916) that there is no mention in either Old or New Testament of a Rod, Mr. Breslar goes on, "Yet there are places such as Job xl. 3I (xli. 7) where the Hebrew words are translated barbed irons and fish spears, and in Job xl. 26 (xli. 2) a thorn. A fishing-rod in the modern sense no one could reasonably demand, though 1 opine that in agmoun (Isaiah lviii. 5), used in that sense in Job xl. 26, we have the nucleus of one." Mr. Breslar is evidently not aware or does not realise that fish spears, bidents, etc., were of the earliest weapons of fishing, long anterior to the Rod, and that these are the weapons referred to in Job. A reference to the Jewish Encyclopedia edited by Isidore Singer, would have shown him that silzal dagim in Job xli. 7 was in all probability a harpoon. Then, "that this phrase (Klei metzooda) or a similar one is not found in the Bible is merely an accidental omission like, I believe, that of the name of 
To account for this absence of direct mention of the Rod in the Bible various reasons have been adduced.

The first: in the only two passages, Isaiah xix. 8, and Habakkuk i. I5, where the word "angle" occurs, and in Matthew xvii. 27, "cast a hook," and in Amos iv. 2, as contended by Mr. Breslar, its use is certainly implied. The validity of this claim remains a question (A) for Hebrew scholars, and (B) for practical fishermen.

From the point of view of the latter, the "casting," "taking," etc., in the above passages can be and probably were accomplished by a hand-line (with or without a weight attached to insure greater length of throw) almost as easily and as effectually as if a Rod were employed. As a matter of fact, for taking good-sized fish some of our professional sea-fishermen prefer the hand-line to that of the Rod.

The words in Matthew xvii. 27, "go thou to the sea and cast a hook" do not either in the Greek or English strongly suggest, much less necessarily imply, a Rod. To a professional fisherman of the Sea of Tiberias like Peter, the more natural, probably the only known method of casting would be by a hand-line.

Turning now to the Hebrew passages, Isaiah xix. 8, "The fishers shall also lament, and all they that cast angle in the Nile (A.V., brooks) shall mourn;" Habakkuk i. I5, " $\mathrm{He}$ taketh up all of them with the angle, he catcheth them in his net, and gathereth them in his drag;" Job xli. I, "Canst thou draw out leviathan with a fish-hook?" in all these we find the same Hebrew word hakkäh.

The R.V. in the first two renders it "angle," and in Job "fish-hook;" in the Greek version ä Septuagint is the usual and in the New Testament (Matt. xvii. 27) the only word for hook, occurs in all three passages.

Whence or from which word can the Rod be implied, or even in fairness claimed? In Isaiah, it is answered, from the Jehovah from the Book of Esther." This is hardly helpful : let us grant that the omission of a name from a short book like Esther was an accident. How can this be "like " the omission of all mention of or allusion to the Rod in the vast literature of the Old and New Testaments and of the Talmud, especially when we find in all three numerous passages dealing with fishing and the tackle employed for fishing ? 
words " cast in the Nile." But in a river, as every child knows, fishing is pursued by more methods than that of the Rod. Judging from the literature of our six Nations fishing by hand-line was far and away more general than by Rod; the ratio between the two would indeed, I think, work out at some Ioo to $I$.

If then the words, " cast in the Nile," do not furnish the implication claimed, can we find any other words in the three passages which do? The one word common to them all is hakkāh, hook: if this fail the claimants, how or whence can they establish the implication?

Let us now see whither the implication from hakkāh leads us. Obviously in Job, to angling with a Rod for "Leviathan " or crocodile! 1 The absurdity is already manifest. Let us, however, in our hunt for the snark-like implication examine the remaining tackle of this intrepid angler. Fortunately for us, conjecture as to the hook or the bait is unnecessary.

The Petrie collection at the University of London preserves a hook, which in Ptolemaic times was employed in the Nile for the capture-not of crocodiles-but merely of large fish, such as Lates niloticus. It measures over one foot in length, with a shank over $2 \frac{1}{2}$ inches in width.

The account of crocodile fishing by the Egyptians left us by Herodotus ${ }^{2}$ prescribes the bait-no less an one than a

1 At the beginning of the world (Buddha tells the Monk of Jetavana) all the fishes chose Leviathan for their King. No hint as to what fish this Leviathan represented is given us: but the Leviathan conceived by the Talmudists seems to have been an indefinable sea-monster, of which the female lay coiled round the earth till God, fearing that her progeny might destroy the new globe, killed her and salted her flesh and put it away for the banquet which at the end awaits the pious of the earth. On that day Gabriel will kill the male also, and make a tent out of his skin for the Elect who are bidden to the banquet (Robinson, op. cit., p. 8). As Robinson is somewhat misleading, especially as regards the word Leviathan, I give the story as told by Buddha with reference to Anqulimäta from Jätaka, nv. 537, vol. V. p. 462 . A certain king had been a Yakkha, and still wanted to eat human flesh. His commanderin-chief tells him a tale to warn him. "Once upon a time there were great fishes in the Ocean. One of them, Annanda, was made king of all the fish, ate the other fish, and finally ate his own tail thinking it was a fish. The remaining fish smelling blood, devoured Ānanda's tail until they reached his head, and all that was left of Ânanda was a heap of bones." Leviathan is a gloss of Robinson's, because the only word in the text which could in any degree correspond to Leviathan is $M a h \bar{a} M a c c h o=$ great fish. For the election

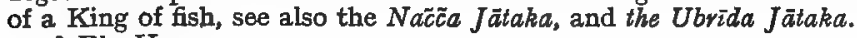

2 Bk. II. 70 . 
chine of pork. The line, then and now (ex necessitate rei), must have been of stout cord, possibly tied to a tree, with probably some protective material of horn, etc., to prevent erosion.

Conjure up the picture of this Egyptian piscator-even in this instance the Jerw does not use the Rod, for there are no Leviathans in Palestine ! 1 Behold him " casting," with a Rod of ancient normal length, about six feet, with a rope line of ancient normal length, from six to ten feet, a bait of even half the back of a porker! Surely a picture for gods and men, more especially the winners of our Casting Competitions, to revere with awe and envy, as a feat of strength and skill unessayable.

From these three passages I can find no reason, contextual or piscatorial, to support the contention that the Rod was used, although to us moderns such use would seem but the natural thing.

Mr. Breslar maintains that Amos iv. 2 authorises the implication. He errs either in translation or through misconception of the tackle described. The words run, "They shall take you away with hooks (zinnoth), and your residue with fish-hooks." The Hebrew word for the second, șīooth dīgäh, means only hooks, plain and simple, while that for the first, zinnoth, signifies also thorns and probably fish-spears, or harpoons.

Amos, however, far from thinking of or suggesting a Rod, is looking contrariwise at the end of a line. His metaphor is drawn from the non-angling custom prevalent and pictured in Assyrian representations of a conqueror having his captives dragged by cords fastened by presumable, but naturally not apparent, hooks firm fixed in their lips. This conception is strengthened by the fact that hakkäh in its primary etymological sense implies merely something connected with the jaws. ${ }^{2}$

1 See, however, an article in The Spectator, Feb. I4, 1920, which asserts that the existence of crocodiles in the Nahr-ez-Zerka, or the River of Crocodiles of the Crusaders, cannot be questioned, and also H. B. Tristram, Land of Israel (London, 1865), p. I03, to similar but unconvincing effect.

"Cf. Isaiah xxxvii, 29, "Therefore will I put my hook (hoh) in thy nose, and my bridle in thy lips," and 2 Chron. xxxiii, I I, "Which took Manasseh with hooks" (R.V. margin). 
If Mr. Breslar surmises (though his words convey no such hint) that for his " rudimentary type of Rod in the Scriptures" Israel affixed a line to his fishing spear, thus squaring with my conjecture in the Introduction as to the evolution of the modern Rod, may I respectfully ask why did a race, so preeminently alert and proverbially acquisitive, handicap itself by the selection of such a "rudimentary type" in preference to a weapon long invented, ready to hand, and far superior ?

A friend, in the hope of helping me to some authoritative information as regards Angling, suggested Jagd, Fischfang, und Bienenzucht bei den Juden in der tannäischen Zeit, by Herr Moritz Mainzer, as the very last word on Jewish fishing. Unable (owing to the War) to obtain this in book form, I tracked it eventually to some articles under the same title in the magazine, Monatsschrift für Geschichte und Wissenschaft des Judentums (Ig09). Except for a pearl or two such as "Fishermen, then as now in Palestine, worked lightly dressed or naked," -was this suggested by St. John, or P. Fletcher's, "Now when Simon heard, he girt his fisher's coat unto him, for he was naked "? - Fischfang (at any rate) far from rewards one's search.

Mainzer's two sentences (p. 463) assist not at all in determining whether or not the Jews used the Rod. "Die eigentliche hakkäh war ein eiserner an eine Leine (hebhel) befestigter Haken. Die Leine selbst konnte mit einer Rute oder einem Stabe verbunden sein der zuwweilen mehrere Schnüre mit Angeln trug" (the hakkāh proper was an iron hook fastened to a fishing hebhel. This line might be attached to a rod or stick, which sometimes had on it several cords with fishing hooks).

The supporting references come from no Israelitish source, but from Assyrian representations of hand-lining in Layard's Nineveh, and from Egyptian delineations of Rod fishing in Wilkinson's Ancient Egyptians. Not a single word does Mainzer quote from any authority on Jewish Angling. The words, "to a Rod which sometimes had on it several cords with fishing hooks," simply translate Wilkinson's Plate 37 I.

Had I weighed the title and duly appreciated the combination of Hunting, Fishing, and Bee-culture! I would have been perhaps prepared for a disappointment, but the output 
of, or the " cultural associations" in, a German work often defy prediction from its mere headings. Mainzer, in his Fischfang, serves to recall Porson's lines, which are themselves but an adaptation of a Greek epigram, 1

\author{
"The Germans in Greek \\ Are sadly to seek, \\ Not five in five score \\ But ninety-five more. \\ All save only Hermann, \\ And Hermann's a German!"
}

Lest my own conclusion-that neither in the Old or New Testament is the implied use of the Rod established-carry little weight, I subjoin the conclusions (stated in letters to me) arrived at by two well-known Hebrew scholars.

The first comes from Professor A. R. S. Kennedy (the writer of the article on Fishing in the Encyclopadia Biblica): "In short you are entirely justified, so far as evidence goes, in saying that the Jews did not use the Rod."

The second comes from Dr. St. Clair Tisdall : "We find in the Bible no proof of fishing with Rod and line : on the contrary the fact that no mention whatever, direct or indirect, of the fishing Rod occurs either in the Bible or (as far as my reading goes) in the Talmud, makes it almost certain that the Rod was not used by the Jews. At any rate the use of any such instrument is not implied in either Book."

A second reason for the absence of the Rod may be that of dates. The Jews, it might be urged, were not and could not be aware of Egyptian Angling, because it sprang up subsequent to their Exodus from the country. The reply I offer involves, it is true, that bewildering factor, Egyptian chronology. But even if a thousand years are as nothing in the sight of Manetho and many others, surely one epoch correlates with another, and the shifting of one date automatically involves the shifting of others.

1 In a letter to A. Dalziel, Sept. 3, 1803, Porson states that these lines were an effort made to English an epigram by an Etonian friend, in imitation of Phocylides's saw (Strabo, X. p. 487): 
The date of the Exodus, like most Egyptian dates, hitherto a matter of considerable contention, is now generally agreed as falling between 1300 and I200 B.C. Petrie ${ }^{l}$ fixes on " I220 B.C. or possibly rather later," Hanbury Brown places the Flight ten years earlier, i.e. I230, for reasons based mainly on the stele of King Menephtah. ${ }^{2}$

So if the contention that the Israelites could not well know of the Rod because of its invention after their flight holds water, any representation of Rod fishing must obviously be subsequent to the year I230 or I220 B.C. Only two such representations exist: (A) (in Wilkinson's Plate 370) comes from the tomb (No. 93) of Kenamūm at Thebes, and dates from about the second half of the XVIIIth Dynasty, or some 200 years before the Exodus, while (B) (in Wilkinson's Plate 37I, and in Newberry's Beni Hasan, vol. I. Plate XXIX.) goes back to the early XIIth Dynasty or some 750 years before the Exodus. ${ }^{3}$

The Exodus, whatever date be assigned, probably occurred in the time of and was occasioned by a dynasty non-Semitic, and unfavourable to Israel. The corvêe enforced doubtless by the kourbash was exacted from the aliens, whose task (Exodus i. II) included the building of two brick fortresses to block the eastern road into Egypt.

1 Op. cit., p. 53.

2 The inscription mentions the existing conditions of foreign affairs with neighbouring countries as satisfactory. It is in this connection that the "people of Israel " come in. Their Exodus, according to Pharaonic fashion, would have been described by the King as an expulsion and not as an escape against his will. The author of the inscription, who wrote from a point of view which was not that of the Biblical account, seems not unsupported by Exodus xii. 39, "Because they were thrust out of Egypt and could not tarry." Even stronger is the Revised Version marginal rendering in Exodus xi. I, "When he shall let you go altogether, he shall utterly thrust you out hence." Sir Hanbury Brown, Journal of Egyptian Archaology (Jan. Igr7), p. I9.

a In connection with, perhaps even helping to fix, the date of the Exodus, it is in the victorious hymn of Menephtah that the earliest written reference to Israel appears: "Israel is desolated: her seed is not. Palestine has become a (defenceless) widow of Egypt" (Breasted), or "The Israelites are swept off: his seed is no more" (Naville). Petrie's translation, "The people of Israel is spoiled : it has no corn (or seed)," does not for various reasons seem to find favour. The majority of Egyptologists now identify Aahmes $I$. with the "new king who knew not Joseph," $c$. (I 582), Rameses II. as the first Pharaoh of the Oppression, and of Exodus ii. I5 (c. I300), and Menephtah the son of Rameses II. with the Pharaoh of the Plagues and the Flight from Egypt (c. 1234). 
To most of us unacquainted with the making of bricks the cruelty of the Pharaonic command, "There shall be no straw given you, yet shall ye deliver the tale of bricks," seems to consist in demanding from the sojourners the same quantity of output without their possessing, as the Egyptian workers did possess, an essential constituent in the brick-straw.

But Petrie points out that straw, so far from being an essential of the mixture, is absent from most ancient and modern bricks. The complaint arose because finely chopped straw is very useful for preventing the mud from sticking to the hand, for dusting over the ground, and for coating each lump before dropping it in the mould, thus enabling the work to go on quickly and easily. From the strawless Jew, however, was extorted for the same hours a tale of bricks equal to that of the Egyptian enjoying these advantages.

In direct opposition to Petrie, Maspero states, and Erman 1 agrees, that the ordinary Egyptian brick, both ancient and modern, is " a mere block of mud, mixed with chopped straw and a little sand."

Other reasons for the Jewish unfamiliarity with the Rod, viz. its merely local use, and their settlement in the North East of Egypt remote from " the River of Egypt," would fully be met, were it not for Isaiah, with the simple statement that at present they can neither be proved nor disproved.

But the words of Isaiah xix. 8, "The fishers also shall lament, and all they that cast angle into the Nile shall mourn," surely demonstrate-if we allow that "cast angle" is the proper technical translation, and that the two words cannot mean the mere throwing of a hook with a hand-line-that the Israelites during the 430 years (Exodus xii. 40) of their sojourn in Egypt did acquire familiarity with the methods of fishing employed by their taskmasters.

Still, even if we take it as proved that for some reason Angling was at the time of the Exodus an unknown art to the Jews, why with all the intercourse of the subsequent centuries

1 Egyptian Archaology (1902), 3-4. Erman, op. cit., 417. The English translators state that the bricks were usually unburnt and mixed with short pieces of straw. 
was the knowledge of the existence and value of the Rod not acquired ? 1

Those and other queries may have found a ready reply in the reputed but lost Book of Solomon on Fishes. ${ }^{2}$ It may possibly have contained some clue, such as a command or custom, totemistic or other, common to the old Semitic stock, or some trait of temperament which caused Angling to be regarded as too slow or too unremunerative a pastime.

Without its guidance one is almost driven to the conclusion that the ancient Israelites (like the early Greeks and Romans) were pot-hunters, bent on the spoil rather than on the sport of their catch, but (unlike them) continued this characteristic throughout their history, and remained to the end uninfected by the joy or passion of Angling. Their desire was fish-abundant and cheap, or better still gratis: hence when "fed up" with Manna (Numbers xi. 5) they fell a-lusting - "Who shall give us flesh to eat? We remember the fish we did eat in Egypt for nought."

This apparent lack of the sporting instinct contrasts strangely with the fact that modern Jews rank among our foremost anglers, and that to a Jew we owe the greatest book written within the last generation, if not the practical establishment on a scientific basis of the dry-fly, that most finished form of Angling.

Dr. Kennet, Professor of Hebrew at Cambridge, while holding no brief either way, has, at my request, most kindly suggested some reasons which may conceivably account for the Biblical absence of Angling. To my mind none of these affords adequate proof of its existence.

A. The physical characteristics of the country preclude many references to fishing in the Old Testament. However keen their desire, the majority of the population were in the position of Simple Simon, when he " went a-fishing for to catch a whale."

1 If the Egyptian Rod was unknown, "the Egyptian fish (probably salted) that came in baskets "were regularly imported. Mishna Makhshirin, VI. 3 ,

2 See I Kingstiv. 33, "And he spake also of beasts, and of fowl, and of creeping things, and of fishes." Some authorities hold that this mention of Solomon's natural history researches is quite late, and meant to be a set off against Aristotle's. 
Sea-fishing was out of the question, for with the doubtful exception of a small bit of the Galilæan coast-probably not held continuously-no part of the Mediterranean sea-shore belonged to Israel during the Monarchy, while the climate and intense heat of the Valley of the Jordan, the only real river, kept its inhabitants apart from the dwellers on the mountains.

But contra: even if the majority were Simple Simons, the numerous references (about 74) in the Bible to fishes, fishing, and fishing implements indicate a wide, if perhaps impersonal, knowledge of the practice. The fact that the larger number of these were used as metaphors or similes evidences a more than local knowledge of fishing, because for a metaphor or simile to be telling it usually must, as do the Homeric, appeal to a well-known, common, and long-established custom or craft.

B. Although fishing apparently prevailed always in the Sea of Galilee, it must be remembered that practically the whole literature of the Old Testament emanates from central and southern Palestine, and (as is the case with Egyptian literature as regards Deltaic conditions) contains but scant allusion to life among the Northern Tribes. Hence possibly the silence about the Rod, which may nevertheless have been employed.

C. The Old Testament stories, although some belong to the same period as the Homeric, are told in a manner very different from the latter. Every picture is sketched with the fewest strokes, and accordingly details are, have to be, taken for granted. Thus, although the majority of the people subsisted largely on milk, there is not one reference to milking.

But contra: this omission seems to me hardly on all fours with that of the Rod. The word milk, when not expressly limited, e.g. " of thy bosom," or used metaphorically, signifies solely the lacteal liquid extruded from the teats of an animal, and so implies milking or a previous act of extrusion, whereas the word fishing connotes no single method of taking fish, as the Old Testament in its mention of the implements, Spear, Hook and Line, and Nets, demonstrates. Then again Job xxi. 24 (R.V. margin), " his milk-pails are full of milk," and Judges 
iv. Ig, " she opened a bottle of milk," both demand an extrusion effected by one and only one method, whereas "jars of fish" may have been filled by any piscatorial method.

$D$. There is no evidence that the Israelites brought from Egypt a single particle of Egyptian civilisation. Nomads they were when they entered, and nomads they were when they left Egypt. Their kultur was taken over from the Canaanites, and their later civilisation, despite periods of subjection to Egypt, owed far less to that country than to Babylonia.

Even if we grant that no actual evidence of Egyptian culture exists, the probabilities incline the other way. Their abiding place was in no sterile or out-of-the-way corner of that country, but in Goshen, where we read " they gat them possessions therein," and was in close proximity to the great high road, which bore the commerce between Egypt and Asia, and vice versâ. They were certainly familiar with the manufacture of bricks, and presumably the building of houses, etc.

E. The verse, "The fishers shall also lament and they that cast angle in the brooks shall mourn," which may betray knowledge of the Rod, is apparently much later than Isaiah, and may, perhaps, be assigned to the second century B.C., and refer to the campaign of Antiochus Epiphanes in Egypt.

Even if we allow that this date accounts for all omission of Angling during the millennium between the Exodus and this campaign, why is there no actual or implied reference in subsequent literature, especially in the voluminous Talmud ?

But the Jewish lack of sport is evidenced not only in their methods of fishing, but, what is more remarkable, in those of their hunting, or rather non-hunting. While Assyrian, Egyptian, and Persian Monarchs were famous for their hunting exploits, no single Jewish king, except Herod, is handed down to us delighting in or even taking part in the chase. ${ }^{1}$

We find no Hebrew counterpart to Tiglath-pileser, with his historical bag of " 4 wild bulls mighty and terrible, Io elephants and I20 lions" on foot, and I30 speared from his chariot, or

1 Herod seems, from notices in Josephus, to have been quite a sportsman, for he kept a regular stud (Ant., XVI. IO, s. 3 ), and hunted bears, stags, wild asses, etc., with a record bag of forty head in one day (ibid., XV. 7. 5. 7; and B. J., I. 21, s. 13). 
even of a mild understudy to Ashur-bani-pal. 1 The Bible gives but two-Esau's brother scarcely ranks as one-huntercharacters : Esau " a cunning hunter," and Nimrod " a mighty hunter before the Lord." Even the latter of these two heroes was no Israelite, but a king " of Accad," a Sumero-Assyrian, whom some writers identify with Gilgamesh.

Such indifference to or aversion from the chase cannot either at the time of the invasion of Palestine (Exodus xxiii. 29), or subsequently be ascribed to the lack of wild beasts or of game, for we read of lions, bears, jackals, foxes, etc., and of hart, fallow deer, and antelope.

Two reasons-neither, to my mind, satisfactory-have been advanced to explain this attitude as regards hunting, a pursuit which admittedly has played, both as a necessity and a pastime, an important part in the education and evolution of mankind.

The first : the Hebrews, as described in the Old Testament, had already reached the stage of pastoral nomads, when " hunting, which is the subsistence of the ruder wanderer, has come to be only an extra means of life." 2

The second: the Hebrews, hampered perhaps by certain peculiarities of their religion, or on account of the density of the population were not often induced " to revert for amusement to what their ancestors had been compelled to practise from necessity." 3

Either, or both, of these reasons might have carried weight, had it not been for the existence hard by in Assyria of a people, among whom, although sprung from the Semitic stock, hunting was a recognised and popular pastime, and this despite a population far denser.

Nor, again, when we compare the culture of the two nations, can Lacépede's previously quoted dictum that in civilisation the fisher nation is usually more advanced than the hunter

It is fair to record that some of the Assyrian monarchs preferred a battle mid safer surroundings, for in representations the head keepers are seen letting the lions, etc., out of cages for their royal master to pot I Parks

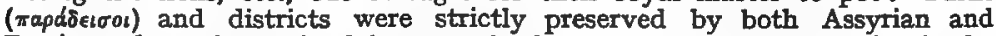
Persian rulers; in England for several reigns the penalty for poaching in the New and other Royal Forests was death.

2 E B. Tylor, Anthropology (London, I88r), p. 220.

3 M. G. Watkins, Gleanings from Natural History (London, I885), ch. ro. 
nation help the Hebrews, for apart from the fact of the indisputable and immeasurable superiority of the Assyrian civilisation we discover no sign of angling in Israel.

As in their fishing, they were "out for" the meat, not for the sport, so was it, I fear, in their hunting. If they found no pleasure in the chase, they assuredly delighted in the eating of game and were dexterous trappers of animals. Their methods were :-

(a) By digging a pitfall for the larger animals, e.g. for a lion in 2 Sam. xxiii. 20 ;

(b) By traps, which were set in the runs of the animals (Prov. xxii. 5) and caught them by the leg (Job xviii. 9), or were set underground (ibid. Io) ; and

(c) By nets of various kinds-for an antelope in Isaiah (li. 2o, R.V.). 


\section{CHAPTER XXXIX}

\section{FISH WITH AND WITHOUT SCALES-METHODS OF FISHING-VIVARIA}

IN Moses' enumeration of what the tribesmen might or might not eat, there is a careful distinction by their names of the creatures in fur and feathers, but the fishes are merely divided (as were the animals entering the ark into "clean and unclean," Gen. vii.) into "all that have fins and scales ye shall eat: and whatsoever hath not fins and scales ye shall not eat; it is unclean unto you" (Deut. xiv. 9, Io).

This classification has often been assumed to have been taken from the prohibitions enjoined by the Egyptian priesthood, but without any authority, because we do not know what fish were actually ruled out by their dietary canon. Moses not only limits the use of fish as an article of food, as originally granted in the covenant with Noah (Gen. ix. 2, 3), but fails to discriminate between fish from the sea and elsewhere. He does, however, exclude all scaleless fish such as the important group of siluridæ, skates, lampreys, eels, and every variety of shell fish. ${ }^{1}$

1 The classification, if unscientific and incorrect-e.g. Eels possess rudimentary scales-had as its practical purpose the elimination of the Siluridai.e. the Catfish Clarias, Bagrus, Synodontis, etc.-which even if, as with the Catfish, pleasant to the taste were very unwholesome, causing diarrhoea, rashes, etc. Doctors inform me that even in our day Jews who eat crustaceos, especially lobsters, are far more liable to these diseases than Christianspresumably from an abstention of centuries. The ban on Eels from their infrequency in Palestine was almost superfluous, but on the Clarias, which abounds in and near the sea of Tiberias, very practical. The abstention, whether originating from supposed reasons of health or from some obscure tabu, was and still is prevalent in Asia, Africa, and South America. A curious trace of it at Rome is discoverable in Numa's ordinance that in sacrificial offerings no scaleless fish, and no scarus should figure (Pliny, N. H., XXXII. ro). The abstention is sometimes merely partial, as with the Karaýas in the Amazon valley, see W. A. Cook, op. cit., p. 96. 
As may naturally be expected, this law and other decisions. which by debarring so many species ${ }^{1}$ of fish denied to the people a food supply at once plentiful and cheap, were in time whittled away. Fish with "at least two scales and one fin" were gradually permitted. Eventually, as experience proved that all fish with scales have also fins, Israel was allowed as food any part of any fish on which only scales were visible. ${ }^{2}$

In the west this whittling was carried even further. 'Ab. Zarah, $39 a$, expressly states that no one need hesitate about eating the roe of any fish, because no unclean fish is to be found there $!^{3}$ The Jews of Constantinople in Belon's time had more scruples; debarred of caviare proper, i.e. made from the roe of the sturgeon, they discovered an excellent and legal substitute in the roe of the Carp.

It is a strange fact that these many references to fishing neither in the Old, where they are mostly metaphorical, nor in the New Testament, where they are chiefly historical, give the specific name of a single fish family. Dag and nun are the generic terms covering all species. The large sea fish are collectively termed "tannim." 4 The fish of Tobit, of Jonah, of the Psalms, are only spoken of generically. None of the Apostles, of whom four, Peter, Andrew, James, and John, were professional fishermen, has troubled himself to identify by name even the actual fish of the miraculous draught. ${ }^{5}$

1700 ! according to the Talmud, Hul., $83^{\text {b. }}$.

2 Cf. Nidda, $5^{\mathbf{I}^{\mathrm{b}}}$. For authoritative decisions regarding clean and unclean !fish, see Hamburger, vol. I., Art. Fisch, Die jüdischen Speisegesetse (Wien, 1895), p. 310 ff.

${ }^{3}$ Forlong, in his Rivers of Life, asserts that even at the present day the Eastern Jews do not eat fresh fish, but at marriages they place one on the ground, and the bride and bridegroom walk round or step over it seven times as an emblem of fecundity.

It is curious to note the mistake of Pliny in XXXI. 44: "Aliud vero castimonarium superstitioni etiam, sacrisque Judæis dicatum, quod fit e piscibus squama carentibus." C. Mayhoff's edition (Lipsix, r897), however, runs, XXXI, 95: "Aliud vero est castimoniarum superstitioni etiam sacrisque Judaeis dicatum, quod," etc.

- Sir Thomas Browne, in his Miscellaneous Writings, discourses of fish mentioned in the Bible.

Walton (in his Introduction) makes Piscator, after speaking of these four Apostles as "men of mild and sweet, and peaceable spirits (as indeed most fishermen are)," continues, " it is observable that it is our Saviour's will that his four Fishermen Apostles should have a prioritie of nomination in the catalogue of his Twelve Apostles. And it is yet more observable that at his Transfiguration, when he left the rest of his Disciples and chose only 


\section{I6 FORBIDDEN FISH-NETTING-VIVARIA}

The Jews acquired no intimate knowledge of the ichthyic branch of natural history. Although acquainted with some of the names given by the Egyptians and Alexandrians to different species (Josephus compares a fish found in the sea of Gennesaret to the Coracirus ${ }^{1}$ ) they adopted no similar method of distinguishing them, or any classification beyond the broad division of clean and unclean. The biological knowledge concerning fish shown in the Talmud was of a very primitive order, not merely in regard to embryology and propagation, but also as to hatching. ${ }^{2}$

It does, indeed, require the firmly-shut eye of faith to conceive that the fish of Raphael's great Madonna del Pesce, which scarcely weighs two pounds and is carried on a string by the youth Tobias, can have been to him an object of danger and terror, or that it "leaped out of the river and would have swallowed him" had it not been for the Angel's command to seize the brute (Tobit vi. 2, 3). Raphael's cartoon is another instance of the untrammelled liberty of the Italian artist. Most of the fishes are mere nondescript piscine forms of artistic fancy, but two are certainly of the Skate or Ray family, which is never found in fresh water 1

Then, again, how oddly Botticelli and other painters misconceive their man-eating fish, which must have been a crocodile strayed from the Indus or the Nile to the waters of the Tigris.

Fortunately Dr. Tristram ${ }^{3}$ comes to our aid as regards the fresh-water fish of modern, and probably of ancient Palestine. Of his forty-three species, only eight are common to the more westerly Mediterranean rivers and lakes. Of thirty-six found in the Jordan and its affluents, but one occurs in the ordinary

three to accompany him, that these three were all Fishermen." As a contrast to the excellent character given to the four fisher Apostles by Walton, a learned divine of Worms, J. Ruchard, found it incumbent in 1479 to defend Peter from the charge of instituting abstinence from flesh, so that he could profitably dispose of his fish! Keller, op. cit., p. 335 .

$1 B$. J., III. Io, I8. "It is watered by a most fertile fountain. Some have thought it to be a vein of the Nile, as it produces the Coracin fish as well as that lake does, which is near Alexandria."

2 Smith's Hist. of the Bible (1890), and Singer's Jewish Encyclopadia, V., p. 403, however, mention the Tunny, Herring, Eel, etc.

See, also, E. W. G. Masterman, Studies in Galilee, Chicago, rgog. 
Mediterranean fresh-water fauna, two in the Nile, seven in the Tigris, Euphrates, and adjacent rivers, ten in other parts of Syria, while sixteen are quite peculiar to the basin of the Jordan. The fish fauna is very isolated, but shows affinities to that of the Ethiopian zoo-geographical region, and probably dates from a geological time when the Jordan and the rivers of North-East Africa belonged to the same system. ${ }^{1}$

Of these fish, two demand notice.

(I) Chromis simonis. In the rare instances where fish take any care of their eggs or young, the task nearly always devolves on the male; here, the husband performs it by taking the ova into his mouth, till their development in the large cheek-pouches causes such swelling that he is unable to use his mouth. This uncomfortable condition exists and increases until as fry about four inches long they quit the paternal abode. ${ }^{2}$

(2) Clarias macracanthus, found in the Nile, as well as in the Lake of Gennesaret. In their spawning migration they have often to travel stretches of dwindling streams with water insufficient to cover them, or absent altogether. ${ }^{3}$ By means of an accessory bronchial organ they can live at least two whole days out of water. When they thus behold all the wonders of terrestrial existence, including its choicest perfection, Man, is it surprising that they "utter a squeaking or hissing sound," or teste Masterman, "cat-like squeak"?

1 Dr. Boulenger points out, however, that the affinity between the two rivers is restricted to a few species of the Silurids and Cichlids, whose importance is outweighed by the total absence from the Jordan of such characteristic African families as the Polypteridæ, Mormyridæ, and Characinidæ.

2 This statement of Tristram's is controverted by Masterman, op. cit., p. 44, note I, who writes, "This is impossible. They leave the shelter of their fathers' mouths when about the size of a lentil, and apparently never return." The male Pipe fish Syngnathus acus not only carries the eggs, but also the young fish in a pouch, in a manner similar to the kangaroo. The young, even after they have begun to swim about, return when alarmed to the parental cavity. There are only one or two instances of a female fish taking sole charge of the ova: of these is Aspreto batrachus, which by lying on the top of her eggs presses them in to her spongy body and carries them thus, till they are hatched.

In islands off Northern Australia are found walking and climbing fish, Periophthalmus koelveuteri and $P$. australis, which ascend the roots of the mangrove by the use of ventral and pectoral fins, and jump and skip on the mud with the alertness of rabbits (The Confessions of a Beachcomber, p. $20_{4}$. London, 1913).

Ktesias, a possible contemporary of Herodotus, writes that in India are little fish whose habit it is now and then to have a ramble on dry land. 
The methods of fishing in Palestine, like those (save Angling) of Egypt and the ancient world, were :-

(A) The spear, harpoon, and bident (still used in Lebanon and Syria) of which we read in Job xli. 7 ." Canst thou fill his skin with barbed irons, or his head with fish spears?"

(B) The line and hook. The line occurs only in Job xli. I, "Canst thou draw out Leviathan (i.e. the crocodile) with a fish hook (hakkāh), or press down his tongue with a cord (hebel) ?" (R.V.). The hook, designated by several names, finds frequent place in descriptions and metaphors in the O.T.

The difficult verse (Job xli. 2), "Canst thou put a rope (agmōn, literally, as in R.V. margin, a rope of rushes) into his (Leviathan's) nose?" is possibly explained by the ordinary procedure of fishermen in carrying their fish. 1 The (marginal) "rope of rushes" will recall to many a boy and many a man how often a handy rush has served for carrying home his catch of small fish. For the crocodile, however, such means of portage, as it is the intent of the verse to make clear, would in Bret Harte's parlance be " onsatisfactory."

The word, it has been held, probably means a ring, placed in the mouth of a fish by a rope of reeds tied to a stake, for the purpose of keeping it alive in the water. The use of a ring would give a perfect parallelism, "a ring in his nose" and "a hook in his jaw." Benzinger, however, makes it very doubtful whether this practice of keeping fish alive by a ring ever prevailed among the Jews.

The lure, or esca, was ground bait. Travellers maintain that even now no Nile or Palestine fish is educated enough to rise to a fly. But my friend Dr. Henry Van Dyke, author of Little Rivers and other fascinating books, shows me from a diary kept during his visit to Palestine in 1907 that this rule certainly has exceptions.

Wading from shore near the mouth of a stream flowing into Lake Tiberias, and again near the head waters of the Jordan above the Lake of Merom, he found pleasant clear streams where fish took the fly willingly. Whether this departure from traditional habit was due to the skill of the super-man, 
or the enticing cunning of the American flies used, viz. "Queen of the Water," " Beaverkill," and "The Abbey" (size No. I2 American) the diarist stateth not.

(C) The hand net ( $\left.\alpha \mu \phi i \beta \lambda_{\eta \sigma \tau} \rho \nu \nu\right)$, mentioned in New Testament, still holds its own in the Sea of Galilee, and the coast. It in the main resembles the Roman funda.

" 1 t is like the top of a tent in shape, with a long cord fastened to the apex. This is tied to the arm, and the net so folded that when it is thrown, it expands to its utmost circumference, around which are strung beads of lead to make it drop suddenly to the bottom. As soon as the game is spied, away goes the net, expanding as it flies, and its leaded circumference strikes the bottom ere the fish know its meshes have closed on them. By the aid of his cord the fishermen leisurely draws up the net, and the fish with it." I A fuller description of the various nets now in use on the lake, with an account of presentday methods of fishing, will be found in Dr. Masterman's interesting volume, chap. ii, The Inland Fisheries of Galilee (also in Pal. Explor. Fund Quarterly Statement, Igo8, p. 40).

Netting was the almost universal method. On Lake Tiberias (or the Sea of Galilee, or Lake of Gennesaret) which yielded then, as it does now, a most copious supply of fish, night lines and line and hook were also in vogue. The highest value was attached to these fisheries. According to tradition one of the so-called Laws of Joshua, while reserving certain privileges to dwellers on its shores, opened its waters to every comer. Weirs and fences, because of the damage their stakes inflicted on fishing boats, were strictly forbidden.

The observance of this custom may have originated from a compact made by all the tribes, as the Talmud states, or from "the blessing" (in Deut. xxxiii. 23) conditioning the allotment of the territory of Napthali and the Sea of Tiberias"Possess thou the sea, and the south" (" the sea " is the alternative version in R.V. for " the west ") ; or perhaps (according to Baba Kamma) from an absolute order of Joshua to the tribe of Napthali (Jew. Encyc., v. 404).

By law, or rather custom, fishing was, except in private 1 Encyl. Bibl., ii. col. 1528, from Thomson, The Land and the Book, p. 402. 
vivaria, etc., universally free; thus " in the Sea of Tiberias fishing with hook and net was everywhere allowed" (Krauss, Talmud Archäol., ii. I46, with references to Bab. Kam. 8I'. Cf. the Roman Digest which lays down that "omnia animalia qua terra, mari, calo capiuntur, id est ferce bestice, et volucres, et pisces, capientium fiunt." 1

Mainzer, however, severely restricts this freedom of fishing. ${ }^{2}$ "Incidentally information is given of a modification of the regulation. For instance, if any one set up a net on a shore or a bank, others were not allowed to fish in proximity to it. They were only allowed to cast their nets at a distance of one parasang away."

This sentence apparently implies that the first comer to some position on land acquired a legal temporary possession of fishing for the distance of a parasang. This regulation (extracted, apparently, from the reference 5, i.e. to Baba Bathra, 2I b) came into being (according to Rabbi Gershom, as cited by Mainzer), " because the fisherman scatters bait in the water which attracts the fish to his net. But if another person sets up his net near by, the fish at the sight of the fresh bait would swim to the other spot, and so the first fisherman would suffer loss."

The first (comer), adds Mainzer, " by the setting up of his net has acquired a priority claim over all the fish of a definite area."

This theory of possession appears to me quite untenable, for two reasons.

The first, because no words, judgment, or even obiter dictum contained in the reference given, support it. A Rabbi's pious opinion does not suffice, as Baba Bathra, 2I $I^{\mathrm{b}}$, makes clear. ${ }^{3}$ The passage runs :

" Rabbi Hona said, 'If a man who lives in a passage has set up a mill, and another in the same passage comes and likewise sets up one, the former has the right to prevent him, for he can say to him, Thou cuttest off my means of livelihood."' In

1 Justinian, Corpus Juris Civilis, vol. I., Digest, 4r, I, I.

2 Op. cit., supra, p. 405.

a Goldschmidt's Der Babylonische Talmud, vol. VI. p. I005. 
support may be quoted: "The fish net must be removed from the fish which another is already trying to catch as far as to allow the fish to escape." "How far is that?" Rabba, son of Rabbi Hona answered, "As far as a parasang." The case is otherwise with fish to which lines have been cast." 1

My second reason is the manifest absurdity of the enormous area allotted to the individual netter. Our latest authority, Westberg, computes that the parasang was equal to 3 miles I335 yards, or about $3 \frac{7}{10}$ miles (Klio, xiv. $338 \mathrm{ff.}$.) ${ }^{2}$

Let us now see how this parasang possession works out on Lake Tiberias, the only sheet of water where netting widely prevailed.

Its extreme length is about thirteen miles: its greatest width less than seven. Allowing for sinuosities of coast line, let us concede fifty miles in circumference. This extent of shore, if the area of a parasang is possessed on only one side of the netter, would suffice for $13 \frac{1}{2}$ netters, or, if on both sides, for 63 netters, i.e. a monopoly on the most prolific water, which, in Euclidian parlance, "is absurd."

If we disregard the words "set up a net on a bank," and allow that the parasang possession holds merely for the surface area, we are immediately confronted by two different questions.

First, does this allotted space spread from the boat by a parasang only North, or by a parasang only South, etc ? Second, if not, but extends for a circumference of which the boat is the centre, how is the possessory area to be measured, known, or shown? Oppian, it is true, sings with poetical license of " Nets, Which like a city to the floods descend," but even he does not vouchsafe to us a picture of netting on such a grandiose scale as seven and a half miles.

Before this area of possession can be definitely established, far weightier authority must be produced than a casual sentence

I "The first fisherman has already bestowed labour on the fish, and regards them as his property."

2 Zuckermann, a leading Jewish authority, in Das jüdische Maassystem, p. $3^{\mathrm{I}}$, gives, it is true, the following equivalents: I Parasang $=4$ Mil. (Lat. mille $=$ 30 Ris (stadia)-80oo Hebrew cubits. Reckoning the cubit at, in round figures, 18 inches, we get a parasang of 4000 yards, or about 21 miles. Later authorities, however, are agreed that the Persian parasang was at least $3 \frac{1}{2}$ miles, or more. 
from a commentator, whose very lateness of date is betokened by his employment of the Persian word, parasang.

In dealing with the Talmud, we must always bear in mind that a large part was written as late as between (say) 250 and $55^{\circ}$ A.D., and by men dwelling mostly at a distance from the Holy Land, who not infrequently show themselves unfamiliar with or ignoring the conditions of the earlier days.

In early times, possibly because of the small coast-line and poor harbours which Palestine possessed on the Mediterranean, little or no reference to fishing on the coast crops up. Later, a considerable trade in fish, salted or pickled, was carried on by the Syrians (some writers even claim a monopoly in such fish for the Phœnicians) at Jerusalem, ${ }^{1}$ where undoubtedly in the northern part of the city a market gave its name to the neighbouring Fish-Gate.

Perhaps to avoid a similar monopoly, definite and strictly enforced prices were periodically fixed by the authorities of the town of Tiberias. By the time of Our Lord thriving fisheries had grown up on the coast, especially in the neighbourhood of Acre, so thriving indeed that the equivalent (in later Hebrew)

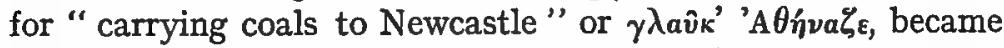
"taking fish to Acco." On the Sea of Galilee in especial did the industry prosper; one town seems to have been built up by-it certainly derived its name, Taricheæ-from the trade of salting fish.

Four ways of preparing fish were according to custom ${ }^{2}$ -pickled, roasted, baked, or boiled; with the latter, eggs were permissible.

The absence of vivaria till a very late period presents another instance of the lack in the ancient of the alertness so typical of the modern Jew. It is hard to deduce why Israel neglected to borrow from Egypt an institution yielding so valuable and lucrative a supply of food. If the spirit of sport, which was one of the attractions of these ponds to the Egyptian gentry, did not appeal in Palestine, the advantages of a ready store, during the hot weather, of fresh fish would surely have

2 Talmud, Ned. $20^{\circ}$. 
been obvious to and eagerly utilised by a race whose passionate plaint was for " a plenty of fish."

Their great Eastern neighbour inculcated the same object lesson. Most Assyrian towns and temples possessed an artificial or semi-artificial piscina. Yet not till some I60o years after the Exodus do we glean in the Talmudic term bibar (an attempt at transliteration of the Roman word, vivaria, which of itself betokens the lateness of the effort) the first indication of their employment by the Jews.

This may read as flat heresy, when compared with Isaiah's words (xix. Io), "And they shall be broken in the purposes thereof, all that make sluices and ponds for fish." The translation, however, in the R.V. (N.B., there is no word equalling fish in the Hebrew text), "Her pillars shall be broken in pieces, all they that work for hire shall be grieved in soul," shatters the assertion that vivaria, or fish lakes, were early institutions in Palestine. This shattering is complete, when the only other buttress, the passage in Canticles vii. 4, "Thine eyes (are) like the fish pools in Heshbon," falls to the ground with the R.V. rendering, "Thine eyes are as the pools of Heshbon."

If the Israelites, on the one hand, lacked till late the constructive ability of the Romans with regard to vivaria, they, on the other, seem to have lacked or failed to apply the destructive devices employed by the latter for the wholesale slaughter of fish by poison and drugs, made familiar to us by Oppian and $\mathbb{E l i a n .}$

Nore.-With reference to Mainzer's absurd contention, Prof. Kennedy writes me as follows: "Naturally the working of the large drag net required considerable elbow-room, and it was understood, as Krauss points out ( $\mathrm{Talm}$. Avchäol., ii. 145), that a fisherman would not encroach on his neighbour's ground. If we assume, for the sake of argument, that the ancient drag was as long as those used by the Galilean fishermen of to-day-i.e. about 400 metres ( 437 yards) according to Masterman (op. cit., 40)-a boat's crew, working from the beach and spreading their drag in a semi-circle, would not monopolise more than $250-280$ yards of sea-front, a very different "proposition 'from the Talmud's or Mainzer's parasang." 


\section{CHAPTER XL}

ICHTHYOLATRY IMPROBABLE-FISH NOT IN SACRIFICES OR AUGURIES

Although nothing is said of sacrificial fish, it is possible that Ichthyolatry did prevail in Israel to some extent. In Deut. iv. I8, 1 we find an express commandment or law laid down by Moses against the making of a graven image of "the likeness of any fish that is in the water under the earth ": in Exodus xx. 4, we read, "Thou shalt not make unto thee a graven image, nor the likeness of any form that is in heaven above, or that is in the earth beneath, or that is in the water under the earth."

If Ichthyolatry existed, it could hardly have sprung up among a nomad people living in the Desert, as did the Jews for years before they entered the Promised Land. Such a cult with other customs was probably adopted from the Canaanites by their conquerors. Psalm cvi. $35 \mathrm{ff}$., expressly tells us, " but they mingled themselves with the nations and learned their works; and they served their idols which became a snare unto them." Any argument in favour of the existence of Ichthyolatry which rests mainly on Deut. iv. I8, and Ex. xx. 4, can to my mind carry little or no weight. They simply embody a comprehensive command against making a graven image of any kind whatever, celestial, terrestrial, or aquatic.

As to the observance of the commandment, Petrie writes:-2 "It is often assumed that the prohibition to make a graven

1 Many hold that Deuteronomy was written not earlier than the seventh century, or even as late as $55^{\circ}$ B.c., previous to which there had taken place a large influx of foreigners, especially from N.W. Mesopotamia and Babylon, where gods were represented by scores.

2 Egypt and Isvael, pp. 60, 6x. Objection to the use of images in Israel was not apparently general till the latter half of the eighth century B.c. Their existence may, perhaps, be explained by (A) the universal existence of such worship among the Canaanites, (B) the proportion of Israelites to Canaanites being about as small as that of the Normans to the Saxons in England. 
image was as rigidly carried out in Israel as in Islam-the second monotheistic revival of the Semites. The holy of holies in Solomon's Temple contained, however, two enormous cherubim, about I 7 feet high, side by side, right across the back of the shrine. ... Not only were these figures in the holiest place, but in the court stood the brazen sea on twelve oxen, and figures of lions, oxen, and cherubim covered the tanks. In earlier times Micah had a graven image, and a molten image of silver, weighing about six pounds, in his private chapel of Yahweh, served by a Levite, and they, with the ephod and teraphim, were adopted for tribal worship by part of the tribe of Dan until the captivity."

The author adds " there was neither officially nor privately any objection to the use of images." He also shows that even " in the holiest of all things, the Ark of Yahweh, there were cherubs, one on each side of the mercy seat, with their wings covering the mercy seat," in which design and other religious matters he discerns clear instances of Egyptian influence.

However this may be, it is plain from Ezekiel (viii. I0-II) that the Israelites worshipped graven representations of " every form of creeping things and abominable beasts, and all the idols of the House of Israel, pourtrayed up on the wall round about. And there stood before them seventy men of the elders of Israel ... with every man his censer in his hand: and the odour of the cloud of incense went up." Some scholars go indeed as far as the assertion that until the prophetic reformation in the seventh and sixth centuries B.C., the popular religion of Israel was about on a level with unreformed Hinduism.

We stand on surer ground in the statement that Ashtoreth, a goddess of the Zidonians and Canaanites, was worshipped by Israel, for in I Kings xi. 5 and 33, we read "Solomon went after Ashtoreth, the goddess of the Zidonians," and, "because they have forsaken me and have worshipped Ashtoreth." 1 From this acknowledged worship of Ashtoreth,

1 Of the fate of this and other temples erected by Solomon we read in 2 Kings xxiii. I3, " and the high places which Solomon had builded for Ashtoreth, the abomination of the Zidonians, and for Chemosh, the abomination of Moab, and for Milcom, the abomination of the children of Ammon, did the king defile," i.e. King Josiah some three centuries and a half after. 
sometimes identified with Astarte and with Atargatis 1-undoubtedly a fish goddess-Ichthyolatry has been claimed for Israel.

But Cheyne, after showing that the mistake of identification arose from Carnaim, where (Maccabees v. 26) the temple of

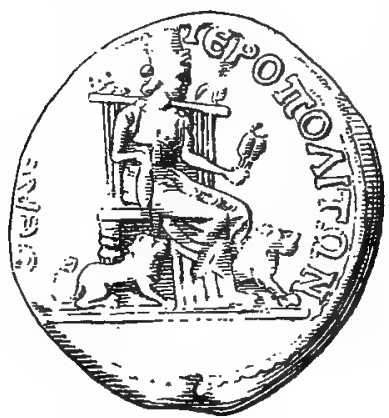

ATARGATIS.

From a coin of Hierapolis. See Brit. Mus. Cat. of Coins, Galatia, Pl. I8, I4, or B.V. Head, Historia Numorum ${ }^{2}$ (Oxford, I9II), p. 777. For Atargatis, see ante, 127. Atargatis stood, being also called (Gen. xiv. 5) Ashtoreth-Carnaim, disputes the deduction, and denies that these goddesses were one and the same. He points out that at Ascalon there were two separate temples, one to Astarte (Ashtoreth) and one to Atargatis (Derceto), standing side by side. ${ }^{2}$

Strabo, however, states (XVI. p. 748) that in Hierapolis, or Bambyce, or Magog, " there was worshipped the Syrian goddess Atargatis," and on p. 785 that this same goddess is called by the historian Ctesias Derceto, and by others Athara. In Strabo's day apparently the name, if not the cult, of Atargatis and Ashtoreth were considered identical. ${ }^{3}$

Milton, at any rate, evinces no doubt,

"Came Ashtoreth, whom the Phœnicians called Astarte, queen of heaven, with crescent horns : In Sion also not unsung, where stood Her temple on the offensive Mount." 4

1 For data on Atargatis and Derceto, and for various Syrian coins bearing fish, see J. B. Pitra, Spicilegium Solesmense, III. pp. 503-4 (Paris, 1855).

Ency. Bibl., p. 379.

3 In Some Palestinian Cults in the Greek and Roman Age (Proceedings of British Academy, vol. V. p. 9), Mr. G. F. Hill, speaking of the worship in the two cities, concludes that the one at Ascalon is identified by Herodotus with that of Aphrodite Urania, and that at Gaza with Derceto, or Atargatis. Iucian (if he wrote De dea Syria) distinguishes the goddess of Ascalon from her of Hierapolis, who was worshipped in human not semi-human form, but there is little doubt of the connection between them. The Greeks identified both with Aphrodite. Other writers state that the Canaanite Ashtoreth, pre-eminently the goddess of reproduction and fecundity, became the goddess of fish (which, as sacred to her, were forbidden food) and of the pomegranate, both of which from their thousands of eggs or seeds are striking emblems of fertility.

4 Graf Wolf von Baudissin in Hauck's Protestantische Realencycl., 3rd ed., 
The origin, the nature, and the worship of Dagon, the fish god of the Philistines, whose temple stood at Ashdod, 1 are discussed in Chapter xxxiii.

The Scape-Goat is perhaps the best known of the Israelitish offerings to the deity. The annual ceremony of "the driving away" became a service of the highest pomp and solemnity. For it two goats were necessary : the first to be drawn by lot was killed as a Sin Offering unto Yahweh, the second, the Scape-Goat, after being laden by the High Priest with all the sins of the people for the past year, was sent away into the wilderness, " to Azazel" (Levit. xvi. 8, Io, R.V.).

This symbolic bearing away of the sins of the people is somewhat analogous to that in Lev. xiv. $4 \mathrm{ff}$., where for the purification of the leper one bird is killed, and the other, charged with the disease, let loose in the open field. In Zech. v. 5 ff., Wickedness is carried away bodily into the land of Shinar.

The resemblance of this periodic offering ${ }^{2}$ and of many other Jewish institutions to those of Babylon is striking. The letting loose and driving away of the Mashlulduppu, or ScapeGoat, was similarly the occasion of an annual ceremony of imposing ritual.' The first account of this appears in an inscription of the Cassite period, which avows itself merely a copy of an earlier record, the original of which may well have existed in the time of Hammurabi.

To fish figuring as symbolical bearers away of sins we have references, according to Pitra, ${ }^{3}$ in the Talmud, though not

vol. II., p. I77, s.v. Atargatis, "If Atargatis be, as we suppose, originally identical with Astarte, and if the latter be the representative of the generative night-sky-in particular of the Moon-then the representation of the former as a water and fish deity will be connected with the conception, so wide-spread in antiquity, of the Moon being the principle of generative moisture."

1 I Sam. v. 4.

2 Frazer, The Golden Bough, I. pp. I4 and 70 , gives many instances similar to the periodic offering by the Scape-Goat among the Chinese, Malayans, and Esquimaux.

Pitra, op. cit., p. 5 I 5 (who refers to Buxtorf, Synag. Jud., chapter XXIV.), is incorrect, according to the Jewish Ency. (New York, Igo6, vol. XII. $66 \mathrm{f}$.), which states the Tashlik-the propitiatory rite referred to-does not occur in the Talmud or the geonic writers. Fish illustrate man's plight and arouse him to repentance, "As the fishes that are taken in an evil net," Eccl. ix. I2; and, as they have no eyebrows and their eyes are always open, they symbolise the Guardian of Israel, who slumbereth not. See R. I. Harowitz, Shelah, p. $2 I_{4}$. 
in the Bible. On New Year's Day (about mid-September), when in the fulness of time God will judge mankind, it was the custom (based on Micah vii., "Thou wilt cast all their sins into the sea ") to assemble near some lake or stream. If goodly numbers of fish were spied, the omen of the expiation of human sins was accepted. Forthwith the crowd jumped for joy, and shed their garments, likewise their sins, on to the fishes, who swam away, heavily laden.

Religious customs in Israel and Assyria both correspond and differ. Thus the sacrifices of fish found in Assyria are absent in Israel, although we read passim of offerings of domestic animals, of wine, of pigeons, and of doves. The former (despite Sayce and Jastrow) were guiltless of human sacrifices, the latter "sacrificed their sons and their daughters" (even) "unto demons." 1

From the words of Exod. xiii. 2, and Numbers xviii. $15 \mathrm{f}$., Mr. Campbell Thompson holds that the God of Israel plainly regarded the firstborn of men and the firstlings of animals as his own. The Israelites certainly offered up some of their children, generally the firstborn (cf. Isaac), either as a tribute regularly due to their Deity or to appease his anger at times of calamity or danger. ${ }^{2}$ Other writers disavow a general sacrificing of the firstborn as part of the religion of Israel; they attribute individual instances occurring towards the close of the monarchy to the influence of surrounding nations. ${ }^{3}$

I have come across no counterpart to the Babylonian or Roman custom of taking auguries or making oracular responses from the movements, etc., of fish. If the Hebrews apparently lacked some modes of divining which were employed by the Greeks, Romans, Arabs, etc., such as observation of the flight and cries of birds, the movements of fish, the inspection of the entrails of animals (for it was a King of Babylon, not of Israel,

1 Psalm cri. $36 \mathrm{ff}$.

2 Semitic Magic, 1908.

3 See Bennett, Exodus, p. I78, where he cites Baentsch, and E. Meyer. Other writers, who admit the sacrifice, deduce its cause from some very early rite by which the bride was deflowered by some god or his representatives, the Holy Men: hence what the deity had given, the deity claimed. See infra, p. 435, n. 2, where this view is brought out. 
who "looked in the liver "), the Bible reveals signs and omens resembling or identical with those in use elsewhere.

We read, for instance, of Rhabdomancy, or divination by rods, "my people asketh counsel at their stock, and their staff declareth unto them." 1 Drawing of Lots, probably by different coloured stones, ${ }^{2}$ Astrology, ${ }^{3}$ and Oneiromancy, or dream divination. 4

Strabo reports as attached to the Temple at Jerusalem a class of official dreamers, apparently for purposes of divination or prophetic deliverances. Of the important part played by dreams in both the Old and New Testaments, those of Jacob, Joseph, Solomon, and Joseph the husband of Mary, are inter alia evidence. In the Temple institution ${ }^{5}$ may possibly be detected the continuance of the Semitic pre-Mosaic custom of sleeping places before a temple (as at Serabīt-al-Khādim) for dreamers 6 in quest of omens, although the references to it in the O.T. itself are very slight, and only occur in connection with Bethel stones and Seers. ${ }^{7}$

The Seers were a recognised class of persons, who by an exceptional gift could disclose to inquirers secrets of the present and immediate future (I Sam. ix. 6, and x, 2-6). Samuel himself belonged to the college or class of Seers. Like the diviners, they received fees; thus Saul's servant suggests the giving to the Seer, whose words invariably come to pass, "a quarter of a shekel of silver."

1 Hosea, iv. I2. Cf. Herodotus, IV. 67.

2 I Sam. xiv. $4^{\mathrm{I}-2}$. Urim and Thummin seem pebbles kept in the Ephod.

3 Isaiah, xlvii. I3.

4 Gen. xxxi. IO-r3; Judges, vii. I 3 .

5 Petrie, op. cit., p. 49.

B Cf. the custom at certain Greek temples, whereby every person, who paid the fee and complied with the rules laid down, was allowed to sleep in or near the sanctuary for the purpose of receiving omens in a dream. The men slept in the east, the women in the west of the dormitory. Frazer, op. cit., II. 44. A good monograph on the subject is by Miss M. Hamilton, Incubation, London, I906. Oneiromancy was highly esteemed in Israel, as in Egypt and elsewhere. Joseph's skill (Gen. xl. and xli.) no doubt aided his rapid advancement by Pharaoh.

7 "Sacred stones or monoliths were regular features of Canaanite or Hebrew sanctuaries: many of these have been excavated in modern times." Some of these Bethel stones are described " as uttering oracles in a whistling voice, which only a wizard was able to interpret." Frazer, op. cit., II., p. 59 and p. 76 . 


\section{FISH NOT IN SACRIFICE OR AUGURY}

As regards the diviners, etc., we find in Isaiah ii. 6, "Thou hast forsaken thy people the house of Jacob, because they be filled with customs from the East and are soothsayers like the Philistines," and in Deut. xviii. I0-I2, "one that useth divination, or practiseth augury, or an enchanter, or a sorcerer, or a charmer, or a consulter with a familiar spirit, or a wizard, or a necromancer," all these are abominations unto the Lord.1

1 T. Davies in Magic Divination and Demonology among the Hebrews, etc., I 898 , especially in chs, ii. and iii., has much of interest on these subjects. 


\section{CHAPTER XLI}

\section{THE FISH OF TOBIAS-DEMONIC POSSESSION}

THE fish in Tobit, apart from its ichthyic, possesses two other points of interest, its magical and its medical power. As in Assyria we have found beliefs in magical charms very prevalent, and exorcisms of demons or devils accomplished by various methods, so with the Jews, especially with the Babylonian Jews, the interest in magical charms was very strong, and the means employed for exorcism very similar.

In both nations it is necessary to have some object into which the spirit may be attracted or driven, in point of fact a Leyden jar in which the malign influence may be isolated under control. It is all the same whether the devils are sent into the Gadarene swine or the jinni corked up in the brass bottle of Solomon. The disease (or oppressing devil) must be gently or forcibly persuaded to leave the human body and enter the dead animal or waxen figure close at hand, and so be brought into subjection, or by cleansing with water or fumigation (often with a censer) banished, and its possession or persecution of the person made of no effect. ${ }^{1}$

As now-a-days even Macaulay's schoolboy wots little of the Apocrypha, a short résumé of the book of Tobit seems not amiss.

Tobit has become blind, and fallen on evil days in Nineveh ; he bids his son Tobias set forth and fetch a sum of money deposited with Gabael in Media. He chooses as a trustworthy companion Azarias, who turns out to be no other than the

1 Cf. R. Campbell Thompson, Semitic Magic, p. I8. Not analogous but not unakin seems the passage in Theocritus (Idyll, II. 28-9) of the love-slighted maiden melting the wax, "so that Delphis may be soon wasted by my love." Diáper (in his Nereides or Sea Eclogues) imitates the scene, but for the waxen image of the lover and its wasting, substitutes a poor dog-fish, which is pierced so as to torture Phorbas by proxy. Cf. Virgil, Ecl., VIII. 80. 
angel Raphael, whom God, compassionating both Tobit's plight and Sara's subjection to a demon, has sent purposely from heaven.

On the journey Tobias (R.V.) " went down to wash himself in the Tigris and a fish leaped out of the river and would have swallowed him. But the angel said unto him, "Take hold on the fish." " And the young man caught hold of the fish and cast it on the land. The angel bids him, "Cut the fish open, and take the heart, the liver, and the gall, and put them up safely," giving as his reasons, "touching the heart and liver, if a devil or evil spirit trouble any, we must make a smoke thereof before the man or woman, and the party shall be no more vexed. As for the gall, it is good to anoint a man that hath white films in his eyes, and he shall be healed." Of the healing of his father's blindness we read later in xi. II-I3, where Tobias " strake of the gall on his father's eyes."

The great act of the drama, however, is staged in Ecbatana, where the travellers break their journey at the house of a kinsman Raguel, whose daughter Sara " had been given in marriage to seven husbands, but Asmodeus the evil spirit (or demon) slew them before they had lain with her." Tobias, not to be daunted, marries Sara, not, however, before Raguel " took paper and did write an instrument of covenant (or marriage contract) and sealed it."

"And when they had finished their supper, they brought Tobias in unto her. But as he went he remembered the words of Raphael, and took the ashes of the incense, and put the heart and the liver of the fish thereupon, and made a smoke therewith. But when the devil had smelled the smell he fled into the uppermost parts of Egypt, and the angel bound him" (viii. I, 2, 3). Cf. Milton, P.L. iv. "Asmodeus of the fishy fume," etc.

Dr. Gaster has given us a version, hitherto unpublished, in which "Tobiyah took the heart of $a$ fish and put it in a censer and burnt it under the clothes of Sarah. And Ashmedai (the demon) received the smells and fled instantly." This contra-demonical property in a fish appears elsewhere, e.g. in the Macedonian charm, which prescribes for one possessed the 
wearing of and the fumigation with the glands of a fish; to ensure that " the demons will flee from him."

The jealous passion of demons or devils for maidens colours Asian, African, and European folk-lores. They lie in wait for married couples ; sternly guard their so-called brides. 1 Otherwise they were usually innocuous. Tobias argues with the angel, "If I go in unto her, I die as the others before: for a wicked spirit loveth her, which hurteth nobody, but those that come in unto her" (vi. I4).

According to the Testament of Solomon, Asmodeus (the demon) avows, "my business is to plot against the newly wedded, so that they may not know one another. I sever them by many calamities, and I waste away the beauty of virgin women." In Asmodeus we recognise a male counterpart of Lilith and her dangerous relations with men. The demon, in fact, regards the virgin as his own, himself as her true and constant lover, and resents, prevents, or " avenges any infringement of his jus primae noctis." 2

The misconception, evident in the last eight words of this learned writer, as to what constituted the jus prime noctis prevails widely. As the jus is the child, strange as the parentage may appear, of the tale of Tobias and Sara, it seems worth our while to notice the strangely erroneous views held both as to the possessor of the jus and the occasion of its exercise, and shortly to explain, even at the risk of seeming to stray from fishing into folklore, the origin and the establishment of the custom.

According to popular belief the superior or lord of the fee, among other feudal privileges, possessed, as such, the vested right of connection with the daughters of his tenantry or of holders of land under him on the first night of their marriages. Some writers on the French Revolution, indeed, indignantly class the wide and brutal exercise of this right on chaste maidens by licentious seigneurs as not the least, perhaps one of the most provocative, of the social causes, which led to the detestation and subsequent massacre of the noblesse in many départements and to the overthrow of the old landed system!

1 J. G. Frazer, Folk-Love in the Old Testament (London, 1918), 520 ff.

2 R. Campbell Thompson, Semitic Magic (London, I go8), pp. 74-75. 


\section{THE FISH OF TOBIAS-DEMONIC POSSESSION}

But alas! "this sad old romance, this unchivalrous story" (to vary Lucille) must go to the wall. The jus, as thus conceived and described, never in fact existed anywhere in civilised Europe. The figment of its ruthless exercise as a legal right by licentious lordlings owes its existence to a vivid imagination uninfected by one germ of truth, as Lord Hailes, M. L. Veuillot, and others clearly demonstrate. ${ }^{1}$

It must come as a severe shock to preconceived ideas to run up against the dull facts of history, and thence discover that the jus prime noctis, so far from being the barbarous privilege of deflowering an unwilling bride, was merely a right accorded by the Church to the husband on the payment of a varying fee to the bishops, etc., for the privilege of disregarding the ecclesiastical ordinance, which required that his bride should remain in a state of virginity for one, two, or three days ${ }^{2}$

Continence for one night was first enjoined in the decree passed by the Fourth Council of Carthage in 398 A.D. ${ }^{3}$. This, extended to "two or three days," figured not only in the Capitularies of Charlemagne, 4 but was received into the Canon Law, and was twice repeated in the decretals of the Catholic Church. ${ }^{5}$

But what, it may be fairly asked, has the jus prima noctis got to do with our Tobias and Sara? The history of the connection deserves tracing, not only to clear away its obscurity, but also to show how a custom-important in result but based simply on a variant version of Tobit-was by the Church early adopted and widely inculcated. The days, during which the

1 Annals of Scotland (Edinburgh, I797), III. Appendix I, pp. I-2I ; Le Droit $d u$ Seigneur (Paris I864), I9I ff., 232-243, and 276 ff. As to the supposed exception owing to the mythical law by that mythical king, Evenus or Eugenius, by the provisions of which according to Boece (who in his History of Scotland, published in 1527 , seems to have been the first to resurrect or create the law, and the monarch) landlords were permitted to "deflower the virgin brides of their tenantry," see Cosmo Innes's Lectures on Legal Antiquities, I872, "in Scotland there is nothing to ground a suspicion of such a right," and J. G. Frazer, op. cit., vol. I. pp. 485-493.

2 See the judgment delivered in 1409 in the case brought to the Bishop of Amiens against the Mayor, etc., of Abbeville to establish his right to receive such fees, which were "sometimes ten, sometimes twelve, sometimes twenty Parisian sous."

- See Martine, de Antiq. Eccles. Ritibus, I. ix. 4.

4. P. Migne, Patrologia Latina (Paris, I862), tom. I., p. 859, par. 463.

5 Lord Hailes, op. cit., iii. I 5. 
continence enjoined on the newly married could only be disregarded if the husband had previously paid for the privilege a fee to some religious authority, came to be known as "Tobias Days."

No searching, however diligent, of the Septuagint or of our A. or R. Versions, nor (it seems) of the Aramaic text of the tale of Tobit sheds light on the origin of the custom or of the application of the name.

The Vulgate, however, which the Roman Church adopts, sets forth the story of the abstinence of Tobias from Sara. "Then Tobias exhorted the virgin, and said unto her: Sara, arise, and let us pray to God to-day, and to-morrrow, and the next day : because for these three nights we are joined to God : and when the third night is over we will be in our wedlock. For we are the children of the Saints, and we must not be joined together like the heathen who know not God." 1

From this (apparently) solitary and quite different version sprang the custom of the "Tobias Days," and the jus prima noctis, of which the usual conception is " a monstrous fable born of ignorance, prejudice, and confusion of ideas." 2

The custom of continence for varying periods probably springs from the common widespread belief (of which Tobit affords a Semitic example) that demons lie in wait to harm newly-married couples, and from the hope that if allowed free

1 Tobit, viii. 4 and 5 (Douaj version). The fatuity of his reasoning, although with seven predecessors slain by the demon much must be pardoned to Tobias, is obvious, when we discover that the practice of deferring the consummation of marriage for a certain time is older than Tobit and Christianity, and has been observed by heathen tribes, not on any ascetic principle, in many parts of the world. Hence, "we may reasonably infer that far from instituting the rule and imposing it on the pagans, the Church, on the contrary, borrowed it (like much else) from the heathen, and sought to give it a scriptural sanction by appealing to the authority of the angel Raphael." Frazer, op. cit., I. 505 .

2 The whole question is fully treated by J. G. Frazer, op. cit., vol. I., pp. 485-530, and Adonis, Attis, and Osiris, 3rd ed., vol. I., pp. 57-60. Some writers hold that the period of continence originated at an ancient time when it was deemed advisable that the deflowering should be effected by a god or his representatives-in Israel the Sacred Men-so that the woman should receive strength to bear children to her husband. For the practice they rely on Hosea iv. $\mathrm{I}_{4}$, and for the deferment to the seventh night on Gen. xxix. 27 , and in the correction of the reading in Judges, xiv. I8, from " before the sun went down " to "before he went into her chamber." The evidence to my mind is far from convincing. 
scope for making love to the bride their jealous wrath might be appeased, or the danger, at any rate, minimised. The alternative to appeasement was deception of the demon; whence women sometimes disguised themselves as men, and even wore false beards !

We find, on returning from this semi-folklore excursion, Prof. Langdon asserting that in Sumero-Babylonian religion each individual is guarded by a divine spirit or god. ${ }^{1} \mathrm{He}$ is called the "Man's God," and the man is defined, in a religious sense, as a "Son of God." But this term applies to no females.

This can hardly be attributed to accident, for our sources of information mention hundreds, even thousands, of men bewitched, and by demonic force abandoned by their indwelling gods, but never a roman. Women not infrequently figure as causing the condition of tabu, but never as having fallen to the powers of devils, or witches, or as being under the protection of a personal god. They never appear in the private penitential psalms.

But when we recall the high position occupied by women, not only in Babylonian society, but also in the eye of the civil law, which regarded their rights, as often as not, equal to those of men, and that women are often found as priestesses of religious orders, Langdon's statements, resting on recent discoveries, create grounds for surprise.

To explain the anomaly he conjectures that when the texts refer to sinners, penitents, or sufferers, the title "son of his god " applies in all probability also to women.

The book of Tobit, whether Persian in its source or Aramaic in its original text, furnishes an example of demonic possession of a woman, a Hebrew of the Hebrews.

The Jewish conception of demonic possession resembles, indeed probably descends from, the Babylonian. The "seven devils" of Matt. xii. 45, Luke xi. 26, and viii. 2, simply reflect the evil spirits, called in a famous incantation The Seven, who play no small part in Babylonian mythology. ${ }^{2}$

1 Babylonian Magic (London, 1914), Pp. 223-224, and Le Poime Sumérien, already cited, p. 72, note 3 .

2 Maspero, Dawn of Civilisation, pp. 634, 776. 
The N.T. confines the instances of evil spirits possessing mankind-more frequently in the psychical rather than in the physical sense-to the Gospels and the Acts, which illustrate demonic possession of women by (inter alias) the Canaanitish woman (Matt. xvi. 22) and Mary Magdalene, "from whom seven devils had gone out" (Luke viii. 2). ${ }^{1}$

1 It would seem that the Babylonians intelligently, if unconsciously, anticipated our law of germs, for " the doctrine of disease was that the swarming demons could enter a man's body and cause sickness." On a fragment of a tablet, Budge has found six evil spirits mentioned by name, each of which specialised in attack, the first going for the head, and so on. See Encyc. Bibl., I073. 


\section{CHAPTER XLII}

THE FISH OF MOSES-JONAH-SOLOMON'S RING

THE many versions of "the fish of Moses" are but delightful explanations of the flat fish having more meat on one side than another, or being white or colourless on one side and darkish coloured on the other.

In one story the Almighty, annoyed with Moses for answering some one's query "Who was the most knowing of men ?" with a simple "I," instead of accrediting his wisdom to God, revealed unto him, "verily, I have a servant at a place where the two seas meet, and he is more knowing than thou." The legend, with the direction to Moses to take a fish and put it in a measure, and the fish's escape by God's aid, etc., is too well known for recital.

But the conclusion of Hamid of Andalusia as to the nature of the fish is not, and may be added. "The fish of Moses which I saw in the Mediterranean is of the breed of that fried fish, a half of which Moses and Joshua ate, and the other half God revived. It is about a span long. On one side it has bristles and its belly is covered with a thin skin. It has but one eye and half a head. Looking at it on one side you would deem it dead, but the other side is perfect in all its parts." 1

To account for the difference in colour the legend of the Arabs ${ }^{2}$ runs thuswise:- "Moses was once cooking a fish, and when it had been broiled till it was brown on one side, the fire or oil gave out, and Moses angrily threw the fish into the sea, when, although it had been half broiled, it came to life

1 Robinson, op. cit., p. 4o. In S. Bochart's Hierozoicon (Leipzig, I 796), p. 869, Abuhamed Hispanus gives quite a different account.

In Klunzinger's Upper Egypt, London, 1878 . 
again, and its descendants have ever since preserved the same peculiarities of colour."

The half-destroyed fish which recovers life meets us also in the belief which unto this day lingers in some towns on the Black Sea, but on the Rhombus, not on the Sole, is the miracle wrought.

According to a Russian legend, the tidings of the Resurrection were brought to the Virgin Mary, when at food: incredulous and as one of little faith she flung the uneaten half of a Rhombus into the water, bidding it, were the message true, come back to life whole! And lo! this it instantly did.

Pictures of the Virgin, commemorating the incident are painted on a Rhombus, nailed to a board, thoroughly dried, and ornamented with a background of gold. A great ceremonial marks their removal to a shrine hermetically sealed. The custom, no doubt, sprang from the belief

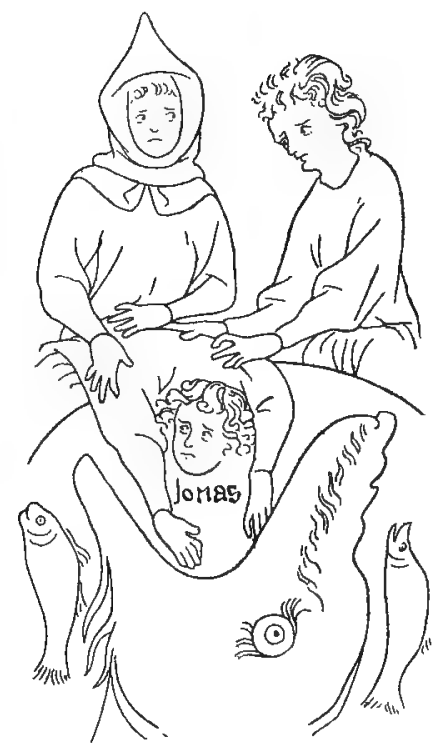

JONAH ENTERING THE WHALE'S MOUTH.

From a I4th Century MS. in H. Schmidt, Jona, p. 94, fig. I6. that fishing enjoyed the special protection of the Holy Mother. ${ }^{1}$

Mahometan tradition abounds with fish lore of the oddest kind. The commentators of the Koran vie, indeed, with the Talmudists in the curious subjects to which they often devote serious study, and in their grotesqueness of invention. The learned Rabbi el Bassam seems to have spent fifteen whole years in the vain endeavour to discover the name of the chef who made the pottage for Esau !

The story of the fishes, who made a point of coming every Saturday morning to tempt the Hebrews to the sin of catching

1 See Keller, op. cit., p. 369. 
them illustrates Koranic invention. Thinking to avoid the sin and yet secure their seducers, the sojourners went out, dammed the channels, and ate the fish on the next day. But as there was, and in some parts of Scotland still is, little difference as regards working on the Sabbath between fishing and damming, the violation of the day-the punishment scarcely fits the crime-involved their metamorphosis into apes ! 1

The Koran denies to the faithful on pilgrimage any hunting of game en route, but allows fishing and eating of fish from the sea. ${ }^{2}$ At first, eating of fish was apparently unlawful, because the name of Allah could not always be pronounced over them before they died.

To remedy this enforced abstinence from such a wealth of healthy food Mahomet blessed a knife and cast it into the sea, thus all fish were blessed and had their throats cut before they were brought to shore. "The large openings behind the gills are of course the wounds thus miraculously made without killing the fish!" 3

We discover in another legend that an accidental act on the part of Abraham-not a designed ceremony on the part of Mahomet-gave Mussulmans their liberty of ichthyophagy. The patriarch, after sacrificing the ram instead of Isaac, threw the knife into a stream and incidentally struck a fish, whence fishes are the only animals eaten by Mahometans without their throats being previously cut.

1 Cf. with these inciters to Sabbath-breaking, (A) The fish, "called the Jererish Sheikh, which with a long white beard and a body as large as a calf, but in shape like a frog and hairy as a cow, comes out of the sea every Saturday and remains on land until sundown on Sunday " (Robinson, op. cit., p. 35), and (B) the story of how on a Friday during St. Corbinian's pilgrimage to Rome, when although meat and all else abounded-the Saint had always been a bit of a bon viveur !-there was an absolute dearth of fish, an eagle suddenly dropped from the clouds and let fall at the feet of the chef a fine fish. Baring-Gould, Lives of the Saints, vol. X. 123 (London, 1897).

2 "O True Believers, kill no game while ye are on pilgrimage. It is lawful for you to fish in the sea and eat what ye shall catch as a provision for you and for those that travel." The Koran (Sale, chap. V. or " on Contracts "). "This passage," says Jallaleddin, "is to be understood only of fish which live altogether in the sea, and not of those which live partly in the sea and partly on land, such as crabs." The Turks, who are Hanifites, never eat of the latter class ; but some sects have no scruples.

s Robinson, op. cit., p. 4I. See the Koran (Sale, vol. II. 89), " God hath only forbidden you that which dieth of itself, and blood, and swine's flesh, and that which has been siain in the name of any besides God." 
The place of fish in the Zodiac has been already noticed. Apparently the position of the Pisces led Kepler to believe that he had discovered the means of determining the true year of our Saviour's birth. From the conjunction of Jupiter and Saturn and Mars in I604, the astronomer working backward found that Jupiter and Saturn were in the constellation of the Pisces (a fish, be it noted, being the astrological symbol for Judæa) in the latter half of the year of Rome 747 , and were joined by Mars in 748. Their first union in the East awoke the attention of the Magi, told them that the expected time had come, and bade them set forth for Judæa.

Astronomy has been to archæology a most helpful handmaiden in establishing not only this but other dates of ancient, especially of Assyrian, history.1

.If the surmise of Isaak Walton ${ }^{2}$ that Seth, the son of Adam, taught his son to cast a line, and engraved the mystery of the craft on those pillars of which Masons are supposed to know so much, or even if the statement that,

"Deucalion did first this art invent

Of Angling, and his people taught the same,"

could have been verified, how many discussions on the questionformerly almost as hotly combated as some religious doctrineas to what was the first method of fishing would have been avoided. Alas! an authoritative answer is even yet to seek. The nature of the "great fish" of Jonah will, I fear, no longer prove an attractive subject for sermons. Identification of "the beast " ranging through all the fishes of Ichthyology, from the celebrated "first, aiblins it was a whale," down to " nineteenthly" (whose precise species I forget), will alas! with

1 See antea, p. 388, n. 1 .

2 The Compleat Angler, ch. I. "Others say that he left it (the Art of Angling) engraven on those pillars which he erected to preserve the knowledge of Mathematicks, Musick, and the rest of those precious Arts, which by God's appointment or allowance, and his noble industry were thereby preserved from perishing in Noah's Floud." According to Manetho, Syncell Chron., 40, these tables engraved with sacred characters were translated into the Greek tongue in hieroglyphic characters, and committed to writing and deposited in the temples of Egypt. See the Epistle of Manetho, the Sebennyte, to Ptolemæus Philadelphus, and I. P. Cory, Ancient Fragments of Phonician, Egyptian and other writings (London, 1832), pp. I68-9, and Eusebius, Chron. 6. Cf. Georgius Syncellus, Chronographia (Bonnæ, 1829), i. pp. 72-3. 
the development of the higher criticism and of comparative mythology hardly draw the tensely interested congregations of yore.

Tylor points out that at the root of the apologue of Jonah lies the widely-spread Nature-myth of the sea-monster or

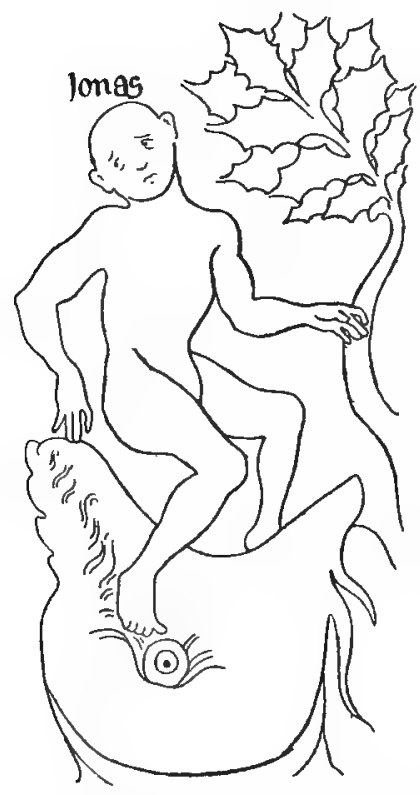

JONAH LEAVING THE WHALE'S MOUTH.

From a $1_{4}$ th Century MS. in H. Schmidt, Jona, p. 94, fig. I7.

The picture shows that while the whale's gastric juices had completely absorbed Jonah's clothes and curls, they prevailed not, possibly from callosity of hide, against his body. dragon, of which the fight between Tiāmat and Marduk, and of Andromeda and the sea-monster. are analogous developments. 1

Cheyne detects the link between the original myth and the story of Jonah in Jeremiah li. 34, "he hath swallowed me up as a dragon: he hath filled his maw with my delicates: he hath cast me out," and again in verse 44 , " and I will bring forth out of his mouth that which he has swallowed up."

Allusions to mythical dragons occur elsewhere, as in Psalm lxxiv. I3, "Thou breakest the heads of the dragons (or sea-monsters) in the water." The curious belief in a dragon or fish that swallows the moon spreads wide. This draws from Mr. R. C. Thompson 2 the comment, "when it is remembered that Jonah was swallowed by the 'great fish' for three days (the period of the moon's disappearance at the end of the month), the coincidence is well worth considering; especially as Jonah is the Hebrew word for dove, and it was at Harrān, the city sacred to the Moon God, that the dove was sacrificed (Al. Nadim, 294)."

But whatever the "great fish," and whatever the story's

1 An excellent monograph by Hans Schmidt (Jona Eine Untersuchung sur vergleichenden Religionsgeshichte, Göttingen, 1907) gives 39 cuts.

op. cit., p. 53 . 
derivation, the whimsical treatment of the prophet's imprisonment in a poem by the Rev. Zachary Boyd, Rector of Glasgow University in the seventeenth century, demands some quotation :-

"What house is this? here's neither coal nor candle ;

Where I no thing but guts of fishes handle;

The like of this on earth man never saw,

A living man within a monster's mawe!'

He then goes on to contrast Noah's freedom of movement in the ark with his enforced immobility:

"He and his ark might goe and also come, But I sit still in such a straitened roome, As is most uncouth, head and feet together Among such grease as would a thousand smother ;

I find no way now for my shrinking hence,

But here to byde and die for mine offence;

Eight persons were in Noah's hulk together,

Comfortable they were each one to other.

In all the earth like unto me is none

Farre from all living I heere byde alone,

Where I, entombed in melancholy sink,

Choakt, suffocat, with excremental stink." 1

I close this, as my other chapters, with a legend which makes fish directly or indirectly responsible for some historical happening.

It was through a fish (according to the Talmud) that Solomon regained his kingdom. The King one day, while bathing, confided his signet ring to one of his many concubines, Amina. Was it her eyes, I wonder, or those of that Queen, Pharaonic or other (by whose happy influence Solomon, eschewing evil and cleaving only unto her, was perhaps inspired to

1 Four Poems from Zion's Flowers, etc., by Mr. Zacharie Boyd, printed from his manuscripts in the Library of the University of Glasgow, edited by G. Neil, Glasgow, I855. Perhaps the Rector's Muse was spurred to these heights of poesie by the fact that the arms of the City of Glasgow bear a salmon with a ring in its mouth, illustrative of the miracle wrought by St. Kentigern, the founder of the See and first bishop. At the Reformation the revenue of the church included one hundred and sixty-eight salmon. See T. Moule, Hevaldyy of Fish (London, I842), Pp. 124-5. In the recovery of the keys of cathedrals and episcopal rings, fish play a part, as the adventures of St. Egwin (vol. i. 16I), of St. Benno (vol. vi. 224), and of St. Maurilius (vol. x. I88), described by Baring-Gould (op. cit.) all testify. 


\section{FISH OF MOSES-JONAH-SOLOMON'S RING}

write The Song of Songs), which he likens to the pools of Hesbon?

A devil named Sakhar, the Talmud goes on, coming in the shape of Solomon, obtained the ring from Amina, and by virtue of its possession sat on the throne in Solomon's guise. After forty days the devil flew away, and threw the ring into the sea. The signet was immediately swallowed by a fish, which on being caught was given to Solomon. The ring was found in its stomach, and he, who without its credentials had been compelled to beg for bread and from his appearance being changed by the devil had been regarded as a preposterous pretender, " by this means recovered his kingdom, and taking Sakhar and tying a great stone to his neck, threw him into the sea of Tiberias." 1

In another version 2 -very probable because more characteristic of Solomon, in that he annexes another wife-the King after the loss of his throne became a cook in the palace of a foreign sovereign, married his master's daughter, bought a fish with the ring inside, and so recovered his realm.

In another legend fish play, if not a historical, yet no small part in connection with a famous historical character.

St. Brandan in his travels encountered Judas Iscariot, whose allotted punishments at any rate lacked not monotony, for after each spell of pitch and sulphur he was condemned to sit on a desolate rock in the frozen regions. To the query as to the purpose of a cloth bandage worn round the head, Judas made answer that it was an effectual charm against the ferocious fishes among which he was often doomed to be thrown, for at its sight they lost their will to bite. He had obtained

1 Sale, Sura 38 of the Koran, gives, as regards the incident, references to: (A) The Talmud, probably to the treatise Gittin, pp. 68, $u, b$. See Jew. Encycl., xi. $44^{8}$, and cf. p. $443 b$. (B) $E n J a c o b$, Pt. ii.-probably to a work of this title, Well of Jacob, a collection of legends and parables by Jacob ben Solomon ibn Chabib from the Babylonian Talmud, 2 vols. (Amsterdam, 1684-85). (C) Yalkut in lib. Reg., P. I82-this is a collection of expositions of the O.T. books and first printed in I52I. Solomon's throwing of the demon seems quite justifiable, if Sakhar and Asmodeus were under different names one and the same, for from Gittin, $68 b$, we learn that the demon, after swallowing Solomon, "spat him a distance of 400 miles," a feat in ballistics, or " the art of propelling heavy bodies," which surpasses even the German long-range gun.

2 Jewish Ency., xi. 44 I. 
this shield because on earth he had once given a piece of cloth to a naked beggar, and so, even unto him, a deed of charity was not allowed by the Almighty to pass without reward. ${ }^{1}$

When, in Matthew Arnold's poem, "St. Brandan sails the northern main" and comes across Judas on an iceberg, the fishes occur not, but the cloth appears :

"And in the street a leper sate

Shivering with fever, naked, old;

Sand raked his sores from heel to pate,

The hot wind fevered him five-fold.

He gazed upon me as I passed

And murmur'd : Help me or I die !-

To the poor wretch my cloak I cast,

Saw him look eased, and hurried by."

For which act of charity Judas was permitted by the angel every Christmas night to

"Go hence and cool thyself an hour."

1 R. Blakey, op. cit., p. $\mathrm{I} 45$ (move suo), gives as his authority merely " one of the poetical effusions of the Anglo-Norman Trouvères." 



\section{CHINESE FISHING}






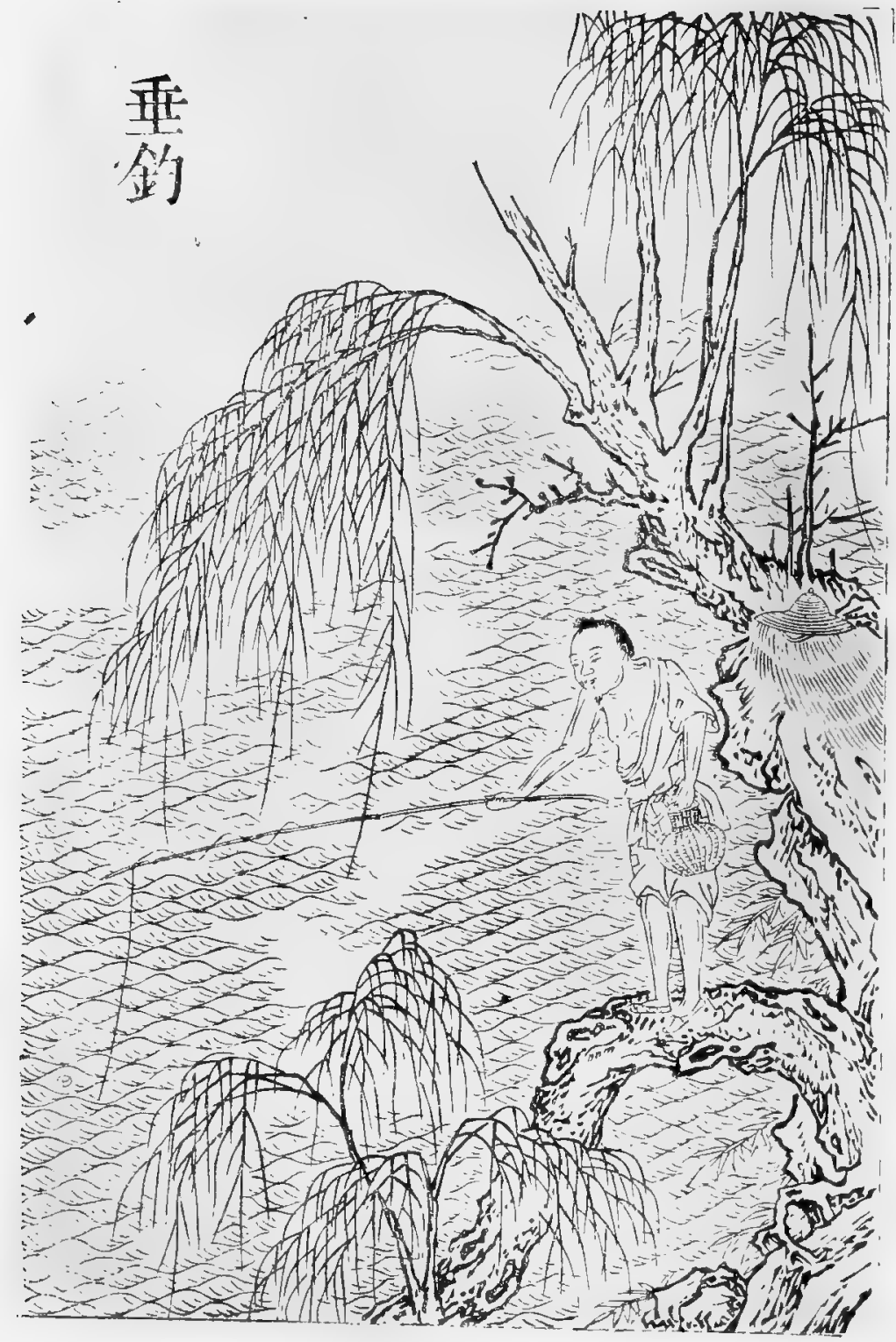

CHINESE ANGLING.

From $T \breve{u}$ Shu Chi Ch'éng, XVII, Pl. I6. 


\section{CHINESE FISHING}

\section{CHAPTER XLIII}

\section{"PLUS UN PAYS PRODUIT DES POISSONS, PLUS IL PRODUIT D'HOMMES "}

If the above dictum ${ }^{1}$ and Williams's statement that "in no country, except Japan, is so much food derived from the water," 2 be accurate, modern China should lack not folk nor food. Every method of fishing obtains in one part of the country or other, and scarce a sea or stream exists unvexed by some piscatorial implement.

"Fish are killed by the spear, caught with the hook, scraped up by the dredge, ensnared in traps, and captured by nets: they are decoyed to jump into boats by painted boards, and frightened into nets by noisy ones, taken out of the water by lifting nets, and dived in for by birds, for the cormorant seizes what his owner can not easily reach." 3

This description, minus the cormorant but plus leistering, applies fairly well to Ancient China., Mr. Werner's great work discloses no distinct mention of fishing previous to II22 B.C., although the present to a Viceroy of "cuttle fish condiment" apparently implies it. From that date the Spear, the Net, the Line, the Rod, and divers strange devices figure frequently and historically. 4 In the earlier centuries

1 See P. Dabry de Thiersant, La Pisciculture et la Pêche en Chine, Paris, I872.

2 The Middle Kingdom (New York, I900), vol. I., p. 276 . Cf. S. Wright, op. cit., p. 204 , "In China there are more river-fishers than all the sea-fishers of Europe and America put together."

3 S. W. Williams, op. cit., I., p. $779 \mathrm{f}$.

4 E. T. C. Werner, Descriptive Sociology: Chinese, London, rgri. This work, an abiding monument of twenty years of unabated toil and unceasing research into Chinese literature, ancient and modern, was published by the Herbert Spencer Trustees. 
covered by this period, if the Line claimed adherents, ${ }^{1}$ Nets made of fine bamboo, with bags arranged in front of wooden stockades planted on the banks of rivers, ${ }^{2}$ were the general method. ${ }^{3}$

Although the Chinese have produced quite a considerable literature on Fishing, the path of a writer unversed in their language is, from the absence of translations, compassed about with many difficulties. The trail winds dim and Serbonian, even if, as was my good fortune, a friendly hand holds out now and then a torch to guide his faltering steps. 4

The dividing line between the historical and the nonhistorical in China does not cut clearly and without breaks. History as distinct from legend was assumed till recently to begin between 900 and 800 B.c., but three archæological discoveries have affected previous chronological conceptions.

I. The inscribed bone fragments (till the advent of paper, c. Ioo B.c., bones, stones, bronzes and tablets of wood served for papyri) found in Honan apparently carry as far back as c. I500 B.C., and shed quite new light on the character of the early Chinese script. Among the divination tablets I had hoped for some fish omens similar to those of Assyria, Greece, and Rome, or some trace of the belief still current in Southern China that certain fish, as the Dolphin in the Mediterranean, were weather-prophets: but, owing probably to the dry character of the country of which they are the voice or rather the testament, none survive. ${ }^{5}$

2. The wooden tablets at Tunhuang along the Great Wall which illumine social conditions and deal largely with the commissariat of the army.

3. The MSS. at the Caves of the Thousand Buddhas, found about I907. Coming from a Buddhist monastery, they give in the main Buddhist texts, but also (as do the Egyptian

1 I shih ching, i. 5, v. i., ii. 8, apud Werner.

2 Ibid. i. 5, iii. 4 .

3 Ibid. i. 8 , ii. 5.

4 To my friend Dr. Lionel Giles of the British Museum, and to his father, Prof. H. A. Giles of Cambridge, my thanks are due for leading and kindly lights.

s See L. C. Hopkins in New China Review, 1917, 1918, 1919. 
Papyri) many quite new excerpts from lost writers, in addition to accounts, etc. ${ }^{1}$

A goodly store of stories and descriptions of prehistoric Fishing and Fishers exists in ancient and modern works.

The statement that "Fishermen used the silk from the cocoon for their lines, a piece of sharpened iron for their hook, thorn-stick for their rod, and split grain for their bait" 2 carries us back to an age very early and indefinite. On asking a high Sinitic authority what was the date of the Emperor in whose reign this tackle was employed, he rapped out, " Date! What was Adam's date?"

The use of gut was familiar at any rate about the fourth century B.C., judging from the sentence in Lieh Tzŭ: "By making a line of cocoon silk, a hook of a sharp needle, a rod of a branch of bramble or dwarf bamboo, and using a grain of cooked rice as bait, one can catch a whole cartload of fish." 3

Angling as a pastime must have secured the Imperial favour in early ages, as its metaphorical use by Sung Yü, fourth century B.c., indicates. "In the golden age," he tells us, "the Emperors were fishers of men, using sages as their rod, the true doctrine as their line, charity of heart and duty to one's neighbour as their bait, the world being their fishing ground, and the people their fishes."

Strolling down the lane of Time, we meet (c. II22 B.C.) with Chiang Tzŭ-ya, the first statesman to recognise the importance of fishing, and its allied industry, the manufacture of salt. 4

The tale-not of Chiang's rise from a very lowly station to governance of a great Empire, for history furnishes many

1 If the Chinese were behind the Egyptians in inscriptions on material such as papyrus, they anticipated Gutenberg and printing by some 600 years, as is proved by the recent discovery of the first specimen of block printing in the roll containing the Diamond Sutra, with woodcut of 868 A.D., which deprives Fêng Tao (of the tenth century) of the fame of being the inventor of printing.

Cf. Introduction, p. 6o. I shih chi shih, or The Origin of Things, although of modern date, gives an account of the introduction of the various Things among the Chinese.

3 A pud Werner, op. cit., p. 277.

4 Mr. Wei-Ching W. Yen, Address before the fourth International Fishery Congress, Washington, I908. 
parallels-but of his Angling is morally edifying, piscatorially instructive, and is possibly responsible for the rise in Great Britain and America of the barbless school of anglers. As yet its pupils, despite the missionary zeal of Mr. Rhead, are scattered few and far between. The limitation of their numbers can doubtless be ascribed to their introspective and becoming fear lest the "real attraction," which, according to a Chinese classic, was in our hero's case not his straight iron but his innate virtue, should with them, either from sparsity or lowness of power, lack the requisite magnetism !

But retournons a nos poissons! King Wên, the founder of the Chou Dynasty, and one of the great sages - whence, perhaps, his intelligent annexation of Chiang, for all Anglers ex necessitate are, or should be, also sages-comes across our hero fishing with a piece of straight iron instead of a barbed hook. This tackle, he explains to the unrecognised monarch, is based on principles dear to our Conscientious Objectors, viz. voluntaryism-_" for only volunteers would suffer themselves to be caught thuswise "-and of mercy- " since it gave all those who wished a chance of escape."

Wên, from his many campaigns, observed much and missed little. He noticed the full creel. Thence, as a Sage would, deduced that since a virtuous man's wants are always satisfied, Chiang must be just such a man. He felt instinctively that here indeed was the statesman whom his grandsire-observe the ancestor-reverence!-would have selected. So without more ado or any references as to character, Wên carried Chiang off, whether with or without the full creel history deigns no word, to his palace, installed him as Viceroy, and ever after termed him "my Grandfather's Desire," a sobriquet which, however well meant, our philosophic piscator-he was only eighty when caught straight-ironing-must at times have resented. 1

Not dissimilar in method if unlike in emolument, stands out the historical (for he shone in the eighth century A.D.) Chang Chih-ho, that " glittering example of humorous romantic detachment and carelessness of public opinion, who spent his

${ }^{1}$ See H. A. Giles, Chinese Biographical Dict., 1898, p. I35, No. 343. 
time in angling, but used no baits, as his object was not to catch fish." 1

But the greatest Sage of them all, Confucius, whose philosophy has for 2400 years permeated, perhaps even dominated, public polity and private action, was not as one of these. Humane, practical, and a sportsman, "The Master angled, but did not use a net: he shot, but not at birds perching," which Legge 2 in a note kindly expands into "Confucius would only destroy what life was necessary to him!" Since netting in his era (c. 500 B.c.), as now, held the field, or rather the water, the touch of the philosopher's sole device being the rod implies a compliment, confirmed by the context, to his humane sportsmanship.

To Mr. Yen's statement as to the importance of fish, marine or freshwater, as a staple of subsistence in China can be added the evidence as regards ancient times collated by Werner, ${ }^{3}$ later times by Du Halde, ${ }^{4}$ and modern times by Williams, ${ }^{5}$ Gray, ${ }^{6}$ and Dabry de Thiersant. ${ }^{7}$ While they agree with the rest of the world in the economic necessity of fisheries, the people, and especially the epicures of China, differ profoundly from the European or American in ichthyic appreciation.

As the Greeks and Latins at times saw not eye to eye as to the palatal primacy of certain fishes, the people of the Middle Kingdom eat not, and never ate, tooth to tooth with those of the West. To the Sinitic opsophagist his salmon, indeed most of the deep sea fishes, appeals not at all.

"We delight," says Mr. Yen, "in eating those of the finny tribe whose meat is soft and fine, and they are caught for the most part in rivers, brooks, lakes, ponds, and the surface of the ocean. On the other hand, there are products of the sea which are regarded by us as delicacies of the table, but which have little or no consumption in the West. Just to mention

1 See Ibid., No. 34.

2 Legge, Chinese Classics, I. p. 67.

3 Op. cit., p. $25^{\circ}$.

1 J. B. du Halde, Description geographique (etc.) de l'Empire de la Chine (etc.), Paris, $\mathbf{I} 735$.

5 Op. cit., vol. II. p. 780 , ff.

6 J. H. Gray, China (London, 1878), vol. II., 29I-30I.

Op. cit., passim. 
a few well-known ones, the fins of the shark, ${ }^{1}$ the bêche-de-mer, the cuttlefish, the jellyfish, and the scollop form important articles of domestic commerce, but are not bought or sold to any extent in the West." 2

The cuttlefish as a dining delicacy appealed to very early palates. The Records of Chou recount that on the appointment of Yi Yin to Viceroyalty, T'ang "bestowed-could he do more?-on him cuttle-fish condiment." 3

In China, as elsewhere, the priority of fishing implement furnishes a problem not easy of solution. Professor Giles's statement that "it is clear the net preceded the hook " demands for its gainsaying a knowledge equal, if possible, to his, and, in addition, more than triple brass. Mr. Yen, in his " our ancient classics refer to a time when our primitive ancestors tied ropes together to form fishing nets," seemingly confirms Giles. Legge is uncommittal: "they fished with the line, but the ordinary method was with the net." 4

Search in the great Chinese Encyclopædia endorses the precedence of the Net over the Rod, but not by overwhelming length of time. Its first reference to the former comes from the I Ching or Book of Changes, which may date from the eleventh century B.c.; to the latter from the Shih Ching or Book of Odes, which apparently ranges from the eleventh to the seventh century B.C.

This last passage runs-" What are used in Angling? Silk threads formed into lines. The son of the reverent Marquis and the grand-daughter of tranquil King." The startling identification of the silk threads with a son of a reverent Marquis and a grand-daughter of a King of Peace (according to another translation) shows that in the matter and measure of his metaphors in the millennium preceding the Christian era the Turanian was far from played out.

Fortunately our deus ex machina Prof. Legge again comes

1 These, with fish-maws, and birds' nests-of the swallow species, Collocalia-are esteemed for their stimulating (or aphrodisiacal) qualities. Williams, op. cit., II. 397.

2 op. cit.

3 Pei t'ang shu ch'ao, apud Werner, op. cit., p. 264.

- Op. cit., vol. IV., Pt. I. p. I48. 
to our aid by his assurance that " the allusion to silk threads twisted into fishing lines would seem simply to be to the marriage of the princess and the young noble-not to the lady's holding fast of wifely ways to complete the virtues of reverence and harmony." 1 Another interpretation - " the metaphor indicates that the union of man and wife, like the silk twisted into fishing lines, is a lasting one "-recks not of post-war divorce courts, or post-war tackle.

The next reference in the Shih Ching strikes a sad note. Unless we knew that it was not the grand-daughter of the peaceful King, we might almost fancy we hear the heroine of the silk-line boast bewailing her virginal home.

"With your long and tapering ${ }^{2}$ bamboo rods you angle in the Ch' $\mathrm{i}$ " (a river in Honan). "How should I not think of you? But I am too far away to reach you. When a maiden leaves her home to be married, her parents and brethren are left behind. Calmly flows the current of the Ch'i. There are oars of cypress and boats of pine. Would that I might drive thither and rid me of my sorrow."

The third reference strikes also a note of sadness, caused now by the absence of a husband. "When he went a-hunting, I put the bow in the case for him. When he went a-fishing, I arranged his line for him. What did he take in Angling? Bream and tench-bream and tench, while the people looked on to see." 3

Angling appears in the $M u t^{\prime}$ ien tzü chuan, a work assigned to the tenth century B.C., but probably of much later date. "The pith of the $t i$, tied half-way up the fishing-line," about

1 Op. cit., vol. IV., Pt. I., 36.

2 Ibid., IV. 5, v. "Tapering" according to Prof. Giles should be "very long." To judge from Iepresentations, the rod was about six feet long, although for fresh-water turtles a stouter one of four feet was more usual.

Ibid., II. 8 , ii. $(3,4)$. Neither the value nor the valour of the fishes seem worthy of onlookers. Perhaps the husband had invented-China seems to have anticipated most of our inventions-and was displaying the Double Spey or Steeple cast. But a rod, like a wedding, invariably attracts a crowd, as a stroll on the Seine any Sunday will verify. Some years ago Mr. Kelson and I were trying a new salmon rod, faute de mieux, from the south bank of the Thames. In ten minutes the Surrey side of the Waterloo Bridge was black with folk, hoping, perchance, to witness a capture of the mythical Thames salmon. 
500 B.C. took the place of our modern float: the moment the Angler " saw it sink, he knew a fish was on." 1

In the first century before and after the Christian era the germ of Imperial ostentation and extravagance in tackle raged virulently. Spreading, if not from China to Peru, at any rate like silk ${ }^{2}$ from China to Rome, it claimed among its victims the Emperor Nero and the Emperor Wu of the Han dynasty. The bacillus found the better host in Nero, who ${ }^{3}$ fished with golden nets drawn by purple ropes, while his brother of Asia confined himself to angling from a boat with a hook of pure gold, a line of white silk, and red carp for a lure. ${ }^{4}$

But the commonality of one State, at any rate, ran no bad second to the Imperial pair. "The people of Lu," we read, " were fond of fishing: they used cinnamon bark for bait, forged gold for hooks, which were variegated with silver or green colours, while their fishing line was ornamented with the feathers of the turquoise kingfisher." 5 Here perhaps, as the bird lives on fish, we can detect a conscious or unconscious touch of homœopathic magic.

Lures such as the natural or artificial fly obtain no record: even now the Chinese and Japanese try most things before an artificial fly. The baits consisted of worms, grain, fish, meat, and cassia. The latter aromatic herb recalls the anglers of Oppian and Pliny, who believed in the attraction of fish by the sense of smell. ${ }^{6}$

In their unusual baits our authors suggest their confreves of Greece and Rome. Thus in size of prey, and similarity of bait, the author of the $K^{\prime} u n g$ ts'ung $t z \breve{u}$ and Herodotus

1 Apud Werner, op. cit., 277.

2 In 325 B.c. Chinese silks were sold in Greek markets (Werner, op. cit., Table III.), while by the first century B.C. there was a brisk trade in them with Rome, through Parthia. Cf. Pliny, N. H., XXIV. 8, and XXXIV. 4I ; Virgil, Georg., II. I2I ; Horace, Epod, VIII. I5 ; Mela, III. 7 " . . . pretiosis vestibus in omnes terræ partes mittere solebant," and Seneca's protest $E p$. 90, "posse nos vestitos esse sine commercio Serico. Pliny, XII. 4I, estimates that for luxuries from China, India, and Arabia, Rome was paying annually over 100,000,000 sesterces.

Eutropius, VII. I4.

- Han Wu Ku Shih, apud Werner, op. cit., p. 278. Imperial hunting and fishing expeditions are described on the stone drums of the Chou Dynasty c. $75^{\circ}$ B.C. now at Peking. See Journal N.-C., R.B.A.S., N.S., VIII. 146-1 52 .

B Ch'iieh Tzil, apud Werner, p. 276.

- Antea, p. 238. 


\section{A BAIT OF "FIFTY WHOLE OXEN!"}

coincide. As the former lived not two centuries later than the Father of History, the tip had possibly just reached China from Egypt-" from Africa comes ever something new"viz. the chine of a porker for a crocodile.

The story runs that Tzŭ-ssŭ, a grandson of Confucius, witnessed the landing from the Yellow River of a fish " as big as a cart." The fishermen had baited first with bream, but as the monster, like the law, de minimis non curavit, they substituted half a sucking pig with instantaneous success.

But the bait handed down to us by Chuang Tzŭ (fourth century B.c.), if it faintly recall, completely eclipses " the lungs of a wild bull," which Ælian recommended for the capture of the Silurus, in that it was no less an one than " fifty whole oxen!" 1

As a producer and as a user of Nets, China ranked and ranks perhaps higher than any country. The number and variety of Nets in Julius Pollux can well be matched, while the Oppianic opulence of

"A thousand names a fisher might rehearse

Of Nets, intractable in smoother verse,"

meets its peer, if not its superior in Scarth, Gray, or Dabry de Thiersant, ${ }^{2}$ who devotes thirty-five pages to what Plutarch terms these " engines of encirclement."

If the Net proper, the barrage, and the fish fence sprang from the same parent, ${ }^{3}$ then in China the fish fences of bamboo, erected for catching and spawning purposes, should be included in the term Net. 4

If this be the case, the Chinese stand out as experts both in the diversity and the ingenuity of their devices. Passages from old Chinese authors justify this appreciation. ${ }^{5}$ They are too numerous for quotation here, but three or four seem worthy of notice.

1 Antea, p. 243.

2 La Pisciculture et la Pêche en Chine (Paris, 1872) was written, not by a globe-trotter, but by an expert sent out by the French Government to report fully on Fishing in China.

${ }^{3}$ See antea, p. 43 .

4 Legge speaks of the Nets being made of very fine bamboo.

5 Werner, op. cit., $280 \mathrm{ft}$. 
The Chronicles of the Elders of Hsiang Yang set forth that the villages, when forbidden to catch the fine bream of the Han river, achieved their purpose by erecting a fence, probably of the same nature as that which in Lu Kuei-mêng's History is called Wei hsiao- " which name was taken from the kind of fence used to catch crabs."

The Shan t'ang ssu $K^{\prime}$ ao describe the mêng sou as a basket net, plaited of small bamboos: "The cover of its mouth was woven of bamboo splints : to it hairy and bristling bamboos were fixed: it gradually decreased in size from the mouth to the junction with the hairy and bristling bamboos (elsewhere, bamboos with whiskers) so preventing the fish from going out after they had got in."

From the same source we learn that the mêng chou resembled in shape a sieve. When the water became cold, the fish hid in it. ${ }^{1}$ It was used for fishing, but how it, the $c h$ ' $u$ kuo, or the chao were used or found useful, deponent maketh not clear. But the hung, a sort of bamboo dam, holds the record. With but one of these the people of Ch'ien T'ang obtained during the Chin Dynasty a million fish a year, whence the name Wan chiang hung, or "the million-worker dam." 2 The Odes of Lu Kuei-mêng tell of a bamboo fence ro,00o feet or about 2 miles long. 3

We read in the Kuang chou of baiting the nets with the whites of eggs. In the Ko Kai we encounter a method and a net, both of which to me, at any rate, are new and may be unique. The San ts'ai t'u hui states the ko kai was the net commonly called the kai tou-literally " striking net." It was an implement for taking fish out of a larger net. The kai tou was brought down with force on to the larger net near the fish, which thus were made to rebound into it.

But the device, which the Ching chih ch'i wu lei describes and gravely explains, must act as the limit at once of our

1 Compare another trap which is made by " the people piling up wooden logs in the water. The fish, feeling cold, take shelter under these, and are caught by means of a bamboo screen." Erh ya, apud Werner, p. 276.

a Yu yang tsa tsu, apud Werner, p. 279. It should really be the tenthousand, not million, worker.

s Ibid., p. 28I. 


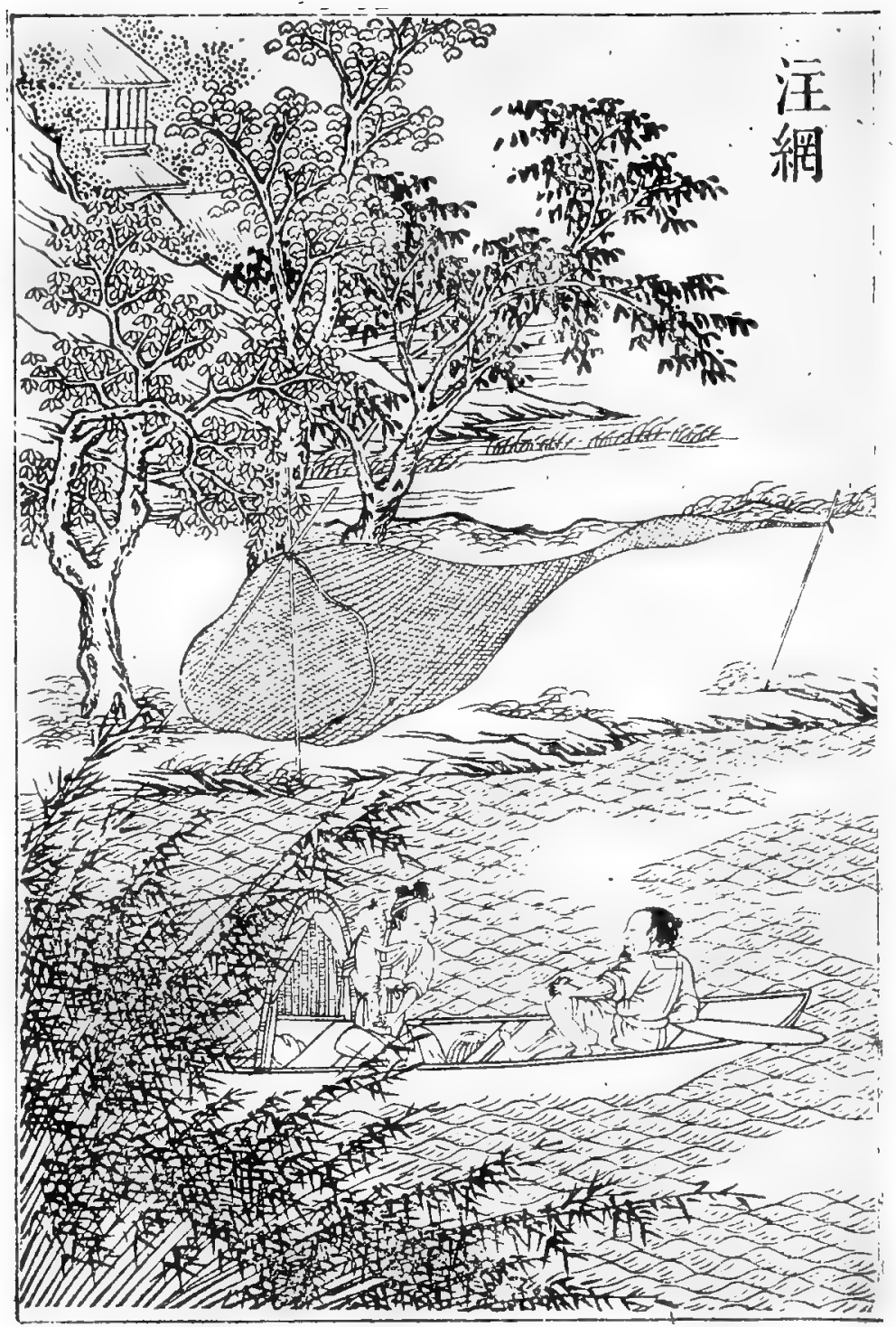

CHINESE NETTING

From Tht Shu Chi Ch'tng, XVII, Pl. 9. 

wonder and of our space. "Fishermen (we are told) used to put the hair of small monkeys on the four corners of their nets, by which means they succeeded in taking large numbers. It is said that the fish seeing the hair were attracted towards it, as a man to embroidery!" 1

The infrequent mention of what was probably the oldest fishing implement of Palæolithic man, the Spear, admits of no satisfactory explanation. For some reason the Chinese seem to have employed the Spear-harpoon but rarely.

Pictures of fishing in $T^{\prime} u$ shu Encyclopadia (extracted from a work of the sixteenth century A.D.) confirm this view. If numbers be any test, the Spear found least favour-it is represented but once-while the Rod appears four, and the Net seventeen times.

Lu Kuei-mêng, the Izaak Walton of China, in his book of the ninth century A.D., does, it is true, include spearing ( $c h^{\prime} a i$ $y \ddot{u})$ with a four-pronged weapon among other fishing methods, such as shooting with bow and arrow (shê $\left.c h^{\prime} i e n\right)$ and driving into shallow water with the aid of a wooden rattle (ming lang) for stockade work. A curious variation of the spear-harpoon (hsien) was an iron instrument having at the end of a bamboo a cock's spur, which was used for iguanas. ${ }^{2}$

The Chinese were evidently familiar with our Otter, i.e. a line carrying hooks at short intervals, and fastened at either end. The Yo Yang fêng t'u chi, a work of the Han Dynasty (about the time of the Christian era) expressly states that this method, with the line made fast across a river between two boats at anchor, accounted for many big fish.

But enough evidence has, I believe, been adduced to prove that the Sinitic piscator had little to learn of his craft.

$\mathrm{He}$ apparently lacked Oppian's pantomimic but scarcely aromatic method of clothing himself in the skin of a she-goat, probably because he lacked its victim, the salacious Sargus. If he knew not Elian's pneumatic device of capturing the eel by the aid of a sheep's bowels, he was no ignoramus of the habits of the Muranida, for he watched carefully and waited

1 Ibid., p. 25 I.

${ }^{2}$ Ch'u hsiueh chi. Ibid., p. $28 \mathrm{I}$. 
patiently for air-bubbles, like a destroyer hunting German U-boats, to rise to the surface and betray the fishes' lair in the mud, and then plunged home his depth-charge, or rather his bident.

Fishing by cormorant was unique and peculiar to China alone, according to $\mathrm{Mr}$. Yen, who adds that " in our country it was confined to one family, the Liu. ${ }^{1}$ The fishes thus caught, however, are limited to those of small streams, unpalatable, and eaten only by very poor people."

Few realise how great is the patience necessary for the training of an expert cormorant, or how good is the reward. These seemingly altruistic piscatores are taught to fish an area in flocks, and at a given signal return to their master with their prey, made unswallowable by means of a neck-ring. One boatman watches twelve to twenty of the birds, each one of whom, although hundreds may similarly be hunting the same water, knows its own master. If one seize a fish too heavy for him, another comes to its aid, and together they fetch it to the boat. More generally the ally (not unlike certain nations in history) hustles the weaker and despoils him of his catch, and of his titbit reward.

The barndoor fowl, whose hospitable warmth and credulity all the world abuses, usually hatches out the young birds, whose piscatorial propensities increase and accentuate on a diet of fish hash and eel's blood.

A curious and vicarious manner of Indian fishing can be witnessed on the Brahmaputra. Birds of the cormorant family range themselves midstream in line, and advance towards a bank, making a prodigious pother by flapping the water with their wings. The fish, panic-stricken, flee to the shallows and even throw themselves on land. The birds, still in close array, pursue and gorge themselves on their penned-in prey.

1 Op. cit., but in Japan, especially at Gifu, the cormorant is in common use, while D. Ross, The Land of Five Rivers and Sindh (London, I883), states that on the Indus not only the Cormorant (Graculus carbo), but also the Pelican and the Otter are similarly employed. Early in the seventeenth century an attempt was made to introduce Cormorant fishing into England as a sport, but failed (cf. Wright, op. cit., p. I82). There was at one time a court official, styled The Master of the Herons. 
" Now enter villagers," who as soon as feeding ceases, rush to the bank and by drums, gongs, and every conceivable noise frighten the cormorants. Heavy from over-repletion, they have, before they can fly, to lighten themselves of most of their meal, which in due time provides the peasants' supper! This method, if it does not appeal to the palate, possesses the merit of semi-poetic and retributive justice. ${ }^{1}$

De Thiersant's assertion that to the Chinese belongs the honour of being the first to invent pisciculture can only be allowed to pass, if the term be restricted to hatching out by natural means, bringing up, and caring for young fish. From this, pisciculture proper differs as chalk from cheese. Originated by Rémy in the last century, it consists of artificial fecundation by the extrusion and mixture of the milt of the male and of the eggs of the female, the hatching out of the eggs on specially constructed trays of wire, etc., set in running water, and the nurture of the fry on specially adapted food in carefully prepared and graduated ponds.

De Thiersant himself, a few pages later, ${ }^{2}$ makes the point clear. Chinese fish-breeders do not resort to artificial fecundation, with which they were even in 1870 very faintly acquainted, for several reasons, not least of which was their contention that fish thus produced were predisposed to quick deterioration. ${ }^{3}$

The Chinese (like the Roman) method of fish-breeding in the eighteenth century, 4 and till 1872 , consisted in gathering from collecting fences constructed for the purpose ${ }^{5}$ eggs which had been fertilised naturally. These were carried (sometimes hundreds of miles, for the secret of safe transportation had early been mastered) to ponds or streams for natural, not artificial hatching. The young fry were guarded carefully, and fed most watchfully.

Gray ${ }^{6}$ enumerates some of the many and minute precautions

1 Blackwood's Magazine, March, 1917, p. 32.

op. cit., V.

s The ichthyologists divided fresh-water fishes into two kinds-Yeh yiz, wild, and Chia $y \tilde{u}$, tame fish: the former cannot live, much less propagate their species, in waters lacking a stream.

Du Halde, op. cit., vol. I. p. $36 \mathrm{f}$.

${ }^{6}$ The $Y \bar{u}$ of a pond, according to the Shan $t^{\prime}$ ang $s s \ddot{c} k^{\prime} a o_{\text {, was }}$ the name of "a fence of bamboo set up in the water, and used for rearing fish."

op. cit., ch. XXX. 
as to shelter and food. Rockeries were erected in the ponds to shelter the alevin from the sun. Bananas were planted on the sides and banks, because the rain which falls from their leaves during a shower promoted health. Forbidden, however, were all pigeons, whose dung was held hurtful, and also (contrary to our experience of the haunt of many and good fish) all willows, whose leaves were deemed inimical to the growth, even to the life of the fry.

"The earliest pisciculturist of ancient China," states $\mathrm{Mr}$. Yen, " was T'ao Chu-kung, " who lived in the fifth century B.C. His method of fish culture combined both knowledge and ignorance. He dug a pond of the size of an acre, leaving nine small islands scattered about it. In one pond he placed twenty female carp, three feet in length, and four males of similar size. This was done in the month of March. Exactly one year later, there were 5000 fishes one foot long, I0,000 two feet long, and 15,000 three feet long. In the third year the number had multiplied ten or twenty times, in the fourth year it was not possible to keep count."

While congratulating $T$ 'ao on the nimbleness of his enumerators and his success, and haggling not at the numbers (for the Cyprida breed prolifically), both the disparity in growth and the similarity of the exactly graded variations in size of these, all yearling, fish are unto the practical pisciculturist a stumbling-block, which neither cannibalism nor luck of food can displace.

But to return to T'ao, or rather to his islands. "The nine islands were to deceive the fishes, who would believe that they were in the big ocean, travelling round the nine continents." We may complacently smile at these fancies, but at any rate let us humbly recall the 2300 years we took to solve the problem of the generation of eels, and the fantastic theories propounded by Aristotle, by Izaak Walton, and others, some of which, e.g. the Cairncross, read as ludicrous as T'ao's " Happy Isles." 2

Fan $\mathrm{Li}$ apparently was the first to practise fish breeding

1 Op. cit. This is but another name assumed by Fan $\mathrm{Li}$.

2 See antea, 25I ff. 
not only in China, but in the world. ${ }^{1}$ Living in the early fifth century B.C. he antedates the Roman Varro, our earliest authority, by some three hundred years. He not only bred, but wrote about fish. But to brother-breeder and brotherwriter of the present century like myself, the process as set forth in his Yang Yii Ching (Treatise on Fish-breeding), is not only difficult to follow in detail, but sadly lacking in result.

As an example, take his method with the bastard carp, or Carassius pekinensis. "In order to breed from the chi fish, it is ripped up with a bamboo knife, and small quantities of quicksilver, mixed with river sediment, and $y u$-ts'ai are introduced into the belly. The fish is then stuffed with cabbage leaves, and hung up for forty-nine days " (note here, the time is pre-ordained, and alters not, as with us nowadays, with changes in the temperature of the water flowing over the eggs) " in an empty place, after which river water is used to extract one or two eggs from the belly. These are placed in water, and covered up with something, and after a while each egg turns into a fish."

Such ingenious industry, coupled with no small expenditure on quicksilver, $y u-t s^{\prime} a i$, and cabbage, deserved a far better return. Had Fan Li intelligently anticipated a method in vogue among his countrymen some two and a half millennia later, money, labour, time, would all have been saved. But as Rome was not built in a day, so centuries were necessary for the evolution of a method of fish-hatching absolutely (to me) unique.

"Not once or twice in its rough " world's story must the ample, yet guileless, bosom of the domestic hen have swelled with anticipatory pride, and subsequent resentful curiosity, as the results of her "watchful waiting" emerged in guise of ugly ducklings, swans, or cormorants.

But of all the sittings to borrow her body's warmth, the strangest and the most incongruous-after all, the ducklings were terrestrial, of a kith akin to her, and not aquatic and unregistered aliens-was that composed of hundreds of fish eggs !

Lest this last sentence seem to label me as a descendant of

1 Biog. Dict., 540. Li's fish-ponds are mentioned in the Wu Yüeh $C h^{\prime} u n$ $C h$ 'iu, or Annals of the States of $W u$ and $Y$ iueh. 
"the first pre-Pelasgian piscator" from whom, in Sir O. Seaman's witty verse,

"From whom have sprung (I own a bias

To ways the cult of rod and fly has)

All fishermen-and Ananias!"

or lest it seem to disqualify me for the character bestowed by Alciphron on an angler, of being one "who would never even slip into misrepresentation," I call no less a witness than Mr. S. Wells Williams, LL.D., late Professor of the Chinese Language and Literature at Yale College, and author of Tonic and Syllabic Dictionaries of the Chinese Language.

From page 349 come ipsissima verba: ${ }^{1}$ "The Bulletin Universel for I829 asserts that in some parts of China spawn is carefully placed in an empty egg-shell, and the hole closed : the egg is then replaced in the nest and after the hen has sat a few days upon it reopened, and then placed in vessels of water warmed in the sun, where it soon hatches!"

De Thiersant, in his assertion that "from time immemorial it has been the policy of the Government and officials to protect fishing in every way," and Mr. Yen in his that "our ancient classics mention the appointment, several centuries before the Christian era, of special officials to rule over and protect our fishermen," indicate that a Board of Fisheries came into existence at an early date.

The Chou Li, or The Rites of the Chou Dynasty (c. I000 B.c.) point distinctly to wardens being appointed for fishing purposes. We read, in fact, of an official staff, called Fishermen attached to the Imperial Court: "They were entrusted with the fishing appropriate to each season, and made dams for catching fish."

Private fisheries, with some few exceptions such as the Imperial preserves, apparently were not allowed, or seem not to have existed. All waters were free and open to all citizens of ancient China. In modern times fishing belongs to the State, and licenses to fish, which are strictly limited in each canton, are obligatory. District magistrates are bound to care for and police the rivers: to put down fry in suitable streams: to enforce the laws, especially those dealing with a

1 Op. cit., vol. I. 
close time, and to permit no cutting of weeds in the waters during the spawning season. 1

The Emperors, especially the earlier Emperors, were keen all-round sportsmen, ${ }^{2}$ but especially zealous disciples of the craft of Angling. Like all good fishermen, they rejoiced in having themselves or sharing with their friends a good day. Sometimes their keen hospitality made them entirely forget, or turn a blind eye on their own ordinances. Even fear of the wardens attached to the Imperial Court, to whom was entrusted (according to the Chou Li) "the fishing appropriate to each season," served not at times to stay their ardour.

Fortunately they were saved from themselves and from breaches of the law, as Mr. Werner shows in a sentence, which in manner and "superior man" strangely recalls Sandford and Merton, and Mr. Barlow. "It appears from edifying anecdotes that the pleasures of the chase, etc., were a snare to the Chinese monarchs, but they were seldom left without some superior man to keep before them the moral ideas of earlier days."

That such was the case some 3000 years ago the story of one of the Chou Dynasty demonstrates. He was anxious in the extreme to go a-fishing with the Empress. None of his courtiers and none of his laws could deter him, although it was the fourth moon, when fish are spawning.

At last his great minister, Tchang-sy-pe, flung himself at the Imperial feet, implored him not to violate one of the most essential laws of the realm, and so set an example which, if followed generally, would destroy one of "the commonest and amplest staples of food." The "superior man " succeeded. The Emperor, struck by Tchang's reasoning, and perhaps by the enormity of his wrong-doing, immediately called the party off.

Another "superior man" later on saves the situation, and his monarch, also one of the Chou Dynasty.

1 De Thiersant, op. cit.

2 Though they and their subjects rejoiced greatly in cock and quail fighting, nature denied to them the "fighting fish," which in Siam are the occasion of weekly contests, heavy wagering, and a fruitful source of revenue to the government from the sale of special licenses (cf. Wright, op. cit., I87-8). 
This time we have no excuse of hospitality, no fair Empress before whose eyes our angler, as Antony with Cleopatra, wanted to display his prowess, or a new cast. No! he was " merely amusing himself "- think of the crime!- "by fishing in one of the Palace lakes."

But alas! 'twas the fifth moon, when fishes were still busy breeding the nation's common and ample staple of food. The line raised for a fresh throw was suddenly cut by the Viceroy, Ly-Ke. "What the deuce are you doing?" thundered the Emperor, aghast at the audacity of the act. "My duty," quietly answered Ly-Ke. "All must obey the laws which you have bidden me enforce."

The voice is the voice of $\mathrm{Ly}-\mathrm{Ke}$, but the sentence and sentiment smack of Mr. Barlow! Such, however, is the power of the "superior man," that the contrite autocrat not only bestowed a present on the intrepid Atropos who shore his line, but commanded that its severed bits should hang for all to see in the ante-chamber of the Palace, as a warning to future ages. ${ }^{1}$

Whether in ancient China a fish-god, such as Ebisu in Japan, ${ }^{2}$ or fish-gods existed, I have not ascertained, but in our day the fishermen on the southern coasts celebrate in spring or autumn a festival to propitiate the gods of the waters. An immense display of lanterns lights the path for a huge dragon, made out of slender bamboo frames covered with strips of coloured cotton or silk: the extremities represent his gaping head and frisking tail. The monster, symbolising the ruler of the watery deep, is preceded by huge models of fish gorgeously illuminated. ${ }^{3}$

But whether the Sinitic Pantheon lacked or held a deity of fishermen, it was reserved for Hsii, the hero of one of the stories in Liao Chai Chih $I$, to summon from the vasty

1 For these two stories, see de Thiersant, op. cit., VII. ff.

2 The earliest drawings represent Ebisu holding a red tai (Chrysophis cardinalis) in one hand, and a fishing-rod in the other. In popular sketches he is usually shown with a laughing countenance, watching the struggles of the $t a i$ at the end of his line, or else banqueting with his companion gods on the same fish. In placing a fisherman god among the Seven Deities of Happiness the Japanese display shrewdness of observation and skill in selection.

3 Williams, op. cit., I. p. 818. 
deep and hold in willing peonage a piscatorial power all his own. 1

This djin of the water was both recognisant and staticno twelve-day banquets speeded him to Æthiopia-and far more instant in service than Hermes or Aphrodite, as Heliodorus and other epigrammatists plainly prove. Not infrequent must have been the occasions when Greek and Roman fishermen returning, despite their sacrificial offerings, with empty creels, met the taunt,

"They're gods : perchance they sleep,

Cry out, and know what prayers are worth,

Thou dust and earth."

Had the fishermen of the Dodekanese and of Italy, following the example of Hsï, poured oblations of the wine of the islands, or deprompted the old Falernian, perhaps the deities of their craft, who oft-times must have jibbed at repeated hecatombs of fish, even if "spiced," and at the sight of the Olympian boxrooms littered with cobbled cobles and torn tackle, would have been more regular in attendance and more prompt in aid.

The story runs that " every night, when Hsiu fared forth to fish, he would carry some wine with him, and drink and fish by turns, always taking care to pour out a libation on the ground, accompanied by the invocation, 'Drink, too, ye drowned spirits of the River!' Such was his regular custom : and it was noticeable that, even on occasions when others caught naught, he always got a full basket."

The means by which this success was attained and other pleasant details are set forth fully in that delightful book by Professor Giles, Strange Stories from a Chinese Studio. ${ }^{2}$ Suffice it, however, here to recount that one drowned Spirit of the River, the genius of Hsü's beat, touched, perhaps even affected, by the alcoholic libation, at first invisibly, afterwards openly

1 In Chuang Tzá (translated by Professor Legge, and also by Professor Giles) a good deal about fishermen, but very little technical can be read.

2 Second edition (London, I909), p. 390 . Then on p. 250 there is a weird story of the goblins who ate the bodies of nineteen men drowned in the river, but spared the father of Wang Shih-hsiu, because he was a skilled dropkicker in the football matches played on a mat in the middle of Lake Tungt'ing. The ball was a fish's bladder I 
glided down stream, quietly drove the lower reaches, and shepherded the fishes towards our angler's bait.

Like his Chinese brother, the British angler, when he goes a-fishing, carries a flask : unlike him, he does not, and cannot, unless he have the grand accommodation of a Loch Leven boatman thirty years ago, "drink and fish by equal turns." Even if the difficulty of equal drinking turn by turn on the part of the sportsman and sprite be overcome, it is doubtful whether a British angler, however adaptive and alert to learn, can in these days ensure a full creel by adopting Hsü's tip, having regard to the scanty stock and prohibitive price of whisky. Whether in the near or even far future the recipe can be thoroughly tested lies on the niggard lap of the Board of Control. 
"Oh! never fly conceals a hook Fish say, in the Eternal Brook, But more than mundane weeds are there, And mud, celestially fair;

Fat caterpillars drift around, And Paradisal grubs are found;

Unfading moths, immortal flies, And the worm that never dies. And in that Heaven of all their wish, There shall be no more land, say fish."

RUPERT BROOKE. 


\section{N D E X}

Аввотт, F. F., 285

Abram, 398

Abstention from fish by-

Egyptians, 319-23

Greeks, 98, 201

Jews, 4I4

Syrians, 98, 123

Achilles, Shield of, 71

Acipenser, 257

Acta Dimrna, 167

Adapa, 354, 369-7I

AElfric, Colloquy of, 55

Ælian, Nat. Hist., I85-93

-, I $52, I 64, I 65,243,245,246,304$

Æschylus, I03

Agassiz, A., 245

Agathemeros Relief, 236

Agathias, I4O

Akki, 387

Albertus Magnus, 94, 245

Alcæus, II 7

Alciatus, 277

Alciphron, I I9, I25, I30, I38, 236, 258

Alec, $2 I_{3}$

Alexander Aphrodisiensis, 280

Alexander the Great, i Io

Alge, 154

Allen, T. W., 86

Altamira, 15

Amia, 238

Amorini, r 30

Anatomy of Melancholy, The, 169

Anaxandrides, 211, 248

Anaximander, 98, 217

Angling definitions, 45-7

Anthias, 232-4, 239

Anthologia Palatina, II7, I2I, I23, 202

Antiphanes, II 8, 247

Antonia, 228

Antony, M., I73

Aphrodisiacs, 284

Aphrodite, 126-7, 271, 275

Apicius, M. G., 209, 248, 255 ,
Apollonius of Tyana, 98, 129, 297

Apostolides, N. C., I 78, 24I, 266

Apuleins, 203

Arallu, 385

Archestratus, I6I, I78, 249, 257, 259, $26 \mathrm{I}, 263$

Archimedes, 225

Archippus, 1 I 8

Arethusa, 220

Ariosto, 230

Ariphron, 278

Aristophanes, 10I, I48, I5I, I98, 219, $229,247,249$

Aristotle, I06-I 5

- and Alexander, i 10

-, dissection of human body, I I 4

-, knowledge of fish, IO7, I IO-I2

-, love of rings and plate, I I I

-, Natural History, Iro

- the first reader of fish's age by scales, 108-9

-, 8r, I04, I53, I55, I64, I78, I93, $239,244,250-51,266,339$

Arrow-heads, 36

Artemis, 126, 220, 272

Asellus, 259, 261

Asmodeus, 432

Asphodel-food for the dead, $3^{85}$

Assyria-

association with Egypt, 349-54

dates, 353,388

fish identified, $375-7$

fishing from goat-skins, 356

rod absent, 349

Astarte, I27, 426

Astrology, 282

Astronomy, 388, 398, 44I

Asur-banipal, $375,3^{8} 3$

Asur-nasixpal, 374

Atargatis, 124, I27-8, 426

Athenæus, Deipnosophista, I8I-4

- $64,80,128,164,181,198,203$, $209,228,242,245,279$

Ausonius, Ad Mosellam, 194-7

$-, 52,207,2$ I I -12

Aztecs, 21 
Babylonians, 35 I

Baessler, A., 24

Badham, C. D., 206, $213,250,254$, $264,282,289,293$

Baire, I 45, r66

Baits, 238, 3I5, 456

Barton, G., 400

Balfour, Henry, 34, 42

Banfield, E. J., 25, 83, I56, 4I 7

Banquets, 206 $\rightarrow 9$

Baring-Gould, S., 95, 259, 440, 443

Barker, T., 8, $4 \mathrm{I}$

Bass, Sea, 244

Bates, Oric, 8, 301, 305, 308, 309, 314, 315,326

Baudissin, W. v., 426

Bede, 57

Bekten Stele, The, 354

Bellonius, P., I98

Beni Hasan, 3II, 3I4, 3I5, 322

Bennett, W. H., 428

Beowulf, 392

Berard, V., 85

Berners, Dame Juliana, see Boke of St. Albans.

Bibliotheca Piscatoria, 187, 189, 252

Blackman, A. M., 3 I I, 332

Blakey, R., 53, 255, 280, 445

Blümner, H., 80, I2I, I9O, 285

Boar fish, 263

Bochart, S., $59,43^{8}$

Bosanquet, R. C., 10

Bouché Leclerq, A., 2 I 8

Boulenger, G. A., 3I9, 330, 375-6, $4^{\mathrm{I}} 7$

Boyd, Zachary, 443

Braested, J. H., 302, 32I, 324, 354, 397

Brandt, P., I 78

Bream, 292, 455

Breslar, 401, 404

Breuil, H,, I8, 3 I

British Museum, Catalogue of -

Bronzes : Greek, Roman, etc., 237

Coins, 272

Lamps, $\mathbf{I}_{49}$

Sculpture, 236, 265

Vases, 18I

Broca, P., 38

Brosses, C. de, 98

Browne, Moses, II9, I20, I72

Browne, Sir T., 3, I75, 4I5

Browne, Wm., I3, I 9

Brugsch, H. K., $30^{\circ}$

Buddha, 49, 403

Budge and King, 373

Bunsmann, I2I, I30

Bunyan, J., 3

Burton, R., I69-7I, 280
Bushmen, African, I9

Australian, 27

Butcher, S. H., 65

Butcher and Lang, I3, 77

Byron, I06

CISAR, 223

Cahier, C., 275

Cairncross, D., 251

Calderwood, W. L., 42

California, 4I

Caligula, 226, 228

Callimachus, 136

Campaux, A., I2I

Capart, J., 324

Caper, 263

Carm. Medicorum Reliquice, 282

Carp, 25, 200, 273

Cartailhac, E., $17,18,26$

Carteia, 220, 272

Carthage, Council of, 434

Cassiodorus, $180,256,260$

Catacombs, 275

Catapatha Brāhmana, 49, 27 I

Cato, M. P., 200, 224, 265

Cato, P., poet, I 48

Catullus, 268

Celsus, 260, 28I

Cestreus, see Mugil capito.

Chabura, 380

Chantepie de la Saussaye, D. P., 243

Charlemagne, 29I

Chaucer, G., I07

Cheyne, T. K., 387,426

Chiang Tzŭ-ya, 451

China-

dates, $45^{\circ}$

fishermen, 6, 64, 449

importance of fish in, 449, 453

Cholmeley, R. J., I33, I35

Christ, W., 53, I75

Chromis simonis, $4^{\mathrm{I}} 7$

Cicero, I80, 227, 257

Clarias macracanthus, 325, 4I7

Claudian (poet), I8o

Cleopatra's fishing, I73

Clerke, A. M., 74

Cobern, C. M., 259

Cockles, 7o, 224

Coins of-

Abdera, 273

Ascalon, 128

Carteia, 220,272

Cyzicus, 272

Hierapolis, 128,426

Iasos, 96

Olbia, 219, 272

Syracuse, 221

Tarentum, 220 
Columella, 205, 212, 222, 225, 229, 249

Comacchio, 229

Como, $\mathrm{r}_{43-4}$

Confucius, 453

Conjecture Halieutices, 58

Contest of Homer and Hesiod, 86-9

Cook, A. B., 95, I57, I95

Cooks, 2 I0-II

Copais, 20I, 215

Corks, 239

Cormorant, 460

Corneille, T., 178

Cornelius Nepos, 26I

Corp. Inscript. Lat., I5I

Crescens-arundo, I47-5I

Crete, 6, 43, 3I 4

Crocodile, 33I, 403, 4I 8

Curtius, E., 68, 79

Cuvier and Valenciennes, $25, \mathrm{I}_{53}$, I97, 336

Cyclamen, $24^{\circ}$

DAGON, 27I, 363-7

Dall, W. H., 30, 38

Daphnis and Chloe, $\mathrm{r} 39$

Dapping, I 56

Daremberg and Saglio, Io, 69, I49, 202

Darwin, C. R., 4I, I 55, 335

Davies, N. de G., 3I6-7

Dawkins, W. Boyd, I8

Day, F., II 3

Dead, Book of the, 344,385

Dead, offerings to the, $303,3^{85}$

Delegation en Perse, 367

Delta, The, 302, 32I-2

Democritus, 282

Depreciation of money inEgypt, 336-8

Rome, 285

Derceto, 124, 127, 271

Dialogus creaturarum optime moralizatus, 55

Diaper, J., II9, 43 I

Diaper and Jones, I77, 235

Dion Cassius, 202, 208

Diocletian's Edict, 203, 285-8

Diodorus Siculus, 3I2, 334

Diogenes the Cynic, 205

Dioscorides, I8I, 280, 282

Diphilus, 164, 181, 258, 264, 279

Dit Boecxken leert, etc., 54

Dolphin, 9I-6

helps fishermen, 93

Joves boys, 94-5

loves music, 9 I

predicts weather, 92
Dolphin-contd. saves lives, 92 swiftness of, 92 voice of, r64

Dölger, F. J., 274

Domitian, I66, 259, 273

Dorion, $26 I$

Dryden, J., II9

Du Halde, J. B., I60, 29I, 453, 46I

EA, 363, 369-71, 386

Echineis, see Remora.

Edmonds, J. M., I35

Eels, 25, 216, 246-54 as a dainty, 248-50 as a diet, 279

Copais, 2 I 5

fecundity of, 253

fishing for, $246-7$

in Egypt, 247, 33r

in Greece, 248-9, 262

in Homer, 85

in Rome, 248, 262

propagation of, 250-2

silver, $25 \mathrm{x}-2$

Eglinus, R., 58

Egypt-

angling, 3I $4-5$

dates, $3^{\circ 0}$

debt of fishermen to, $30_{4}$

fish cemetries in, 326

fish not eaten by kings and priests, $3^{23}$

importance of fish in, 304

pin-money from fisheries for Queens of, 334

price of fish in XXth Dynasty, 336

Elite des Monuments Ceramographiques, 236, 349

Ellis, Robinson, 268

Elops, $25^{8}$

Empedocles, 279

Encyclopadia Biblica, 406, 419, 426, 437

Encyclopadia, Jewish, 40r, 4I6, 427 , 444

Ennius, I6r, 255, 263

Epicharmus, I6I, 258, 284

Erman, A., 322, 408

Eskimos, 19, 20

Esox lucius, see Pike.

Ethiopian History, The, 122

Eubulus, 249

Euphrates, 377

Euripides, 297

Eustathius, 77, 80

Euthydemus, 219

Eutropius, 176 
Evans, Sir A., 6, I5, 64, 66, 72 Exodus, The, 407

FABER, G. L., 102, 268

Fan-li, 462

Festus, 2I7

Feist, S., 68

Firdausi, I 76

Fish, as sin bearers, 383,427

fresh water, $85,201-2$

in auguries, 218,389

infatuation for, 20I-8

in medicine, $278-84$

in myths, $270-72$

in nostrums, $280-82$

in sacrifice, $215-8,3^{82-3}$

in Zodiac, $124,39^{\circ}$

marine, preference for, $85,202-3$

marked, 58-9

on coins, 128, 219, 220-I, 272-3, 426

on land, 380,417

on tombs, 275

sacred, I29, I36, 201, 2I5, 247 , 327-3I

scaleless, $163,4 \mathrm{~T} 4$

symbols, 273-5

tail preferred, 255, 280

unwholesome, I63, 279

wholesome, 279-80

Fisheries, taxes on, 96, 334

Fishermen, hospitality of, I22

humour, I25

old age, 130

piety, I22

poverty, I20

toil, I3I

Fishing contract, the first, 360-2

Fishing-frog, I2

"Fishing Prohibited"-first notice, I66

Fishing by music, 242

Fishmongers, $2 \mathrm{I}_{4}$

Fletcher, P., II9

Floats, 315, $35^{8}$

Flood, the, $37 \mathrm{I}$

Fly, artificial, 56, 557

first mention of, $\mathrm{I}_{52}-8$

Macedonian, 185-93

Folkard, R., 207

Forlong, J. G., 349, 365, 4I 5

Fosbroke, T. D., 262

de Fournival, R., 54, I87

Franck, R., 107, 25I

Frank, K., 369

Frazer, J.' G., 96, 98, 372, 387, 429, 433

Friedländer, L, 153

Frog, 28?
Furtwängler, A., Io

Furtwängler and Reichhold, 295

Gadida, 108

Gaff, 40

Galandruccio, 252

Galen, I62, I8I, 202, 260, 264, 278 , 282

Gardiner, Alan H., 335, 352

Garr, 42

Garum, 2 I2

Gaster, M., 432

Gay, J., II 9

Geikie, A., 65, 201

Geoponika, 53

Gifford, W., 205, 268

Gilbert, I 53

Giles, H. A., 450, 454, 467

Giles, L., $45^{\circ}$

Gilgamesh, 316, 367, 386

Gill, T., 245

Giovio, Paolo, 144

Glanis, II I, 244

Glaucus, 140, I96

Glaucus, 264

Gods of fishing, I25-8

Gorges, 3I-3, 80

Gout, I8I

Grassi, 252

Gray, J. H., 453

Grayling, I93

Grenfell, B. P., 34 $1-2$

Grenfell and Hunt, 334, 362

Grey, Zane, 4 I

Griffith, F. Ll., 31 I

Ground Bait, 239, 3r5, 358

de Gubernatis, A., 207, 250, 271, 275

Gunnar's Slaying, 34I

Günther, IO7

Gurob, 326, 327

Gut, 40, 45I

Guyet, M., I 73

HAILES, Lord, 434

Haime, J., 290

Hall, H. M., I I 7, I2I, I 30, I38

Halliday, W. R., 218

Hamilton, M., 274

Hammurabi, $379,388,389,398$

Harowitz, R. I., 427

Harpoon, see Spear.

Harris, I. Rendel, 274

Hartwig, P., I 3I

Haskins, C. E., 84

Hayman, H., 82

Hayward, A., 161

Head, B. V., 96, I28, 220 
Hearing of fish, Aristotle, Irz

Day, II 3 experiments, II 3-4

Hedyle, $\mathbf{r}_{40}$

Hedylus, 182

Hegesippus, I 23

Heiss, A., 220, 273

Helen's Ring, 295, 297

Heliodorus, I2I, I23, I39, 30r

Heller, E., I 35

Heracles, Shield of, 90

Heresbach, C., $24 \mathrm{I}$

Hermes, I25

Herod, 4II

Herodotus, 96, 99, 127, 209, 242, 297. $328,334,338$

Herring, 199,276

Hesiod, 86-9, 9 I

Heuzey, L., 359, 367

Hicesius, 260

Hieronymus, Bp., I77

Highlanders, 57

Hill, G. F., I28, 2 I9, 22 r, 367, 426

Hippocrates, 250,278

Hippopotamus, 3I2

Hoffmann, W., 20

Hogarth, D. G., 68

Holma, H., 376

Homer, contest with Hesiod, 86-9

Homer, death of, 88

epitaph on, 88

fish as food in, 69-7I

fishermen in, 64-8

fishes in, 85

hooks in, $76,80,83$

hunting in, 72

iep $\delta s, 78-9$

képas, $8 \mathrm{I}-4$

rod in, $76-80$

similes, fishing, in, 74

traders in, $64 \rightarrow 7$

Honan, $45^{\circ}$

Hook, Assyrian, 356-7

barbed or bent, I3-I 4, 3I 3, 452

Chinese, 454

derivation of word, 237,357

Egyptian, 312-3

from insect, 34

gold, 35

Greek-Roman, 237-8

Jewish, 402-4, 418

Old Stone, 3I-35

thorn, 35

Horace, I 27, I 59, 257, 258, 260

Horse-hair, lines, 7,236

Hortensius, 224, 227

Houghton, W., 332

Hovelacque, A., 39

Howlett, R., I2
Hsŭ, 467

Hultsch, F., 67,285

Hyksos, the, 397

Issos, boy and dolphin of, 95

Ichthyophagi, 97-8

'Iepos, see Homer.

I Ching, 454

Indian fishing, 49

I shih ching, $45^{\circ}$

I shih chi shih, 45I

Ishtar, 38r, 386

Isidorus, 262

JACOBI, S. L., 292

Janus, 125

Japanese, 51

Jastrow, M., 359, $3^{8} 3$

Jebb, R. C., 69, r95

Jews, connection with Egypt, 397400

fish classified, 4I 4

rod absent, 402-6

-, reasons for, 406-II

Joel, 66

Johnson, Dr., I I9, I72

Johnston, H. W., I08

Johnston, T. B., 248

Jonah, 442-3

Josephus, 416

Joyce, T. A., 24, 35, 399

Judas, 444

Jus prime noctis, 433-6

Juvenal, I44, 204-5, 225, 248, 258, $268,33^{\circ}$

KAMAL, A. B., 304, 327

Kán pos, 263

$K a r$, fish, 49

Keats, J., I19, 2 I2

Keller, F., 30, r97

Keller, Otto, 85, 102, 213, 214, 2 I7, 439

Kennedy, A. R. S., 397, 406

Kennett, R. H., $4^{\circ 9}$

Kent's Cave, I5

Kepler, 44I

King, L. W., 352, 359, 364, 373, 385

Kite fishing, 4I

Koran, the, $390,440,444$

Krause, E., 3r, 33, 36, 255

Krauss, S., 40I, 420

Kugler, 388,398

$\mathrm{K} \omega \nu \omega \psi,-193$ 
LABERIUS, 26 I

Lacau, P., 325

Lacépède, G. E., 3, I59

Lactantius, 286

La Madelaine, 25, 3 I

Lambert, O., I87, 2 I I

Lang, A., $\mathbf{1}_{33}, \mathrm{r}_{34}, \mathrm{r}_{37}$

Langdon, S., $351,354,357,367,376$, $3^{8} 4,3^{86}$

Lates niloticus, 325

Law : Assyrian, 379

-, Chinese, 464

-, Jewish, 4r9-20

-, Roman, 23I-4

Layard, H., 354, 356, 364, 376

Leaf, W., 65, 84, 297

Le Clerq bronze, 386

Legge, J., 453, 454, 467

Leistering, I 79

Leonidas of Tarentum, II9, I33, 136-7

Lepidotus, 329

Lepsius, R. P., 3I 3

Les Ruses Innocentes, to

Leviathan, 403, 4I 8

Line, Assyrian, 356

-, Chinese, 454

-, dead man's hair, 340-2

-, Egyptian, 3 I I

-, Greek-Roman, 237

一, in Homer, 76

-, Jewish, 4I 8

-, Old Stone, 40

-, running, 8-9

-, tight, 9, I0, I2

Loki, 255

Lones, T. E., I07, I 55

Longus, I39

Lucan, 334

Lucian, 9I, I27, I 38, I45, 2 I I, 250, 426

Lucilius, 260

Lucretius, I34

Lucrinus, oysters of, $\mathrm{x}_{4} 6$

Lund, P., 292

Lupus, 25, 198, 259

MACALISTER, R. A., 400

Macdonell, A. A., $4^{8}$

Macedonian fly, I87-92

Mackail, J. W., 71, 74, I16, I44, I94, 201

Mackerel, 213

Macrobius, 204, 257, 260

Magic, 27-30, 305, 344, 43I

Magna Charta, 290

Mabler, E., 327
Mahomet, $44^{\circ}$

Mainzer, V. M., 405, 420-I

Manu, 49, $27 \mathrm{I}$

Marco Polo, 97

Marduk, 39I-3

Mariette, 323

Martial, I44

books of, I66

love of angling, I 44, 146

rod in, $\mathrm{I}_{47} \mathrm{I}^{\mathrm{I}} \mathrm{I}$

Scarus in, I52-I 54

一, I62, 192, 203, 204, 210, 227, 257

Marston, R. B., 40, 55, I72, 292

Mascall, L., 200, 292

Maspero, G. C., 84, 307, 324, 333, 352, $37^{2}$

Matron, 206, 256, 265

Maundy Thursday, 276

Maxwell, Sir H., II3, 25 I

Mayas, see Mexico.

Mayer, $\mathrm{H}$., 187

Mead, C. W., 24

Meek, A., I97, 252

Meissner, B., 360

Melanurus, 166

Menander, IoI, II $8,249,278$

Menant, J., 365

Mendoza Codex, 22

Menelaus, 77, I 38, 297

Merry, W. W., 72, 8I

Mexico, 2 I

Microscope, 108

Migne, J. P, 434

Milton, J., I7I, 366,426

Minchin, C. O., 82

Maotes, $33 \mathrm{I}$

Monro, D. M., 71, 83

Monkfish, 277

Montet, P., 319, 322, 375

de Montfaucon, B., 277

de Morgan, J., 335

Mormyrus, 330

de Mortillet, G., 19, 31, 39, 42, 197

Moschus, II 9

Moses, $387,4{ }^{1} 4$

fish of, $43^{8}$

Mosquito, 193

Moule, T., 96, 197, 443

Mugil Capito, 164, 239, 260, 266-8, 287,335

Muller, W. Max, 352

Mullet, 203, 256

Mundus Symbolicus, 276-7

Munro, R., 30

Murana, I82, 228, 248, 26I

Murex, age by scales, ro 8

Musco, or musca, $153^{-6}$

Myths, fish in, 270-2 
Narke fish, see Torpedo.

Narwhal, 282

Nero, 92, 259, 273

Net, Assyrian, 349, 358-9

-, Chinese, 450, 457-8

-, Egyptian, 3I6-7

-, Greek-Roman, 76, 235

-, Jewish, 4 I9

-, Old Stone, 30,42

-, spider's, 43

Newberry, P. E., 3I I, 3I 2

Nikolshi, 382

Nile, the, 30r, $3^{\circ} 4$

Nineveh, $3^{81}$

Ningirsu, 359

Nonnius, I62, I63, 254, 255, 263

Numa Pompilius, 216

OANNES, 364

Octopus, $44,178,273$

Odysseus, 77

Olbia, 219, 272

Old Stone Men, Art, I 5-6, 26-7 Implements, $34^{-8}$ stations, I5

Oliver, S., 187

Oppian, Cynegetica, I48, 179

-, Halieutica, 174-8

-, -, payment for, 175

-, I53, I54, I55, I64, I65, 239, 240, $249,250,267$

Opsophagist, 206

Orata, S., I60, 212, 223

Osborne, H. J., 3r, 38

Osiris, 329

Ovid, II9, 124, 128, 130, 215, 239, $257,258,260$

Owen, R, 155

Oxyrhynchus, I98, 248, 326, 327

Oysters, 7o, 223

-, English, $I_{4} 6$

-, Lucrine, 145, 223

- Mycenæan, 70

-, poems to, 2 I2

PAley, F. A., I48, 153

Palæolithic, see Old Stone.

Pan, 125

Papyri, II7, 121, 133, 301, 337, 338, 354,362

Parker, C. A., 243

Parker, Eric, 56

Parkyn, E. A., I6, I9, 27, I97

Passer, 264

Pastinaca, 77, 28I

Pauly-Winowa, 53, 285
Pausanius, 87, 123, 242, 266, 297

Pearls, British, 223

Pearson, A. C., 77

"Pelorus Jack," I82

Perch, 292

Persian fishing, 50-r

Peru, 24, 367

Petrie, F., 5, 35, 237, 308, 309, 314, $317,335,351,352,353,400,408$

Petronius, 122, I48, 160, 224

Phagrus, 329, 33I

Philæterus, 249

Philemon, 203, 263

Philoxenus, 205

Phoenicians, 65-6

Phylakopi, vase of, 63

Pianki, 32I

Pichon, Dom., 54, 291

Picinelli, D. P., 276-7

Piers of Fulham, 55

Pike, 25, 196-9

Pilot fish, 182

Pinna, I83

Pisciculture in China, 29I, $46 \mathrm{I}$

一, in Rome, 289, 29r

Pitra, J. B., 220, 273, 274, 364, 427

Plato, defines fishing, 45, I06, I80, $33 \mathrm{I}, 334$

Plato, comedian, II 7

Plautus, I4I, I48, 250, 257, 266, 284

Pliny the Elder, Nat. Hist., I4I, I42, $I_{53}, I_{54}, I_{59}, I_{62}, I_{80}, 203,2 I_{3}$, $223,227,238,239,242,255,258$, $260,267,282,284,380$, 4I5

Pliny the Younger, I42-3

Plutarch, cleared from Burton's charge, $x 69-72$;

$-7,82,85,86,89,98$, I29, I63, I72, 182, 196, 201, 206, 216, 217 , $237,319,322,330,332$

Poaching, first case of, 379

Poisons in fishing, 239

Poissons d'Auril, 275

Pollux, J., 43, II8, 3I7, 335

Polycrates, ring of, 344

Porson, B., 406

Porta, G., 24I

Poseidon, 125, 201, 272

Posidonius, 209, 215

Poulsen, F., 69

Pretextatus, 262

Pratt, E. A., 43

Prawn, 199

Priapus, 125

Prices, correlation of, in-

Egypt, 335-8

Rome, 285-8

Printing, 6, 45I

Propertius, 148 
Proteus, 85,138

Pythagoras, I63, 284

RABELAIS, I07, 262, 279

Rameses II., 354, 407

Rau, C., 20, 38

Rawlinson, G., 356

Reel, 8, 238, 3 II

Regimen Sanitatis Salerni, 264

Reinach, S., IO, 20, 27, 3I, 79, 345

Reisner, G. A., 308

Remora, $180,256,28 \mathrm{I}$

Rémy and Gehin, 289, 293

Rhazes, 280

Rhode, P., IOI, 2I5, 221

Rhodian Law, I79

Rhombus, 258, 439

Rich, A., I 49

Ridgeway, W., 35, 67, 336

Rings on Rod, first, I2

Roach, 77

Robinson, Phil., I99, 228, 265, 27I, $276,44^{\circ}$

Rod, China, 454

-, Egypt, 3I5

-, fowling, 149

-, Homeric, 76-8

-, Macedonian, I88

-, Martial's, r $47-5$ I

-, tapered, 236

Rodenwaldt, G., 73

Romanticists, Greek, I2 I

Ronalds, A., II 4

Rondolet, G., 94,242

Rose, flower of Venus, 207, 277

Roth, H. Ling, I9

Rouse, J., $7_{70}$

St. Albans, The Boke of, 8, 56, 80, I87, I89

St. Bertin, MS. of, 52

St. Brandan, 444

St. Wilfrid, 57

Sakkar, 444

Sakuntala's Ring, 49

Salmon, 25, 139, 194, 255, 277, 290, 358

Salmonidae, 196

Salpe, 28z,

Salsamentum, 219

Sanchouniathon, 33, 367

Sannazaro, J., II9, I20

Sappho, II6

Sargus, 24I, 276

Sauces, 2I2-4

Sayce, A. H., 30I, 381, 383

Scaliger, 175,245
Scarus, 159-66

acclimatisation, 160

as a dainty, I6I

as a diet, 162

characteristics of, I64-5

rumination of, 155

Scheftelowitz, I., 273

Schliemann, H., 70

Schmidt, Hans, 442

Schmidt, J., 253

Schneider, J. G., 7I, I42, I98

Schneider, K., 68

Schrader, O., 69, 389

Scolopendra, 239, 282

Sea-hare, I62, $28 I$

Seals, 27,85

Seneca, 204, $210,225,256$

Seymour, T. D., 65, 70, 79, 115

Shakespeare, W., I22, 224

Shark, 7, 244

Sheringham, H. T., 33, 40

Shewan, A., 206

Shorr, B., 36I

Sidetes, M., 283

Sidonius, I 94

Silius Italicus, 147

Silurus, 243, 245, 246

Siret, L., 222

Skeat, W. W., 55, 248

Slate palettes, 305

Smith, A. H., IO, 265

Smith, W. Robertson, 320

Snow, H., I 34

Socrates, I $8 \mathrm{I}$

Sole, $264-6,287$

Sollas, W. J., I9

Solomon, 409, 444

Sophron, II 7

Spanish stations, I5, I6, 36

Spawning, theories of, I82, 250-2 $33^{8-9}$

Spears, Chinese, 449, 459

-, Egyptian, 307-I I

-, Greek-Roman, 76

$\rightarrow$ Jewish, 4 I 8

-, Old Stone, 30, 36-9

Spearing fish, 76, 310-r I

Spenser, E., I I9

Spiegelberg, G., 335

Steindorf, G., 3I I, 3I 5, 3 I 8

Stengel, P., 216

Stephanus, 264

Stesichorus, 297

Strabo, I28, 325, 326, 426

Strombus, 281

Sturio, 257

Suetonius, I67 203, 207, 218, 223. 226

Suidas, I6I, 262 
Sulpicius Severus, I99

Sumeria, $35^{\circ}$

Sung Yü, 45I

Superstitions of fishing, 28-9, 59-60

Sybaris, 250

Symbols, fish in, 270,275

Syngnathus acus, 4I7

Tabu, 99, 384

Tacitus, I43, 208, 222

Tackle, pedigree of, $3^{8-43}$

Talmud, 366, 377, 4I 5, 420, 439, 444

Tariche, 219, 335

Tasmanians, 18, 19, 21

Tasso, 230

Tennyson, A., I34

Terence, 266

Theocritus, $I d y l l X X I$., I33-6

一, influence of, II9-20

一, II8, I29, I54, 2I5, 431

Theodoric, 200, 295

Theophrastus, 334

de Thiersant, B., 43, 449, 453, 46I

Thompson, D'Arcy W., I07, I08

Thompson, R. Campbell, 383, 428, 431

Thompson, W., IIg

Thomson, J., I 35

Thomson, J. S., 108

Thor, 243,255

Thrissa, 242

Thymalus, 193

Tiāmat, $39 \mathrm{r}-3$

Tiberius, 273

Tibullus, I 5 I, 226

Tickling, 39, 24 I

Tiglath-Pileser I., 354, 364, 373

Tillyard, E. M. Y., Io

Tisdall, W. Sr. C., 5I, 406

Tobias, 43I-2

"Tobias Days," 433-5

Torpedo fish, r80-I, 282

Trichias, 242

Trimmering, 4I

Tripatinium, 262

Tristram, H. B., 4I 6

Tuna, size of, I04, 244

Tunny, 99-I05, 221

Turrell, W. J., 8, 9, I87

Tylor, E. B., $18,4^{2}, 83,4^{12}$
Tylor, J. J., 31 8

Tyrrhenus, 122

UNGNAD, A., 360

VAN DYKE, H., 47, 418

Van Leeuwenhoek, A., 108

Varro, 202, 21 7, 224, 257, 261, 284

Venables, R., 35

Venice, 345

Venus, see Aphrodite.

Vettersfelde, 64

Veuillot, L., 434

Virgil, I20, I29, I 48

Vishnu, 27I

Vitellius, 207, 255

Vivaria, 224-9, 3I5, 378, 422

Volcanalia, $2 \mathrm{I} 7$

Voltaire, I73

Von Helmont, 25 I

WALDSTEIN and Shoobridge, 237

Walters, H. B., I2, I49, 237

Walton, Izaak, 3, 8, 9, I06, I69, I72, $242,25 I, 4 I 5,44 I$

Walton and Franck, 107, 25I

Ward, W. H., 363, 375, 386

Watkins, M. G., 4I2

Werner, E. T. C., 449, 454, 455, 457 , $45^{8}$

Whibley, L., 226

Whitney, J., I72

Wilcken, U., 334

Wilkinson, J. G., 302, 309, 315, 326

Williams, S. W., 449, 464

Wine, fishing with, 239

Wissowa, G., 2 I 7

Wollaston, A., 5 I

Women, prescription for ... telling the truth, 282

Wright, S., 239, 449, 460

Xenocrates, $162,255,256,25 \varepsilon_{\text {, }}$ 264,280

Xenophon, 88, 206

ZiMMERN, W., 39I 







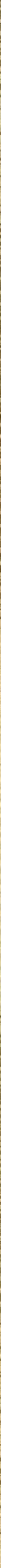

